\title{
Caddo Archaeology in the Caddo Creek Valley of the Upper Neches River Basin, Anderson and Henderson Counties, Texas
}

Timothy K. Perttula

Heritage Research Center, Stephen F. Austin State University

Mark Walters

Heritage Research Center, Stephen F. Austin State University

Follow this and additional works at: https://scholarworks.sfasu.edu/ita

Part of the American Material Culture Commons, Archaeological Anthropology Commons, Environmental Studies Commons, Other American Studies Commons, Other Arts and Humanities Commons, Other History of Art, Architecture, and Archaeology Commons, and the United States History Commons

Tell us how this article helped you.

This Article is brought to you for free and open access by the Center for Regional Heritage Research at SFA ScholarWorks. It has been accepted for inclusion in Index of Texas Archaeology: Open Access Gray Literature from the Lone Star State by an authorized editor of SFA ScholarWorks. For more information, please contact cdsscholarworks@sfasu.edu. 


\section{Caddo Archaeology in the Caddo Creek Valley of the Upper Neches River Basin, Anderson and Henderson Counties, Texas}

\section{Creative Commons License}

\section{(c) (1) \&}

This work is licensed under a Creative Commons Attribution-NonCommercial 4.0 International License 


\section{Caddo Archaeology in the Caddo Creek Valley of the Upper Neches River Basin, Anderson and Henderson Counties, Texas}

Timothy K. Perttula and Mark Walters

with contributions from Arlo McKee, P. Shawn Marceaux, and Bo Nelson

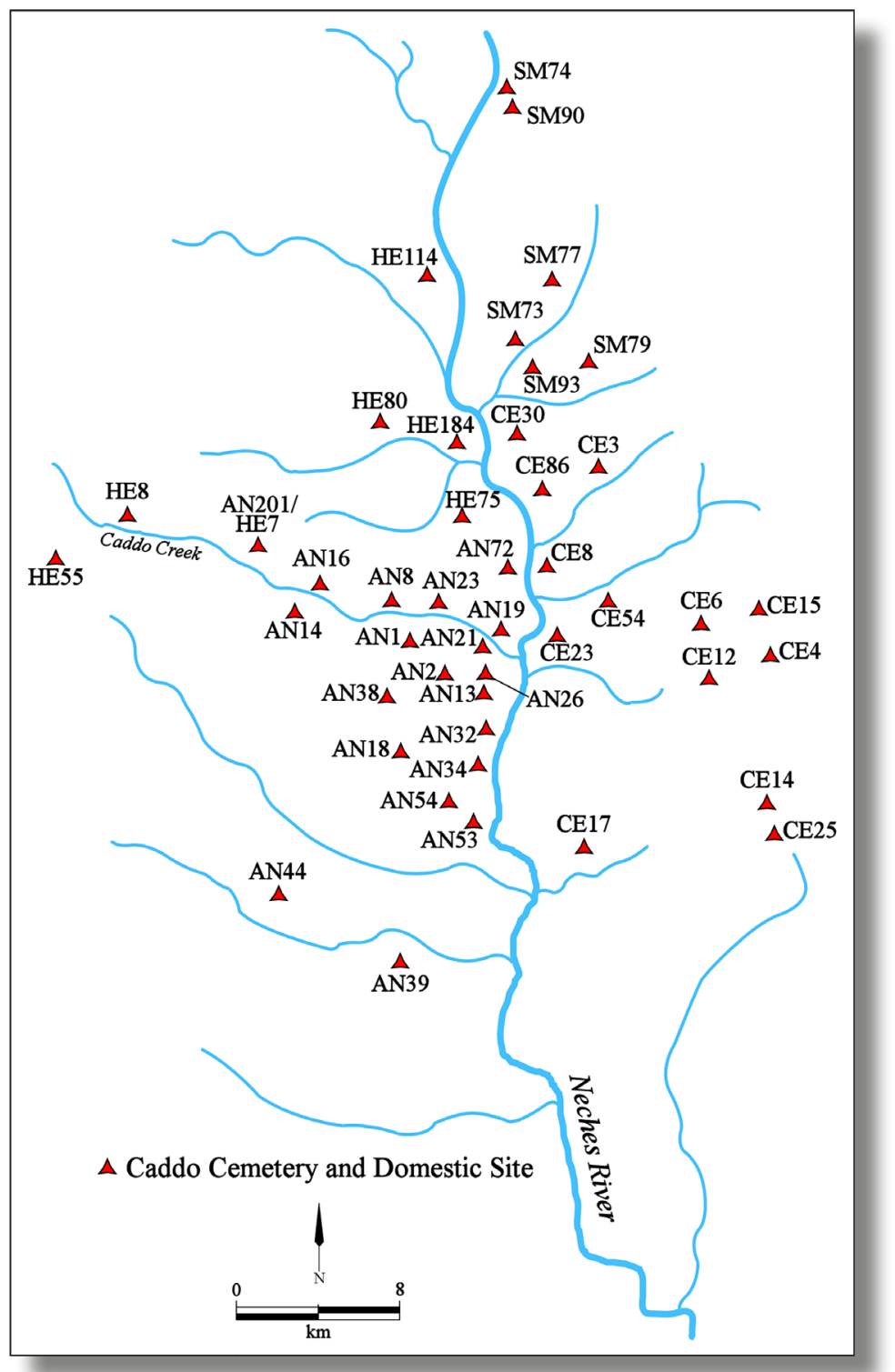

Special Publication No. 43

Friends of Northeast Texas Archaeology, Austin and Pittsburg 
Friends of Northeast Texas Archaeology Editor, Timothy K. Perttula 10101 Woodhaven Dr.

Austin, Texas 78753

tkp4747@aol.com

Friends of Northeast Texas Archaeology, Distribution, Bo Nelson, 344 CR 4154

Pittsburg, Texas 75686

RBoNelson@aol.com

Cover art: Known Caddo cemetery sites in the upper Neches River basin.

Copyright@ 2016 , Friends of Northeast Texas Archaeology

(Pittsburg and Austin) 


\section{Table of Contents}

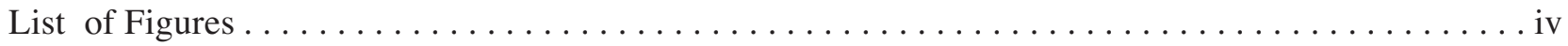

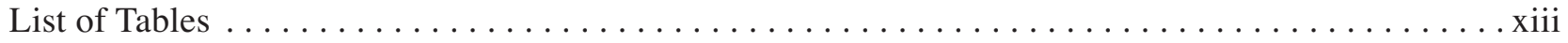

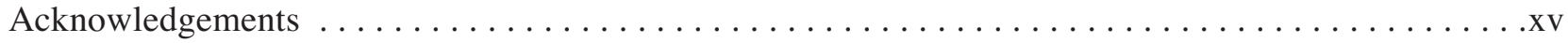

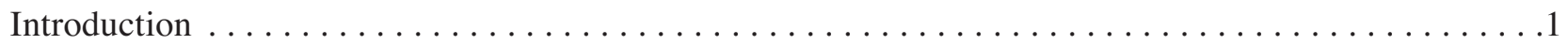

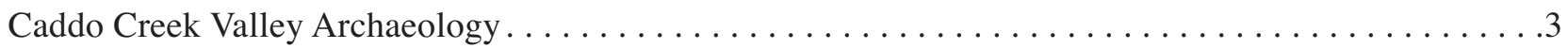

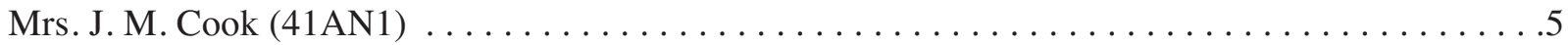

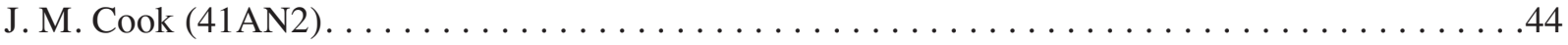

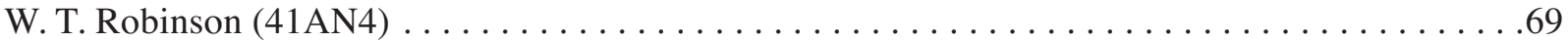

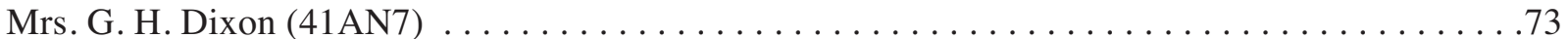

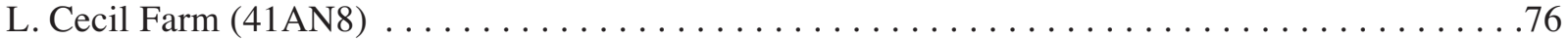

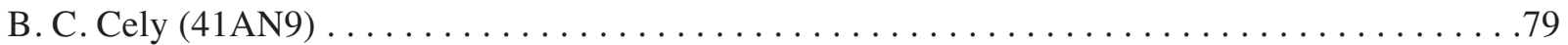

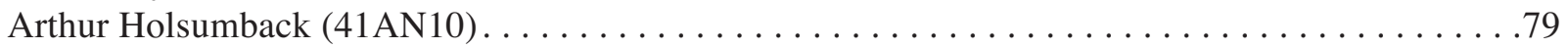

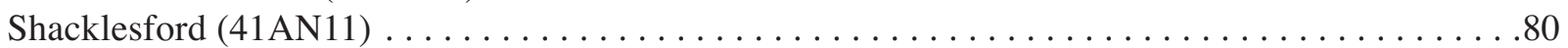

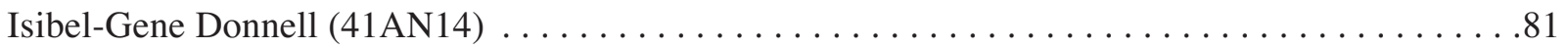

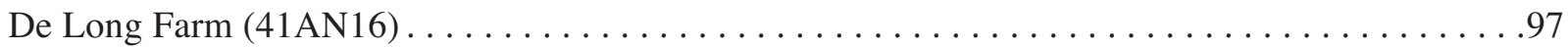

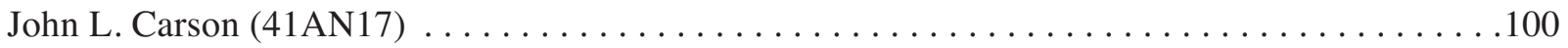

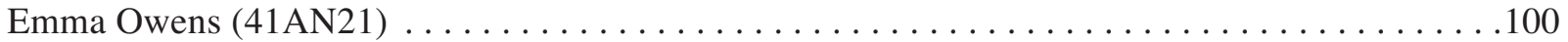

Rose Daniels $(41 \mathrm{AN} 23) \ldots \ldots \ldots \ldots$. . . . . . . . . . . . . . . . . . . . . . . . . . . . . . 106

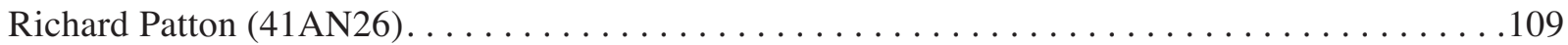

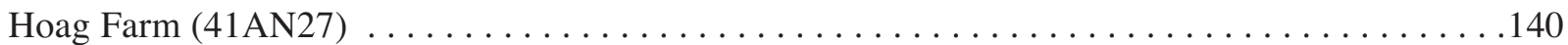

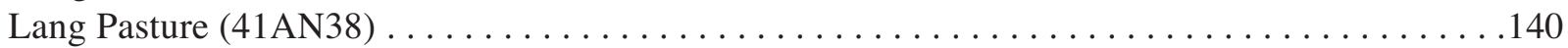

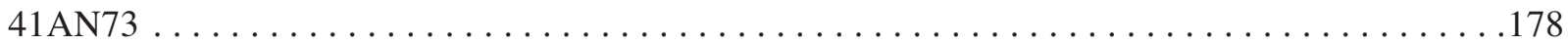

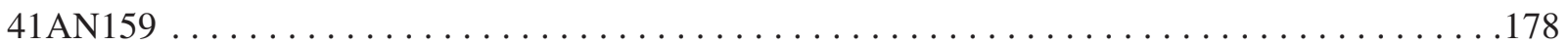

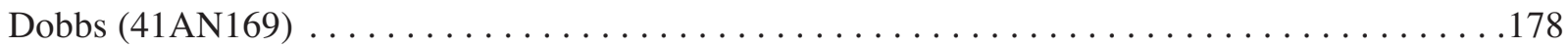

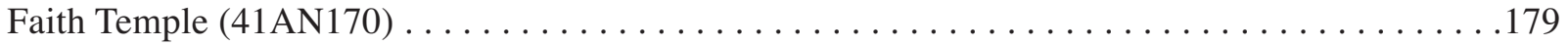

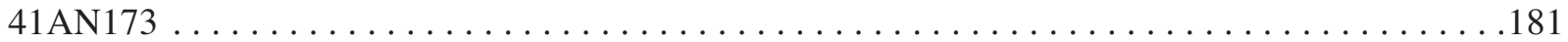

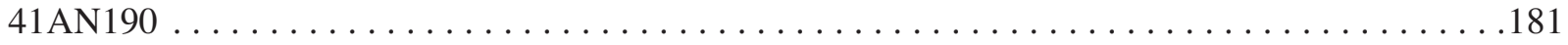

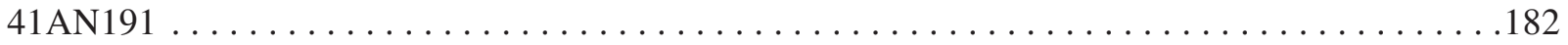

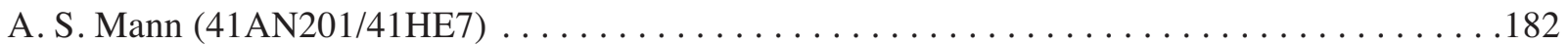

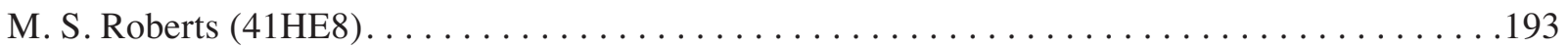

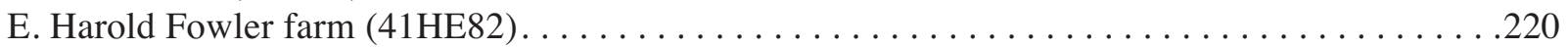

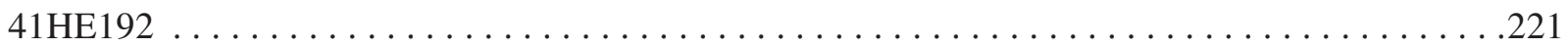

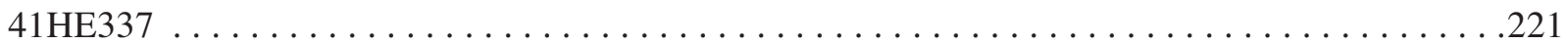

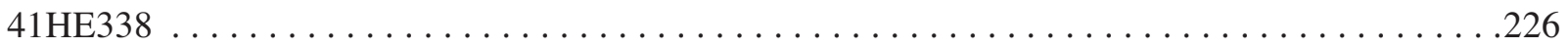

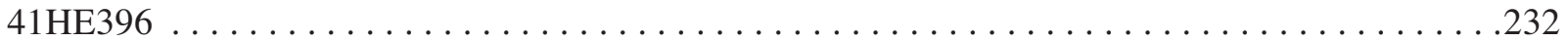

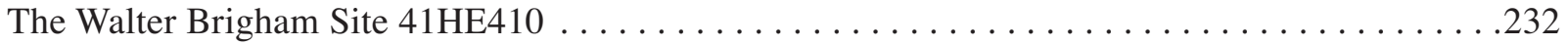

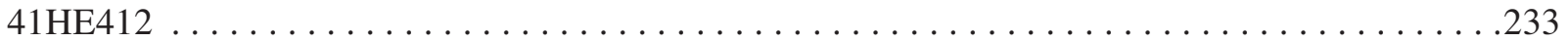

An Unrecorded Caddo Site in the Caddo Creek Valley, Henderson County, Texas . . . . . . . . . . 233

Caddo Settlement in the Caddo Creek Valley in the Upper Neches River Basin . . . . . . . . . . . .242

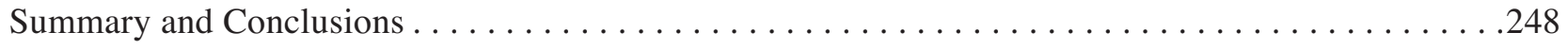

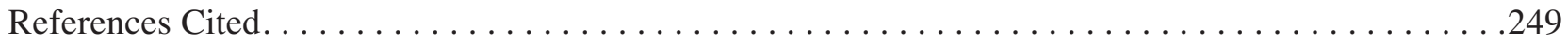




\section{List of Figures}

Figure 1. The Caddo Creek valley in the Upper Neches River basin: a, stream drainages;

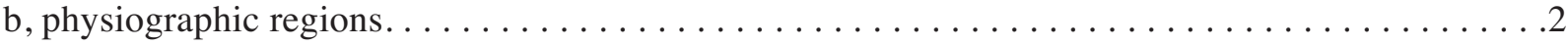

Figure 2. Important excavated Caddo sites in the Caddo Creek valley and surrounding drainages in Anderson and Henderson counties, Texas. . . . . . . . . . . . . . . . . 4

Figure 3. The Caddo cemetery at the Mrs. J. M. Cook site (41AN1): a, the cemetery

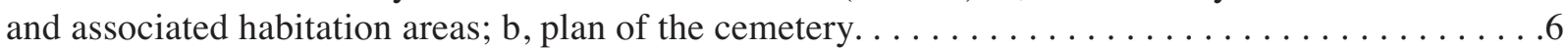

Figure 4. Vessel 41AN1-1, Poynor Engraved, var. Cook carinated bowl... . . . . . . . . . . .7

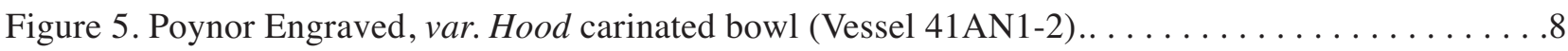

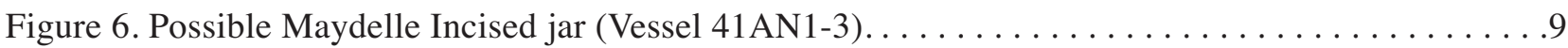

Figure 7. Poynor Engraved, var. $R$ carinated bowl (Vessel 41AN1-4) $\ldots \ldots \ldots \ldots \ldots \ldots \ldots \ldots$

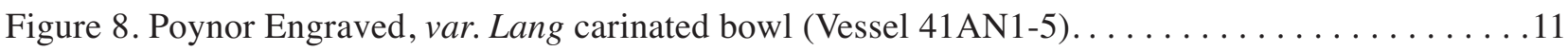

Figure 9. Killough Pinched rattle bowl (Vessel 41AN1-6) $\ldots \ldots \ldots \ldots \ldots \ldots \ldots \ldots \ldots \ldots \ldots$

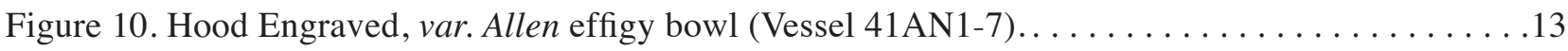

Figure 11. Poynor Engraved, var. $Q$ bowl (Vessel 41AN1-8) $\ldots \ldots \ldots \ldots \ldots \ldots \ldots \ldots \ldots \ldots$

Figure 12. Poynor Engraved, var. Cook carinated bowl (Vessel 41AN1-9) . . . . . . . . . . . . 15

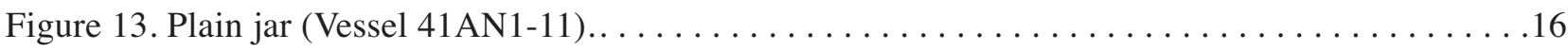

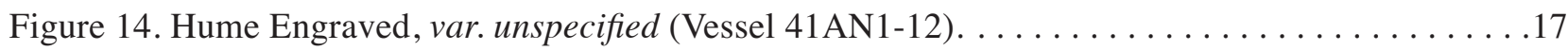

Figure 15. Poynor Engraved, var. Hood carinated bowl (Vessel 41AN1-13).. . . . . . . . . . 18

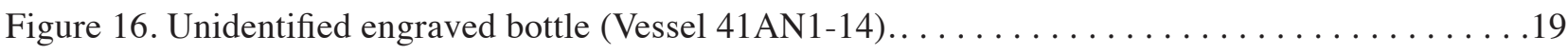

Figure 17. Poynor Engraved, var. Lang compound bowl (Vessel 41AN1-15) . . . . . . . . . . . 20

Figure 18. Large Poynor Engraved, var. Hood carinated bowl (Vessel 41AN1-116).. . . . . . . . . .21

Figure 19. Poynor Engraved, var. Blackburn carinated bowl (Vessel 41AN1-17)............22

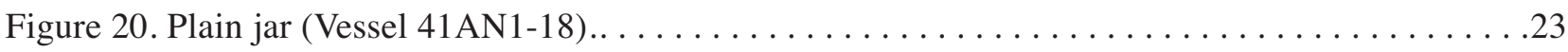

Figure 21. La Rue Neck Banded jar (Vessel 41AN1-19) . . . . . . . . . . . . . . . . . 24

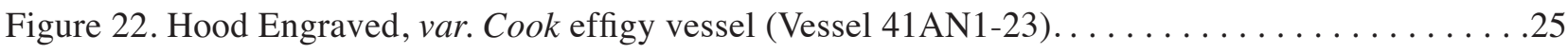

Figure 23. Poynor Engraved, var. Cook carinated bowl (Vessel 41AN1-24) . . . . . . . . . . 26 
Figure 24. Killough Pinched jar (Vessel 41AN1-25) $\ldots \ldots \ldots \ldots \ldots \ldots \ldots \ldots \ldots \ldots \ldots \ldots \ldots \ldots \ldots \ldots \ldots \ldots$

Figure 25. Poynor Engraved, var. Cook carinated bowl (Vessel 41AN1-26) . . . . . . . . . . . 28

Figure 26. Hume Engraved, var. unspecified bottle (Vessel 41AN1-27) . . . . . . . . . . . . . .29

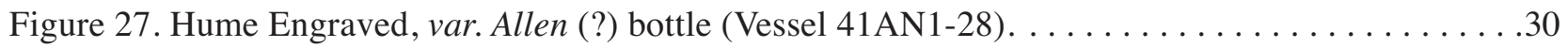

Figure 28. Poynor Engraved, var. Blackburn carinated bowl (Vessel 41AN1-29)...............31

Figure 29. Killough Pinched jar (Vessel 41AN1-30) $\ldots \ldots \ldots \ldots \ldots \ldots \ldots \ldots \ldots \ldots \ldots \ldots \ldots \ldots \ldots \ldots \ldots$

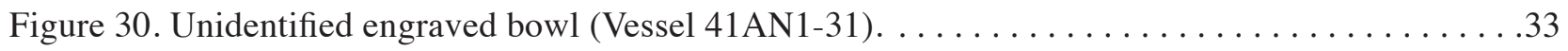

Figure 31. Hood Engraved, var. Hood effigy bowl (Vessel 41 AN1-34).. . . . . . . . . . . . . . 34

Figure 32. Poynor Engraved, var. Blackburn carinated bowl (Vessel 41AN1-35) . . . . . . . . . 35

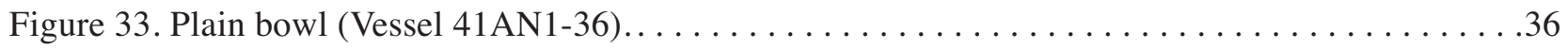

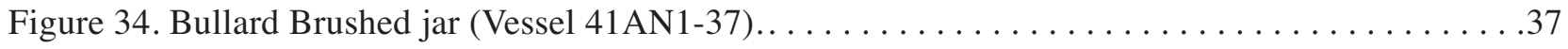

Figure 35. Killough Pinched jar $($ Vessel 41 AN1-38) $\ldots \ldots \ldots \ldots \ldots \ldots \ldots \ldots \ldots \ldots \ldots \ldots \ldots \ldots$

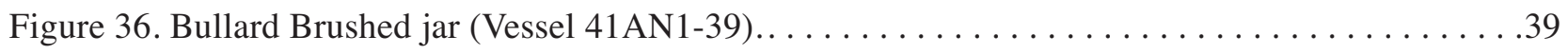

Figure 37. Selected decorative elements on engraved sherds

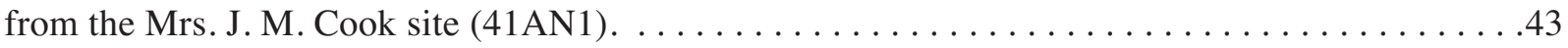

Figure 38. Decorated ceramic effigy bowl head from the Mrs. J. M. Cook site (41AN1) . . . . . . . . .44

Figure 39. Habitation areas and cemetery at the J. M. Cook site $(41 \mathrm{AN} 2) \ldots \ldots \ldots \ldots \ldots \ldots \ldots$

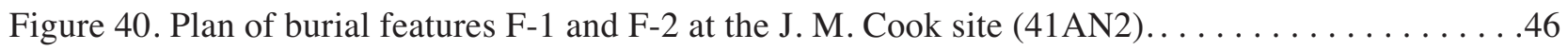

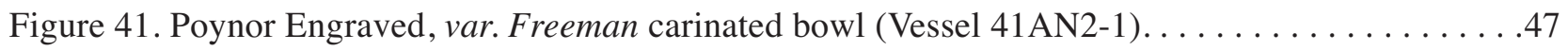

Figure 42. Poynor Engraved, var. Freeman carinated bowl (Vessel 41AN2-2) . . . . . . . . .48

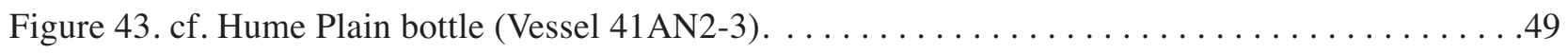

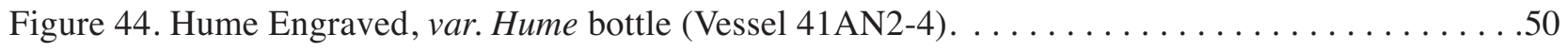

Figure 45. Poynor Engraved, PP variety carinated bowl (Vessel 41 AN2-5) . . . . . . . . . . .51

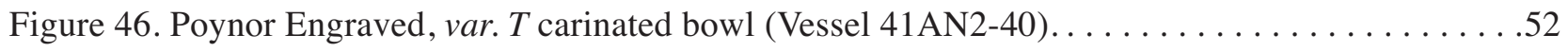

Figure 47. Poynor Engraved, var. Cook carinated bowl (Vessel 41 AN2-41) . . . . . . . . . . . .53

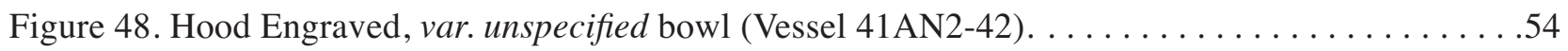


Figure 49. Poynor Plain miniature carinated bowl (Vessel 41AN2-43) $\ldots \ldots \ldots \ldots \ldots \ldots \ldots \ldots . \ldots 5$

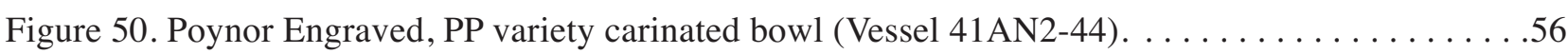

Figure 51. Poynor Engraved, var. Freeman carinated bowl (Vessel 41AN2-45) . . . . . . . . . .57

Figure 52. Patton Engraved, var. Freeman carinated bowl (Vessel 41AN2-51)............58

Figure 53. Probable brushed body of a Poynor Engraved carinated bowl (Vessel 41 AN2-52). . . . . . .59

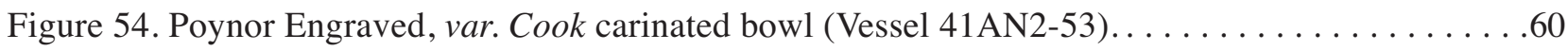

Figure 55. Patton Engraved, var. unspecified carinated bowl (Vessel 41AN2-54)...........61

Figure 56. Probable Bullard Brushed jar body section (Vessel 41AN2-55) . . . . . . . . . . . .62

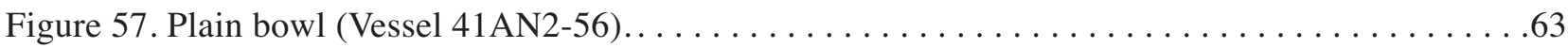

Figure 58. Selected decorative elements on fine ware and incised sherds

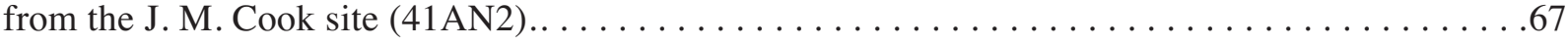

Figure 59. Selected incised-punctated sherds from the J. M. Cook site $(41 \mathrm{AN} 2) \ldots \ldots \ldots \ldots \ldots$

Figure 60 . Incised pipe sherd bowl from the J. M. Cook site $(41 \mathrm{AN} 2) \ldots \ldots \ldots \ldots \ldots \ldots \ldots \ldots$

Figure 61. The location of the W. T. Robinson Farm site (41AN4) site in East Texas.. . . . . . . . . . 69

Figure 62. Selected fine ware decorative elements in the W. T. Robinson Farm site (41AN4)

ceramic assemblage: a, Poynor Engraved, var. Cook rim sherd; b, possible Poynor

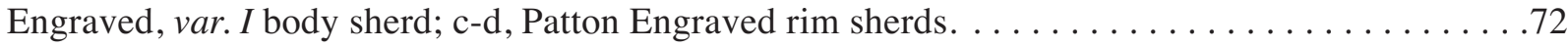

Figure 63. Selected decorative elements represented in the fine ware sherds

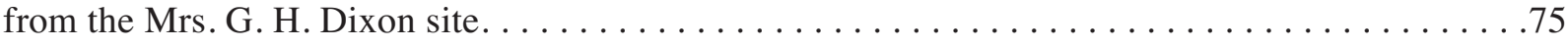

Figure 64. Selected decorative elements on fine ware sherds from the L. Cecil Farm (41AN8) . . . . .80

Figure 65. Decorative elements on trailed and incised-punctated sherds

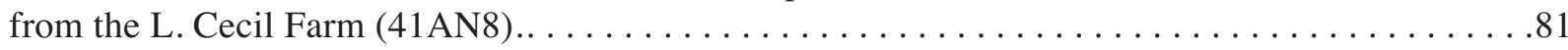

Figure 66. Isibel-Gene Donnell site (41AN14): a, map of excavations and the location

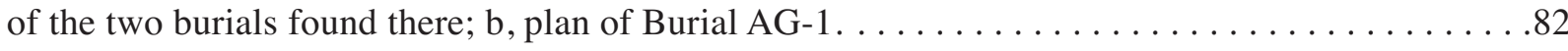

Figure 67. Decorative elements on engraved bottle (No. 1, Purchased)

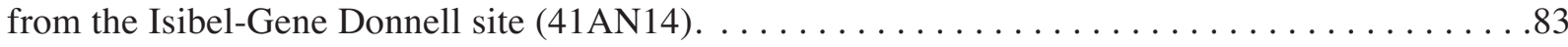

Figure 68. Decorative elements on a Poynor Engraved, var. unspecified bottle

(No. 3, Purchased) from the Isibel-Gene Donnell site $(41 \mathrm{AN} 14) \ldots \ldots \ldots \ldots \ldots \ldots \ldots \ldots$

Figure 69. Decorative elements on Poynor Engraved, var. Hood carinated bowl

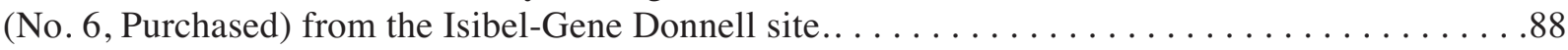


Figure 70. Decorative elements on Poynor Engraved, var. $P^{\prime}$ carinated bowl

(No. 7, Purchased) from the Isibel-Gene Donnell site.. . . . . . . . . . . . . . . . . .89

Figure 71. Decorative elements on Poynor Engraved, var. Hood carinated bowl

(No. 1, Burial AG-1) from the Isibel-Gene Donnell site. . . . . . . . . . . . . . . . . . 90

Figure 72. Decorative elements on Poynor Engraved, var. Hood carinated bowl

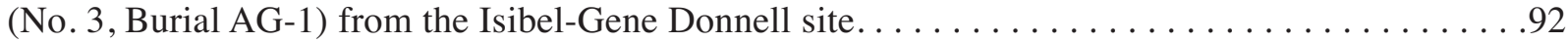

Figure 73. Decorative elements on Poynor Engraved, var. Freeman carinated bowl

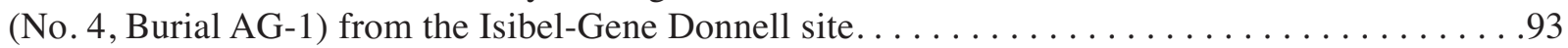

Figure 74. Decorative elements on Poynor Engraved, var. E carinated bowl

(No. 5, Burial AG-1) from the Isibel-Gene Donnell site . . . . . . . . . . . . . . . . . . .94

Figure 75. Decorative elements on Poynor Engraved, var. Hood carinated bowl

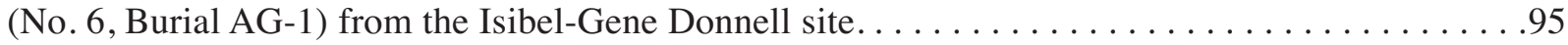

Figure 76. Decorative elements on Poynor Engraved, var. Hood carinated bowl

(No. 7, Burial AG-1) from the Isibel-Gene Donnell site. . . . . . . . . . . . . . . . . . . 96

Figure 77 . The location of the De Long Farm site (41AN16) in East Texas. . . . . . . . . . . . .97

Figure 78. 1935 excavations by UT archaeologists at the De Long Farm site (41AN16) . . . . . . .98

Figure 79. Poynor Engraved, var. Hood carinated bowl from the De Long Farm site (41AN16). . . . .99

Figure 80. cf. Poynor Engraved, var. Freeman bowl from the Mrs. Emma Owens site... . . . . . . . 101

Figure 81. Decorated elbow pipe (Var. E) from the Emma Owens site (41AN21) . . . . . . . . . 101

Figure 82. Selected decorative elements on engraved fine ware sherds

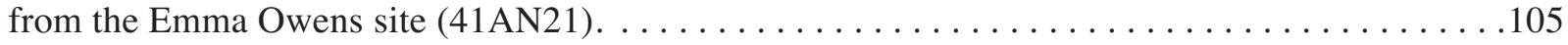

Figure 83. Brushed-incised-punctated rim sherd from the Emma Owens site (41AN21) . . . . . . 106

Figure 84. Decorative elements on Poynor Engraved, var. $O$ carinated bowl

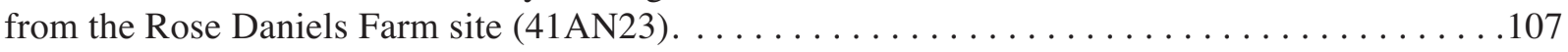

Figure 85 . Selected decorative elements on engraved fine ware sherds

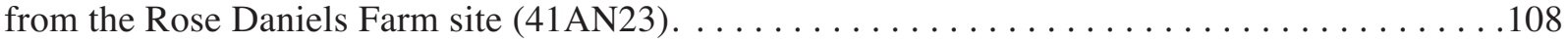

Figure 86. The Allen phase Caddo cemetery at the Richard Patton site (41AN26) . . . . . . . . . . 109

Figure 87. Patton Engraved, var. Patton carinated bowl from the Richard Patton site. . . . . . . . . 110

Figure 88. Patton Engraved, var. Patton carinated bowl from the Richard Patton site. . . . . . . . . 111

Figure 89. cf. Patton Engraved, var. Patton carinated bowl from the Richard Patton site...........112 
Figure 90. Patton Engraved, var. Patton carinated bowl from the Richard Patton site. . . . . . . . . 113

Figure 91. Patton Engraved, var. unspecified carinated bowl from the Richard Patton site......... 114

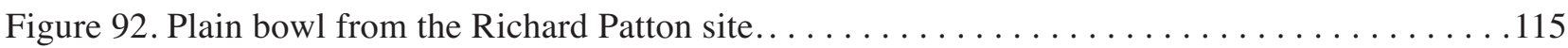

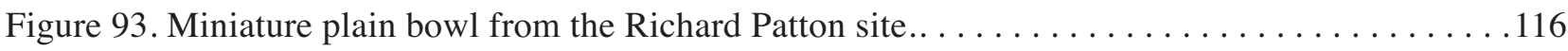

Figure 94. Patton Engraved, var. unspecified square bowl from the Richard Patton site........... 117

Figure 95. Patton Engraved, var. Freeman globular bowl from the Richard Patton site. . . . . . . . 118

Figure 96. cf. Poynor Engraved, var. unspecified bottle from the Richard Patton site............. 119

Figure 97. Patton Engraved, var. Freeman globular bowl from the Richard Patton site. . . . . . . . . 120

Figure 98. Poynor Engraved, var. Freeman globular bowl from the Richard Patton site.. . . . . . . . 121

Figure 99. Patton Engraved, var. Freeman globular bowl from the Richard Patton site. . . . . . . . 122

Figure 100. Patton Engraved, var. Freeman globular bowl from the Richard Patton site. . . . . . . . . 123

Figure 101. Patton Engraved, var. Fair globular bowl from the Richard Patton site.. . . . . . . . . 124

Figure 102. cf. Patton Engraved, var. Freeman globular bowl from the Richard Patton site.........125

Figure 103. Patton Engraved, var. Freeman globular bowl from the Richard Patton site. . . . . . . . 126

Figure 104. Patton Engraved, var. Freeman globular bowl from the Richard Patton site. . . . . . . . 127

Figure 105. Patton Engraved, var. Freeman globular bowl from the Richard Patton site. . . . . . . . 128

Figure 106. Patton Engraved, var. Allen globular bowl from the Richard Patton site. . . . . . . . . . . 129

Figure 107. Patton Engraved, var. Allen globular bowl from the Richard Patton site. . . . . . . . . 130

Figure 108. Patton Engraved, var. Allen globular bowl from the Richard Patton site. . . . . . . . . 131

Figure 109. cf. Patton Engraved, var. Allen globular bowl from the Richard Patton site.. . . . . . . . 132

Figure 110. cf. Patton Engraved, var. Fair globular bowl from the Richard Patton site. . . . . . . . . 133

Figure 111. Patton Incised bowl from the Richard Patton site: a, view of lug handles;

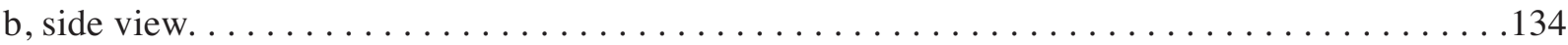

Figure 112. Patton Engraved, var. Freeman globular bowl from the Richard Patton site. . . . . . . . 135

Figure 113. Patton Engraved, var. Allen globular bowl from the Richard Patton site. . . . . . . . . 136

Figure 114. Patton Engraved, var. Patton carinated bowl from the Richard Patton site. . . . . . . . 137 
Figure 115. Poynor Engraved, var. Freeman globular bowl from the Richard Patton site... . . . . . 138

Figure 116. Decorated elbow pipes from the Richard Patton site. . . . . . . . . . . . . . . . 139

Figure 117. Plan of the structures, outdoor work/activity areas, and the cemetery

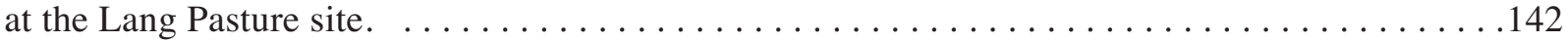

Figure 118. Likely arrangement of upper Neches River basin ancestral

Caddo farmstead compounds. . . . . . . . . . . . . . . . . . . . . . . . . . 143

Figure 119. Plain carinated bowl (Vessel 1) from Feature 8 at the Lang Pasture site. . . . . . . . . 143

Figure 120. Plain carinated bowl from Feature 8 (Vessel 2) from the Lang Pasture site. . . . . . . . . 144

Figure 121. Poynor Engraved, var. F carinated bowl, Feature 8, Vessel 3

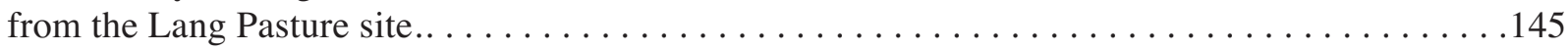

Figure 122. Plain bowl from Feature 8 (Vessel 4) at the Lang Pasture site. . . . . . . . . . . . . . 146

Figure 123. Red-slipped carinated bowl from Feature 8 (Vessel 5) at the Lang Pasture site. . . . . . . . 147

Figure 124. Maydelle Incised jar from Feature 8 (Vessel 6) at the Lang Pasture site. . . . . . . . . . 148

Figure 125. Plain bottle from Feature 8 (Vessel 7) at the Lang Pasture site. . . . . . . . . . . . . . 149

Figure 126. cf. Poynor Plain carinated bowl sherds from Feature 76B (Vessel 1)

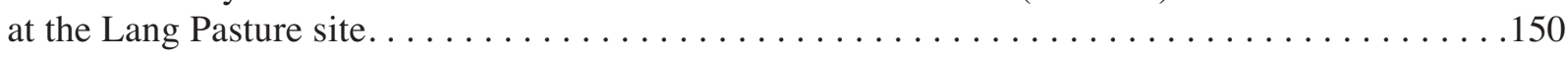

Figure 127. Two views of engraved-rocker stamped vessel (Vessel 2) from Feature

76B at the Lang Pasture site: a, view showing suspension holes and decoration;

b, view showing decorative elements on vessel rim and body.................. 151

Figure 128. Plain globular bowl sherds from Feature 76C (Vessel 1) at the Lang Pasture site. . . . . . 152

Figure 129. Plain bowl from Feature 76D (Vessel 1) at the Lang Pasture site................ 153

Figure 130. cf. Poynor Engraved, var. B compound vessel or wide-mouthed

bottle from Feature 88 (Vessel 1$)$ at the Lang Pasture site. . . . . . . . . . . . . . . . . . 154

Figure 131. Plain carinated bowl rim sherds from Feature 88, Vessel 2 at the Lang Pasture site. . . . 155

Figure 132. Poynor Engraved, local variety 2, compound bowl sherds from Feature 91,

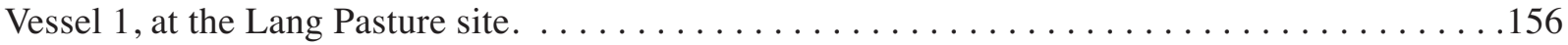

Figure 133. Poynor Engraved carinated bowl, local variety 3, from Feature 91 (Vessel 2)

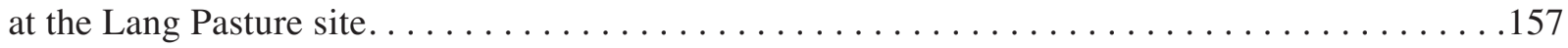

Figure 134. Rim sherds from plain bowl in Feature 92 (Vessel 1) at the Lang Pasture site..........158 
Figure 135. Two views of the plain rectangular-shaped bowl from Feature 92 (Vessel 2)

at the Lang Pasture site: a, looking down on the vessel; b, side and basal view. . . . . . . . . . 159

Figure 136. Plain bowl from Feature 93 (Vessel 1) at the Lang Pasture site. . . . . . . . . . . . 160

Figure 137. Poynor Engraved carinated bowl, local variety 4, from Feature 93 (Vessel 2)

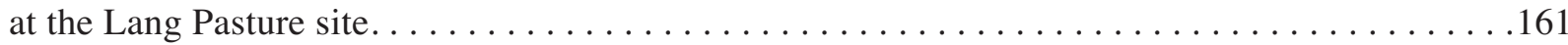

Figure 138. Poynor Engraved compound bowl, local variety 5, from Feature 93 (Vessel 3)

at the Lang Pasture site: a-b, upper and low rim panels; c, disk base . . . . . . . . . . . . 162

Figure 139. Rim sherds from plain bowl (Vessel 4B) in Feature 93 at the Lang Pasture site. . . . . . .163

Figure 140. Poynor Engraved, var. F bowl in Feature 93 (Vessel 5) at the Lang Pasture site. . . . . . . 164

Figure 141. Plain carinated bowl from Feature 93 (Vessel 6) at the Lang Pasture site. .......... 165

Figure 142. Plain bottle from Feature 93 (Vessel 7) at the Lang Pasture site. . . . . . . . . . 166

Figure 143. Plain carinated bowl from Feature 83 (Vessel 8) at the Lang Pasture site. . . . . . . . 167

Figure 144. Rim sherds from a Maydelle Incised jar in Feature 93 (Vessel 9)

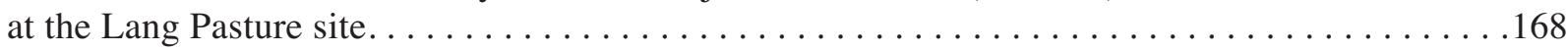

Figure 145. Plain bowl in Feature 94 (Vessel 1) at the Lang Pasture site. . . . . . . . . . . . . . . . 169

Figure 146. Poynor Plain compound bowl or globular carinated bowl from

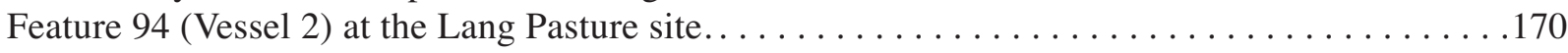

Figure 147. Killough Pinched rim, body, and base sherds from Feature 94 (Vessel 3)

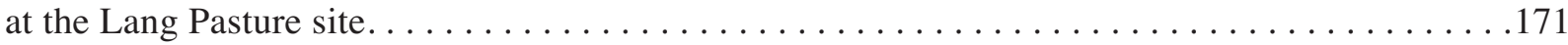

Figure 148. Plain vessel from Feature 94 (Vessel 4) at the Lang Pasture site. . . . . . . . . . . . 172

Figure 149. Plain bowl rim sherds from Feature 94 (Vessel 5) at the Lang Pasture site. . . . . . . . 173

Figure 150. Decorative elements on selected engraved sherds from the

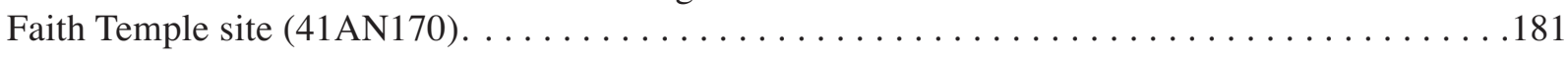

Figure 151.1935 excavations at the A. S. Mann site... $\ldots \ldots \ldots \ldots \ldots \ldots \ldots \ldots \ldots \ldots \ldots \ldots \ldots \ldots$

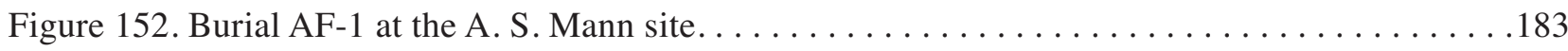

Figure 153. Decorative elements on a Poynor Engraved, var. unspecified bottle

(Vessel 1, Burial AF-1) from the A. S. Mann site. . . . . . . . . . . . . . . . . 184

Figure 154. Decorative elements on Poynor Engraved, var. unspecified carinated bowl

(Vessel 6, Burial AF-1) from the A. S. Mann site. . . . . . . . . . . . . . . . . . . . . . . . . 189 
Figure 155. Decorative elements on Poynor Engraved, var. unspecified beaker

(Burial AF-1, Vessel 7) from the A. S. Mann site.

Figure 156. The topographic setting of the M. S. Roberts site.

Figure 157. Selected incised decorative elements on sherds from the 1931 UT work

at the M. S. Roberts site: a-c, rim sherds; d-e, body sherds.. . . . . . . . . . . . . . . . . 195

Figure 158. Selected appliqued and incised-punctated elements on sherds from the 1931 UT

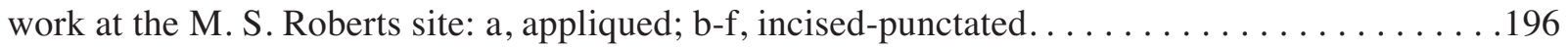

Figure 159. Selected decorative elements on engraved sherds from the 1931 UT work at the M. S. Roberts site: a-e, rim sherd; f-g, lower rim sherds; $h$, bottle sherd. . . . . . . . . . . 197

Figure 160. The M. S. Roberts mound (41HE8): a, looking south at the mound and the surrounding pasture; $b$, looking generally east at the mound.

Figure 161. The DJI Phantom 2 quadrotor unmanned aerial vehicle used in the aerial survey

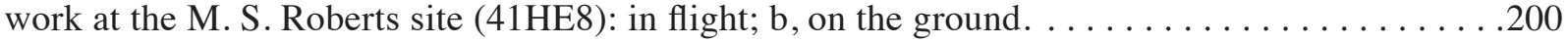

Figure 162. Map showing the DEM and orthophoto overlay of the 41HE8 study area.

The locations of representative shovel tests and an artificial cross section (A) through the mound and borrow pit are also shown.

Figure 163. A cross section showing the variation of the ground surface across

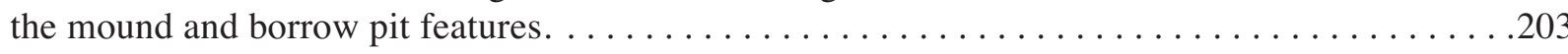

Figure 164. Map showing the DEM and orthophoto overlay of the 41HE8 study area. The locations of representative shovel tests and an artificial cross section (B) through the mound and low lying area to the north are also shown.

Figure 165. A cross section showing the variation of the ground surface

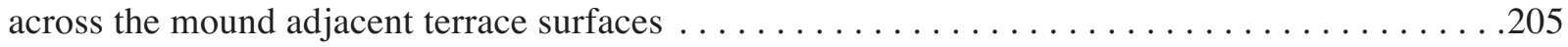

Figure 166. Images showing the vertical exaggerated 3D orthophoto and DEM

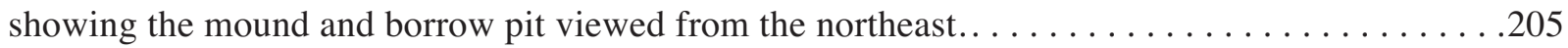

Figure 167. Location of ST 5, and 9-24, and Auger holes 6, 7, 7a, and 8

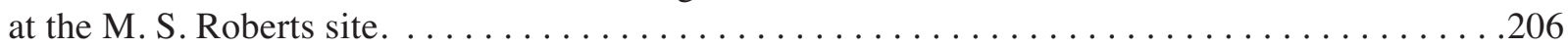

Figure 168. Recorded profiles in ST 5 and Auger holes $6,7,7$ a, and $8 \ldots \ldots \ldots \ldots \ldots \ldots \ldots$

Figure 169. Selected decorative elements on utility ware sherds from the M. S. Roberts site: a, appliqued strap handle (ST 21, $40 \mathrm{~cm} \mathrm{bs);} \mathrm{b,} \mathrm{circular} \mathrm{punctated} \mathrm{body} \mathrm{sherd}$ (ST 14, 0-20 cm bs); c, incised-punctated body sherd (Surface collection)... . . . . . . . . . 213 
Figure 170. Selected decorative elements on fine ware sherds from the M. S. Roberts site: a, curvilinear and diagonal engraved lines (ST 19, 40-60 cm bs), Poynor Engraved;

b, diagonal and horizontal engraved lines (ST 19, 20-40 cm bs); c, diagonal and horizontal engraved lines (ST 21, 20-40 cm bs); d, diagonal opposed engraved lines (ST 17, 0-20 cm bs); e, horizontal engraved line and hatched triangle element (ST 15, 40-60 cm bs), Poynor Engraved; f, curvilinear hatched area (Surface collection), Poynor Engraved).

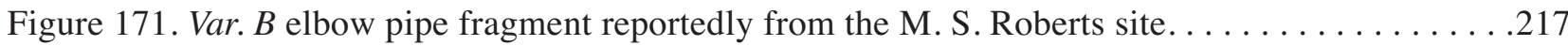

Figure 172. Decorative elements on Hume Engraved, var. unspecified bottle from the E. Harold Fowler site $(41 \mathrm{HE} 82) \ldots \ldots \ldots \ldots \ldots \ldots$. . . . . . . . . . . . . . . . . . . . . 221

Figure 173. Selected decorative elements in utility wares from 41HE337: a, diagonal opposed Maydelle Incised rim; b, e, incised triangles filled with punctations; c, diagonal incised panels filled with tool punctations; $d$, curvilinear incised zones filled with tool punctations; $f$, straight incised line framing fingernail

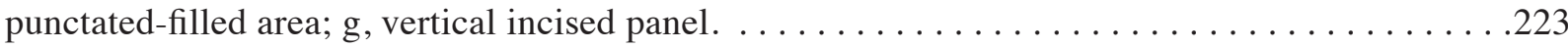

Figure 174. Selected decorative elements on engraved fine ware sherds from 41HE337:

a, horizontal and diagonal semi-circle (Poynor Engraved); b, horizontal and opposed engraved lines; c, nested triangle (Poynor Engraved); d, hatched scroll element (Poynor Engraved); e, hatched triangles and circle (Poynor Engraved); f, hatched ladder; $g$, hatched triangle and diagonal engraved lines (Poynor Engraved);

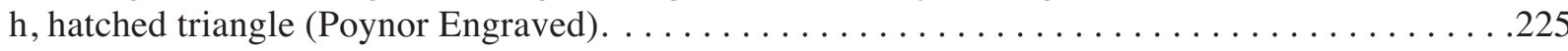

Figure 175. Selected brushed-incised, brushed-incised-punctated, and incised decorative elements on sherds in the ceramic assemblage; a, brushed-incised body sherd;

b, brushed-incised-punctated body sherd; c-e, incised rim sherds. . . . . . . . . . . . 236

Figure 176. Selected incised-punctated and punctated decorative elements on sherds in the ceramic assemblage: a-d, incised punctated sherds;

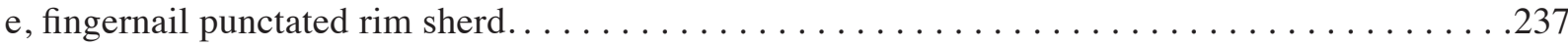

Figure 177. Selected engraved decorative elements on sherds in the ceramic assemblage: a-h, carinated bowl sherds; $i-j$, bottle sherds. . . . . . . . . . . . . . . . . . . . 239

Figure 178. Known Caddo cemetery sites in the upper Neches River basin. . . . . . . . . . . 245

Figure 179. Map of $19^{\text {th }}$ century land surveys, Caddo and Kickapoo villages, and Caddo and Kickapoo trails. Map provided courtesy of Bob D. Skiles. . . . . . . . . . . . 246

Figure 180.1871 GLO map No. 776 that shows "Old Indian Village" at the mouth of Caddo Creek on the W. F. Pool League in Anderson County, Texas. Map provided courtesy of Bob D. Skiles.. . . . . . . . . . . . . . . . . . . . . . . 247 


\section{List of Tables}

Table 1. Sherds from ceramic wares at the Mrs. J. M. Cook site $(41 \mathrm{AN} 1) \ldots \ldots \ldots \ldots \ldots \ldots \ldots \ldots$

Table 2. Decorative methods and decorative elements in the fine ware and utility ware sherds from the Mrs. J. M. Cook site $(41 \mathrm{AN} 1) \ldots \ldots \ldots \ldots \ldots \ldots \ldots \ldots \ldots \ldots \ldots \ldots \ldots$

Table 3. Sherds from ceramic wares at the J. M. Cook site $(41 \mathrm{AN} 2) \ldots \ldots \ldots \ldots \ldots \ldots \ldots \ldots \ldots$

Table 4. Decorative methods and decorative elements in the fine ware and utility

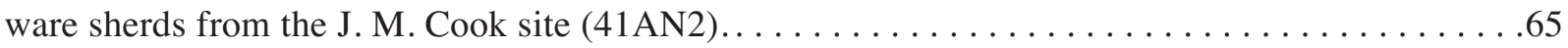

Table 5. Ceramic sherds from the W. T. Robinson Farm site (41AN4) $\ldots \ldots \ldots \ldots \ldots \ldots \ldots \ldots$

Table 6. Decorated methods and decorative elements represented in the ceramic

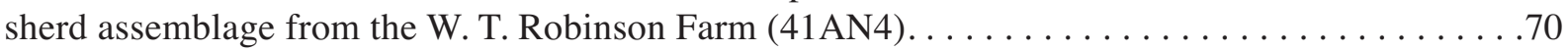

Table 7. Ceramic sherds from the Mrs. G. H. Dixon site $(41$ AN7) $\ldots \ldots \ldots \ldots \ldots \ldots \ldots \ldots \ldots$

Table 8. Decorated methods and decorative elements represented in the ceramic

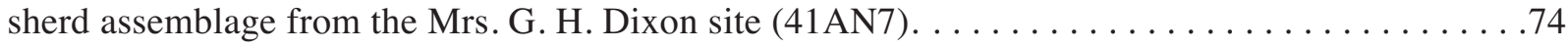

Table 9. Ceramic sherds from the L. Cecil Farm site $(41 \mathrm{AN} 8) \ldots \ldots \ldots \ldots \ldots \ldots \ldots \ldots \ldots \ldots$

Table 10. Decorated methods and decorative elements represented in the ceramic sherd assemblage from the L. Cecil Farm site $(41$ AN8) $\ldots \ldots \ldots \ldots \ldots \ldots \ldots \ldots \ldots \ldots \ldots$

Table 11. Ceramic sherds from the Emma Owens site $(41 \mathrm{AN} 21) \ldots \ldots \ldots \ldots \ldots \ldots \ldots \ldots \ldots \ldots \ldots$

Table 12. Decorated methods and decorative elements represented in the ceramic

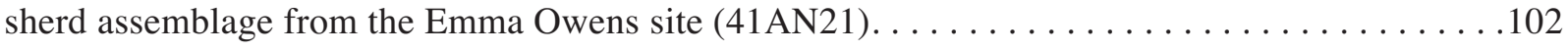

Table 13. Ceramic wares from the Faith Temple site $(41 \mathrm{AN} 170) \ldots \ldots \ldots \ldots \ldots \ldots \ldots \ldots \ldots \ldots$

Table 14. Decorative methods and elements in the ceramic sherd assemblage

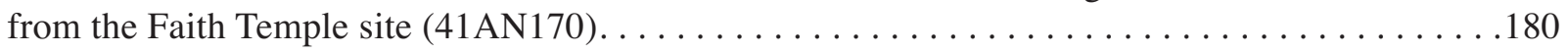

Table 15. Input parameters for the aerial survey of the M. S. Roberts site (41HE8). . . . . . . . . . 199

Table 16. Recovered artifacts in the June 2015 archaeological investigations

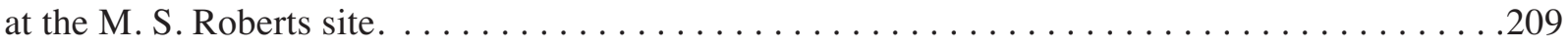

Table 17. Depth of recovered artifacts in the June 2015 shovel tests at the M. S. Roberts site. . . . . 210

Table 18. Ceramic sherds from the June 2015 M. S. Roberts site investigations... . . . . . . . 210

Table 19. Temper use in ceramic sherds from June 2015 investigations at the M. S. Roberts site.. . . . 211 
Table 20. Decorative methods and elements in utility ware and fine ware sherds from the June 2015 investigations at the M. S. Roberts site . . . . . . . . . . . . . 211

Table 21. Summary of the ceramic sherd assemblage from the M. S. Roberts site. . . . . . . . . . 214

Table 22. Comparative sherd assemblage data from Lake Palestine Caddo sites, nearby Caddo sites, and the M. S. Roberts site in the upper Neches River basin . . . . . . . . . 215

Table 23. Lithic artifacts recovered in the June 2015 archaeological investigations

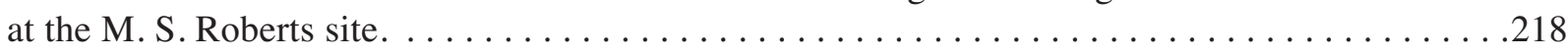

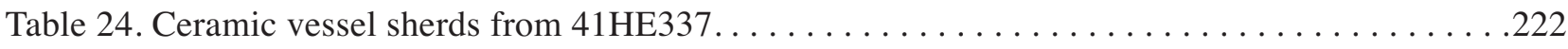

Table 25. Use of bone temper in the different ceramic wares at $41 \mathrm{HE} 337 \ldots \ldots \ldots \ldots \ldots \ldots \ldots$

Table 26. General characteristics of the 17.78 percent sherd sample* from $41 \mathrm{HE} 338 \ldots \ldots \ldots \ldots . . \ldots 227$

Table 27. Decorated sherds in 17.78 percent sample from 41 HE338 $\ldots \ldots \ldots \ldots \ldots \ldots \ldots \ldots .228$

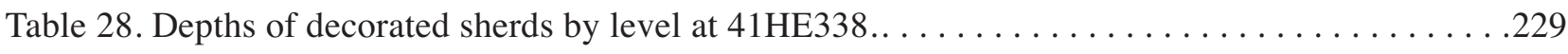

Table 29. Changes by depth in proportional representation of decorated

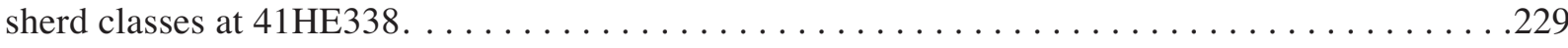

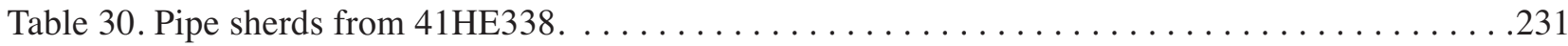

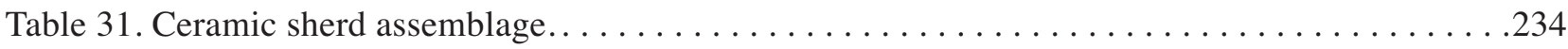

Table 32. Decorative methods and elements in the utility wares in the ceramic

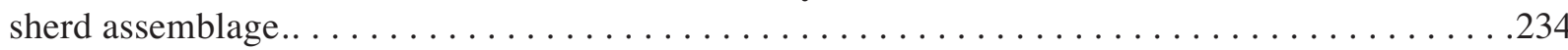

Table 33. Decorative methods and elements in the fine wares in the ceramic

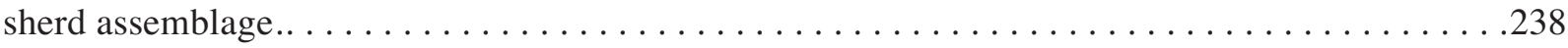

Table 34. Database of Ceramic Vessels from the Caddo Creek basin

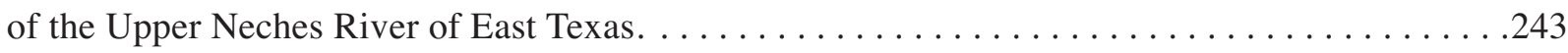




\section{Acknowledgments}

We thank Scott Pletka of the Texas Department of Transportation (TxDOT) for permission to reproduce text and figures from the 2011 TxDOT report on archaeological investigations at the Lang Pasture site (41AN38). Thanks also to Jim and Denise Renfroe for permission to carry out archaeological investigations at the M. S. Roberts site (41HE8) on their property, and for making sure the site is protected and well preserved.

The folks at the Texas Archeological Research Laboratory (TARL), in particular Laura Nightengale, Marybeth Tomka, and Jonathan Jarvis have greatly facilitated the study of ancestral Caddo collections from the Caddo Creek valley in the collections at TARL. Without their cooperation and support, this study would not have been possible. The support of past Chairmen of the Caddo Nation of Oklahoma and Tribal Historic Preservation Officers has also been crucial over the years to the study of the ancestral Caddo archaeology of the Caddo Creek valley.

Thanks also to Chris Goodmaster, who provided a PDF of his 2015 report on the archaeological survey of sections of the proposed U.S. 175 expansion in Anderson and Henderson counties, Texas, and shared the results of his radiocarbon dating of the site's archaeological deposits. Bo Nelson took many of the photographs of the vessels used in that report. Lance Trask and Sandy Hannum prepared a number of figures used in this Special Publication. 



\section{Introduction}

Caddo Creek is a generally eastward-flowing tributary of the Neches River that originates in Henderson County in East Texas (Figure 1a-b). The creek flows ca. $30 \mathrm{~km}$ to its confluence with the Neches River, just south of the A. C. Saunders site (41AN19), one of the more important ancestral Caddo mound centers in this part of East Texas (see Kleinschmidt 1982).

Caddo Creek flows from west to east across the eastern edge of the Post Oak Savannah and into the Pineywoods physiographic regions of East Texas (see Figure 1b; see also Diggs et al. 2006). The Pineywoods cover large parts of East Texas, have medium-tall to tall broadleaf deciduous forests in more mesic habitats, and shortleaf and loblolly pines are common on upland fine sandy loam soils with adequate moisture. Small areas of tall grass prairie may be present in both communities throughout the region, and this may be particularly the case in more xeric sandy lands. The "Redlands" around Nacogdoches are often mentioned, but prairies were also found elsewhere in East Texas (Diggs et al. 2006:82). Fray Francisco Hidalgo noted in 1710 that, "The whole country, as far as it has been examined, is wooded. It contains many small open spaces, and stretches of sand and marshes where the Indians live" (Hatcher 1927:55). Bottomland communities along the major river and creek drainages, such as the Neches River, Caddo Creek, and Walnut Creek, contain a diverse hardwood and swamp forest (including cypress, tupelo, and sweet gum), with natural levees and alluvial terraces, point bar deposits, old stream channels, oxbow lakes, and backwater swamps. A less diverse bottomland hardwood community is present along the smaller creeks and their tributaries.

The Post Oak Savannah is a narrow southwest-northeast trending woodland that marks an ecotone between the more xeric Blackland Prairie to the west and south (Diggs et al. 2006:Figure 2) and the more mesic Pineywoods to the east. The woodlands in the Post Oak Savannah consist of broadleaf deciduous forests, primarily including several species of oak as well as hickory and pecan. Small areas of tall grass prairie were present in this physiographic province (see Diggs et al. 2006:Figure 5) that ran from the Colorado River on the west to near the Trinity River on the east. Bottomland communities along the rivers and major tributaries in the Post Oak Savannah had a diverse hardwood and/or swamp forest, including cypress, sweet gum, and other hardwoods that tolerant periodic flood waters, on natural levees and alluvial terraces, point bar deposits, old stream channels and oxbow lakes.

An 1840 Texas General Land Office map shows a "Comanche Indian Trail" extending along the Caddo Creek valley, which likely coincides with the "grand hunting Trace of the Caddos and Kickapoos" recorded in 1854 property records in the Henderson County Clerk's office (Goodmaster 2015:33). Goodmaster (2015:33) also notes that this area is "purported to be the location if a Caddo encampment raided by General Thomas J. Rusk in 1839 during the final stages of Native American removal from the Republic of Texas." 


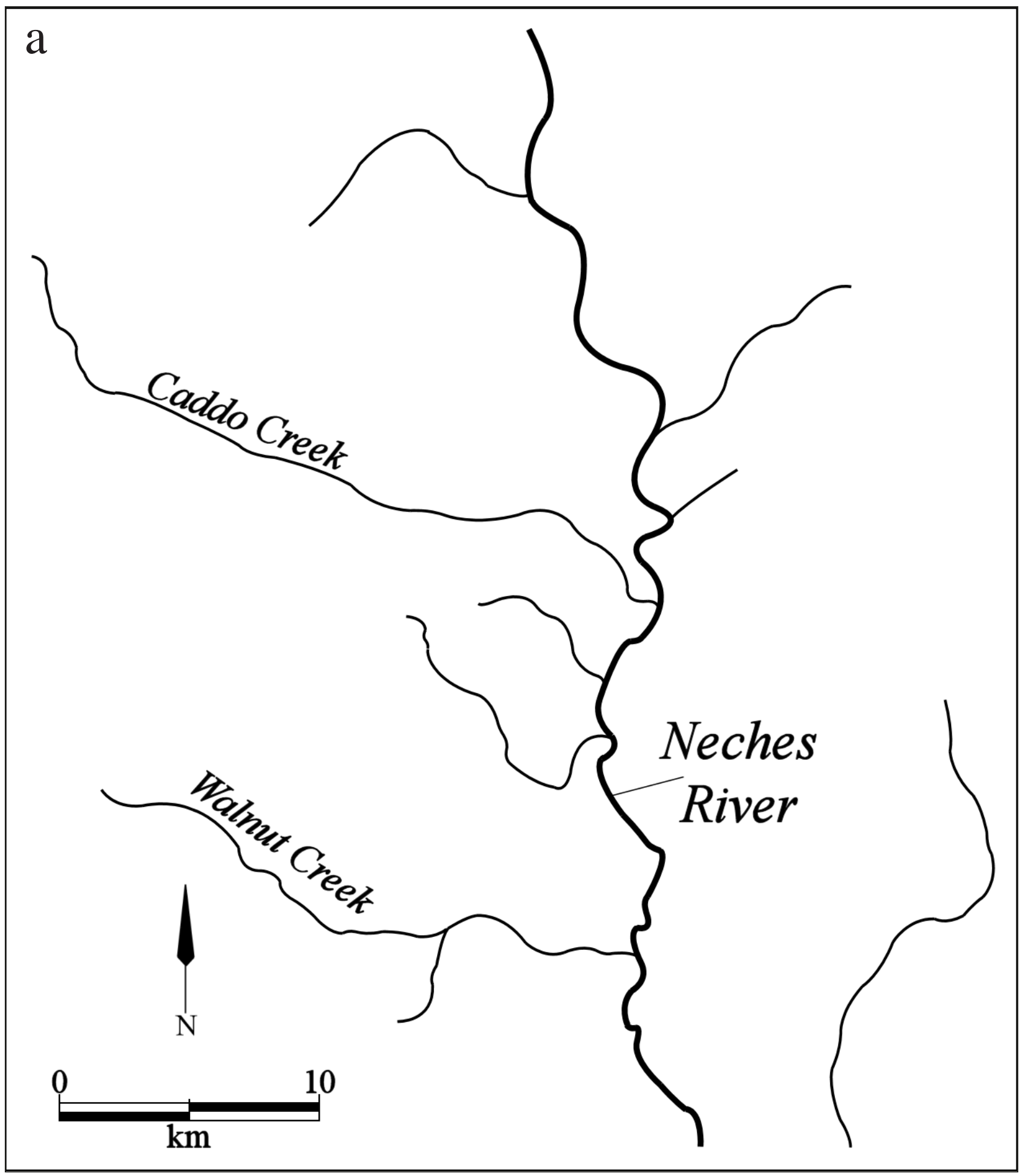

Figure 1. The Caddo Creek valley in the Upper Neches River basin: a, stream drainages. 


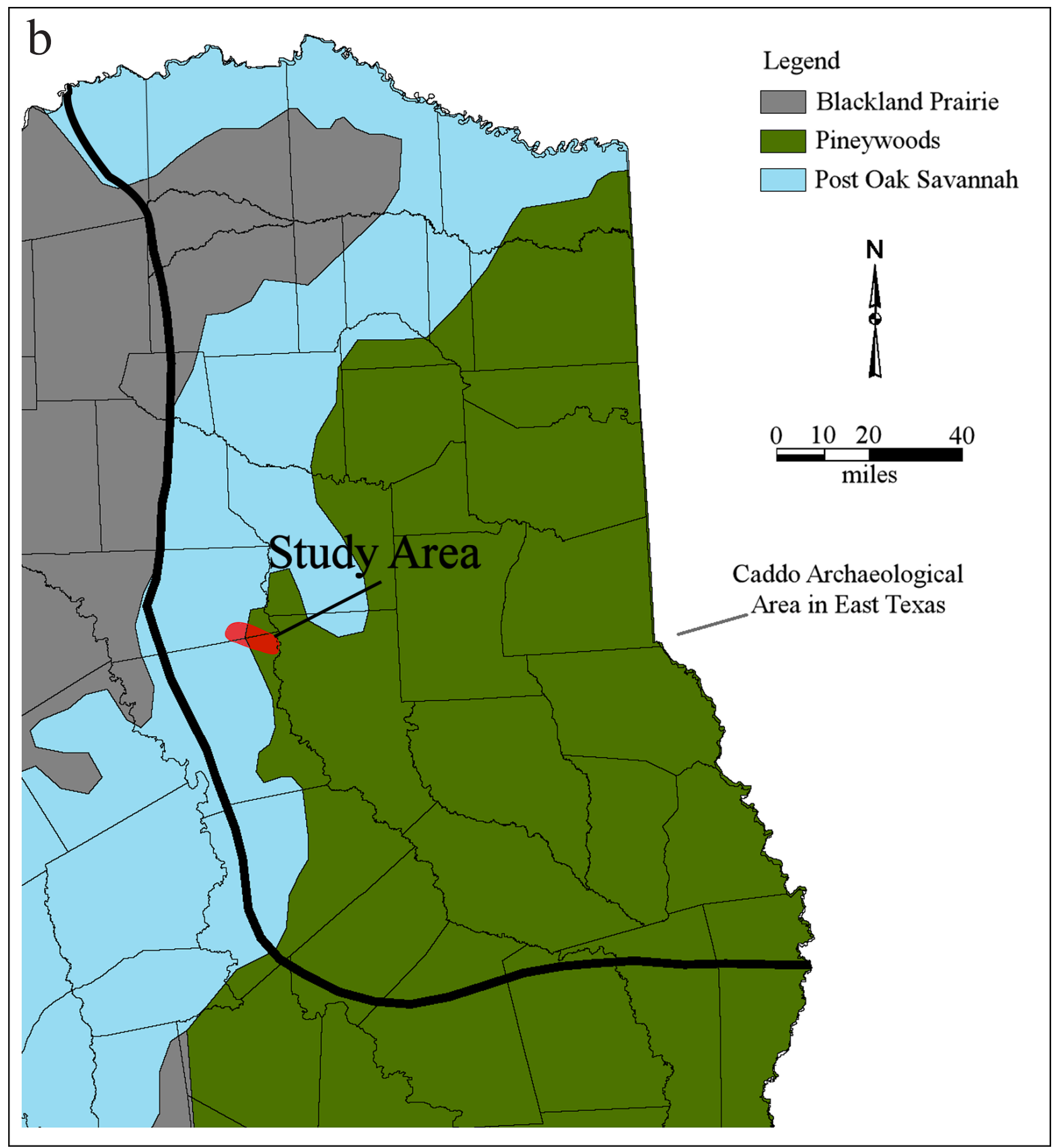

Figure 1. The Caddo Creek valley in the Upper Neches River basin: b, physiographic regions.

\section{Caddo Creek Valley Archaeology}

The Caddo Creek valley in the upper Neches River basin has a particularly notable density of known ancestral Caddo sites, particularly sites of Late Caddo Frankston phase (ca. A.D. 1400-1680) and Historic Caddo Allen phase (ca. A.D. 1680-1830) age (Figure 2). For the most part, the sites have been found haphazardly over the years, beginning in the 1920s, by archaeologists from The University of Texas (UT), and most sections of the valley have never received an intensive archaeological survey. 


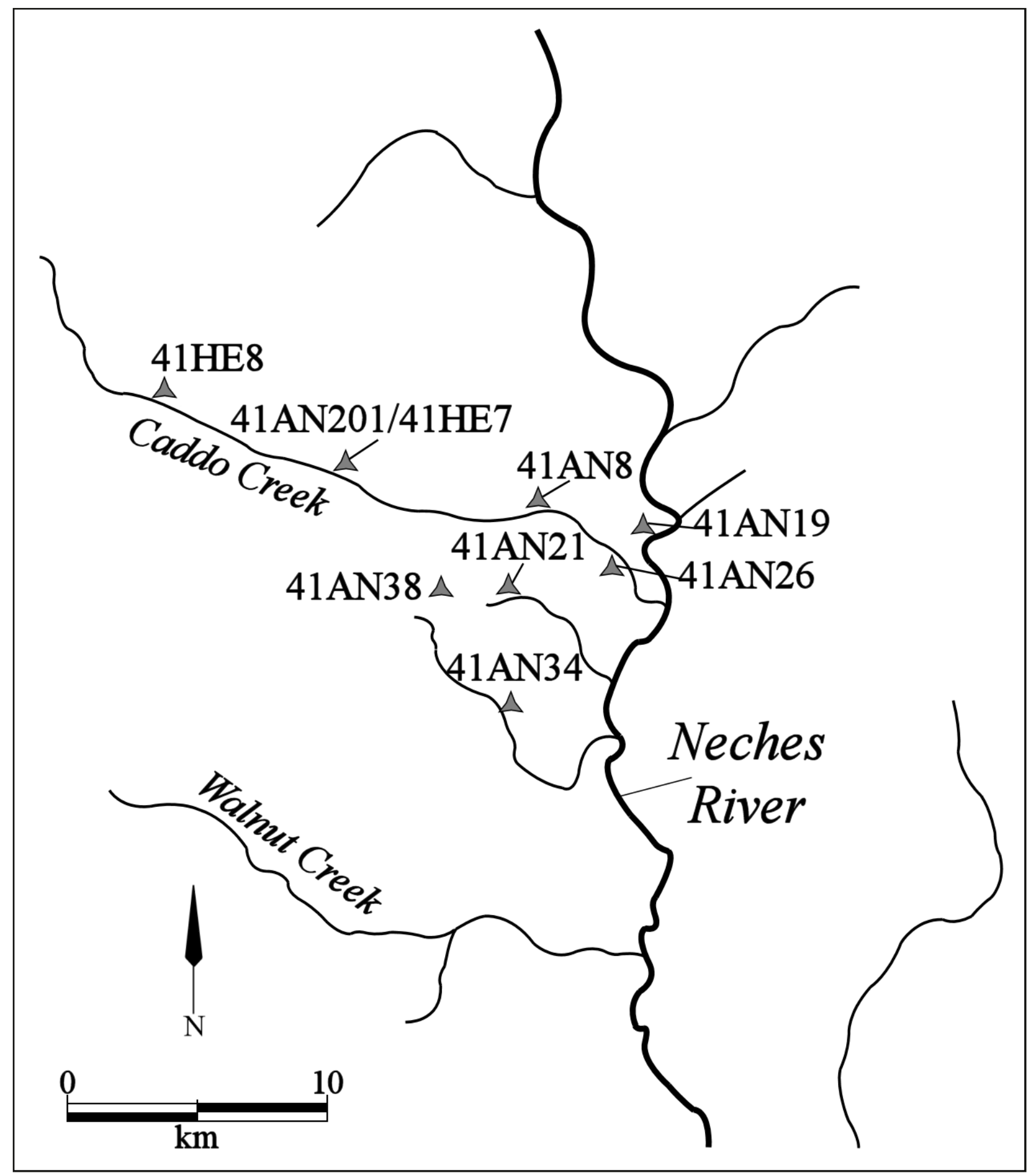

Figure 2. Important excavated Caddo sites in the Caddo Creek valley and surrounding drainages in Anderson and Henderson counties, Texas. 
This Special Publication concerns itself with presenting what is known of the character and age of ancestral Caddo sites in the Caddo Creek valley. We are concerned as well with understanding the Caddo native history of this important place in East Texas, a place in which things happened (cf. Barr 2015). Much of our understanding comes from the renewed study of the collections of artifacts from sites held at the Texas Archeological Research Laboratory at The University of Texas at Austin (TARL), and recent excavations at the Lang Pasture site (41AN38), 41HE338, and A. S. Mann (41AN201/41HE7) sites in the valley.

\section{Mrs. J.M. Cook (41AN1)}

The Mrs. J. M. Cook site is a Frankston phase cemetery on an upland landform (410 ft. amsl) overlooking Caddo Creek to the north. Two associated habitation areas were noted ca. $200 \mathrm{~m}$ south of the cemetery, and a third a short distance to the north, closer to the cemetery (Figure 3a).

Some time prior to October 1931, a local farmer had found ceramic vessels that had eroded out of the landform at the Mrs. J. M. Cook site. In October and November 1931, A. T. Jackson, a UT archaeologist, excavated six ancestral Caddo burials (E-1 to E-6) at the site (see Figure 3b) (Jackson 1931:25-51). The cemetery covered a ca. $24 \times 12 \mathrm{~m}$ area, and the burials were laid out in an extended supine position with their heads facing to the southwest. Associated funerary offerings included 35 vessels (a mean of 5.8 vessels per burial).

A total of 33 vessels are in the TARL collections from the site. They include 11 carinated bowls, one compound bowl, nine jars, eight bowls, and four bottles.

The 11 carinated bowls are all of the Poynor Engraved type, even though there are inverted rim forms, direct rim forms, and globular carinated bowls. Recognized varieties include Poynor Engraved, var. Cook $(\mathrm{n}=4)$, Poynor Engraved, var. Hood ( $\mathrm{n}=2$, including one with brushing on its body), Poynor Engraved, var. Blackburn ( $\mathrm{n}=3)$, and Poynor Engraved, var. Lang ( $\mathrm{n}=1$, with brushing on the body). The last engraved carinated bowl is a Poynor Engraved, var. $R$ vessel, with concentric semi-circles on the rim panel (see below).

The one compound bowl-with two distinct panels - has a var. Lang motif on the lower body panel. The upper rim panel is plain.

Only one of the bowls in the mortuary assemblage is plain, and this particular vessel has lip tabs. A second bowl is a Killough Pinched rattle bowl with pinching rows covering the entirety of the vessel and the four large rattle nodes. The other bowls have engraved designs.

Three of the engraved bowls from the Mrs. J. M. Cook site are Hood Engraved effigy bowls, including one each of var. Cook, var. Hood, and var. Allen with its zoomorphic tail rider. Two other bowls have Poynor Engraved designs: Poynor Engraved, var. Hood and Poynor Engraved, regional variety $\mathrm{Q}$ (hatched nested triangles, see below). The one remaining bowl is a simple bowl with cross-hatched vertical panels and pendant triangles. Kleinschmidt (1982) includes this design as Motif 4 for Hume Engraved, although the same elements occur on several different but unnamed varieties of Poynor Engraved recognized in the upper Neches River basin.

There are three different bottle forms in the Mrs. J. M. Cook mortuary vessels: (a) a single example of a form with globular body and a short but wide neck, (b) a bottle form ( $n=2)$ with an elongated body and a short neck, and (c) one bottle with an elongated neck and a squat body. The globular-bodied bottle, Hume Engraved, var. unspecified, has vertical engraved panels on the body, and the body-neck juncture 

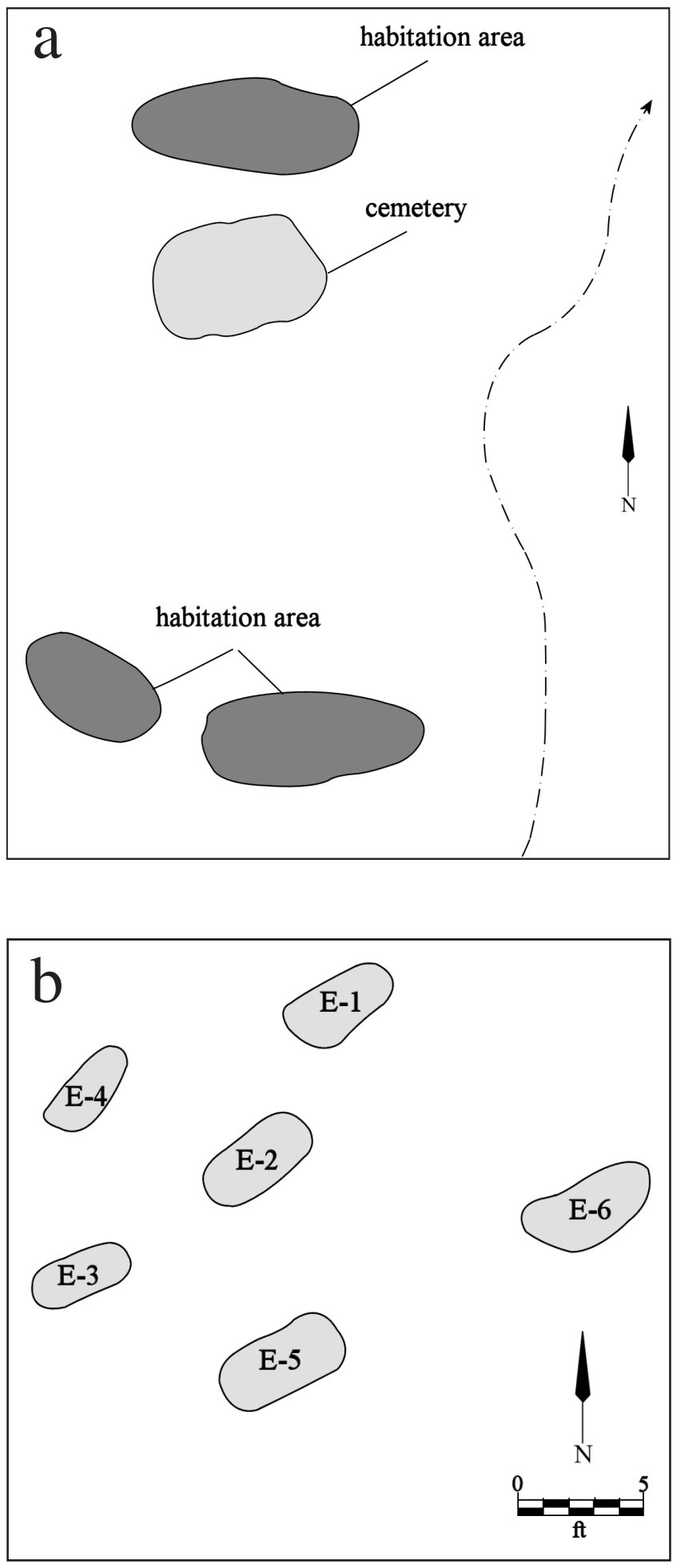

Figure 3. The Caddo cemetery at the Mrs. J. M. Cook site (41AN1): a, the cemetery and associated habitation areas; $b$, plan of the cemetery. is encircled with a row of large hatched pendant triangles. The Fair Engraved bottle with the Fair Plain shape (see Perttula 2011:Figure 6-26c) has large hatched triangles on the bottle neck. The two other Hume Engraved bottles include one with cross-hatched vertical panels and hatched pendant triangles and another with broad closely-spaced horizontal engraved lines on the short neck, and the body is plain.

Two of the nine jars, both with lug handles, are plain. Another two are Bullard Brushed jars, one has a neck banded rim and a vertically brushed body (La Rue Neck Banded), and there is an interesting Maydelle Incised jar with a cross-hatched incised rim design. In addition, there are a series of appliqued nodes under the lip and the vessel body is covered with large tool punctations.

The remaining jars $(n=3)$ are Killough Pinched. These have vertical pinched rows on the rim and pinched concentric circles and spirals covering the vessel body. Two have pinched strap handles and the other has pinched lug handles. The Killough Pinched jars with strap handles also have a substantial pedestal base with four legs; the pedestal base itself is undecorated, but the legs have vertical rows of pinching.

The full range of vessel sizes and shapes occur in the mortuary vessel assemblage from the Mrs. J. M. Cook site. This includes one size of bottle, a number of medium-sized jars, and small to large bowls.

Carinated bowls range from small in size ( $<1$ liter), to medium-sized (1-1.5 liters), large (1.5-3 liters), and one very large carinated bowl ( $>4$ liters). The number of large carinated bowls suggests that communal food service may have been a common part of the burial rituals at the Mrs. J. M. Cook site. 
SITE NO.: 41AN1

FEATURE: Burial E-1

VESSEL NO.: 41AN1-1

NON-PLASTICS: grog

VESSEL FORM: Miniature carinated bowl with a direct rim and a flat lip

CORE COLOR: A (fired and cooled in an oxidizing environment, following Teltser 1993:Figure 2a-h)

WALL THICKNESS: $4.6 \mathrm{~mm}$, rim

INTERIOR SURFACE TREATMENT: smoothed

EXTERIOR SURFACE TREATMENT: smoothed

HEIGHT: $5.4 \mathrm{~cm}$

ORIFICE DIAMETER: $6.7 \mathrm{~cm}$

DIAMETER AT BOTTOM OF RIM OR NECK: $6.7 \mathrm{~cm}$
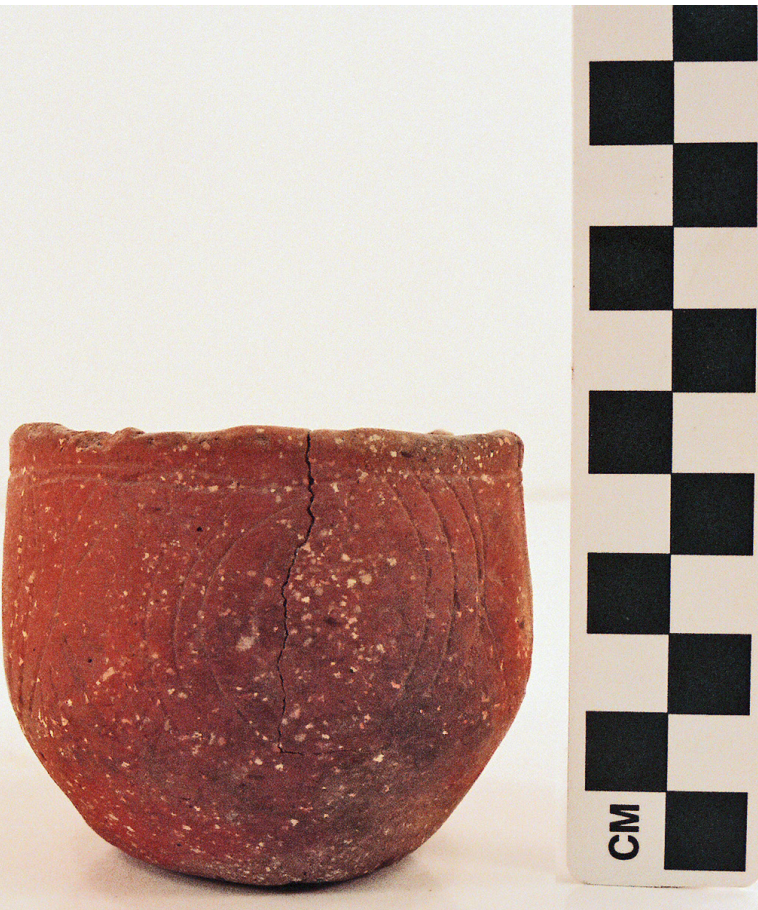

Figure 4. Vessel 41AN1-1, Poynor Engraved, var. Cook carinated bowl.

DECORATION: The vessel has an engraved panel on the rim (Figure 4). Within the panel are four negative ovals. These negative ovals are defined by sets of three closely-spaced vertical curvilinear lines, and they also have triangular hatched areas at the upper and lower ends of the vertical lines.

TYPE: Poynor Engraved, var. Cook 
SITE NO.: 41AN1

FEATURE: Burial E-1

VESSEL NO.: 41AN1-2

NON-PLASTICS: grog and hematite

VESSEL FORM: Globular carinated bowl with a direct to slightly everted rim and a rounded lip, as well as four rim peaks

CORE COLOR: A (fired in an oxidizing environment)

WALL THICKNESS: $6.9 \mathrm{~mm}$

INTERIOR SURFACE TREATMENT: smoothed

EXTERIOR SURFACE TREATMENT: burnished

HEIGHT: $9.0 \mathrm{~cm}$

ORIFICE DIAMETER: $12.0 \mathrm{~cm}$

DIAMETER AT BOTTOM OF RIM

OR NECK: $11.68 \mathrm{~cm}$

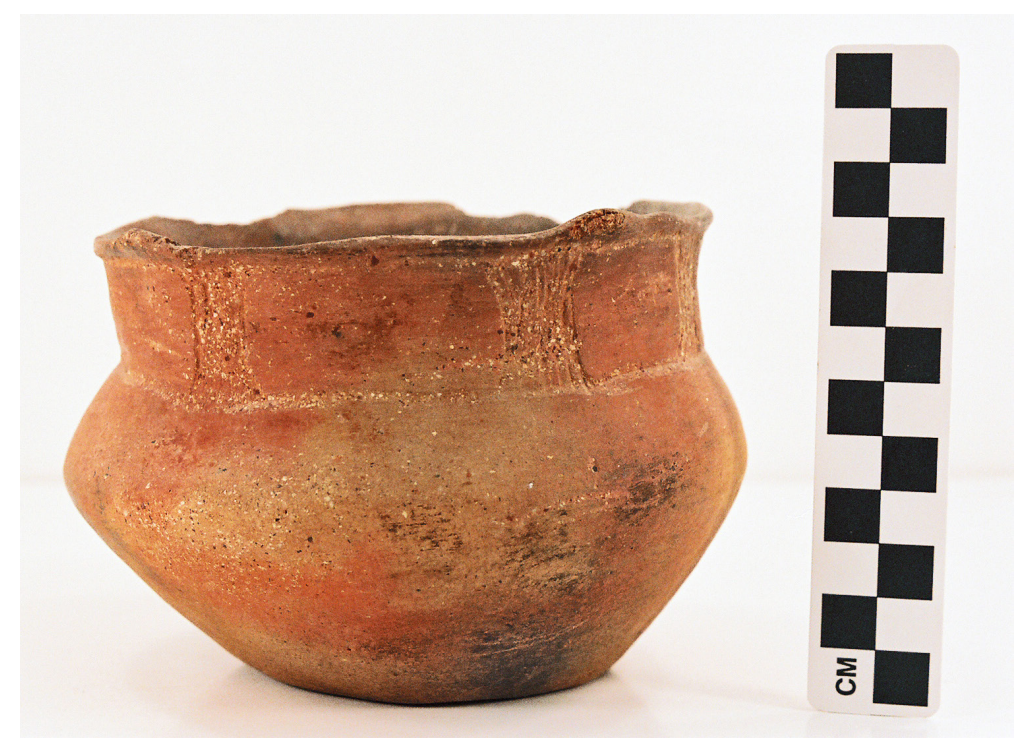

Figure 5. Poynor Engraved, var. Hood carinated bowl (Vessel 41AN1-2).

BASE DIAMETER: $7.2 \mathrm{~cm}$

ESTIMATED VOLUME: 0.65 liters

DECORATION: The rim has an engraved motif composed of six negative ovals. The negative ovals are each defined by two hour glass-shaped excised zones (Figure 5).

TYPE: Poynor Engraved, var. Hood 
SITE NO.: 41AN1

FEATURE: Burial E-1

VESSEL NO.: 41AN1-3

NON-PLASTICS: grog

VESSEL FORM: Jar with a direct rim and a rounded lip

CORE COLOR: Undetermined

WALL THICKNESS: $5.7 \mathrm{~mm}$, rim

INTERIOR SURFACE TREATMENT: smoothed

EXTERIOR SURFACE TREATMENT: none

HEIGHT: $12.0 \mathrm{~cm}$

ORIFICE DIAMETER: $13.2 \mathrm{~cm}$

DIAMETER AT BOTTOM OF RIM OR NECK: $12.3 \mathrm{~cm}$

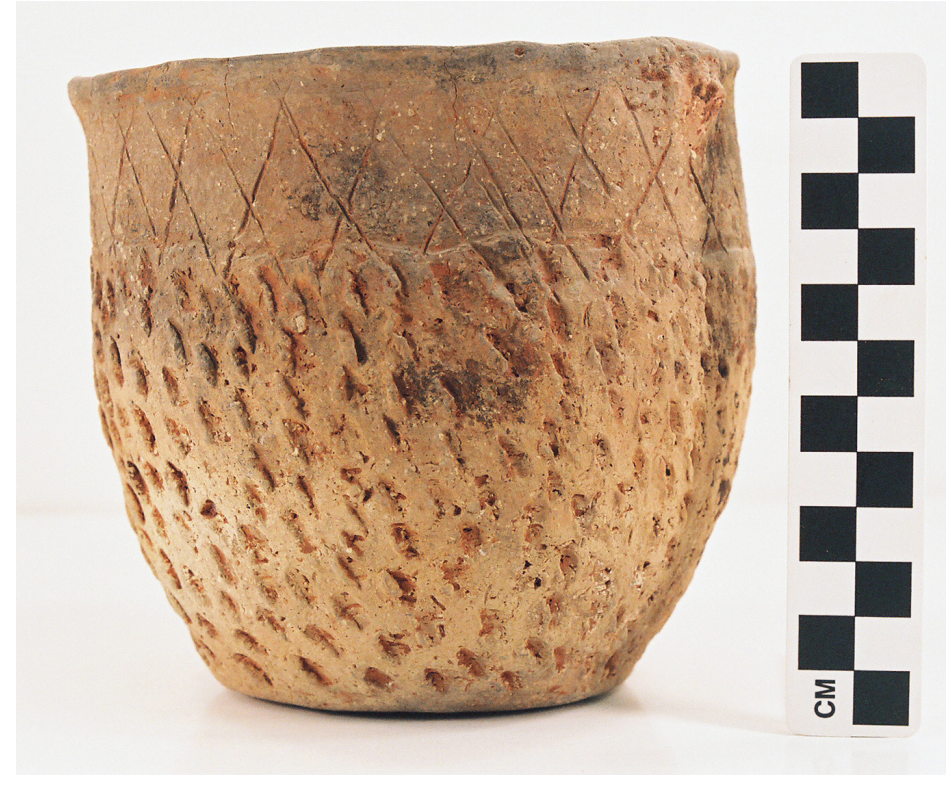

Figure 6. Possible Maydelle Incised jar (Vessel 41AN1-3).

ESTIMATED VOLUME: 1.0 liters

DECORATION: The rim has a cross-hatched incised motif; there are also two small appliqued nodes on the rim, just under the lip (Figure 6). On the remainder of the vessel, beginning at the rim-body juncture, are vertical rows of large tool punctations. These punctated rows reach to the base of the vessel.

TYPE: possible Maydelle Incised jar 
SITE NO.: 41AN1

FEATURE: Burial E-1

VESSEL NO.: 41AN1-4

NON-PLASTICS: grog

VESSEL FORM: Carinated bowl with an inverted rim and a rounded lip

CORE COLOR: Undetermined

WALL THICKNESS: $5.5 \mathrm{~mm}$

INTERIOR SURFACE TREATMENT:

smoothed

EXTERIOR SURFACE TREATMENT:

smoothed

HEIGHT: $7.5 \mathrm{~cm}$

ORIFICE DIAMETER: $11.5 \mathrm{~cm}$

DIAMETER AT BOTTOM OF RIM OR

NECK: $12.2 \mathrm{~cm}$

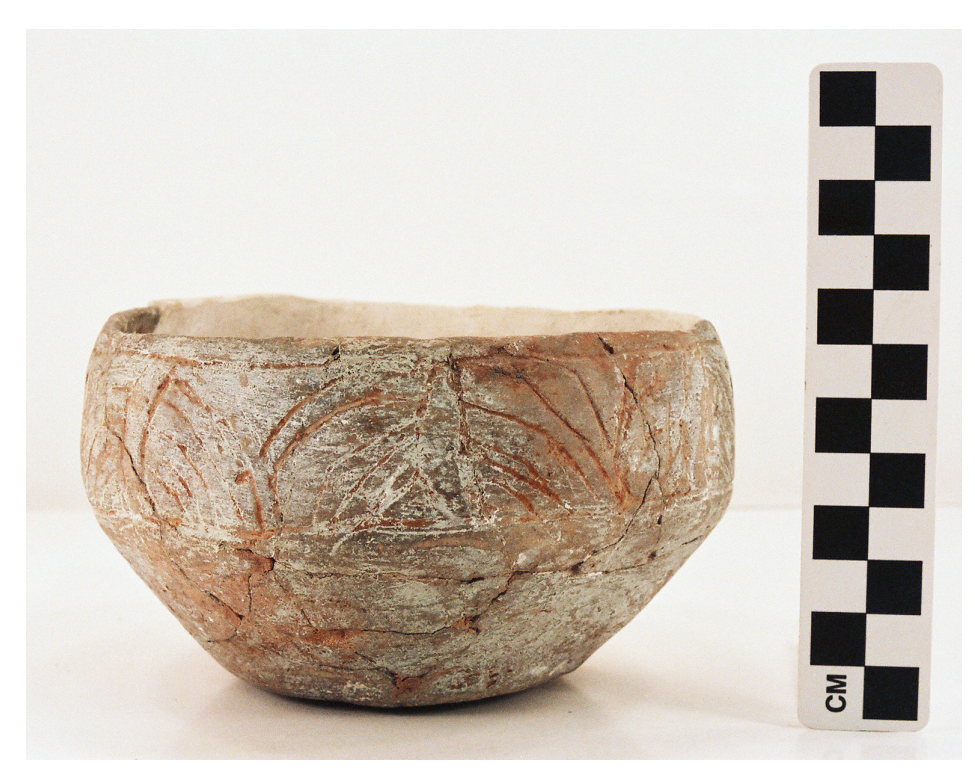

BASE DIAMETER: $7.1 \mathrm{~cm}$

ESTIMATED VOLUME: 0.5 liters

Figure 7. Poynor Engraved, var. $R$ carinated bowl (Vessel 41AN1-4).

DECORATION: The vessel has a series of four engraved concentric semi-circles on the rim. Each set of concentric semi-circles has five engraved lines (Figure 7). There are also single horizontal engraved lines at the top of the vessel-under the lip - and at the vessel carination.

TYPE: Poynor Engraved, var. $R$ in the upper Neches River basin 
SITE NO.: 41AN1

FEATURE: Burial E-1

VESSEL NO.: 41AN1-5

NON-PLASTICS: grog

VESSEL FORM: Carinated bowl with inverted rim and rounded lip

CORE COLOR: $\mathrm{H}$ (fired in a reducing environment but cooled in the open air); pinkware

WALL THICKNESS: $8.0 \mathrm{~mm}$, rim

INTERIOR SURFACE TREATMENT:

burnished on the rim, and smoothed on the body

EXTERIOR SURFACE TREATMENT:

burnished on the rim

HEIGHT: $14.2 \mathrm{~cm}$

ORIFICE DIAMETER: $23.1 \mathrm{~cm}$

DIAMETER AT BOTTOM OF RIM OR

NECK: $23.1 \mathrm{~cm}$

BASE DIAMETER: $9.5 \mathrm{~cm}$

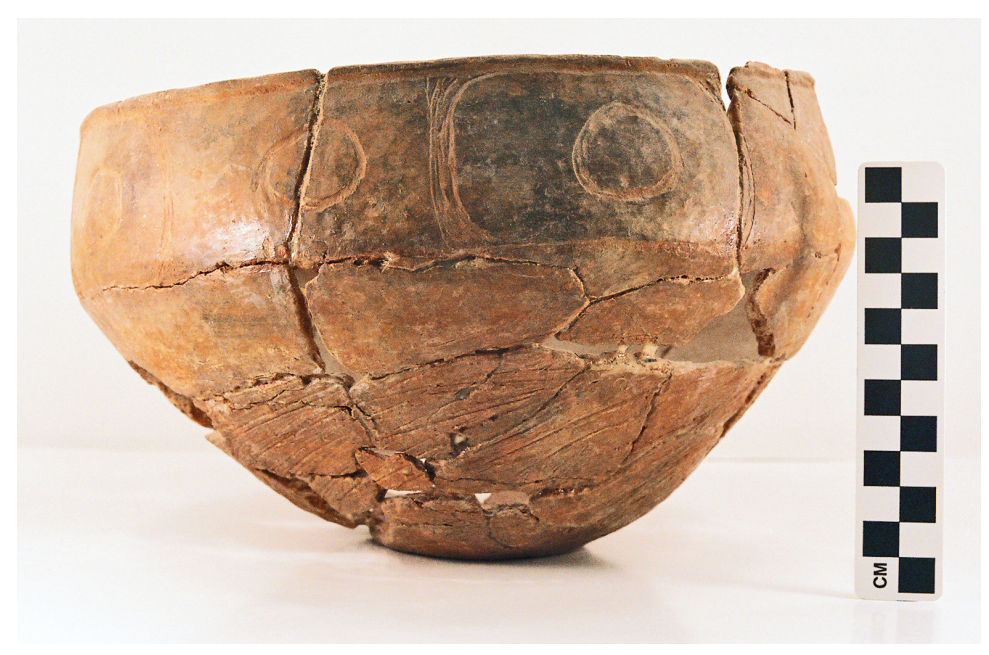

Figure 8. Poynor Engraved, var. Lang carinated bowl (Vessel 41AN1-5).

ESTIMATED VOLUME: 2.9 liters

DECORATION: The vessel is engraved on the rim with five negative circles (Figure 8). There are smaller engraved circles at the center of the negative circles, which are defined by four closely-spaced vertical engraved arcs. Five small engraved circles fill each of the negative circles. Portions of the vessel body have diagonal brushing marks.

TYPE: Poynor Engraved, var. Lang 
SITE NO.: 41AN1

FEATURE: Burial E-1

VESSEL NO.: 41AN1-6

NON-PLASTICS: grog

VESSEL FORM: Rattle bowl with a direct rim and a rounded lip; four attached rattles

CORE COLOR: Undetermined

WALL THICKNESS: $8.2 \mathrm{~mm}$

INTERIOR SURFACE TREAT-

MENT: smoothed

EXTERIOR SURFACE TREATMENT: none

HEIGHT: $11.5 \mathrm{~cm}$

ORIFICE DIAMETER: $21.5 \mathrm{~cm}$

DIAMETER AT BOTTOM OF RIM OR NECK: N/A

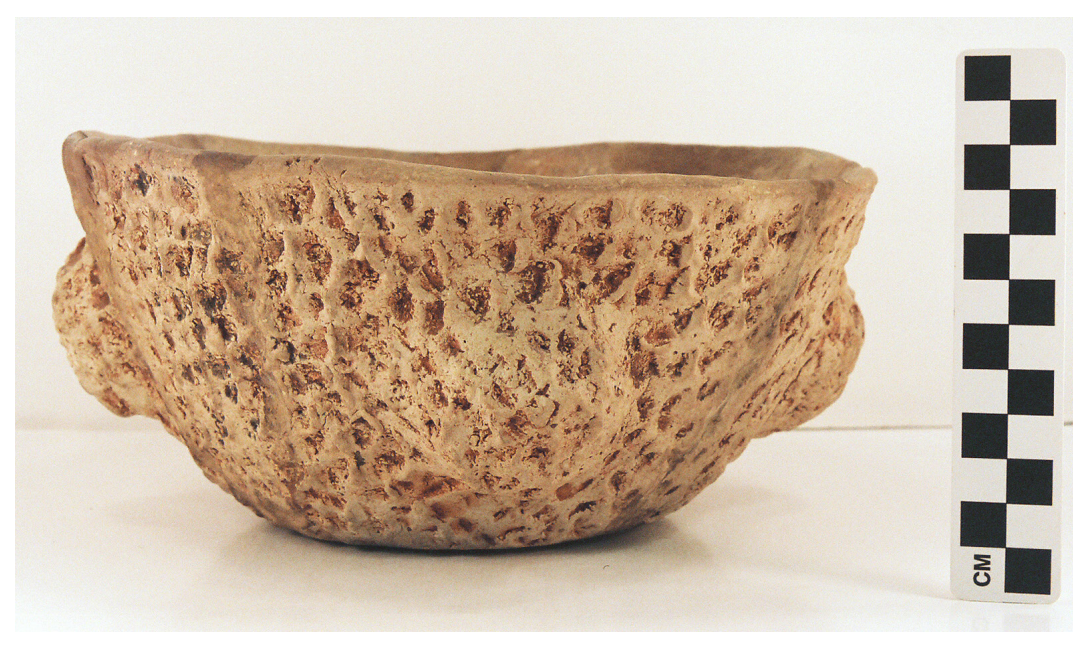

BASE DIAMETER: $10.5 \mathrm{~cm}$

Figure 9. Killough Pinched rattle bowl (Vessel 41AN1-6).

ESTIMATED VOLUME: 1.0 liters

DECORATION: The entire vessel rim and body is covered in vertical pinched rows, as are the four attached rattles (Figure 9).

TYPE: Killough Pinched rattle bowl (Suhm and Jelks 1962:Plate 46e). 
SITE NO.: 41AN1

FEATURE: Burial E-2

VESSEL NO.: 41AN1-7

NON-PLASTICS: grog

VESSEL FORM: Effigy bowl with a direct rim and a rounded lip; effigy head (reconstructed bird head) on one side of the vessel and a tail rider (a four-legged animal with a tail) on the opposing side (Figure 10)

CORE COLOR: Undetermined

WALL THICKNESS: $7.8 \mathrm{~mm}$

INTERIOR SURFACE TREAT-

MENT: smoothed

EXTERIOR SURFACE TREAT-

MENT: burnished

HEIGHT: $10.5 \mathrm{~cm}$

ORIFICE DIAMETER: $18.5 \mathrm{~cm}$

DIAMETER AT BOTTOM OF

RIM OR NECK: N/A

BASE DIAMETER: $4.0 \mathrm{~cm}$

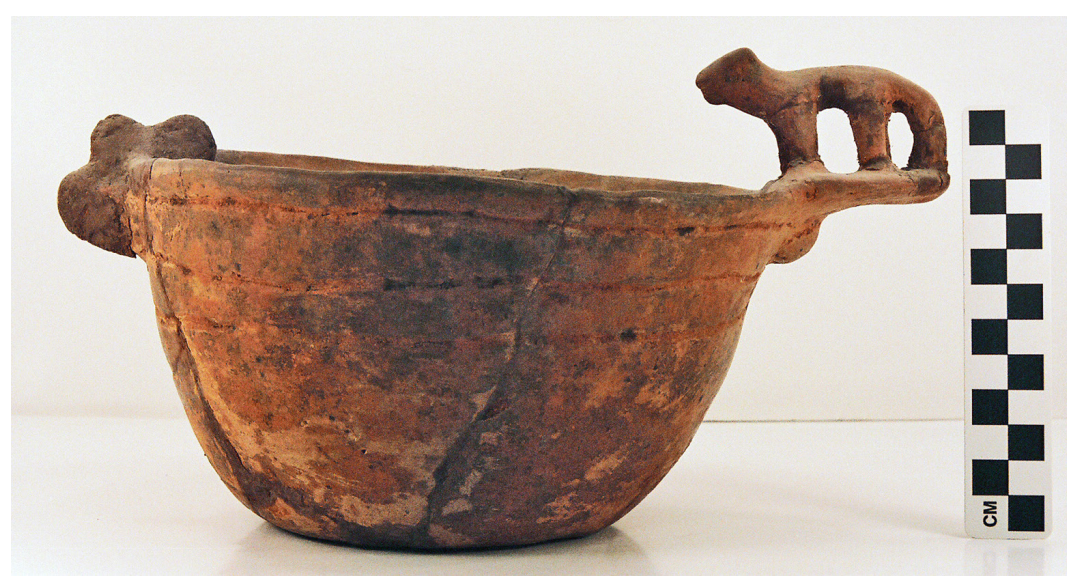

Figure 10. Hood Engraved, var. Allen effigy bowl (Vessel 41AN1-7).

ESTIMATED VOLUME: 0.8 liters

DECORATION: There are three widely-spaced horizontal engraved lines on the upper part of the vessel along with the effigy head and tail rider (Figure 10).

TYPE: Hood Engraved, var. Allen effigy vessel, previously referred to as an example of a Fulton Aspect effigy bowl (cf. Suhm and Jelks 1962:Plate 24f; see also Perttula and Selden 2015) 
SITE NO.: 41AN1

FEATURE: Burial E-2

VESSEL NO.: 41AN1-8

NON-PLASTICS: grog and hematite

VESSEL FORM: Globular bowl with a direct rim and a rounded lip

CORE COLOR: Undetermined

WALL THICKNESS: $5.4 \mathrm{~mm}$, rim

INTERIOR SURFACE TREATMENT: burnished on rim and smoothed on the body

EXTERIOR SURFACE TREATMENT: burnished

HEIGHT: $11.3 \mathrm{~cm}$

ORIFICE DIAMETER: $16.3 \mathrm{~cm}$

DIAMETER AT BOTTOM OF RIM OR NECK: $15.2 \mathrm{~cm}$

BASE DIAMETER: $7.5 \mathrm{~cm}$

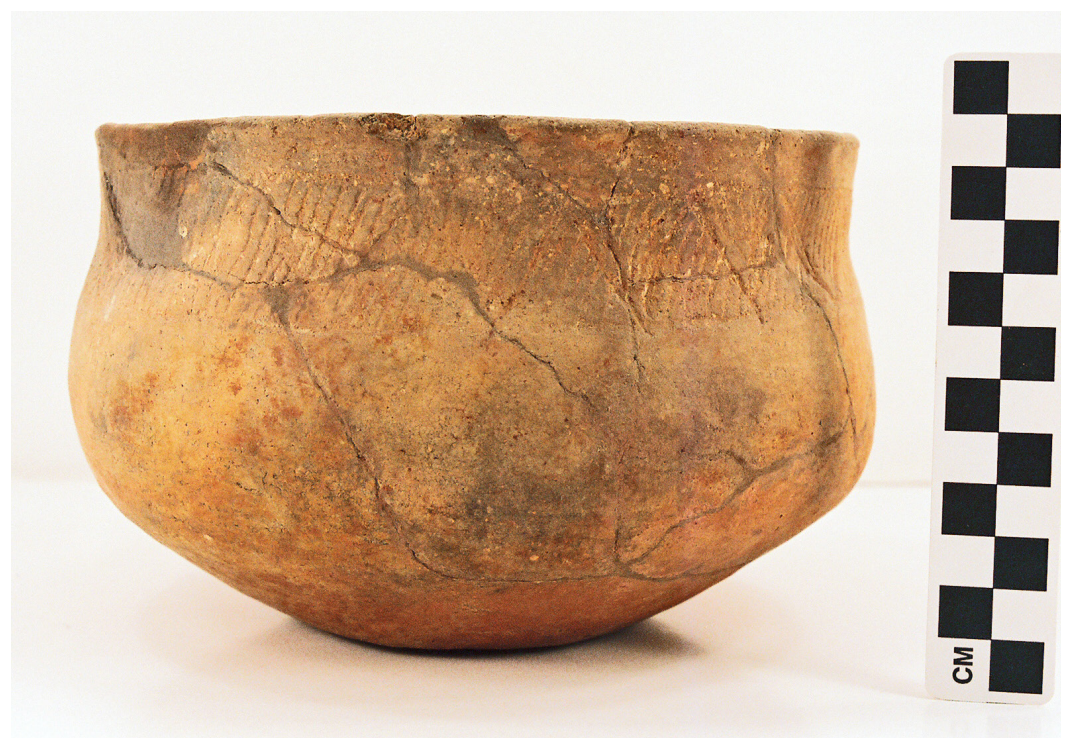

Figure 11. Poynor Engraved, var. $Q$ bowl (Vessel 41AN1-8).

ESTIMATED VOLUME: 0.8 liters

DECORATION: There is an engraved panel (defined by upper and lower horizontal lines) on the upper part or rim of the vessel (Figure 11). The panel is comprised of 36 alternating engraved triangles in six distinct sets. Thirty-one of the engraved triangles have diagonal hatched lines within the triangles, while one set has five triangles with horizontal hatched lines within them.

TYPE: Poynor Engraved, var. $Q$ in the upper Neches River basin 
SITE NO.: 41AN1

FEATURE: Burial E-2

VESSEL NO.: 41AN1-9

NON-PLASTICS: grog

VESSEL FORM: Globular carinated bowl with a direct rim and a rounded and exterior folded lip CORE COLOR: Undetermined

WALL THICKNESS: $5.7 \mathrm{~mm}$

INTERIOR SURFACE TREAT-

MENT: smoothed

EXTERIOR SURFACE TREATMENT: burnished

HEIGHT: $13.0 \mathrm{~cm}$

ORIFICE DIAMETER: $17.5 \mathrm{~cm}$

DIAMETER AT BOTTOM OF

RIM OR NECK: $20.0 \mathrm{~cm}$

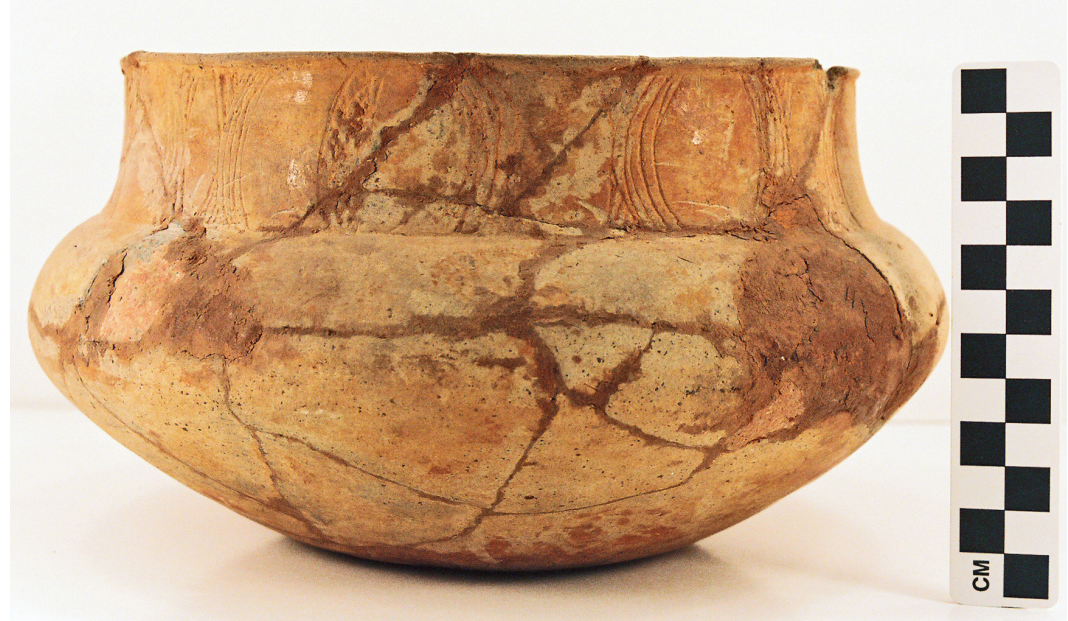

Figure 12. Poynor Engraved, var. Cook carinated bowl (Vessel 41AN1-9).

ESTIMATED VOLUME: 1.4 liters

DECORATION: The engraved panel on the rim (defined by upper and lower horizontal lines) has nine closely-spaced semi-circles or ovals (Figure 12). Each semi-circle or oval is defined by two sets of closelyspaced engraved arcs comprised of three or four lines.

TYPE: Poynor Engraved, var. Cook 
SITE NO.: 41AN1

FEATURE: Burial E-2

VESSEL NO.: 41AN1-11

NON-PLASTICS: grog and hematite

VESSEL FORM: Deep Jar with a direct rim and a flat lip, two lug handles $(21$ x $17 \mathrm{~mm}$ in height and width) (Figure 13)

CORE COLOR: A (fired and cooled in a high oxygen environment); pinkware

WALL THICKNESS: $6.3 \mathrm{~mm}$

INTERIOR SURFACE TREATMENT: smoothed; fire clouds

EXTERIOR SURFACE TREATMENT: none

HEIGHT: $15.3 \mathrm{~cm}$

ORIFICE DIAMETER: $13.1 \mathrm{~cm}$

DIAMETER AT BOTTOM OF RIM OR NECK: 13.1

BASE DIAMETER: $8.2 \mathrm{~cm}$

ESTIMATED VOLUME: 1.2 liters

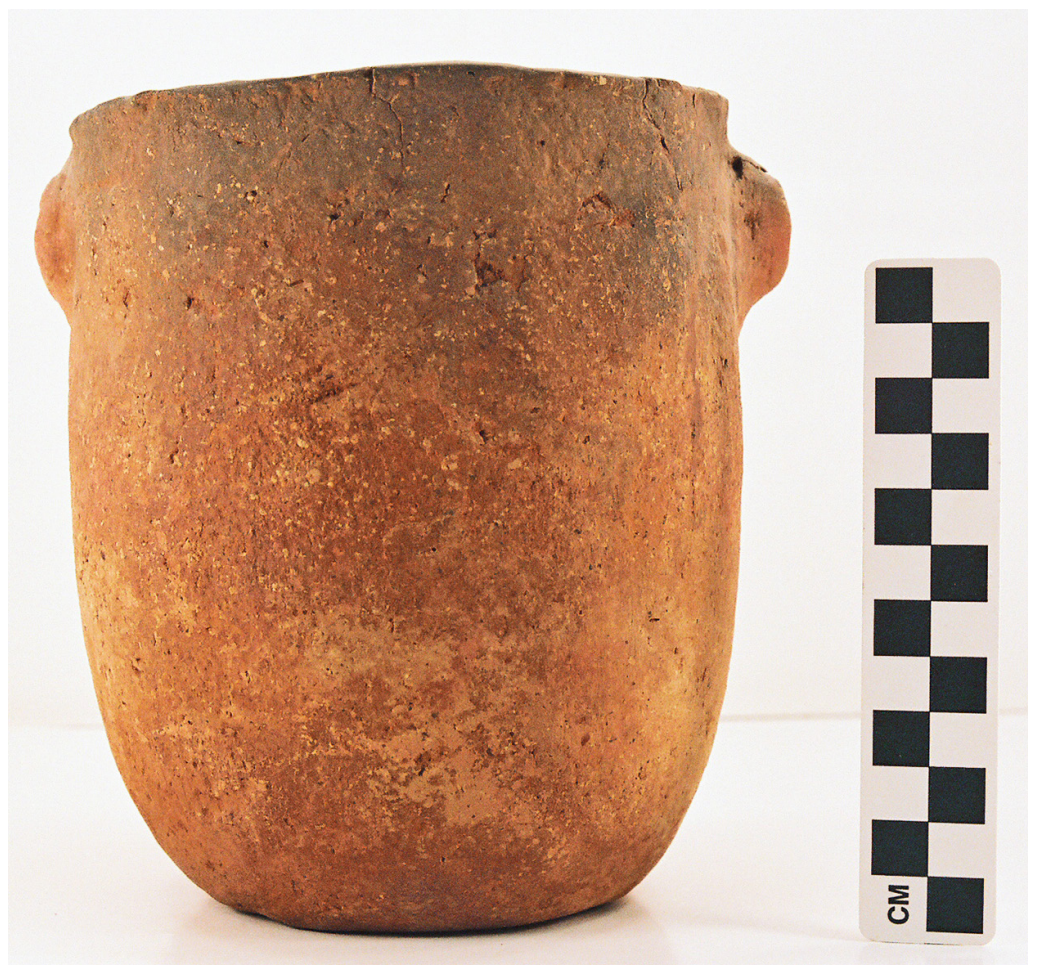

Figure 13. Plain jar (Vessel 41AN1-11).

DECORATION: plain (Figure 13)

TYPE: Undetermined plain ware vessel 
SITE NO.: 41AN1

FEATURE: Burial E-3

VESSEL NO.: 41AN1-12

NON-PLASTICS: grog, hematite, and bone

VESSEL FORM: Bottle with a short neck, an elongated body, a direct rim, and a rounded lip

CORE COLOR: B (fired and cooled in a reducing environment)

WALL THICKNESS: $6.7 \mathrm{~mm}$

INTERIOR SURFACE TREATMENT: none

EXTERIOR SURFACE TREATMENT:

smoothed

HEIGHT: $26.0 \mathrm{~cm}$

ORIFICE DIAMETER: $4.2 \mathrm{~cm}$

DIAMETER AT BOTTOM OF RIM OR

NECK: $11.5 \mathrm{~cm}$ on lower body

BASE DIAMETER: $8.9 \mathrm{~cm}$

ESTIMATED VOLUME: 0.95 liters

DECORATION: The upper body has a row of 10 hatched pendant triangles suspended from a single horizontal engraved line (Fig-

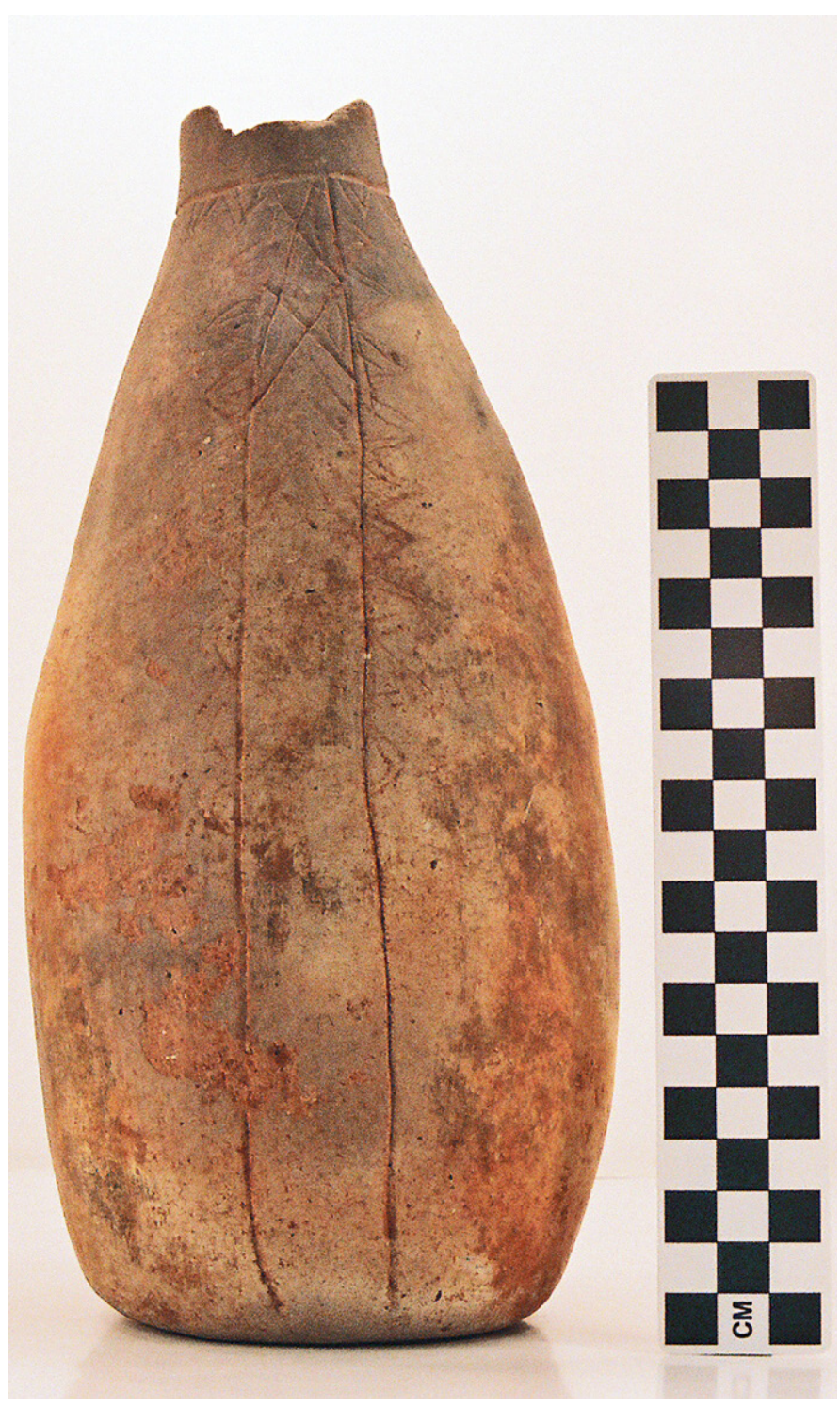

Figure 14. Hume Engraved, var. unspecified (Vessel 41AN1-12).

ure 14). On the remainder of the body are two vertical panels with two deeply-cut vertical engraved lines. On the first panel, there are a series of small hatched pendant triangles on each vertical engraved line. The second panel has eight hatched pendant triangles and eight small engraved semi-circles on the two vertical engraved lines.

TYPE: Hume Engraved, var. unspecified 
SITE NO.: 41AN1

FEATURE: Burial E-3

VESSEL NO.: 41AN1-13

NON-PLASTICS: grog

VESSEL FORM: Globular carinated bowl with a short everted rim and a rounded lip

CORE COLOR: A (fired and cooled in an oxidizing environment)

WALL THICKNESS: $7.0 \mathrm{~mm}$, rimbody juncture

INTERIOR SURFACE TREATMENT: burnished

EXTERIOR SURFACE TREATMENT: burnished

HEIGHT: $10.2 \mathrm{~cm}$; rim height, 1.9 $\mathrm{cm}$

ORIFICE DIAMETER: $11.5 \mathrm{~cm}$

DIAMETER AT BOTTOM OF RIM OR NECK: $11.4 \mathrm{~cm}$

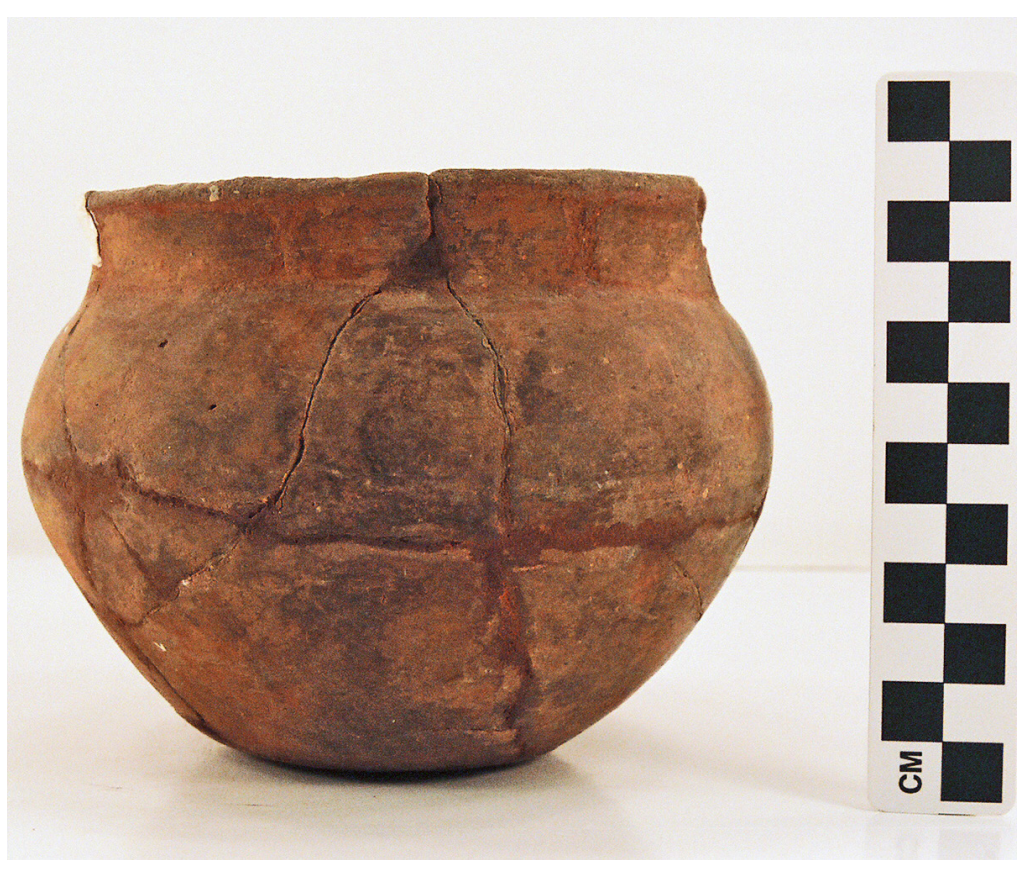

Figure 15. Poynor Engraved, var. Hood carinated bowl (Vessel 41AN1-13).

BASE DIAMETER: $6.9 \mathrm{~cm}$

ESTIMATED VOLUME: 0.5 liters

DECORATION: The rim has an engraved panel comprised of seven negative rectangles (Figure 15). Each rectangle is defined by hour glass-shaped excised areas. A red clay pigment has been rubbed in the engraved lines.

TYPE: Poynor Engraved, var. Hood 
SITE NO.: 41AN1

FEATURE: Burial E-3

VESSEL NO.: 41AN1-14

NON-PLASTICS: grog and bone

VESSEL FORM: Bottle with a short neck, a direct rim, and a flat lip

CORE COLOR: B (fired and cooled in a reducing environment)

WALL THICKNESS: $6.0 \mathrm{~mm}$, rim

INTERIOR SURFACE TREATMENT: none

EXTERIOR SURFACE TREATMENT:

burnished

HEIGHT: $20.0 \mathrm{~cm}$

ORIFICE DIAMETER: $4.0 \mathrm{~cm}$ at the neck

DIAMETER AT BOTTOM OF RIM OR

NECK: $4.8 \mathrm{~cm}$

\section{BASE DIAMETER: $7.7 \mathrm{~cm}$}

ESTIMATED VOLUME: 0.6 liters

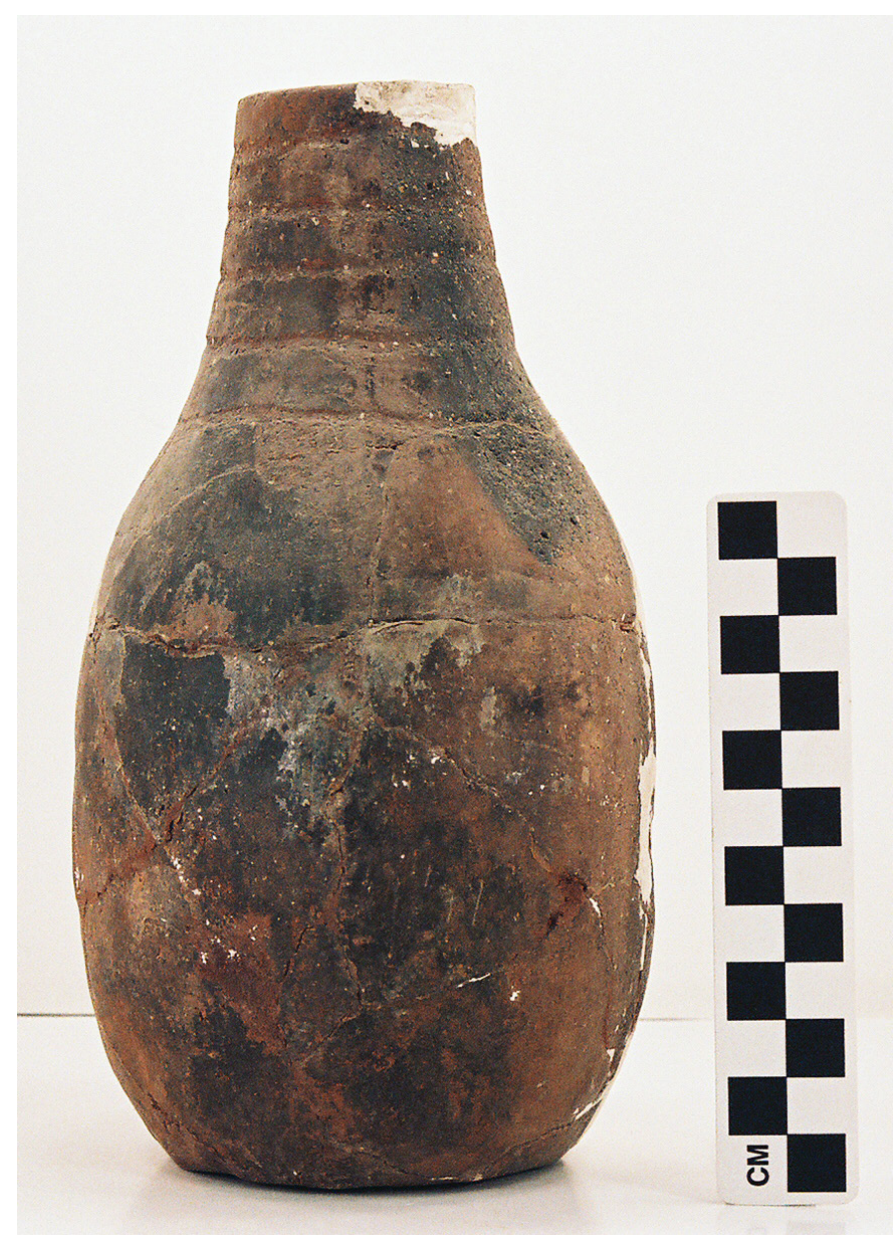

Figure 16. Unidentified engraved bottle (Vessel 41AN1-14). graved lines on the bottle neck (Figure 16). A red clay pigment has been rubbed in the engraved lines.

TYPE: Undetermined engraved fine ware bottle, but related to both Poynor and Hume Engraved bottle forms. 
SITE NO.: 41AN1

FEATURE: Burial E-3

VESSEL NO.: 41AN1-15

NON-PLASTICS: grog and bone

VESSEL FORM: Compound bowl with a direct rim and a rounded lip

CORE COLOR: Undetermined

WALL THICKNESS: $7.1 \mathrm{~mm}$

INTERIOR SURFACE TREAT-

MENT: none

EXTERIOR SURFACE TREATMENT: none

HEIGHT: $11.0 \mathrm{~cm}$

ORIFICE DIAMETER: $16.0 \mathrm{~cm}$

DIAMETER AT BOTTOM OF RIM OR NECK: $15.8 \mathrm{~cm}$ on the upper panel, $16.6 \mathrm{~cm}$ on the lower panel

BASE DIAMETER: $8.0 \mathrm{~cm}$

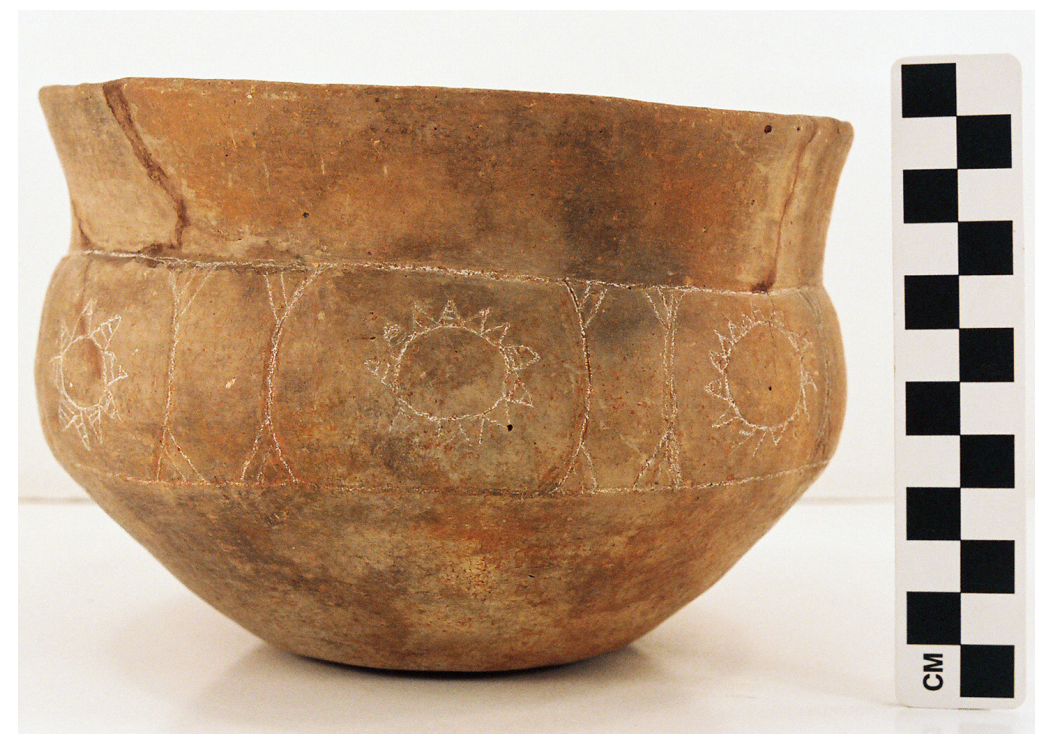

Figure 17. Poynor Engraved, var. Lang compound bowl (Vessel 41AN1-15).

ESTIMATED VOLUME: 1.2 liters

DECORATION: The upper rim panel is plain, but the lower rim panel (defined by upper and lower horizontal engraved lines) has seven negative ovals or semi-circles (Figure 17). At the center of each oval or semi-circle are small negative circles defined by seven to 14 hatched triangles. The negative ovals or semi-circles are each divided from the other by two hour glass-shaped engraved elements with hatched triangles at their four corners. There is a white kaolin clay pigment rubbed in the engraved lines.

TYPE: Poynor Engraved, var. Lang 
SITE NO.: 41AN1

FEATURE: Burial E-3

VESSEL NO.: 41AN1-16

NON-PLASTICS: grog

VESSEL FORM: Carinated bowl with an inverted rim and a rounded lip

CORE COLOR: A (fired and cooled in an oxidizing environment)

WALL THICKNESS: $7.1 \mathrm{~mm}$

INTERIOR SURFACE

TREATMENT: burnished on the rim, smoothed on the body

EXTERIOR SURFACE

TREATMENT: burnished

HEIGHT: $17.7 \mathrm{~cm}$

ORIFICE DIAMETER: 27.2 $\mathrm{cm}$

DIAMETER AT BOTTOM OF RIM OR NECK: $28.4 \mathrm{~cm}$

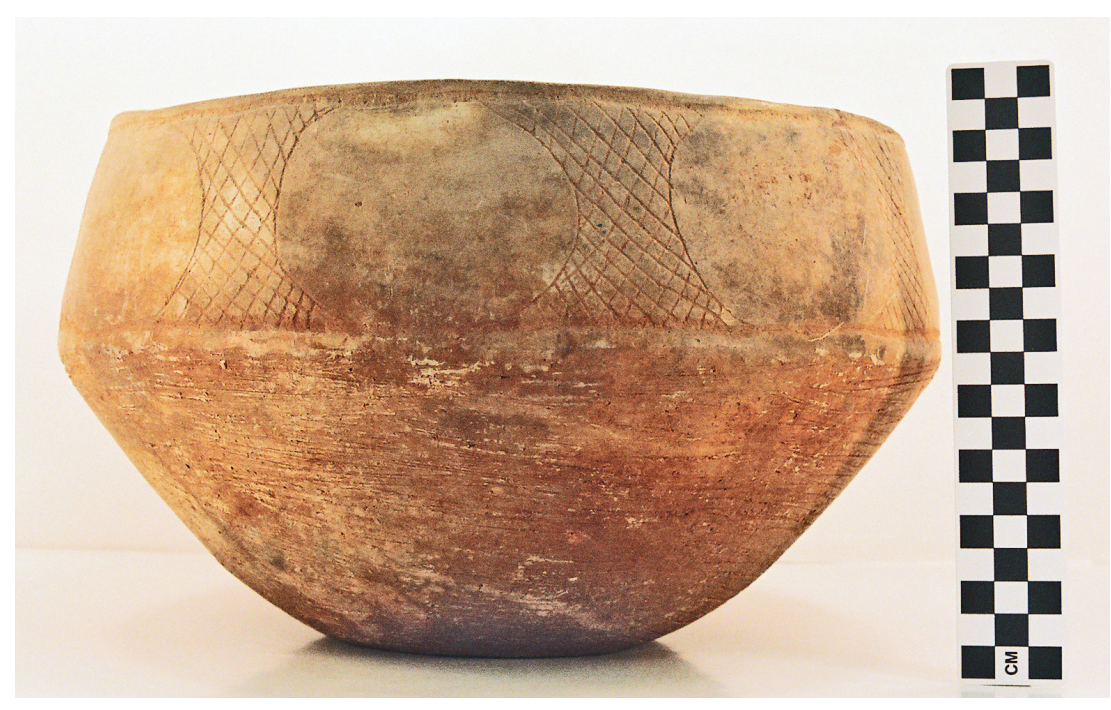

Figure 18. Large Poynor Engraved, var. Hood carinated bowl (Vessel 41AN1-116).

BASE DIAMETER: $9.8 \mathrm{~cm}$

ESTIMATED VOLUME: 4.3 liters

DECORATION: There is an engraved rim panel defined by upper and lower horizontal engraved lines that encircle the vessel. Within the panel are eight negative ovals defined by cross-hatched hour (i.e., brackets) glass-shaped engraved elements (Figure 18). The vessel body and base has horizontal brushing marks.

TYPE: Poynor Engraved, var. Hood 
SITE NO.: 41AN1

FEATURE: Burial E-3

VESSEL NO.: 41AN1-17

NON-PLASTICS: grog and bone

VESSEL FORM: Carinated bowl with a slightly everted rim and a rounded lip

CORE COLOR: F (fired in a reducing environment, but cooled in the open air)

WALL THICKNESS: $6.8 \mathrm{~mm}$

INTERIOR SURFACE TREAT-

MENT: smoothed

EXTERIOR SURFACE TREAT-

MENT: burnished

HEIGHT: $13.0 \mathrm{~cm}$

ORIFICE DIAMETER: $24.5 \mathrm{~cm}$

DIAMETER AT BOTTOM OF

RIM OR NECK: $23.0 \mathrm{~cm}$

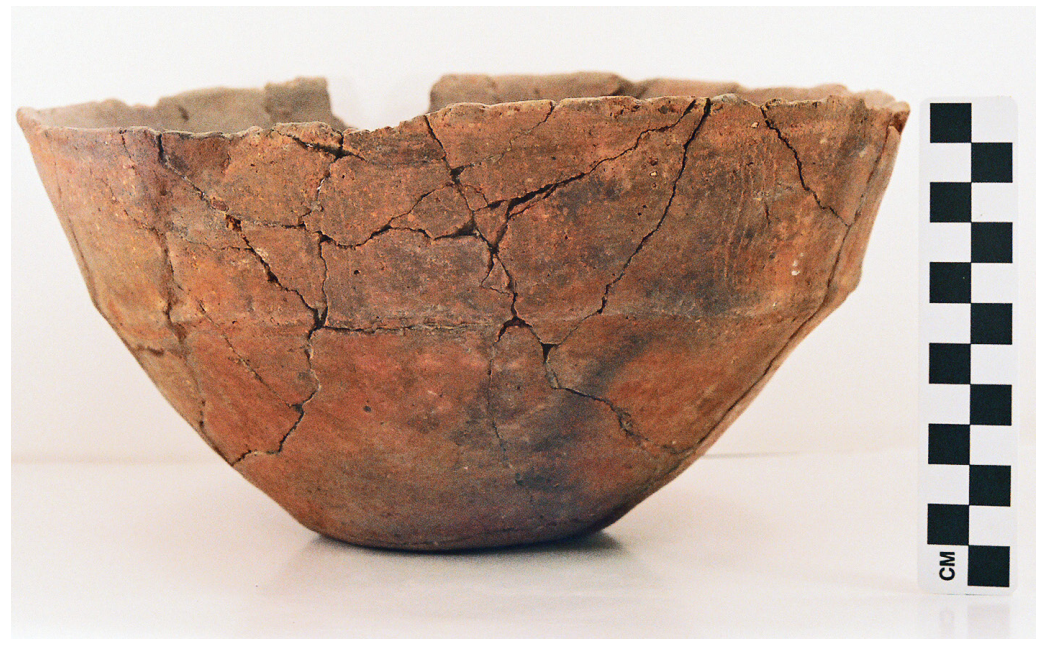

BASE DIAMETER: $8.5 \mathrm{~cm}$

ESTIMATED VOLUME: 1.9 liters

Figure 19. Poynor Engraved, var. Blackburn carinated bowl (Vessel 41AN1-17).

DECORATION: The rim has a panel defined by upper and lower horizontal engraved lines that encircle the vessel. Within the panel are negative rectangular areas defined by two sets of four closely-spaced vertical engraved lines (Figure 19).

TYPE: Poynor Engraved, var. Blackburn 
SITE NO.: 41AN1

FEATURE: Burial E-3

VESSEL NO.: 41AN1-18

NON-PLASTICS: bone and grog

VESSEL FORM: Small jar with a direct rim and rounded lip; the vessel has two opposed lug handles (10.2 $\mathrm{mm}$ wide and $22.2 \mathrm{~mm}$ in height) (Figure 20)

CORE COLOR: $\mathrm{G}$ (fired in a reducing environment and cooled in the open air)

WALL THICKNESS: $7.0 \mathrm{~mm}$

INTERIOR SURFACE TREATMENT: smoothed on rim and upper body

EXTERIOR SURFACE TREATMENT: none

HEIGHT: $8.5 \mathrm{~cm}$

ORIFICE DIAMETER: $12.4 \mathrm{~cm}$

DIAMETER AT BOTTOM OF RIM OR NECK: $12.0 \mathrm{~cm}$

BASE DIAMETER: $6.3 \mathrm{~cm}$

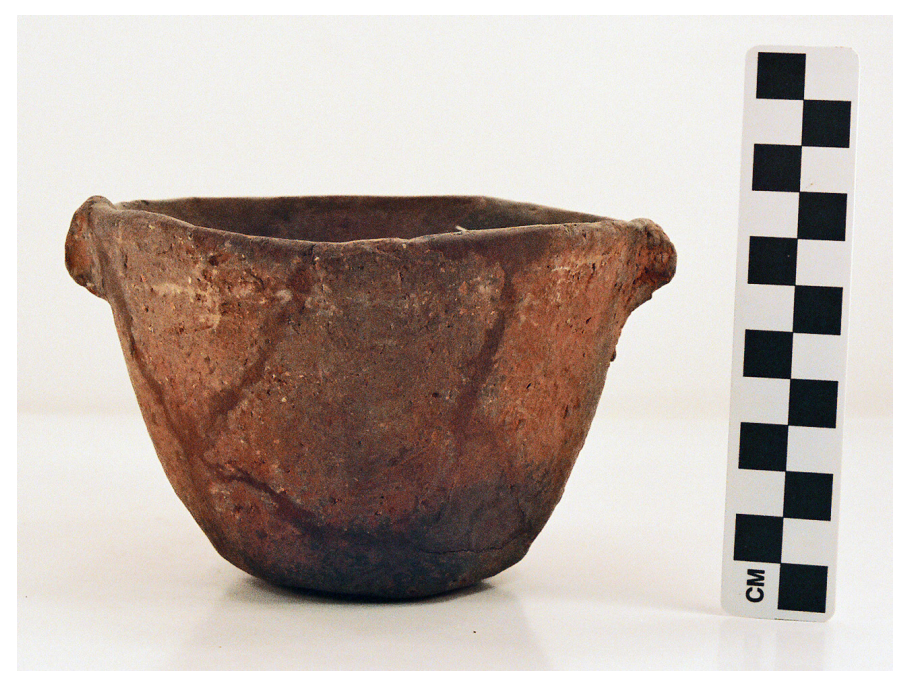

Figure 20. Plain jar (Vessel 41AN1-18).

ESTIMATED VOLUME: 0.6 liters

DECORATION: Plain

TYPE: Undetermined plain ware vessel 
SITE NO.: 41AN1

FEATURE: Burial E-3

VESSEL NO.: 41AN1-19

NON-PLASTICS: grog and hematite

VESSEL FORM: Jar with a direct rim and a flat lip

CORE COLOR: A (fired and cooled in a high oxygen environment)

WALL THICKNESS: $6.5 \mathrm{~mm}$

INTERIOR SURFACE TREATMENT:

smoothed

EXTERIOR SURFACE TREATMENT:

none

HEIGHT: $13.5 \mathrm{~cm}$

ORIFICE DIAMETER: $15.7 \mathrm{~cm}$

DIAMETER AT BOTTOM OF RIM OR

NECK: $11.8 \mathrm{~cm}$

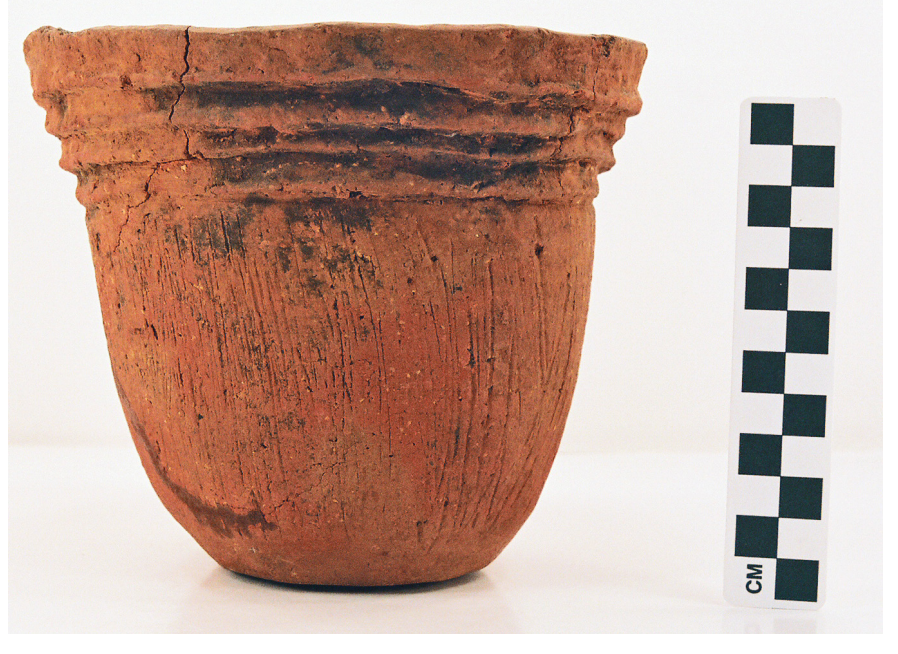

BASE DIAMETER: $7.3 \mathrm{~cm}$

Figure 21. La Rue Neck Banded jar (Vessel 41AN1-19).

ESTIMATED VOLUME: 1.3 liters

DECORATION: The rim has four rows of neck bands or corrugations (i.e., overhanging, unsmoothed coils), while the vessel body has vertical brushed marks that extend to near the base of the vessel (Figure 21).

TYPE: La Rue Neck Banded 
SITE NO.: 41AN1

FEATURE: Burial E-4

VESSEL NO.: 41AN1-23

NON-PLASTICS: grog and small amounts of hematite

VESSEL FORM: Effigy bowl with an everted rim and a rounded lip; the effigy head is missing, but there is a $3.4 \mathrm{~cm}$ wide tab tail on one end of the vessel (Figure 22)

CORE COLOR: A (fired and cooled in an oxidizing environment); pinkware

WALL THICKNESS: $5.6 \mathrm{~mm}$

INTERIOR SURFACE TREATMENT:

burnished

EXTERIOR SURFACE TREATMENT:

burnished

HEIGHT: $7.5 \mathrm{~cm}$

ORIFICE DIAMETER: $14.5 \mathrm{~cm}$

DIAMETER AT BOTTOM OF RIM OR

NECK: N/A

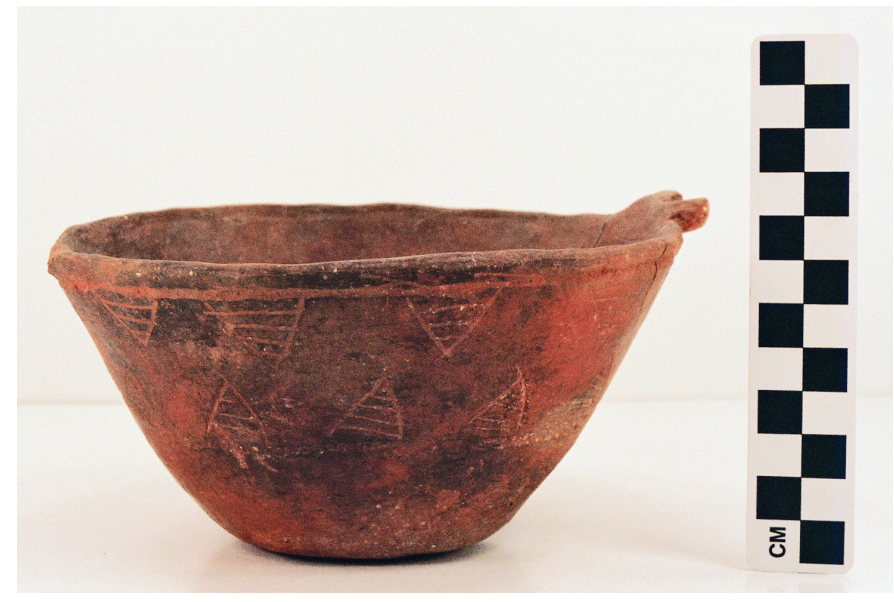

Figure 22. Hood Engraved, var. Cook effigy vessel (Vessel 41AN1-23).

ESTIMATED VOLUME: 0.4 liters

DECORATION: There is an engraved panel on the rim with upper and lower sets of horizontally hatched pendant triangles (Figure 22). Each set has 12 triangles, with the apex of the upper set pointing downward, and the apex of the lower set pointing upwards. The apex of the two sets of triangles do not touch.

TYPE: Hood Engraved, var. Cook effigy bowl 
SITE NO.: 41AN1

FEATURE: Burial E-4

VESSEL NO.: 41AN1-24

NON-PLASTICS: fine grog

VESSEL FORM: Globular carinated bowl with an everted rim and a rounded, exterior folded, lip

CORE COLOR: $\mathrm{G}$ (fired in a reducing environment, and cooled in the open air)

WALL THICKNESS: $3.8 \mathrm{~mm}$

INTERIOR SURFACE TREATMENT: burnished

EXTERIOR SURFACE TREATMENT: burnished

HEIGHT: $8.3 \mathrm{~cm}$

ORIFICE DIAMETER: $10.4 \mathrm{~cm}$

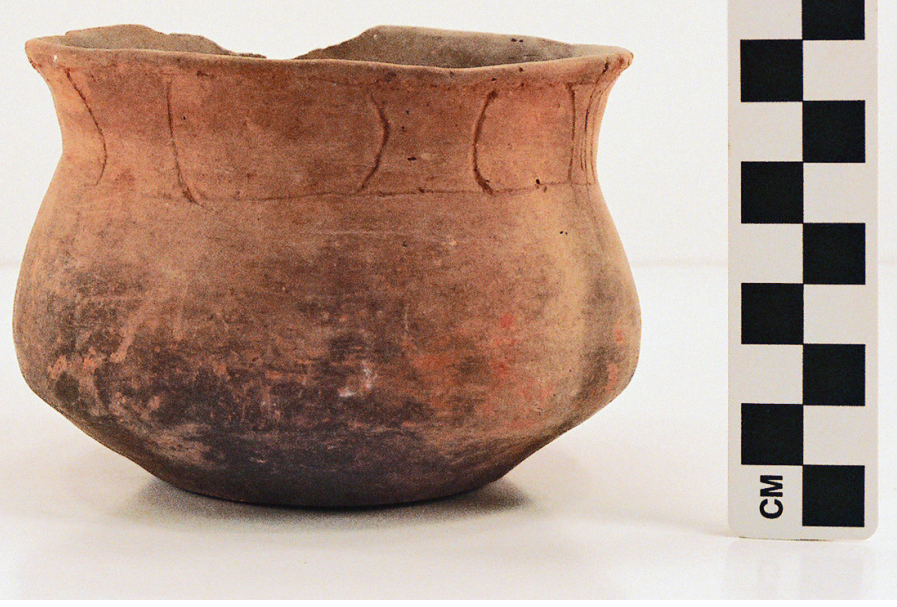

DIAMETER AT BOTTOM OF RIM OR NECK: $9.6 \mathrm{~cm}$

Figure 23. Poynor Engraved, var. Cook carinated bowl

BASE DIAMETER: $6.5 \mathrm{~cm}$ (Vessel 41AN1-24).

ESTIMATED VOLUME: 0.5 liters

DECORATION: The rim has 11 engraved ovals within a panel defined by upper and lower horizontal engraved lines on the rim (Figure 23). The ovals are defined by only two curvilinear engraved lines, and some of the ovals are divided by a single short vertical engraved line.

TYPE: Poynor Engraved, var. Cook 
SITE NO.: 41AN1

FEATURE: Burial E-4

VESSEL NO.: 41AN1-25

NON-PLASTICS: grog

VESSEL FORM: Jar with an everted rim and a rounded, slightly exterior folded, lip; two lug handles

CORE COLOR: $\mathrm{H}$ (fired in a reducing environment, but cooled in the open air)

WALL THICKNESS: $7.7 \mathrm{~mm}$

INTERIOR SURFACE TREATMENT: smoothed

EXTERIOR SURFACE TREATMENT: none

HEIGHT: $12.0 \mathrm{~cm}$

ORIFICE DIAMETER: $11.25 \mathrm{~cm}$

DIAMETER AT BOTTOM OF RIM OR NECK: $10.6 \mathrm{~cm}$

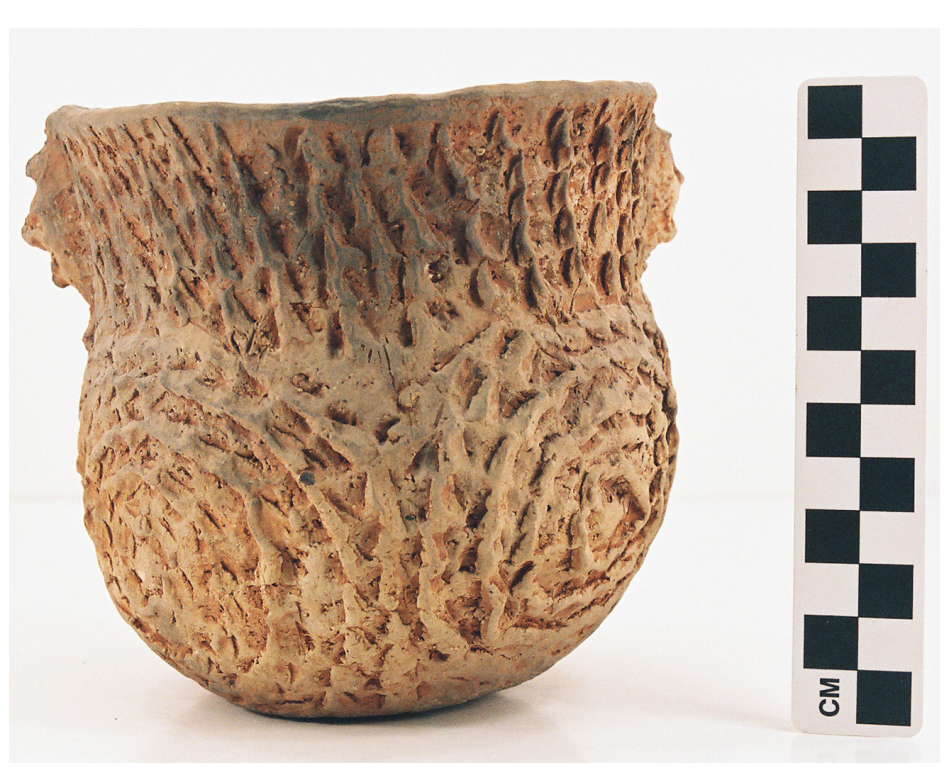

Figure 24. Killough Pinched jar (Vessel 41AN1-25).

BASE DIAMETER: $6.0 \mathrm{~cm}$

ESTIMATED VOLUME: 0.8 liters

DECORATION: The rim and lug handles are decorated with vertical rows of pinching (Figure 24). The body has four repeating pinched circles centered under the lugs.

TYPE: Killough Pinched 
SITE NO.: 41AN1

FEATURE: Burial E-4

VESSEL NO.: 41AN1-26

NON-PLASTICS: grog and hematite

VESSEL FORM: Carinated bowl with an inverted rim and a rounded lip

CORE COLOR: $\mathrm{H}$ (fired in a reducing environment, but cooled in the open air)

WALL THICKNESS: $6.0 \mathrm{~mm}$, rim

INTERIOR SURFACE TREATMENT: burnished on the rim, smoothed on the body

EXTERIOR SURFACE TREATMENT: burnished on the rim, smoothed on the body

HEIGHT: $11.0 \mathrm{~cm}$

ORIFICE DIAMETER: $14.3 \mathrm{~cm}$

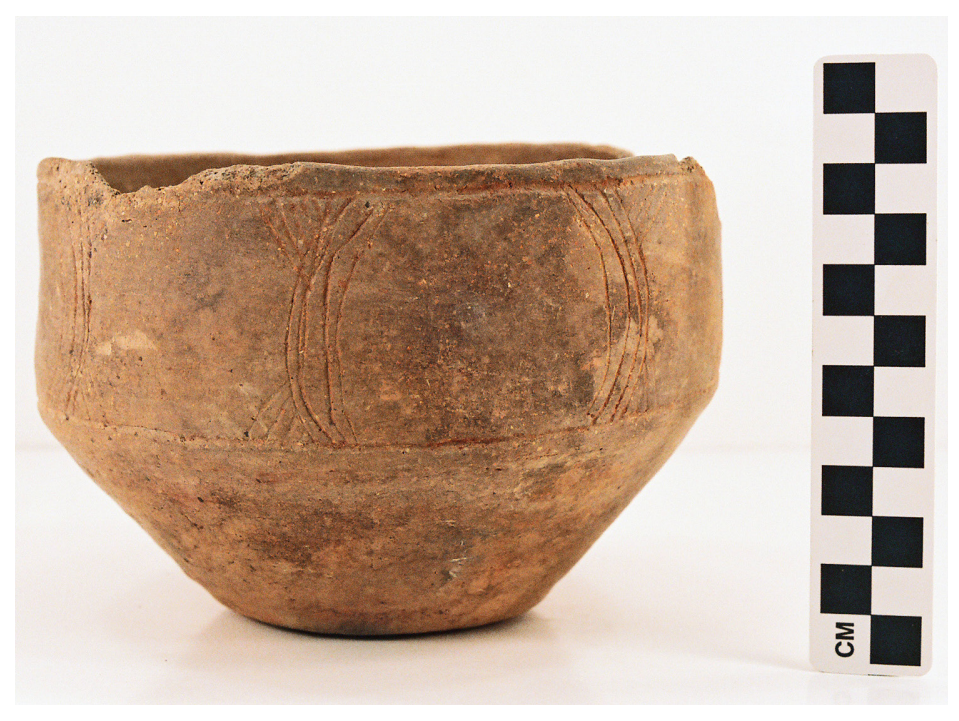

DIAMETER AT BOTTOM OF RIM

OR NECK: $14.6 \mathrm{~cm}$

Figure 25. Poynor Engraved, var. Cook carinated bowl (Vessel 41AN1-26).

BASE DIAMETER: $6.7 \mathrm{~cm}$

ESTIMATED VOLUME: 1.0 liters

DECORATION: The rim has a panel comprised of four ovals. The ovals are defined by sets of four closely-spaced engraved arcs that extend from upper to lower horizontal engraved lines that encircle the rim (Figure 25). There are four hatched triangular elements on the upper and lower parts of the vertical arcs.

TYPE: Poynor Engraved, var. Cook 
SITE NO.: 41AN1

FEATURE: Burial E-5

VESSEL NO.: 41AN1-27

NON-PLASTICS: grog and hematite

VESSEL FORM: Bottle with a short neck, a globular body, a direct rim, and a flat lip

CORE COLOR: Undetermined

WALL THICKNESS: $5.7 \mathrm{~mm}$

INTERIOR SURFACE TREATMENT: none

EXTERIOR SURFACE TREATMENT: smoothed

HEIGHT: $16.0 \mathrm{~cm}$

ORIFICE DIAMETER: $4.0 \mathrm{~cm}$

DIAMETER AT BOTTOM OF RIM OR

NECK: $5.3 \mathrm{~cm}$

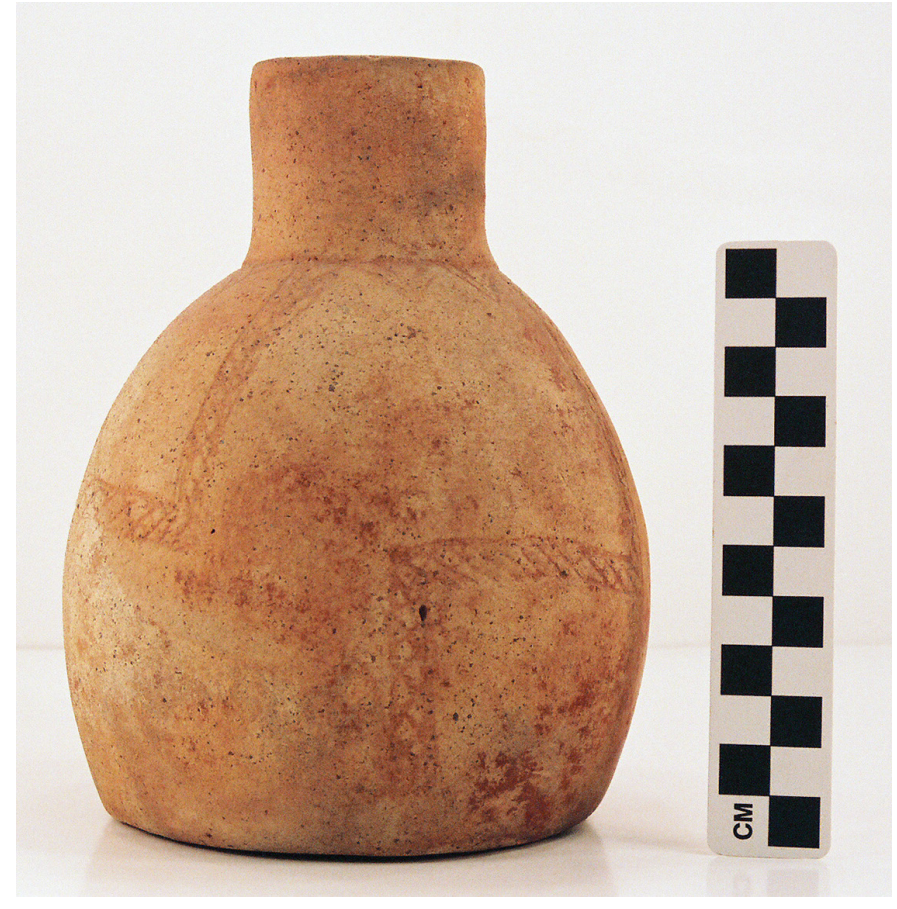

Figure 26. Hume Engraved, var. unspecified bottle (Vessel 41AN1-27).

ESTIMATED VOLUME: 0.65 liters

DECORATION: The body is decorated with two different engraved motifs (Figure 26). There are eight hatched pendant triangles at the upper part of the body, directly under the neck, and three vertically oriented cross-hatched and rectilinear engraved bands (i.e., wide interlocking scrolls) that begin at the body-neck juncture and extend almost to the vessel base.

TYPE: Hume Engraved, var. unspecified 
SITE NO.: 41AN1

FEATURE: Burial E-5

VESSEL NO.: 41AN1-28

NON-PLASTICS: grog

VESSEL FORM: Bottle with a long neck, with a direct rim and a rounded lip, and a short and squat body/base (i.e., a Fair Plain bottle form)

CORE COLOR: A (fired and cooled in an oxidizing environment)

WALL THICKNESS: $4.1 \mathrm{~mm}$, rim

INTERIOR SURFACE TREATMENT: none

EXTERIOR SURFACE TREATMENT: smoothed

HEIGHT: $17.6 \mathrm{~cm}$

ORIFICE DIAMETER: $4.0 \mathrm{~cm}$ (neck)

DIAMETER AT BOTTOM OF RIM OR

NECK: $8.9 \mathrm{~cm}$ on the body

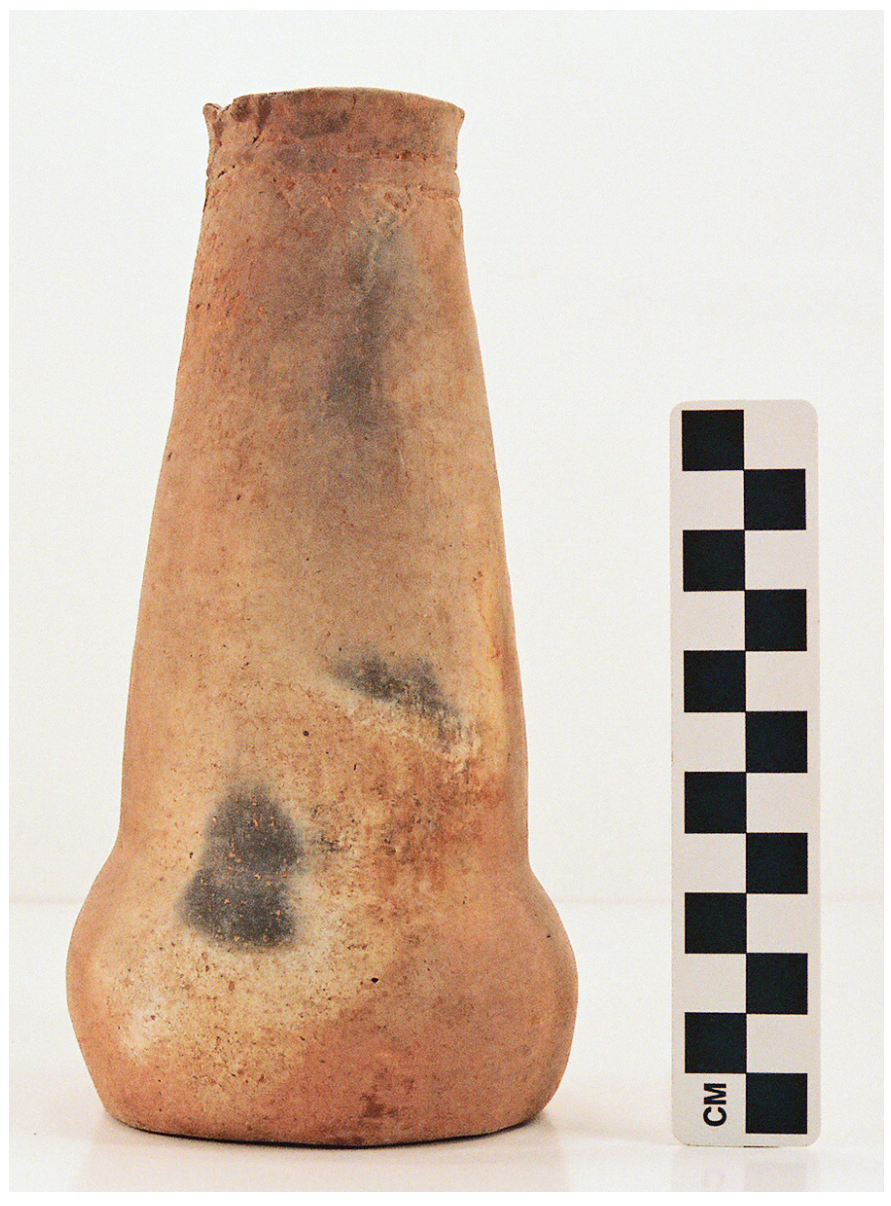

Figure 27. Hume Engraved, var. Allen (?) bottle (Vessel 41AN1-28).

BASE DIAMETER: $7.86 \mathrm{~cm}$

ESTIMATED VOLUME: 0.6 liters

DECORATION: The bottle is decorated only on the neck. There are two horizontal engraved lines near the rim, and the lower engraved line has six hatched pendant triangles (Figure 27).

TYPE: Hume Engraved, var. Allen? 
SITE NO.: 41AN1

FEATURE: Burial E-5

VESSEL NO.: 41AN1-29

NON-PLASTICS: grog

VESSEL FORM: Carinated bowl with a direct rim and a rounded lip

CORE COLOR: B (fired and cooled in a reducing environment)

WALL THICKNESS: $6.3 \mathrm{~mm}$

INTERIOR SURFACE TREAT-

MENT: poorly smoothed

EXTERIOR SURFACE TREAT-

MENT: burnished

HEIGHT: $9.1 \mathrm{~cm}$

ORIFICE DIAMETER: $12.3 \mathrm{~cm}$

DIAMETER AT BOTTOM OF RIM

OR NECK: $12.3 \mathrm{~cm}$

\section{BASE DIAMETER: $5.7 \mathrm{~cm}$}

ESTIMATED VOLUME: 0.7 liters

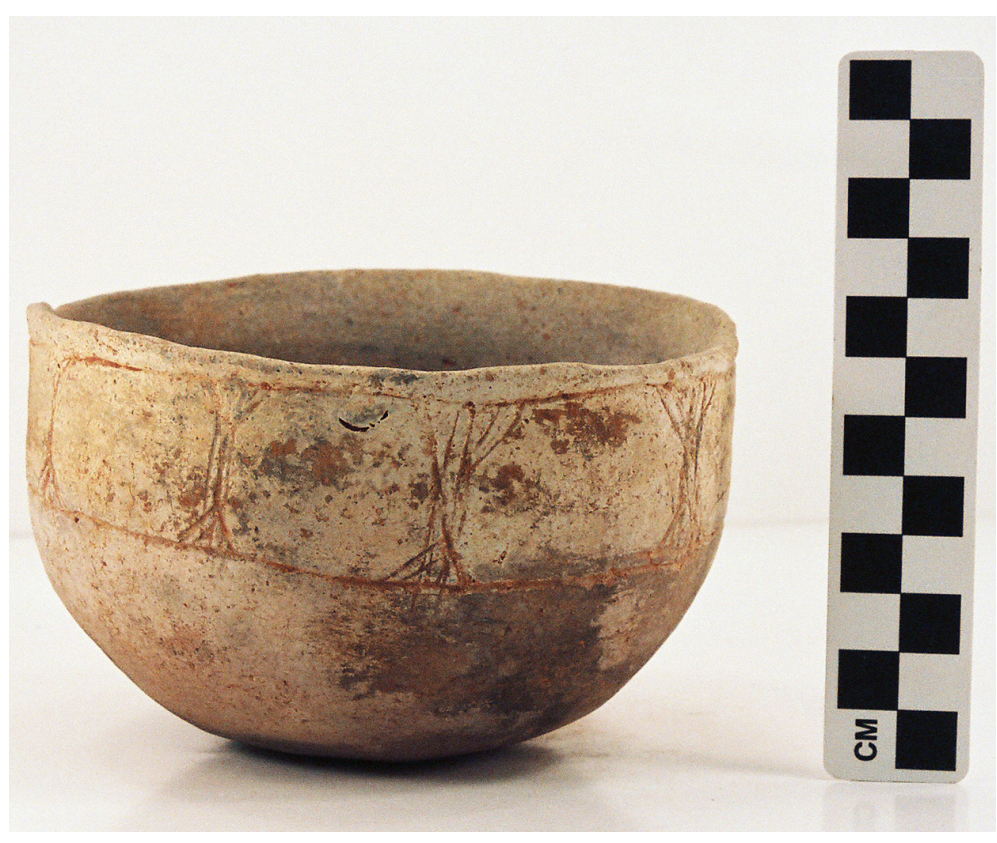

Figure 28. Poynor Engraved, var. Blackburn carinated bowl (Vessel 41AN1-29).

DECORATION: The rim has nine engraved panels - all rectangular - set between horizontal engraved lines under the lip and at the carination. The panels are defined by two vertical engraved lines at opposite ends of the rectangle, with triangular hatched areas in each corner (Figure 28).

TYPE: Poynor Engraved, var. Blackburn 
SITE NO.: 41AN1

FEATURE: Burial E-5

VESSEL NO.: 41AN1-30

NON-PLASTICS: grog and hematite

VESSEL FORM: Jar with a direct rim and a rounded lip, two strap handles, and four legs on a ring or pedestal base (Figure 29)

CORE COLOR: A (fired and cooled in a high oxygen environment); pinkware

WALL THICKNESS: $5.7 \mathrm{~mm}$

INTERIOR SURFACE TREATMENT: smoothed

EXTERIOR SURFACE TREATMENT: none

HEIGHT: $12.0 \mathrm{~cm}$

ORIFICE DIAMETER: $9.0 \mathrm{~cm}$

DIAMETER AT BOTTOM OF RIM OR NECK: $9.7 \mathrm{~cm}$

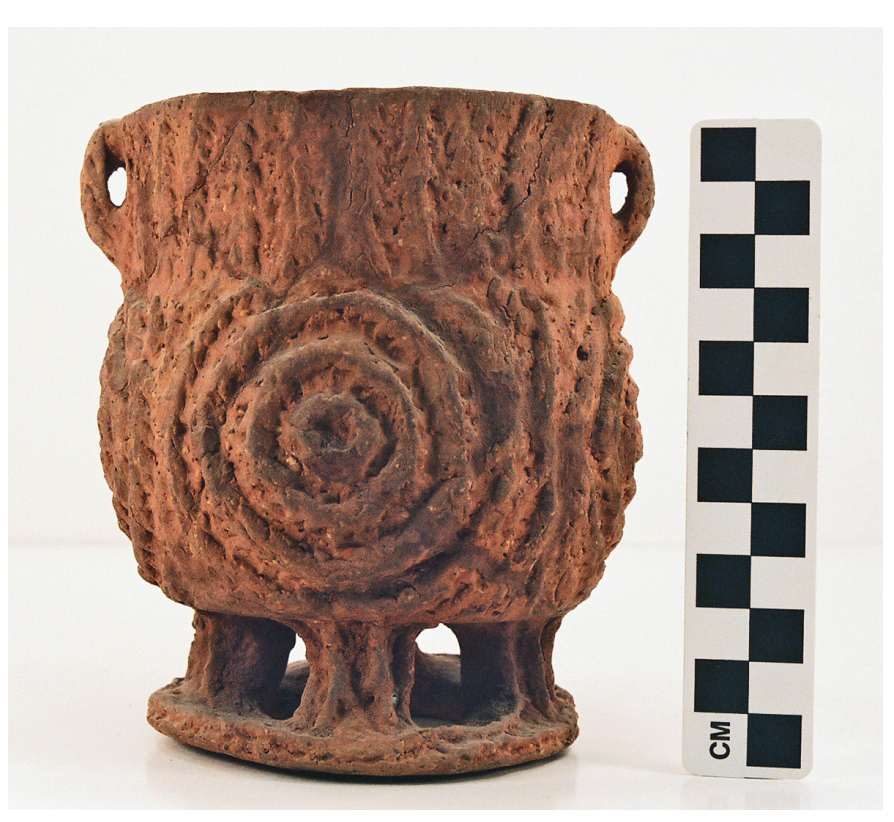

Figure 29. Killough Pinched jar (Vessel 41AN1-30).

BASE DIAMETER: $8.5 \mathrm{~cm}$

ESTIMATED VOLUME: 0.65 liters

DECORATION: Vertical pinched rows on the vessel rim, strap handles, and legs of the ring base, with four sets of circular pinched rows (concentric circles) on the body (Figure 29).

TYPE: Killough Pinched 
SITE NO.: 41AN1

FEATURE: Burial E-5

VESSEL NO.: 41AN1-31

NON-PLASTICS: grog and bone

VESSEL FORM: Bowl with a direct rim and a rounded lip

CORE COLOR: Undetermined

WALL THICKNESS: $5.1 \mathrm{~mm}$

INTERIOR SURFACE TREATMENT:

smoothed

EXTERIOR SURFACE TREATMENT:

burnished

HEIGHT: $7.5 \mathrm{~cm}$

ORIFICE DIAMETER: $16.3 \mathrm{~cm}$

DIAMETER AT BOTTOM OF RIM

OR NECK: N/A

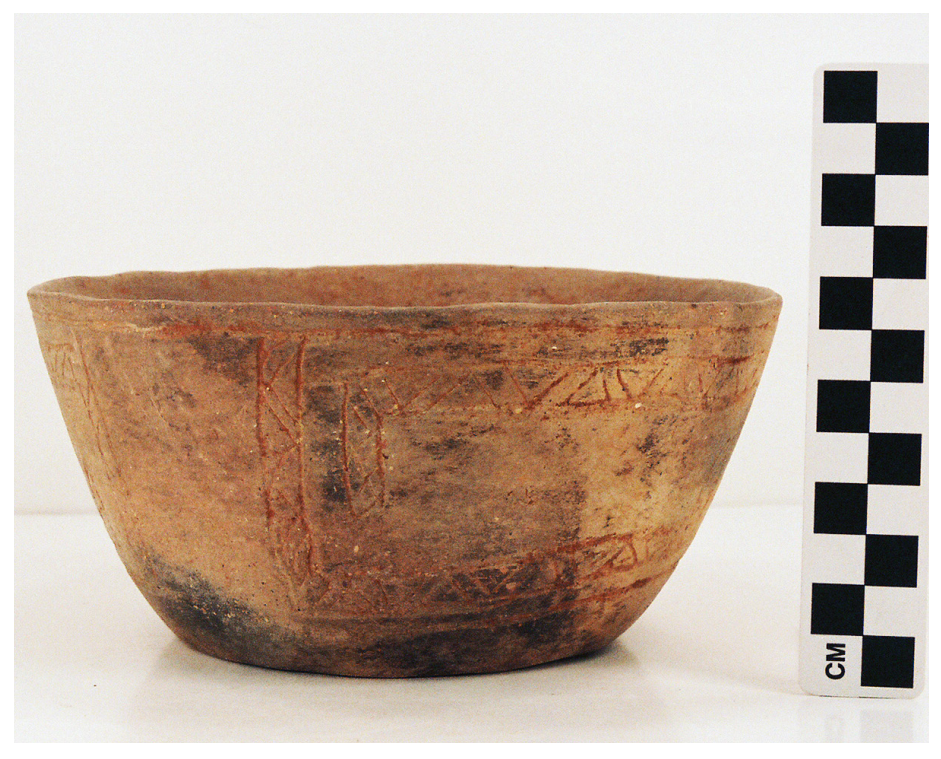

BASE DIAMETER: $9.0 \mathrm{~cm}$

ESTIMATED VOLUME: 0.5 liters

Figure 30. Unidentified engraved bowl (Vessel 41AN1-31).

DECORATION: The rim has an engraved panel set between horizontal lines under the lip and at the vessel carination. There are two distinct motifs comprising the panel, each repeated twice; the panels are divided by a single vertical engraved line with hatched pendant triangles. The first set of panels consists of hatched interlocking horizontal scrolls (Figure 30). The second set of panels has a single hatched and cross-hatched interlocking horizontal scroll, and the cross-hatched areas at the end of the scroll-and in a fill element above the scroll-are diamond-shaped, suggesting part of a canebrake rattlesnake body element (Walters 2006:Figure 31).

TYPE: Undetermined engraved vessel; Kleinschmidt (1982) identifies the engraved motif on this vessel as Hume Engraved, Motif 4. 
SITE NO.: 41AN1

FEATURE: Burial E-6

VESSEL NO.: 41AN1-34

NON-PLASTICS: grog and hematite

VESSEL FORM: Effigy bowl with a direct rim and a rounded lip. The effigy (a bird head) is attached to the rim at one end of the vessel and there is a tab tail at the opposite end of the vessel (Figure 31).

CORE COLOR: Undetermined

WALL THICKNESS: $6.3 \mathrm{~mm}$

INTERIOR SURFACE TREAT-

MENT: smoothed

EXTERIOR SURFACE TREAT-

MENT: smoothed

HEIGHT: $6.3 \mathrm{~cm}$

ORIFICE DIAMETER: $13.0 \mathrm{~cm}$

DIAMETER AT BOTTOM OF RIM OR NECK: N/A

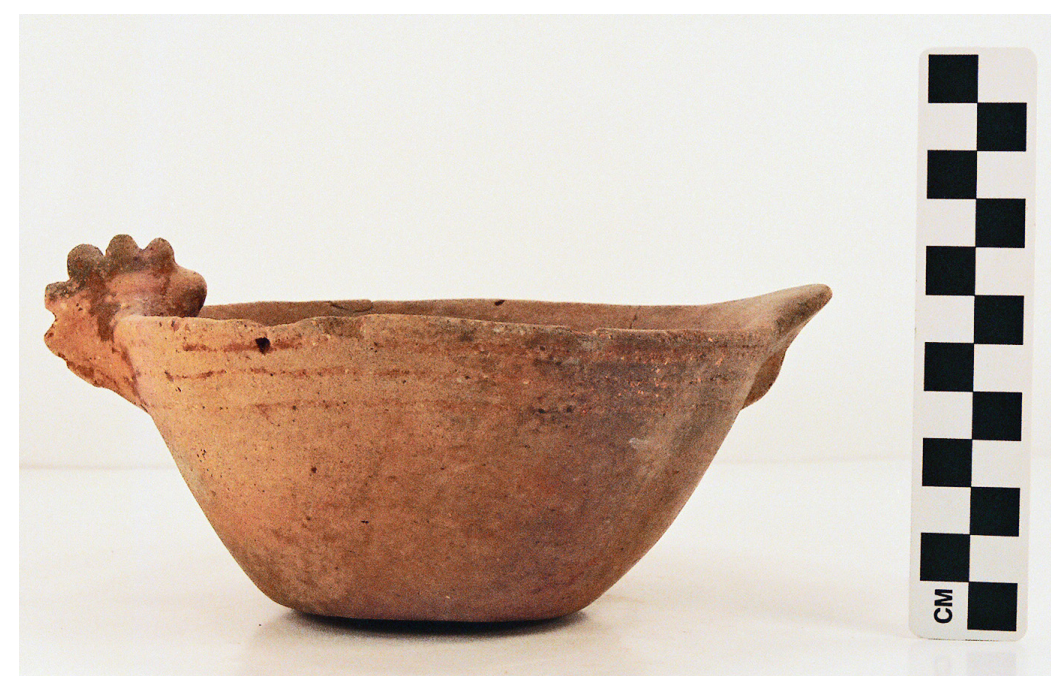

BASE DIAMETER: $7.0 \mathrm{~cm}$

Figure 31. Hood Engraved, var. Hood effigy bowl (Vessel 41AN1-34).

ESTIMATED VOLUME: 0.3

liters

DECORATION: Three broad and widely-spaced horizontal engraved lines on the rim (Figure 31); a red clay pigment has been rubbed in the engraved lines.

TYPE: Hood Engraved, var. Hood effigy vessel 
SITE NO.: 41AN1

FEATURE: Burial E-6

VESSEL NO.: 41AN1-35

NON-PLASTICS: grog

VESSEL FORM: Carinated bowl with a direct rim and a rounded lip

CORE COLOR: F (fired in a reducing environment and cooled in the open air)

WALL THICKNESS: $6.3 \mathrm{~mm}$

INTERIOR SURFACE TREAT-

MENT: smoothed on the rim

EXTERIOR SURFACE TREAT-

MENT: burnished

HEIGHT: $11.8 \mathrm{~cm}$

ORIFICE DIAMETER: $24.0 \mathrm{~cm}$

DIAMETER AT BOTTOM OF RIM

OR NECK: $24.4 \mathrm{~cm}$

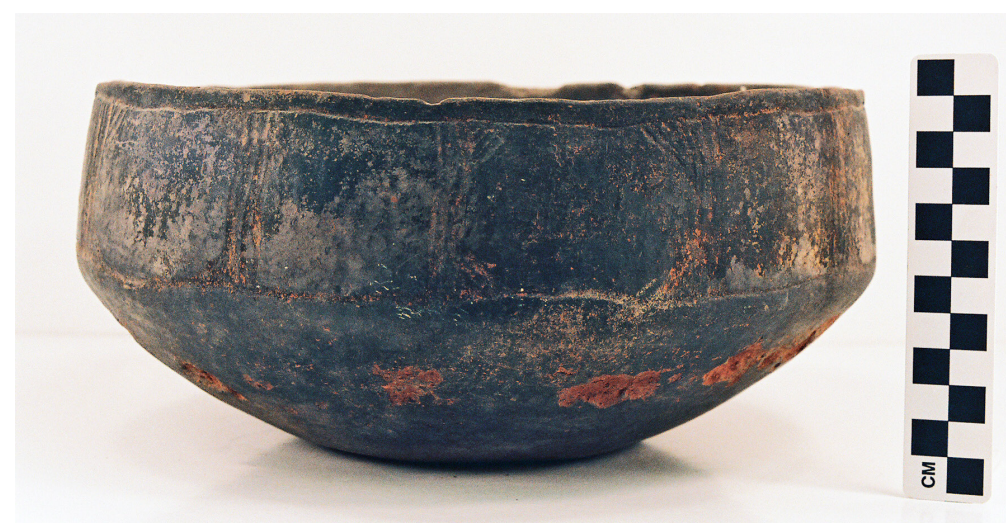

BASE DIAMETER: $9.6 \mathrm{~cm}$

ESTIMATED VOLUME: 1.7 liters

Figure 32. Poynor Engraved, var. Blackburn carinated bowl (Vessel 41AN1-35).

DECORATION: There are seven engraved panels on the rim, and the panels are defined by upper and lower horizontal engraved lines. The panels are large rectangles with hatched triangles at the four corners of the rectangle (Figure 32). Each rectangle is defined by four closely-spaced vertical engraved lines.

There is a narrow blank rectangle created by the sets of vertical engraved lines between each of the rectangular panels.

TYPE: Poynor Engraved, var. Blackburn 
SITE NO.: 41AN1

FEATURE: Burial E-6

VESSEL NO.: 41AN1-36

NON-PLASTICS: hematite

VESSEL FORM: Shallow bowl with four lip tabs (Figure 33)

CORE COLOR: Undetermined

WALL THICKNESS: $4.8 \mathrm{~mm}$

INTERIOR SURFACE TREAT-

MENT: none

EXTERIOR SURFACE TREATMENT: none

HEIGHT: $3.0 \mathrm{~cm}$

ORIFICE DIAMETER: $12.2 \mathrm{~cm}$

DIAMETER AT BOTTOM OF RIM OR NECK: N/A

BASE DIAMETER: $6.8 \mathrm{~cm}$

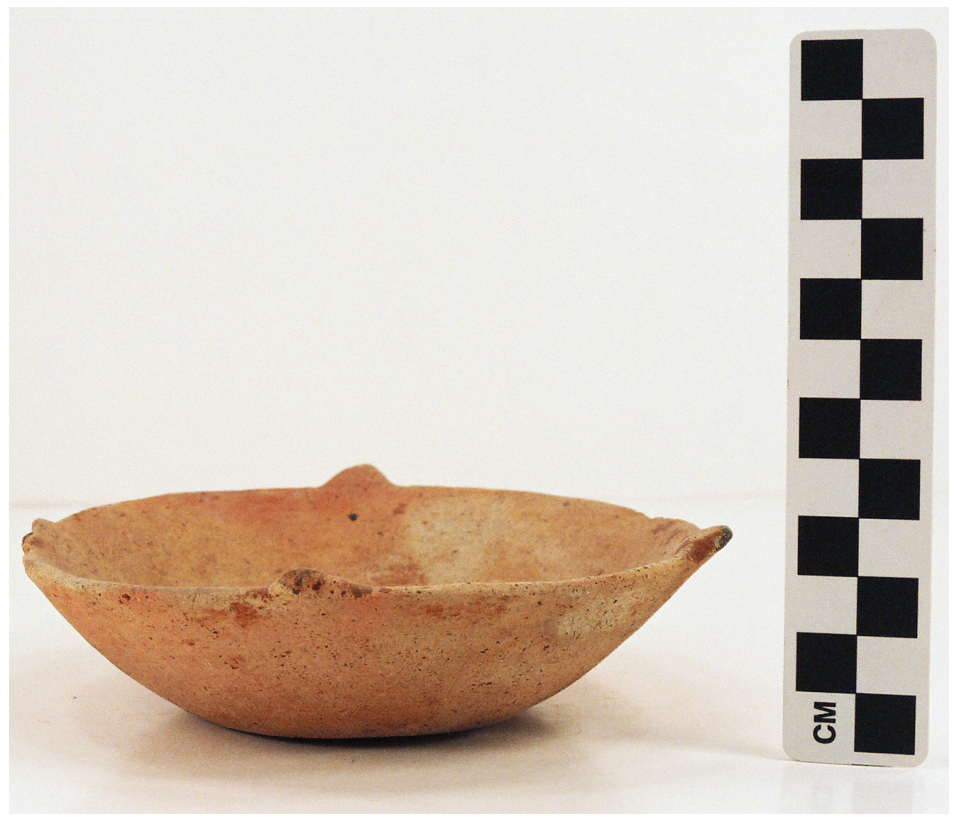

Figure 33. Plain bowl (Vessel 41AN1-36).

ESTIMATED VOLUME: 0.15 liters

DECORATION: plain

TYPE: Undetermined plain ware vessel 
SITE NO.: 41AN1

FEATURE: Burial E-6

VESSEL NO.: 41AN1-37

NON-PLASTICS: bone and grog

VESSEL FORM: Jar with a direct rim and a rounded lip

CORE COLOR: G (fired in a reducing environment and cooled in the open air)

WALL THICKNESS: $6.0 \mathrm{~mm}$

INTERIOR SURFACE TREAT-

MENT: smoothed

EXTERIOR SURFACE TREAT-

MENT: none

HEIGHT: $9.3 \mathrm{~cm}$

ORIFICE DIAMETER: $11.6 \mathrm{~cm}$

DIAMETER AT BOTTOM OF RIM

OR NECK: $11.4 \mathrm{~cm}$

BASE DIAMETER: $6.3 \mathrm{~cm}$
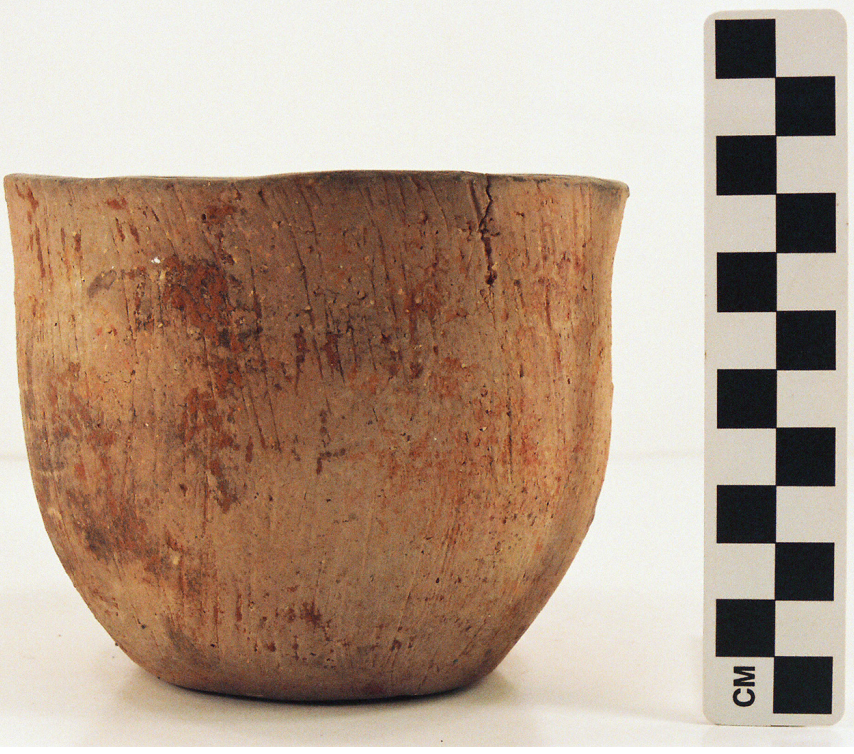

Figure 34. Bullard Brushed jar (Vessel 41AN1-37).

ESTIMATED VOLUME: 0.65 liters

DECORATION: vertical brushing from the rim to the vessel base (Figure 34)

TYPE: Bullard Brushed 
SITE NO.: 41AN1

FEATURE: Burial E-6

VESSEL NO.: 41AN1-38

NON-PLASTICS: grog

VESSEL FORM: Jar with a direct rim and a rounded lip, small strap handles, and four legs on a ring or pedestal base (Figure 35).

CORE COLOR: A (fired and cooled in a high oxygen environment); pinkware

WALL THICKNESS: $6.0 \mathrm{~mm}$, rim INTERIOR SURFACE TREATMENT: smoothed; organic residue

EXTERIOR SURFACE TREATMENT: none

HEIGHT: $17.3 \mathrm{~cm}$

ORIFICE DIAMETER: $12.8 \mathrm{~cm}$

DIAMETER AT BOTTOM OF RIM OR NECK: $12.7 \mathrm{~cm}$

BASE DIAMETER: $13.0 \mathrm{~cm}$ on ring base

ESTIMATED VOLUME: 2.0 liters

DECORATION: Vertical pinching on the vessel rim, four concentric circles comprised of curvilinear pinched rows across the body, and vertical pinching on the strap handles and the ring base legs (Figure 35).

TYPE: Killough Pinched (Suhm and Jelks 1962:Plate 46a) 
SITE NO.: 41AN1

FEATURE: Burial E-6

VESSEL NO.: 41AN1-39

NON-PLASTICS: grog

VESSEL FORM: Jar, no rim present

CORE COLOR: Undetermined

WALL THICKNESS: $8.7 \mathrm{~mm}$

INTERIOR SURFACE TREAT-

MENT: smoothed

EXTERIOR SURFACE TREAT-

MENT: none

HEIGHT: Undetermined

ORIFICE DIAMETER: Undetermined

DIAMETER AT BOTTOM OF RIM OR NECK: $15.3 \mathrm{~cm}$

BASE DIAMETER: $7.8 \mathrm{~cm}$

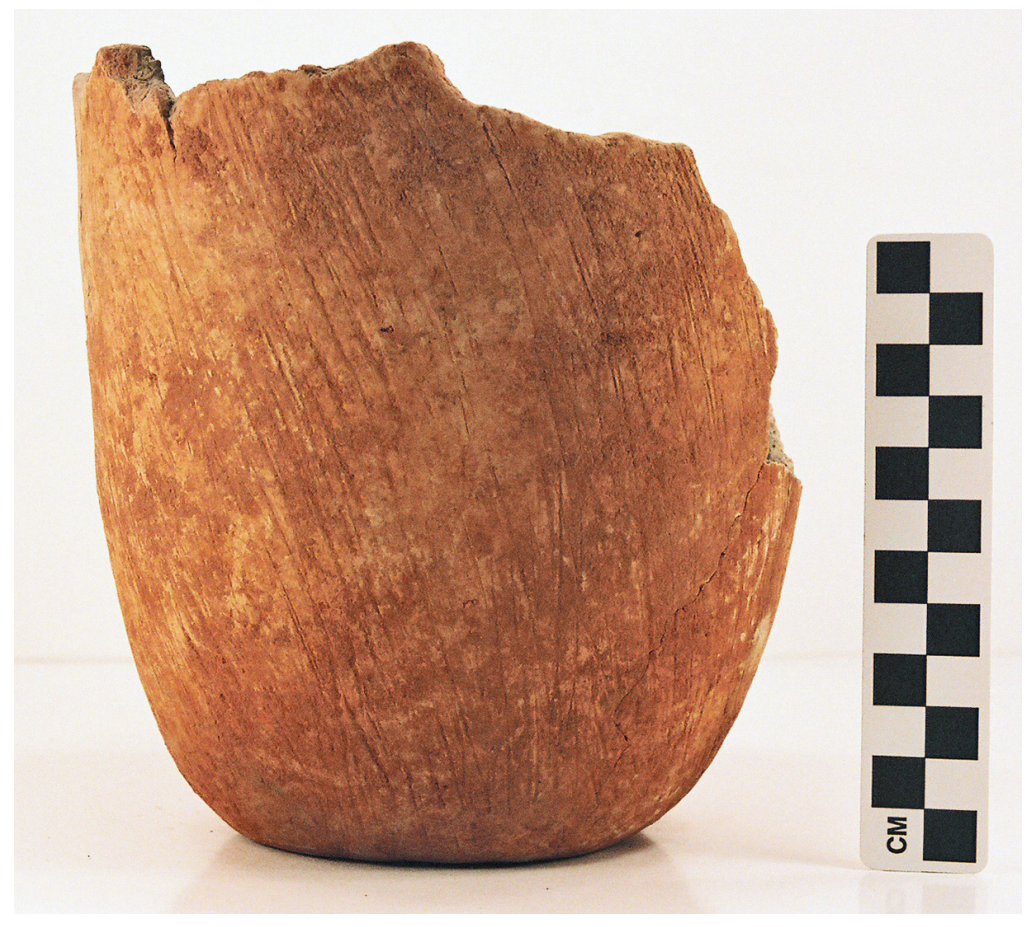

Figure 36. Bullard Brushed jar (Vessel 41AN1-39).

ESTIMATED VOLUME: Undetermined

DECORATION: diagonal brushing marks on vessel body (Figure 36)

TYPE: Bullard Brushed 
Based in part on a 1983 inventory in the TARL files, there are 350 ceramic sherds in the Mrs. J. M. Cook site collection (Table 1); this does not include a ceramic duck head effigy from a Hood Engraved vessel. Most of the vessel sherds - where the information is available-are from grog-tempered vessels (94.9 percent), and only 5.1 percent of the sherds are from vessels tempered with grog and burned bone; most of these are from utility wares.

Table 1. Sherds from ceramic wares at the Mrs. J. M. Cook site (41AN1).

\begin{tabular}{lccc} 
& Grog-tempered & Grog-bone-tempered & N \\
\hline Plain & 9 & 1 & $55+$ \\
Fine & 29 & - & 29 \\
Utility & 37 & 3 & $266^{*}+$ \\
- & 75 & 4 & $350+$ \\
Totals & & &
\end{tabular}

*does not include the punctated ceramic duck effigy head sherd

+based in part on 1983 TARL inventory

The 295 decorated sherds are dominated by sherds from utility ware vessels, as they account for 90 percent of the decorated sherd assemblage (see Table 1). Fine ware sherds, apparently all from Poynor Engraved vessels, represent only 9.8 percent of the decorated sherds in the assemblage (Table 2). The plain to decorated sherd ratio (P/DR) of the assemblage is a low 0.19 .

Table 2. Decorative methods and decorative elements in the fine ware and utility ware sherds from the Mrs. J. M. Cook site (41AN1).

Decorative method/decorative

Rim Body N

element

\section{Fine ware}

\section{Engraved}

curvilinear engraved lines

diagonal and curvilinear engraved lines

diagonal hatched triangle el. and curvilinear hatched

el.

horizontal engraved line

horizontal line and continuous hatched triangles

horizontal line and continuous hatched triangles, two

connected by vertical line/panel divider

horizontal lines and curvilinear engraved line

horizontal and curvilinear lines, hatched triangle el.,

and vertical engraved line

horizontal line and diagonal hatched triangle el.

horizontal line, horizontal hatched oval el., and concentric circle el. 
Table 2. Decorative methods and decorative elements in the fine ware and utility ware sherds from the Mrs. J. M. Cook site (41AN1), cont.

$\begin{aligned} & \text { Decorative method/decorative } \\ & \text { element }\end{aligned}$
Rim

Fine ware, cont.

Engraved

horizontal hatched triangle el.

horizontal-diagonal engraved lines

horizontal and vertical engraved lines

parallel engraved lines

parallel engraved lines and hatched triangle el.

straight engraved line

Engraved-brushed

horizontal engraved on rim and horizontal brushed on body

Excised

horizontal excised line and excised bracket

straight excised lines

$\begin{array}{lll}- & 2 & 2 \\ 3 & - & 3 \\ 1 & - & 1 \\ - & 2 & 2 \\ - & 1 & 1 \\ - & 2 & 2 \\ & & \\ - & 1 & \\ & & \\ & & 1 \\ - & & 2 \\ - & 1 & \end{array}$

\section{Utility ware}

\section{Brushed}

horizontal brushing marks

indeterminate

parallel brushing marks

$\begin{array}{ccl}1 & - & 1 \\ \text { N/A } & \text { N/A } & 226+ \\ - & 5 & 5\end{array}$

\section{Brushed-Incised}

diagonal brushed and overlying horizontal and diagonal incised lines

parallel brushing marks and overlying opposed incised lines

parallel brushing marks and straight incised line

\section{Brushed-Punctated}

parallel brushed and circular punctated row pushed through the brushing

parallel brushed and fingernail punctated rows pushed through the brushing parallel brushed and tool punctated rows pushed

through the brushing 
Table 2. Decorative methods and decorative elements in the fine ware and utility ware sherds from the Mrs. J. M. Cook site (41AN1), cont.

Decorative method/decorative

Rim Body

$\mathrm{N}$

element

Utility ware, cont.

Grooved

parallel grooved

$-\quad 3$

3

Incised

cross-hatched incised lines

diagonal opposed incised lines

straight incised line

$\begin{array}{lll} & & \\ - & 2 & 2 \\ - & 1 & 1 \\ - & 2 & 2\end{array}$

Neck Banded

horizontal neck bands

parallel neck bands

$\begin{array}{lll}2 & - & 2\end{array}$

$\begin{array}{lll}- & 3 & 3\end{array}$

Pinched

parallel pinched ridges

straight and curvilinear pinched ridges

$\begin{array}{lll}- & 2 & 2 \\ - & 1 & 1\end{array}$

Punctated

tool punctated row beneath the lip

tool punctated rows

$\begin{array}{lll}1 & - & 1 \\ - & 4 & 4\end{array}$

Totals

14

55

$295+$

+based in part on the 1983 TARL inventory

A number of the Poynor Engraved sherds may be from Poynor Engraved, var. Freeman carinated bowls with vertical brackets/panel dividers and upper and lower rows of hatched pendant triangle elements (Figure 37a-c; see also Perttula 2011:Figure 6-64h). Two body sherds have large horizontal hatched triangle elements (Figure 37d), which may be from Poynor Engraved, var. $C$ vessels (see Perttula 2011:Figure 6-65). Other Poynor Engraved sherds have diagonal hatched triangle elements (Figure 37e-f), possibly from var. Blackburn or var. Cook vessels, or vertical hatched triangle elements (Figure 37g-h). One Poynor Engraved, var. unspecified rim sherd in the fine wares had a rim panel divided into zones with either concentric circles or a horizontal hatched oval (Figure 37i), and a Poynor Engraved, var. Hood carinated bowl sherd has excised brackets on the rim panel and horizontal brushing marks on the vessel body.

In addition to the 232 rim and body sherds from Bullard Brushed vessels in the assemblage, another four brushed-incised (1.5 percent of the utility wares) and nine brushed-punctated sherds (3.3 percent) are probably also from Bullard Brushed jars. Other utility wares from the Mrs. J. M. Cook site include Lindsey Grooved (1.1 percent), Maydelle Incised (1.9 percent), La Rue Neck Banded (1.9 percent), Killough Pinched (1.1 percent), and jars with rows of tool punctations (1.9 percent of the utility wares) (see Table 2). 


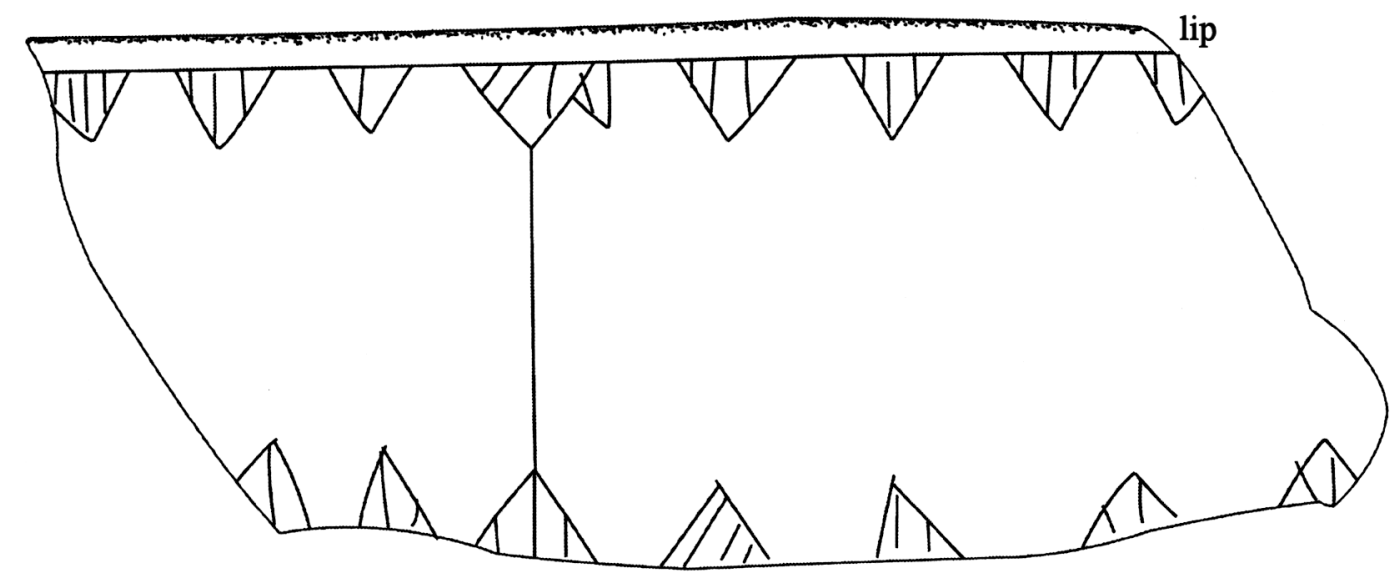

a
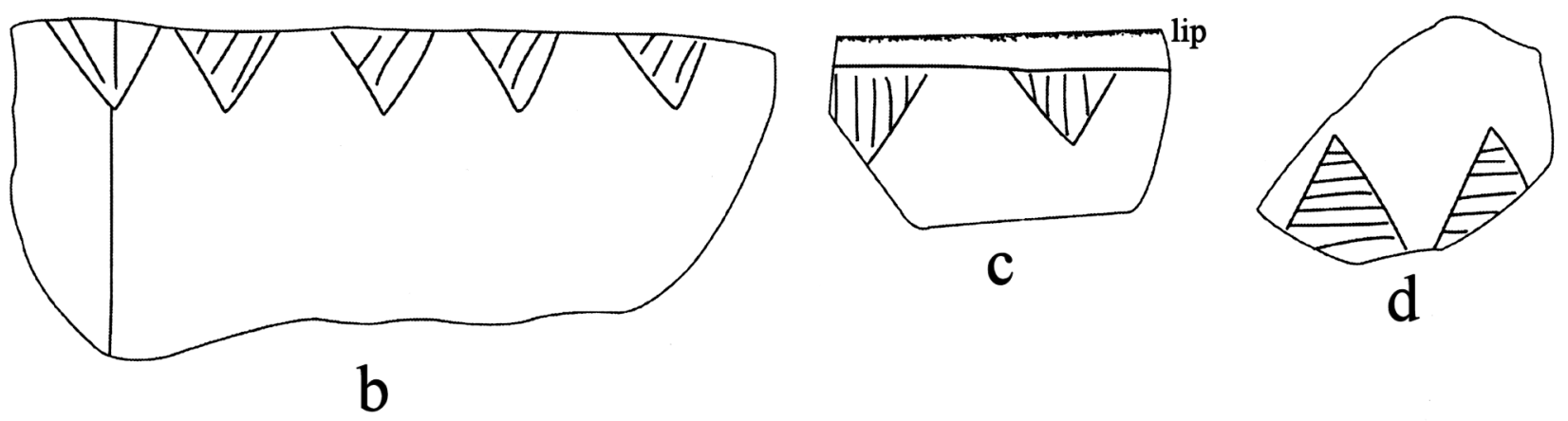

b
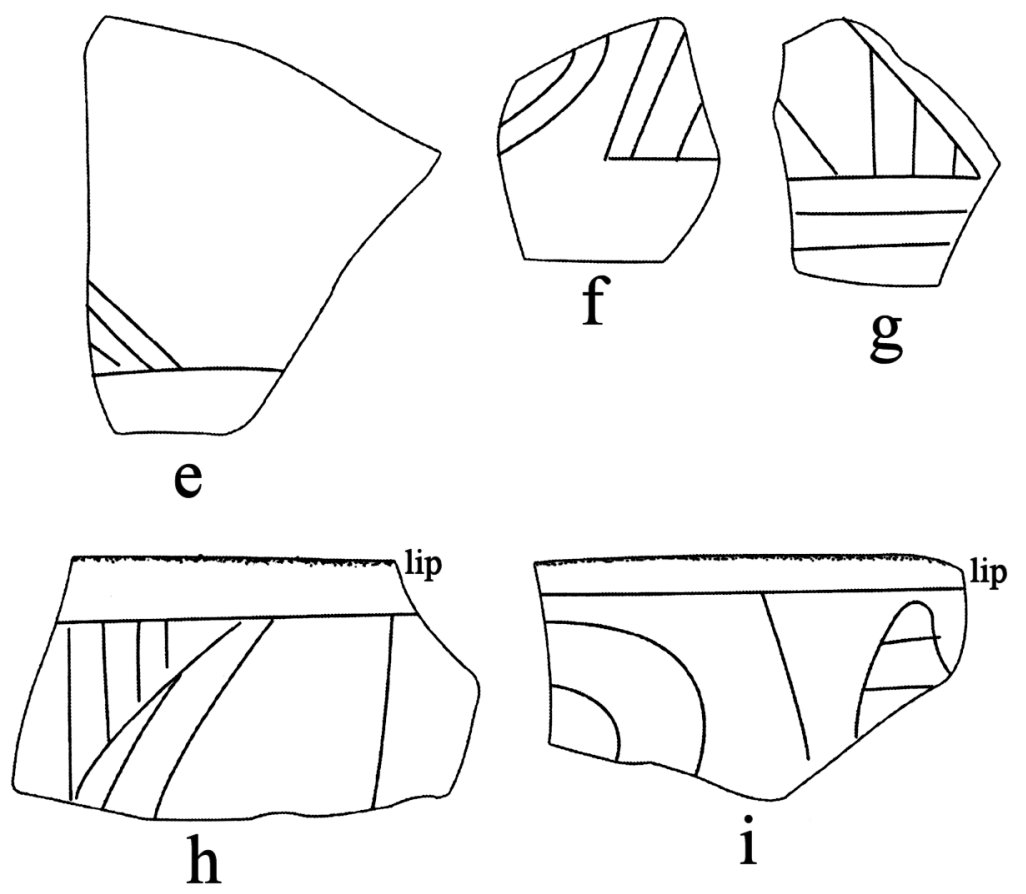

Figure 37. Selected decorative elements on engraved sherds from the Mrs. J. M. Cook site (41AN1). 
One sherd is a duck head effigy attachment to a Hood Engraved bowl (Figure 38). The head has a carved slit for a mouth, and both sides of the head have a number of circular punctations in the central part of the face.

In addition to the ceramic sherds there are three projectile points in the TARL collections from the Mrs. J. M. Cook site. This includes two Woodland period style Gary dart points made from gray chert or quartzite, with stem widths that range from 13.8-17.0 mm, and a dark gray chert Perdiz arrow point.

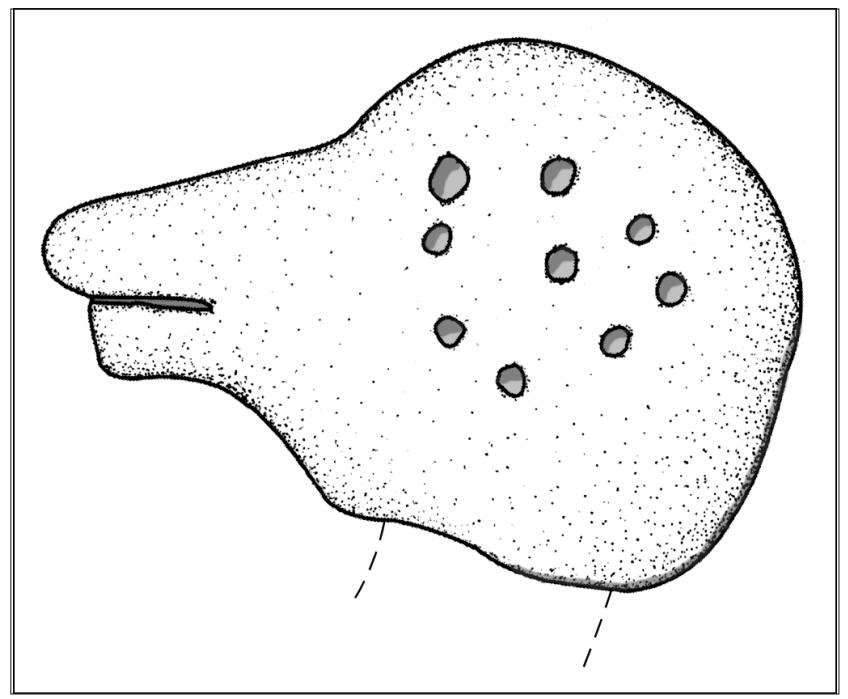

Figure 38. Decorated ceramic effigy bowl head from the Mrs. J. M. Cook site (41AN1).

\section{J.M.Cook (41AN2)}

The J. M. Cook site Caddo cemetery is on an upland landform ( $370 \mathrm{ft}$. amsl) on a spring-fed tributary of Caddo Creek; Caddo Creek lies 0.5 miles to the northeast. Jackson (1931) noted associated Caddo habitation areas ca. $200 \mathrm{~m}$ to the northwest and ca. $300 \mathrm{~m}$ to the southeast (Figure 39).

In November 1931, three ancestral Caddo burials were excavated at the site, one by a local resident and two burials (F-1 and F-2) were investigated by UT archaeologists (Jackson 1931:52-62). The latter two burials were in an extended supine position with the heads of the deceased likely facing west (Figure 40). The burial excavated by the local resident had six ceramic vessels and a ceramic pipe as associated funerary objects. The two burials excavated by UT at the J. M. Cook site had between them 11 ceramic vessels (a mean of 5.7 vessels per burial at the site) as well as 31 arrow points (29 Perdiz and two triangular forms) from Burial F-1, two large chert knives, and a ceramic pipe; the arrow points, the knives, and a ceramic pipe were funerary objects in burial F-1 (Figure 40).

Carinated bowls are well represented in the 17 mortuary vessels from the three burials at the J. M. Cook site (Jackson 1931); they account for 64.7 percent of the vessels. There are also three bowls, two bottles, and a jar in the collection. Vessel and motif seriations indicate that this cemetery dates to subphase 3 of the Frankston phase, ca. A.D. 1560-1680 (Perttula 2011). 


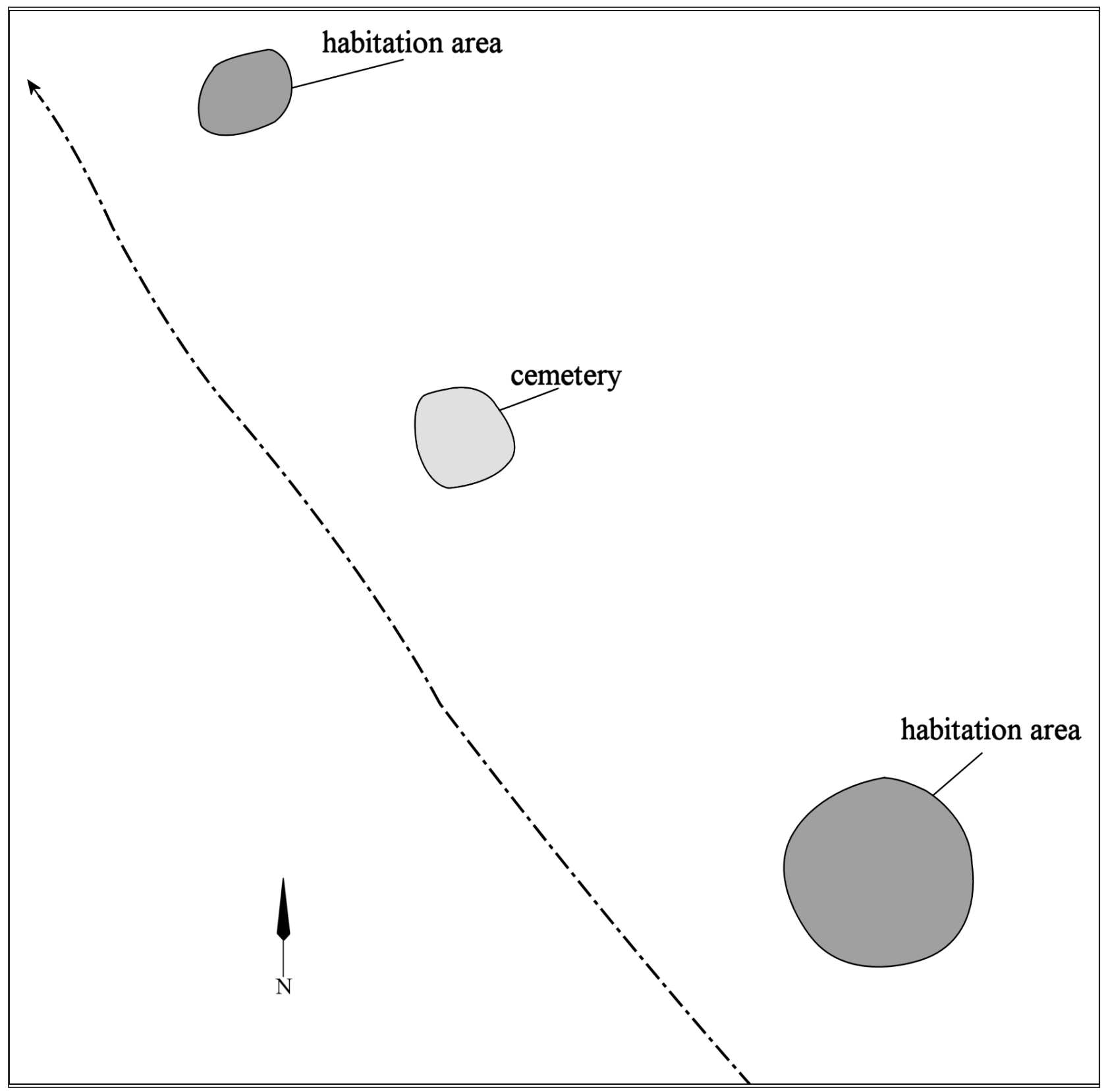

Figure 39. Habitation areas and cemetery at the J. M. Cook site (41AN2).

Only a single plain vessel is amongst the globular and vertical-rimmed carinated bowls from the site. The others are engraved, including Poynor Engraved, var. Freeman $(\mathrm{n}=5)$; Poynor Engraved, var. Cook ( $\mathrm{n}=2$, both with brushed bodies); regional Poynor Engraved, var. $T$ ( $\mathrm{n}=1$, diagonal engraved with small pendant triangles), and one vessel that has elements of both var. $E$ (scroll and circle) and var. $N$ (oval and diamond motif). This particular vssel is also brushed on the body. The last engraved carinated bowl is an unspecified variety of Patton Engraved (Motif 10 in Kleinschmidt [1982]). 


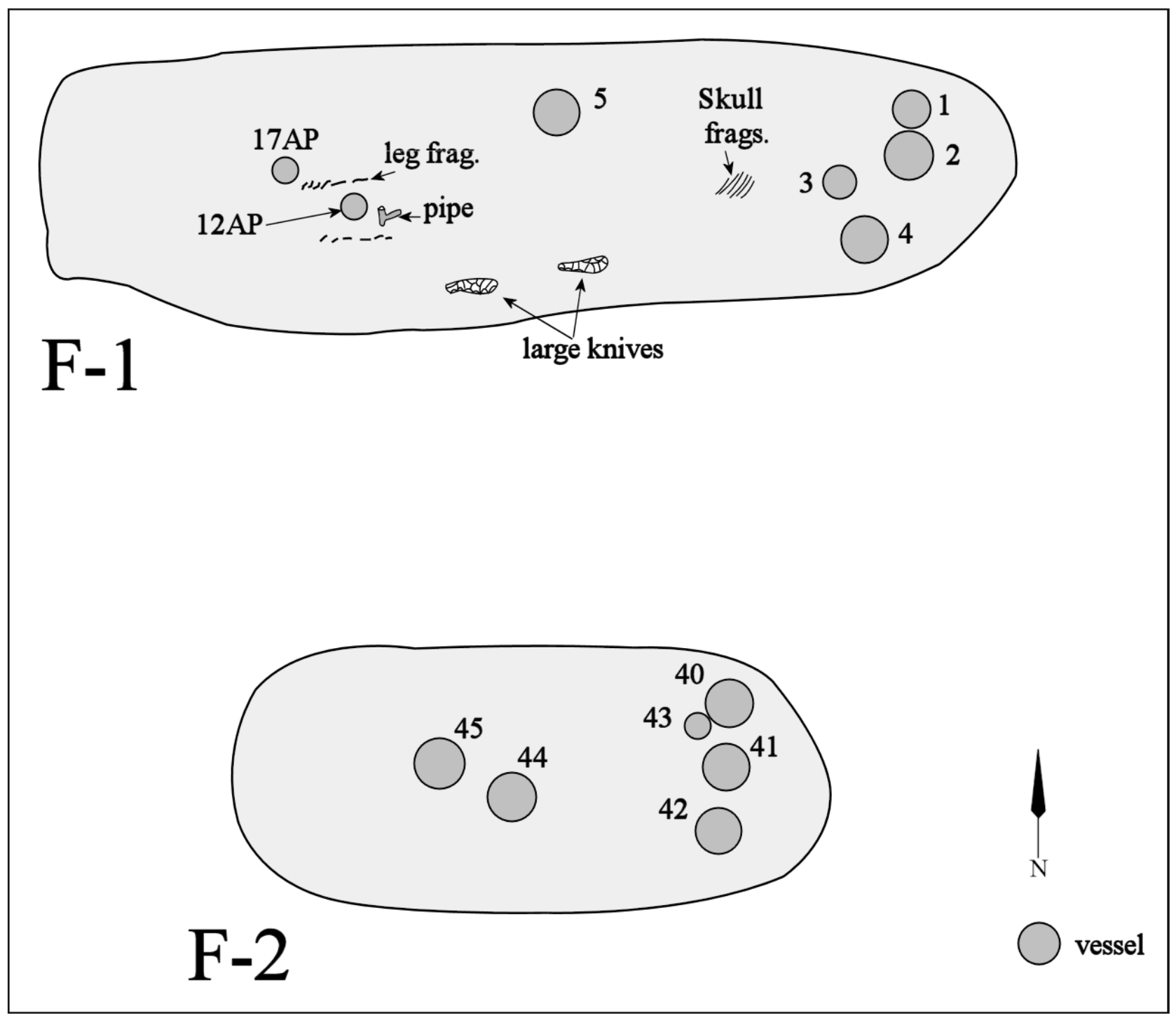

Figure 40. Plan of burial features F-1 and F-2 at the J. M. Cook site (41AN2).

One of the bowls is a Hood Engraved, var. unspecified vessel lacking the effigy head or appliqued tab tail, both of which have broken off. Another is plain, and the third has brushing on it; this vessel appears to be a cut-down carinated bowl that had brushing on the vessel body.

Both bottles have elongated bottles and short necks. One is engraved (Hume Engraved, var. Hume), but the other is a plain Hume Plain bottle.

The one jar from the J. M. Cook site is the lower brushed portion of a probable broken Bullard Brushed vessel.

There is a wide range in vessel sizes in the J. M. Cook mortuary vessels. A number of the carinated bowls are large (2-4 liters) to very large (6 liters) in volume, suggesting some communal use of these serving vessels was intended, but there are also miniature, small, and medium-sized carinated bowls in the assemblage. There is one size of bottle placed in the graves as well as one medium-sized class of bowls. 
SITE NO.: 41AN2

FEATURE: Burial F-1

VESSEL NO.: 41AN2-1

NON-PLASTICS: grog and hematite; sandy paste

VESSEL FORM: Globular carinated bowl with a direct rim and a rounded lip

CORE COLOR: Undetermined

WALL THICKNESS: $5.3 \mathrm{~mm}$, rim

INTERIOR SURFACE TREAT-

MENT: smoothed

EXTERIOR SURFACE TREAT-

MENT: smoothed; organic residue

on the rim and the lower body

HEIGHT: $10.2 \mathrm{~cm}$

ORIFICE DIAMETER: $12.0 \mathrm{~cm}$

DIAMETER AT BOTTOM OF RIM

OR NECK: $10.9 \mathrm{~cm}$

BASE DIAMETER: $4.5 \mathrm{~cm}$

ESTIMATED VOLUME: 0.7 liters

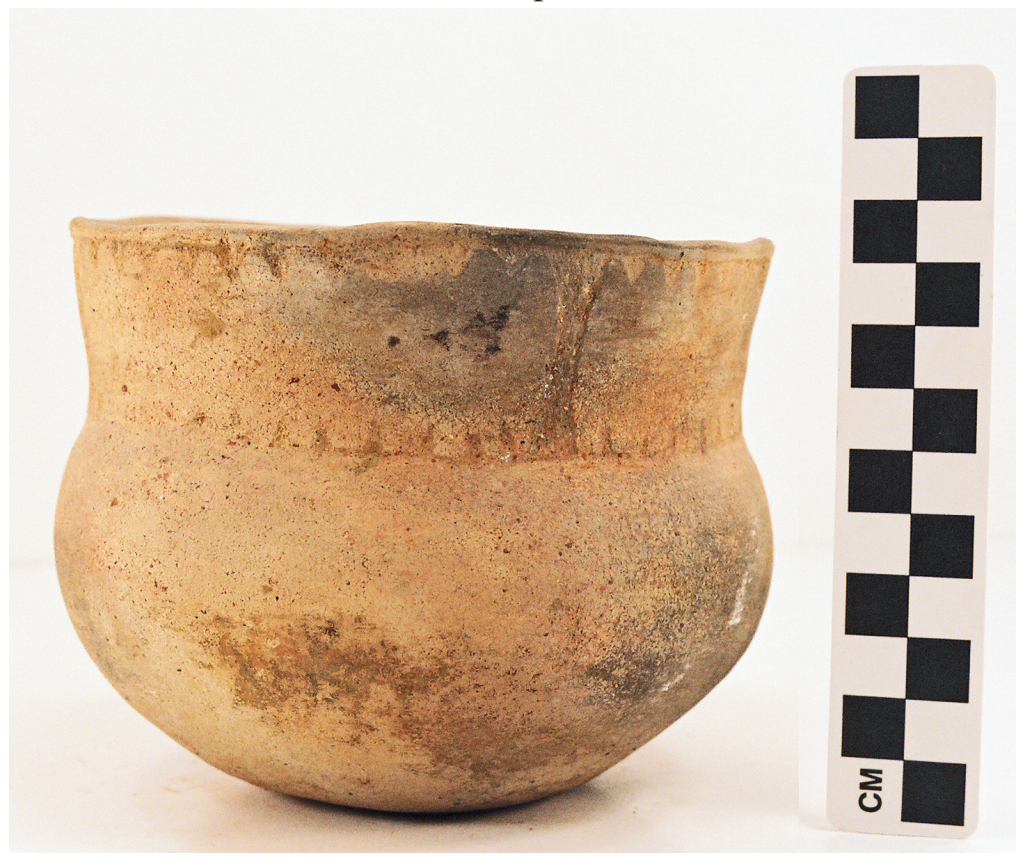

Figure 41. Poynor Engraved, var. Freeman carinated bowl (Vessel 41AN2-1).

DECORATION: There are four engraved panels on the rim (defined by upper and lower horizontal engraved lines under the lip and at the carination). They are defined by excised hour glass-shaped zones and 14 small upper and lower pendant triangles within each of the panels (Figure 41).

TYPE: Poynor Engraved, var. Freeman, also a PP variety defined by Kleinschmidt (1982, Motif 6) 
SITE NO.: 41AN2

FEATURE: Burial F-1

VESSEL NO.: 41AN2-2

NON-PLASTICS: grog and hematite; sandy paste

VESSEL FORM: Globular carinated bowl with an everted rim and a rounded lip

CORE COLOR: A (fired and cooled in an oxidizing environment)

WALL THICKNESS: $4.5 \mathrm{~mm}$, rim

INTERIOR SURFACE TREATMENT: smoothed

EXTERIOR SURFACE TREATMENT: none

HEIGHT: $14.9 \mathrm{~cm}$

ORIFICE DIAMETER: $20.4 \mathrm{~cm}$

DIAMETER AT BOTTOM OF RIM OR NECK: $19.8 \mathrm{~cm}$

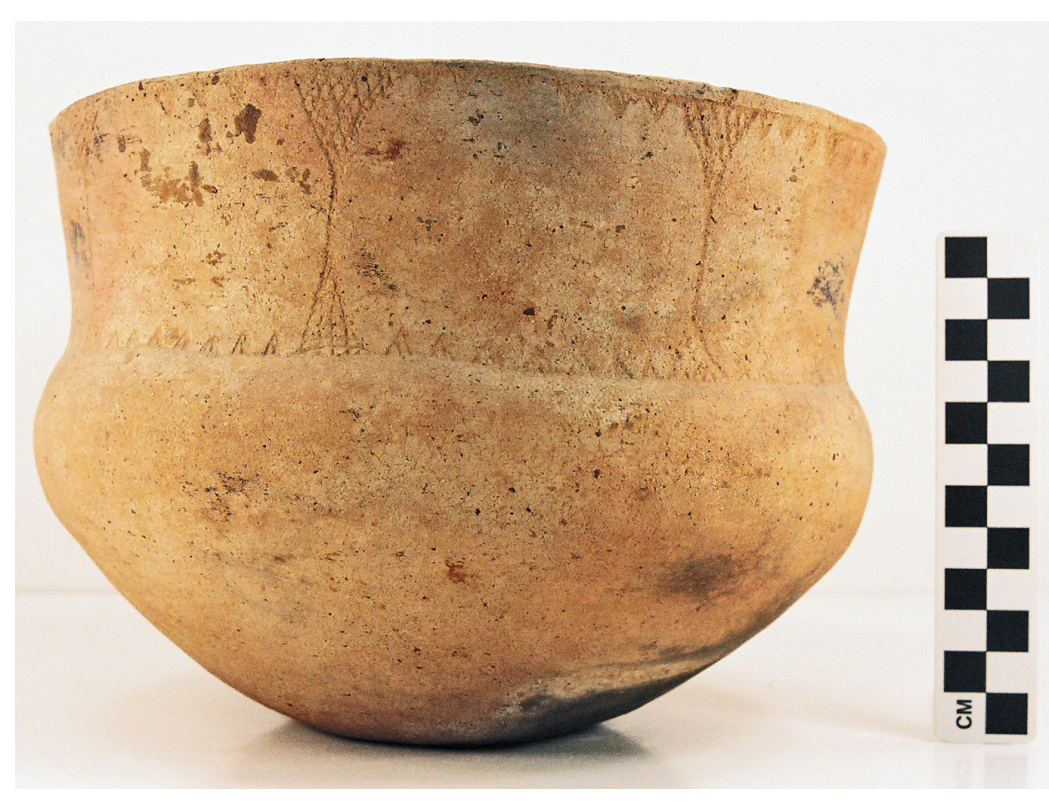

Figure 42. Poynor Engraved, var. Freeman carinated bowl (Vessel 41AN2-2).

BASE DIAMETER: $7.0 \mathrm{~cm}$

ESTIMATED VOLUME: 2.7 liters

DECORATION: There are seven rectangular engraved panels on the rim. Each panel is defined by two vertical engraved lines, and these lines have small cross-hatched pendant triangles at the rim and at the carination. The upper and lower parts of the rectangular panels have large cross-hatched engraved pendant triangles (Figure 42).

TYPE: Poynor Engraved, var. Freeman, also a PP variety of Poynor Engraved as defined by Kleinschmidt (1982, PP variety, Motif 6) 
SITE NO.: 41AN2

FEATURE: Burial F-1

VESSEL NO.: 41AN2-3

NON-PLASTICS: grog and hematite

VESSEL FORM: Bottle with an elongated body, and a short but a broken neck (Figure 43)

CORE COLOR: A (fired and cooled in a high oxygen environment)

WALL THICKNESS: $5.7 \mathrm{~mm}$, neck

INTERIOR SURFACE TREATMENT: none

EXTERIOR SURFACE TREATMENT: smoothed

HEIGHT: $19.0 \mathrm{~cm}+$

ORIFICE DIAMETER: $4.0 \mathrm{~cm}$ at the neck

DIAMETER AT BOTTOM OF RIM OR NECK: $10.02 \mathrm{~cm}$ on the body

BASE DIAMETER: $7.5 \mathrm{~cm}$

ESTIMATED VOLUME: 0.6+ liters

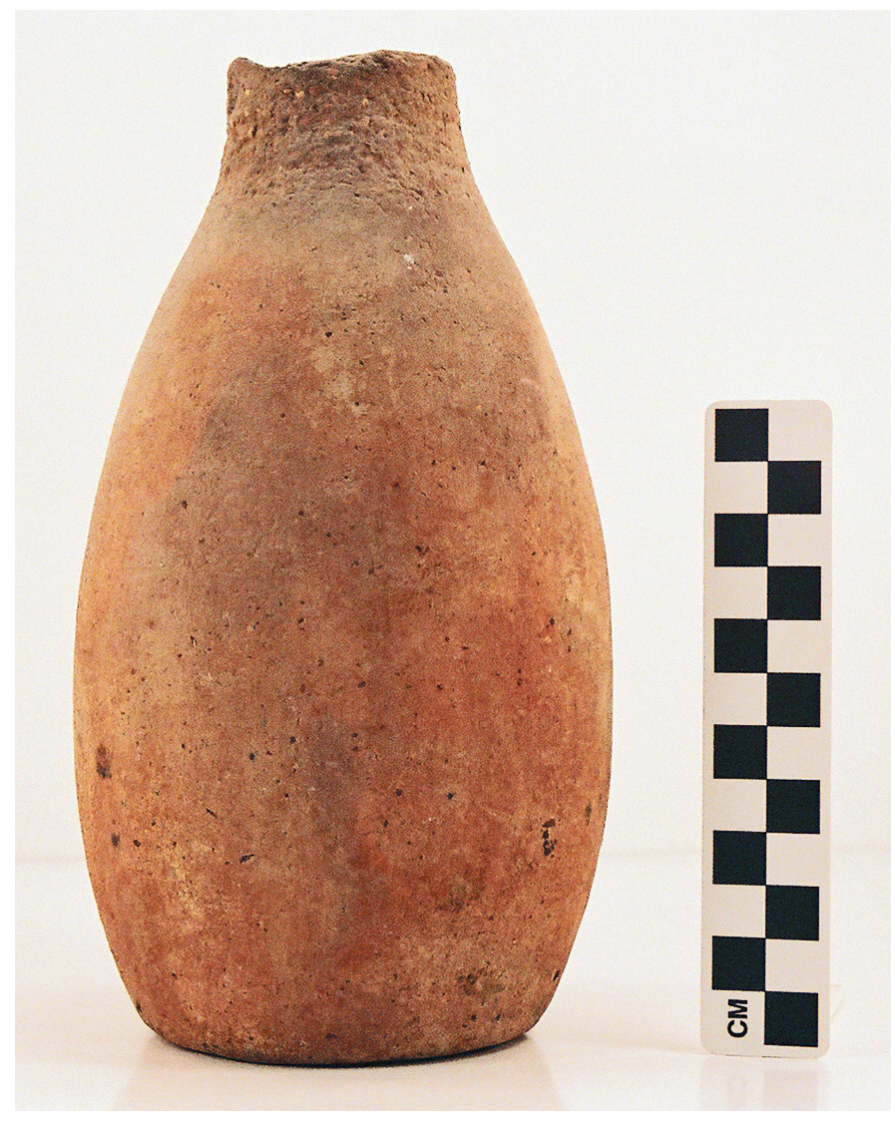

Figure 43. cf. Hume Plain bottle (Vessel 41AN2-3).

DECORATION: plain

TYPE: cf. Hume Plain (Figure 43); a vessel form similar in shape to Hume Engraved bottles, but without any decoration 
SITE NO.: 41AN2

FEATURE: Burial F-1

VESSEL NO.: 41AN2-4

NON-PLASTICS: grog and hematite

VESSEL FORM: Bottle with a short neck, an elongated body, a direct rim, and a flat lip (Figure 44)

CORE COLOR: Undetermined

WALL THICKNESS: $7.9 \mathrm{~mm}$, neck

INTERIOR SURFACE TREATMENT: none

EXTERIOR SURFACE TREATMENT: smoothed

HEIGHT: $25.3 \mathrm{~cm}$

ORIFICE DIAMETER: $4.0 \mathrm{~cm}$ at the neck DIAMETER AT BOTTOM OF RIM OR NECK: $15.6 \mathrm{~cm}$ on the body

BASE DIAMETER: $6.5 \mathrm{~cm}$

ESTIMATED VOLUME: 0.7 liters

DECORATION: There are four engraved vertical panels on the bottle body. Each panel is filled with cross-hatched engraved elements (Figure 44).

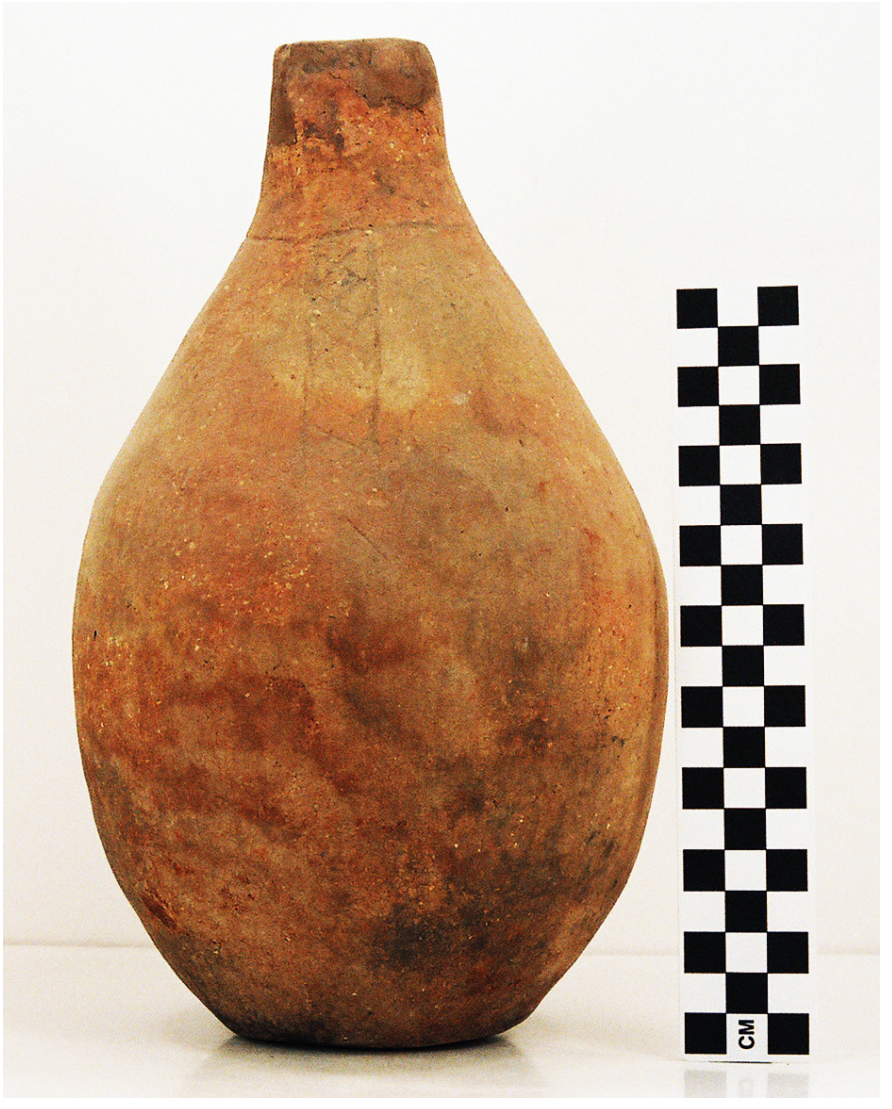

Figure 44. Hume Engraved, var. Hume bottle (Vessel 41AN2-4).

TYPE: Hume Engraved, var. Hume 
SITE NO.: 41AN2

FEATURE: Burial F-1

VESSEL NO.: 41AN2-5

NON-PLASTICS: grog and hematite

VESSEL FORM: Globular carinated bowl with a slightly inverted rim and a rounded lip

CORE COLOR: Undetermined

WALL THICKNESS: $7.2 \mathrm{~mm}$, rim

INTERIOR SURFACE TREATMENT:

none

EXTERIOR SURFACE TREATMENT:

smoothed

HEIGHT: $13.2 \mathrm{~cm}$

ORIFICE DIAMETER: $16.3 \mathrm{~cm}$

DIAMETER AT BOTTOM OF RIM OR

NECK: $16.6 \mathrm{~cm}$

BASE DIAMETER: $6.8 \mathrm{~cm}$

ESTIMATED VOLUME: 1.9 liters

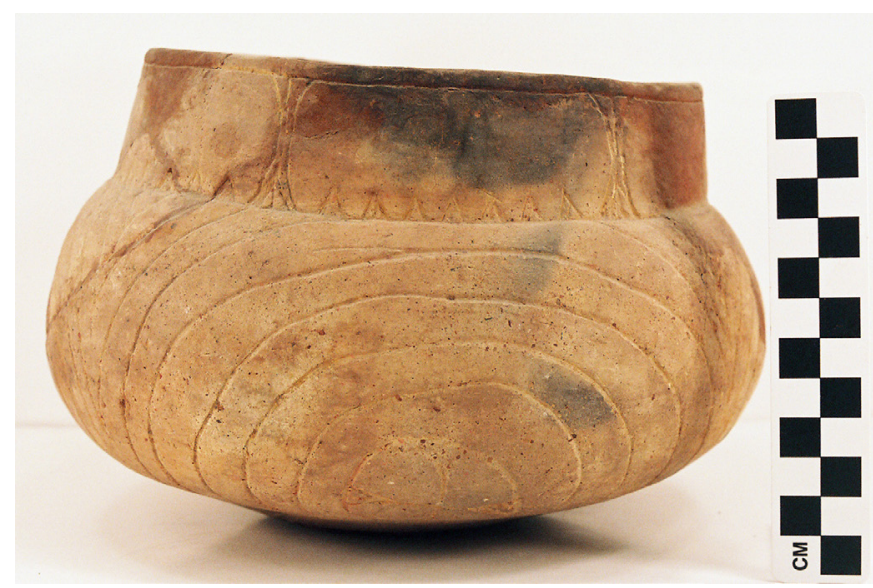

Figure 45. Poynor Engraved, PP variety carinated bowl (Vessel 41AN2-5).

DECORATION: The rim has six rectangular-shaped engraved panels defined by excised hour glassshaped elements or brackets (Figure 45). Within each panel, on the upper and lower parts of the rim, are 14 small pendant triangles. On the body are three repeating engraved concentric circle motifs comprised of five separate circular lines. At the center of these concentric circles is a circle and cross motif (Figure 45). This motif is comprised of intersecting horizontal and vertical lines with four excised triangles pendant from these lines where they meet the central circle.

TYPE: Poynor Engraved, PP variety (Kleinschmidt 1982); the rim panel has the Poynor Engraved, var. Freeman motif, but this vessel is not classified as Poynor Engraved, var. Freeman because of the distinctive engraved design on the vessel body. Nevertheless, because of the decorative elements on the rim panel, this vessel from the J. M. Cook site is stylistically related to Poynor Engraved, var. Freeman. 
SITE NO.: 41AN2

FEATURE: Burial F-2

VESSEL NO.: 41AN2-40

NON-PLASTICS: none apparent

VESSEL FORM: Globular carinated bowl with a direct rim and a rounded lip

CORE COLOR: A (fired and cooled in an oxidizing environment); pinkware

WALL THICKNESS: $5.7 \mathrm{~mm}$

INTERIOR SURFACE TREATMENT:

none

EXTERIOR SURFACE TREATMENT:

smoothed

HEIGHT: $8.7 \mathrm{~cm}$

ORIFICE DIAMETER: $10.8 \mathrm{~cm}$

DIAMETER AT BOTTOM OF RIM OR

NECK: $10.9 \mathrm{~cm}$

BASE DIAMETER: $6.7 \mathrm{~cm}$

ESTIMATED VOLUME: 0.6 liters

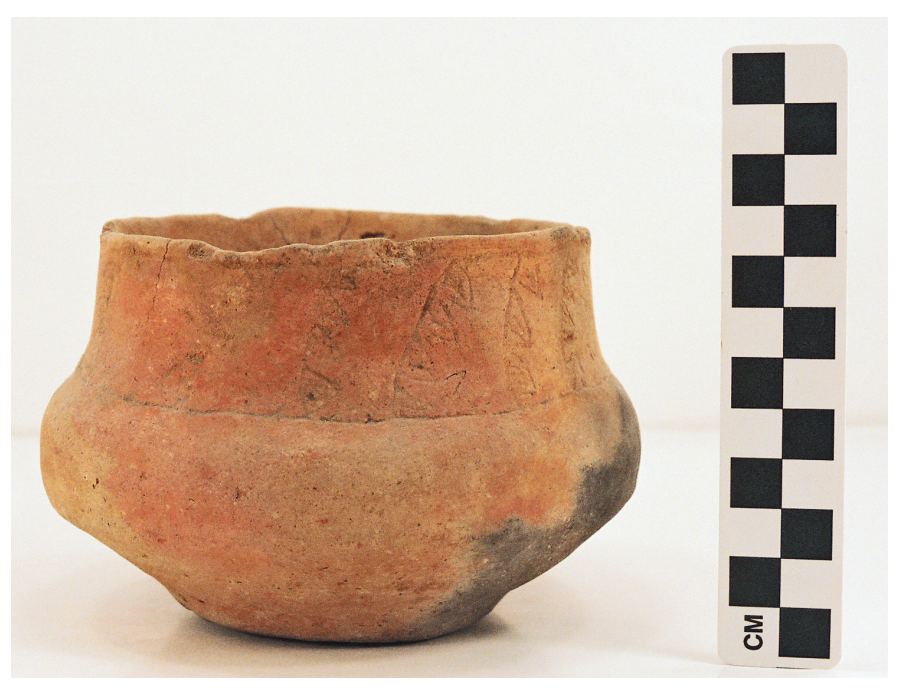

Figure 46. Poynor Engraved, var. $T$ carinated bowl (Vessel 41AN2-40).

DECORATION: There are 10 diagonal engraved panels repeated around the rim. Each panel has two diagonal engraved lines with hatched pendant triangles (Figure 46). The panels are enclosed within upper and lower horizontal engraved lines under the lip and at the carination.

TYPE: Poynor Engraved, var. $T$ in the upper Neches River basin 
SITE NO.: 41AN2

FEATURE: Burial F-2

VESSEL NO.: 41AN2-41

NON-PLASTICS: grog and hematite

VESSEL FORM: Carinated bowl with a direct rim and a rounded lip

CORE COLOR: A (fired and cooled in a high oxygen environment)

WALL THICKNESS: $5.8 \mathrm{~mm}$

INTERIOR SURFACE

TREATMENT: smoothed

EXTERIOR SURFACE

TREATMENT: burnished

HEIGHT: $14.2 \mathrm{~cm}$

ORIFICE DIAMETER: 24.0

$\mathrm{cm}$

DIAMETER AT BOTTOM OF

RIM OR NECK: $23.9 \mathrm{~cm}$

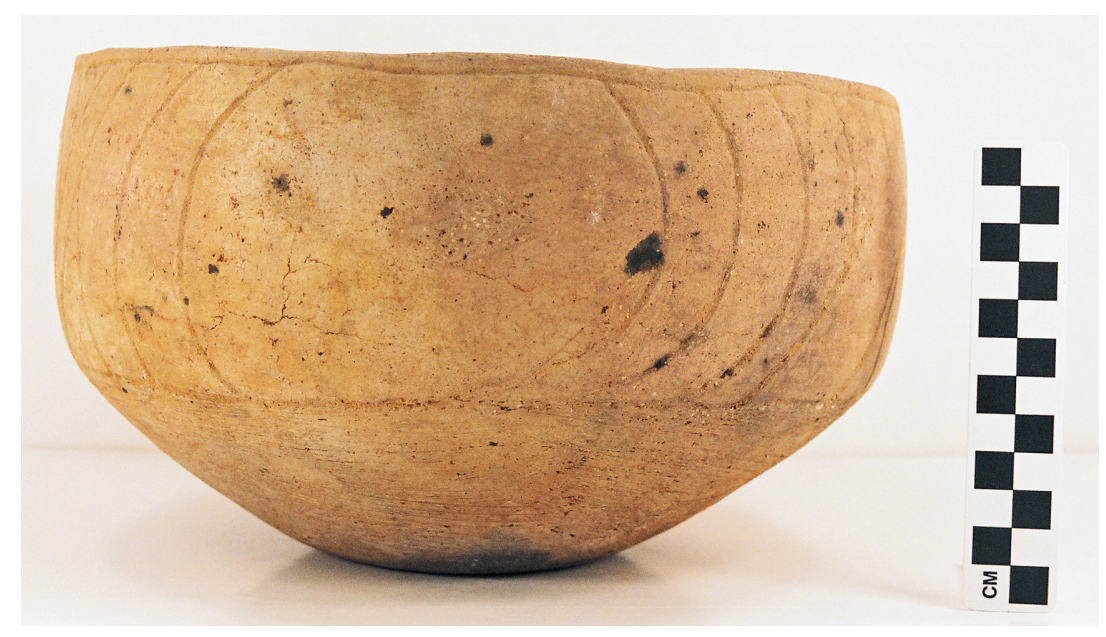

BASE DIAMETER: $8.5 \mathrm{~cm}$

ESTIMATED VOLUME: 3.0

Figure 47. Poynor Engraved, var. Cook carinated bowl (Vessel 41AN2-41).

liters

DECORATION: The rim has three engraved ovals. These ovals are comprised of three concentric semicircular engraved lines, and there are two diagonal engraved lines between each of the negative ovals. The semi-circular lines begin along these diagonal lines. The vessel body has overlapping brushing marks on the body (Figure 47).

TYPE: Poynor Engraved, var. Cook 
SITE NO.: 41AN2

FEATURE: Burial F-2

VESSEL NO.: 41AN2-42

NON-PLASTICS: bone and grog

VESSEL FORM: Bowl with a direct rim and a flat lip; two lip tabs (Figure 48), with the appendage attachments extending onto the rim.

CORE COLOR: Undetermined

WALL THICKNESS: 6.3 $\mathrm{mm}$

INTERIOR SURFACE TREATMENT: smoothed EXTERIOR SURFACE TREATMENT: smoothed

HEIGHT: $9.0 \mathrm{~cm}$

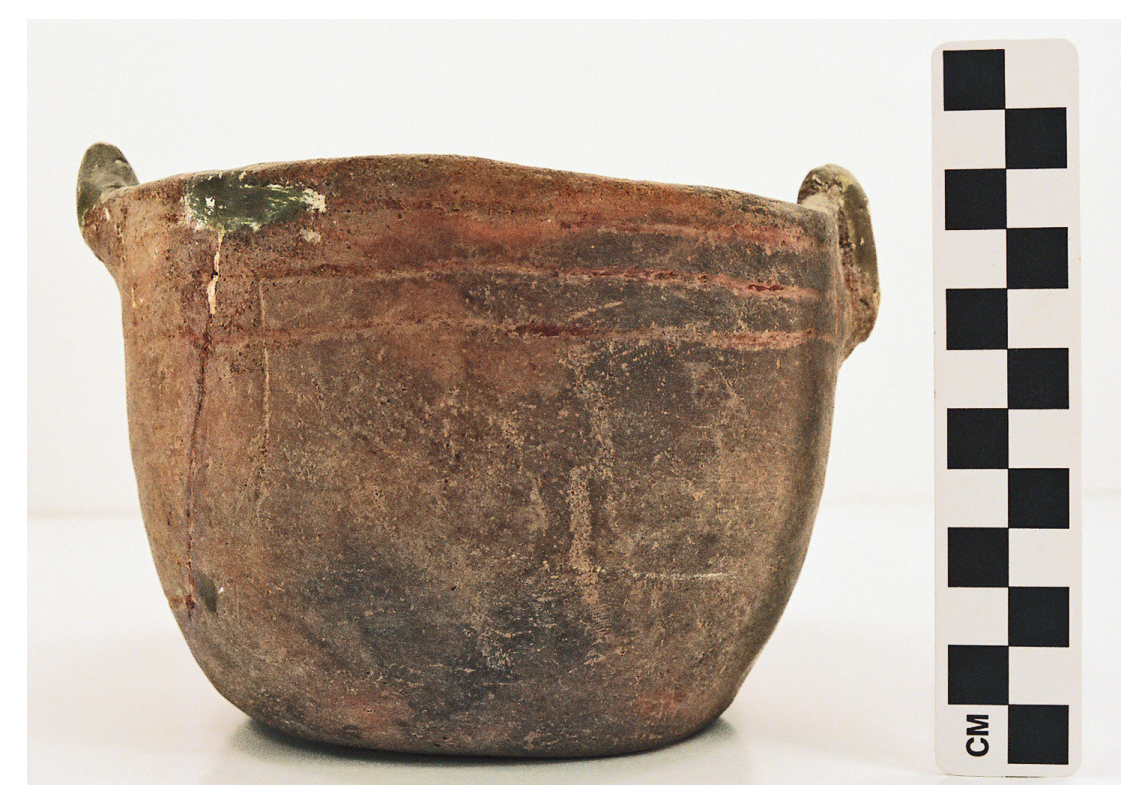

ORIFICE DIAMETER: 13.5 $\mathrm{cm}$

Figure 48. Hood Engraved, var. unspecified bowl (Vessel 41AN2-42).

DIAMETER AT BOTTOM

OF RIM OR NECK:

BASE DIAMETER: $8.4 \mathrm{~cm}$

ESTIMATED VOLUME: 0.5 liters

DECORATION: There are three broad and widely-spaced horizontal engraved lines encircling the vessel rim (Figure 48). A red clay pigment has been rubbed into the engraved lines.

TYPE: Hood Engraved, var. unspecified; if an effigy head had been attached to the vessel, it would have been classified as Hood Engraved, var. Hood. 
SITE NO.: 41AN2

FEATURE: Burial F-2

VESSEL NO.: 41AN2-43

NON-PLASTICS: hematite and bone

VESSEL FORM: Miniature globular carinated bowl with a direct rim and a rounded lip (Figure 49)

CORE COLOR: A (fired and cooled in a high oxygen environment)

WALL THICKNESS: $5.9 \mathrm{~mm}$

INTERIOR SURFACE TREATMENT:

none

EXTERIOR SURFACE TREATMENT: none

HEIGHT: $3.5 \mathrm{~cm}$

ORIFICE DIAMETER: $7.5 \mathrm{~cm}$

DIAMETER AT BOTTOM OF RIM OR NECK: N/A

BASE DIAMETER: $4.0 \mathrm{~cm}$

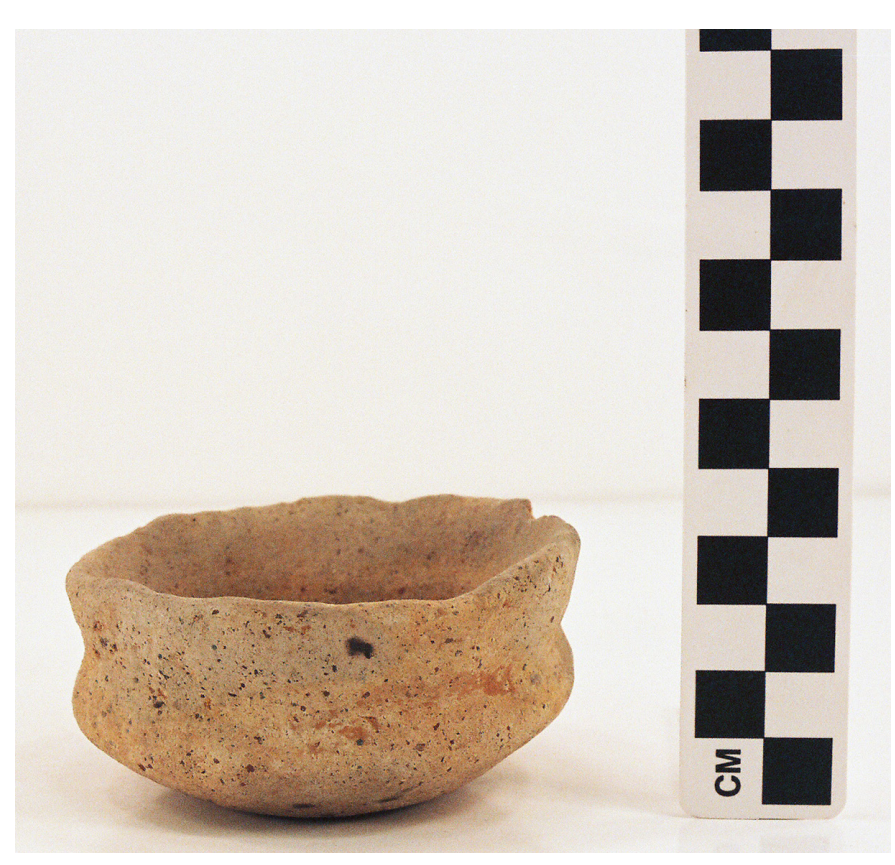

Figure 49. Poynor Plain miniature carinated bowl (Vessel 41AN2-43).

ESTIMATED VOLUME: 0.15 liters

DECORATION: plain

TYPE: Poynor Plain (i.e., the vessel form-globular carinated bowl-is the same as many of the Poynor Engraved vessels, but is undecorated) (Figure 49) 
SITE NO.: 41AN2

FEATURE: Burial F-2

VESSEL NO.: 41AN2-44

NON-PLASTICS: grog and hematite

VESSEL FORM: Carinated bowl with a direct rim and a rounded lip

CORE COLOR: A (fired and

cooled in an oxidizing environment)

WALL THICKNESS: $6.5 \mathrm{~mm}$

INTERIOR SURFACE TREAT-

MENT: smoothed

EXTERIOR SURFACE

TREATMENT: smoothed

HEIGHT: $19.7 \mathrm{~cm}$

ORIFICE DIAMETER: 32.8

$\mathrm{cm}$

DIAMETER AT BOTTOM OF

RIM OR NECK: $33.2 \mathrm{~cm}$

BASE DIAMETER: $7.1 \mathrm{~cm}$

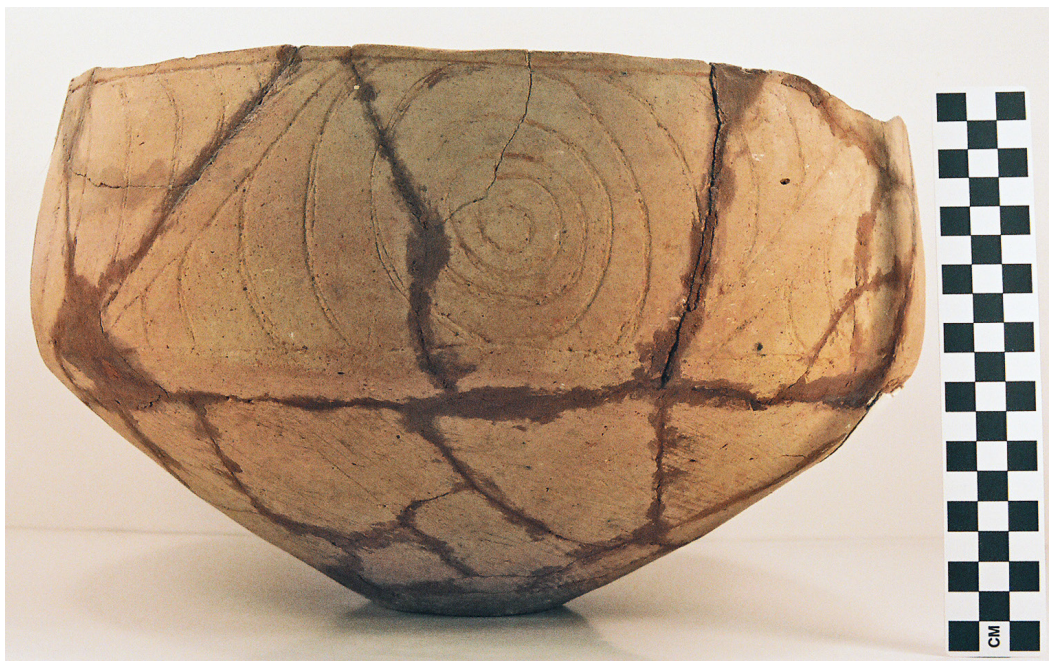

Figure 50. Poynor Engraved, PP variety carinated bowl (Vessel 41AN2-44).

ESTIMATED VOLUME: 5.8

liters

DECORATION: There are two distinct engraved motifs on the rim of the vessel, each executed two times. The first is an oval with small inward pointing hatched pendant triangles. This alternates with a hooked arm scroll motif with curvilinear and diagonal fill elements that extend to two curvilinear engraved lines that further define the ovals. The body and base of the vessel has diagonal and overlapping brushed marks (Figure 50).

TYPE: Poynor Engraved, PP variety (Kleinschmidt 1982) 
SITE NO.: 41AN2

FEATURE: Burial F-2

VESSEL NO.: 41AN2-45

NON-PLASTICS: grog and hematite

VESSEL FORM: Globular carinated bowl with a direct rim and a rounded, exterior folded, lip

CORE COLOR: A (fired and cooled in a high oxygen environment)

WALL THICKNESS: $6.5 \mathrm{~mm}$

INTERIOR SURFACE TREATMENT:

smoothed

EXTERIOR SURFACE TREATMENT:

smoothed

HEIGHT: $16.4 \mathrm{~cm}$

ORIFICE DIAMETER: $22.5 \mathrm{~cm}$

DIAMETER AT BOTTOM OF RIM OR

NECK: $21.5 \mathrm{~cm}$

BASE DIAMETER: $8.0 \mathrm{~cm}$

ESTIMATED VOLUME: 3.2 liters

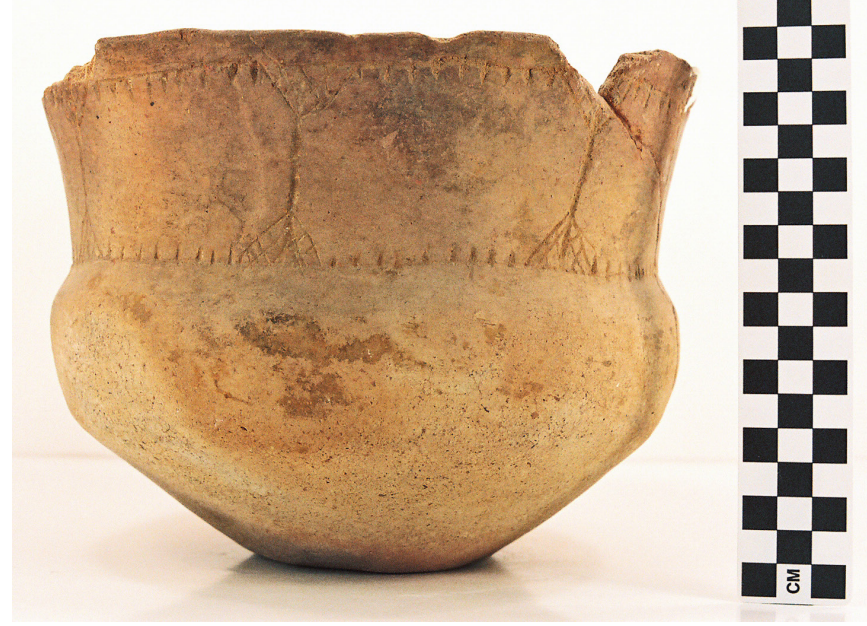

Figure 51. Poynor Engraved, var. Freeman carinated bowl (Vessel 41AN2-45).

DECORATION: There are seven rectangular engraved panels around the rim. The panels are defined by two vertical engraved lines with four cross-hatched engraved pendant triangles at the top and bottom of the vertical lines (Figure 51). Within the panels themselves are a series of small upper and lower excised triangles or triangular tick marks. A white kaolin clay pigment is rubbed in the engraved lines.

TYPE: Poynor Engraved, var. Freeman 
SITE NO.: 41AN2

FEATURE: Unknown

VESSEL NO.: 41AN2-51

NON-PLASTICS: grog and hematite

VESSEL FORM: Globular carinated bowl with a direct rim and a rounded lip

CORE COLOR: $\mathrm{G}$ (fired in a reducing environment and cooled in the open air)

WALL THICKNESS: $6.9 \mathrm{~mm}$

INTERIOR SURFACE TREAT-

MENT: smoothed

EXTERIOR SURFACE TREAT-

MENT: smoothed

HEIGHT: $12.0 \mathrm{~cm}$

ORIFICE DIAMETER: $17.0 \mathrm{~cm}$

DIAMETER AT BOTTOM OF RIM OR NECK: $17.2 \mathrm{~cm}$

BASE DIAMETER: $8.3 \mathrm{~cm}$

ESTIMATED VOLUME: 1.2 liters

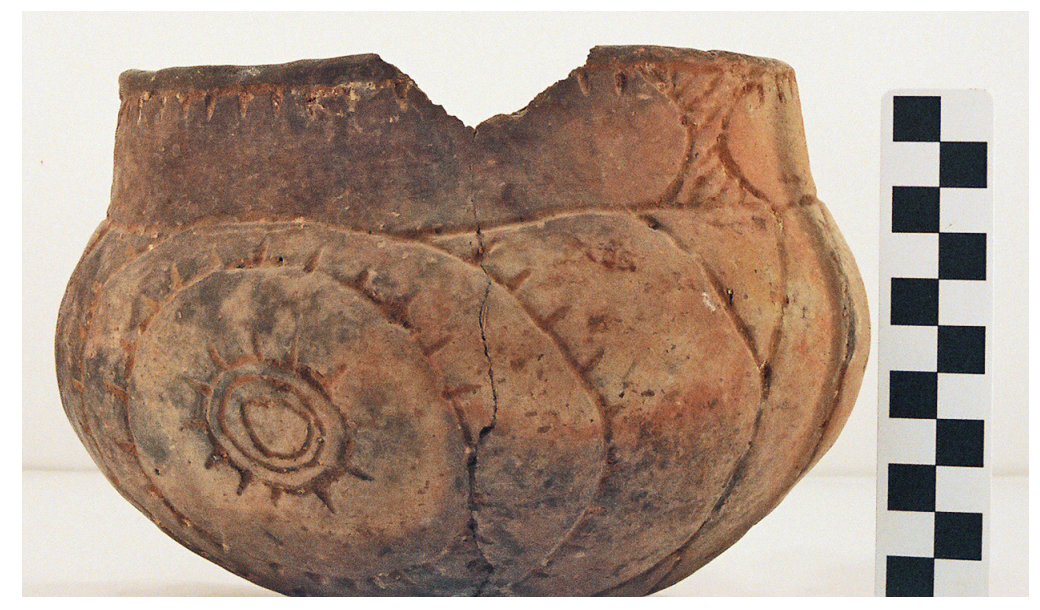

Figure 52. Patton Engraved, var. Freeman carinated bowl (Vessel 41AN2-51).

DECORATION: The rim has engraved panels defined by brackets or hour glass-shaped hatched areas and one row (underneath the rim) of small triangular tick marks (the brackets are stylistically related to the Poynor Engraved, var. Hood rim panel). The body has two series of five concentric circular engraved lines with linear tick marks on the outer three of the circular lines. These circular engraved motifs are divided by a single near-vertical engraved line that ends in large engraved triangles (Figure 52).

TYPE: Patton Engraved, var. Freeman 
SITE NO.: 41AN2

FEATURE: Unknown

VESSEL NO.: 41AN2-52

NON-PLASTICS: grog and hematite

VESSEL FORM: Bowl with a direct rim and a flat lip; the vessel has a cut-down rim, suggesting this is a vessel recycled from a broken carinated bowl with a brushed body (Figure 53)

CORE COLOR: Undetermined

WALL THICKNESS: $5.4 \mathrm{~mm}$

INTERIOR SURFACE

TREATMENT: none

EXTERIOR SURFACE

TREATMENT: smoothed

HEIGHT: $11.0 \mathrm{~cm}$ (original vessel would have been taller)

ORIFICE DIAMETER: 24.2

$\mathrm{cm}$

DIAMETER AT BOTTOM

OF RIM OR NECK: N/A

BASE DIAMETER: $7.9 \mathrm{~cm}$

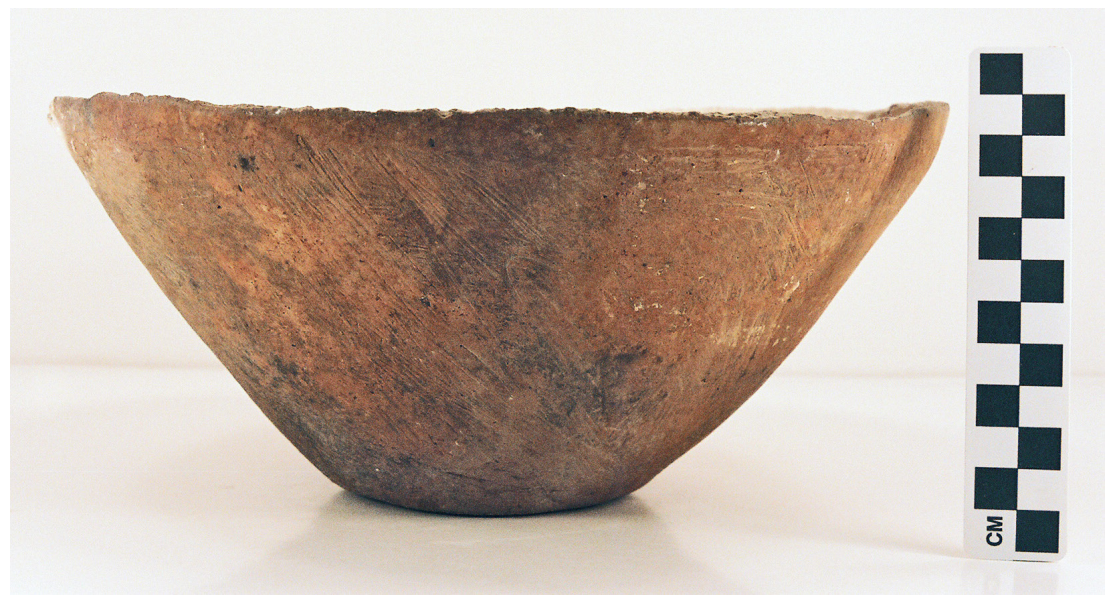

Figure 53. Probable brushed body of a Poynor Engraved carinated bowl (Vessel 41AN2-52).

ESTIMATED VOLUME: $1.6+$

liters

DECORATION: Overlapping brushing marks on the vessel body (Figure 53); the rim (no longer present) would more than likely have had an engraved motif.

TYPE: probable Poynor Engraved vessel 
SITE NO.: 41AN2

FEATURE: Unknown

VESSEL NO.: 41AN2-53

NON-PLASTICS: grog and bone

VESSEL FORM: Carinated bowl with an inverted rim and a rounded lip

CORE COLOR: B (fired and cooled in a reducing environment)

WALL THICKNESS: $5.8 \mathrm{~mm}$, rim

INTERIOR SURFACE TREATMENT:

burnished

EXTERIOR SURFACE TREATMENT:

burnished

HEIGHT: $7.3 \mathrm{~cm}$

ORIFICE DIAMETER: $11.0 \mathrm{~cm}$

DIAMETER AT BOTTOM OF RIM OR

NECK: $11.4 \mathrm{~cm}$

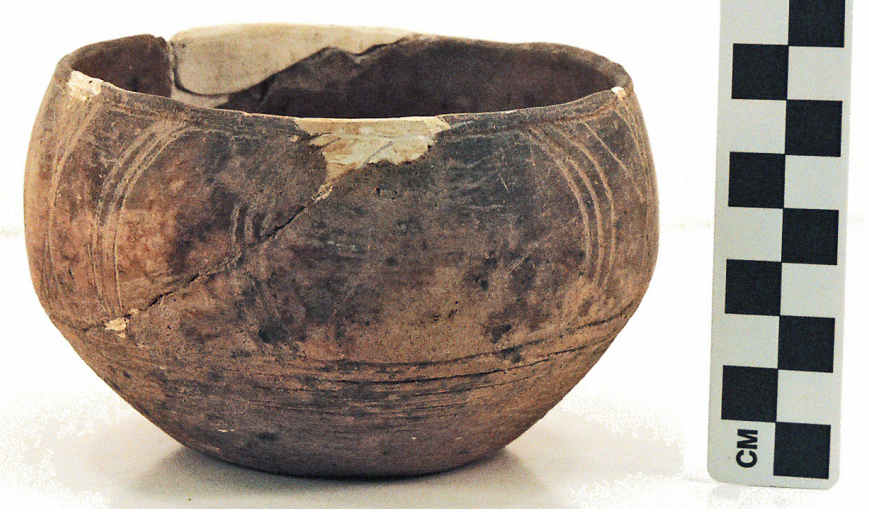

BASE DIAMETER: $6.0 \mathrm{~cm}$

ESTIMATED VOLUME: 0.5 liters

Figure 54. Poynor Engraved, var. Cook carinated bowl (Vessel 41AN2-53).

DECORATION: There are three engraved ovals in a panel on the rim. Each oval is defined by three closely-spaced curvilinear engraved lines on either side of the oval. The remainder of the panels include another set of three closely-spaced curvilinear engraved lines and two cross-hatched hour glass-shaped dividers. The body of the vessel has horizontal and overlapping brushing marks (Figure 54).

TYPE: Poynor Engraved, var. Cook but with additional var. Hood hour glass-shaped vertical columns or brackets 
SITE NO.: 41AN2

FEATURE: Unknown

VESSEL NO.: 41AN2-54

NON-PLASTICS: grog and hematite

VESSEL FORM: Globular carinated bowl with a direct rim and a rounded lip (partially reconstructed)

CORE COLOR: Undetermined

WALL THICKNESS: $6.5 \mathrm{~mm}$

INTERIOR SURFACE TREAT-

MENT: smoothed

EXTERIOR SURFACE TREAT-

MENT: smoothed

HEIGHT: $13.0 \mathrm{~cm}$

ORIFICE DIAMETER: $13.5 \mathrm{~cm}$

DIAMETER AT BOTTOM OF RIM

OR NECK: $13.4 \mathrm{~cm}$

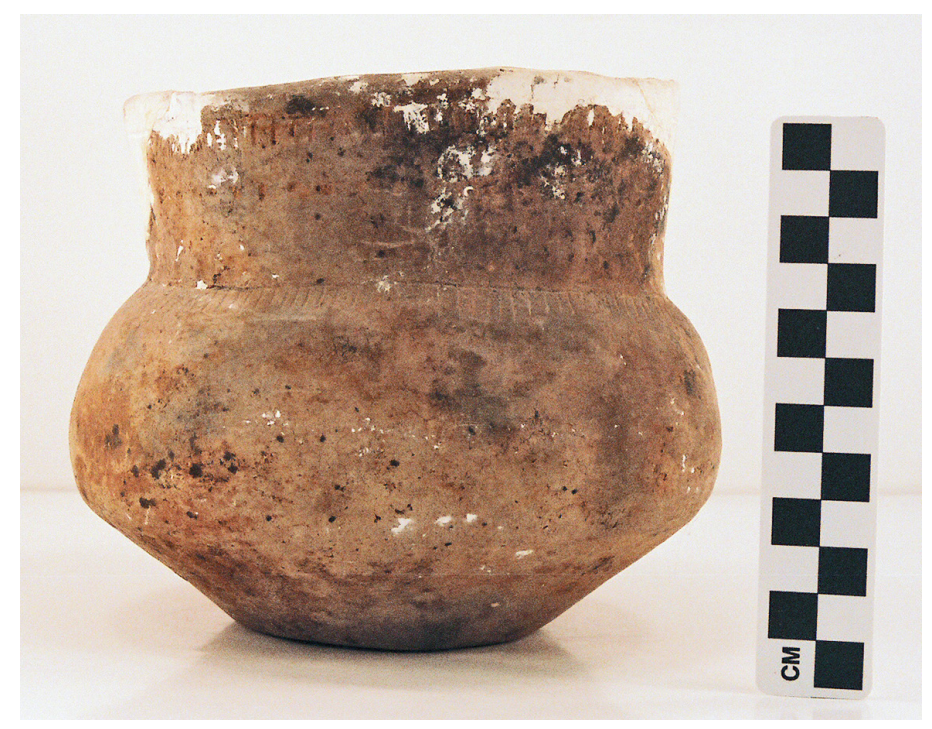

Figure 55. Patton Engraved, var. unspecified carinated bowl (Vessel 41AN2-54).

ESTIMATED VOLUME: 1.2 liters

DECORATION: The rim has upper and lower sets of linear tick marks, the second row (at the carination) pendant from a single horizontal engraved line, and extending onto the vessel body (Figure 55). A single row of tool punctates runs along the central part of the rim.

TYPE: Patton Engraved, Motif 10 (Kleinschmidt 1982) 
SITE NO.: 41AN2

FEATURE: Unknown

VESSEL NO.: 41AN2-55

NON-PLASTICS: grog and hematite

VESSEL FORM: Jar, missing the rim

CORE COLOR: G (fired in a reducing environment and cooled in the open air); pinkware

WALL THICKNESS: $10.6 \mathrm{~mm}$

INTERIOR SURFACE TREATMENT: none

EXTERIOR SURFACE TREATMENT: none

HEIGHT: Undetermined

ORIFICE DIAMETER: Undetermined DIAMETER AT BOTTOM OF RIM OR NECK: Undetermined

BASE DIAMETER: $9.5 \mathrm{~cm}$
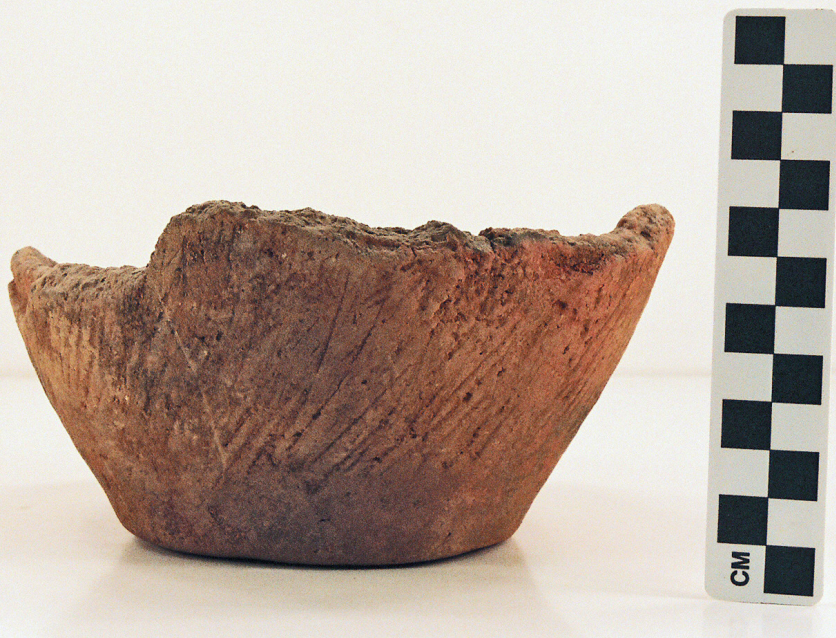

Figure 56. Probable Bullard Brushed jar body section (Vessel 41AN2-55).

ESTIMATED VOLUME: Undetermined

DECORATION: diagonal brushing marks on the vessel body (Figure 56)

TYPE: probably Bullard Brushed 
SITE NO.: 41AN2

FEATURE: Unknown

VESSEL NO.: 41AN2-56

NON-PLASTICS: grog

VESSEL FORM: Bowl with a direct rim and a rounded lip (Figure 57)

CORE COLOR: Undetermined

WALL THICKNESS: $6.7 \mathrm{~mm}$

INTERIOR SURFACE TREATMENT:

smoothed

EXTERIOR SURFACE TREATMENT:

roughened

HEIGHT: $8.9 \mathrm{~cm}$

ORIFICE DIAMETER: $16.4 \mathrm{~cm}$

DIAMETER AT BOTTOM OF RIM OR

NECK: N/A

BASE DIAMETER: $7.5 \mathrm{~cm}$

ESTIMATED VOLUME: 0.6 liters

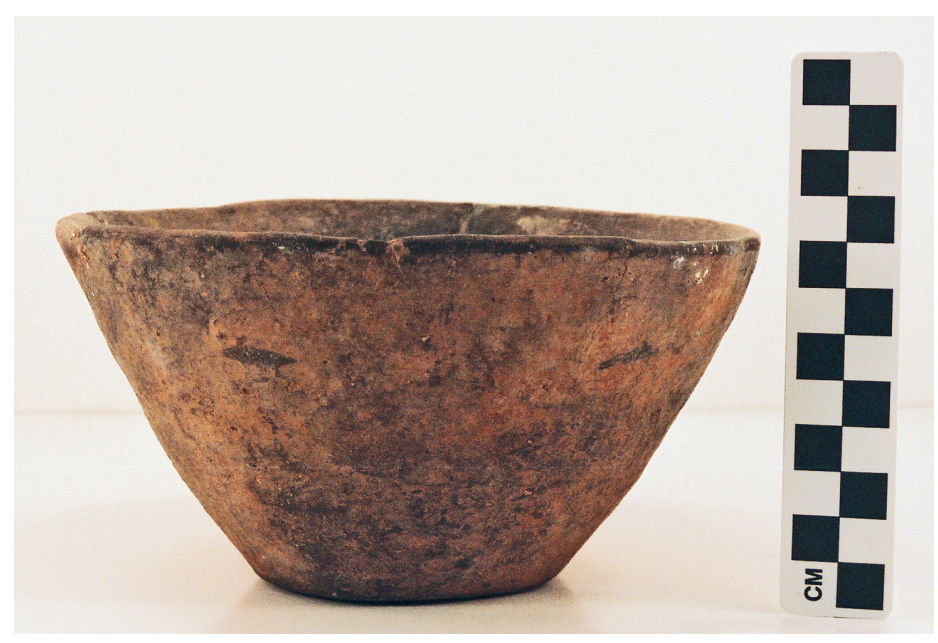

Figure 57. Plain bowl (Vessel 41AN2-56).

DECORATION: plain

TYPE: Undetermined plain ware vessel

Including the plain and brushed sherds on the TARL inventory, there are a total of 215 ceramic vessel sherds in the assemblage from the J. M. Cook site (Table 3). About 88.5 percent of the sherds are from vessels tempered only with grog, and the remainder are from vessels tempered with both grog and burned bone. 
Table 3. Sherds from ceramic wares at the J. M. Cook site (41AN2).

\begin{tabular}{lccc}
\hline Ware & Grog-tempered & Grog-bone-tempered & N \\
\hline Plain & 4 & 1 & $63+$ \\
Fine & 26 & 2 & 28 \\
Utility & 24 & 4 & $124+$ \\
\hline & & & 215 \\
Totals & 54 & 7 & \\
\hline
\end{tabular}

+based in part on the TARL inventory; does not include an effigy bowl fragment

The plain to decorated sherd ratio in this assemblage is 0.41 . About 82 percent of the decorated sherds are from utility ware vessels, and 18 percent are from fine ware vessels (Table 4).

Table 4. Decorative methods and decorative elements in the fine ware and utility ware sherds from the J. M. Cook site (41AN2).

Decorative method/decorative

Rim Body

$\mathrm{N}$

element

Fine ware

Engraved

circular engraved line with excised tick marks

curvilinear engraved lines

curvilinear engraved lines with excised tick marks

horizontal engraved line

horizontal engraved line beneath the lip

horizontal engraved line and excised bracket

horizontal engraved line with excised tick marks and

concentric curvilinear lines

horizontal and diagonal engraved lines

horizontal and diagonal engraved lines with excised

tick marks

horizontal and diagonal lines and curvilinear

hatched scroll fill zone

parallel engraved lines

parallel engraved lines with excised tick marks

slanting engraved scroll el.

straight engraved line

straight engraved line with excised tick marks

straight and diagonal engraved lines with excised

tick marks

$\begin{array}{lll}- & 1 & 1 \\ - & 2 & 2 \\ - & 1 & 1 \\ - & 1 & 1 \\ 1 & - & 1 \\ - & 2 & 2 \\ 1 & - & 1 \\ - & 1 & 1 \\ - & 2 & 2 \\ & & \\ 1 & - & 1 \\ - & & 5 \\ - & 5 & 1 \\ - & 1 & 1 \\ - & 1 & 3 \\ - & 1 & 1\end{array}$


Table 4. Decorative methods and decorative elements in the fine ware and utility ware sherds from the J. M. Cook site (41AN2), cont.

Decorative method/decorative

$\operatorname{Rim}$

Body

$\mathrm{N}$ element

Fine ware, cont.

Engraved-Brushed

horizontal engraved line and excised bracket; horizontal brushing marks on body horizontal engraved line with excised tick marks; horizontal brushing marks on body horizontal and curvilinear engraved lines with excised tick marks; horizontal brushing marks on body

\section{Utility ware}

\section{Brushed}

indeterminate brushing marks

parallel brushing marks

N/A

Brushed-Appliqued

horizontal brushing marks and appliqued lip tab horizontal brushing marks and large appliqued node beneath the lip

\section{Brushed-Punctated}

parallel brushing marks and tool punctates pushed through the brushing

\section{Incised}

curvilinear lines, opposed sets

diagonal opposed incised lines

horizontal line and triangle el. filled with curvilinear incised lines parallel incised lines

rectilinear incised zone with parallel hatched lines

\section{Incised-Punctated}

diagonal incised line separating two zones of fingernail punctates

diagonal opposed lines with triangular-shaped zone of tool punctates between the lines horizontal incised line above zone of tool punctates
$-$

\section{N/A}

1

96+

1

\section{1}

1

-

2

$\begin{array}{lll}- & 1 & 1 \\ - & 1 & 1 \\ - & 1 & 1 \\ - & & 4 \\ - & 4 & 1\end{array}$

1

1

2

1

1

1

4

1

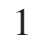

1

1 
Table 4. Decorative methods and decorative elements in the fine ware and utility ware sherds from the J. M. Cook site (41AN2), cont.

Decorative method/decorative

Rim Body

$\mathrm{N}$ element

\section{Utility ware, cont.}

\section{Neck Banded}

horizontal neck bands

parallel neck bands

$\begin{array}{lll}2 & - & 2 \\ - & 5 & 5\end{array}$

\section{Punctated}

fingernail punctated rows

tool punctated rows

tool punctated, diagonal opposed rows

tool punctated, opposed rows

$\begin{array}{lll}- & 1 & 1 \\ - & 2 & 2 \\ - & 2 & 2 \\ - & 1 & 1\end{array}$

Totals

10

46

152

+based in part on the TARL inventory

The fine ware sherds from the J. M. Cook site are from both Poynor Engraved and Patton Engraved vessels, and one rim sherd has attributes of both upper Neches River basin types. The Poynor Engraved rim and body sherds are from var. Cook vessels (Figure 58a-b). One rim sherd has a row of excised tick marks along a horizontal engraved line beneath the vessel lip, suggesting a Patton Engraved rim, as well as a series of concentric curvilinear engraved lines, perhaps an unspecified variety of Poynor Engraved (Figure 58c).

About 40 percent of the engraved sherds are from Patton Engraved vessels (see Figure 58d-j). They have straight, horizontal, horizontal-diagonal, and curvilinear engraved lines with excised tick marks pendant from the engraved lines. One sherd may be from a var. Allen vessel (see Figure 58d), and two others from var. Freeman vessels (see Figure 58g-h), but the remainder of these Patton Engraved sherds from the J. M. Cook site are var. unspecified (see Perttula 2011:Figure 6-66), suggesting the sherds are from vessels made early in the period when Patton Engraved vessels were manufactured in the upper Neches River basin, likely the latter part of the Frankston phase (ca. A.D. 1560-1680). Other aspects of the decorated sherd assemblage - especially the plain to decorated sherd ratio, the percentage of wet paste sherds, and the brushed/wet paste sherd ratio - are also consistent with an ancestral Caddo occupation during that time period.

There is a distinctive grog-bone-tempered rim sherd in the assemblage from an effigy bowl with lip tabs. The shape of the rim suggests it may have come from a four-cornered effigy bowl.

Most of the utility ware sherds in the assemblage are from Bullard Brushed jars (see Table 4); this includes the brushed and brushed-punctated body sherds. Two rim sherds have brushed-appliqued decorative elements, with horizontal brushing marks associated with either an appliqued lip tab or a large appliqued node beneath the vessel lip (see Table 4). 


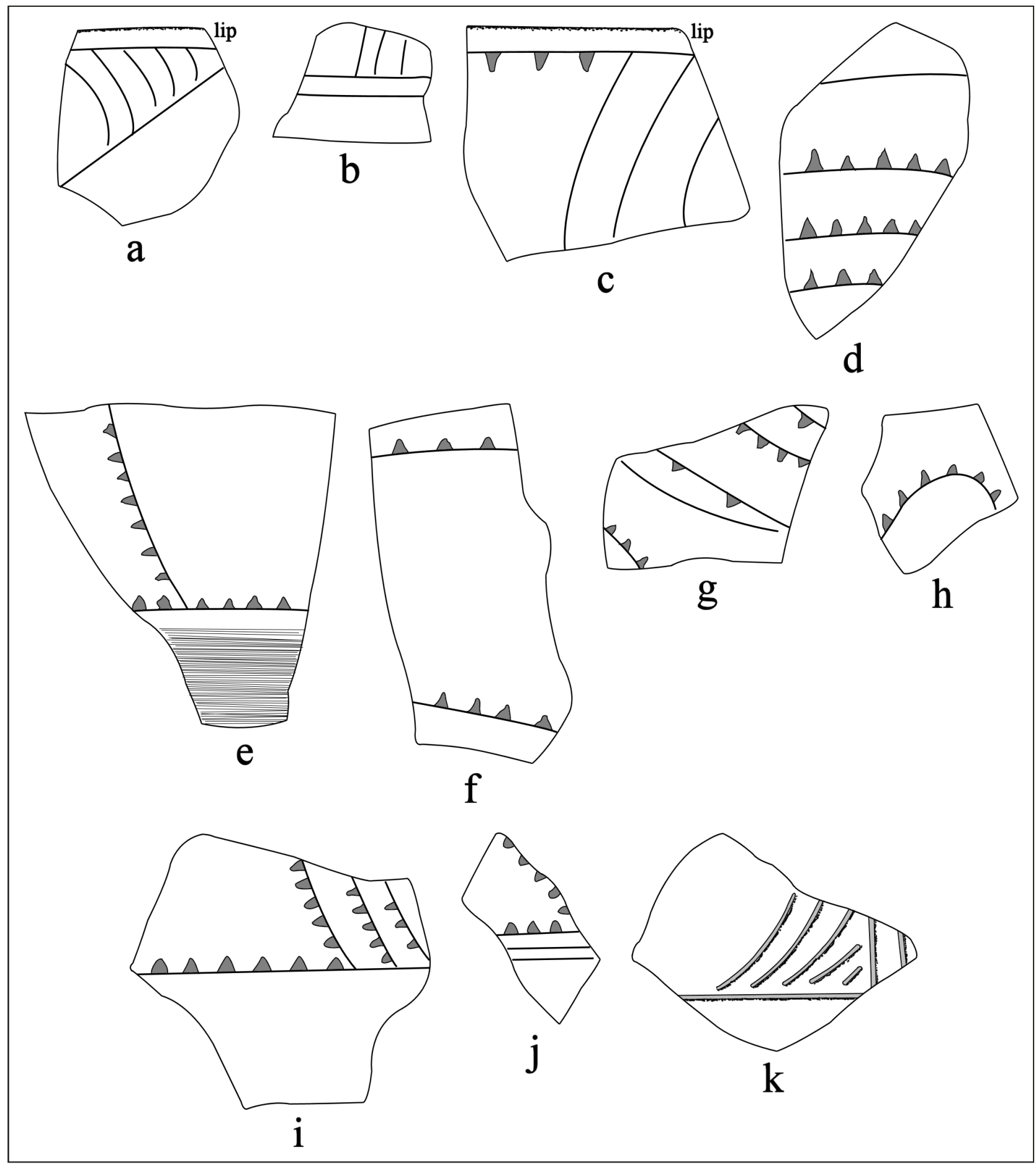

Figure 58. Selected decorative elements on fine ware and incised sherds from the J. M. Cook site (41AN2).

One of the incised sherds has decorative elements similar to those seen on Poynor Engraved vessels, except the decoration is executed with incised lines (see Figure 58k). The other incised sherds in the utility wares have simple geometric or curvilinear elements, and may be from Maydelle Incised jars. 


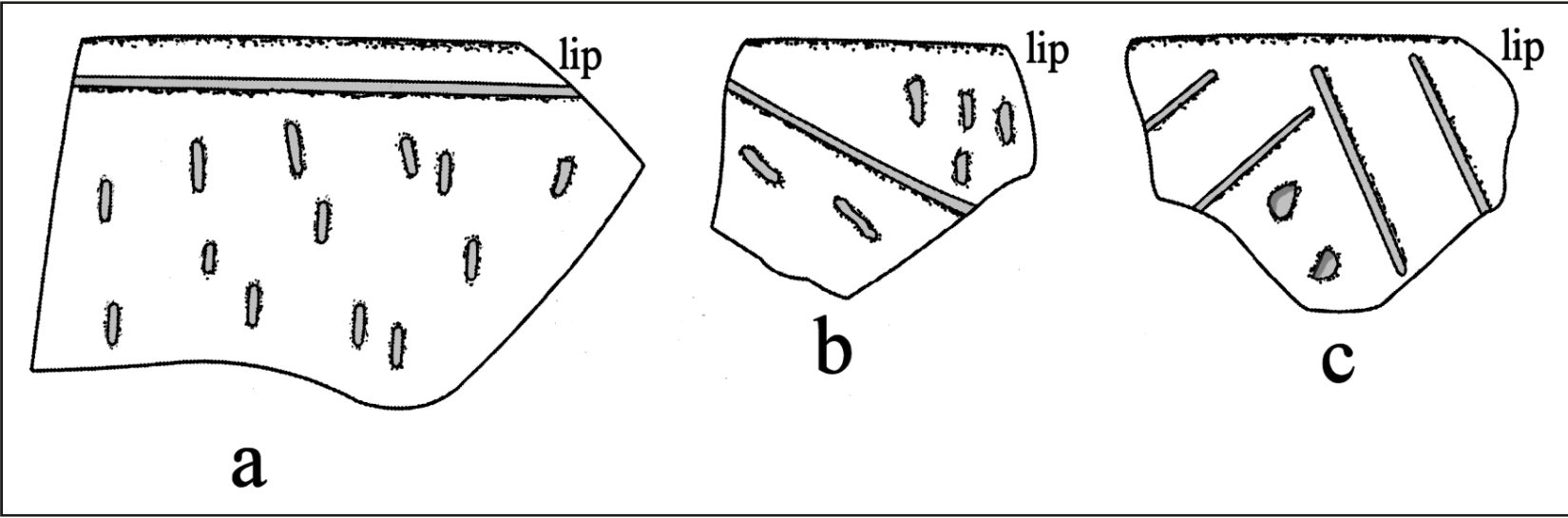

Figure 59. Selected incised-punctated sherds from the J. M. Cook site (41AN2).

Two of the three incised-punctated rim sherds in the assemblage are from Maydelle Incised jars (Figure 59b-c). The other has a single horizontal incised line beneath the lip and above a zone of tool punctates (Figure 59a).

Other utility wares in the assemblage include several La Rue Neck Banded rim and body sherds (5.6 percent of the utility ware sherds) as well as sherds with either fingernail or tool punctated rows (4.9 percent of the utility wares) (see Table 4 ). Three body sherds have opposed or diagonally opposed rows of tool punctations.

There are two grog-tempered elbow pipe sherds in the collections from the J. M. Cook site. One is a plain bowl rim sherd with a flat lip, while the other is a Var. E elbow pipe bowl sherd (see Perttula 2011:Figure 6-23). This variety of elbow pipe has multiple and closely-spaced curvilinear incised lines on the bowl (Figure 60).

Two other ceramic sherds in the J. M. Cook assemblage are from sandy paste Goose Creek Plain, var. unspecified vessels. These sherds are from a Woodland period occupation of the site.

Finally, in addition to one piece of burned clay, the collection from the site includes a large (46 x $38 \times 34 \mathrm{~mm}$ in length, width, and thickness) piece of daub. These two pieces suggest that there was a burned Caddo house at the J. M. Cook site. A dark gray chert unifacial flake tool is also in the collection.

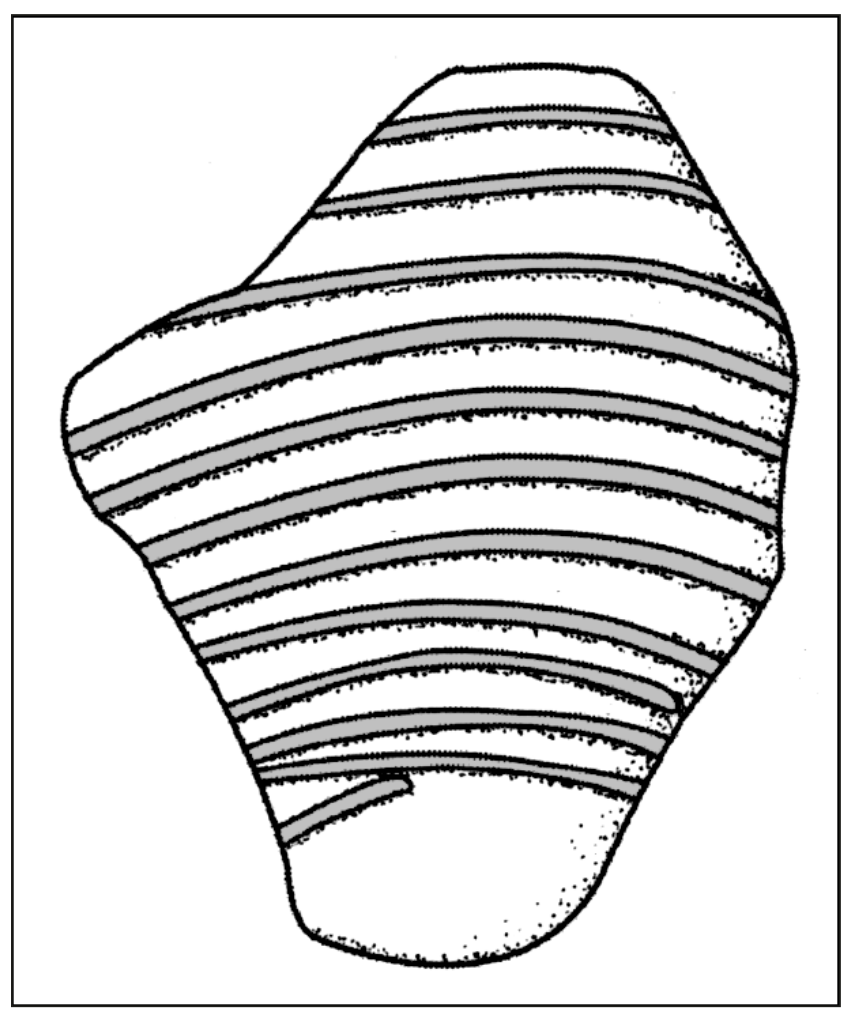

Figure 60. Incised pipe sherd bowl from the J. M. Cook site (41AN2). 


\section{W. T. Robinson (41AN4)}

The W. T. Robinson Farm site (41AN4) is one of a number of ancestral Caddo sites known in the Caddo Creek valley in the upper Neches River basin in East Texas (Figure 61). The site, about 2.5 miles northwest of Frankston, Texas, was investigated by archaeologists from the University of Texas (UT) in 1931 in an area where locals had reportedly excavated 15 Caddo vessels some 20 years earlier. The UT investigations found no Caddo burials or vessels, and recovered only a small assemblage of ceramic vessel sherds.

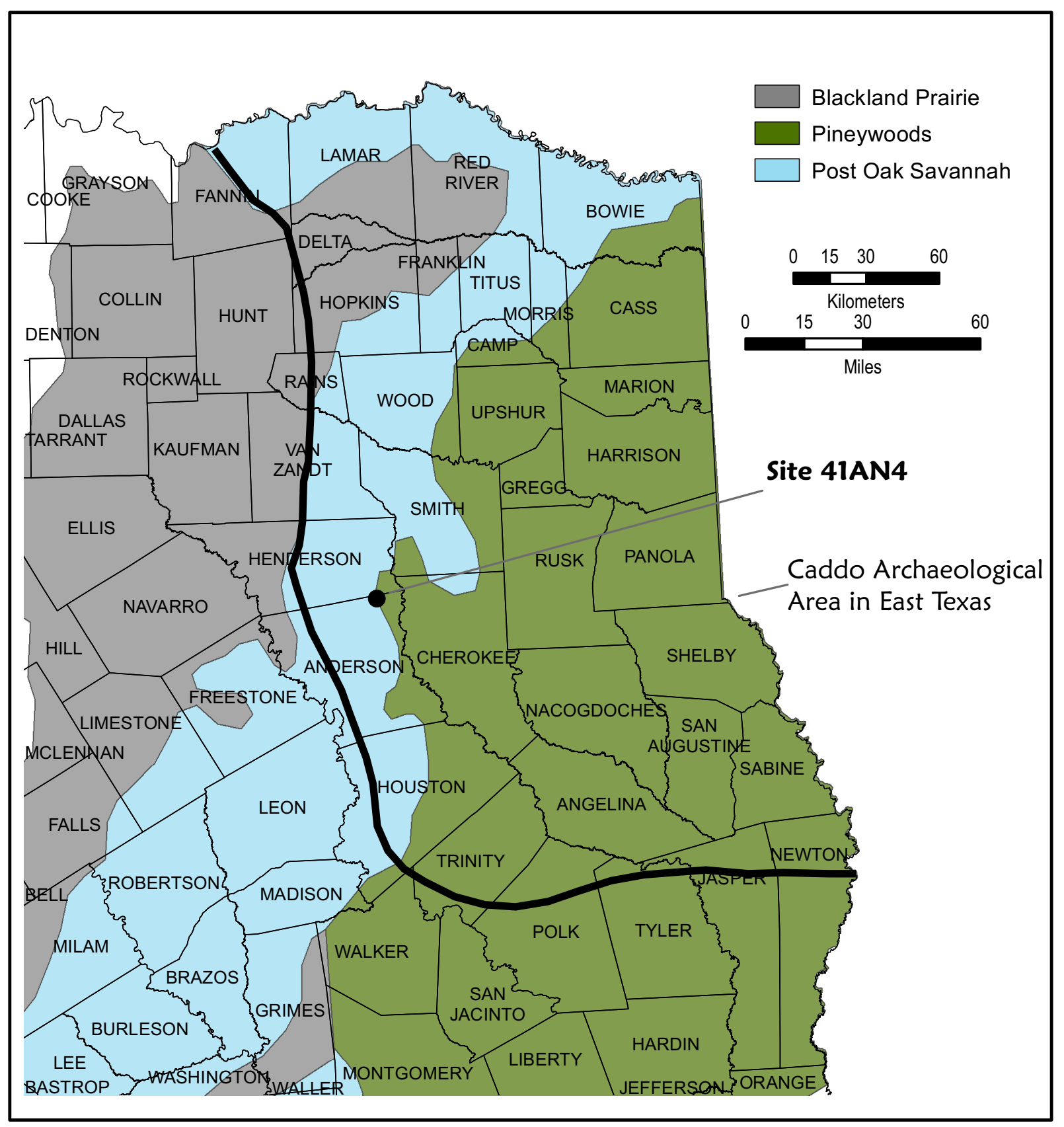

Figure 61. The location of the W. T. Robinson Farm site (41AN4) in East Texas. 


\section{Ceramic Sherd Assemblage}

The Texas Archeological Research Laboratory (TARL) collections from the W. T. Robinson site have 77 sherds from Caddo ceramic vessels (Table 5). About 98.7 percent of the sherds are from grog-tempered vessels, and only 1.3 percent of the sherds are from bone-tempered vessels. The plain to decorated sherd ratio is 0.45 , and almost 90 percent of the decorated sherds are from utility ware jars.

Table 5. Ceramic sherds from the W. T. Robinson Farm site (41AN4).

\begin{tabular}{|c|c|c|c|}
\hline Ware & Grog temper & Bone temper & $\mathrm{N}$ \\
\hline Plain & 23 & 1 & 24 \\
\hline Utility & 47 & - & 47 \\
\hline Fine & 6 & - & 6 \\
\hline Totals & 76 & 1 & 77 \\
\hline
\end{tabular}

The 53 decorated sherds in the assemblage from the W. T. Robinson Farm site are dominated by brushed sherds from utility ware vessels (Table 6). Rim and body sherds with brushing marks comprise 77 percent of all the decorated sherds and 87 percent of the sherds from utility ware vessels. These sherds are from Bullard Brushed vessels.

Table 6. Decorated methods and decorative elements represented in the ceramic sherd assemblage from the W. T. Robinson Farm (41AN4).

Decorative method/decorative

$\operatorname{Rim}$

Body

$\mathrm{N}$

element

\section{Utility ware}

\section{Brushed}

diagonal and vertical brushing marks

horizontal brushed rim and vertical brushed

1

$-$

body

overlapping brushing marks

parallel brushing marks

vertical brushing marks

Neck Banded

horizontal neck bands

Pinched

parallel pinched ridges

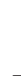

$-$

1

36

1

36

2

1

1

2

2

\section{1}


Table 6. Decorated methods and decorative elements represented in the ceramic sherd assemblage from the W. T. Robinson Farm (41AN4), cont.

Decorative method/decorative

Rim Body

$\mathrm{N}$

element

\section{Utility ware, cont.}

\section{Punctated}

fingernail punctated rows

1

2

Fine ware

\section{Engraved}

closely-spaced curvilinear lines

diagonal lines and diagonal hatched zone

$\begin{array}{lll}- & 2 & 2\end{array}$

horizontal line and sets of curvilinear and

- 1

1

circular lines

horizontal engraved line with excised pendant

1

1 triangles

horizontal engraved lines with excised pendant triangles

Totals

Two sherds are from La Rue Neck Banded jars (3.8 percent of the decorated sherds), and one body sherd is from a Killough Pinched jar (1.9 percent of the decorated sherds). The remaining utility ware sherds (5.7 percent of the decorated sherds) are from jars with rows of fingernail punctations encircling the upper part of the vessel.

The fine ware vessel sherds from the site have engraved decorative elements (see Table 6). Three rim and body sherds are clearly from Poynor Engraved vessels: two are body sherds with closely-spaced curvilinear lines, probably from hatched curvilinear elements at the top and bottom of engraved rim panels, and the third sherd is a rim from a Poynor Engraved, var. Cook vessel (see Perttula 2011:Figure 6-64c). with a horizontal line under the lip as well as sets of curvilinear and circular elements (Figure 62a). Another body sherd has diagonal lines and a diagonal hatched zone (Figure 62b), and this sherd may be part of the scroll fill zone on a Poynor Engraved, var. I vessel (see Perttula 2011:Figure 6-65).

The last two engraved sherds are rims from Patton Engraved, var. unspecified vessels (see Figure $62 c-d)$. These rim sherds have either a single horizontal engraved line under the vessel lip with excised pendant triangles or upper and lower horizontal engraved lines with excised pendant triangles pointing towards each other.

In summary, the ceramic sherd assemblage from the W. T. Robinson site (41AN4), a Caddo habitation site and possible cemetery, is consistent with the upper Neches River basin Caddo ceramic tradition (Perttula 2011:315-318) that dates from ca. A.D. 1320-1700+. A ceramic tradition means that it is "a 


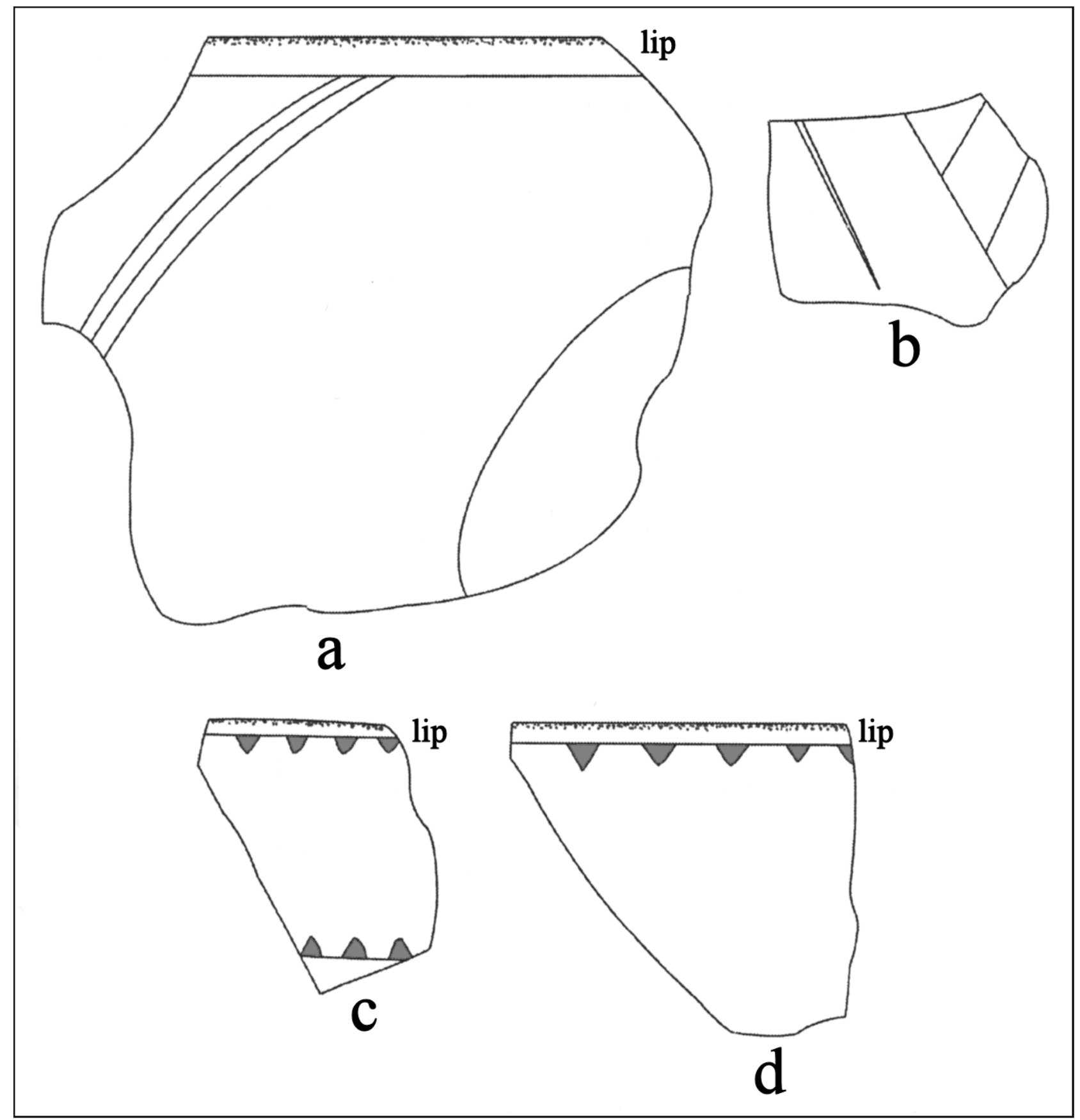

Figure 62. Selected fine ware decorative elements in the W. T. Robinson Farm site (41AN4) ceramic assemblage: a, Poynor Engraved, var. Cook rim sherd; b, possible Poynor Engraved, var. I body sherd; c-d, Patton Engraved rim sherds. 
single, coherent, community of technological and stylistic practice specific to the Caddo peoples of this area." In this tradition, ceramics are (1) almost exclusively grog-tempered; (2) brushed utility ware pottery from Bullard Brushed vessels dominates the decorated sherd assemblages; (3) fine ware sherds are primarily from varieties of Poynor Engraved before ca. A.D. 1650 and Patton Engraved varieties after ca. A.D. 1650; and (4) plain to decorated sherd ratios (P/DR) range from only 0.14-1.50, with most of the sites having P/DR values less than 0.72. Caddo sites of this tradition did not have many plain ware vessels. Finally, the W. T. Robinson site occupation by Caddo peoples likely dates from the late 16th to mid-1 $17^{\text {th }}$ century A.D., based on the occurrence of both Poynor Engraved and Patton Engraved fine ware sherds as well as the very high proportion of brushed utility ware sherds in the assemblage.

\section{Mrs. G. H. Dixon (41AN7)}

The Mrs. G. H. Dixon site is located on an upland landform above Caney Branch, a spring-fed tributary to Caddo Creek. Caddo Creek lies ca. $400 \mathrm{~m}$ to the north of the site.

About 1916, several Caddo burials were found and dug at the site by a local farmer. In November 1931 UT archaeologists investigated the site by trenching and documented the disturbed remains of six burials that had rested between ca. 33-50 cm bs. The burials were oriented east-west, and were closelyspaced. An associated Caddo habitation area was ca. $100 \mathrm{~m}$ north of the cemetery.

UT archaeologists recovered 370 ceramic sherds during the 1931 investigations at the Mrs. G. H. Dixon site (Table 7). About 96.5 percent of the sherds are from vessels that are tempered only with grog; another 3 percent have grog and bone temper, and only 0.5 percent are from vessels tempered with burned bone. The highest proportion of bone as temper is noted in the fine wares (11.4 percent), while only 2 percent of the plain ware sherds are from vessels with bone temper, either as the sole temper or in conjunction with grog.

Table 7. Ceramic sherds from the Mrs. G. H. Dixon site (41AN7).

Ware

Temper

\begin{tabular}{|c|c|c|c|c|}
\hline & Grog & Grog-Bone & Bone & $\mathrm{N}$ \\
\hline Plain ware & 246 & 4 & 1 & 251 \\
\hline Fine ware & 31 & 4 & - & 35 \\
\hline Utility ware & 80 & 3 & 1 & 84 \\
\hline
\end{tabular}

Totals

357

11

370

The plain to decorated sherd ratio in the sherd assemblage is 2.11 . The decorated sherds in the assemblage are comprised of sherds from both fine ware (29.4 percent) and utility ware (70.6 percent) vessels (Table 8). The fine ware sherds are primarily from Poynor Engraved carinated bowls (Figure 63a-f), and there are bottle sherds with curvilinear engraved lines, as well as rim sherds with cross-hatched lines (Figure 63g) and a rim sherd with diagonal engraved lines and a cross-hatched diagonal engraved zone (Figure 63h). 
Table 8. Decorated methods and decorative elements represented in the ceramic sherd assemblage from the Mrs. G. H. Dixon site (41AN7).

Decorative method/decorative

$\operatorname{Rim}$

Body

$\mathrm{N}$

element

Fine ware

Engraved

circular engraved el.

cross-hatched engraved lines

curvilinear engraved lines

diagonal engraved lines

diagonal engraved lines and cross-hatched

diagonal zone

hatched bracket el.

horizontal engraved lines

horizontal engraved lines and curvilinear

hatched zone

horizontal and diagonal engraved lines

horizontal and diagonal engraved lines and diagonal engraved zone

horizontal engraved lines and hatched bracket el.

horizontal and vertical lines and curvilinear

hatched zone

horizontal, vertical, and diagonal engraved

lines

parallel engraved lines

straight engraved line

straight engraved line with excised triangle el.

\section{Utility ware}

\section{Brushed}

opposed brushing marks

overlapping brushing marks

parallel brushing marks

$\begin{array}{lll}1 & 1 & 2 \\ 1 & - & 1 \\ - & 5 & 5 \\ 1 & - & 1 \\ 1 & - & 1 \\ - & & 1 \\ - & 1 & 3 \\ - & 3 & 1 \\ - & 1 & 1 \\ 1 & & 2 \\ - & 1 & 1 \\ - & 1 & 2 \\ - & & 1 \\ 1 & 1 & 8 \\ - & 2 & 4 \\ - & & \end{array}$

\section{Incised}

cross-hatched incised lines

diagonal incised lines

diagonal opposed incised lines

horizontal incised lines

parallel incised lines

straight incised line

vertical incised line and diagonal incised zone

2

2

$-$

1

$-$

$-$
2

1

5

1

1

2

1

39

4

2

2

1

11

4

1 
Table 8. Decorated methods and decorative elements represented in the ceramic sherd assemblage from the Mrs. G. H. Dixon site (41AN7), cont.

Decorative method/decorative

$\operatorname{Rim}$

Body

$\mathrm{N}$

element

Utility ware, cont.

Incised-Punctated

parallel incised lines and adjacent tool punctated-

filled zone

straight incised line and adjacent tool punctated-

filled zone

\section{Punctated}

fingernail punctated rows

tool punctated rows

$-4$

4

2

8

Totals

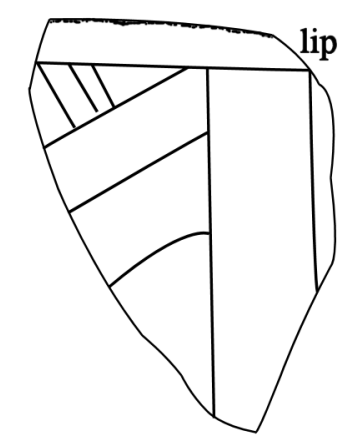

a

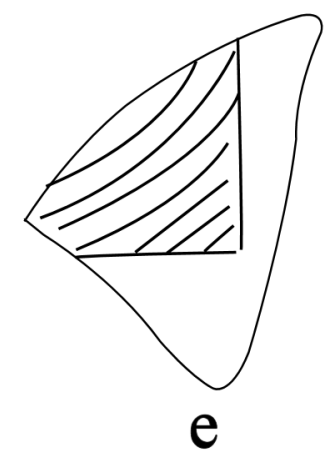

e

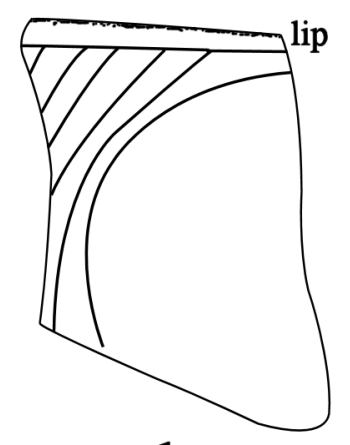

b
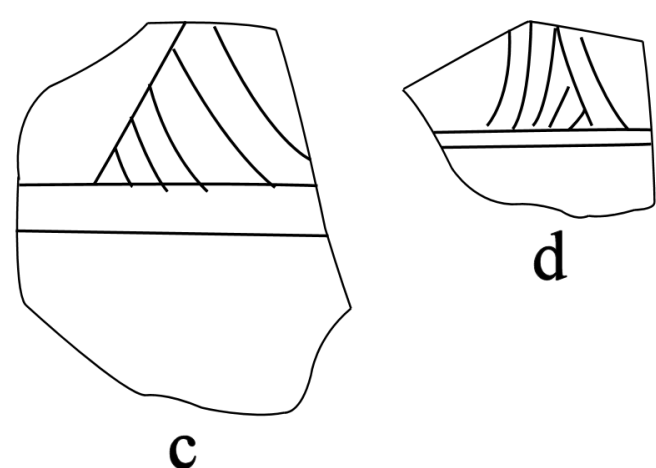

C
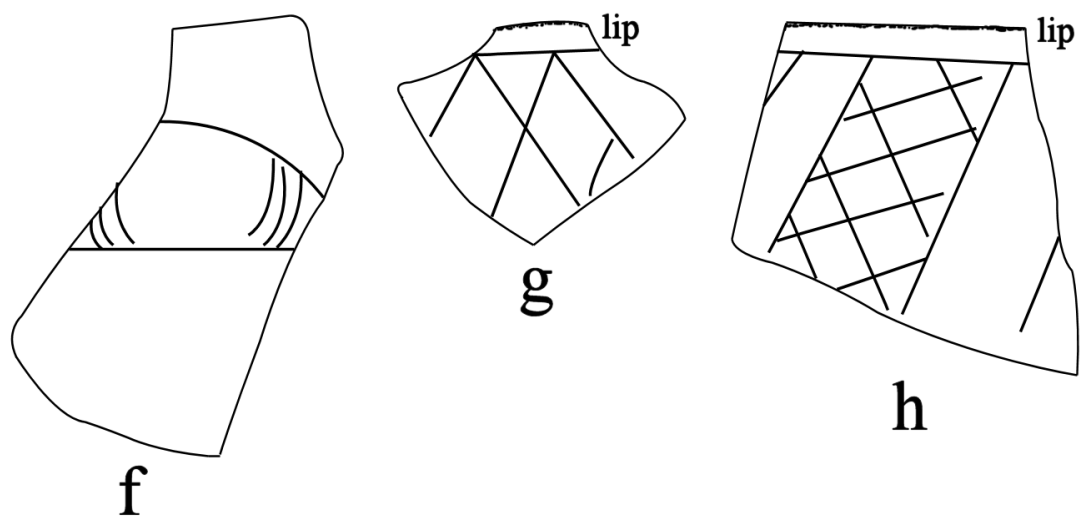

Figure 63. Selected decorative elements represented in the fine ware sherds from the Mrs. G. H. Dixon site. 
The Poynor Engraved sherds from the site include var. Cook (n=2, see Figure 63b-c), var. Blackburn $(\mathrm{n}=1)$, var. Hood $(\mathrm{n}=2$, see Figure 63d), as well as var. unspecified $(\mathrm{n}=4$, see Figure 63a, e-f). These varieties of Poynor Engraved are most common in ca. A.D. 1400-1560 contexts in the upper Neches River basin (see Perttula 2011:Table 6-37).

Among the utility wares, sherds from brushed Bullard Brushed jars are most common, accounting for 35.3 percent of the decorated sherds from the Mrs. G. H. Dixon site, and 50 percent of the utility wares (see Table 8). Incised sherds from Maydelle Incised vessels represent 29.8 percent of the utility wares, while three Maydelle Incised body sherds have incised-punctated decorative elements. Another 16.7 percent of the utility wares from the Mrs. G. H. Dixon site have punctated elements, either rows of fingernail or tool punctates (see Table 8).

The prevalence of Poynor Engraved sherds in the sherd assemblage, along with other sherd metrics a plain to decorated sherd ratio of 2.11, the percentage of brushed sherds in the assemblage (35.3), the percentage of wet paste utility ware sherds (35.3), and the brushed to wet paste ratio (1.0) - is consistent with an occupation by ancestral Caddo people in the early part of the Frankston phase, between ca. A.D. 1400-1480.

\section{Cecil Farm (41AN8)}

In 1933, a local Farmer (Richard Patton, namesake of the Richard Patton site, 41AN26) found and excavated two Caddo burials at the L. Cecil Farm site after a ceramic vessel had been found while a county road was being graded by the site. These burials had five ceramic vessels, one elbow pipe, and 25 Jowell knives, a distinctive Historic Caddo Allen phase chipped stone tool (Cole 1975:83); these artifacts were sold to a collector and were never documented.

This cemetery site lies on a low upland rise ca. 0.25 miles north of Caddo Creek. UT trenching of the cemetery area in 1933 recovered two more Jowell knives and a Cuney arrow point found together, suggesting a third Caddo burial was present at the site (Cole 1975:83-84). A. T. Jackson of UT, in 1933, noted that an associated Caddo habitation area was ca. $200 \mathrm{~m}$ to the north of the cemetery:

Some 200 yards $\mathrm{N}$ of this burial...is an extensive campsite. On the surface are many potsherds, showing various types of decorations. the predominant decoration on the thick, heavy ware (large pots) is the scratched or combed lines - shallowly incised and without regularity. The thin sherds - from small vessels - are frequently of ornate decoration, embodying incised sun symbols, concentric lines made of grooved or trailed work - wide smooth-bottomed lines. Others employ incised crosshatch, gouged indentations and fingernail impressions.

UT archaeologists returned to the L. Cecil Farm site in October 1935 after a tenant farmer found a fourth grave at the site; this grave had four ceramic vessels as funerary offerings (Woolsey 1935d; Cole 1975:84). Trenching by UT archaeologists did not identify any further Caddo burials at the site.

Although the provenience of the ceramic sherds from the L. Cecil Farm site is not known, it is likely that most, if not all, of the sherds are from the habitation area ca. $200 \mathrm{~m}$ north of the cemetery. The predominance of Patton Engraved sherds, a key decorated fine ware in Historic Caddo Allen phase sites, and the likely Historic Caddo age of the burials from the site, suggests the two contexts are spatially and culturally related. 
The ceramic sherd assemblage from the L. Cecil Farm includes 152 sherds from plain ware, fine ware, and utility ware vessels (Table 9). All but one sherd is from a grog-tempered vessel; 3.3 percent of the sherds are from vessels that have had burned bone added to the paste as a temper. None of the fine ware sherds are from vessels tempered with bone.

Table 9. Ceramic sherds from the L. Cecil Farm site (41AN8).

Ware

Temper

\begin{tabular}{|c|c|c|c|c|}
\hline & Grog & Grog-Bone & Bone & $\mathrm{N}$ \\
\hline Plain ware & 52 & 1 & 1 & 54 \\
\hline Fine ware & 24 & - & - & 24 \\
\hline Utility ware & 71 & 3 & - & 74 \\
\hline Totals & 147 & 4 & 1 & 152 \\
\hline
\end{tabular}

The plain to decorated sherd ratio in this assemblage is 0.55 . Fine ware sherds in the assemblage from the L. Cecil Farm include sherds from Poynor Engraved and Patton Engraved vessels. The Poynor Engraved sherds are from var. Freeman vessels (Figure 64c-d), while there are Patton Engraved, var. Allen (Figure 64e) and var. unspecified vessel sherds in the collection (Figure 64a-b). More than 73 percent of the fine ware engraved sherds have either linear or excised triangular tick marks (Table 10). One grogtempered body sherd has a series of broad curvilinear trailed lines (Figure 65a), and may be from a Keno Trailed vessel.

Table 10. Decorated methods and decorative elements represented in the ceramic sherd assemblage from the L. Cecil Farm site (41AN8).

$\begin{aligned} & \text { Decorative method/decorative } \\ & \text { element }\end{aligned}$
Rim

\section{Fine ware}

\section{Engraved}

horizontal engraved line and long linear tick marks

horizontal engraved line and excised tick marks $\quad 2$

horizontal engraved lines and excised tick marks 3

horizontal and diagonal engraved lines

horizontal engraved line with excised tick

marks and set of vertical engraved lines

horizontal engraved lines with excised tick

marks and set of vertical engraved lines

parallel engraved lines

parallel engraved lines with excised tick marks

straight engraved line

1

1

1

$\begin{array}{lll}- & 2 & 2 \\ - & 2 & 2 \\ - & 2 & 2\end{array}$


Table 10. Decorated methods and decorative elements represented in the ceramic sherd assemblage from the L. Cecil Farm site (41AN8), cont.

Decorative method/decorative

$\operatorname{Rim}$

Body

$\mathrm{N}$

element

Fine ware, cont.

straight engraved line with excised tick marks

straight engraved line with linear tick marks

6

6

Trailed

curvilinear trailed lines

$\begin{array}{lll}- & 6 & 6 \\ - & 1 & 1\end{array}$

1

Utility ware

Brushed

diagonal brushed marks

horizontal brushed marks

opposed brushing marks

parallel brushing marks

vertical brushing marks

$\begin{array}{lll}1 & 1 & 2 \\ 2 & - & 2 \\ - & 5 & 5 \\ - & 43 & 43 \\ - & 4 & 4\end{array}$

\section{Brushed-Appliqued-Punctated}

horizontal brushing marks above horizontal appliqued ridge, and above tool punctated row

\section{Brushed-Incised}

parallel brushed-incised marks and lines

parallel brushed marks and overlying opposed incised lines

parallel brushed-incised marks and lines and overlying straight incised line

\section{Brushed-Punctated}

horizontal brushing marks and tool punctated rows through the brushing parallel brushing marks and tool punctated row through the brushing

\section{Incised}

diagonal incised lines diagonal opposed incised lines

opposed incised lines 
Table 10. Decorated methods and decorative elements represented in the ceramic sherd assemblage from the L. Cecil Farm site (41AN8), cont.

$\begin{aligned} & \text { Decorative method/decorative } \\ & \text { element }\end{aligned}$
Rim $\quad$ Body

Utility ware, cont.

Incised-Punctated

incised diamond element filled with tool

1

1

punctations

Punctated

fingernail punctated rows

1

1

Totals

17

The utility ware sherds are dominated by sherds from vessels decorated with brushed ( $\mathrm{n}=56,57$ percent of the decorated sherds and 75.7 percent of the utility wares), brushed-appliqued-punctated ( $\mathrm{n}=1,1.4$ percent of the utility wares), brushed-incised (13.5 percent of the utility wares), and brushed-punctated $(n=2,2.7$ percent of the utility wares) elements (see Table 10). These sherds are from Bullard Brushed and Spradley Brushed-Incised vessels; the latter vessels, a common utility ware in Historic Caddo period contexts (see Marceaux 2011), have parallel brushed-incised marks and lines and overlying straight and parallel incised lines. The incised and incised-punctated (see Figure 65b) sherds are likely from Maydelle Incised vessels. Two sherds (2.7 percent of the utility wares) are from vessels decorated with rows of fingernail punctations. The utility ware sherd metrics, as well as the occurrence of both Poynor Engraved, var. Freeman and Patton Engraved, var. Allen sherds, suggest the ancestral Caddo occupation at the L. Cecil Farm site took place sometime between ca. A.D. 1560-1680, likely during the latter part of this Frankston phase temporal interval.

\section{B. C.Cely (41AN9)}

The B. C. Cely site was found by a local in the 1930s in the southwestern part of the town of Frankston, Texas, on an alluvial terrace (350 ft. amsl) just north of Caddo Creek. This individual discovered a burial with Caddo vessels and human remains. No archaeologist has investigated the site since it was reported to UT archaeologists more than 80 years ago.

\section{Arthur Holsumback (41AN10)}

This Caddo site on Caddo Creek was reported to UT archaeologists in 1931 that Caddo ceramic vessels had been found there, suggested it was one of many Caddo cemeteries in the Caddo Creek valley. UT archaeologists did not investigate the site. The plotted location of the site was visited by Miller et al. (2014:523-524), but no archaeological deposits were identified in six shovel tests. Miller et al. (2014:524) suggest that the site "has been either destroyed altogether or was mis-plotted during its original recording 80 years ago." 


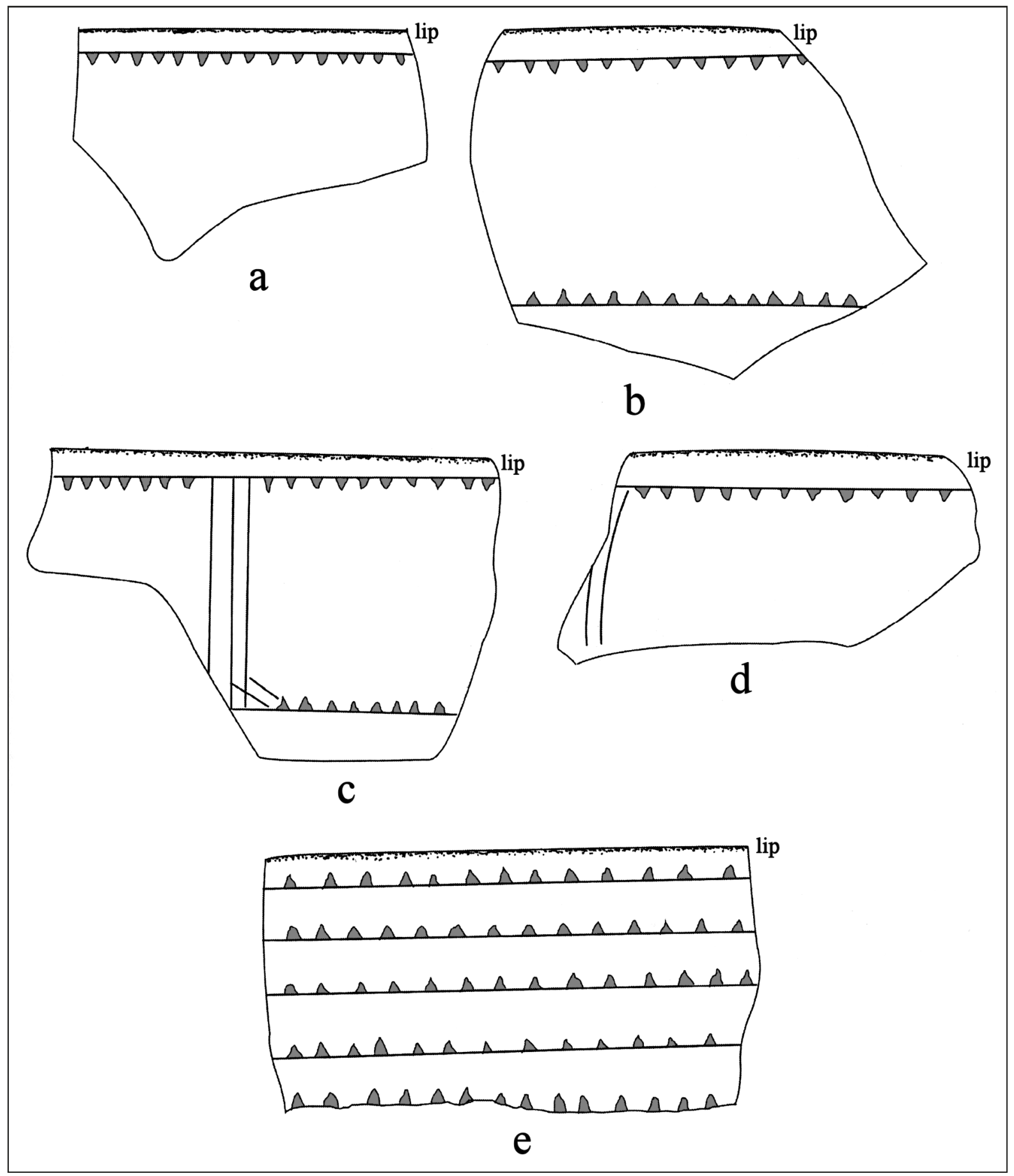

Figure 64. Selected decorative elements on fine ware sherds from the L. Cecil Farm (41AN8).

\section{Shacklesford (41AN11)}

The Shacklesford site was recorded in 1931 by A. T. Jackson as located along a tributary to Caddo Creek where Caddo ceramic vessels had been eroded from a cut bank some years previously. Miller et al. (2014:524) excavated 10 shovel tests at the TARL-plotted location, but did not identify any archaeological deposits there. 


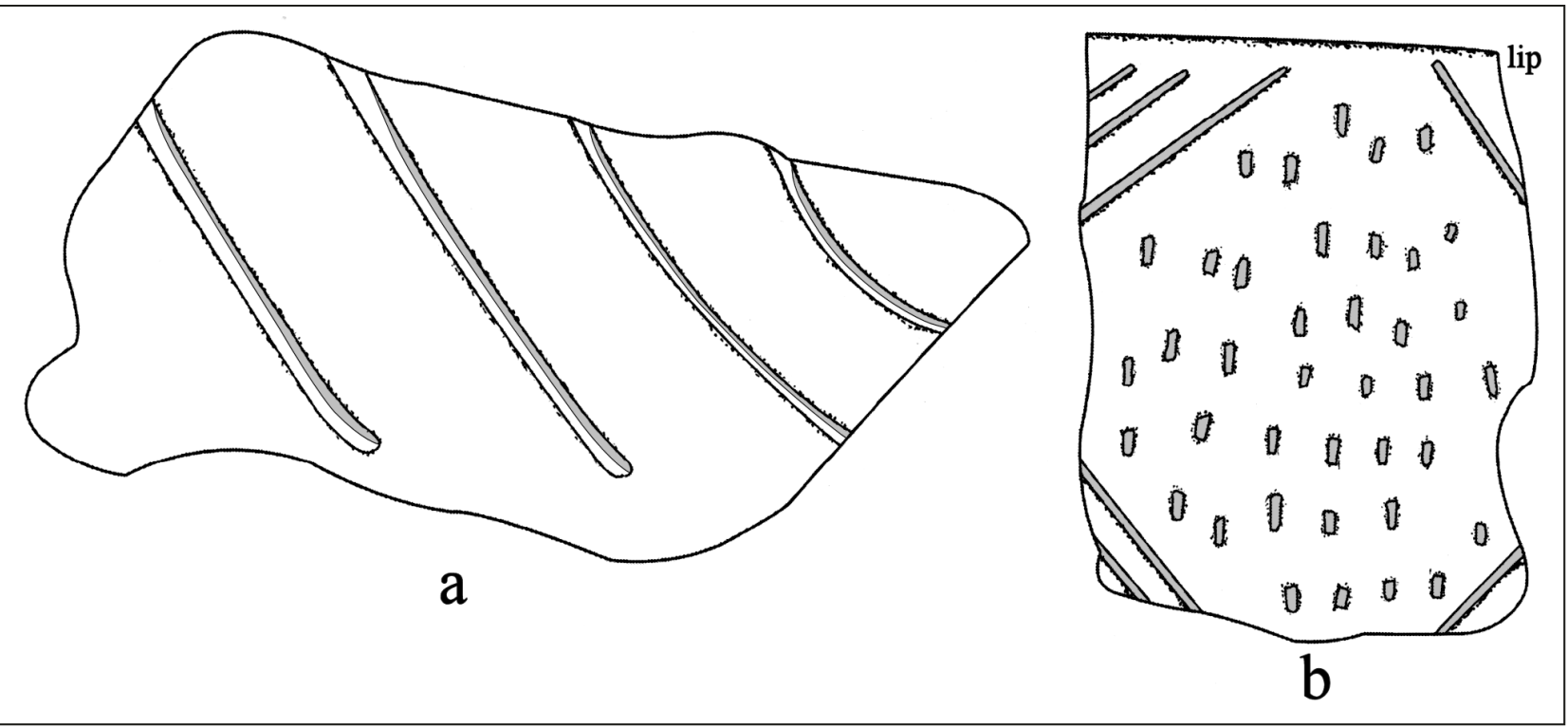

Figure 65. Decorative elements on trailed and incised-punctated sherds from the L. Cecil Farm (41AN8).

\section{Isibel-Gene Donnell (41AN14)}

The Isibel-Gene Donnell site is on the crest of an upland ridge (630 ft. amsl) in the Caddo Creek valley; the creek lies ca. $100 \mathrm{~m}$ to the east of the site. Caddo midden deposits were found ca. $200 \mathrm{~m}$ to the west of the site. In 1934, erosion along a gully exposed an ancestral Caddo burial that had seven associated ceramic vessels; these vessels were subsequently obtained by UT and are in the TARL collections. In October 1935, A. M. Woolsey (1935c) found and excavated another Caddo burial (AG-1) about $13 \mathrm{ft}$. north of the burial earlier exposed by erosion (Figure 66a).

The burial excavated by UT archaeologists was in an east-west oriented grave (measuring $5.5 \times 2.5$ $\mathrm{ft}$. in length and width, and a depth of $3.0 \mathrm{ft}$.), with the head of the deceased facing to the west. Grave goods placed with the burial included eight ceramic vessels on both sides of the body and by the skull, six Perdiz arrow points in various locations on and around the body, and a four-beveled knife found under one of the vessels (see Figure 66b).

There are 14 ceramic vessels in the TARL collections from the Isibel-Gene Donnell site, seven that were purchased by A. T. Jackson and seven vessels from excavated burial AG-1. These include bottles $(n=4)$, including a unique tri-lobed bottle form, jars $(n=2)$, carinated bowls $(n=7)$, and compound bowls $(n=1)$. About 80 percent of the vessels are tempered with grog, 7 percent have grog and bone temper, and 14 percent of the vessels are tempered with burned bone. The identified types and varieties in the vessel assemblage include Poynor Engraved, var. Hood $(\mathrm{n}=5)$, Poynor Engraved, var. Freeman $(\mathrm{n}=1)$, Poynor Engraved, var. E (n=1), Poynor Engraved, var. P', Poynor Engraved, var. unspecified $(\mathrm{n}=1)$, and Bullard Brushed $(\mathrm{n}=2)$. 

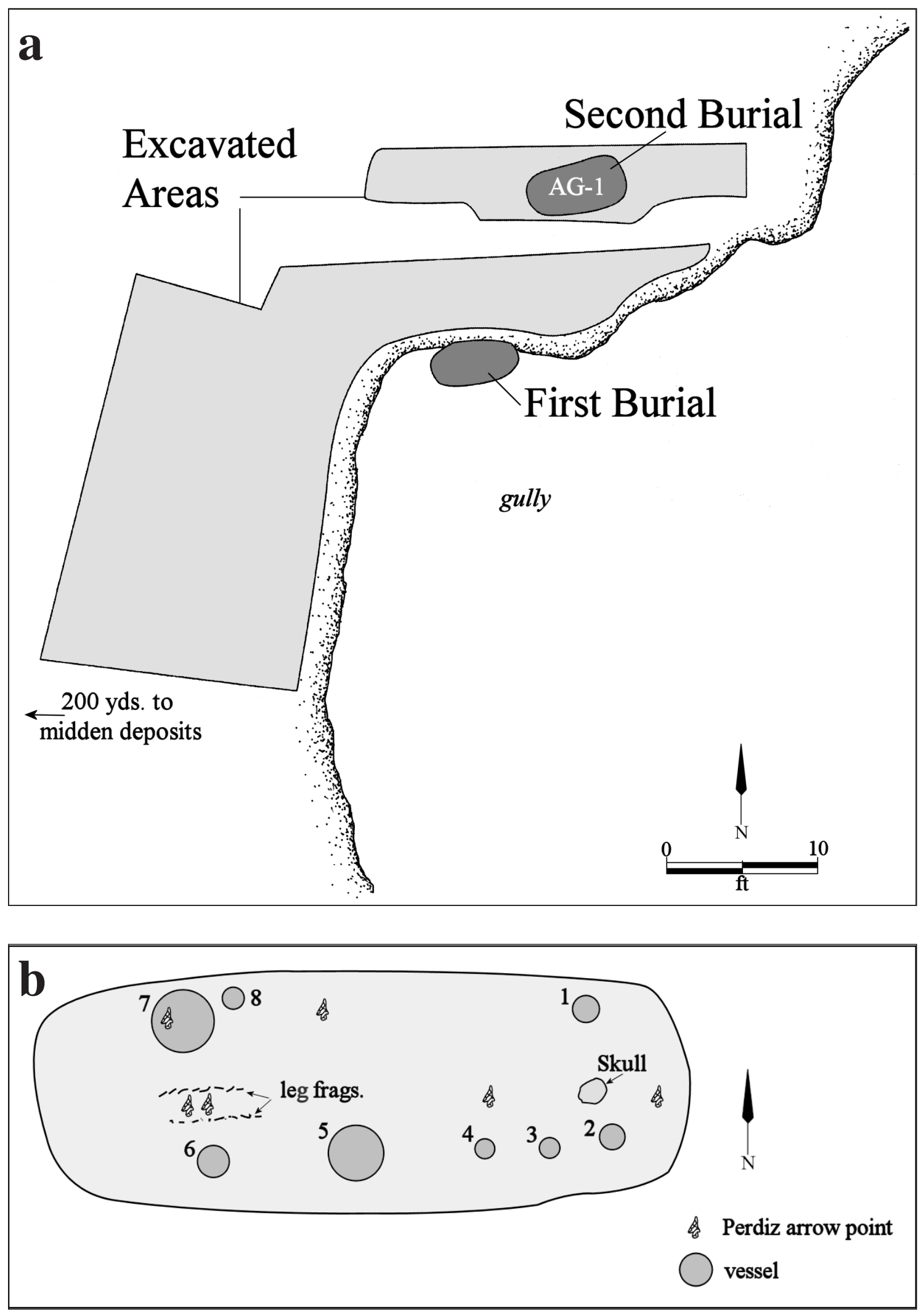

Figure 66. Isibel-Gene Donnell site (41AN14): a, map of excavations and the location of the two burials found there; $b$, plan of Burial AG-1. 
SITE NAME OR SITE NUMBER: Isibel-Gene Donnell

VESSEL NO.: 1, Purchased

VESSEL FORM: Bottle

NON-PLASTICS AND PASTE: grog

RIM AND LIP FORM: Direct rim and flat lip

CORE COLOR: F (fired in a reducing environment and cooled in the open air)

INTERIOR SURFACE COLOR: reddish-brown

EXTERIOR SURFACE COLOR: brown to reddish-brown; fire clouds on the neck and body

WALL THICKNESS (IN MM): rim, 8.4 mm

INTERIOR SURFACE TREATMENT: none

EXTERIOR SURFACE TREATMENT: burnished

HEIGHT (IN CM): 27.8

ORIFICE DIAMETER (IN CM): 5.7

DIAMETER AT BOTTOM OF RIM OR NECK (IN CM): 7.5; maximum body diameter is $21.5 \mathrm{~cm}$ BASE DIAMETER (IN CM) AND SHAPE OF BASE: 9.5; circular and flat ESTIMATED VOLUME (IN LITERS): 1.1

DECORATION (INCLUDING MOTIF AND ELEMENTS WHEN APPARENT): The bottle body is divided into two panels by single vertical engraved lines with triangular and semi-circular attachments. The panels themselves have concentric curvilinear engraved lines that end in a hooked arm element (Figure 67).

PIGMENT USE AND LOCATION ON VESSEL: none

TYPE AND VARIETY (IF KNOWN): Unidentified fine ware

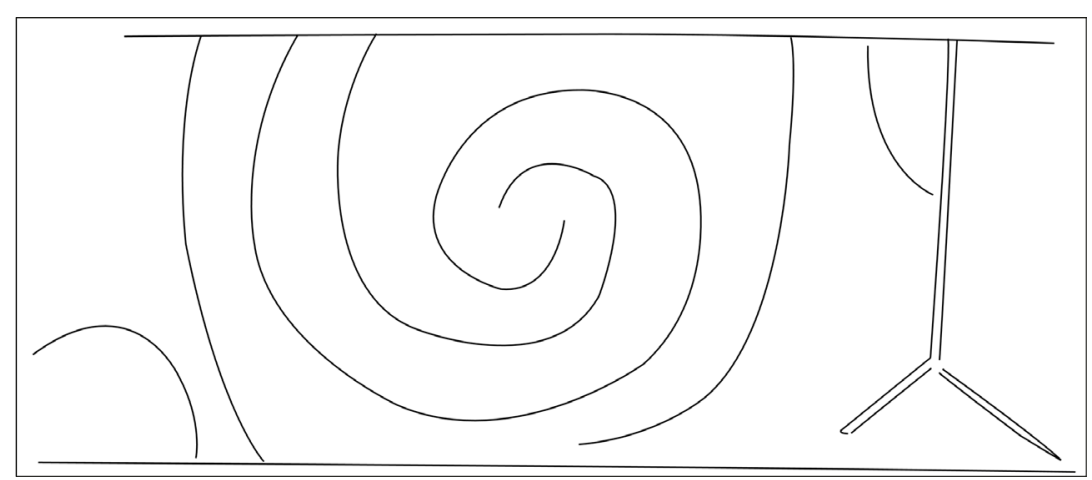

Figure 67. Decorative elements on engraved bottle (No. 1, Purchased) from the Isibel-Gene Donnell site (41AN14). 
SITE NAME OR SITE NUMBER: Isibel-Gene Donnell

VESSEL NO.: 2, Purchased

VESSEL FORM: Tri-lobed bottle

NON-PLASTICS AND PASTE: grog and bone

RIM AND LIP FORM: Inverted rim and rounded lip

CORE COLOR: A (fired and cooled in an oxidizing environment)

INTERIOR SURFACE COLOR: yellowish-brown

EXTERIOR SURFACE COLOR: yellowish-brown; fire clouds on the rim, body, and base

WALL THICKNESS (IN MM): rim, 6.4 mm

INTERIOR SURFACE TREATMENT: none

EXTERIOR SURFACE TREATMENT: smoothed

HEIGHT (IN CM): 21.5

ORIFICE DIAMETER (IN CM): 3.7

DIAMETER AT BOTTOM OF RIM OR NECK (IN CM): 7.0; maximum body diameter is $11.7 \mathrm{~cm}$ BASE DIAMETER (IN CM) AND SHAPE OF BASE: 5.1; circular and flat ESTIMATED VOLUME (IN LITERS): 0.44

DECORATION (INCLUDING MOTIF AND ELEMENTS WHEN APPARENT): Plain PIGMENT USE AND LOCATION ON VESSEL: none TYPE AND VARIETY (IF KNOWN): Unidentified plain ware 
SITE NAME OR SITE NUMBER: Isibel-Gene Donnell

VESSEL NO.: 3, Purchased

VESSEL FORM: Bottle

NON-PLASTICS AND PASTE: grog

RIM AND LIP FORM: Direct rim and flat lip

CORE COLOR: B (fired and cooled in a reducing environment)

INTERIOR SURFACE COLOR: dark grayish-brown

EXTERIOR SURFACE COLOR: dark grayish-brown; fire clouds on the body

WALL THICKNESS (IN MM): rim, 4.9 mm

INTERIOR SURFACE TREATMENT: none

EXTERIOR SURFACE TREATMENT: smoothed

HEIGHT (IN CM): 15.8

ORIFICE DIAMETER (IN CM): 4.5

DIAMETER AT BOTTOM OF RIM OR NECK (IN CM): 5.2; maximum body diameter is $11.0 \mathrm{~cm}$ BASE DIAMETER (IN CM) AND SHAPE OF BASE: 6.8; circular and flat

ESTIMATED VOLUME (IN LITERS): 0.43

DECORATION (INCLUDING MOTIF AND ELEMENTS WHEN APPARENT): The vessel body is divided into two panels by two vertical engraved zones with a horizontal hatched bracket element and single upper and lower horizontal hatched pendant triangles (Figure 68). Each of the panels have three upper and lower hatched or cross-hatched pendant triangles; these elements resemble Var. $C$ on Poynor Engraved carinated bowls (Perttula 2011:Figure 6-65).

\section{PIGMENT USE AND LOCATION ON VES-}

SEL: none

TYPE AND VARIETY (IF KNOWN): Poynor Engraved, var. unspecified

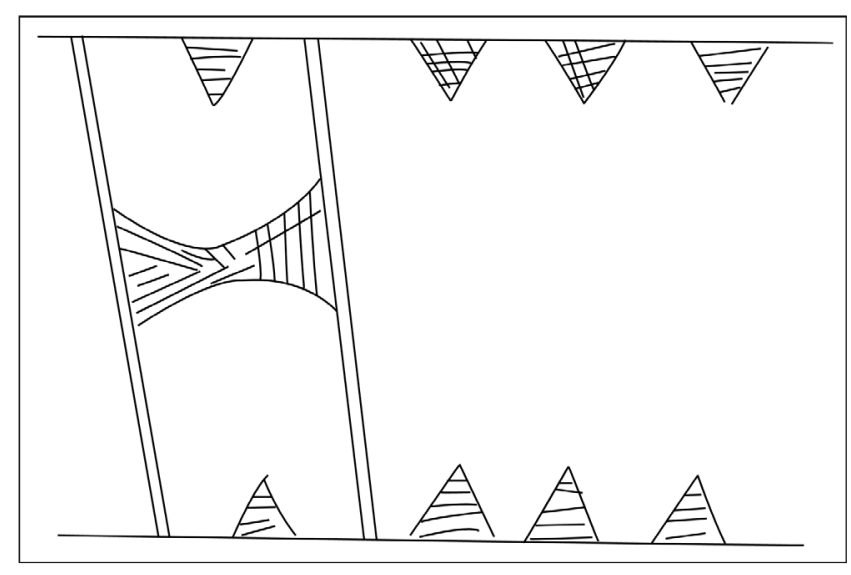

Figure 68. Decorative elements on a Poynor Engraved, var. unspecified bottle (No. 3, Purchased) from the Isibel-Gene Donnell site (41AN14). 
SITE NAME OR SITE NUMBER: Isibel-Gene Donnell

VESSEL NO.: 4, Purchased

VESSEL FORM: Jar with two lug handles (19 x $10 \mathrm{~mm}$ in length and width)

NON-PLASTICS AND PASTE: grog

RIM AND LIP FORM: Everted rim and rounded lip

CORE COLOR: G (fired in a reducing environment and cooled in the open air)

INTERIOR SURFACE COLOR: very dark grayish-brown

EXTERIOR SURFACE COLOR: dark yellowish-brown; fire clouds on the rim, body, and base

WALL THICKNESS (IN MM): rim, $5.0 \mathrm{~mm}$

INTERIOR SURFACE TREATMENT: smoothed

EXTERIOR SURFACE TREATMENT: none

HEIGHT (IN CM): 21.6

ORIFICE DIAMETER (IN CM): 13.3

DIAMETER AT BOTTOM OF RIM OR NECK (IN CM): 12.6

BASE DIAMETER (IN CM) AND SHAPE OF BASE: 6.4; circular and flat

ESTIMATED VOLUME (IN LITERS): 2.6

DECORATION (INCLUDING MOTIF AND ELEMENTS WHEN APPARENT): The rim is decorated with horizontal brushing marks, and the vessel body has vertical brushing marks that extend to within 2.0 $\mathrm{cm}$ of the base.

PIGMENT USE AND LOCATION ON VESSEL: none

TYPE AND VARIETY (IF KNOWN): Bullard Brushed 
SITE NAME OR SITE NUMBER: Isibel-Gene Donnell

VESSEL NO.: 5, Purchased

VESSEL FORM: Jar with two lug handles (12 x $11 \mathrm{~mm}$ in length and width)

NON-PLASTICS AND PASTE: grog

RIM AND LIP FORM: Everted rim and rounded lip

CORE COLOR: $\mathrm{G}$ (fired in a reducing environment and cooled in the open air)

INTERIOR SURFACE COLOR: dark grayish-brown

EXTERIOR SURFACE COLOR: reddish-brown; fire clouds on the rim, body, and base

WALL THICKNESS (IN MM): rim, $6.0 \mathrm{~mm}$

INTERIOR SURFACE TREATMENT: none

EXTERIOR SURFACE TREATMENT: none

HEIGHT (IN CM): 8.9

ORIFICE DIAMETER (IN CM): 8.9

DIAMETER AT BOTTOM OF RIM OR NECK (IN CM): 8.8

BASE DIAMETER (IN CM) AND SHAPE OF BASE: 5.2; circular and flat

ESTIMATED VOLUME (IN LITERS): 0.47

DECORATION (INCLUDING MOTIF AND ELEMENTS WHEN APPARENT): the rim and vessel body are decorated with vertical brushing marks that extend from the rim to within $1.0 \mathrm{~cm}$ of the vessel base.

PIGMENT USE AND LOCATION ON VESSEL: none

TYPE AND VARIETY (IF KNOWN): Bullard Brushed 
SITE NAME OR SITE NUMBER: Isibel-Gene Donnell

VESSEL NO.: 6, Purchased

VESSEL FORM: globular Carinated Bowl

NON-PLASTICS AND PASTE: grog

RIM AND LIP FORM: Direct rim and rounded lip

CORE COLOR: B (fired and cooled in a reducing environment)

INTERIOR SURFACE COLOR: very dark grayish-brown

EXTERIOR SURFACE COLOR: very dark grayish-brown; fire clouds on the body and base

WALL THICKNESS (IN MM): rim, 5.4 mm

INTERIOR SURFACE TREATMENT: burnished on the rim and smoothed on the body

EXTERIOR SURFACE TREATMENT: burnished

HEIGHT (IN CM): 10.2

ORIFICE DIAMETER (IN CM): 12.9

DIAMETER AT BOTTOM OF RIM OR NECK (IN CM): 12.9

BASE DIAMETER (IN CM) AND SHAPE OF BASE: 7.4; circular and flat

ESTIMATED VOLUME (IN LITERS): 0.8

DECORATION (INCLUDING MOTIF AND ELEMENTS WHEN APPARENT): The rim has upper and lower horizontal engraved lines, and the remainder of the rim is divided into eight oval-shaped panels by eight sets of excised bracket elements (Figure 69).

PIGMENT USE AND LOCATION ON VESSEL: white clay pigment in engraved lines

TYPE AND VARIETY (IF KNOWN): Poynor Engraved, var. Hood

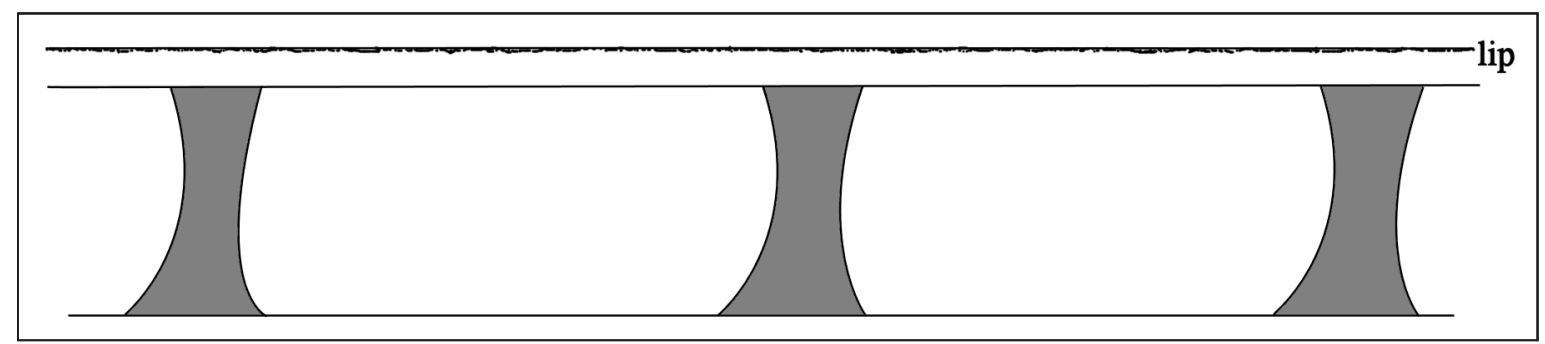

Figure 69. Decorative elements on Poynor Engraved, var. Hood carinated bowl (No. 6, Purchased) from the Isibel-Gene Donnell site. 
SITE NAME OR SITE NUMBER: Isibel-Gene Donnell

VESSEL NO.: 7, Purchased

VESSEL FORM: globular Carinated Bowl

NON-PLASTICS AND PASTE: grog

RIM AND LIP FORM: Everted rim and rounded lip

CORE COLOR: F (fired in a reducing environment and cooled in the open air)

INTERIOR SURFACE COLOR: dark reddish-brown

EXTERIOR SURFACE COLOR: dark reddish-brown; fire clouds on the rim, body, and base

WALL THICKNESS (IN MM): rim, $5.2 \mathrm{~mm}$

INTERIOR SURFACE TREATMENT: smoothed

EXTERIOR SURFACE TREATMENT: smoothed

HEIGHT (IN CM): 11.2

ORIFICE DIAMETER (IN CM): 13.3

DIAMETER AT BOTTOM OF RIM OR NECK (IN CM): 12.8

BASE DIAMETER (IN CM) AND SHAPE OF BASE: 6.4; circular and flat

ESTIMATED VOLUME (IN LITERS): 0.9

DECORATION (INCLUDING MOTIF AND ELEMENTS WHEN APPARENT): The rim panel has three sets of hatched hooked arm elements (Figure 70).

PIGMENT USE AND LOCATION ON VESSEL: none

TYPE AND VARIETY (IF KNOWN): Poynor Engraved, var. P' (Perttula 2011:Figure 6-65)

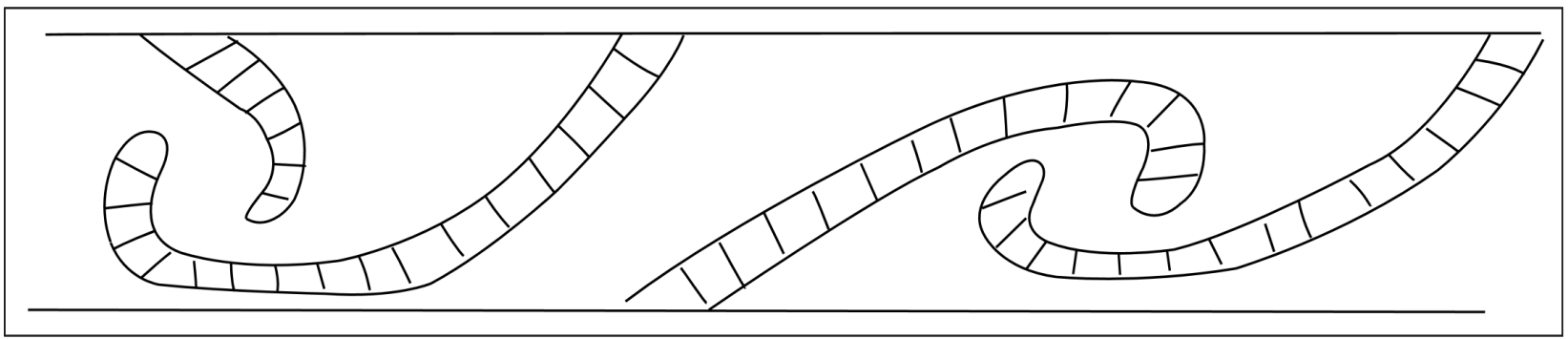

Figure 70. Decorative elements on Poynor Engraved, var. P' carinated bowl (No. 7, Purchased) from the Isibel-Gene Donnell site. 
SITE NAME OR SITE NUMBER: Isibel-Gene Donnell

VESSEL NO.: 1, Burial AG-1

VESSEL FORM: Carinated bowl

NON-PLASTICS AND PASTE: grog

RIM AND LIP FORM: Inverted rim and rounded lip; lip notched

CORE COLOR: A (fired and cooled in an oxidizing environment)

INTERIOR SURFACE COLOR: yellowish-brown

EXTERIOR SURFACE COLOR: yellowish-brown

WALL THICKNESS (IN MM): rim, 4.9 mm

INTERIOR SURFACE TREATMENT: smoothed

EXTERIOR SURFACE TREATMENT: burnished

HEIGHT (IN CM): 10.3

ORIFICE DIAMETER (IN CM): 12.7

DIAMETER AT BOTTOM OF RIM OR NECK (IN CM): 14.4

BASE DIAMETER (IN CM) AND SHAPE OF BASE: 7.0; circular and flat

ESTIMATED VOLUME (IN

LITERS): 0.8

DECORATION (INCLUDING MOTIF AND ELEMENTS

WHEN APPARENT): The rim panel is defined by single upper and lower horizontal engraved lines. The rim panel is divided into three oval-shaped sections by three vertical hatched brackets (Figure 71).

PIGMENT USE AND LOCA-

TION ON VESSEL: none

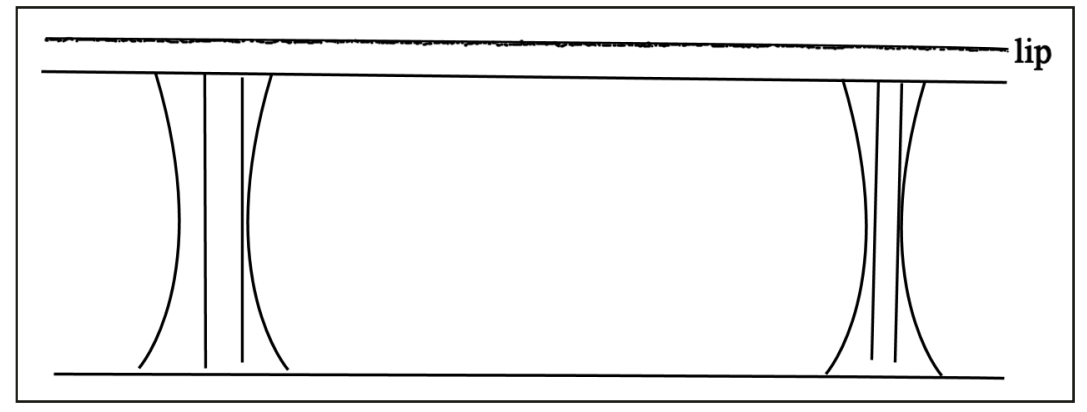

Figure 71. Decorative elements on Poynor Engraved, var. Hood carinated bowl (No. 1, Burial AG-1) from the Isibel-Gene Donnell site.

TYPE AND VARIETY (IF KNOWN): Poynor Engraved, var. Hood 
SITE NAME OR SITE NUMBER: Isibel-Gene Donnell

VESSEL NO.: 2, Burial AG-1

VESSEL FORM: Bottle with a short neck

NON-PLASTICS AND PASTE: bone

RIM AND LIP FORM: Direct rim and rounded lip

CORE COLOR: B (fired and cooled in a reducing environment)

INTERIOR SURFACE COLOR: grayish-brown

EXTERIOR SURFACE COLOR: grayish-brown; fire clouds on the rim and body

WALL THICKNESS (IN MM): rim, $6.3 \mathrm{~mm}$

INTERIOR SURFACE TREATMENT: none

EXTERIOR SURFACE TREATMENT: none

HEIGHT (IN CM): 18.4

ORIFICE DIAMETER (IN CM): 4.4

DIAMETER AT BOTTOM OF RIM OR NECK (IN CM): 5.1 ; maximum body diameter is $8.9 \mathrm{~cm}$

BASE DIAMETER (IN CM) AND SHAPE OF BASE: 7.2; circular and flat

ESTIMATED VOLUME (IN LITERS): 0.53

DECORATION (INCLUDING MOTIF AND ELEMENTS WHEN APPARENT): The neck of the bottle is decorated with four horizontal engraved lines.

PIGMENT USE AND LOCATION ON VESSEL: none

TYPE AND VARIETY (IF KNOWN): Unidentified fine ware 
SITE NAME OR SITE NUMBER: Isibel-Gene Donnell

VESSEL NO.: 3, Burial AG-1

VESSEL FORM: globular Carinated Bowl

NON-PLASTICS AND PASTE: bone

RIM AND LIP FORM: Everted rim and rounded lip

CORE COLOR: A (fired and cooled in an oxidizing environment)

INTERIOR SURFACE COLOR: dark reddish-brown

EXTERIOR SURFACE COLOR: dark reddish-brown; fire clouds on the rim, body, and base

WALL THICKNESS (IN MM): rim, $4.3 \mathrm{~mm}$

INTERIOR SURFACE TREATMENT: smoothed

EXTERIOR SURFACE TREATMENT: burnished

HEIGHT (IN CM): 12.1

ORIFICE DIAMETER (IN CM): 14.0

DIAMETER AT BOTTOM OF RIM OR NECK (IN CM): 13.6

BASE DIAMETER (IN CM) AND SHAPE OF BASE: 7.6; circular and flat

ESTIMATED VOLUME (IN LITERS): 1.0

DECORATION (INCLUDING MOTIF AND ELEMENTS WHEN APPARENT): The rim is divided into four large oval-shaped panels by four excised brackets (Figure 72).

PIGMENT USE AND LOCATION ON VESSEL: none

TYPE AND VARIETY (IF KNOWN): Poynor Engraved, var. Hood

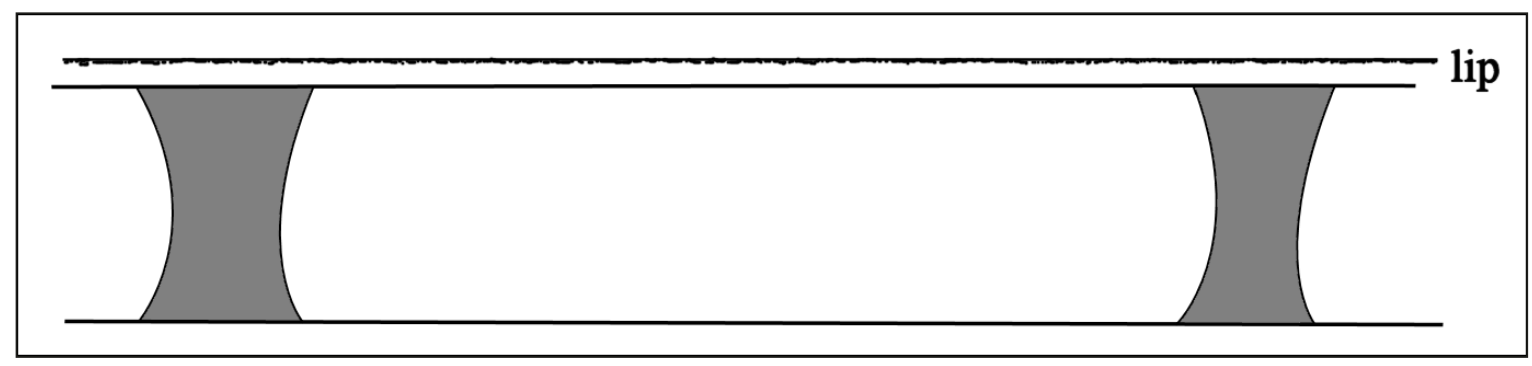

Figure 72. Decorative elements on Poynor Engraved, var. Hood carinated bowl (No. 3, Burial AG-1) from the Isibel-Gene Donnell site. 
SITE NAME OR SITE NUMBER: Isibel-Gene Donnell

VESSEL NO.: 4, Burial AG-1

VESSEL FORM: Carinated bowl

NON-PLASTICS AND PASTE: grog

RIM AND LIP FORM: Inverted rim and possible rounded lip

CORE COLOR: A (fired and cooled in an oxidizing environment)

INTERIOR SURFACE COLOR: yellowish-brown

EXTERIOR SURFACE COLOR: yellowish-brown; fire clouds on the body and base

WALL THICKNESS (IN MM): rim, $5.3 \mathrm{~mm}$

INTERIOR SURFACE TREATMENT: smoothed

EXTERIOR SURFACE TREATMENT: smoothed

HEIGHT (IN CM): 7.0+

ORIFICE DIAMETER (IN CM): 11.2

DIAMETER AT BOTTOM OF RIM OR NECK (IN CM): 13.2

BASE DIAMETER (IN CM) AND SHAPE OF BASE: 5.3; circular and flat

ESTIMATED VOLUME (IN LITERS): 0.5+

DECORATION (INCLUDING MOTIF AND ELEMENTS WHEN APPARENT): The rim has upper and lower rows of large hatched pendant triangles that are divided by single vertical engraved lines that end in hatched pendant triangles (Figure 73).

PIGMENT USE

AND LOCATION

ON VESSEL: none

TYPE AND VARIETY (IF KNOWN):

Poynor Engraved, var. Freeman

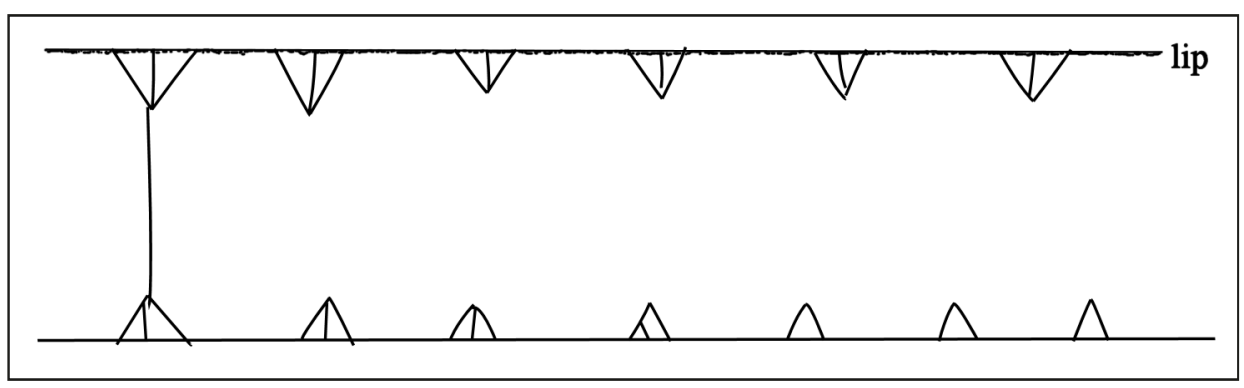

Figure 73. Decorative elements on Poynor Engraved, var. Freeman carinated bowl (No. 4, Burial AG-1) from the Isibel-Gene Donnell site. 
SITE NAME OR SITE NUMBER: Isibell-Gene Donnell

VESSEL NO.: 5, Burial AG-1

VESSEL FORM: Carinated bowl

NON-PLASTICS AND PASTE: grog

RIM AND LIP FORM: Inverted rim and rounded lip

CORE COLOR: $\mathrm{G}$ (fired in a reducing environment and cooled in the open air)

INTERIOR SURFACE COLOR: grayish-brown

EXTERIOR SURFACE COLOR: yellowish-brown; fire clouds on the body and base; organic residue on the rim and body

WALL THICKNESS (IN MM): rim, $6.8 \mathrm{~mm}$

INTERIOR SURFACE TREATMENT: burnished on the rim and smoothed on the body

EXTERIOR SURFACE TREATMENT: burnished

HEIGHT (IN CM): 19.1

ORIFICE DIAMETER (IN CM): 30.3

DIAMETER AT BOTTOM OF RIM OR NECK (IN CM): 31.0

BASE DIAMETER (IN CM) AND SHAPE OF BASE: 9.5; circular and flat

ESTIMATED VOLUME (IN LITERS): 5.2

DECORATION (INCLUDING MOTIF AND ELEMENTS WHEN APPARENT): The rim has an engraved slanting scroll motif between four large circle elements (Figure 74). The upper and lower scroll fill zones have a series of curvilinear engraved lines. The vessel body has horizontal brushing marks that begin $2.5 \mathrm{~cm}$ below the carination and end $3.7 \mathrm{~cm}$ above the vessel base.

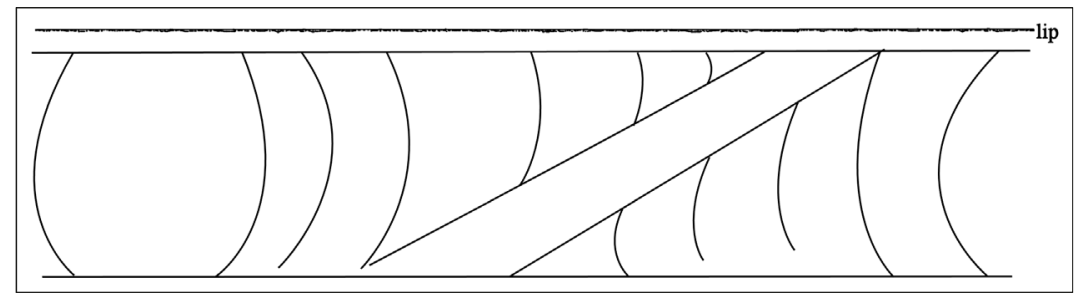

Figure 74. Decorative elements on Poynor Engraved, var. $E$ carinated bowl (No. 5, Burial AG-1) from the Isibel-Gene Donnell site.

PIGMENT USE AND LOCATION ON VESSEL: none

TYPE AND VARIETY (IF KNOWN): Poynor Engraved, var. E (Perttula 2011:Figure 6-65) 
SITE NAME OR SITE NUMBER: Isibel-Gene Donnell

VESSEL NO.: 6, Burial AG-1

VESSEL FORM: globular Carinated Bowl

NON-PLASTICS AND PASTE: grog

RIM AND LIP FORM: Direct rim and rounded lip

CORE COLOR: $\mathrm{G}$ (fired in a reducing environment and cooled in the open air)

INTERIOR SURFACE COLOR: grayish-brown

EXTERIOR SURFACE COLOR: reddish-brown; fire clouds on the rim, body, and base; organic residue on the body

WALL THICKNESS (IN MM): rim, $5.9 \mathrm{~mm}$

INTERIOR SURFACE TREATMENT: smoothed

EXTERIOR SURFACE TREATMENT: smoothed

HEIGHT (IN CM): 13.5

ORIFICE DIAMETER (IN CM): 17.1

DIAMETER AT BOTTOM OF RIM OR NECK (IN CM): 17.0

BASE DIAMETER (IN CM) AND SHAPE OF BASE: 6.4; circular and flat

ESTIMATED VOLUME (IN LITERS): 2.1

DECORATION (INCLUDING MOTIF AND ELEMENTS WHEN APPARENT): The rim is divided into eight oval-shaped panels by a series of eight hatched bracket elements (Figure 75).

PIGMENT USE AND

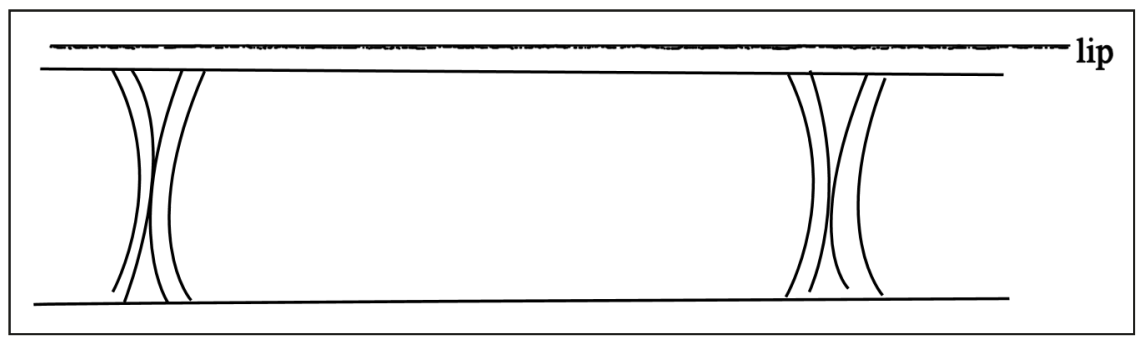

Figure 75. Decorative elements on Poynor Engraved, var. Hood carinated bowl (No. 6, Burial AG-1) from the Isibel-Gene Donnell site. LOCATION ON VESSEL:

none

TYPE AND VARIETY (IF KNOWN): Poynor Engraved, var. Hood 
SITE NAME OR SITE NUMBER: Isibel-Gene Donnell

VESSEL NO.: 7, Burial AG-1

VESSEL FORM: Carinated bowl

NON-PLASTICS AND PASTE: grog

RIM AND LIP FORM: Inverted rim and rounded lip

CORE COLOR: A (fired and cooled in an oxidizing environment)

INTERIOR SURFACE COLOR: dark yellowish-brown; fire clouds on the rim, body, and base

EXTERIOR SURFACE COLOR: yellowish-brown; fire clouds on the rim

WALL THICKNESS (IN MM): rim, $7.3 \mathrm{~mm}$

INTERIOR SURFACE TREATMENT: burnished on the rim and smoothed on the body

EXTERIOR SURFACE TREATMENT: burnished

HEIGHT (IN CM): 16.5

ORIFICE DIAMETER (IN CM): 29.0

DIAMETER AT BOTTOM OF RIM OR NECK (IN CM): 31.0

BASE DIAMETER (IN CM) AND SHAPE OF BASE: 7.6; circular and flat

ESTIMATED VOLUME (IN LITERS): 4.3

DECORATION (IN-

CLUDING MOTIF AND

ELEMENTS WHEN

APPARENT): The rim is

divided into eight large

oval-shaped panels by

nine excised bracket

elements (Figure 76). The

vessel body has horizontal brushing marks that begin

$4.6 \mathrm{~cm}$ below the vessel

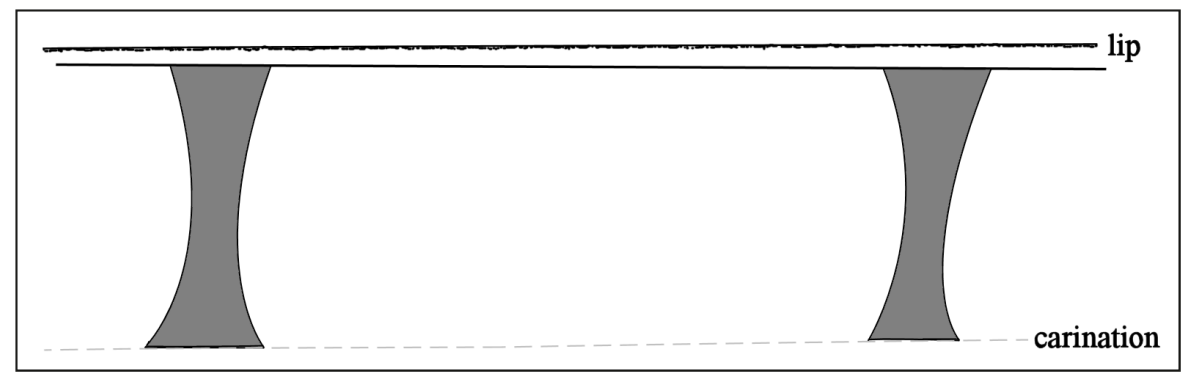

Figure 76. Decorative elements on Poynor Engraved, var. Hood carinated bowl (No. 7, Burial AG-1) from the Isibel-Gene Donnell site. carination and extend to the vessel base.

PIGMENT USE AND LOCATION ON VESSEL: none

TYPE AND VARIETY (IF KNOWN): Poynor Engraved, var. Hood 
According to a 1983 TARL inventory, there were 25 sherds recovered in the Woolsey excavations, but a 1983 inventory only listed 21 sherds. These included eight plain sherds, one Killough Pinched sherd, two sherds with incised decorative elements - including one with curvilinear lines and the other a sherd from a Maydelle Incised vessel with cross-hatched incised lines, seven Bullard Brushed sherds, and three sherds from Poynor Engraved carinated bowls.

\section{De Long Farm (41AN16)}

The De Long Farm site (41AN16) is in the Caddo Creek valley in the upper Neches River basin in East Texas, about $3.2 \mathrm{~km}$ northwest of the small town of Frankston, Texas (Figure 77). A Caddo midden area was about $200 \mathrm{~m}$ to the east of a suspected burial feature.

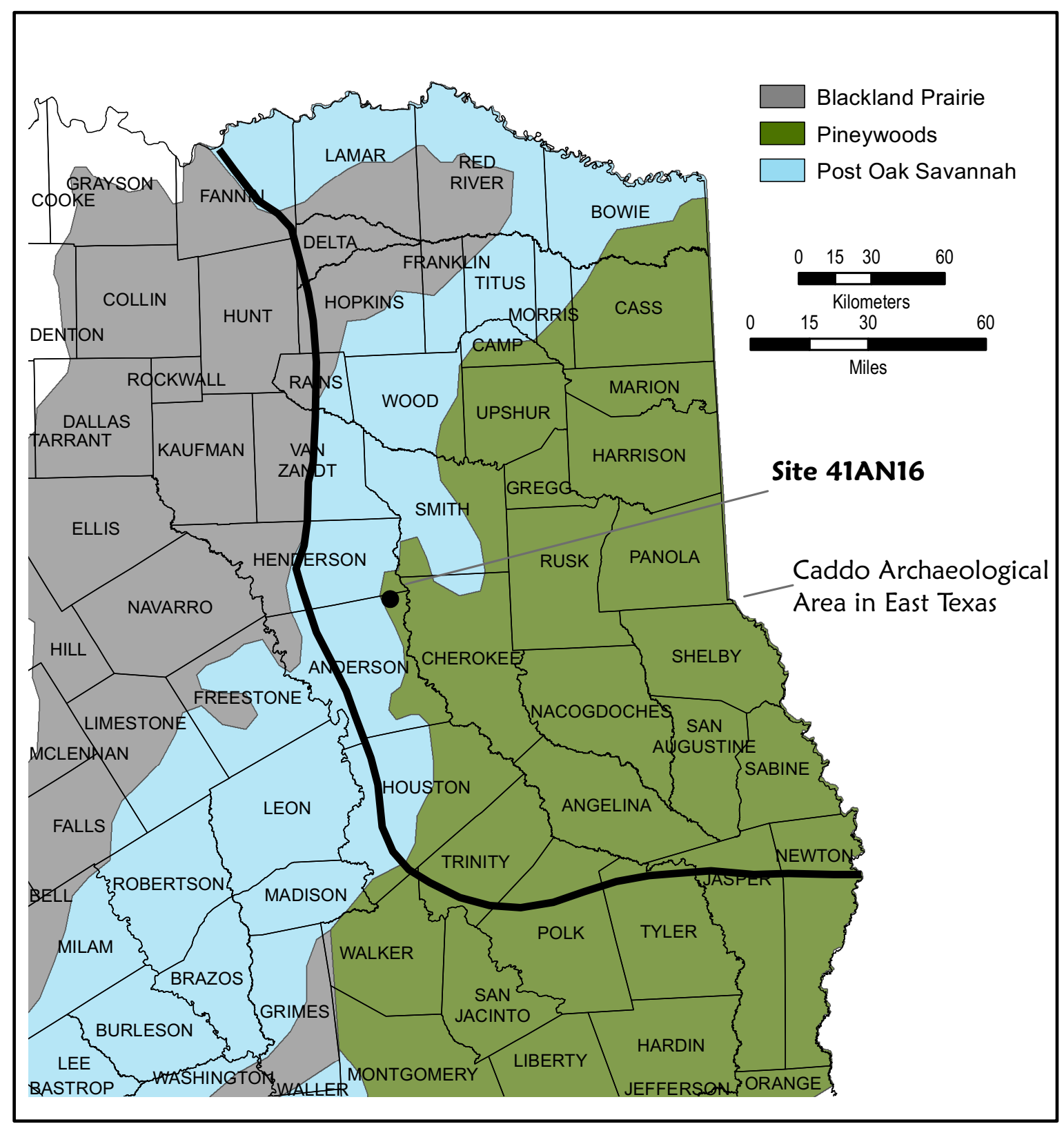

Figure 77. The location of the De Long Farm site (41AN16) in East Texas. 
The site was found by a local farmer after a vessel was discovered in a gully in a field after plowing. University of Texas archaeologists investigated the find spot in October 1935 (Woolsey 1935a), but after excavating a large area around the vessel find spot (Figure 78), no other vessels or any evidence of burials were found. UT did purchase the one vessel from the local farmer.

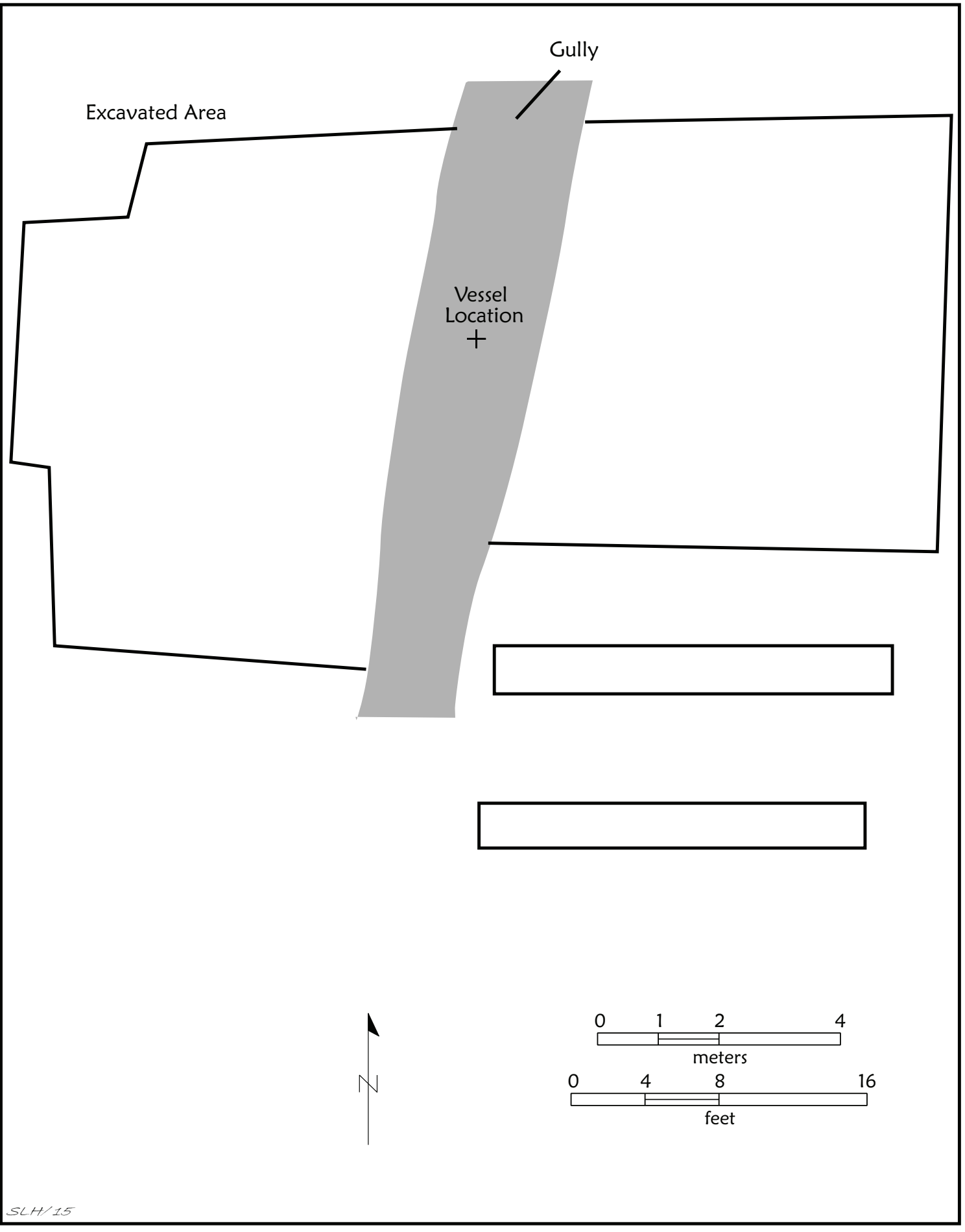

Figure 78. 1935 excavations by UT archaeologists at the De Long Farm site (41AN16). 


\section{Ceramic Vessel from the De Long Farm Site}

SITE NAME OR SITE NUMBER: De Long Farm, also known as Stevenson Estate; 41AN16

VESSEL NO.: 41AN16-1

VESSEL FORM: globular Carinated Bowl

NON-PLASTICS AND PASTE: grog

RIM AND LIP FORM: Direct rim and a rounded lip

CORE COLOR: $\mathrm{F}$ (fired in a reducing environment and cooled in the open air)

INTERIOR SURFACE COLOR: dark reddish-brown

EXTERIOR SURFACE COLOR: dark reddish-brown

WALL THICKNESS (IN MM): rim, $5.1 \mathrm{~mm}$

INTERIOR SUR-

FACE TREAT-

MENT: smoothed

EXTERIOR SUR-

FACE TREAT-

MENT: burnished

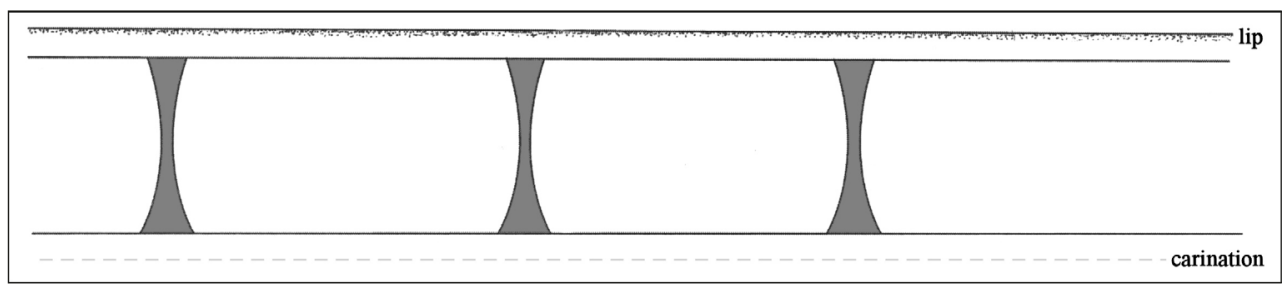

HEIGHT

(IN CM): 7.3

Figure 79. Poynor Engraved, var. Hood carinated bowl from the De Long Farm site (41AN16).

ORIFICE DIAM-

ETER (IN CM): 9.8

DIAMETER AT BOTTOM OF RIM OR NECK (IN CM): 9.8

BASE DIAMETER (IN CM) AND SHAPE OF BASE: 6.4; circular and flat

ESTIMATED VOLUME (IN LITERS): 0.43

DECORATION (INCLUDING MOTIF AND ELEMENTS WHEN APPARENT): The rim panel (as defined by upper and lower horizontal engraved lines, one under the lip and the other just above the vessel carination) is divided into eight sections by a repeating series of excised brackets (Figure 79).

PIGMENT USE AND LOCATION ON VESSEL: none

TYPE AND VARIETY (IF KNOWN): Poynor Engraved, var. Hood (see Perttula 2011:Figure 6-64e). 
In summary, an ancestral Caddo ceramic vessel was discovered by a farmer on the De Long Farm in 1935, and UT archaeologists excavated a large area around the vessel find spot in October 1935, but found no other vessels or evidence of any burials. Given that the vessel was found in an eroded gully, it is likely that a single Caddo burial had been eroded away some time previously, and the one vessel remaining was one (if not the only) funerary offering associated with this burial.

The ceramic vessel found at the De Long Farm site is a globular Poynor Engraved, var. Hood carinated bowl. This style of engraved vessel is common in ca. A.D. 1480-1650 Frankston phase contexts in the upper Neches River basin in East Texas (Perttula 2011:Table 6-37).

\section{John L. Carson (41AN17)}

The John L. Carson Farm is on Caddo Creek. In 1933, UT archaeologists noted that there were many Caddo ceramic sherds visible on the plowed surface of the site, but they did no archaeological investigations there. No archaeologists have been to the site since that time.

\section{Emma Owens (41AN21)}

The Mrs. Emma Owens site is on an unnamed tributary of Caddo Creek. UT archaeologists excavated here in 1931, exposing one burial, midden deposits, and a pit feature (Cole 1975:120); the burial was ca. $14 \mathrm{~m}$ southeast of the midden. One of the associated funerary offerings in the burial was a ceramic vessel from the site that had been placed by the left shoulder of a Caddo adult man, along with a clay elbow pipe and a metal knife blade (Cole 1975:125).

SITE NAME OR SITE NUMBER: Emma Owens

VESSEL NO.: G-1/41AN21-9

NON-PLASTICS AND PASTE: grog-hematite and a fine sandy paste

VESSEL FORM: Bowl

RIM AND LIP FORM: Everted rim and a rounded lip

CORE COLOR: A (fired and cooled in an oxidizing environment)

INTERIOR SURFACE COLOR: light yellowish-brown; fire clouds on the base

EXTERIOR SURFACE COLOR: light yellowish-brown

WALL THICKNESS (RIM, BODY, AND BASE IN MM): rim, 3.8 mm

INTERIOR SURFACE TREATMENT: smoothed on the rim and body

EXTERIOR SURFACE TREATMENT: smoothed on the rim

HEIGHT (IN CM): 7.5 
ORIFICE DIAMETER (IN CM): 9.0

\section{DIAMETER AT BOTTOM OF RIM OR NECK (IN CM): 8.7}

\section{BASE DIAMETER (IN CM) AND SHAPE OF BASE: 4.5}

\section{ESTIMATED VOLUME (IN LITERS): 0.3}

\section{DECORATION (INCLUDING MOTIF} AND ELEMENTS WHEN APPARENT):

The rim has two horizontal engraved lines that encircle the vessel, and these lines have upwards- and downwards-pointing excised tick marks. The vessel body has an engraved concentric circle motif repeated four times around the vessel (Figure 80).

\section{PIGMENT USE AND LOCATION ON VESSEL: none}

TYPE AND VARIETY [IF KNOWN]: cf. Poynor Engraved, var. Freeman

The ceramic pipe in the burial at the Mrs. Emma Owens site is a var. E elbow pipe (Perttula 2011:Figure 6-23). The pipe is decorated with opposed incised lines that cover the stem as well as the pipe bowl (Figure 81; see also Jackson 1933:Plate 17:45). According to Jackson (1933a:77), the "pipe was just outside the left humerus slightly above the elbow. It had a conical bowl andsave for a shorter stem - was much the same as the pipes found in prehistoric graves in the vicinity. There was much carbon inside the stem. Well made, but crudely decorated, on bowl and stem, with deeply incised lines." There is also a grog-tempered plain elbow pipe bowl sherd from the midden deposits at the site.

The TARL collections from the Emma Owens site has sherds from plain ware, fine ware, and utility ware vessels. All of the 173 sherds are from grog-tempered vessels, and 1.1 percent of the sherds are from vessels that have also had burned bone added as a temper (Table 11).

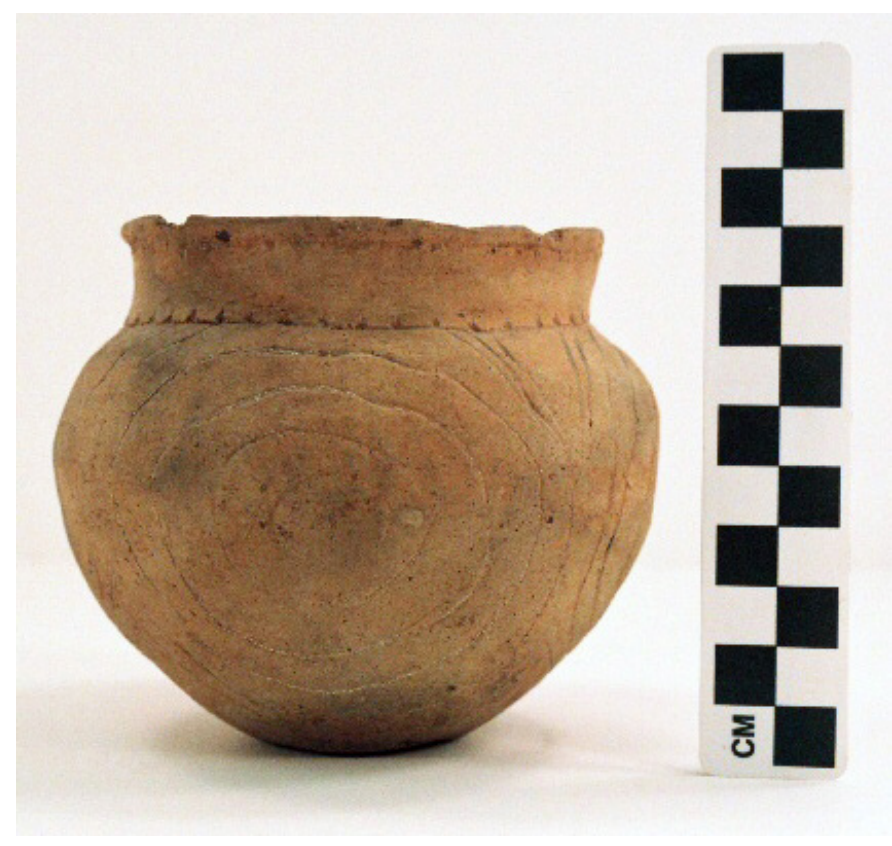

Figure 80. cf. Poynor Engraved, var. Freeman bowl from the Mrs. Emma Owens site.

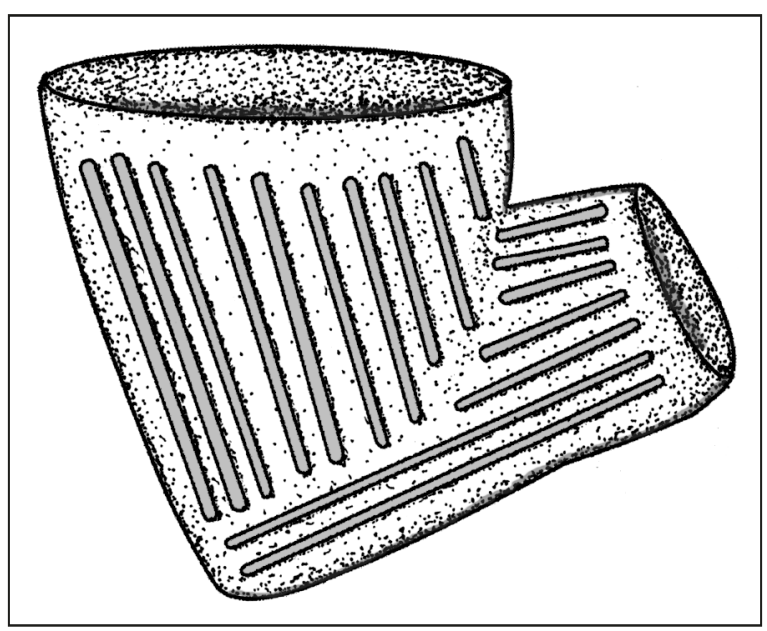

Figure 81. Decorated elbow pipe (Var. E) from the Emma Owens site (41AN21). 
Table 11. Ceramic sherds from the Emma Owens site (41AN21).

\begin{tabular}{llcc}
\hline Ware & Grog temper & Grog-Bone temper & N \\
\hline Plain ware & 40 & - & 40 \\
Fine ware & 21 & 1 & 22 \\
Utility ware & 110 & 1 & 111 \\
\hline & & & 173 \\
Totals & 171 & 2 & \\
\hline
\end{tabular}

The plain to decorated sherd ratio in the Emma Owens sherd assemblage is 0.30 . Fine wares comprise only 12.7 percent of the sherds, while the remainder of the decorated sherds are from utility ware vessels.

The fine ware sherds include one body sherd with an exterior reddish-brown slip, a body sherd with parallel trailed lines (Keno Trailed?), and 20 engraved rim and body sherds (Table 12). Several are from Poynor Engraved vessels (Figure 82h), including several from likely Poynor Engraved, var. Freeman carinated bowls with horizontal or curvilinear engraved line elements; the horizontal engraved lines have excised tick marks (Figure 82e-g).

Table 12. Decorated methods and decorative elements represented in the ceramic sherd assemblage from the Emma Owens site (41AN21).

$\begin{aligned} & \text { Decorative method/decorative } \\ & \text { element }\end{aligned}$
Rim

\section{Fine ware}

Engraved

cross-hatched engraved zone

curvilinear engraved lines

curvilinear engraved lines with excised tick

marks

horizontal engraved line

horizontal engraved line with excised tick marks

horizontal engraved lines with excised tick marks

horizontal excised line

horizontal and curvilinear engraved lines with

excised tick marks

horizontal and curvilinear engraved lines with

excised tick marks on horizontal line

horizontal and diagonal engraved lines and

diagonal excised zone

horizontal and diagonal engraved lines with

excised tick marks 
Table 12. Decorated methods and decorative elements represented in the ceramic sherd assemblage from the Emma Owens site (41AN21), cont.

Decorative method/decorative

$\operatorname{Rim}$

Body

$\mathrm{N}$ element

Fine ware, cont.

horizontal and vertical engraved lines, excised tick marks on upper horizontal lines

parallel engraved lines, with excised tick marks on one line

parallel engraved lines, with linear tick marks on one line

straight engraved line with excised tick marks

Slipped

exterior reddish-brown slip

Trailed

parallel trailed lines

\section{Utility ware}

\section{Appliqued-Incised}

straight appliqued ridge and diagonal incised lines

\section{Brushed}

horizontal brushing marks

opposed brushing marks

overlapping brushing marks

parallel brushing marks

vertical brushing marks

\section{Brushed-Incised}

parallel brushed-incised marks and lines

\section{Brushed-Incised-Punctated}

tool punctated rows beneath rim, with horizontal brushing marks and diagonal incised lines 
Table 12. Decorated methods and decorative elements represented in the ceramic sherd assemblage from the Emma Owens site (41AN21), cont.

Decorative method/decorative

$\operatorname{Rim}$

Body

$\mathrm{N}$

element

Utility ware

Brushed-Punctated

diagonal brushed and tool punctated row pushed

1

through the brushing

overlapping brushing marks and adjacent row of circular tool punctations

parallel brushed with tool punctates pushed through the brushing

Grooved

horizontal grooved

parallel grooved ridges

Incised

parallel incised lines

Incised-Punctated

tool punctated rows on either side of horizontal incised line

\section{Pinched}

parallel pinched ridges

\section{Punctated}

tool punctated row beneath the lip tool punctated rows
1

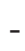

-

1

1

1

1

$\begin{array}{ll}- & 1\end{array}$

Totals

14

119

133

The other engraved fine ware sherds are from Patton Engraved, var. unspecified vessels. These sherds have horizontal and sets of curvilinear engraved lines with excised tick marks (see Figure 82a, c), sets of horizontal engraved lines with excised tick marks (see Figure 82d), and horizontal and diagonal engraved lines with sets of excised tick marks (see Figure 82b).

The utility ware sherds are dominated by those with brushing marks (see Table 12), either as the sole decoration or in combination with incised lines, incised and punctated decorative elements (Figure 83), and punctations pushed through the brushing marks. Approximately 75.9 percent of all the decorated sherds from the Emma Owens site have brushing marks; this comprises 91.0 percent of the utility ware sherds in the assemblage. 


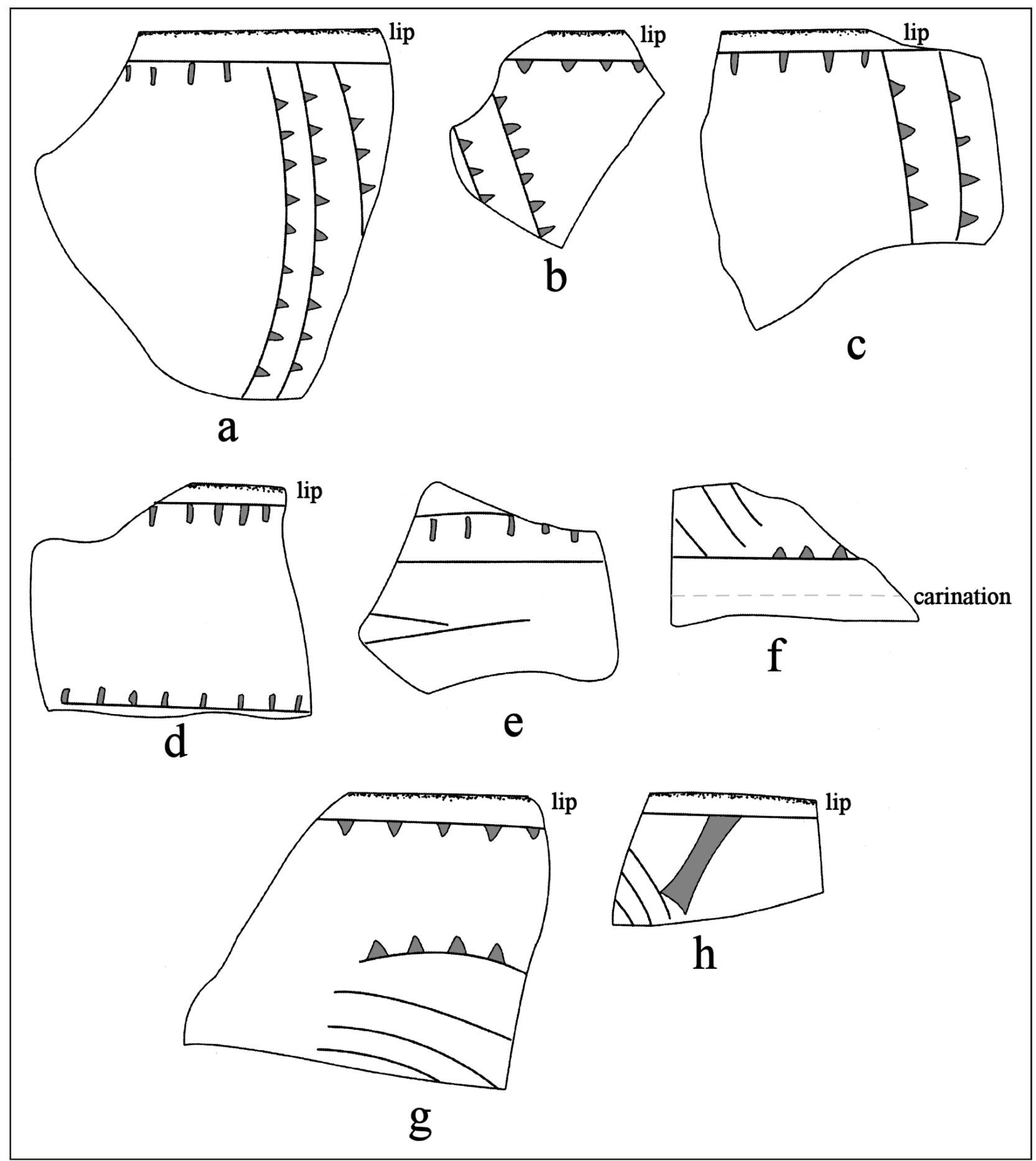

Figure 82. Selected decorative elements on engraved fine ware sherds from the Emma Owens site (41AN21). 


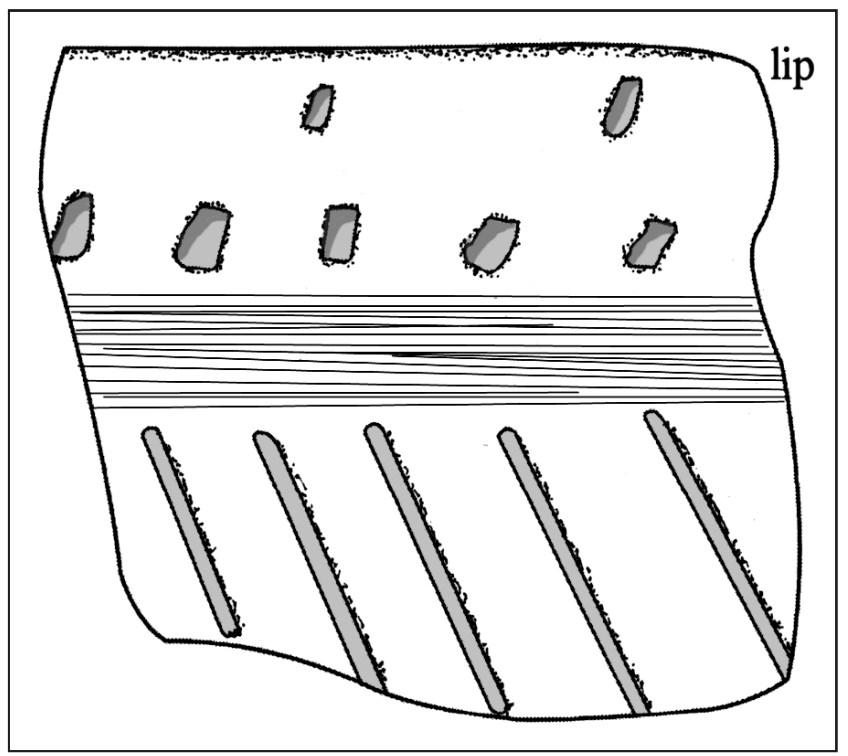

Figure 83. Brushed-incised-punctated rim sherd from the Emma Owens site (41AN21).
There are other utility wares in the collection (see Table 12). They include sherds with appliqued-incised decorative elements $(0.9$ percent of the utility wares at the site), Lindsey Grooved rim and body sherds (1.8 percent of the utility wares), incised sherds ( 0.9 percent), incised-punctated sherds ( 0.9 percent), Killough Pinched body sherds (1.8 percent of the utility wares), and tool punctated sherds (2.7 percent of the utility wares).

The utility ware metrics for this assemblage suggest that the midden deposits at the Emma Owens site are earlier in time than the one burial with a metal knive, likely dating to the latter part of the Frankston phase (after ca. A.D. 1600). This is based primarily on the percentage of brushed sherds (75.9), the percentage of wet paste sherds (17.1 percent), and the brushed-wet paste ratio of 5.32 .

\section{Rose Daniels (41AN23)}

The Rose Daniels Farm site is situated about 200 m east of an unnamed tributary of Caddo Creek. Several ancestral Caddo burials had been plowed up by the landowner near the edge of a county road, and in October 1931, UT archaeologists investigated the site with trenching. During that work, in addition to the recovery of a Late Paleoindian San Patrice point, and sherds from Late Caddo Frankston phase vessels, two ceramic vessels from a burial were located, along with an associated human molar and femur fragments. A deer bone flaking tool was recovered in the trenching at a depth of ca. $26 \mathrm{~cm} \mathrm{bs}$.

The one vessel from the site that remains in the TARL collections is a Poynor Engraved globular carinated bowl with two perforated lug handles. The vessel is $7.6 \mathrm{~cm}$ in height, with an $8.6 \mathrm{~cm}$ orifice diameter.

SITE NAME OR SITE NUMBER: Rose Daniels Farm

VESSEL NO.: 1

VESSEL FORM: Globular carinated bowl with two loop handles (20.5 x $7.6 \mathrm{~mm}$ in length and width)

NON-PLASTICS AND PASTE: grog

RIM AND LIP FORM: Direct rim and rounded lip

CORE COLOR: B (fired and cooled in a reducing environment)

INTERIOR SURFACE COLOR: very dark grayish-brown; organic residue on the rim and body

EXTERIOR SURFACE COLOR: very dark grayish-brown; organic residue on the rim 
WALL THICKNESS (IN MM): rim, 4.9 mm

INTERIOR SURFACE TREATMENT: none

EXTERIOR SURFACE TREATMENT: smoothed

HEIGHT (IN CM): 7.6

ORIFICE DIAMETER (IN CM): 8.6

DIAMETER AT BOTTOM OF RIM OR NECK (IN CM): 8.4

BASE DIAMETER (IN CM) AND SHAPE OF BASE: 5.4; circular and flat

ESTIMATED VOLUME (IN LITERS): 0.4

DECORATION (INCLUDING MOTIF AND ELEMENTS WHEN APPARENT): The rim panel on the vessel is divided into two panels by the loop handles. Within each of the panels are three upper and lower sets of stacked hatched engraved triangle elements (Figure 84).

PIGMENT USE AND LOCATION ON VESSEL: none

TYPE AND VARIETY (IF KNOWN): Poynor Engraved, var. O (Perttula 2011:Figure 6-65)

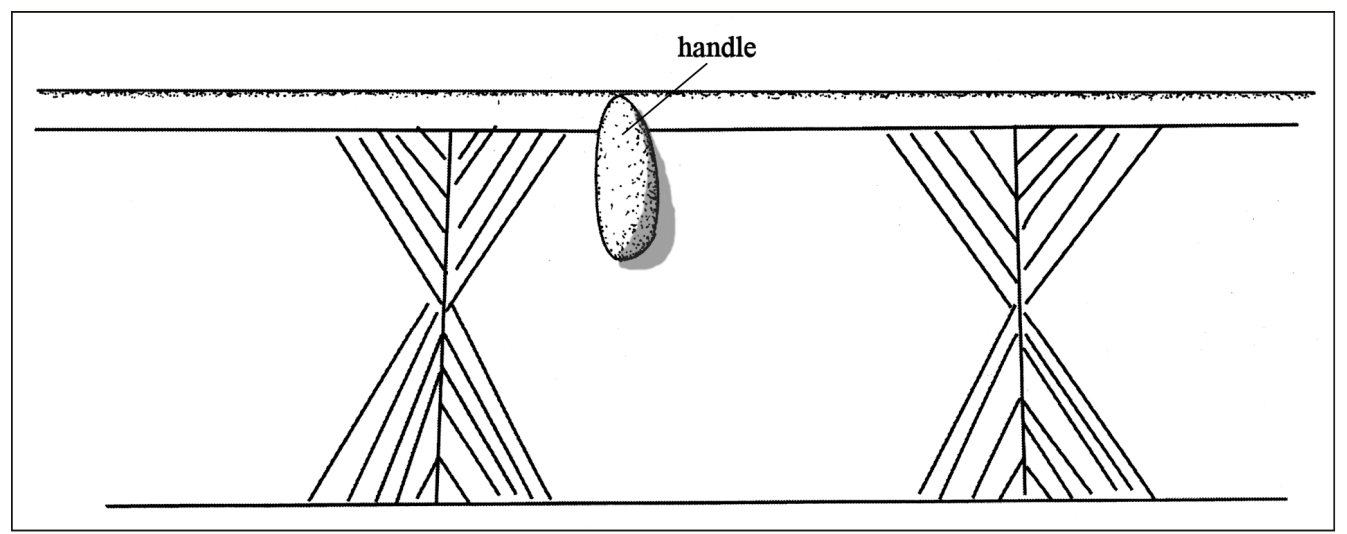

Figure 84. Decorative elements on Poynor Engraved, var. $O$ carinated bowl from the Rose Daniels Farm site (41AN23).

Var. $O$ of Poynor Engraved at the Rose Daniels Farm site is also present in a burial feature at the Lang Pasture site (41AN38) (Perttula 2011:Table 6-37). This suggests that the burial feature at the site likely dates to the early part of the Frankston phase (ca. A.D. 1400-1480).

There is a small assemblage of Frankston phase vessel sherds $(n=36)$ and a ferruginous sandstone abrader in the TARL collections from the Rose Daniels Farm site. The sherds include eight plain body sherds, 12 engraved fine ware sherds, and 16 utility ware sherds. All of the sherds are from grogtempered vessels, and only one sherd (2.8 percent) is from a vessel with both grog and bone temper. 
The engraved sherds are from Poynor Engraved carinated bowls and compound bowls. The one compound bowl has a plain upper panel and sets of three curvilinear engraved lines above two horizontal engraved lines on the lower panel of the vessel (Figure 85a-b). Other Poynor Engraved sherds from the site include a carinated bowl with horizontal and diagonal opposed engraved lines on the rim panel and diagonal brushing on the vessel body (Figure 85c), as well as carinated bowl sherds with hatched triangle elements (Figure 85d-e); these latter may be from Poynor Engraved, var. $O$ vessels. Another distinctive Poynor Engraved carinated bowl sherd has two narrow vertical engraved zones with diagonal hatched lines (Figure 85f).

The utility wares from the Rose Daniels Farm site include 15 brushed body sherds from Bullard Brushed vessels and one body sherd from a Killough Pinched vessel. The brushing marks on the body sherds are diagonal $(n=2)$, opposed $(n=1)$, and parallel $(n=12)$.

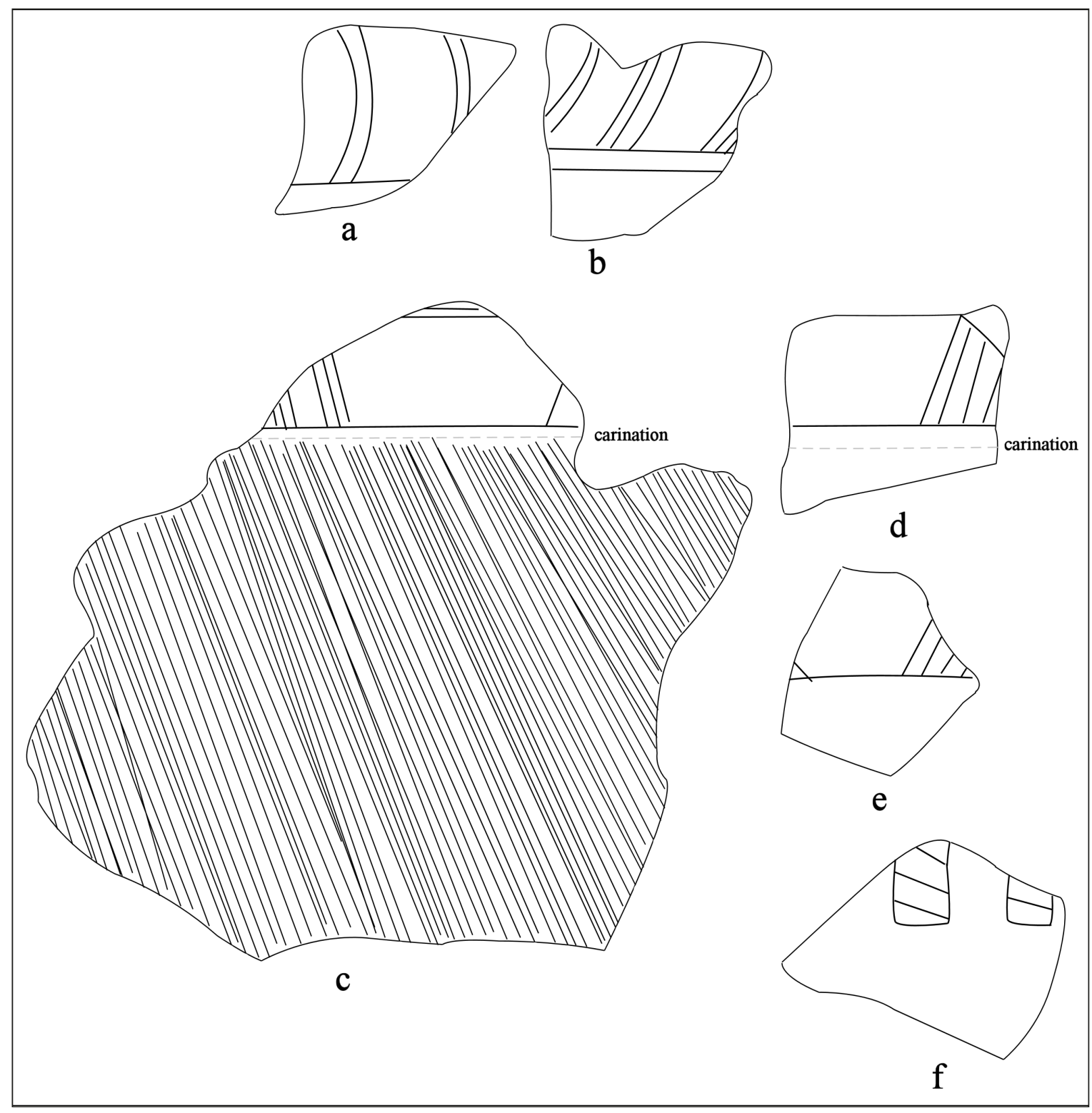

Figure 85. Selected decorative elements on engraved fine ware sherds from the Rose Daniels Farm site (41AN23). 


\section{Richard Patton (41AN26)}

The Richard Patton site has ancestral Caddo habitation deposits as well as a small cemetery (Figure 86) that dates to the Historic Caddo period. The landowner, Mr. Patton, located and excavated 12 burials there, along with the help of a Mr. George Adams, that were in two north-south rows, and recovered 29 ceramic vessels (Cole 1975:129). These vessels were purchased in 1933 by The University of Texas (UT) (Jackson 1933b; Marceaux 2011:418). Two blue glass beads were found in one of the burials (N1-N3) reinvestigated by UT in August 1933 (Cole 1975:Table 8).

In October 1958, R. W. Stephenson visited the Patton site. He noted that there were new potholes at the site, and when he inquired of locals, he was told that they had been dug by George Adams, the "same neighbor who had dug the 12 graves with Patton previous to the University excavations" (letter on file, TARL).

The vessel forms represented in the vessels from the Richard Patton include bowls $(n=4)$, carinated bowls $(n=6)$, globular bowls $(\mathrm{n}=18)$, and one bottle with a collared neck. Types include Patton Engraved, var. Allen $(\mathrm{n}=4)$, cf. Patton Engraved, var. Allen $(\mathrm{n}=1)$, Patton Engraved, var. Fair ( $\mathrm{n}=1)$, cf. Patton Engraved, var. Fair ( $\mathrm{n}=1)$, Patton Engraved, var. Freeman $(\mathrm{n}=8)$, cf. Patton Engraved, var. Freeman $(\mathrm{n}=1)$, Patton Engraved, var. Patton $(\mathrm{n}=4)$, cf. Patton Engraved, var. Patton $(\mathrm{n}=1)$, Patton Engraved, var. unspecified $(\mathrm{n}=2)$, Patton Incised $(\mathrm{n}=1)$, Poynor Engraved, var. Freeman $(\mathrm{n}=2)$, and cf. Poynor Engraved, var. unspecified $(\mathrm{n}=1)$. These vessels were predominantly tempered with grog, and most commonly fired and cooled in an oxidizing environment. Many of the vessels found in Caddo mortuary contexts in the upper Neches River basin have a reddish to reddish-brown color because of high oxygen firing. One of the Patton vessels is "pinkware." These pinkware vessels are vessels with a distinctive red to pink-colored paste after firing." These vessels were made with a clay with a moderate to high iron content. Although the source of this clay is not known, we suspect it derives locally from iron-rich Weches Formation outcrops in the southwestern part of Smith County, the northwestern part of Cherokee County, and in northeastern Anderson County (see Bureau of Economic Geology 1965).

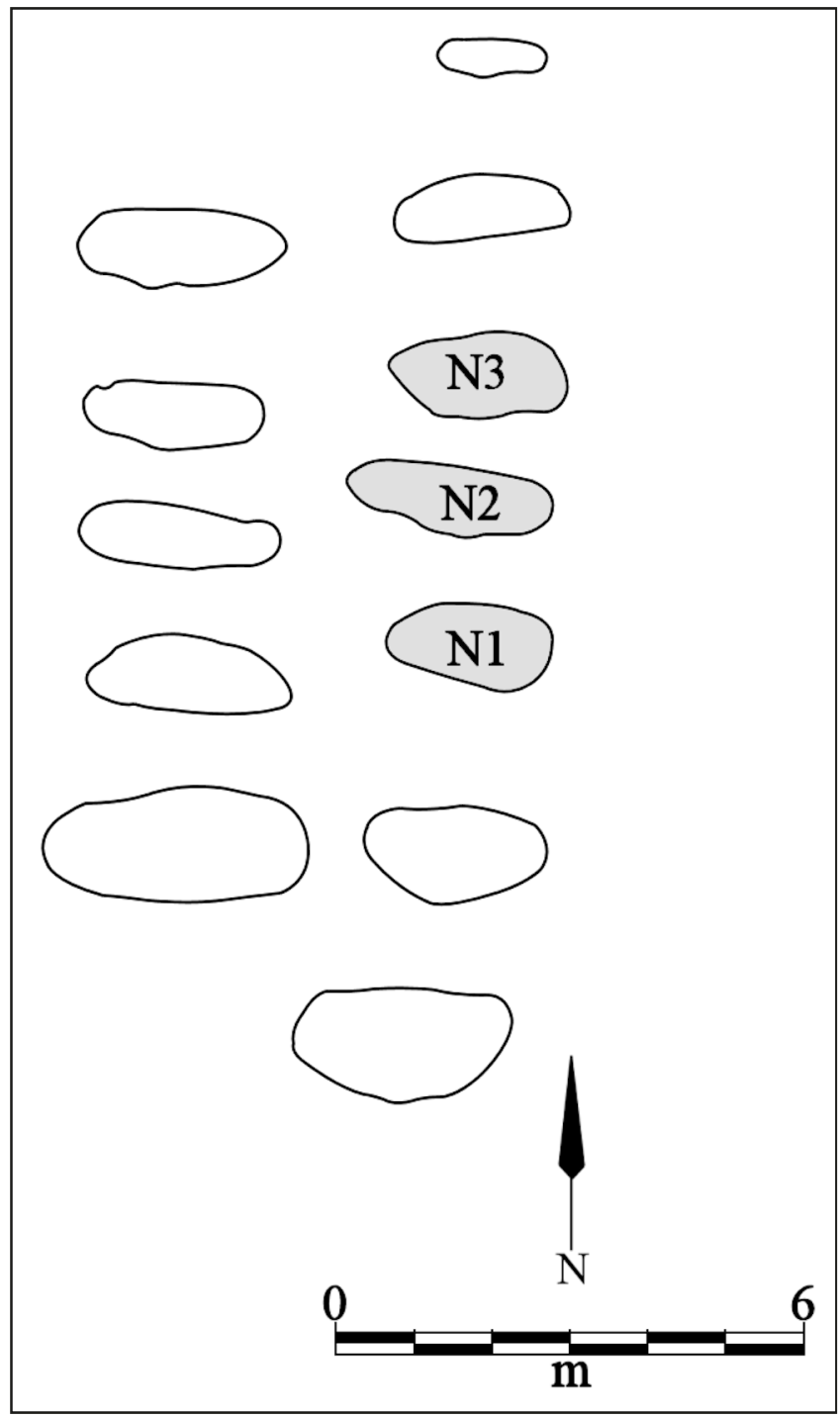

Figure 86. The Allen phase Caddo cemetery at the Richard Patton site (41AN26). 
SITE NAME OR SITE NUMBER: Richard Patton

VESSEL NO.: 41AN26-1

NON-PLASTICS AND PASTE: fine grog; sandy paste

VESSEL FORM: Carinated Bowl

RIM AND LIP FORM: Inverted rim and flat lip

CORE COLOR: A (fired and cooled in an oxidizing environment)

INTERIOR SURFACE COLOR: light gray

EXTERIOR SURFACE COLOR: light gray

WALL THICKNESS (RIM, BODY, AND

BASE IN MM): rim, $6.4 \mathrm{~mm}$

INTERIOR SURFACE TREATMENT:

smoothed on the rim

EXTERIOR SURFACE TREATMENT:

poorly smoothed on the rim

HEIGHT (IN CM): 19.5

ORIFICE DIAMETER (IN CM): 27.2

DIAMETER AT BOTTOM OF RIM OR

NECK (IN CM): 29.0

BASE DIAMETER (IN CM) AND

SHAPE OF BASE: 9.3; circular and flat

ESTIMATED VOLUME (IN LITERS): 4.8

DECORATION (INCLUDING MOTIF AND ELEMENTS WHEN APPARENT): The rim panel is defined by single upper and lower horizontal engraved lines with either downward- or upwards-pointing linear tick marks. The panel itself has three sets of upper and lower hooked arm elements that are each comprised of five closely-spaced arcing lines; the inner and outer lines of each set of engraved lines have outward-pointing excised tick marks (Figure 87). The hooked arm elements are divided by near vertical arcing sets of six engraved lines; the inner and outer lines have outward-pointing excised tick marks. The lower part of the vessel body has horizontal brushing marks.

PIGMENT USE AND LOCATION ON VESSEL: none

TYPE AND VARIETY [IF KNOWN]: Patton Engraved, var. Patton 
SITE NAME OR SITE NUMBER: Richard Patton

VESSEL NO.: 41AN26-3

NON-PLASTICS AND PASTE: grog and hematite; fine sandy paste

VESSEL FORM: Carinated Bowl

RIM AND LIP FORM: Inverted rim and rounded lip

CORE COLOR: A (fired and cooled in an oxidizing environment)

INTERIOR SURFACE COLOR: very pale brown

EXTERIOR SURFACE COLOR: very pale brown

WALL THICKNESS (RIM, BODY, AND

BASE IN MM): rim, $6.5 \mathrm{~mm}$

INTERIOR SURFACE TREATMENT:

smoothed on the rim and base

EXTERIOR SURFACE TREATMENT:

smoothed on the rim

HEIGHT (IN CM): 15.4

ORIFICE DIAMETER (IN CM): 19.6

DIAMETER AT BOTTOM OF RIM OR

NECK (IN CM): 22.4

BASE DIAMETER (IN CM) AND SHAPE

OF BASE: 8.4; circular and flat

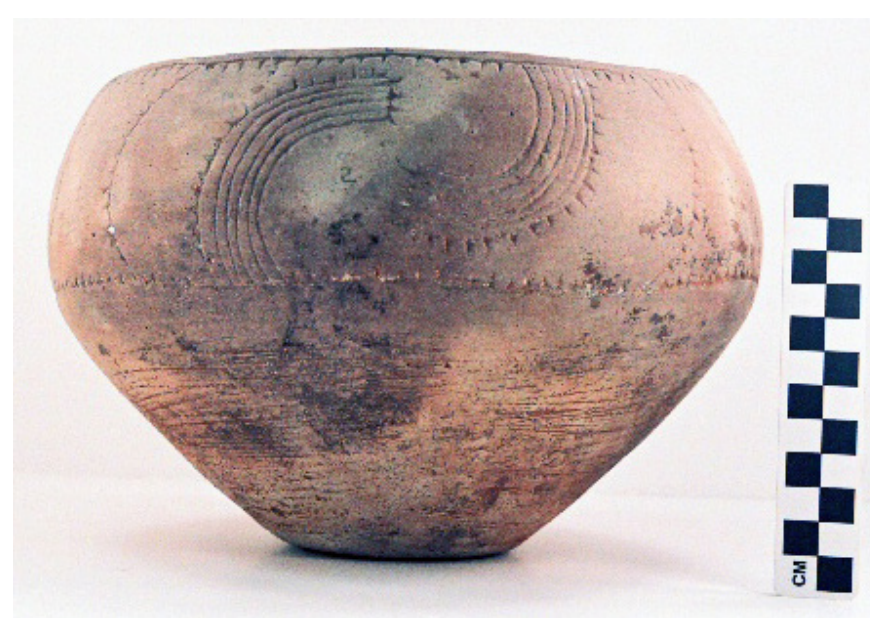

Figure 88. Patton Engraved, var. Patton carinated bowl from the Richard Patton site.

ESTIMATED VOLUME (IN LITERS): 2.7

DECORATION (INCLUDING MOTIF AND ELEMENTS WHEN APPARENT): The rim panel is defined by single upper and lower horizontal engraved lines with upwards- or downwards-pointing linear tick marks. The rim panel itself has three sets of hooked arm elements comprised of six curvilinear arcing lines (Figure 25). The outer lines of each set of hooked arm elements have outward-pointing excised tick marks, and there are also excised tick marks at the vertical end of the hooked arms. The hooked arm elements are divided by open engraved bracket elements with inward-pointing excised tick marks on each side of the bracket (Figure 88). The vessel body has horizontal brushing marks.

PIGMENT USE AND LOCATION ON VESSEL: white pigment in the engraved lines TYPE AND VARIETY [IF KNOWN]: Patton Engraved, var. Patton 
SITE NAME OR SITE NUMBER: Richard Patton

VESSEL NO.: 41AN26-4

NON-PLASTICS AND PASTE: grog and hematite

VESSEL FORM: Carinated bowl

RIM AND LIP FORM: Inverted rim and a rounded lip

CORE COLOR: A (fired and cooled in an oxidizing environment)

INTERIOR SURFACE COLOR: very pale brown; fire clouds on the base

EXTERIOR SURFACE COLOR: very pale brown

WALL THICKNESS (RIM, BODY, AND

BASE IN MM): rim, $5.7 \mathrm{~mm}$

INTERIOR SURFACE TREATMENT:

smoothed on the rim

EXTERIOR SURFACE TREATMENT:

smoothed on the rim; black film/smudging

in patches across the vessel body

HEIGHT (IN CM): 10.5

ORIFICE DIAMETER (IN CM): 16.0

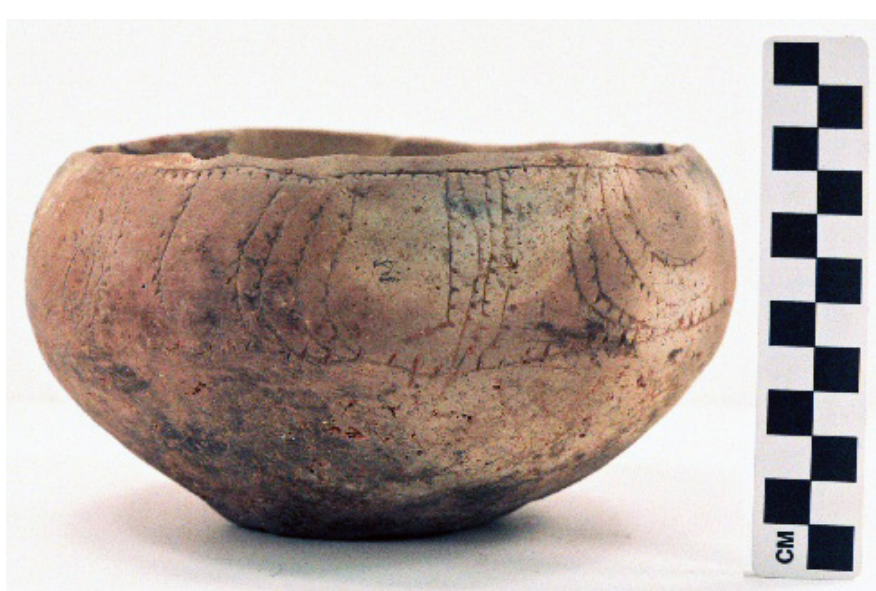

Figure 89. cf. Patton Engraved, var. Patton carinated bowl from the Richard Patton site.

DIAMETER AT BOTTOM OF RIM OR

NECK (IN CM): $19.0 \mathrm{~cm}$

BASE DIAMETER (IN CM) AND SHAPE OF BASE: 8.0; circular and flat

ESTIMATED VOLUME (IN LITERS): 1.0

DECORATION (INCLUDING MOTIF AND ELEMENTS WHEN APPARENT): The rim panel is defined by single upper and lower horizontal engraved lines with either downwards- or upwards-pointing excised tick marks. The panel has six sets of closely-spaced curvilinear engraved lines that are each divided by five closely-spaced near-vertical engraved lines; four of these lines have outwards-pointing excised tick marks (Figure 89). The curvilinear engraved motif has five lines, each with outwards-pointing excised tick marks.

PIGMENT USE AND LOCATION ON VESSEL: none

TYPE AND VARIETY [IF KNOWN]: cf. Patton Engraved, var. Patton 
SITE NAME OR SITE NUMBER: Richard Patton

VESSEL NO.: 41AN26-5

NON-PLASTICS AND PASTE: grog and hematite

VESSEL FORM: Carinated Bowl

RIM AND LIP FORM: Inverted rim and rounded lip

CORE COLOR: A (fired and cooled in an oxidizing environment)

INTERIOR SURFACE COLOR: yellowish-brown; fire clouds on the base

EXTERIOR SURFACE COLOR: brown; fire clouds on the rim

WALL THICKNESS (RIM, BODY, AND

BASE IN MM): rim, $6.2 \mathrm{~mm}$

INTERIOR SURFACE TREATMENT:

smoothed on the rim and body

EXTERIOR SURFACE TREATMENT:

smoothed on the rim and body

HEIGHT (IN CM): 14.5

ORIFICE DIAMETER (IN CM): 18.0

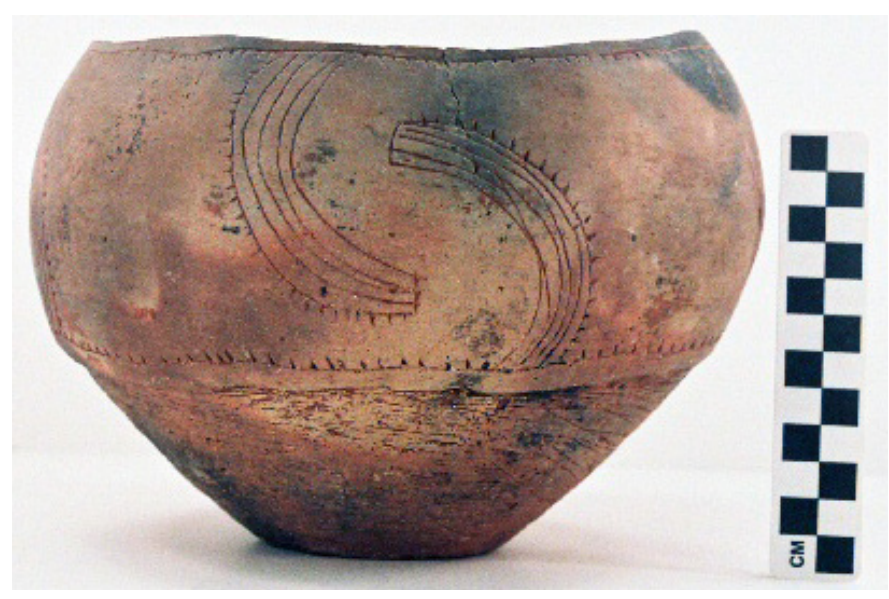

Figure 90. Patton Engraved, var. Patton carinated bowl from the Richard Patton site.

DIAMETER AT BOTTOM OF RIM OR

NECK (IN CM): $21.5 \mathrm{~cm}$ at the widest

point on the body

BASE DIAMETER (IN CM) AND SHAPE OF BASE: 7.0; circular and flat

ESTIMATED VOLUME (IN LITERS): 2.3

DECORATION (INCLUDING MOTIF AND ELEMENTS WHEN APPARENT): The rim panel is defined by single upper and lower horizontal engraved lines with either downwards- or upwards-pointing excised tick marks. The panel has four sets of upper and lower enclosed hooked arm elements (Figure 90). The hooked arm elements each have five curvilinear lines, and the outer line has outwards-pointing excised tick marks. The vessel body has diagonal brushing marks.

PIGMENT USE AND LOCATION ON VESSEL: none

TYPE AND VARIETY [IF KNOWN]: Patton Engraved, var. Patton 
SITE NAME OR SITE NUMBER: Richard Patton

VESSEL NO.: 41AN26-6

NON-PLASTICS AND PASTE: grog

VESSEL FORM: Carinated bowl

RIM AND LIP FORM: Inverted rim and rounded lip

CORE COLOR: A (fired and cooled in an oxidizing environment)

INTERIOR SURFACE COLOR: light yellowish-brown

EXTERIOR SURFACE COLOR: light yellowish-brown; fire clouds on the body and base

WALL THICKNESS (RIM, BODY, AND BASE IN MM): rim, $7.5 \mathrm{~mm}$

INTERIOR SURFACE TREAT-

MENT: smoothed on the rim

EXTERIOR SURFACE TREAT-

MENT: smoothed on the rim

HEIGHT (IN CM): 9.5

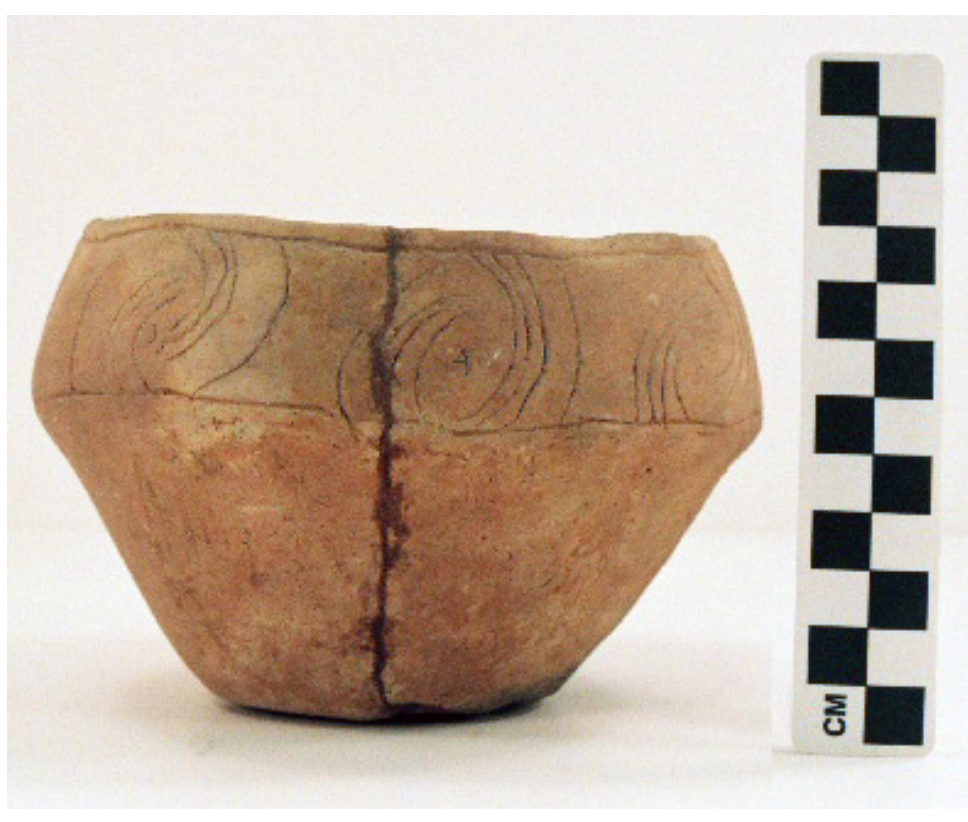

Figure 91. Patton Engraved, var. unspecified carinated bowl from the Richard Patton site.

ORIFICE DIAMETER (IN CM): 12.0

DIAMETER AT BOTTOM OF RIM OR NECK (IN CM): 14.0

BASE DIAMETER (IN CM) AND SHAPE OF BASE: 6.5; circular and flat

ESTIMATED VOLUME (IN LITERS): 0.7

DECORATION (INCLUDING MOTIF AND ELEMENTS WHEN APPARENT): The rim panel is defined by single upper and lower horizontal engraved lines. On the panel are seven sets of upper and lower curvilinear hooked arm elements (Figure 91). None of the hooked arm elements or the horizontal engraved lines at the top and bottom of the panel have tick marks.

PIGMENT USE AND LOCATION ON VESSEL: none

TYPE AND VARIETY [IF KNOWN]: Patton Engraved, var. unspecified 
SITE NAME OR SITE NUMBER: Richard Patton

VESSEL NO.: 41AN26-9

NON-PLASTICS AND PASTE: grog and hematite

VESSEL FORM: Bowl

RIM AND LIP FORM: Direct rim and rounded lip

CORE COLOR: A (fired and cooled in an oxidizing environment)

INTERIOR SURFACE COLOR: very pale brown; fire clouds on the base

EXTERIOR SURFACE COLOR: very pale brown; fire clouds on the base

WALL THICKNESS (RIM, BODY, AND BASE IN MM): rim, $5.3 \mathrm{~mm}$

INTERIOR SURFACE TREATMENT: none

EXTERIOR SURFACE TREATMENT: smoothed on the base

HEIGHT (IN CM): 4.0

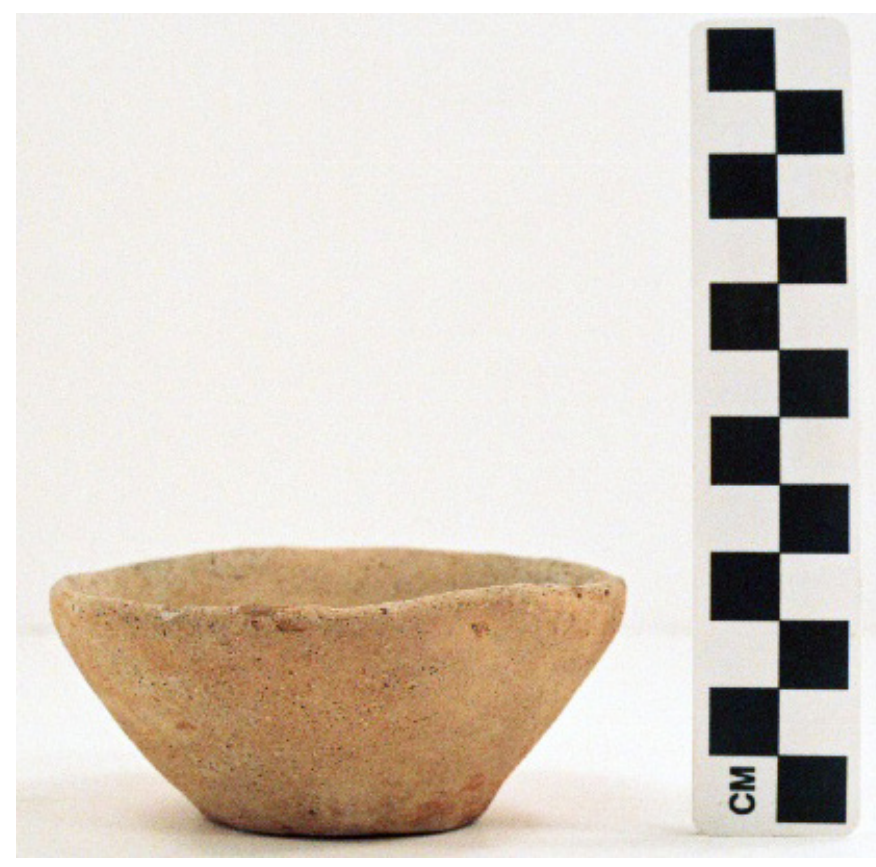

Figure 92. Plain bowl from the Richard Patton site.

ORIFICE DIAMETER (IN CM): 9.0

DIAMETER AT BOTTOM OF RIM OR NECK (IN CM): N/A

BASE DIAMETER (IN CM) AND SHAPE OF BASE: 4.5; circular and flat

ESTIMATED VOLUME (IN LITERS): 0.14

DECORATION (INCLUDING MOTIF AND ELEMENTS WHEN APPARENT): Plain (Figure 92).

PIGMENT USE AND LOCATION ON VESSEL: none

TYPE AND VARIETY [IF KNOWN]: Unidentified plain ware 
SITE NAME OR SITE NUMBER: Richard Patton

VESSEL NO.: 41AN26-10

NON-PLASTICS AND PASTE: grog and hematite

VESSEL FORM: Miniature bowl

RIM AND LIP FORM: Direct rim and rounded $\operatorname{lip}$

CORE COLOR: A (fired and cooled in an oxidizing environment)

INTERIOR SURFACE COLOR: light gray

EXTERIOR SURFACE COLOR: very pale brown

WALL THICKNESS (RIM, BODY, AND

BASE IN MM): rim, $8.3 \mathrm{~mm}$

INTERIOR SURFACE TREATMENT: none

EXTERIOR SURFACE TREATMENT: none

HEIGHT (IN CM): 4.3

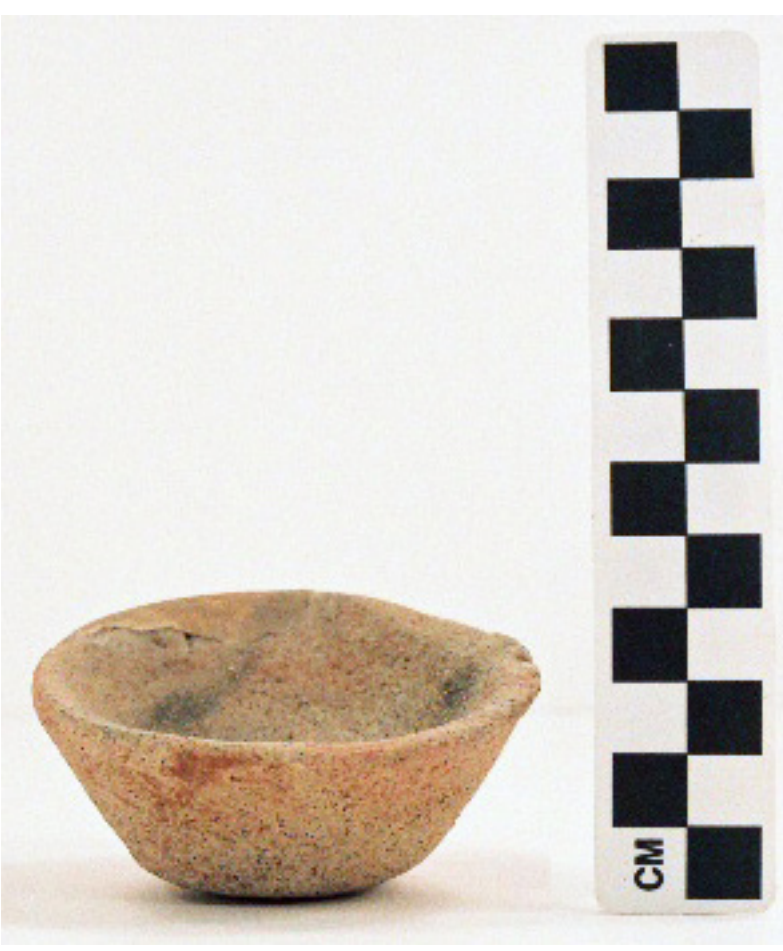

ORIFICE DIAMETER (IN CM): 7.5

Figure 93. Miniature plain bowl from the

DIAMETER AT BOTTOM OF RIM OR NECK Richard Patton site.

(IN CM): N/A

BASE DIAMETER (IN CM) AND SHAPE OF BASE: 4.0; circular and flat

ESTIMATED VOLUME (IN LITERS): 0.13

DECORATION (INCLUDING MOTIF AND ELEMENTS WHEN APPARENT): Plain (Figure 93).

PIGMENT USE AND LOCATION ON VESSEL: none

TYPE AND VARIETY [IF KNOWN]: Unidentified plain ware 
SITE NAME OR SITE NUMBER: Richard Patton

VESSEL NO.: 41AN26-11

NON-PLASTICS AND PASTE: grog and hematite

VESSEL FORM: Square bowl with two perforated lug handles (Figure 94)

RIM AND LIP FORM: Direct rim and rounded lip

CORE COLOR: $\mathrm{F}$ (fired in a reducing environment and cooled in the open air)

INTERIOR SURFACE COLOR: yellowishbrown

EXTERIOR SURFACE COLOR: brown; fire clouds on the body and base

WALL THICKNESS (RIM, BODY, AND BASE IN MM): rim, $5.3 \mathrm{~mm}$

INTERIOR SURFACE TREATMENT: smoothed on the body

EXTERIOR SURFACE TREATMENT: smoothed on the body

HEIGHT (IN CM): 8.5

ORIFICE DIAMETER (IN CM): 9.3

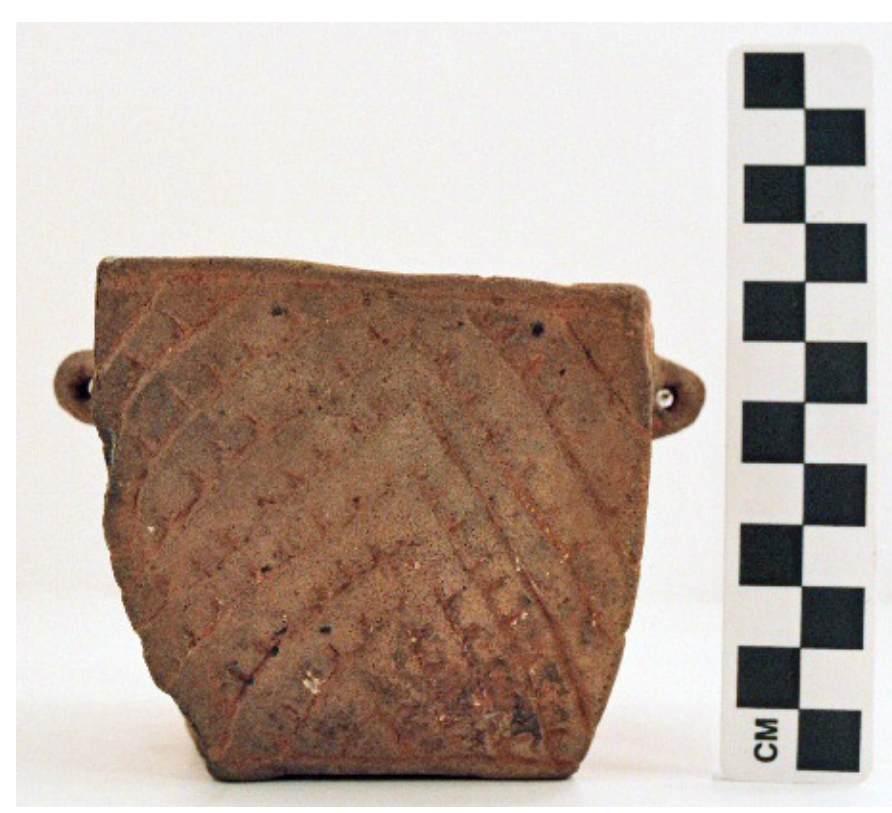

Figure 94. Patton Engraved, var. unspecified square bowl from the Richard Patton site.

DIAMETER AT BOTTOM OF RIM OR NECK (IN CM): N/A

BASE DIAMETER (IN CM) AND SHAPE OF BASE: 6.5; square and flat

ESTIMATED VOLUME (IN LITERS): 0.3

DECORATION (INCLUDING MOTIF AND ELEMENTS WHEN APPARENT): There are single horizontal engraved lines under the lip and just above the base of the vessel. Only on two sides of the vessel do the lines under the lip have downward-pointing excised tick marks (Figure 94). The vessel body has a series of six diagonal opposed engraved lines; on two sides the lines have excised tick marks that are upwards-pointing, while on the other two sides the tick marks point downwards. At the base of the design on each side is an engraved triangle (Figure 31). On two sides, the triangles have outward-pointing tick marks (and a smaller inner and open triangle), while the other side has a basal triangle element with inward-pointing tick marks.

PIGMENT USE AND LOCATION ON VESSEL: white pigment in the engraved lines

TYPE AND VARIETY [IF KNOWN]: Patton Engraved, var. unspecified (see Suhm and Jelks 1962:Plate 59c). 
SITE NAME OR SITE NUMBER: Richard Patton

VESSEL NO.: 41AN26-13

NON-PLASTICS AND PASTE: grog and hematite

VESSEL FORM: Globular bowl

RIM AND LIP FORM: Direct rim and rounded lip

CORE COLOR: $\mathrm{G}$ (fired in a reducing environment and cooled in the open air)

INTERIOR SURFACE COLOR: light

yellowish-brown

EXTERIOR SURFACE COLOR: brown

WALL THICKNESS (RIM, BODY, AND

BASE IN MM): body, $5.0 \mathrm{~mm}$

INTERIOR SURFACE TREATMENT:

smoothed on the rim and body

EXTERIOR SURFACE TREATMENT:

smoothed on the rim and body

HEIGHT (IN CM): 15.2

ORIFICE DIAMETER (IN CM): 18.0

DIAMETER AT BOTTOM OF RIM OR

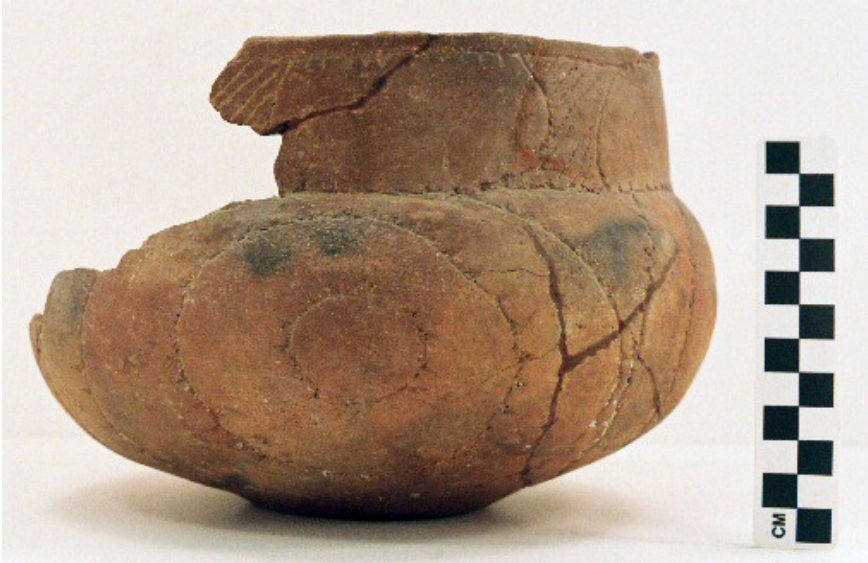

Figure 95. Patton Engraved, var. Freeman globular bowl from the Richard Patton site.

NECK (IN CM): $23.5 \mathrm{~cm}$ at the widest part

of the vessel body

BASE DIAMETER (IN CM) AND SHAPE OF BASE: 8.5; circular and flat

ESTIMATED VOLUME (IN LITERS): 2.5

DECORATION (INCLUDING MOTIF AND ELEMENTS WHEN APPARENT): The rim panel is defined by upper and lower single horizontal lines with either downward- or upward-pointing excised tick marks (Figurer 95). The panel is divided by an unknown number of diagonal hatched brackets. The vessel body has three sets of engraved concentric circles (four concentric circles per set) with outward-pointing excised tick marks. There is also a single engraved line that extends around the base, but it does not have any tick marks.

PIGMENT USE AND LOCATION ON VESSEL: white pigment in engraved lines

TYPE AND VARIETY [IF KNOWN]: Patton Engraved, var. Freeman 
SITE NAME OR SITE NUMBER: Richard Patton

VESSEL NO.: 41AN26-15

NON-PLASTICS AND PASTE: grog

VESSEL FORM: Bottle with a collared neck

RIM AND LIP FORM: N/A

CORE COLOR: $\mathrm{F}$ (fired in a reducing environment and cooled in the open air)

INTERIOR SURFACE COLOR: light yellowish-brown

EXTERIOR SURFACE COLOR: light yellowish-brown

WALL THICKNESS (RIM, BODY, AND BASE IN MM): body, $8.0 \mathrm{~mm}$

INTERIOR SURFACE TREATMENT: none

EXTERIOR SURFACE TREATMENT: smoothed on the body

HEIGHT (IN CM): body height is $17.5 \mathrm{~cm}$

ORIFICE DIAMETER (IN CM): N/A

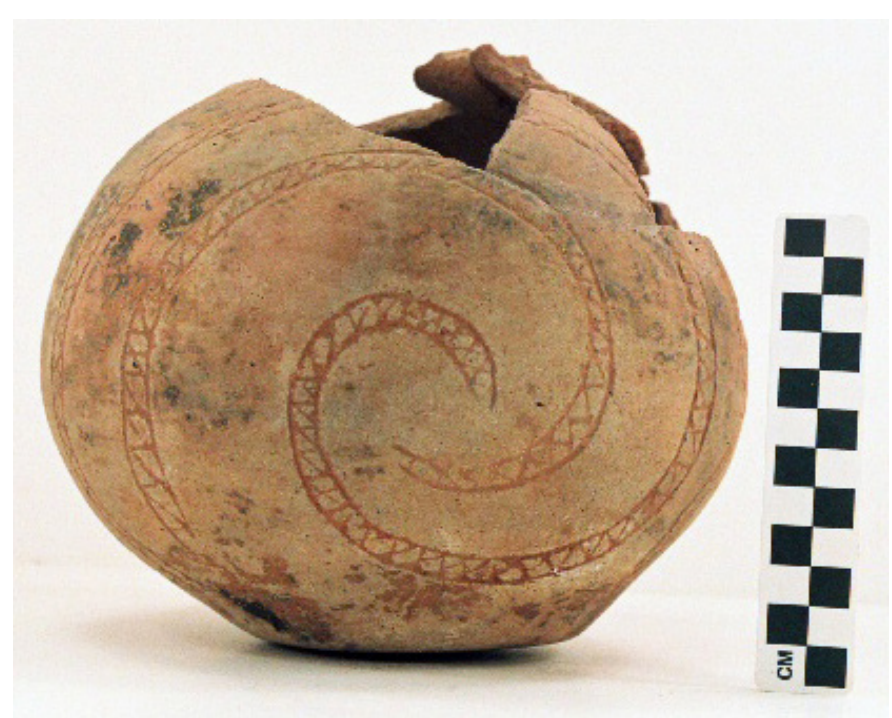

Figure 96. cf. Poynor Engraved, var. unspecified bottle from the Richard Patton site.

DIAMETER AT BOTTOM OF RIM OR

NECK (IN CM): $20.0 \mathrm{~cm}$ at the widest point on the body

BASE DIAMETER (IN CM) AND SHAPE OF BASE: 10.0; circular and flat

ESTIMATED VOLUME (IN LITERS): $>0.7$

DECORATION (INCLUDING MOTIF AND ELEMENTS WHEN APPARENT): The vessel body has one set of cross-hatched hooked arm zones and another set of cross-hatched engraved spirals (Figure 96). These elements are divided by two intersecting diagonal cross-hatched zones.

PIGMENT USE AND LOCATION ON VESSEL: none

TYPE AND VARIETY [IF KNOWN]: cf. Poynor Engraved, var. unspecified 
SITE NAME OR SITE NUMBER: Richard Patton

VESSEL NO.: 41AN26-16

NON-PLASTICS AND PASTE: grog and hematite

VESSEL FORM: Globular Bowl

RIM AND LIP FORM: Direct rim and rounded lip

CORE COLOR: A (fired and cooled in an oxidizing environment)

INTERIOR SURFACE COLOR: light

yellowish-brown

EXTERIOR SURFACE COLOR: light yellowish-brown; black film/smudging on the rim and body

WALL THICKNESS (RIM, BODY, AND

BASE IN MM): rim, $5.4 \mathrm{~mm}$

INTERIOR SURFACE TREATMENT:

smoothed on the rim and body

EXTERIOR SURFACE TREATMENT:

smoothed on the rim and body

HEIGHT (IN CM): 11.7

ORIFICE DIAMETER (IN CM): 13.8

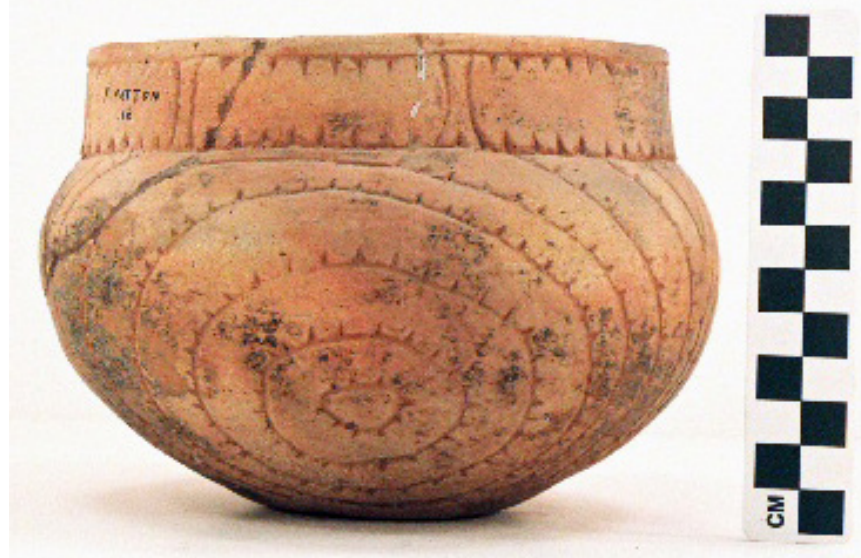

Figure 97. Patton Engraved, var. Freeman globular bowl from the Richard Patton site.

DIAMETER AT BOTTOM OF RIM OR

NECK (IN CM): 14.2

BASE DIAMETER (IN CM) AND SHAPE OF BASE: 6.5; circular and flat

ESTIMATED VOLUME (IN LITERS): 1.0

DECORATION (INCLUDING MOTIF AND ELEMENTS WHEN APPARENT): The rim panel is defined by single upper and lower horizontal engraved lines that have either downward- or upward-pointing excised tick marks. The rim panel is divided by six open brackets (Figure 97). The vessel body has three sets of six engraved concentric circles, and each concentric circle has outward-pointing excised tick marks. There are open triangle elements between the upper end of each set of concentric circles.

PIGMENT USE AND LOCATION ON VESSEL: none

TYPE AND VARIETY [IF KNOWN]: Patton Engraved, var. Freeman 
SITE NAME OR SITE NUMBER: Richard Patton

VESSEL NO.: 41AN26-17

NON-PLASTICS AND PASTE: grog

VESSEL FORM: Globular bowl

RIM AND LIP FORM: Direct rim and rounded lip

CORE COLOR: G (fired in a reducing environment and cooled in the open air)

INTERIOR SURFACE COLOR: grayish-brown

EXTERIOR SURFACE COLOR: brown; fire clouds

WALL THICKNESS (RIM, BODY, AND

BASE IN MM): rim, $5.9 \mathrm{~mm}$

INTERIOR SURFACE TREATMENT:

smoothed on the rim and body

EXTERIOR SURFACE TREATMENT:

burnished on the rim and smoothed on the body

HEIGHT (IN CM): 13.6

ORIFICE DIAMETER (IN CM): 15.4

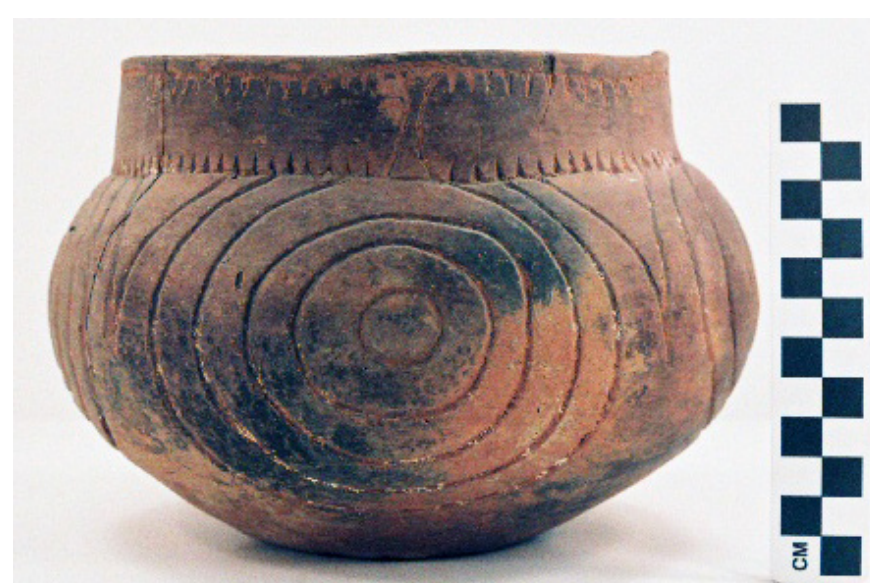

Figure 98. Poynor Engraved, var. Freeman globular bowl from the Richard Patton site.

DIAMETER AT BOTTOM OF RIM OR

NECK (IN CM): 15.6

BASE DIAMETER (IN CM) AND SHAPE OF BASE: 7.8; circular and flat

ESTIMATED VOLUME (IN LITERS): 1.8

DECORATION (INCLUDING MOTIF AND ELEMENTS WHEN APPARENT): The rim panel is defined by single upper and lower horizontal engraved lines with upwards- and downwards-pointing excised tick marks. The rim panel is divided by four open brackets (Figure 98). The vessel body has four sets of engraved concentric circles. The concentric circles are divided at their upper end by large open pendant triangles with their apexes pointing towards the vessel base.

PIGMENT USE AND LOCATION ON VESSEL: white pigment in the engraved lines

TYPE AND VARIETY [IF KNOWN]: Poynor Engraved, var. Freeman 
SITE NAME OR SITE NUMBER: Richard Patton

VESSEL NO.: 41AN26-18

NON-PLASTICS AND PASTE: grog

VESSEL FORM: Globular Bowl

RIM AND LIP FORM: Direct rim and a rounded lip

CORE COLOR: A (fired and cooled in an oxidizing environment)

INTERIOR SURFACE COLOR: very pale brown; fire clouds on the rim

EXTERIOR SURFACE COLOR: grayishbrown; black film/smudging

WALL THICKNESS (RIM, BODY, AND

BASE IN MM): rim, $6.1 \mathrm{~mm}$

INTERIOR SURFACE TREATMENT:

burnished on the rim and smoothed on the body

EXTERIOR SURFACE TREATMENT:

burnished on the rim and smoothed on the body

HEIGHT (IN CM): 11.8

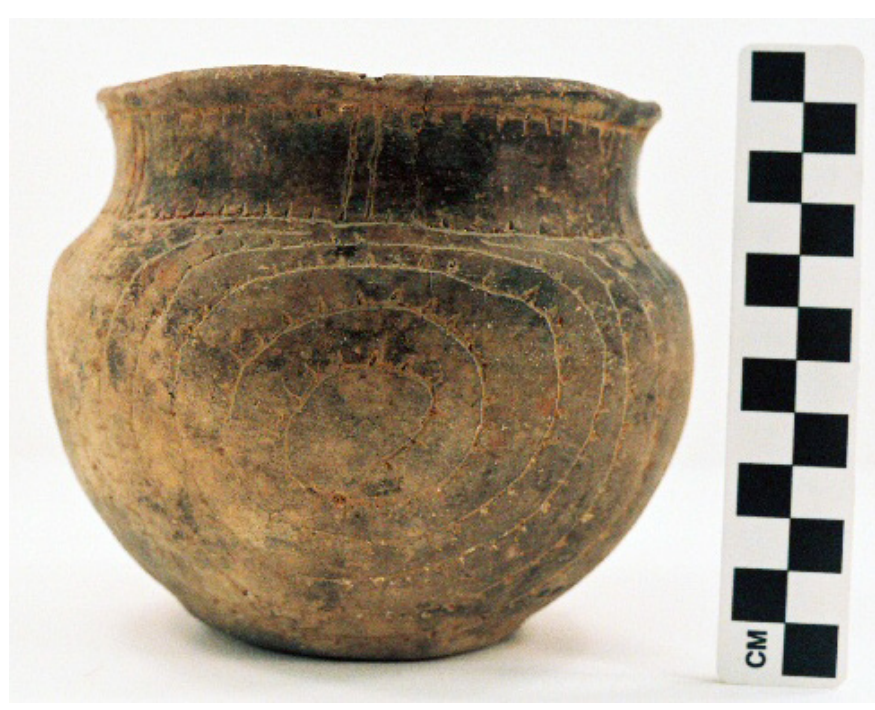

Figure 99. Patton Engraved, var. Freeman globular bowl from the Richard Patton site.

ORIFICE DIAMETER (IN CM): 11.8

DIAMETER AT BOTTOM OF RIM OR NECK (IN CM): 10.8

BASE DIAMETER (IN CM) AND SHAPE OF BASE: 6.8; circular and flat

ESTIMATED VOLUME (IN LITERS): 0.8

DECORATION (INCLUDING MOTIF AND ELEMENTS WHEN APPARENT): The rim panel is defined by single upper and lower horizontal engraved lines with tick marks. The rim is divided into six sections by six sets of two closely-spaced vertical engraved lines (Figure 99). The vessel body has three sets of engraved concentric spirals that have outward-pointing tick marks on each spiral line. The concentric spirals are divided at their upper ends by three large open pendant triangles, one of which has tick marks on its outer lines as well as a single inner vertical engraved line (Figure 99).

PIGMENT USE AND LOCATION ON VESSEL: red pigment on engraved lines on the rim, and white pigment on engraved lines on the vessel body

TYPE AND VARIETY [IF KNOWN]: Patton Engraved, var. Freeman 
SITE NAME OR SITE NUMBER: Richard Patton

VESSEL NO.: 41AN26-19

NON-PLASTICS AND PASTE: grog

VESSEL FORM: Globular Bowl

RIM AND LIP FORM: Direct rim and rounded lip

CORE COLOR: F (fired in a reducing environment and cooled in the open air)

INTERIOR SURFACE COLOR: light yellowish-brown

EXTERIOR SURFACE COLOR: light brownish-gray; fire clouds on the body

WALL THICKNESS (RIM, BODY, AND

BASE IN MM): rim, $4.4 \mathrm{~mm}$

INTERIOR SURFACE TREATMENT:

smoothed on the rim and body

EXTERIOR SURFACE TREATMENT:

smoothed on the rim and body

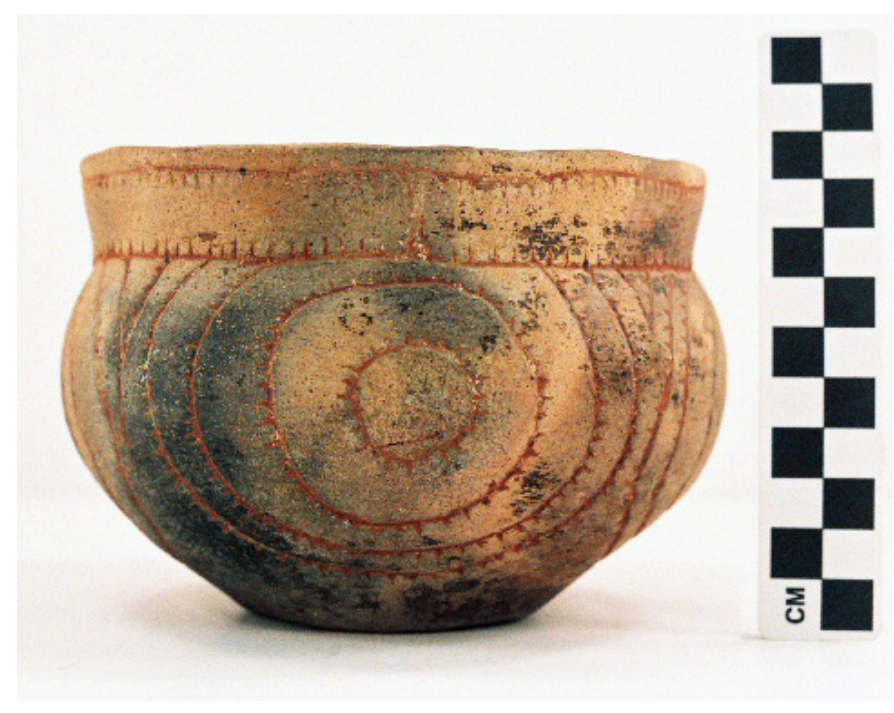

HEIGHT (IN CM): 9.8

ORIFICE DIAMETER (IN CM): 12.8

Figure 100. Patton Engraved, var. Freeman globular bowl from the Richard Patton site.

DIAMETER AT BOTTOM OF RIM OR

NECK (IN CM): 12.5

BASE DIAMETER (IN CM) AND SHAPE OF BASE: 6.2; circular and flat

ESTIMATED VOLUME (IN LITERS): 0.8

DECORATION (INCLUDING MOTIF AND ELEMENTS WHEN APPARENT): The rim panel is defined by single upper and lower horizontal engraved lines with excised tick marks that point either downwards or upwards. The panel is divided by two excised brackets and two vertical lines (Figure 100). The vessel body has four sets of concentric circles with outward-pointing tick marks. The concentric circles are divided at their upper ends by four large pendant triangles with inward-pointing tick marks on two sides of the triangles.

PIGMENT USE AND LOCATION ON VESSEL: red pigment in engraved lines

TYPE AND VARIETY [IF KNOWN]: Patton Engraved, var. Freeman 
SITE NAME OR SITE NUMBER: Richard Patton

VESSEL NO.: 41AN26-20

NON-PLASTICS AND PASTE: grog and hematite

VESSEL FORM: Globular Bowl

RIM AND LIP FORM: Direct rim and rounded lip

CORE COLOR: F (fired in a reducing environment and cooled in the open air)

INTERIOR SURFACE COLOR: light yellowish-brown

EXTERIOR SURFACE COLOR: reddish-yellow

WALL THICKNESS (RIM, BODY, AND BASE IN MM): rim, $5.1 \mathrm{~mm}$

INTERIOR SURFACE TREATMENT: smoothed on the rim and body

EXTERIOR SURFACE TREATMENT: smoothed on the rim and body

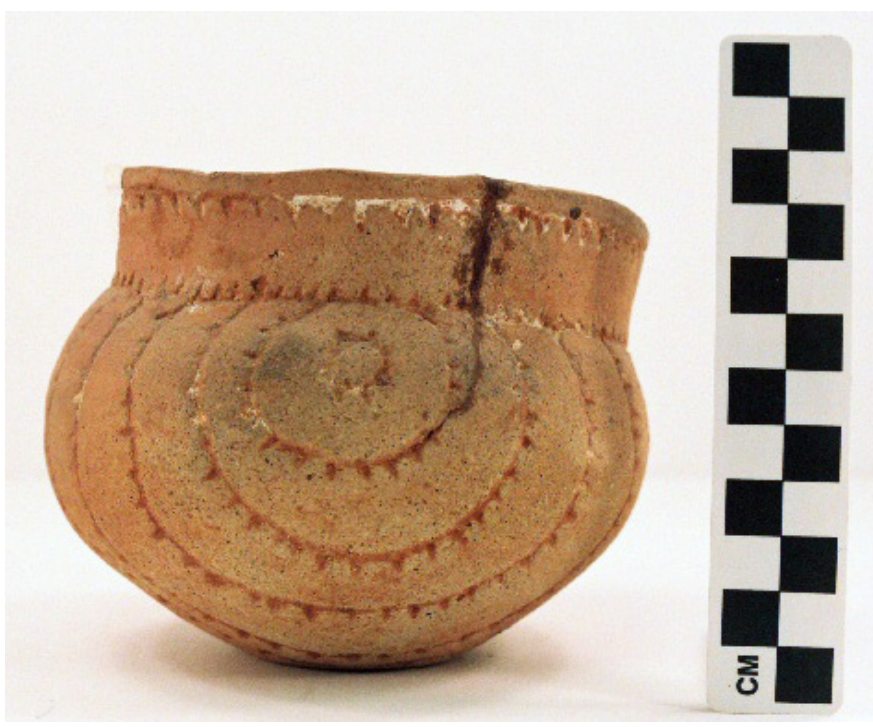

HEIGHT (IN CM): 10.2

ORIFICE DIAMETER (IN CM): 10.8

Figure 101. Patton Engraved, var. Fair globular bowl from the Richard Patton site.

DIAMETER AT BOTTOM OF RIM OR

NECK (IN CM): 10.2

BASE DIAMETER (IN CM) AND SHAPE OF BASE: 4.5; circular and flat

ESTIMATED VOLUME (IN LITERS): 0.7

DECORATION (INCLUDING MOTIF AND ELEMENTS WHEN APPARENT): The rim has single upper and lower horizontal engraved lines with downward- or upward-pointing excised tick marks. The vessel body has two sets of engraved concentric semi-circles and circles, each line with outward-pointing tick marks (Figure 101).

PIGMENT USE AND LOCATION ON VESSEL: white pigment in the engraved lines TYPE AND VARIETY [IF KNOWN]: Patton Engraved, var. Fair 
SITE NAME OR SITE NUMBER: Richard Patton

VESSEL NO.: 41AN26-21

NON-PLASTICS AND PASTE: grog

VESSEL FORM: Globular Bowl

RIM AND LIP FORM: Direct rim and rounded lip

CORE COLOR: A (fired and cooled in an oxidizing environment)

INTERIOR SURFACE COLOR: reddish-yellow

EXTERIOR SURFACE COLOR: reddish-yellow; fire clouds

WALL THICKNESS (RIM, BODY, AND BASE IN MM): rim, $6.3 \mathrm{~mm}$

INTERIOR SURFACE TREATMENT: smoothed on the rim and body

EXTERIOR SURFACE TREATMENT: smoothed on the rim and body

HEIGHT (IN CM): 14.0

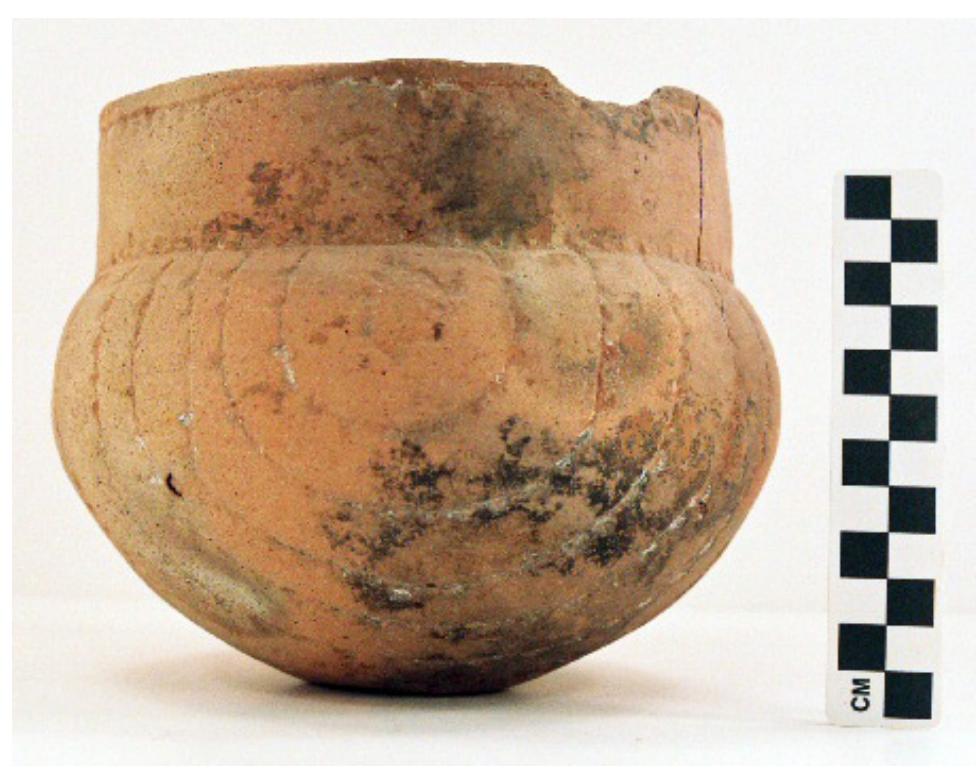

Figure 102. cf. Patton Engraved, var. Freeman globular bowl from the Richard Patton site.

ORIFICE DIAMETER (IN CM): 15.2

DIAMETER AT BOTTOM OF RIM OR NECK (IN CM): 15.4

BASE DIAMETER (IN CM) AND SHAPE OF BASE: 5.0; circular and flat ESTIMATED VOLUME (IN LITERS): 1.7

DECORATION (INCLUDING MOTIF AND ELEMENTS WHEN APPARENT): The rim is divided into rectangular panels by two hatched engraved brackets. The vessel body has two sets of engraved concentric semi-circles and circles with outward-pointing triangular tick marks (Figure 102).

PIGMENT USE AND LOCATION ON VESSEL: white pigment in engraved lines

TYPE AND VARIETY [IF KNOWN]: cf. Patton Engraved, var. Freeman 
SITE NAME OR SITE NUMBER: Richard Patton

VESSEL NO.: 41AN26-22

NON-PLASTICS AND PASTE: grog and hematite

VESSEL FORM: Globular Bowl

RIM AND LIP FORM: Direct rim and rounded lip

CORE COLOR: A (fired and cooled in an oxidizing environment)

INTERIOR SURFACE COLOR: light grayish-brown; fire clouds on the rim

EXTERIOR SURFACE COLOR: light grayish-brown; fire clouds

WALL THICKNESS (RIM, BODY, AND BASE IN MM): rim, $5.5 \mathrm{~mm}$

INTERIOR SURFACE TREATMENT: smoothed on the rim and body

EXTERIOR SURFACE TREATMENT: smoothed on the rim and body (patchy)

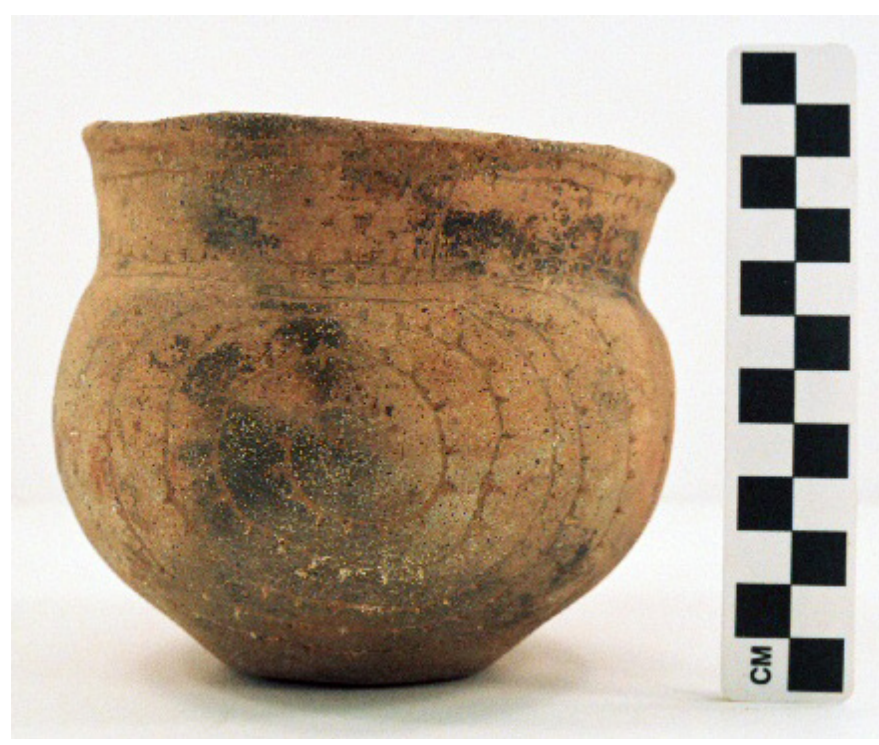

HEIGHT (IN CM): 10.2

ORIFICE DIAMETER (IN CM): 11.5

Figure 103. Patton Engraved, var. Freeman globular bowl from the Richard Patton site.

DIAMETER AT BOTTOM OF RIM OR

NECK (IN CM): 10.5

BASE DIAMETER (IN CM) AND SHAPE OF BASE: 5.5; circular and flat

ESTIMATED VOLUME (IN LITERS): 0.9

DECORATION (INCLUDING MOTIF AND ELEMENTS WHEN APPARENT): The rim panel is defined by two closely-spaced sets of upper and lower horizontal engraved lines; each of the lines has either downward- or upward-pointing triangular excised tick marks (Figure 103). The rim panel is divided by two vertical engraved lines. The vessel body has two sets of concentric engraved spirals, and each concentric spiral has outward-pointing excised tick marks.

PIGMENT USE AND LOCATION ON VESSEL: white pigment in engraved lines

TYPE AND VARIETY [IF KNOWN]: Patton Engraved, var. Freeman 
SITE NAME OR SITE NUMBER: Richard Patton

VESSEL NO.: 41AN26-24

NON-PLASTICS AND PASTE: grog and hematite

VESSEL FORM: Globular Bowl

RIM AND LIP FORM: Direct rim and rounded lip

CORE COLOR: $\mathrm{F}$ (fired in a reducing

environment and cooled in the open air)

INTERIOR SURFACE COLOR: pale brown

EXTERIOR SURFACE COLOR: light brown; fire clouds

WALL THICKNESS (RIM, BODY, AND

BASE IN MM): rim, $5.5 \mathrm{~mm}$

INTERIOR SURFACE TREATMENT:

burnished on the rim and smoothed on the body

EXTERIOR SURFACE TREATMENT: smoothed on the rim and body

HEIGHT (IN CM): 10.0

Figure 104. Patton Engraved, var. Freeman globular bowl from the Richard Patton site.

ORIFICE DIAMETER (IN CM): 10.2

DIAMETER AT BOTTOM OF RIM OR NECK (IN CM): 10.3

BASE DIAMETER (IN CM) AND SHAPE OF BASE: 5.5; circular and flat

ESTIMATED VOLUME (IN LITERS): 0.8

DECORATION (INCLUDING MOTIF AND ELEMENTS WHEN APPARENT): The rim panel is defined by single upper and lower horizontal engraved lines with either downward- or upward-pointing excised tick marks. The panel is divided by six sets of vertical engraved lines (Figure 104). The vessel body has three sets of concentric circles and semi-circles, with each line having an outward-facing tick mark. The sets of concentric circles and semi-circles are divided at their upper end by three large open pendant triangles as well as a single curvilinear line that extends towards the vessel base from its beginning at the apex of the pendant triangle elements (Figure 104). There are inward-pointing tick marks on two sides of the triangles, and the curvilinear line has outward-pointing excised tick marks.

PIGMENT USE AND LOCATION ON VESSEL: white pigment in the engraved lines

TYPE AND VARIETY [IF KNOWN]: Patton Engraved, var. Freeman 
SITE NAME OR SITE NUMBER: Richard Patton

VESSEL NO.: 41AN26-26

NON-PLASTICS AND PASTE: grog

VESSEL FORM: Globular Bowl

RIM AND LIP FORM: Direct rim and rounded lip

CORE COLOR: A (fired and cooled in an oxidizing environment)

INTERIOR SURFACE COLOR: very pale brown; fire clouds on the base

EXTERIOR SURFACE COLOR: very pale brown; fire clouds on the rim, body, and base

WALL THICKNESS (RIM, BODY, AND BASE IN MM): rim, $7.1 \mathrm{~mm}$

INTERIOR SURFACE TREATMENT: smoothed on the rim and body

EXTERIOR SURFACE TREATMENT: smoothed on the rim and body

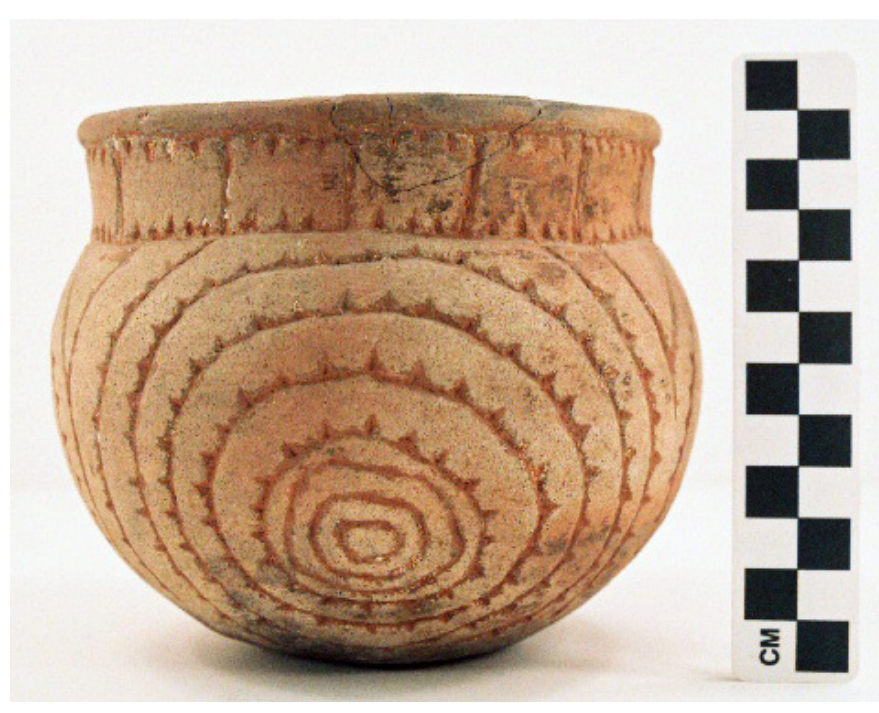

Figure 105. Patton Engraved, var. Freeman globular bowl from the Richard Patton site.

ORIFICE DIAMETER (IN CM): 12.2

DIAMETER AT BOTTOM OF RIM OR

NECK (IN CM): 11.5

BASE DIAMETER (IN CM) AND SHAPE OF BASE: 5.6; circular and flat

ESTIMATED VOLUME (IN LITERS): 1.1

DECORATION (INCLUDING MOTIF AND ELEMENTS WHEN APPARENT): the rim panel is defined by single upper and lower horizontal engraved lines with upwards- or downwards-pointing excised tick marks. The panel is divided into 14 rectangular areas by 14 equally-spaced vertical engraved lines (Figure 105). The vessel body has three sets of concentric circles; all but the inner three circles have outwards-pointing tick marks. The sets of concentric circles are divided by large open pendant triangles by their upper ends, as well as a single curvilinear line that extends from the apex of the triangles.

PIGMENT USE AND LOCATION ON VESSEL: white pigment in engraved lines

TYPE AND VARIETY [IF KNOWN]: Patton Engraved, var. Freeman 
SITE NAME OR SITE NUMBER: Richard Patton

VESSEL NO.: 41AN26-28

NON-PLASTICS AND PASTE: grog

VESSEL FORM: Globular Bowl

RIM AND LIP FORM: Direct rim and rounded lip

CORE COLOR: B (fired and cooled in a reducing environment)

INTERIOR SURFACE COLOR: grayish-brown

EXTERIOR SURFACE COLOR: grayishbrown

WALL THICKNESS (RIM, BODY, AND

BASE IN MM): rim, $4.8 \mathrm{~mm}$

INTERIOR SURFACE TREATMENT:

burnished on the rim and smoothed on the body

EXTERIOR SURFACE TREATMENT:

burnished on the body

HEIGHT (IN CM): 10.0

ORIFICE DIAMETER (IN CM): 12.5

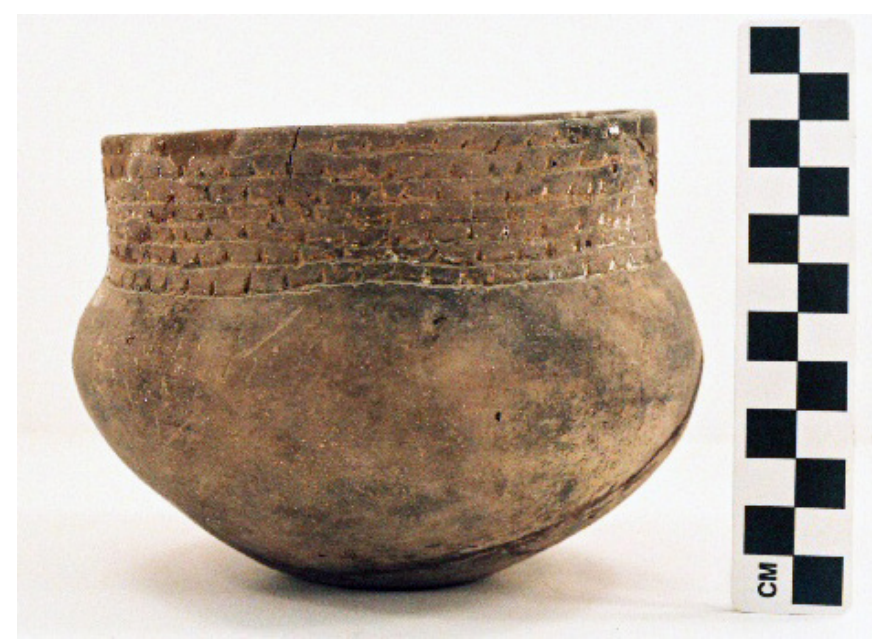

Figure 106. Patton Engraved, var. Allen globular bowl from the Richard Patton site.

DIAMETER AT BOTTOM OF RIM OR

NECK (IN CM): 12.2

BASE DIAMETER (IN CM) AND SHAPE OF BASE: 4.8; circular and flat

ESTIMATED VOLUME (IN LITERS): 0.8

DECORATION (INCLUDING MOTIF AND ELEMENTS WHEN APPARENT): The rim is decorated with seven horizontal engraved lines, each with upwards-pointing excised tick marks (Figure 106).

PIGMENT USE AND LOCATION ON VESSEL: white pigment in engraved lines

TYPE AND VARIETY [IF KNOWN]: Patton Engraved, var. Allen 
SITE NAME OR SITE NUMBER: Richard Patton

VESSEL NO.: 41AN26-29

NON-PLASTICS AND PASTE: grog

VESSEL FORM: Globular Bowl

RIM AND LIP FORM: Direct rim and rounded lip

CORE COLOR: A (fired and cooled in an oxidizing environment)

INTERIOR SURFACE COLOR: light

yellowish-brown

EXTERIOR SURFACE COLOR: light yellowish-brown

WALL THICKNESS (RIM, BODY, AND

BASE IN MM): rim, $3.6 \mathrm{~mm}$

INTERIOR SURFACE TREATMENT:

smoothed on the rim and body

EXTERIOR SURFACE TREATMENT:

smoothed on the rim and body

HEIGHT (IN CM): 11.0

ORIFICE DIAMETER (IN CM): 10.6

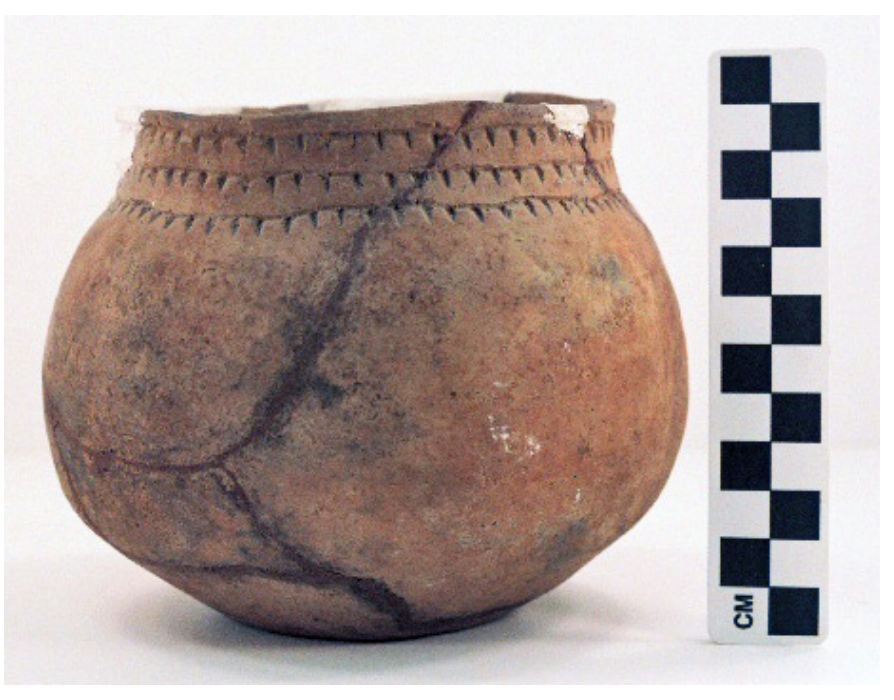

Figure 107. Patton Engraved, var. Allen globular bowl from the Richard Patton site.

DIAMETER AT BOTTOM OF RIM OR

NECK (IN CM): 10.0

BASE DIAMETER (IN CM) AND SHAPE OF BASE: 6.3; circular and flat

ESTIMATED VOLUME (IN LITERS): 0.9

DECORATION (INCLUDING MOTIF AND ELEMENTS WHEN APPARENT): The rim panel has three horizontal engraved lines with downward-pointing excised tick marks (Figure 107).

PIGMENT USE AND LOCATION ON VESSEL: none

TYPE AND VARIETY [IF KNOWN]: Patton Engraved, var. Allen 
SITE NAME OR SITE NUMBER: Richard Patton

VESSEL NO.: 41AN26-30

NON-PLASTICS AND PASTE: grog

VESSEL FORM: Globular bowl

RIM AND LIP FORM: Direct rim and rounded lip

CORE COLOR: F (fired in a reducing envi-

ronment and cooled in the open air)

INTERIOR SURFACE COLOR: light yellowish-brown

EXTERIOR SURFACE COLOR: pale brown; black film/smudging on vessel body; fire clouds on the rim

WALL THICKNESS (RIM, BODY, AND BASE IN MM): rim, $4.9 \mathrm{~mm}$

INTERIOR SURFACE TREATMENT: smoothed on the rim

EXTERIOR SURFACE TREATMENT: burnished on the rim and body

HEIGHT (IN CM): 9.7

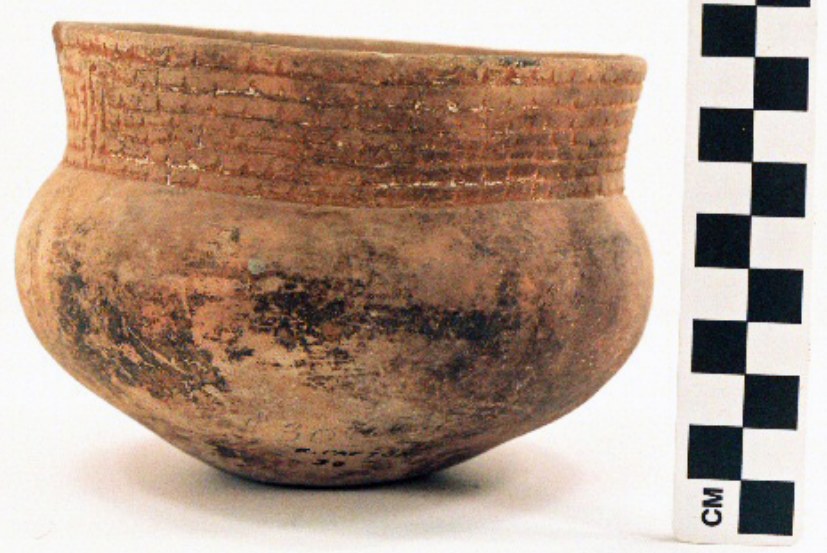

Figure 108. Patton Engraved, var. Allen globular bowl from the Richard Patton site.

ORIFICE DIAMETER (IN CM): 12.5

DIAMETER AT BOTTOM OF RIM OR NECK (IN CM): 11.5

BASE DIAMETER (IN CM) AND SHAPE OF BASE: 4.5; circular and flat

ESTIMATED VOLUME (IN LITERS): 0.9

DECORATION (INCLUDING MOTIF AND ELEMENTS WHEN APPARENT): The rim panel has seven horizontal engraved lines with upward-pointing excised tick marks (Figure 108). In two places, the horizontal lines end abruptly at two short vertical engraved lines that have outward-pointing tick marks; the horizontal lines begin again on the other side of the vertical engraved element.

PIGMENT USE AND LOCATION ON VESSEL: white pigment in engraved lines

TYPE AND VARIETY [IF KNOWN]: Patton Engraved, var. Allen 
SITE NAME OR SITE NUMBER: Richard Patton

VESSEL NO.: 41AN26-31

NON-PLASTICS AND PASTE: grog and hematite; fine sandy paste

VESSEL FORM: Globular Bowl

RIM AND LIP FORM: Direct rim and rounded lip

CORE COLOR: $\mathrm{G}$ (fired in a reducing environment and cooled in the open air)

INTERIOR SURFACE COLOR: brown

EXTERIOR SURFACE COLOR: reddishyellow

WALL THICKNESS (RIM, BODY, AND

BASE IN MM): rim, $5.5 \mathrm{~mm}$

INTERIOR SURFACE TREATMENT:

smoothed on the rim

EXTERIOR SURFACE TREATMENT:

smoothed on the rim

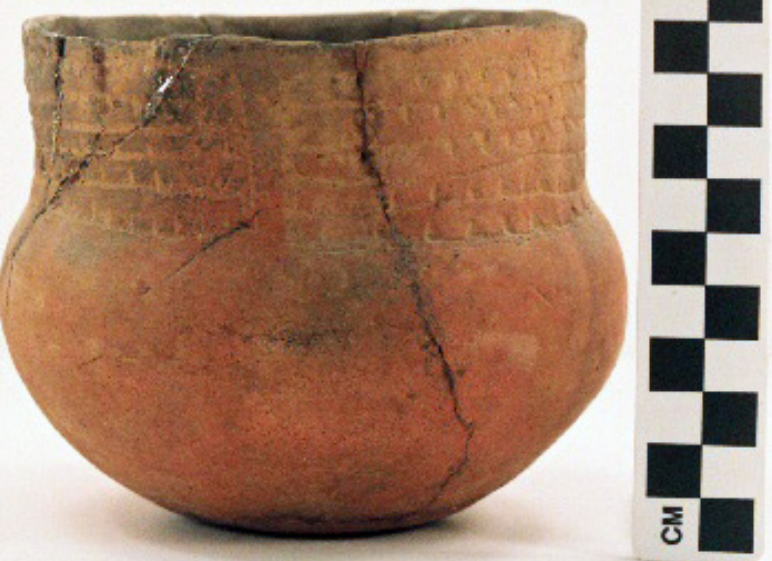

HEIGHT (IN CM): 10.2

ORIFICE DIAMETER (IN CM): 11.2

Figure 109. cf. Patton Engraved, var. Allen globular bowl from the Richard Patton site.

DIAMETER AT BOTTOM OF RIM OR

NECK (IN CM): 10.6

BASE DIAMETER (IN CM) AND SHAPE OF BASE: 5.8; circular and flat

ESTIMATED VOLUME (IN LITERS): 0.8

DECORATION (INCLUDING MOTIF AND ELEMENTS WHEN APPARENT): The rim is divided into three rectangular panels with sets of six horizontal engraved lines (Figure 109). The horizontal lines have either upwards- or downwards-pointing excised tick marks, and one line on one of the panels has no tick marks.

PIGMENT USE AND LOCATION ON VESSEL: none

TYPE AND VARIETY [IF KNOWN]: cf. Patton Engraved, var. Allen 
SITE NAME OR SITE NUMBER: Richard Patton

VESSEL NO.: 41AN26-79

NON-PLASTICS AND PASTE: grog

VESSEL FORM: Globular Bowl

RIM AND LIP FORM: Direct rim and a rounded lip

CORE COLOR: $\mathrm{G}$ (fired in a reducing environment and cooled in the open air)

INTERIOR SURFACE COLOR: dark grayish-brown

EXTERIOR SURFACE COLOR: light yellowish-brown

WALL THICKNESS (RIM, BODY, AND BASE IN MM): rim, $5.8 \mathrm{~mm}$

INTERIOR SURFACE TREATMENT: smoothed on the rim and body

EXTERIOR SURFACE TREATMENT: burnished on the rim; patches of smoothing on the body

HEIGHT (IN CM): 11.6

Figure 110. cf. Patton Engraved, var. Fair globular bowl from the Richard Patton site.

ORIFICE DIAMETER (IN CM): 10.0

DIAMETER AT BOTTOM OF RIM OR

NECK (IN CM): 9.4

BASE DIAMETER (IN CM) AND SHAPE OF BASE: 4.0; circular and flat ESTIMATED VOLUME (IN LITERS): 0.9

DECORATION (INCLUDING MOTIF AND ELEMENTS WHEN APPARENT): The rim panel has four horizontal engraved lines with downward-pointing excised tick marks; the bottom row of tick marks extends onto the vessel body (Figure 110). The vessel body has four sets of engraved concentric spirals with each line of the spirals having outward-pointing tick marks.

PIGMENT USE AND LOCATION ON VESSEL: white pigment in engraved lines TYPE AND VARIETY [IF KNOWN]: cf. Patton Engraved, var. Fair 
SITE NAME OR SITE NUMBER: Richard Patton

VESSEL NO.: 41AN26-83

NON-PLASTICS AND PASTE: grog and hematite

VESSEL FORM: Bowl with two opposed lug handles; the handles have drilled holes through the lugs (Figure 111a)

RIM AND LIP FORM: Direct rim and rounded lip

CORE COLOR: A (fired and cooled in an oxidizing environment)

INTERIOR SURFACE COLOR: pink

EXTERIOR SURFACE COLOR: brown

WALL THICKNESS (RIM, BODY, AND BASE IN MM): rim, $6.0 \mathrm{~mm}$

INTERIOR SURFACE TREATMENT: smoothed on the rim

EXTERIOR SURFACE TREATMENT: smoothed on the rim and body

HEIGHT (IN CM): 6.3

ORIFICE DIAMETER (IN CM): 9.0

DIAMETER AT BOTTOM OF RIM OR NECK (IN CM): N/A

BASE DIAMETER (IN CM) AND SHAPE OF BASE: 4.8; circular and flat
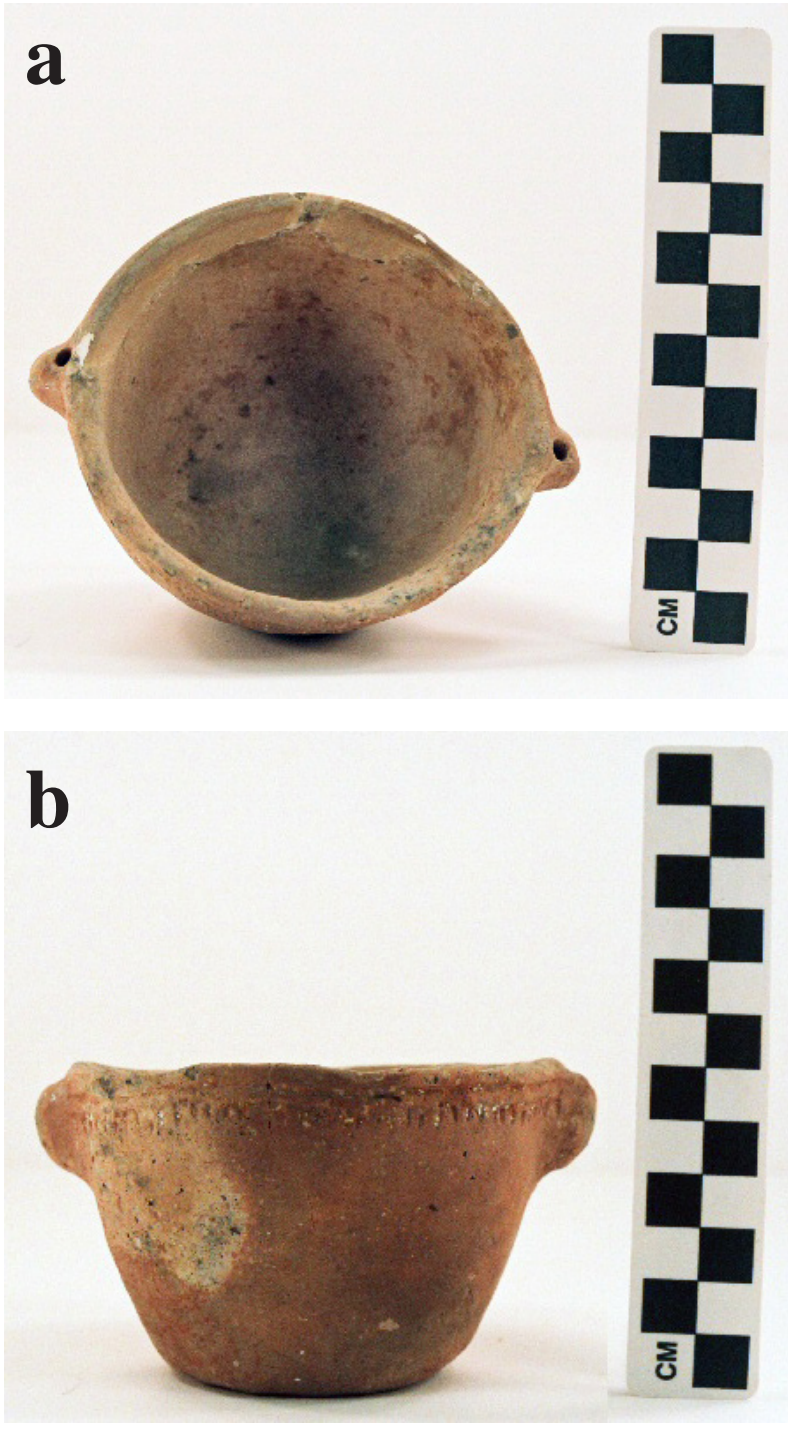

Figure 111. Patton Incised bowl from the Richard Patton site: a, view of lug handles; $b$, side view.

ESTIMATED VOLUME (IN LITERS): 0.2

DECORATION (INCLUDING MOTIF AND ELEMENTS WHEN APPARENT): The rim has two horizontal incised lines. The lowermost line has linear tick marks (Figure 111b).

PIGMENT USE AND LOCATION ON VESSEL: white pigment in incised lines TYPE AND VARIETY [IF KNOWN]: Patton Incised 
SITE NAME OR SITE NUMBER: Richard Patton

VESSEL NO.: 41AN26-91

NON-PLASTICS AND PASTE: grog and hematite

VESSEL FORM: Globular Bowl

RIM AND LIP FORM: Direct rim and rounded lip

CORE COLOR: A (fired and cooled in an oxidizing environment)

INTERIOR SURFACE COLOR: light yellowish-brown

EXTERIOR SURFACE COLOR: light yellowish-brown; black film/smudging on the rim and body

WALL THICKNESS (RIM, BODY, AND BASE IN MM): rim, $6.4 \mathrm{~mm}$

INTERIOR SURFACE TREATMENT: smoothed on the rim and body

EXTERIOR SURFACE TREATMENT: smoothed on the rim; burnished patches on the body

HEIGHT (IN CM): 16.5

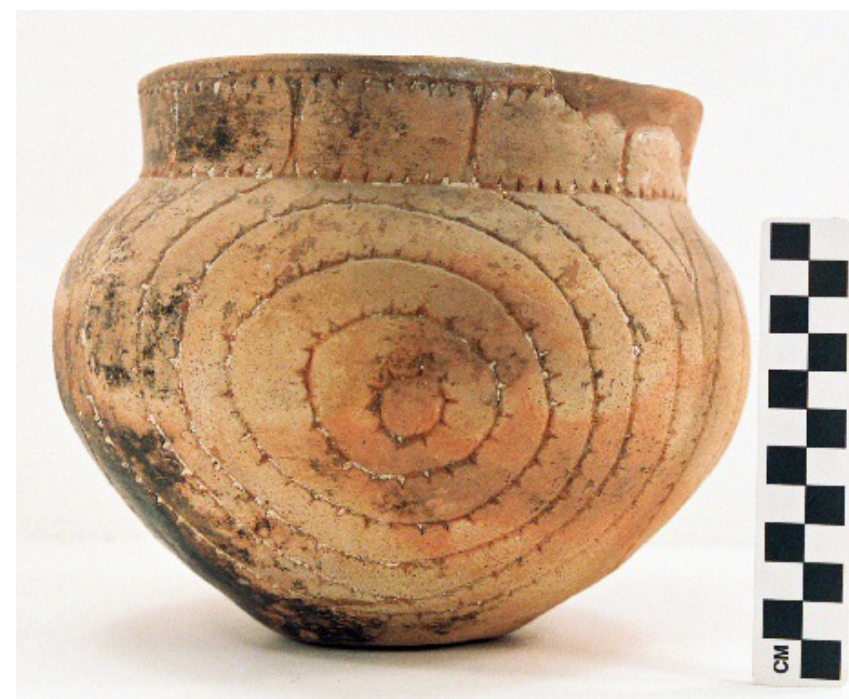

Figure 112. Patton Engraved, var. Freeman globular bowl from the Richard Patton site.

ORIFICE DIAMETER (IN CM): 16.5

DIAMETER AT BOTTOM OF RIM OR NECK (IN CM): 15.2

BASE DIAMETER (IN CM) AND SHAPE OF BASE: 7.0; circular and flat

ESTIMATED VOLUME (IN LITERS): 2.2

DECORATION (INCLUDING MOTIF AND ELEMENTS WHEN APPARENT): The rim panel is defined by single upper and lower horizontal engraved lines with either upwards- or downwards-pointing excised tick marks. The panel is also divided into 10 sections by sets of excised vertical lines (Figure 112). The vessel body has three repeating sets of concentric circles and semi-circles with outward-pointing excised tick marks. These sets of concentric circles and semi-circles are divided at their upper end by large open pendant triangles with a short spur line from the apex of each triangle (Figure 112).

PIGMENT USE AND LOCATION ON VESSEL: white pigment in engraved lines

TYPE AND VARIETY [IF KNOWN]: Patton Engraved, var. Freeman 
SITE NAME OR SITE NUMBER: Richard Patton

VESSEL NO.: 41AN26-92

NON-PLASTICS AND PASTE: grog-hematite; fine sandy paste

VESSEL FORM: Globular Bowl

RIM AND LIP FORM: Direct rim and rounded lip

CORE COLOR: A (fired and cooled in an oxidizing environment)

INTERIOR SURFACE COLOR: reddishyellow

EXTERIOR SURFACE COLOR: reddishyellow

WALL THICKNESS (RIM, BODY, AND

BASE IN MM): rim, $4.6 \mathrm{~mm}$

INTERIOR SURFACE TREATMENT:

smoothed on the rim

EXTERIOR SURFACE TREATMENT:

smoothed on the rim and body; black film/

smudging on the rim and body

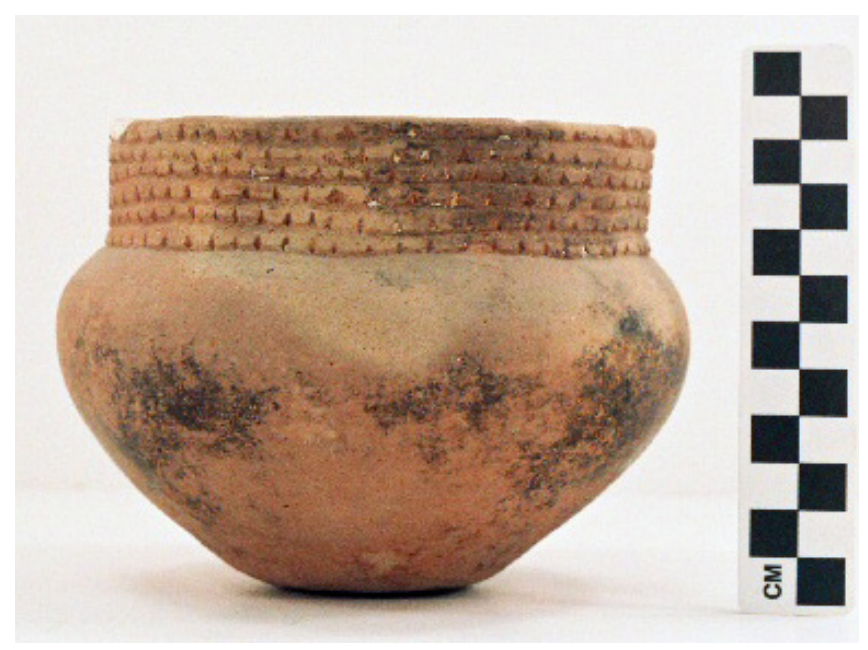

HEIGHT (IN CM): 10.5

ORIFICE DIAMETER (IN CM): 12.2

Figure 113. Patton Engraved, var. Allen globular bowl from the Richard Patton site.

DIAMETER AT BOTTOM OF RIM OR

NECK (IN CM): 12.1

BASE DIAMETER (IN CM) AND SHAPE OF BASE: 4.9; circular and flat

ESTIMATED VOLUME (IN LITERS): 1.0

DECORATION (INCLUDING MOTIF AND ELEMENTS WHEN APPARENT): The rim panel has six horizontal engraved lines with upward-pointing excised tick marks on each engraved line (Figure 113).

PIGMENT USE AND LOCATION ON VESSEL: white pigment in engraved lines

TYPE AND VARIETY [IF KNOWN]: Patton Engraved, var. Allen 
SITE NAME OR SITE NUMBER: Richard Patton

VESSEL NO.: 41AN26-120

NON-PLASTICS AND PASTE: grog

VESSEL FORM: Carinated Bowl

RIM AND LIP FORM: Inverted rim and rounded lip

CORE COLOR: A (fired and cooled in an oxidizing environment)

INTERIOR SURFACE COLOR: brown

EXTERIOR SURFACE COLOR: light yellowish-brown; black film/smudging on the rim and body; fire clouds on the base

WALL THICKNESS (RIM, BODY, AND

BASE IN MM): rim, $6.5 \mathrm{~mm}$

INTERIOR SURFACE TREATMENT:

smoothed on the rim and upper body

EXTERIOR SURFACE TREATMENT: burnished on the rim

HEIGHT (IN CM): 17.6

ORIFICE DIAMETER (IN CM): 23.7

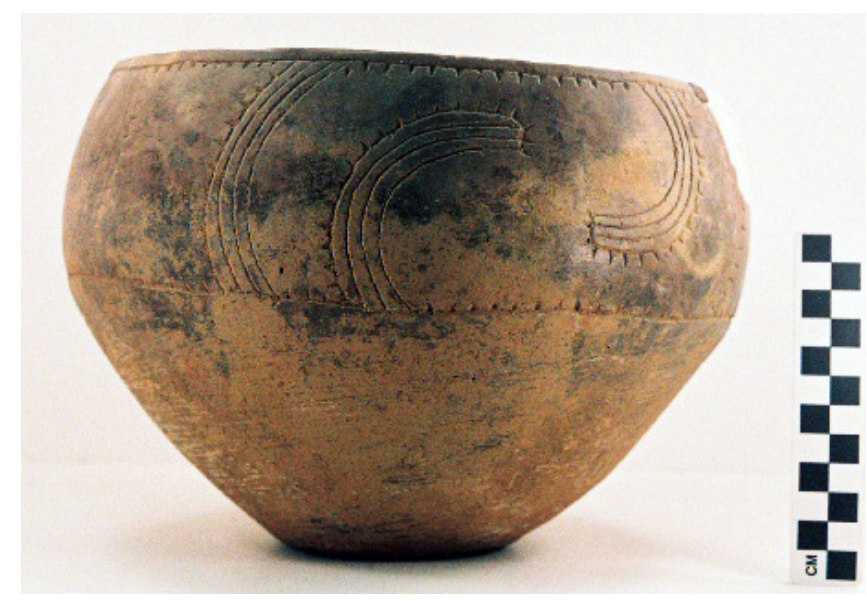

Figure 114. Patton Engraved, var. Patton carinated bowl from the Richard Patton site.

DIAMETER AT BOTTOM OF RIM OR

NECK (IN CM): 23.9

BASE DIAMETER (IN CM) AND SHAPE OF BASE: 9.5; circular and flat

ESTIMATED VOLUME (IN LITERS): 3.7

DECORATION (INCLUDING MOTIF AND ELEMENTS WHEN APPARENT): The rim panel is defined by single upper and lower horizontal engraved lines with either downward- or upward-pointing excised tick marks. On the panel are three sets of hooked arm elements, each with four curvilinear engraved lines; the outermost line has outward-pointing tick marks (Figure 114). The hooked arm elements are divided by three sets of four closely-spaced near vertical and arcing engraved lines; the outermost line has outward-pointing tick marks. The vessel body has horizontal and overlapping brushing marks.

PIGMENT USE AND LOCATION ON VESSEL: none

TYPE AND VARIETY [IF KNOWN]: Patton Engraved, var. Patton 
SITE NAME OR SITE NUMBER: Richard Patton

VESSEL NO.: 41AN26-121

NON-PLASTICS AND PASTE: grog

VESSEL FORM: Globular Bowl

RIM AND LIP FORM: Direct rim and rounded lip

CORE COLOR: A (fired and cooled in an oxidizing environment)

INTERIOR SURFACE COLOR: very pale brown

EXTERIOR SURFACE COLOR: very pale brown; black film/smudging on the vessel body

WALL THICKNESS (RIM, BODY, AND

BASE IN MM): rim, $5.4 \mathrm{~mm}$

INTERIOR SURFACE TREATMENT:

smoothed on the rim and upper body

EXTERIOR SURFACE TREATMENT:

smoothed on the rim and body

HEIGHT (IN CM): 10.4

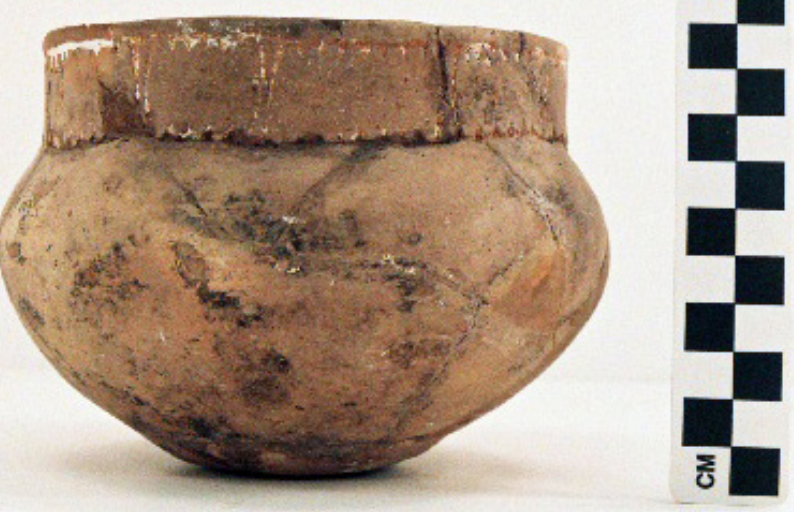

ORIFICE DIAMETER (IN CM): 12.2

Figure 115. Poynor Engraved, var. Freeman globular bowl from the Richard Patton site.

DIAMETER AT BOTTOM OF RIM OR NECK (IN CM): 12.2

BASE DIAMETER (IN CM) AND SHAPE OF BASE: 6.0; circular and flat

ESTIMATED VOLUME (IN LITERS): 1.0

DECORATION (INCLUDING MOTIF AND ELEMENTS WHEN APPARENT): The rim panel is defined by single upper and lower horizontal engraved lines with either upward- or downward-pointing excised tick marks. The panel is divided into 11 sections by excised brackets (Figure 115).

PIGMENT USE AND LOCATION ON VESSEL: white pigment in engraved lines

TYPE AND VARIETY [IF KNOWN]: Poynor Engraved, var. Freeman 
There are 93 ceramic vessel sherds in the TARL collections from the Richard Patton site. These include 23 plain sherds, 15 brushed sherds, one La Rue Neck Banded rim sherd, one Maydelle Incised sherd, one Poynor Engraved sherd, 40 Patton Engraved sherds, and 12 incised or engraved sherds of unidentified type. The plain to decorated sherd ratio in this small assemblage is 0.33 .

There are three whole grog-tempered elbow pipes in the TARL collection from the Richard Patton site. One is a cf. Var. C pipe with horizontal incised lines around the bowl, the stem, and along the distal knob of the stem (Figure 116a). This pipe is $65.0 \mathrm{~mm}$ in height, $77.7 \mathrm{~mm}$ in length, with a bowl orifice diameter of $53.9 \mathrm{~mm}$, and a stem diameter of $23.0 \mathrm{~mm}$.

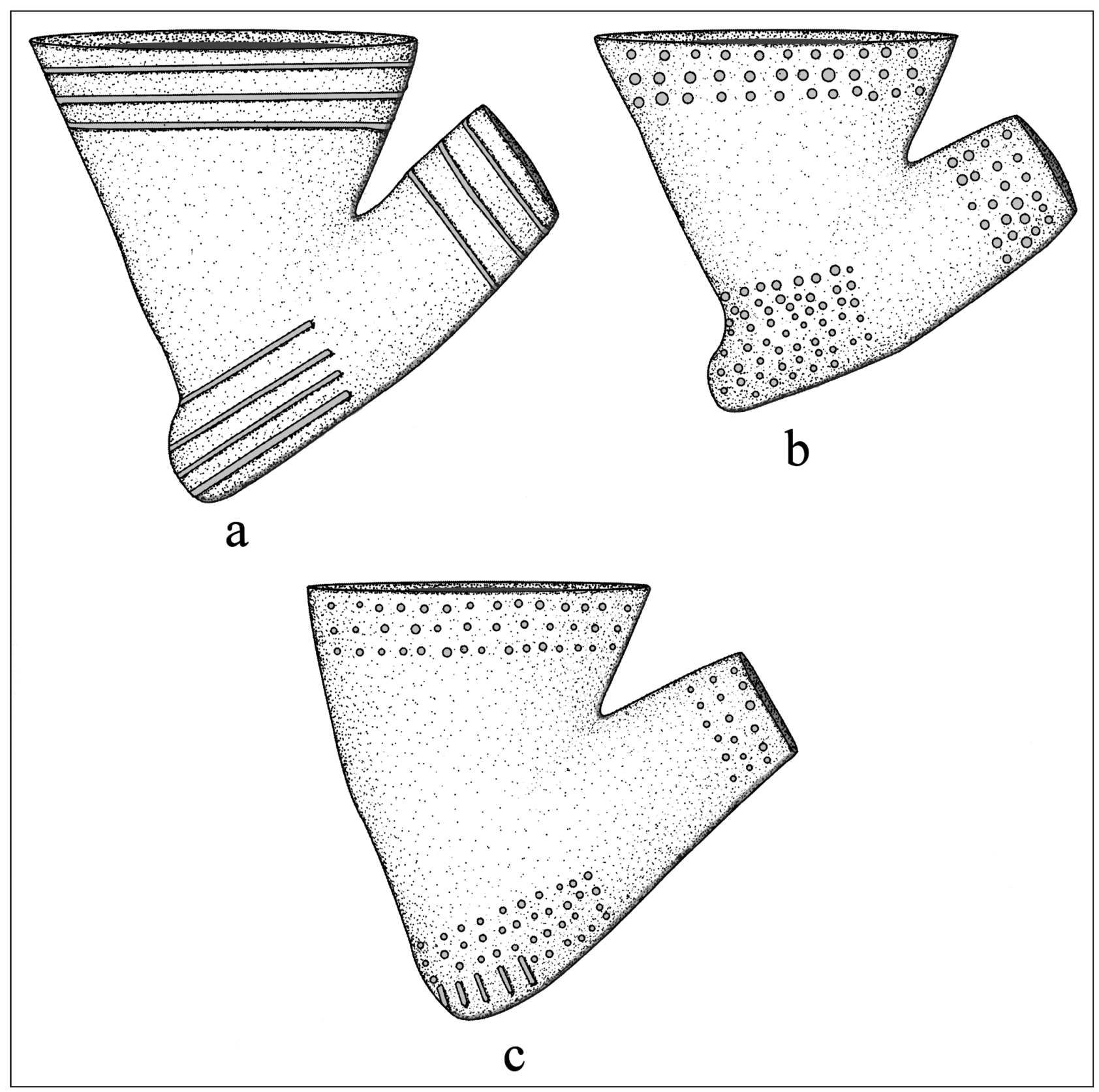

Figure 116. Decorated elbow pipes from the Richard Patton site. 
The other two pipes are Var. G elbow pipes, a newly recognized elbow pipe form in the upper Neches River basin. Both pipes are decorated with between 3-7 rows of small circular punctations on the bowl beneath the lip, along the pipe stem, and at the distal end of the stem (see Figure 116b-c). One pipe, from Burial N-3, also has a series of diagonal incised lines adjacent to rows of punctations at the distal end of the stem (see Figure 116c). These two pipes range from 48.1-55.0 mm in height and 63.9-68.2 mm in length. Bowl orifice diameters of the Var. G pipes range from 43.0-45.0 mm, and the stem diameters range between 19.3-19.4 $\mathrm{mm}$.

In addition to the complete pipes, there are two elbow pipe sherds in the collection. One is a plain stem sherd, and the other is a stem sherd with parallel incised lines. This sherd is from either a var. B or var. C elbow pipe sherd (see Perttula 2011;Figure 6-23).

Other artifacts in the collection from the Richard Patton site are glass beads and red ochre. The two blue glass beads were recovered in burial N-3, while burials N-2 and N-3 had 659 grams of red ochre, probably used in pigments.

\section{Hoag Farm (41AN27)}

The Hoag Farm site is a probable ancestral Caddo cemetery situated 0.5 miles north of Caddo Creek and 1.5 miles northeast of the Richard Patton site (41AN26) (see Figure 2). It was reported to UT archaeologists in 1931 that three ceramic vessels had been washed out at the site, but they did not investigate the site at that time, and no professional archaeologist has returned to the site since.

\section{Lang Pasture (41AN38)}

The Lang Pasture site (41AN38) is a multi-component prehistoric site situated on an upland ridge and toe slope in the Caney Branch Creek valley in the Caddo Creek basin, a few miles south of the community of Frankston, Texas. Test excavations in 2004 (Lohse 2004) and extensive block excavations in 2006 reported by Perttula et al. (2011) indicate that the principal occupation was by ancestors of the modernday Caddo Nation of Oklahoma some 600 years ago, who established a permanent domestic settlement of indeterminate size and complexity (more than 90 percent of the site occurs on private land, and little is known about the archaeological deposits there, see Perttula et al. 2007). A household cemetery with nine burial features is part of this ancestral Caddo settlement.

The recovered archaeological materials found at the site indicate that this landform was used only lightly and periodically from the Middle Archaic (ca. 6000 years ago) until about A.D. 900, and this is based almost exclusively on the recovery of a series of dart and arrow points of a variety of styles, but little else in the way of identifiable features or clearly discrete or concentrated archaeological deposits. OSL dating of sand grains indicate that the landform was very slowly aggrading beginning about 8000 years ago, and ending around 900 years ago. Radiocarbon dates (from charred plant materials incorporated in the fill of various pit features) indicate relatively ephemeral use (presumably for hunting purposes and tool refurbishing, as well as some hot rock cooking, as little in the way of other associated artifacts or features can be associated with these earlier remains) of the Lang Pasture site around 1040-840 B.C., A.D. 70-330, and A.D. 570-1030.

When the landform was essentially a stable topographic surface, it was occupied by a group of Caddo Indians, and it was the location of a permanent settlement of Caddo peoples from the first quarter of the $14^{\text {th }}$ century to the early part of the $15^{\text {th }}$ century A.D. Associated with the domestic settlement was a small family cemetery of Caddo peoples that likely resided at the Lang Pasture site. At least one of the seven 
Caddo burial features (Feature 8) found in the associated family cemetery at the site appears to have been interred shortly after the domestic occupation ended in the portion of the site investigated during the data recovery project. Otherwise, the stylistic character of the recovered ceramic vessels, particularly the engraved fine wares, from the burial features indicate that the Lang Pasture burials share stylistic features with both pre-A.D. 1400 and early (ca. A.D. 1400-1450) Frankston phase mortuary ceramics in the upper Neches River basin. Ceramic sherds recovered from a midden on another portion of the Lang Pasture site suggests that domestic activities in other compounds likely continued into the $16^{\text {th }}$ and $17^{\text {th }}$ centuries (Perttula et al. 2007).

The principal Caddo component in the investigated portion of the Lang Pasture site included two circular domestic structures (Structures 1 and 2) that were inhabited by at least one family of Caddo adults and children (Figure 117). The structures were built of wood, grass, and thatch that were between 6.8-9 m in diameter; these structures were marked by arcs of post holes. The structures were less than $5 \mathrm{~m}$ apart. No entrances were apparent along the wall arc of posts in the TxDOT project right-of-way, and thus it is likely that the entrances to both structures opened to the west to face the remainder of the Caddo community (now on private property). The two structures are considered, based on spatial proximity and a broad similarity in the ceramic material culture found in the excavations, to be part of a household compound, probably one of at least several such compounds that may be preserved at the Lang Pasture site.

Such a compound at Caddo sites in the upper Neches River basin of East Texas would have consisted of a series of domestic structures set around an open courtyard, with outdoor activity areas and ancillary facilities (Figure 118). At Lang Pasture, these outdoor activity areas were marked by pits, smudge pits, and hearths not far removed to either the north and east of the domestic structures; these were also trash disposal areas, based on the broad scatter of broken ceramic vessels and pipe sherds in these same areas. Outdoor storage pits were also found in these areas. Ancillary facilities include at least one small ( 2 x 4 m) arbor or ramada (i.e., elevated work platform, Structure 3) east of Structure 1 (see Figure 117).

As noted above, there was also an associated Caddo family household cemetery north and northeast of Structure 1, but physically distant from it. A total of seven burial features (including one feature with three individuals interred in it) were identified and excavated at the Lang Pasture site, and they were found in two distinct groups. Based on the size of the cemetery, it is unlikely that it was in use for any substantial period of time by any one household compound or related group of households, perhaps no longer than 10-30 years.

One group of burials was composed of adults (Features 8, 88, and 91-94) and the other, not far removed from Structure 1, was composed of children (Features 76B, 76C, and 76D). The deceased Caddo adults and children were laid out in extended supine positions, with their heads either facing west (adults) or northwest (children) towards the House of Death and the setting sun, and they were accompanied by a modicum of funerary offerings (ceramic vessels and elbow pipes) that would have served as provisioning on the deceased's journey. The mortuary practices evidenced with the Lang Pasture burials are clearly comparable to the practices employed by other Caddo populations that lived in the upper Neches River basin from the $14^{\text {th }}$ century to the early $18^{\text {th }}$ century (Perttula et al. 2011:403-433). Descriptions of the ceramic vessels placed in the burial features as funerary offerings are provided below.

Among the funerary offerings placed with the Caddo burials at the Lang Pasture site are 10 carinated bowls, 11 bowls, three compound bowls (apparently a rare vessel form in the upper Neches), three jars, and four bottles (see below). These are the same vessel forms used in domestic contexts, but with significantly higher numbers of serving vessels in mortuary contexts; this is a practice shared with later upper Neches Caddo groups. 


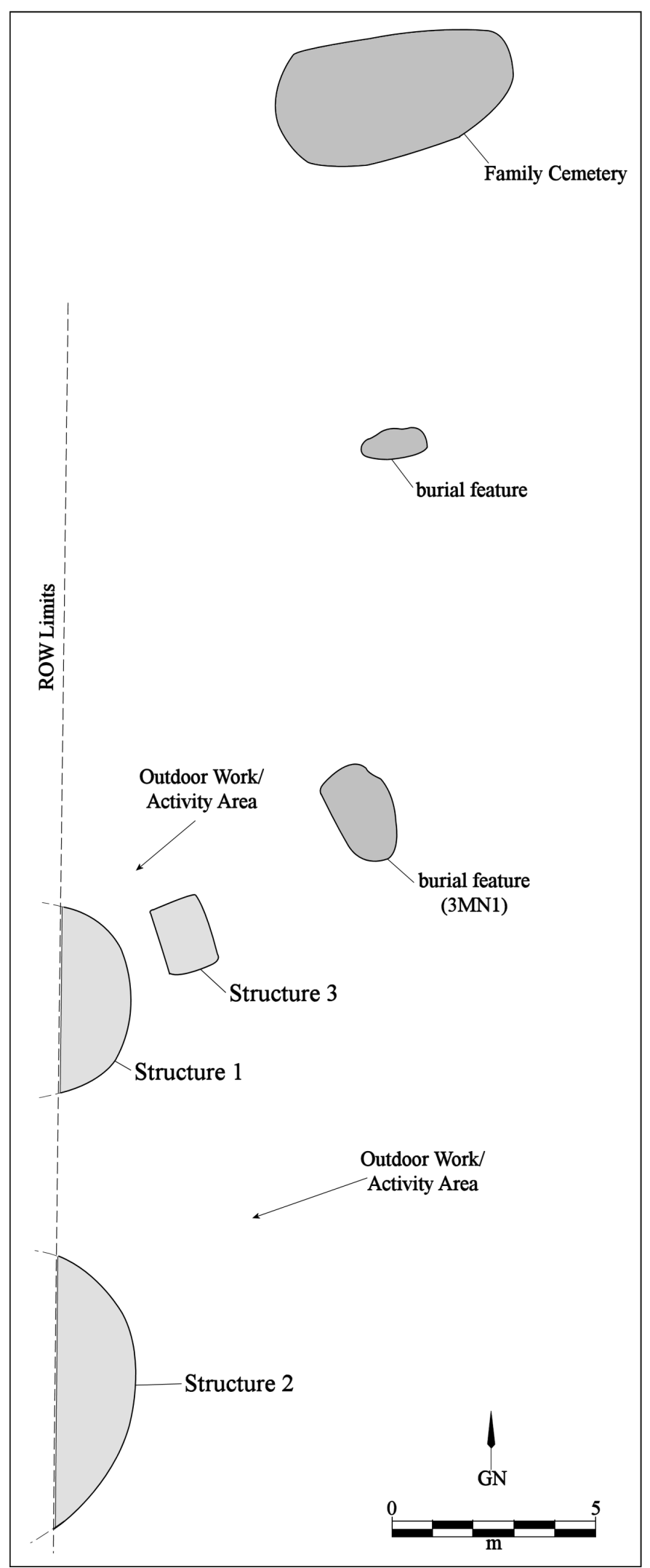

Figure 117. Plan of the structures, outdoor work/activity areas, and the cemetery at the Lang Pasture site. 


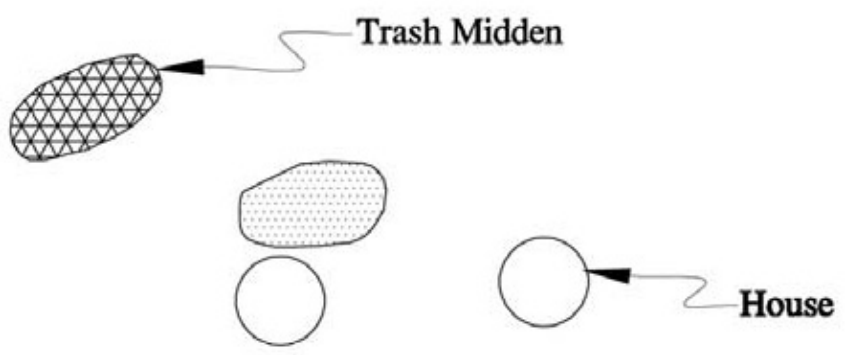

\section{Courtyard}
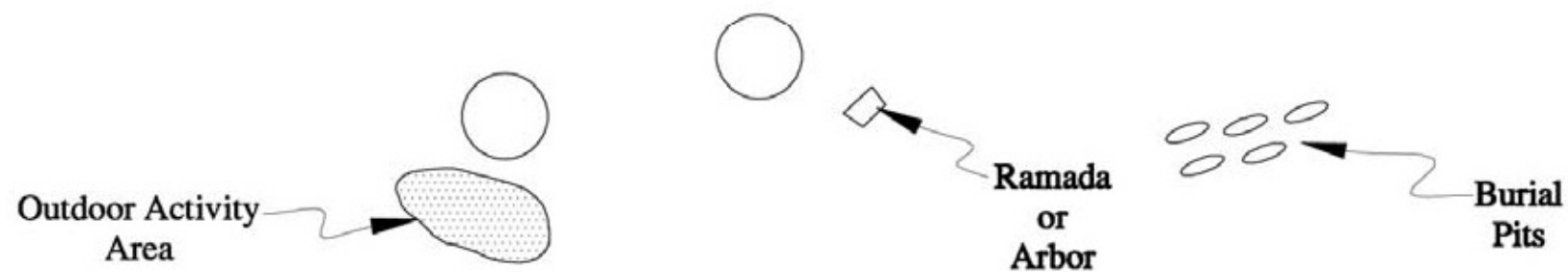

Figure 118. Likely arrangement of upper Neches River basin ancestral Caddo farmstead compounds.

One of the more distinctive features of the mortuary vessels from the site is the high frequency of plain vessels (61 percent). The carinated bowls, bowls (with one exception), and bottles, if decorated, have engraved motifs, particularly several distinctive regional and local varieties of Poynor Engraved that appear to have been common only before ca. A.D. 1480. Decorated utility wares from the burials include Maydelle Incised jars and a pinched bowl.

\section{FEATURE: 8}

VESSEL NO.: 1

NON-PLASTICS: grog

VESSEL FORM: Carinated bowl with a notched rim and an interior beveled/ thickened lip (Figure 119)

CORE COLOR: reduced firing

INTERIOR SURFACE COLOR: N/A; fire clouding

EXTERIOR SURFACE COLOR: N/A; fire clouding

WALL THICKNESS: $6.7 \mathrm{~mm}$, rim; 6.5 $\mathrm{mm}$, body; $9.9 \mathrm{~mm}$, base

INTERIOR SURFACE TREATMENT: smoothed and burnished

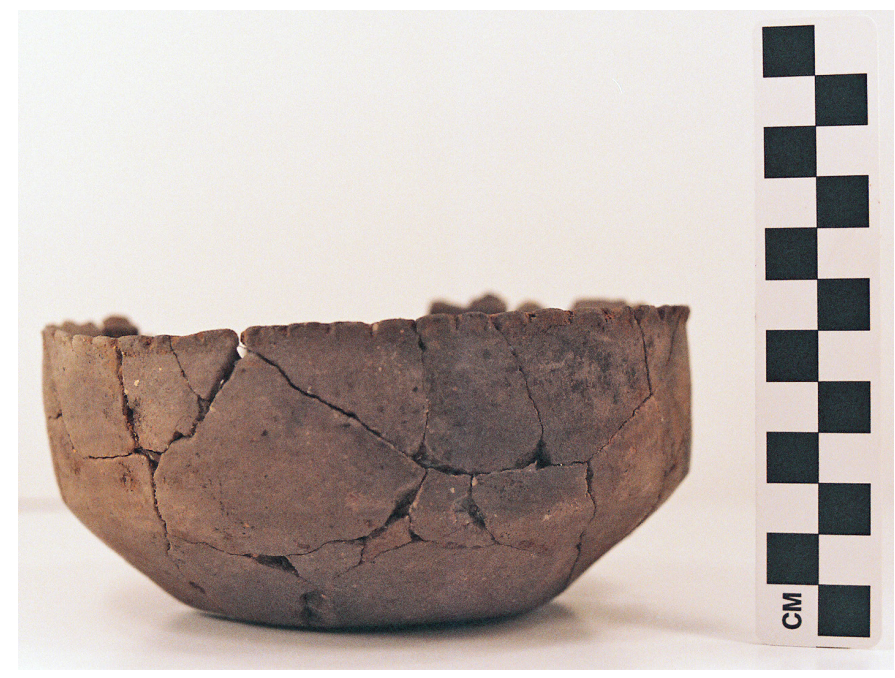

Figure 119. Plain carinated bowl (Vessel 1) from Feature 8 at the Lang Pasture site. 
EXTERIOR SURFACE TREATMENT: smoothed

HEIGHT: $5.9 \mathrm{~cm}$, rim height is $3.4 \mathrm{~cm}$

ORIFICE DIAMETER: $14.3 \mathrm{~cm}$

DIAMETER AT BOTTOM OF RIM OR NECK: $14.2 \mathrm{~cm}$

BASE DIAMETER: $6.5 \mathrm{~cm}$

ESTIMATED VOLUME: 0.3 liters

DECORATION: plain

TYPE: Undetermined plain ware vessel

FEATURE: 8

VESSEL NO.: 2

NON-PLASTICS: grog-hematite

VESSEL FORM: Carinated bowl with a direct rim and a rounded lip (Figure 120)

CORE COLOR: fired in a reducing environment

INTERIOR SURFACE COLOR: Not recorded

EXTERIOR SURFACE COLOR: Not recorded

WALL THICKNESS: $6.0 \mathrm{~mm}$, rim; $6.5 \mathrm{~mm}$, body

INTERIOR SURFACE TREATMENT:

smoothed

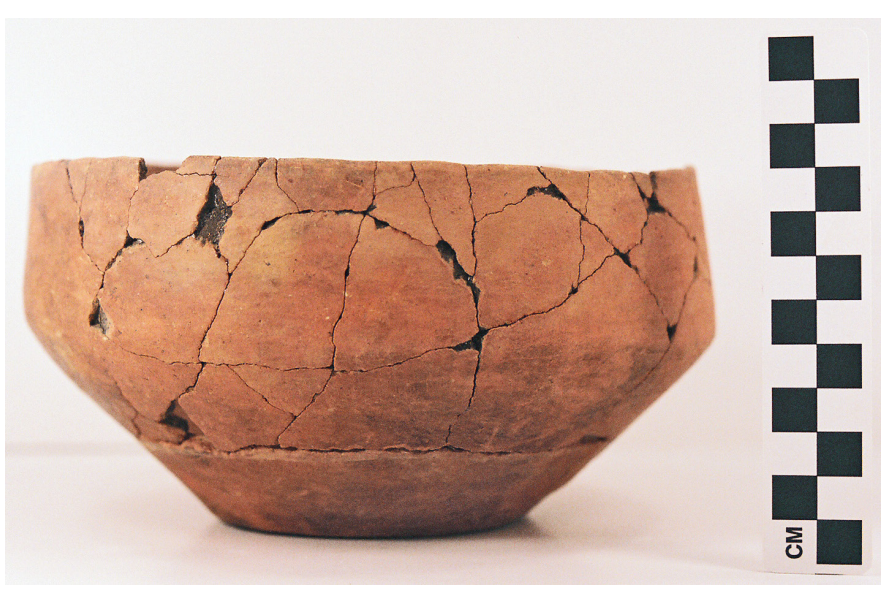

Figure 120. Plain carinated bowl from Feature 8 (Vessel 2) from the Lang Pasture site.

EXTERIOR SURFACE TREATMENT: burnished

HEIGHT: $9.5 \mathrm{~cm}$; rim height, $4.5 \mathrm{~cm}$

ORIFICE DIAMETER: $16.8 \mathrm{~cm}$

DIAMETER AT BOTTOM OF RIM OR NECK: 17.2

BASE DIAMETER: $6.2 \mathrm{~cm}$ 
ESTIMATED VOLUME: 1.0 liters

DECORATION: plain

TYPE: Undetermined plain ware vessel

FEATURE: 8

VESSEL NO.: 3

NON-PLASTICS: grog-bone

VESSEL FORM: Carinated bowl with a direct Redwine or pie-crust rim (see Walters 2010) and a rounded lip

CORE COLOR: fired in a reducing environment

INTERIOR SURFACE COLOR: Not recorded

EXTERIOR SURFACE COLOR: Not recorded

WALL THICKNESS: $5.0 \mathrm{~mm}$, rim; $4.1 \mathrm{~mm}$, body

INTERIOR SURFACE TREATMENT:

burnished

EXTERIOR SURFACE TREATMENT:

burnished

HEIGHT: $9.1 \mathrm{~cm}$; rim height is $3.5 \mathrm{~cm}$

ORIFICE DIAMETER: $17.8 \mathrm{~cm}$

DIAMETER AT BOTTOM OF RIM OR

NECK: $18.3 \mathrm{~cm}$

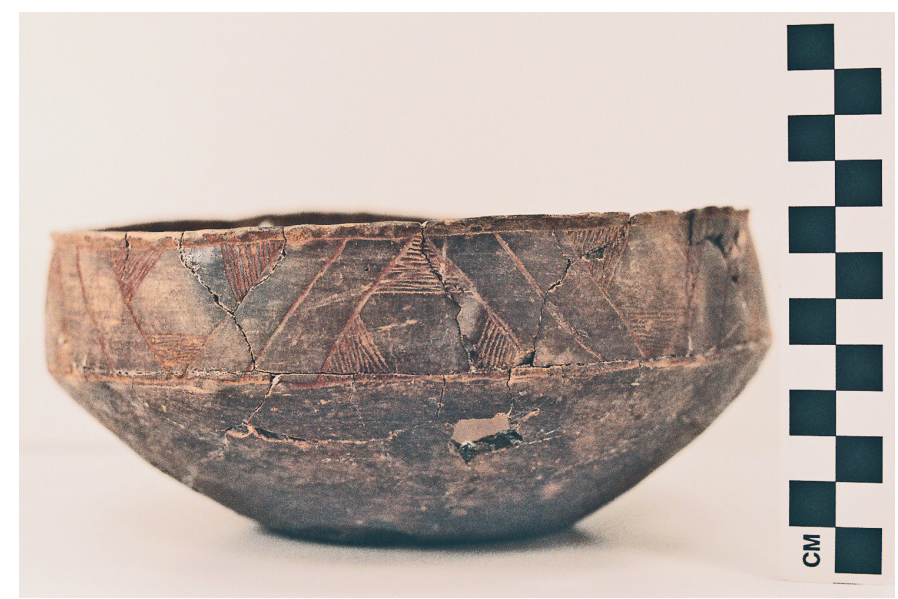

Figure 121. Poynor Engraved, var. F carinated bowl, Feature 8, Vessel 3 from the Lang Pasture site.

ESTIMATED VOLUME: 1.0 liters

DECORATION: The rim has an engraved motif repeated 10 times around the vessel between upper and lower horizontal engraved lines that encircle the vessel (Figure 121). The motif is comprised of an engraved triangle with either horizontal or diagonal hatched lines at each of the three corners of the triangle. The points or apex of the triangle rotate from touching the tip of the rim to touching the carination. The triangles are separated from each other by two diagonal engraved lines.

TYPE: Poynor Engraved, var. F 
FEATURE: 8

VESSEL NO.: 4

NON-PLASTICS: grog-bone-hematite

VESSEL FORM: Bowl with an interior thickened and a rounded scalloped lip, probably a Redwine mode rim (see Walters 2010) (Figure 122)

CORE COLOR: fired in an reducing environment

INTERIOR SURFACE COLOR: Not recorded

EXTERIOR SURFACE COLOR: Not recorded

WALL THICKNESS: 5.4 mm, rim; 4.7

$\mathrm{mm}$, body

INTERIOR SURFACE TREATMENT:

burnished

EXTERIOR SURFACE TREATMENT:

burnished

HEIGHT: $5.5 \mathrm{~cm}$; Rim height, $11.0 \mathrm{~mm}$ in non-scalloped sections and $16.5 \mathrm{~mm}$ in scalloped lip sections

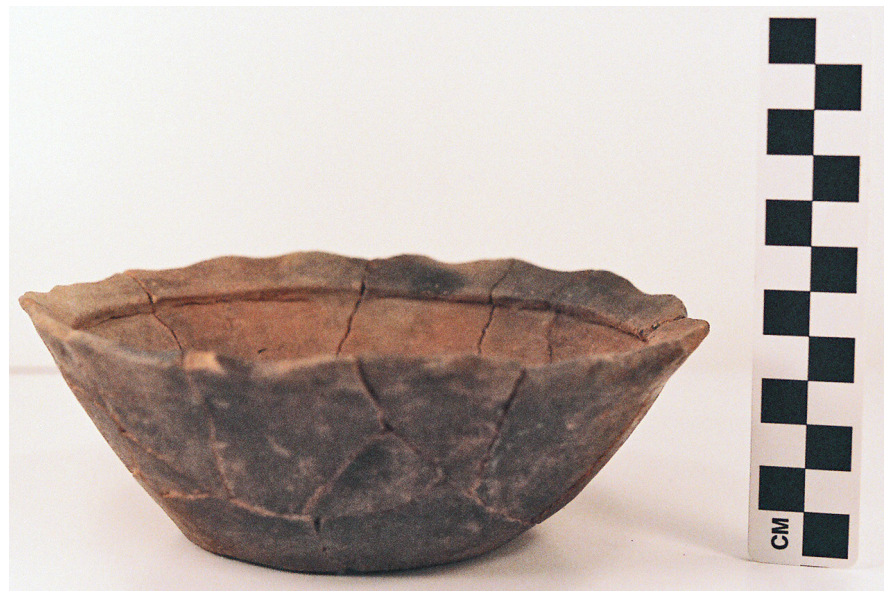

ORIFICE DIAMETER: $16.3 \mathrm{~cm}$

DIAMETER AT BOTTOM OF RIM OR

Figure 122. Plain bowl from Feature 8 (Vessel 4) at the Lang Pasture site.

NECK: N/A

BASE DIAMETER: $6.0 \mathrm{~cm}$

ESTIMATED VOLUME: 0.35 liters

DECORATION: plain

TYPE: Undetermined plain ware vessel 
FEATURE: 8

VESSEL NO.: 5

NON-PLASTICS: grog

VESSEL FORM: Carinated bowl with a direct rim and a flat but interior beveled lip (Figure 123); there are a regular series of small lip nodes that are repeated at $20 \mathrm{~mm}$ intervals around the lip.

CORE COLOR: fired in a reducing environment but cooled in the open air

INTERIOR SURFACE COLOR: red (2.5YR 5/6)

EXTERIOR SURFACE COLOR: red (2.5YR $5 / 6)$

WALL THICKNESS: $5.1 \mathrm{~mm}$, rim; $5.0 \mathrm{~mm}$, body; $10.5 \mathrm{~mm}$, base

INTERIOR SURFACE TREATMENT: burnished

EXTERIOR SURFACE TREATMENT: burnished

HEIGHT: $6.8 \mathrm{~cm}$; rim height is $3.5 \mathrm{~cm}$

ORIFICE DIAMETER: $17.8 \mathrm{~cm}$

DIAMETER AT BOTTOM OF RIM OR

NECK: $17.6 \mathrm{~cm}$

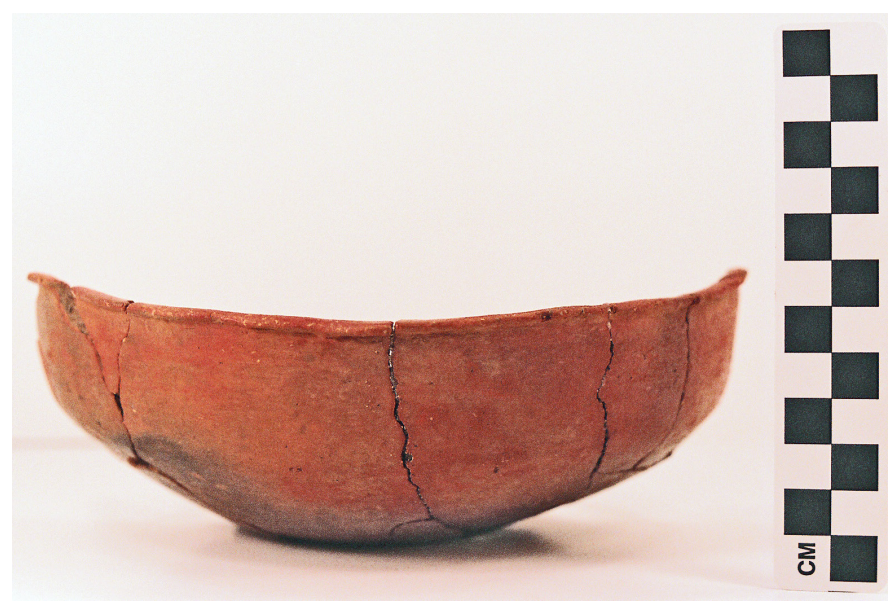

Figure 123. Red-slipped carinated bowl from Feature 8 (Vessel 5) at the Lang Pasture site.

BASE DIAMETER: $5.5 \mathrm{~cm}$

ESTIMATED VOLUME: 0.75 liters

DECORATION: Red-slipped on interior and exterior vessel surfaces

TYPE: Undetermined fine ware and red-slipped vessel 
FEATURE: 8

VESSEL NO.: 6

NON-PLASTICS: grog

VESSEL FORM: Jar with a direct rim and a rounded lip

CORE COLOR: fired in a reducing environment

INTERIOR SURFACE COLOR: Not recorded

EXTERIOR SURFACE COLOR: Not recorded

WALL THICKNESS: 4.9-6.0 mm, rim; 6.4 $\mathrm{mm}$, body

INTERIOR SURFACE TREATMENT:

smoothed

EXTERIOR SURFACE TREATMENT:

smoothed on the lower vessel body; organic residue across the vessel body

HEIGHT: $14.1 \mathrm{~cm}$; rim height, $4.8 \mathrm{~cm}$

ORIFICE DIAMETER: $14.5 \mathrm{~cm}$

DIAMETER AT BOTTOM OF RIM OR

NECK: $14.7 \mathrm{~cm}$

BASE DIAMETER: $6.8 \mathrm{~cm}$

ESTIMATED VOLUME: 1.2 liters

DECORATION: Cross-hatched incised lines in a panel on the rim, with a single horizontal incised line along the lower part of the cross-hatched incised motif (Figure 124).

TYPE: Maydelle Incised 
FEATURE: 8

VESSEL NO.: 7

NON-PLASTICS: grog

VESSEL FORM: Bottle with a direct neck and a flat lip (Figure 125)

CORE COLOR: fired in a reducing environment

INTERIOR SURFACE COLOR: Not recorded

EXTERIOR SURFACE COLOR: Not recorded

WALL THICKNESS: $5.7 \mathrm{~mm}$, rim; 6.5 $\mathrm{mm}$, base

INTERIOR SURFACE TREATMENT: none

EXTERIOR SURFACE TREATMENT: burnished on lower vessel body

HEIGHT: $11.4 \mathrm{~cm}$; neck height, $5.2 \mathrm{~cm}$

ORIFICE DIAMETER: $4.0 \mathrm{~cm}$

DIAMETER AT BOTTOM OF RIM OR NECK: $4.0 \mathrm{~cm}$

BASE DIAMETER: $8.0 \mathrm{~cm}$

ESTIMATED VOLUME: 0.2 liters

DECORATION: plain

TYPE: Undetermined plain ware vessel

Figure 125. Plain bottle from Feature 8 (Vessel 7) at the Lang Pasture site.

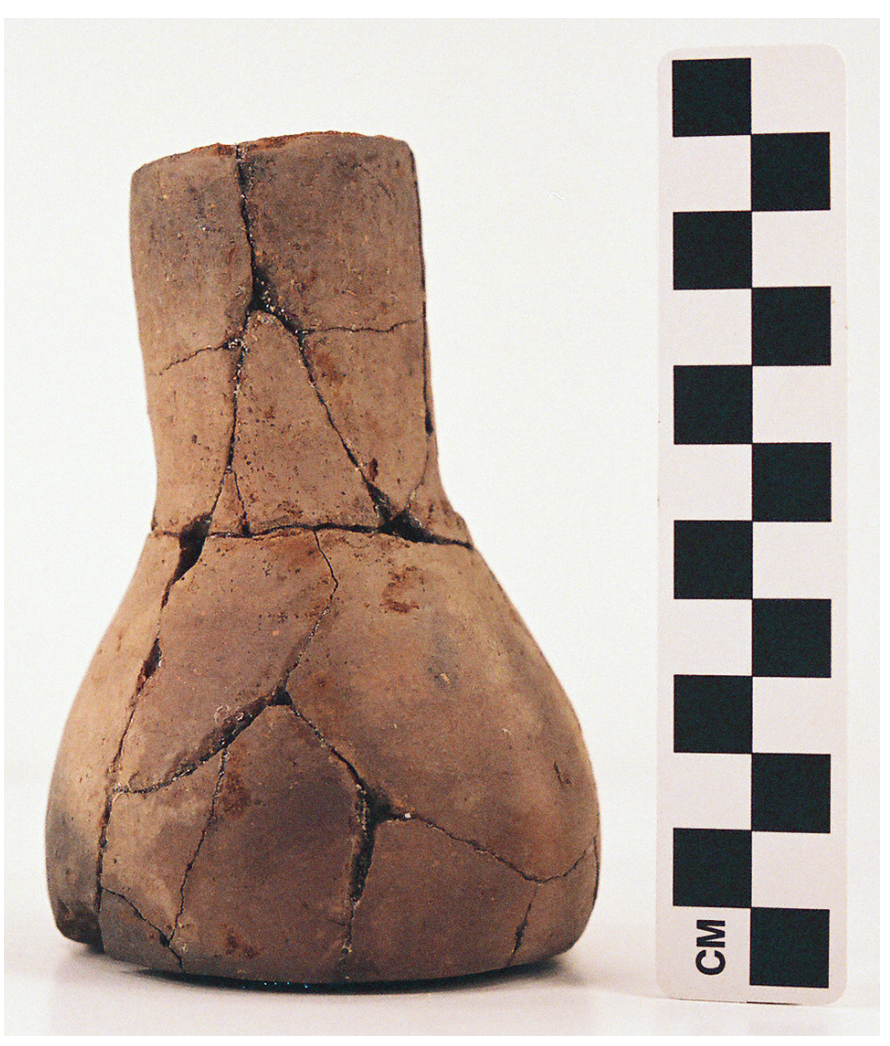


FEATURE: 76B, 74-86 cm bs (N199 E203)

VESSEL NO.: 1

NON-PLASTICS: grog-hematite

VESSEL FORM: Globular carinated bowl with an inverted rim (Figure 126) and a rounded lip

CORE COLOR: $\mathrm{G}$ (fired in a reducing environment, but cooled in the open air, see Teltser 1993:Figure 2)

INTERIOR SURFACE COLOR: brownishyellow (10YR 6/6)

EXTERIOR SURFACE COLOR: dark yellowish-brown (10YR 4/4)

WALL THICKNESS: $5.1 \mathrm{~mm}$, rim; 6.1 $\mathrm{mm}$, body

INTERIOR SURFACE TREATMENT: none; fire clouding on base

EXTERIOR SURFACE TREATMENT: none

HEIGHT: $39.2 \mathrm{~mm}$, rim height

ORIFICE DIAMETER: $15.0 \mathrm{~cm}$

DIAMETER AT BOTTOM OF RIM OR NECK: N/A

BASE DIAMETER: N/A

ESTIMATED VOLUME: Undetermined

DECORATION: plain

TYPE: cf. Poynor Plain

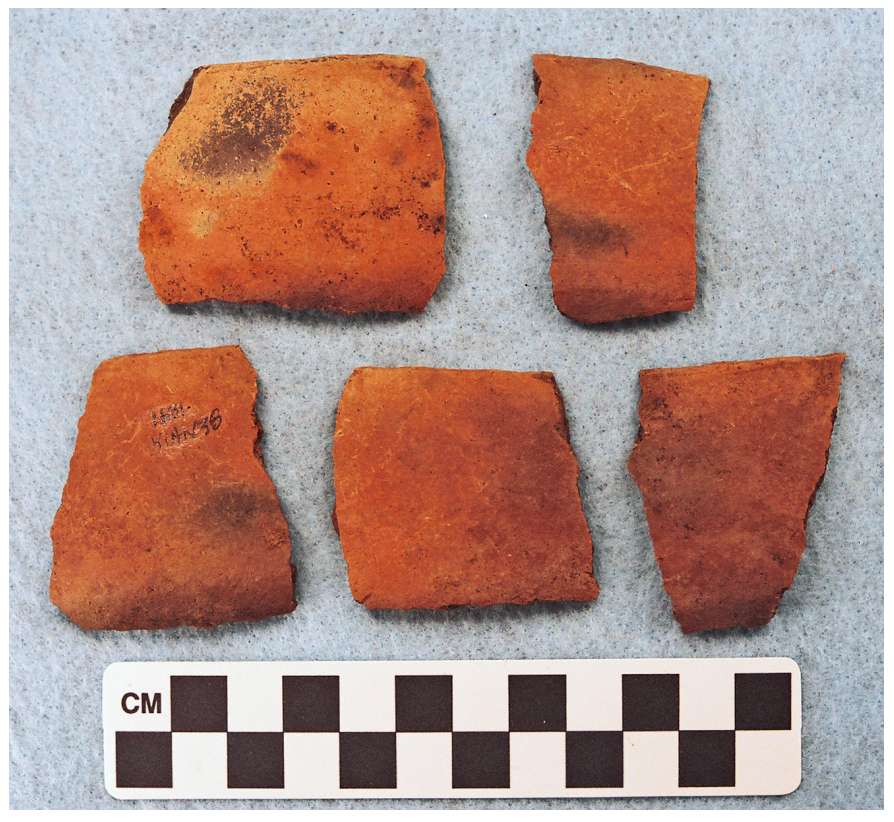

Figure 126. cf. Poynor Plain carinated bowl sherds from Feature 76B (Vessel 1) at the Lang Pasture site. 
FEATURE: 76B, 75-89 cm bs (N199 E203)

VESSEL NO.: 2

NON-PLASTICS: bone

VESSEL FORM: Seed jar or neckless bottle with two suspension holes $(6.4 \mathrm{~mm}$ in diameter) (Figure 127a)

CORE COLOR: Undetermined, but apparently fired in a reducing environment

INTERIOR SURFACE COLOR: Dark brown (7.5YR 3/3)

EXTERIOR SURFACE COLOR: Dark brown $(7.5 \mathrm{YR} 3 / 3)$

WALL THICKNESS: $4.4 \mathrm{~mm}$ at the neck

INTERIOR SURFACE TREATMENT: none

EXTERIOR SURFACE TREATMENT:

smoothed

HEIGHT: $11.7 \mathrm{~cm}$

ORIFICE DIAMETER: $3.6 \mathrm{~cm}$ at the neck

DIAMETER AT BOTTOM OF RIM OR

NECK: $9.8 \mathrm{~cm}$ near the base

BASE DIAMETER: $6.1 \mathrm{~cm}$

\section{ESTIMATED VOLUME: 0.4 liters}

DECORATION: The vessel is decorated with a series of diagonal panels filled with engraved or rocker-stamped elements. The rim has a single row of rocker stamping (Figures 127a-b).
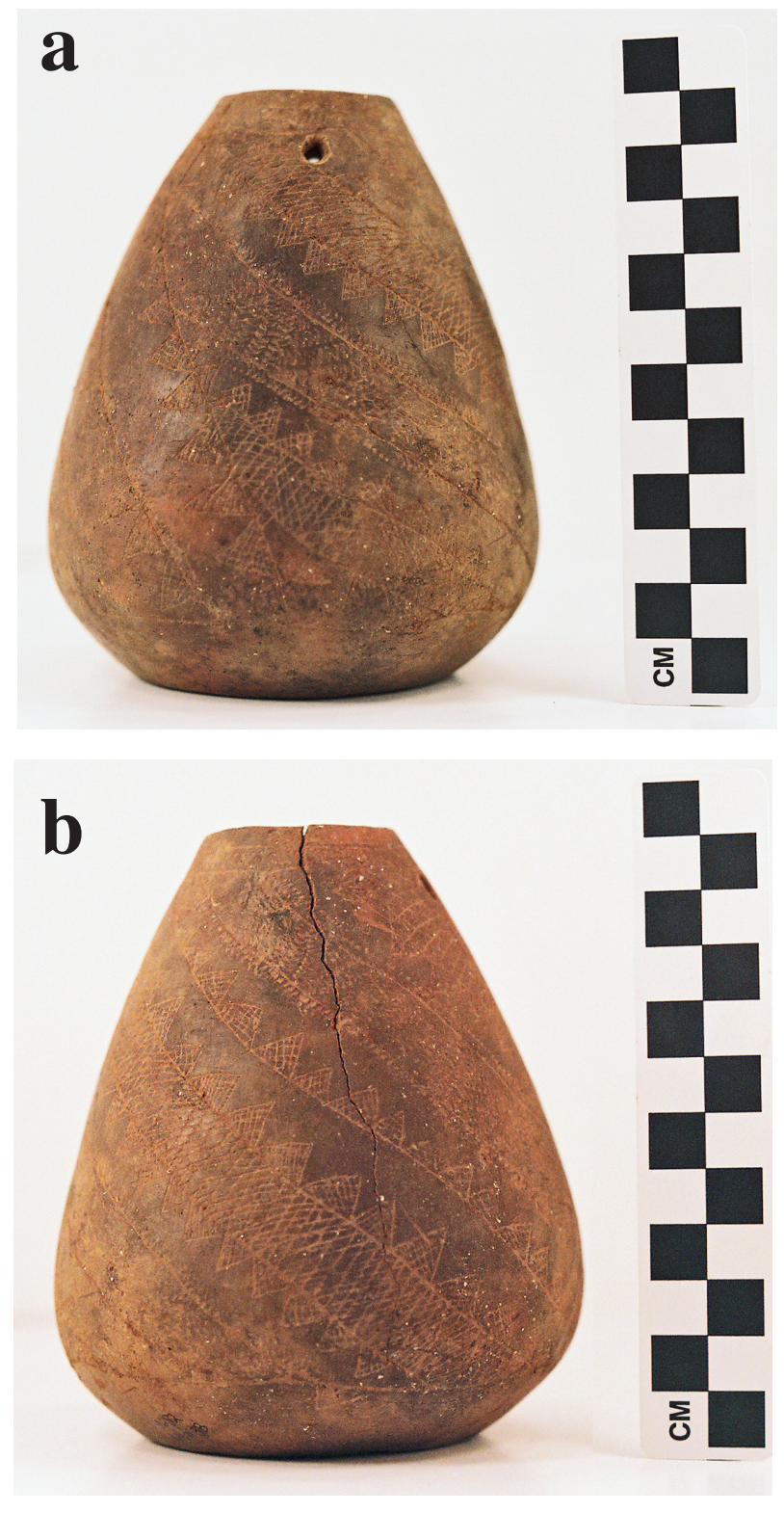

Figure 127. Two views of engraved-rocker stamped vessel (Vessel 2) from Feature 76B at the Lang Pasture site: a, view showing suspension holes and decoration; $b$, view showing decorative elements on vessel rim and body.

From top to bottom on the vessel, the diagonal panels begin with a zone of cross-hatched engraved pendant triangles inside the panel, followed by a rocker-stamped panel with cross-hatched engraved pendant triangles (14 and 18, respectively) on the outside of the panel. The third diagonal panel is filled with rocker stamps (forming triangular areas within the panel) and very small tick-like rocker stamping on either side of the panel. This is followed by a fourth panel that is just like the second in having rocker stamping within the panel (forming triangular areas) and cross-hatched engraved pendant triangles on the outside of the panel. 
The last panel is comprised of two diagonal rows of cross-hatched engraved pendant triangles (13 and 15, respectively), with a row of smaller rocker stamps inside the panel itself (Figure 127a-b).

TYPE: Undetermined engraved-rocker stamped vessel; resembles the Garland Engraved type as described by Early (1993:90) in having the roughened rocker-stamped zones and the cross-hatched background or fill elements. Early (2006 personal communication) indicates that vessels with this shape and decoration may date to ca. A.D. 1400, if not earlier, and are very common in the Hot Spring County, Arkansas area in the Ouachita River valley. This suggests that Vessel 2 from Feature 76B is a trade ware.

FEATURE: 76C, 66-88 cm bs (N196 E197)

VESSEL NO.: 1

NON-PLASTICS: grog, hematite, and bone, with a sandy paste

VESSEL FORM: Globular bowl, based on sherd profiles and curvature; no rims present (1 base sherd and 51 body sherds) (Figure 128)

CORE COLOR: $\mathrm{F}$ (fired in a reducing environment and cooled in the open air)

INTERIOR SURFACE COLOR: strong brown (7.5YR 4/6)

EXTERIOR SURFACE COLOR: brown (10YR 4/3)

WALL THICKNESS: $5.4 \mathrm{~mm}$, body; $6.2 \mathrm{~mm}$, base

INTERIOR SURFACE TREATMENT: none

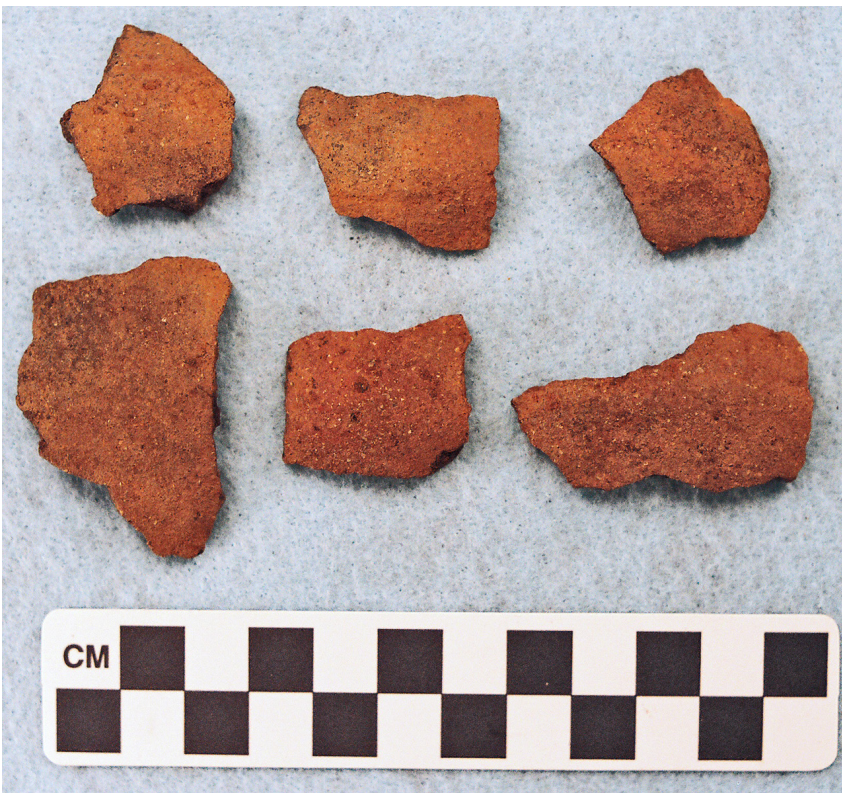

Figure 128. Plain globular bowl sherds from Feature 76C (Vessel 1) at the Lang Pasture site.

EXTERIOR SURFACE TREATMENT: none

HEIGHT: Undetermined

ORIFICE DIAMETER: Undetermined

DIAMETER AT BOTTOM OF RIM OR NECK: Undetermined

BASE DIAMETER: Undetermined

ESTIMATED VOLUME: Undetermined

DECORATION: plain

TYPE: Undetermined plain ware vessel 
FEATURE: 76D, $162 \mathrm{~cm}$ bs (N198 E203)

VESSEL NO.: 1

NON-PLASTICS: grog

VESSEL FORM: Bowl with a direct rim and a flat, exterior folded and scalloped lip (Figure 129)

CORE COLOR: B (fired and cooled in a reducing environment)

INTERIOR SURFACE COLOR: light

yellowish-brown (10YR 6/4)

EXTERIOR SURFACE COLOR: brown (7.5YR 5/4); black (10YR 2/1) fire clouds on body and base

WALL THICKNESS: $5.0 \mathrm{~mm}$, rim; $5.6 \mathrm{~mm}$, body; $10.3 \mathrm{~mm}$, base

INTERIOR SURFACE TREATMENT: smoothed

EXTERIOR SURFACE TREATMENT: smoothed to burnished; organic residue on rim; some body erosion

HEIGHT: $7.4 \mathrm{~cm}$

ORIFICE DIAMETER: $17.0 \mathrm{~cm}$

DIAMETER AT BOTTOM OF RIM OR NECK: N/A

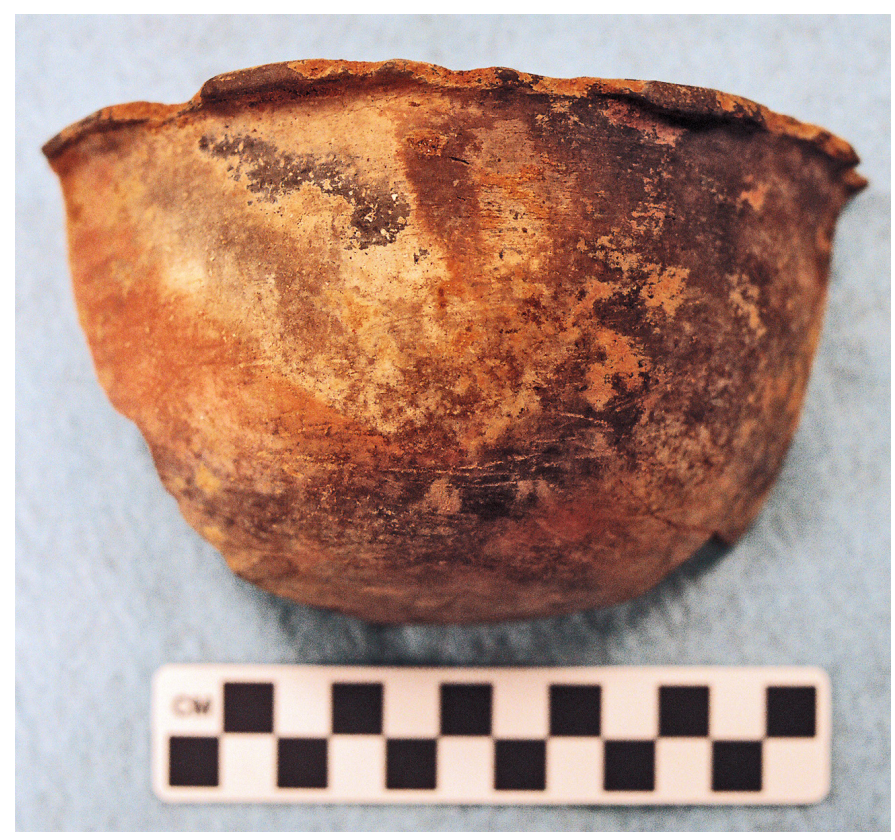

Figure 129. Plain bowl from Feature 76D (Vessel 1) at the Lang Pasture site.

BASE DIAMETER: $8.5 \mathrm{~cm}$

ESTIMATED VOLUME: 0.5 liters

DECORATION: plain

TYPE: Undetermined plain ware vessel 
FEATURE: 88, $12 \mathrm{~cm}$ bs (N215 E204)

VESSEL NO.: 1

NON-PLASTICS: grog-bone

VESSEL FORM: Compound vessel or wide-mouthed bottle with a wide neck with a direct rim and a flat lip; two suspension holes (Figure 130)

CORE COLOR: $\mathrm{F}$ (fired in a reducing environment, and cooled in the open air)

INTERIOR SURFACE COLOR: brown (10YR 4/3)

EXTERIOR SURFACE COLOR: brown (7.5YR 5/4), with fire clouds on the neck and base

WALL THICKNESS: 4.6 mm, neck

INTERIOR SURFACE TREATMENT: none

EXTERIOR SURFACE TREATMENT: burnished on neck and body; base is roughened

HEIGHT: $14.9 \mathrm{~cm}$; the neck height is $9.2 \mathrm{~cm}$

ORIFICE DIAMETER: $9.4 \mathrm{~cm}$

DIAMETER AT BOTTOM OF RIM OR

NECK: $7.9 \mathrm{~cm}$

BASE DIAMETER: $7.9 \mathrm{~cm}$

ESTIMATED VOLUME: 0.5 liters

DECORATION: The neck of the vessel is decorated with horizontal and diagonal hatched engraved zones or narrow panels repeated three times around the neck. The body has interlocking horizontal scrolls repeated six times around the vessel (Figure 130), as in the Poynor Engraved, var. B examples from the upper Neches River basin. A red clay pigment has been rubbed in the engraved lines.

TYPE: The design elements (especially those on the body) are reminiscent of several unnamed varieties of Poynor Engraved, including what has been called Poynor Engraved, var. B. The vessel form is unique, however. 
FEATURE: 88, $14 \mathrm{~cm}$ bs (N215 E204)

VESSEL NO.: 2

NON-PLASTICS: grog

VESSEL FORM: Carinated bowl with a direct rim and a flat lip; approximately 80 percent of the rim is represented (Figure 131), and approximately 30 percent of the vessel.

CORE COLOR: $\mathrm{G}$ (fired in a reducing environment, and cooled in the open air)

INTERIOR SURFACE COLOR: dark gray (10YR 4/1)

EXTERIOR SURFACE COLOR: gray (10YR 5/1)

WALL THICKNESS: $5.0 \mathrm{~mm}$, rim; 5.4

$\mathrm{mm}$, body; $8.9 \mathrm{~mm}$, base

INTERIOR SURFACE TREATMENT:

smoothed

EXTERIOR SURFACE TREATMENT: smoothed

HEIGHT: N/A; rim height is $3.8 \mathrm{~cm}$

ORIFICE DIAMETER: $17.0 \mathrm{~cm}$

DIAMETER AT BOTTOM OF RIM OR

NECK: $17.0 \mathrm{~cm}$

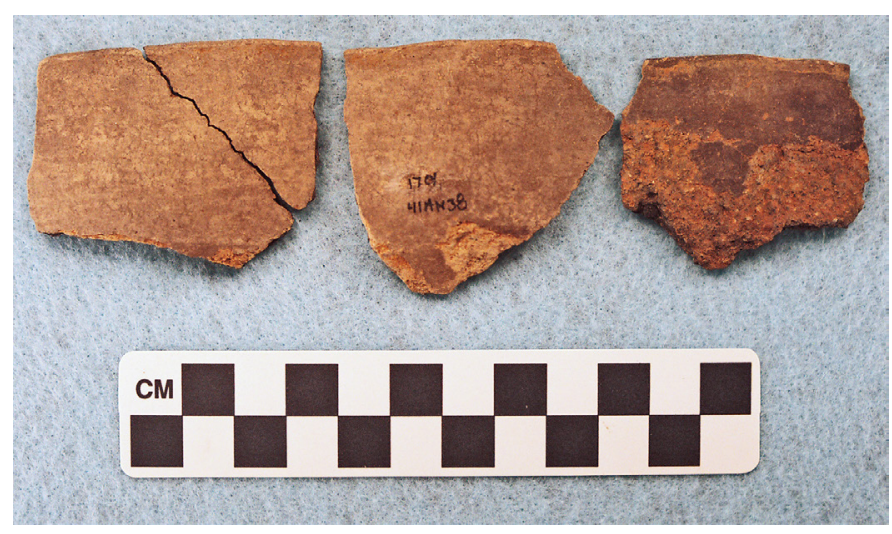

Figure 131. Plain carinated bowl rim sherds from Feature 88, Vessel 2 at the Lang Pasture site.

BASE DIAMETER: N/A

ESTIMATED VOLUME: Undetermined

DECORATION: plain

TYPE: Undetermined plain ware vessel 
FEATURE: $91,7-20 \mathrm{~cm}$ bs (N218 E203)

VESSEL NO.: 1

NON-PLASTICS: grog

VESSEL FORM: Compound bowl with an everted rim and a flat lip (Figure 132)

CORE COLOR: F (fired in a reducing environment and cooled in the open air)

INTERIOR SURFACE COLOR: strong brown $(7.5$ YR 5/6)

EXTERIOR SURFACE COLOR: brown (7.5YR 5/3)

WALL THICKNESS: $6.4 \mathrm{~mm}$, upper rim panel; $5.9 \mathrm{~mm}$, lower rim panel; $5.7 \mathrm{~mm}$, body; $9.4 \mathrm{~mm}$, base

INTERIOR SURFACE TREATMENT: smoothed, fire clouds

EXTERIOR SURFACE TREATMENT: smoothed, fire clouds

HEIGHT: rim panel height $(7.3 \mathrm{~cm})$ : upper panel height is $2.3 \mathrm{~cm}$, and the lower panel height is $5.0 \mathrm{~cm}$

ORIFICE DIAMETER: $16.0 \mathrm{~cm}$

DIAMETER AT BOTTOM OF RIM OR

NECK: Undetermined

BASE DIAMETER: $7.4 \mathrm{~cm}$

ESTIMATED VOLUME: 0.9+ liters

DECORATION: The upper panel is plain, while the lower panel has a series of triangular and circular engraved motifs that are repeated seven times around the vessel (Figure 132). The circles, with small hatched pendant triangles, alternate with the triangular motif, which consists of two triangles that touch at their apex in the central part of the lower panel; the double triangle motif is also seen in examples of Poynor Engraved, var. $O$ in the upper Neches River basin, but examples have hatched triangles. Four of the engraved triangles have triangular hatched areas at each corner of the larger triangle, while three have negative ovals within the larger triangles, outlined by a series of curvilinear hatched lines at the corner of the larger triangles. There is also a single engraved triangle on the interior surface of the upper rim panel.

TYPE: Poynor Engraved, local variety 2 at the Lang Pasture site (Perttula 2011:Figure 6-29b). 
FEATURE: 91, 10-25 cm bs (N217 E203)

VESSEL NO.: 2

NON-PLASTICS: bone

VESSEL FORM: Carinated bowl with a direct rim and a rounded lip

CORE COLOR: F (fired in a reducing environment and cooled in the open air)

INTERIOR SURFACE COLOR: brown

(7.5YR 5/4)

EXTERIOR SURFACE COLOR:

yellowish-red (5YR 5/6)

WALL THICKNESS: $6.7 \mathrm{~mm}$, rim panel

INTERIOR SURFACE TREATMENT:

smoothed on the rim

EXTERIOR SURFACE TREATMENT:

smoothed on the rim and body; fire

clouds on lower body and base

HEIGHT: $6.1 \mathrm{~cm}$; rim height is $4.1 \mathrm{~cm}$

ORIFICE DIAMETER: $14.7 \mathrm{~cm}$

DIAMETER AT BOTTOM OF RIM OR

NECK: $14.6 \mathrm{~cm}$

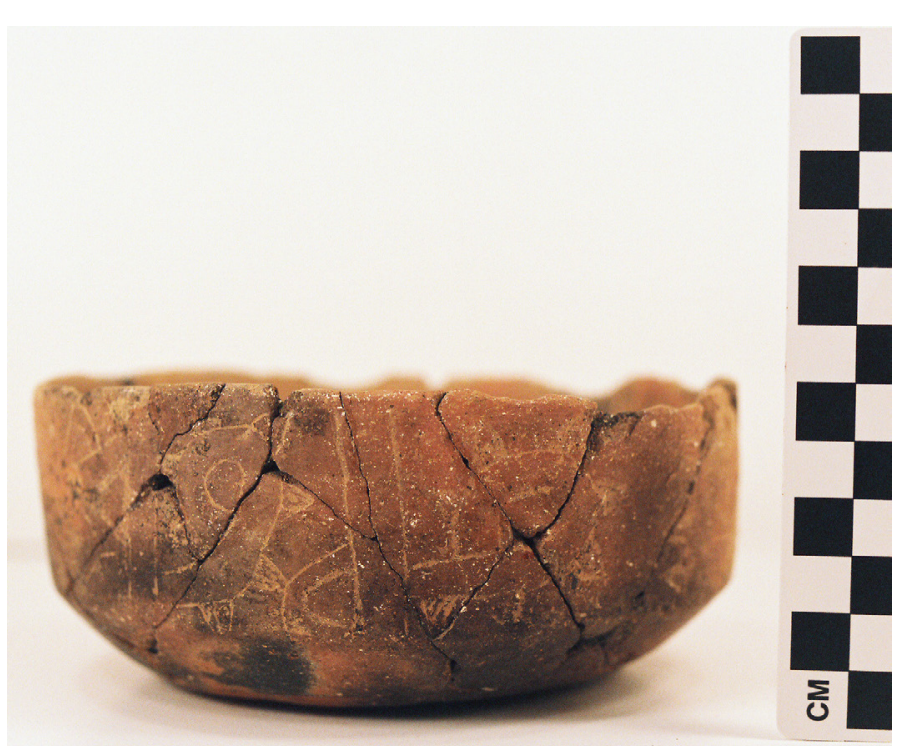

Figure 133. Poynor Engraved carinated bowl, local variety 3, from Feature 91 (Vessel 2) at the Lang Pasture site.

BASE DIAMETER: $10.4 \mathrm{~cm}$

ESTIMATED VOLUME: 0.55 liters

DECORATION: The rim is divided into six panels by sets of vertical engraved lines. Each panel has unique engraved motifs that feature-in varying combinations - circles or ovals, semi-circles, hooked arm scrolls, pendant triangles, and hatched ovals (Figure 133). All these elements are commonly noted on upper Neches River Poynor Engraved vessels, but not in the combinations represented on Feature 91, Vessel 2.

Moving from left to right on the vessel, the first panel has two semi-circles, with small hatched pendant triangles on the outer semi-circle. The second panel has a central oval with hatched pendant triangles, as well as two semi-circles, one of which has pendant triangles; there also is a small triangular element with a negative oval opposite the central oval. The third and fourth panels have hooked arm scrolls with hatched pendant triangles. Where they differ is that the third panel has two semi-circles in one corner of the panel, while the fourth panel has three hatched pendant triangles. The fifth panel has two opposed hooked arm scrolls with hatched pendant triangles, a connecting engraved line from one scroll to the other, a hatched negative oval, and 
semi-circles pendant from the second of the hooked arm scrolls; the outermost semi-circle has hatched pendant triangles. The sixth and last panel has a large semi-circle-with smaller engraved semi-circles within it-and hatched pendant triangles on the outside of the large semi-circle (Figure 133).

TYPE: Poynor Engraved vessel, local variety 3 at the Lang Pasture site (Perttula 2011:Figure 6-29c).

FEATURE: 92, $63 \mathrm{~cm}$ bs (N216 E200)

VESSEL NO.: 1

NON-PLASTICS: bone-hematite

VESSEL FORM: Bowl with a direct rim and a rounded lip; two rim peaks or lip tabs (these are $33 \mathrm{~mm}$ wide and $17.5 \mathrm{~mm}$ in height) (Figure 134)

CORE COLOR: $\mathrm{G}$ (fired in a reducing environment and cooled in the open air)

INTERIOR SURFACE COLOR: pale brown (10YR 6/3)

EXTERIOR SURFACE COLOR: grayishbrown (10YR 5/2)

WALL THICKNESS: $6.2 \mathrm{~mm}$, rim; 6.2 $\mathrm{mm}$, body; $9.4 \mathrm{~mm}$, base

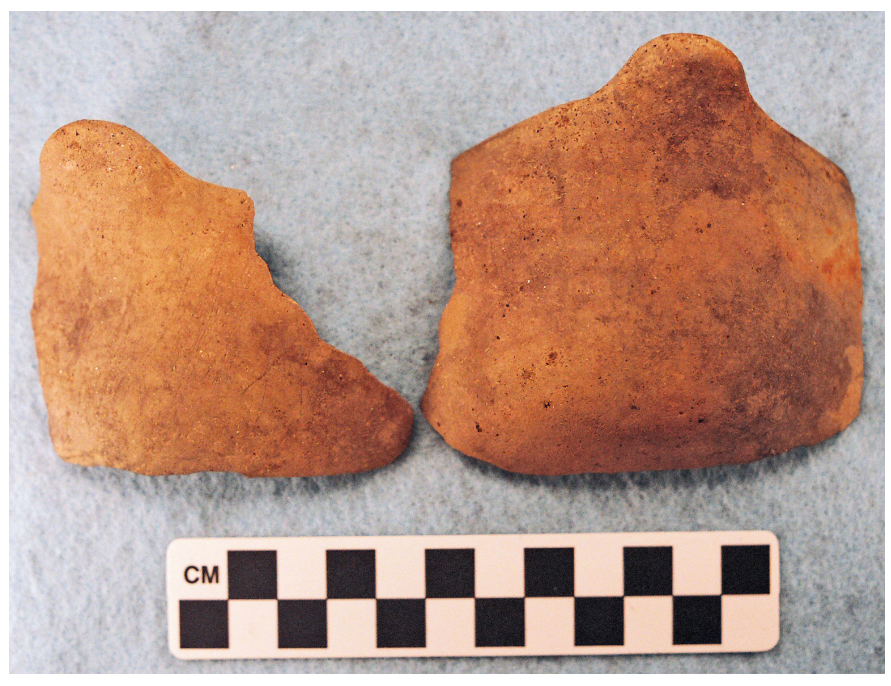

INTERIOR SURFACE TREATMENT:

Figure 134. Rim sherds from plain bowl in Feature 92 (Vessel 1) at the Lang Pasture site. smoothed; fire clouds

EXTERIOR SURFACE TREATMENT: smoothed; fire clouds on base

HEIGHT: $7.1 \mathrm{~cm}$ (without rim peaks); $8.4 \mathrm{~cm}$ (with rim peaks)

ORIFICE DIAMETER: $17.0 \mathrm{~cm}$

DIAMETER AT BOTTOM OF RIM OR NECK: N/A

BASE DIAMETER: $8.5 \mathrm{~cm}$

ESTIMATED VOLUME: 0.5 liters

DECORATION: plain

TYPE: Undetermined plain ware vessel 
FEATURE: 92, 59 cm bs (N216 E200)

VESSEL NO.: 2

NON-PLASTICS: grog-hematite

VESSEL FORM: Rectangular-shaped bowl or small trough with two rim peaks (Figure 135a-b); direct rim and flat lip, except at the rim peaks, where the rim is thickened on the interior surface

CORE COLOR: C (incompletely oxidized during firing)

INTERIOR SURFACE COLOR: yellowishbrown (10YR 5/4)

EXTERIOR SURFACE COLOR: brownishyellow (10YR 6/6)

WALL THICKNESS: $6.2 \mathrm{~mm}$, rim; $5.1 \mathrm{~mm}$, body; $7.1 \mathrm{~mm}$, base

INTERIOR SURFACE TREATMENT: fire clouds on body and base

EXTERIOR SURFACE TREATMENT: poor smoothing

HEIGHT: $5.9 \mathrm{~cm}$

ORIFICE DIAMETER: maximum of 12.9 $\mathrm{cm}$

DIAMETER AT BOTTOM OF RIM OR NECK: N/A

BASE DIAMETER: maximum of $9.6 \mathrm{~cm}$

ESTIMATED VOLUME: 0.3 liters

DECORATION: plain

TYPE: Undetermined plain ware vessel of unique form
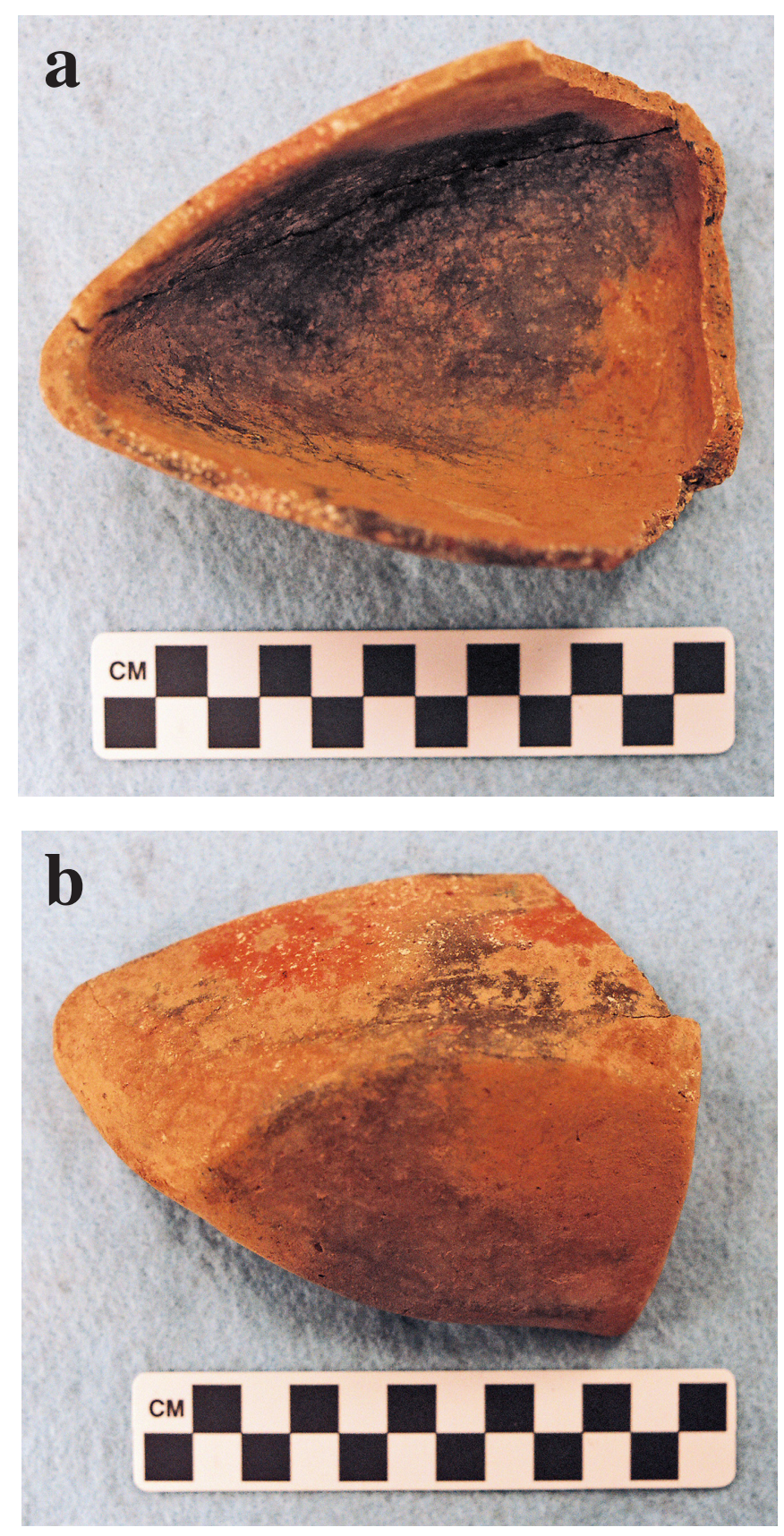

Figure 135. Two views of the plain rectangularshaped bowl from Feature 92 (Vessel 2) at the Lang Pasture site: a, looking down on the vessel; b, side and basal view. 
FEATURE: $93,65-75 \mathrm{~cm}$ bs

VESSEL NO.: 1

NON-PLASTICS: bone and grog

VESSEL FORM: Bowl with a direct rim and a flat lip (Figure 136)

CORE COLOR: $\mathrm{G}$ (fired in a reducing environment but cooled in the open air)

INTERIOR SURFACE COLOR: black (7.5YR 2.5/1)

EXTERIOR SURFACE COLOR: brown (7.5YR 5/4)

WALL THICKNESS: rim, $6.5 \mathrm{~mm}$; midbody, $7.1 \mathrm{~mm}$; base, $7.2 \mathrm{~mm}$

INTERIOR SURFACE TREATMENT: none

EXTERIOR SURFACE TREATMENT:

poorly smoothed; small area of organic residue near rim; fire cloud on rim

HEIGHT: $13.5 \mathrm{~cm}$

ORIFICE DIAMETER: $13.0 \mathrm{~cm}$

DIAMETER AT BOTTOM OF RIM OR

NECK: $13.4 \mathrm{~cm}$

BASE DIAMETER: $6.7 \mathrm{~cm}$

ESTIMATED VOLUME: 1.1 liters

DECORATION: Plain

TYPE: Undetermined plain ware vessel

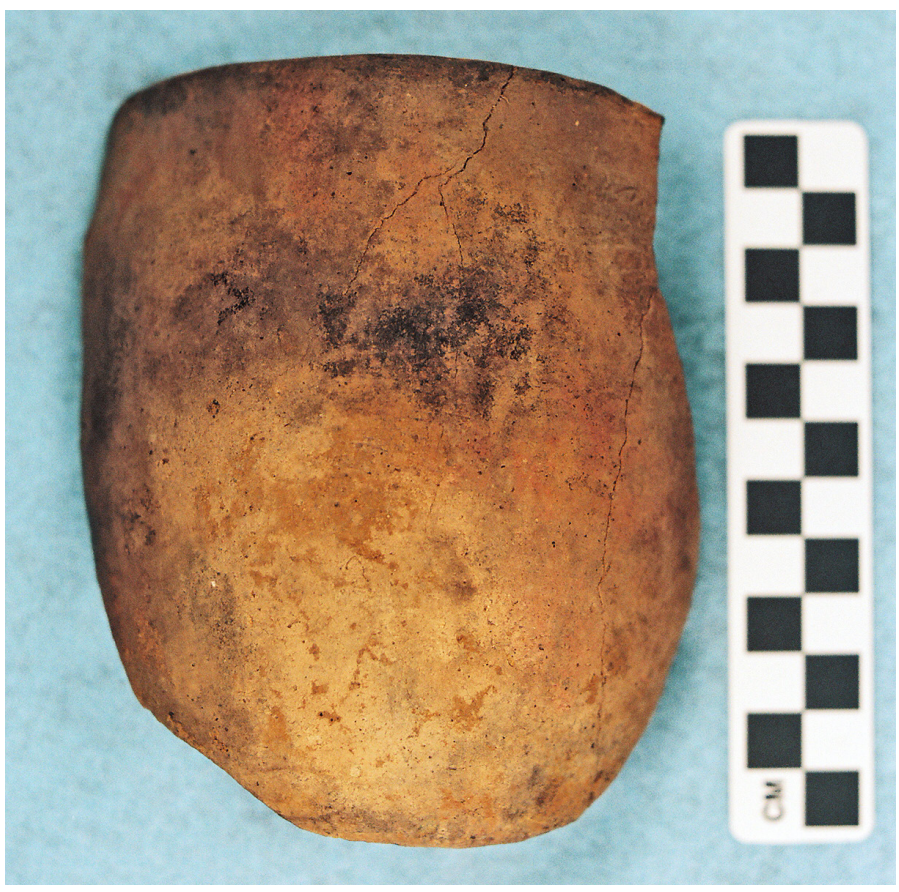

Figure 136. Plain bowl from Feature 93 (Vessel 1) at the Lang Pasture site. 
FEATURE: 93

VESSEL NO.: 2

NON-PLASTICS: grog

VESSEL FORM: Globular carinated bowl with broad rim panel (Figure 137); everted rim and a rounded lip

CORE COLOR: $\mathrm{F}$ (fired in a reducing environment and cooled in the open air)

INTERIOR SURFACE COLOR: dark gray $(10 \mathrm{YR} 4 / 1)$

EXTERIOR SURFACE COLOR: pale brown (10YR 6/3)

WALL THICKNESS: $3.6 \mathrm{~mm}$, rim

INTERIOR SURFACE TREATMENT: smoothed on rim; fire cloud on base

EXTERIOR SURFACE TREATMENT: smoothed; fire clouds on the body and base

HEIGHT: $5.7 \mathrm{~cm}$

ORIFICE DIAMETER: $8.4 \mathrm{~cm}$

DIAMETER AT BOTTOM OF RIM OR

NECK: $7.6 \mathrm{~cm}$ under the lip; $8.9 \mathrm{~cm}$ at the carination

BASE DIAMETER: $7.4 \mathrm{~cm}$

ESTIMATED VOLUME: 0.3 liters

DECORATION: Seven panels with hatched semi-circular engraved elements; alternate semi-circles in panels have a smaller but unhatched semi-circle as part of the motif (Figure 137). Each of the panels are divided by three vertical engraved lines, except in one instance where there is a single vertical line and a horizontal hatched ladder. Poynor Engraved, var. $K$ in the upper Neches River basin sites is comparable to this example from the Lang Pasture site.

TYPE: Poynor Engraved, local variety 4 (Perttula 2011:Figure 6-29d). 
FEATURE: $93,65-71 \mathrm{~cm}$ bs

VESSEL NO.: 3 (also includes Vessel 4A as recognized in the field, which conjoins with Vessel 3)

NON-PLASTICS: grog and bone

VESSEL FORM: Compound bowl with an everted rim and a rounded lip; 47 percent of the rim is present (Figure 138a-b)

CORE COLOR: $\mathrm{G}$ (fired in a reducing environment and cooled in the open air)

INTERIOR SURFACE COLOR: grayish-brown (10YR 5/2) and light brownish-gray (10YR 6/2)

EXTERIOR SURFACE COLOR: yellowish-brown (10YR 5/4) and brown (10YR 5/3)

WALL THICKNESS: upper rim panel, $7.3 \mathrm{~mm}$; lower rim panel, $6.8 \mathrm{~mm}$; lower body, $8.3 \mathrm{~mm}$; base, $9.4 \mathrm{~mm}$

INTERIOR SURFACE TREATMENT: fire cloud on the upper rim panel

EXTERIOR SURFACE TREATMENT: poorly smoothed; organic residue on both rim panels; fire clouds on lower rim panel and base

HEIGHT: $12.7 \mathrm{~cm}$; rim panels height, $8.5 \mathrm{~cm}$; upper panel height, $4.4 \mathrm{~cm}$; lower panel height, $4.1 \mathrm{~cm}$

ORIFICE DIAMETER: $19.0 \mathrm{~cm}$

\section{DIAMETER AT BOTTOM OF RIM OR NECK: N/A}

BASE DIAMETER: $7.9 \mathrm{~cm}$, flat disk base (Figure 138c)

\section{ESTIMATED VOLUME: 1.9 liters}

DECORATION: The upper rim panel is plain (Figure 138a-b). The lower rim panel has an engraved design repeated three times around the vessel, defined by upper and lower horizontal engraved lines.

This design includes two zones with a semi-circle and small pendant triangles (plain and excised); there is a small triangular element (with
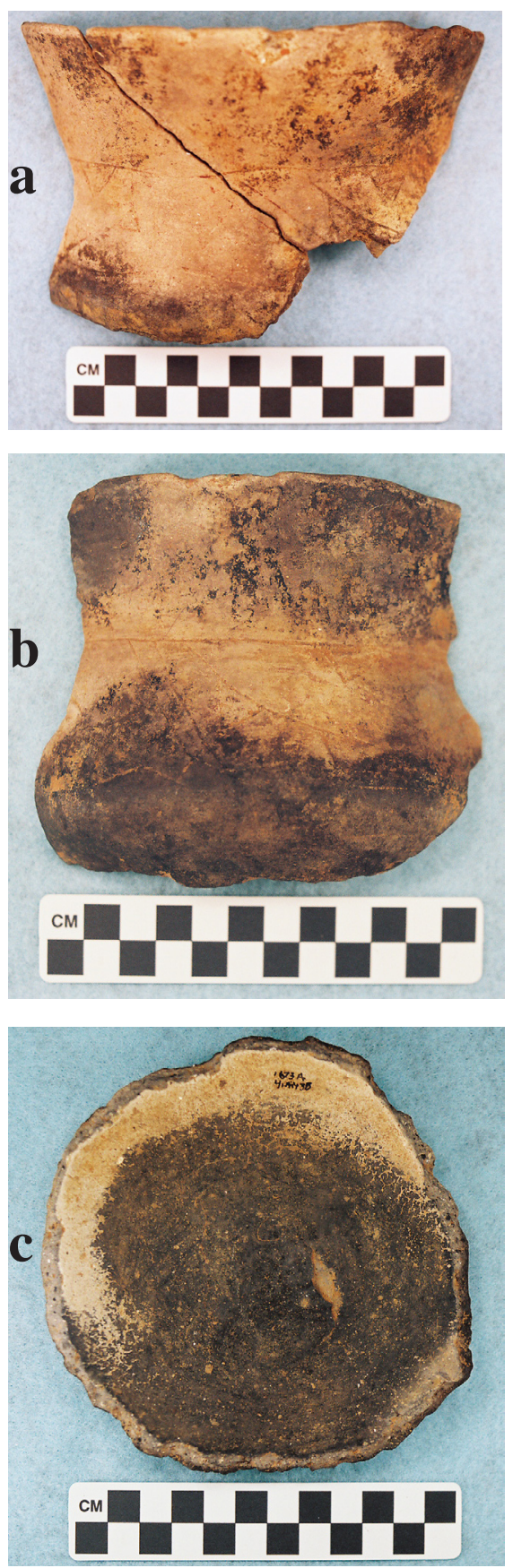

Figure 138. Poynor Engraved compound bowl, local variety 5 , from Feature 93 (Vessel 3) at the Lang Pasture site: $a-b$, upper and low rim panels; c, disk base. hatched corners in one instance) within the semi-circles. These semi-circles are divided by another zone with three engraved diagonal lines, one with a pendant triangle, as well as a hatched pendant triangle suspended from the upper horizontal engraved line on the lower rim panel.

TYPE: Poynor Engraved, local variety 5 (Perttula 2011:Figure 6-29e). 
FEATURE: 93

VESSEL NO.: 4B, 66 percent of the rim is present

NON-PLASTICS: bone and grog

VESSEL FORM: Bowl with a direct rim and a rounded lip; there is at least one rim peak (20.0 $\mathrm{mm}$ in width), with an interior beveled lip at the rim peak (Figure 139)

CORE COLOR: C (incompletely oxidized during firing)

INTERIOR SURFACE COLOR: strong brown $(7.5$ YR 4/6)

EXTERIOR SURFACE COLOR: dark gray (7.5YR 4/1)

WALL THICKNESS: $5.6 \mathrm{~mm}$, rim; 11.0 $\mathrm{mm}$ at the rim peak; $5.2 \mathrm{~mm}$, body; 5.6 $\mathrm{mm}$, base

INTERIOR SURFACE TREATMENT: smoothed; fire cloud on base

EXTERIOR SURFACE TREATMENT: smoothed

HEIGHT: estimated at $15.8 \mathrm{~cm}$

ORIFICE DIAMETER: $18.0 \mathrm{~cm}$

DIAMETER AT BOTTOM OF RIM OR NECK: N/A

BASE DIAMETER: $7.9 \mathrm{~cm}$

ESTIMATED VOLUME: 2.2+ liters

DECORATION: plain

TYPE: Undetermined plain ware vessel

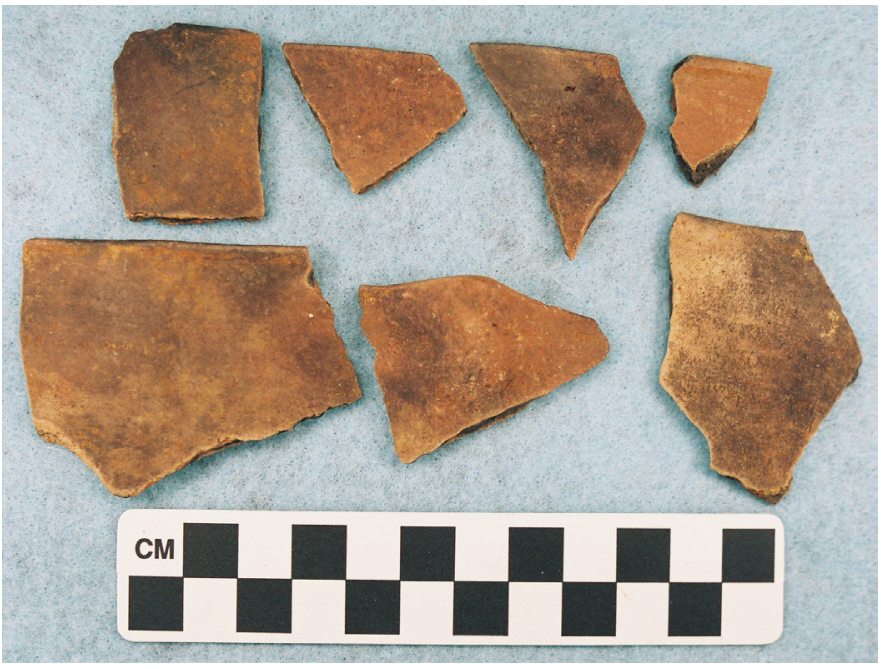

Figure 139. Rim sherds from plain bowl (Vessel 4B) in Feature 93 at the Lang Pasture site. 
FEATURE: 93, 69-72 cm bs

VESSEL NO.: 5

NON-PLASTICS: grog

VESSEL FORM: Bowl with seven rim peaks (31.5 mm in width) (Figure 140); interior beveled rim

CORE COLOR: Undetermined

INTERIOR SURFACE COLOR: light yellowish-brown (10YR 6/4)

EXTERIOR SURFACE COLOR: dark yellowish-brown (10YR 4/4)

WALL THICKNESS: $3.8 \mathrm{~mm}$, rim

INTERIOR SURFACE TREATMENT: fire clouds on base and body

EXTERIOR SURFACE TREATMENT:

smoothed; fire cloud on base

HEIGHT: $5.9 \mathrm{~cm} ; 6.75 \mathrm{~cm}$ at the rim peaks

ORIFICE DIAMETER: $13.0 \mathrm{~cm} ; 13.5 \mathrm{~cm}$ at the rim peaks, as they are angled outward

DIAMETER AT BOTTOM OF RIM OR NECK: N/A

BASE DIAMETER: $6.5 \mathrm{~cm}$

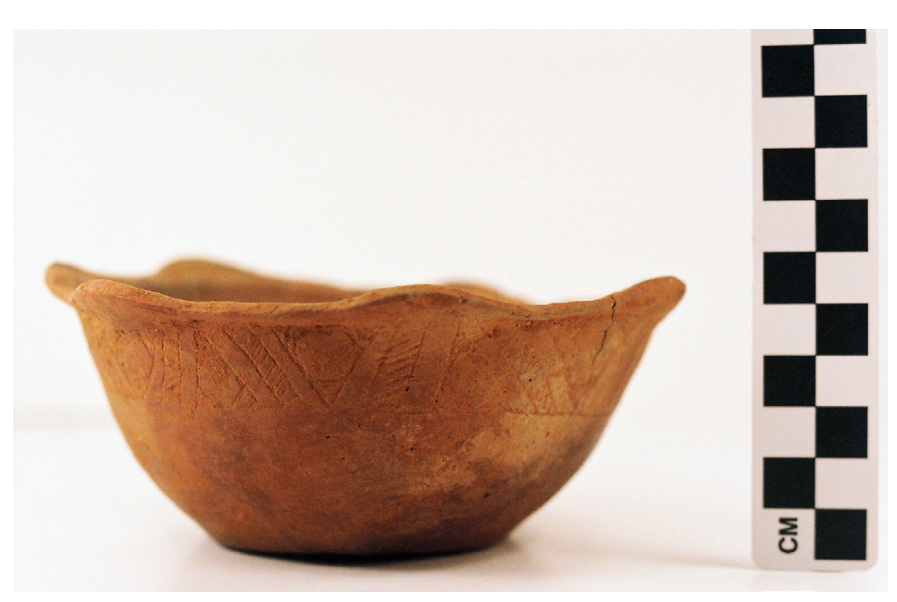

Figure 140. Poynor Engraved, var. $F$ bowl in Feature 93 (Vessel 5) at the Lang Pasture site.

ESTIMATED VOLUME: 0.3 liters

DECORATION: The upper part of the vessel has an engraved motif repeated eight times around the rim, beginning under the rim peaks (Figure 140). Each motif consists of two engraved triangles - one with its apex pointed down and the other with its apex pointing up towards the rim-with hatched corners. The opposed engraved triangles are separated from each other by diagonal hatched ladders or narrow zones.

TYPE: Poynor Engraved, var. $F$ in the upper Neches River basin 
FEATURE: 93, 60-74 cm bs

VESSEL NO.: 6

NON-PLASTICS: grog and bone

VESSEL FORM: Carinated bowl with a direct rim and a flat lip (Figure 141)

CORE COLOR: $\mathrm{F}$ (fired in a reducing environment and cooled in the open air)

INTERIOR SURFACE COLOR: yellowish-red (5YR 4/6)

EXTERIOR SURFACE COLOR: yellowishred $(5 \mathrm{YR} 4 / 6)$

WALL THICKNESS: rim, $7.4 \mathrm{~mm}$; body, $7.9 \mathrm{~mm}$

INTERIOR SURFACE TREATMENT:

smoothed on rim; fire cloud on base

EXTERIOR SURFACE TREATMENT:

smoothed on the rim and body; fire cloud on base

HEIGHT: $10.8 \mathrm{~cm}$; rim height, $4.5 \mathrm{~cm}$

ORIFICE DIAMETER: $15.9 \mathrm{~cm}$

DIAMETER AT BOTTOM OF RIM OR

NECK: $15.6 \mathrm{~cm}$

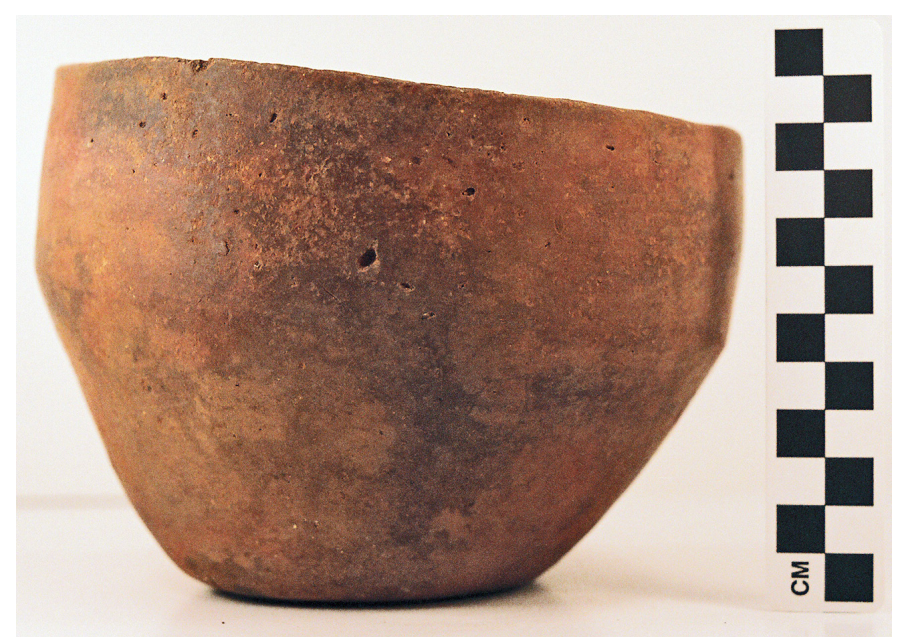

Figure 141. Plain carinated bowl from Feature 93 (Vessel 6) at the Lang Pasture site.

BASE DIAMETER: $8.1 \mathrm{~cm}$

ESTIMATED VOLUME: 1.0 liters

DECORATION: plain

TYPE: Undetermined plain ware vessel 
FEATURE: $93,62-78 \mathrm{~cm} \mathrm{bs}$

VESSEL NO.: 7

NON-PLASTICS: grog and hematite

VESSEL FORM: Carinated bottle with a straight neck, direct rim and a flat lip, and a globular body with a carination near the vessel base (Figure 142)

CORE COLOR: B (fired and cooled in a reducing environment)

INTERIOR SURFACE COLOR: dark yellowish-brown (10YR 4/4)

EXTERIOR SURFACE COLOR: dark yellowish-brown (10YR 4/4)

WALL THICKNESS: $4.9 \mathrm{~mm}$, neck

INTERIOR SURFACE TREATMENT: none

EXTERIOR SURFACE TREATMENT: smoothed in patches; eroded

HEIGHT: $18.9 \mathrm{~cm}$; neck height is $7.7 \mathrm{~cm}$

ORIFICE DIAMETER: $4.4 \mathrm{~cm}$ at the neck

DIAMETER AT BOTTOM OF RIM OR NECK: $11.3 \mathrm{~cm}$ at the widest part of the body (at the body carination)

BASE DIAMETER: $5.3 \mathrm{~cm}$

ESTIMATED VOLUME: 0.4 liters

DECORATION: plain

TYPE: Undetermined plain ware vessel 
FEATURE: $93,58-77 \mathrm{~cm}$ bs

VESSEL NO.: 8

NON-PLASTICS: hematite; sandy paste

VESSEL FORM: Carinated bowl with a direct rim and a flat lip (Figure 143)

CORE COLOR: F (fired in a reducing environment and cooled in the open air)

INTERIOR SURFACE COLOR: dark yellowish-brown (10YR 3/4)

EXTERIOR SURFACE COLOR: dark yellowish-brown (10YR 3/4)

WALL THICKNESS: $6.3 \mathrm{~mm}$, rim

INTERIOR SURFACE TREATMENT:

scraping and limited smoothing; fire cloud on base

EXTERIOR SURFACE TREATMENT:

smoothed; organic residue on the rim; fire clouds

HEIGHT: $9.5 \mathrm{~cm}$; rim height, $5.6 \mathrm{~cm}$

ORIFICE DIAMETER: $19.1 \mathrm{~cm}$

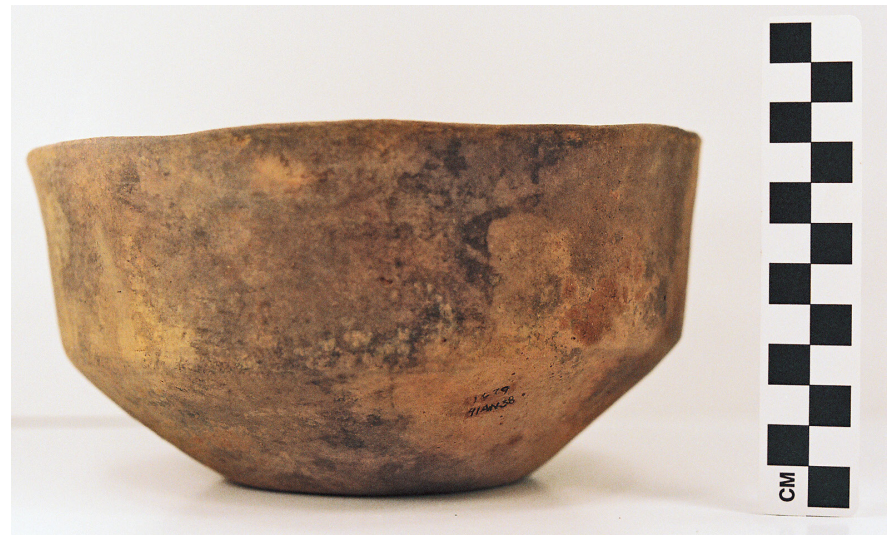

Figure 143. Plain carinated bowl from Feature 83 (Vessel 8) at the Lang Pasture site.
DIAMETER AT BOTTOM OF RIM OR

NECK: $18.8 \mathrm{~cm}$

BASE DIAMETER: $8.3 \mathrm{~cm}$

ESTIMATED VOLUME: 1.1 liters

DECORATION: plain

TYPE: Undetermined plain ware vessel 
FEATURE: $93,59-73 \mathrm{~cm}$ bs

VESSEL NO.: 9

NON-PLASTICS: grog

VESSEL FORM: Jar with a direct rim and a flat lip

CORE COLOR: $\mathrm{G}$ (fired in a reducing environment and cooled in the open air)

INTERIOR SURFACE COLOR: very dark grayish-brown (10YR 3/2)

EXTERIOR SURFACE COLOR: yellowish-brown (10YR 5/4)

WALL THICKNESS: 7.9 mm, body; 9.4 $\mathrm{mm}$, base

INTERIOR SURFACE TREATMENT: smoothed; organic residue on the rim, fire clouds on the lower body

EXTERIOR SURFACE TREATMENT: smoothed on body; organic residue on body and across the rim; fire cloud on base

HEIGHT: est. $11.8 \mathrm{~cm}$; rim height, $4.6 \mathrm{~cm}$

ORIFICE DIAMETER: $13.0 \mathrm{~cm}$

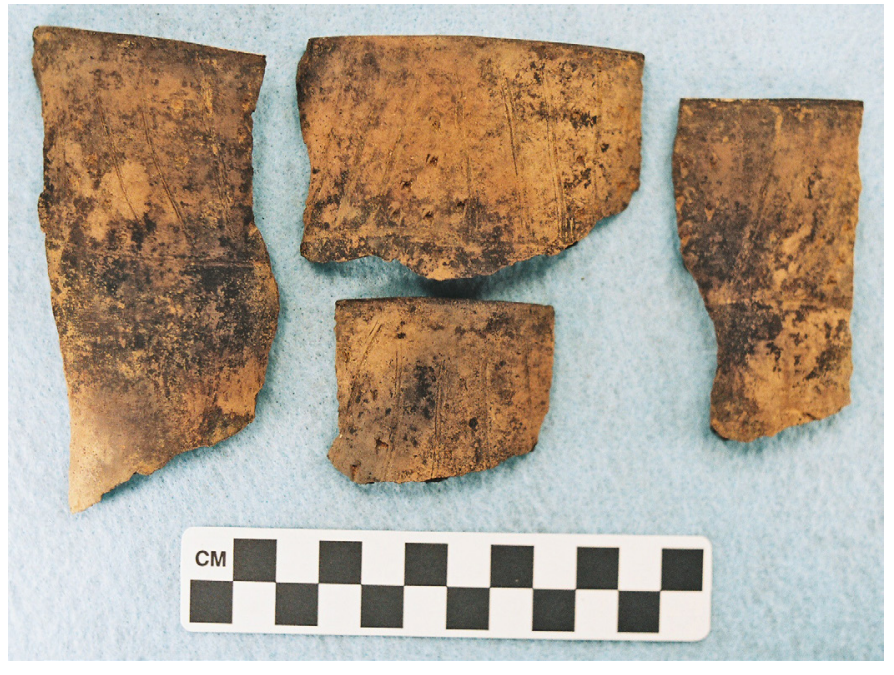

Figure 144. Rim sherds from a Maydelle Incised jar in Feature 93 (Vessel 9) at the Lang Pasture site.

DIAMETER AT BOTTOM OF RIM OR

NECK: N/A

BASE DIAMETER: $7.0 \mathrm{~cm}$

ESTIMATED VOLUME: $1.0+$ liters

DECORATION: The jar is decorated on the rim with incised triangles filled with tool punctations and near vertical incised panels filled with tool punctations (Figure 144). The near vertical incised panels and incised triangles are divided by a single diagonal incised line, and the bottom of the incised-punctated triangles and panels is defined by a single horizontal incised line.

TYPE: Maydelle Incised 
FEATURE: 94, 58-68 cm bs (N215 E200)

VESSEL NO.: 1

NON-PLASTICS: none apparent

VESSEL FORM: Bowl with a direct rim and a rounded lip (Figure 145)

CORE COLOR: Undetermined

INTERIOR SURFACE COLOR: grayishbrown $(10 \mathrm{YR} 5 / 2)$

EXTERIOR SURFACE COLOR: brown (10YR 4/3)

WALL THICKNESS: $4.9 \mathrm{~mm}$, rim

INTERIOR SURFACE TREATMENT:

smoothed; fire clouds on base and rim

EXTERIOR SURFACE TREATMENT: smoothed; fire clouds on base and body

HEIGHT: $8.0 \mathrm{~cm}$

ORIFICE DIAMETER: $11.3 \mathrm{~cm}$

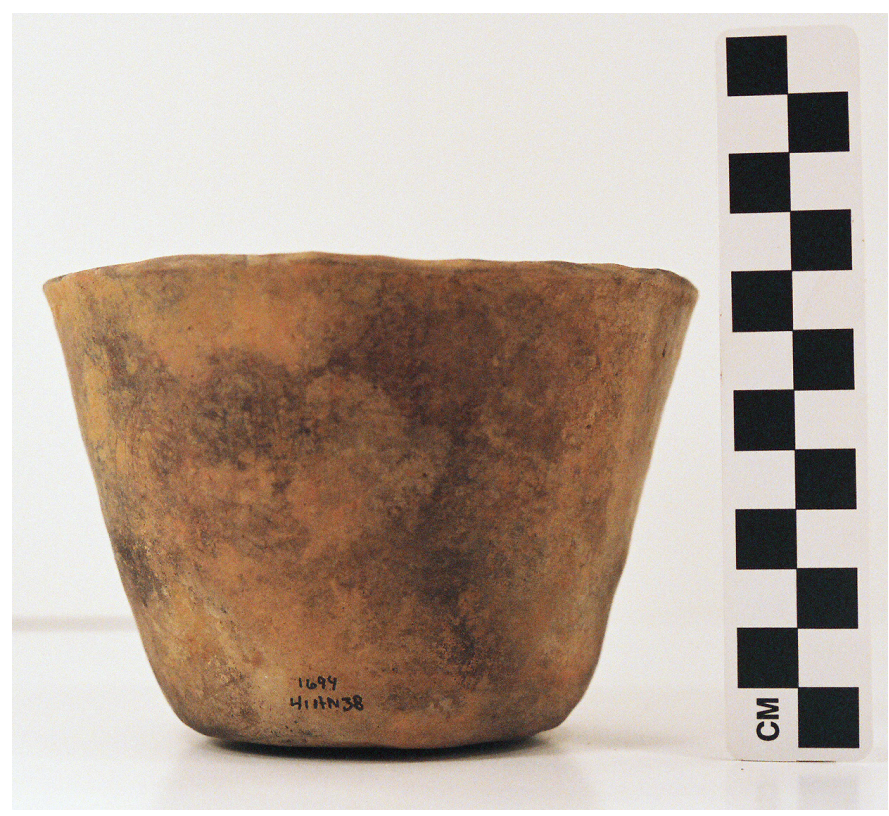

Figure 145. Plain bowl in Feature 94 (Vessel 1) at the Lang Pasture site.

BASE DIAMETER: $6.9 \mathrm{~cm}$

ESTIMATED VOLUME: 0.4 liters

DECORATION: plain

TYPE: Undetermined plain ware vessel 
FEATURE: 94, 59-65 cm bs

VESSEL NO.: 2

NON-PLASTICS: bone

VESSEL FORM: Compound bowl or globular carinated bowl with an everted rim and a rounded lip (Figure 146)

CORE COLOR: B (fired and cooled in a low oxygen environment)

INTERIOR SURFACE COLOR: dark grayish-brown (10YR 4/2)

EXTERIOR SURFACE COLOR: very dark grayish-brown (10YR 3/2)

WALL THICKNESS: rim, $4.3 \mathrm{~mm}$; body, $4.2 \mathrm{~mm}$

INTERIOR SURFACE TREATMENT:

smoothed on rim

EXTERIOR SURFACE TREATMENT:

smoothed

HEIGHT: $8.0 \mathrm{~cm}$

ORIFICE DIAMETER: $12.8 \mathrm{~cm}$

DIAMETER AT BOTTOM OF RIM OR

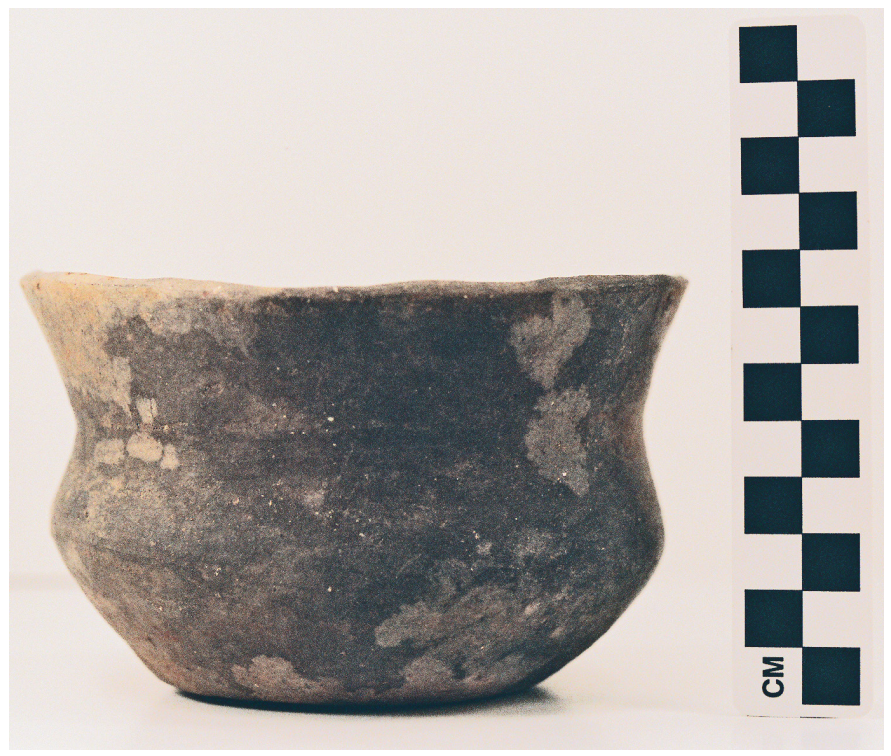

Figure 146. Poynor Plain compound bowl or globular carinated bowl from Feature 94 (Vessel 2) at the Lang Pasture site.

NECK: $10.6 \mathrm{~cm}$ at the upper panel; $12.8 \mathrm{~cm}$ at the lower panel

BASE DIAMETER: $7.3 \mathrm{~cm}$

ESTIMATED VOLUME: 0.8 liters

DECORATION: plain

TYPE: Poynor Plain 
FEATURE: 94, 65-67 cm bs (N215 E200)

VESSEL NO.: 3

NON-PLASTICS: bone and hematite

VESSEL FORM: Bowl with direct rim and a rounded, scalloped lip; the rim is interior thickened and pinched; interior thickened rim height is $16.0 \mathrm{~mm}$

CORE COLOR: $\mathrm{G}$ (fired in a reducing en-

vironment and cooled in the open air)

INTERIOR SURFACE COLOR: dark grayish-brown (10YR 4/2)

EXTERIOR SURFACE COLOR: dark gray (10YR 4/1)

WALL THICKNESS: $5.3 \mathrm{~mm}$, rim; 8.8 $\mathrm{mm}$, thickened portion of rim; $7.1 \mathrm{~mm}$, body; $11.8 \mathrm{~mm}$, base

INTERIOR SURFACE TREATMENT: none

EXTERIOR SURFACE TREATMENT: none

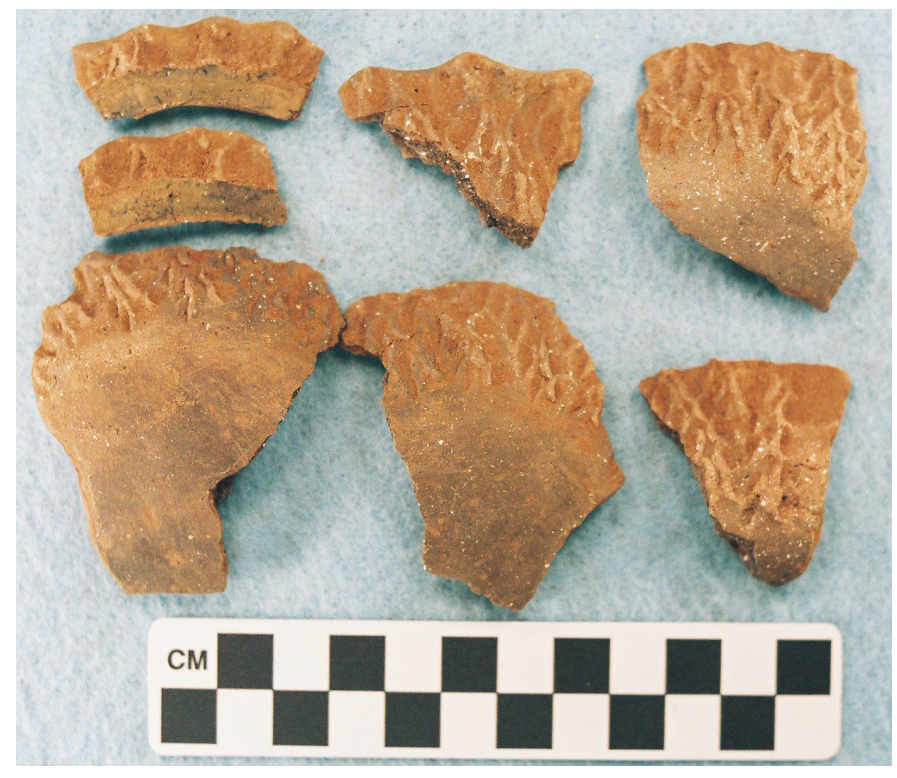

Figure 147. Killough Pinched rim, body, and base sherds from Feature 94 (Vessel 3) at the Lang Pasture site.

ORIFICE DIAMETER: $9.0 \mathrm{~cm}$

DIAMETER AT BOTTOM OF RIM OR

NECK: N/A

BASE DIAMETER: $5.3 \mathrm{~cm}$

ESTIMATED VOLUME: 0.2 liters

DECORATION: vertical pinched rows from the rim to the vessel base (Figure 147)

TYPE: Killough Pinched 
FEATURE: $94,65-69 \mathrm{~cm}$ bs

VESSEL NO.: 4

NON-PLASTICS: bone

VESSEL FORM: Carinated bowl with an inverted rim and a flat lip; one rim peak or vertical tab tail (Figure 148)

CORE COLOR: G (fired in a reducing environment, but cooled in the open air)

INTERIOR SURFACE COLOR: dark grayish-brown (10YR 4/2)

EXTERIOR SURFACE COLOR: very dark grayish-brown (10YR 3/2)

WALL THICKNESS: $6.0 \mathrm{~mm}$, rim

INTERIOR SURFACE TREATMENT: scraping marks

EXTERIOR SURFACE TREATMENT: smoothed on rim

HEIGHT: $4.1 \mathrm{~cm} ; 4.7 \mathrm{~cm}$ at rim peaks; rim height, $2.8 \mathrm{~cm}$

ORIFICE DIAMETER: $6.5 \mathrm{~cm}$

DIAMETER AT BOTTOM OF RIM OR

NECK: $6.5 \mathrm{~cm}$

BASE DIAMETER: $4.4 \mathrm{~cm}$

ESTIMATED VOLUME: 0.2 liters

DECORATION: plain

TYPE: Undetermined plain ware vessel, possibly an effigy vessel, but with a missing effigy head 
FEATURE: 94, 63-70 cm bs

VESSEL NO.: 5

NON-PLASTICS: bone

VESSEL FORM: Bowl with a direct rim and a flat, but exterior folded, lip

CORE COLOR: F (fired in a reducing environment, but cooled in the open air)

INTERIOR SURFACE COLOR: dark grayish-brown (10YR 4/2)

EXTERIOR SURFACE COLOR: grayishbrown $(10 \mathrm{YR} 5 / 2)$

WALL THICKNESS: $4.7 \mathrm{~mm}$, rim; 6.9 $\mathrm{mm}$, base

INTERIOR SURFACE TREATMENT: none

EXTERIOR SURFACE TREATMENT: poorly smoothed

HEIGHT: $4.6 \mathrm{~cm}$

ORIFICE DIAMETER: $9.0 \mathrm{~cm}$

DIAMETER AT BOTTOM OF RIM OR NECK: N/A

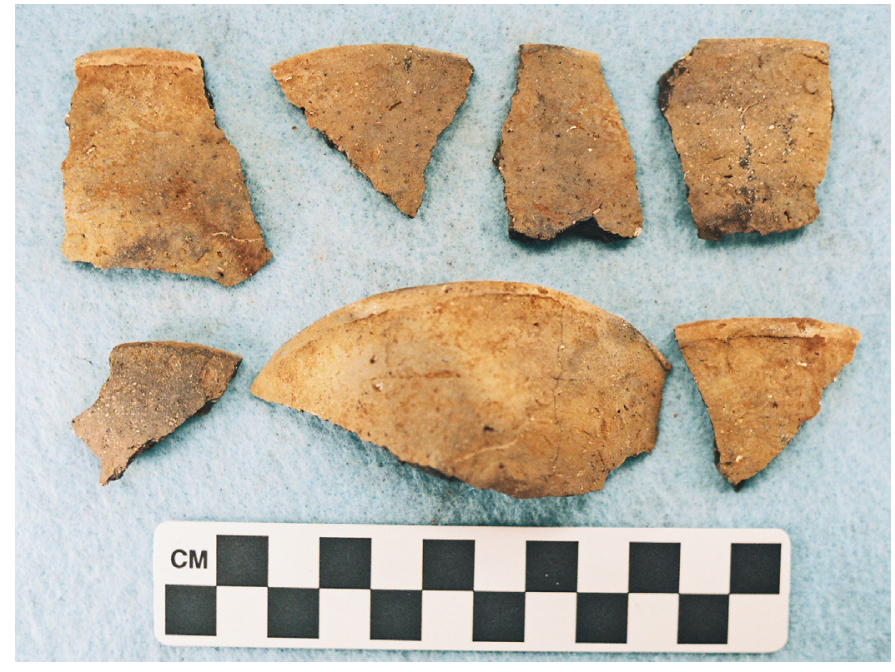

Figure 149. Plain bowl rim sherds from Feature 94 (Vessel 5) at the Lang Pasture site.

BASE DIAMETER: Undetermined

ESTIMATED VOLUME: 0.2 liters

DECORATION: plain (Figure 149)

TYPE: Undetermined plain ware vessel 
The detailed consideration of the style of the decorated fine ware and utility ware vessel sherds recovered at the Lang Pasture site, in conjunction with technological considerations of temper selection, pastes, and means of vessel firing in the different ceramic wares, and a suite of radiocarbon and TL dates suggests that the prehistoric Caddo occupation at the site began in the first quarter of the $14^{\text {th }}$ century A.D. and ended in the early part of the $15^{\text {th }}$ century. Some of the burials found at the site in a small cemetery were associated with the domestic occupation, while others may be slightly younger in age (and perhaps associated with continued occupation from areas of the site outside of the TxDOT right-of-way, see Perttula et al. 2007), but still having been interred by the first half of the $15^{\text {th }}$ century.

The test excavations and data recovery investigations at the Lang Pasture site recovered more than 6840 sherds from plain ware, fine ware, and utility ware vessels. About 62 percent of the sherds are plain, including 144 plain rims. About 21 percent of the decorated sherds are from fine ware vessels (i.e., decorated with engraved elements, as well as trailed and slipped decorative methods), and the remainder are from utility wares decorated with brushing and various wet paste elements (i.e., incised, punctated, appliqued, etc.).

One finding is that there are some substantial intra-site differences in the character of the domestic ceramics, particularly in the proportion of brushed utility wares and plain wares found either in the southern and northern parts of the site. These differences appear to be at least partially grounded in chronological changes in site use from north to south, but in the overall context of the stylistic and technological character of the ceramic assemblage, also reflect the fact that over a short period of time there were significant changes in the proportion of the three wares and in how they were decorated. These changes are embedded in Caddo ceramic assemblages that otherwise share many stylistic and technological practices. These similarities within the southern and northern assemblages at the Lang Pasture site-in conjunction with the associated mortuary vessels - are closely mirrored by the findings from the examination of sherds and vessels from other upper Neches River basin Caddo sites, and led to the formal recognition of a temporally distinctive and spatially coherent Caddo ceramic tradition in this part of East Texas. The spatial context for this Late Caddo ceramic tradition is a ca. $6600 \mathrm{~km}^{2}$ area of the upper Neches, of which the best-studied part is a $1700 \mathrm{~km}^{2}$ area centered on the Lang Pasture site, a number of small to mediumsized cemeteries in the Caddo Creek valley and other tributaries of the Neches River, and domestic ceramic assemblages primarily from the Lake Palestine area (cf. Anderson et al. 1974; Kleinschmidt 1982; Perttula and Middlebrook 2008).

The Caddo ceramics found in domestic, household, contexts at the Lang Pasture site include fine wares (engraved and slipped carinated bowls, bowls, and bottles used for food serving and to hold liquids), utility wares (brushed and wet-paste decorated jars and an occasional bowl used primarily for cooking, but also for storage), and plain wares, including bowls and bottles. There are technological and stylistic differences between the wares, as discussed above, and the Caddo potters that made these vessels clearly had a considerable range in choices and practices in how they were made and decorated, although the range of differences were overall rather minor in technical practices, except in the case of certain decorative and stylistic elements. The ubiquity of these wares in every part of the site indicate that they were available to all the Caddo that lived there, and that there was no restricted access to the use of fine wares. These same wares are also found in the mortuary vessel assemblage at the Lang Pasture site, but in very different proportions, with an increased emphasis on fine wares as one of the principal funerary offerings.

Clays used for vessel manufacture at the Lang Pasture site were likely gathered from nearby alluvial settings, as suggested by instrumental neutron activation analysis, particularly the more easily processed alluvial clay bodies along Caddo Creek, but certainly within a short (1-7 km away, at most) distance from the settlement. Depending upon the area of the site and the type of ware, about 18.4-33.6 percent of the vessel sherds have a fine sandy paste, suggesting that a naturally sandy clay was occasionally selected by 
Caddo potters for use in making particular kinds of vessels, those with a sandy paste facilitated resistance to thermal shock or mechanical breakage. The presence of sand in the clay paste may, in fact, indicate preferential use of alluvial clays by local potters (at least during the $14^{\text {th }}$ century), rather than the harder to process bedrock clay.

Approximately 8 percent of the plain and decorated sherds from domestic contexts at the Lang Pasture site came from "pinkware" vessels. These pinkware are sherds with a distinctive red paste after firing. These vessels were made with a different and second kind of clay with a moderate to high iron content, probably deriving locally from iron-rich Weches Formation outcrops in the southwestern part of Smith County, the northwestern part of Cherokee County, and northeastern Anderson County, 4-20 km from Lang Pasture.

Grog, crushed and burned bone, and crushed hematite are the significant tempers used in the locally produced ceramics at the Lang Pasture site. The differences, by area and by ceramic ware, are very subtle in terms of temper use. However, the temper data strongly supports the notion that the predominant practice of Caddo potters at the site, as at other upper Neches River Caddo sites, was in making grog-tempered plain ware, utility ware, and fine ware pottery in both areas and through time. It would have been important that sources of grog temper would have been abundant at the site, at least after the first few vessels were broken there, as would the fact that including grog in the paste (especially finely crushed pieces) would have helped minimize the likelihood of vessel failure form either mechanical and thermal stress (Steponaitis 1984:94-95, 111). Caddo potters would have discovered the advantages of grog-tempered pastes through trial and error, experience, and learned cultural traditions.

The principal technique used in the manufacture of Lang Pasture and other upper Neches River basin ceramics was the building of vessels using coils, beginning at the flat base and working up the vessel body. Using the coiling method, coils of clay, in the form of ropes, rolls, or fillets, were built up to create the desired size and height of the vessel. Coiling is a technique especially suited to the construction of large, sturdy vessels, such as storage jars (Rice 1987:128), but in the case of the upper Neches Caddo potters, coiling of plastic clays led to the manufacture of a wide variety of vessel forms.

The Lang Pasture site ceramic assemblage also contains very little in the way of waste byproducts from ceramic manufacture, such as coil fragments, lumps and balls of clay, clay scraping tools, or stone polishers. The site assemblage has no sherds identified as wasters - pottery damaged during firing (Rye 1981:147). However, wasters may be rare depending upon the frequency of production, quantities of vessels produced, manufacturing techniques, raw materials, and tempering practices. Waster sherds may also have been used in later firings to protect newly made vessels; sherds used in this manner may not be physically altered to any noticeable degree. Broken pottery vessels in Caddo ceramic assemblages were also readily recycled as grog temper, thus further removing any direct evidence of pottery manufacturing failures.

The sample of 456 rim sherds from the excavated area at the Lang Pasture site appear to be the broken remnants from separate vessels, suggests that there may have been thousands of vessels used by the Caddo during their occupation here, given the apparent size of the site relative to the proportion that was excavated. With a duration of occupation that lasted at least 80 years - but with an unknown number of households - the number of vessels used by each household during the course of occupation was substantial, perhaps 20-30 vessels at any one time, with different functions, sizes, volumes, and use-lives.

The Caddo pottery from domestic contexts at the Lang Pasture site-based on the number of rims from the three different pottery wares found there-is dominated by decorated utility wares, typically jars used for cooking and/or storage activities, and plain wares, generally simple bowls used for food 
serving along with the fine wares. Overall, almost 48 percent of the rims are from utility wares, another 31 percent are plain wares, and the remaining 22 percent are from fine wares: these are from carinated bowls, bottles, and some bowl forms. For the site as a whole, the utility wares include almost 79 percent of all the decorated sherds from non-feature domestic contexts and 70.6 percent of the decorated sherds from features (see Perttula 2011:Tables 6-1 and 6-2).

The rim and lip form data from the ceramic sherds suggest that carinated bowls, bottles, bowls, and jars were made by household potters at the site. The particular shape and form of these vessels is a hallmark of the technology and style of Caddo pottery vessels in the upper Neches River basin ceramic tradition, and these shapes and forms would have been immediately recognizable (e.g., Stark 2003:212) to other Caddo as belonging to those of a particular social group. Sadie Bedoka, a Caddo-Delaware woman, had noted some years ago that potters from one group could tell those of another simply by different pottery shapes (e.g., La Vere 1998:92).

Larger jars (with very thick rim and body walls, $>9-10 \mathrm{~mm}$ ) were probably used for short term storage, simply because they would be less easily moved about during cooking, while larger carinated bowls may have been employed in communal food serving; the majority of the serving vessels and cooking jars were in the 1-2 liter range, and thus likely intended for household use. Most of the utility ware jars were used for cooking, based on their form as open containers, as well as the presence of soot deposits, either heavy or light, as well as preserved charred organic remains. Sherds from jars tend to have residues formed on the interior of vessels that are related directly to cooking, as well as soot deposits on exterior surfaces that would have built up from wood combustion, indicating that vessels were placed over an open fire during use (Hally 1983:9). Bowls may have also been used for serving food, like the carinated bowls, but many of them lacked surface decorative embellishments. Bottle sherds, used for storing and carrying liquids, also were a common utilitarian form made for the use of the site occupants.

Smoothed and burnished grog-tempered pottery made at the Lang Pasture site combined strength, thermal shock resistance, resistance to breakage, and low permeability, and, thus, they may have lasted for a considerable length of time, especially if the vessels being used were large in size (see Arthur 2006:93). Vessel breakage, by whatever means, nevertheless, occurred with regularity at the Lang Pasture site because they were used on a daily basis, particularly among the cooking vessels, and this resulted in a large accumulation of pottery sherds inside and outside house structures.

Caddo domestic ceramics from the Lang Pasture site were relatively variable in size, ranging from about 0.2 liters to as much as 4-6 liters. There were also several notable trends in the vessel rim orifice diameter data: very small to medium-sized vessels are proportionally more abundant in the older, northern component, although small vessels become more commonly used later in time at the expense of medium-sized vessels. Very small vessels (bottles) - all plain wares - were restricted to the northern area (see Perttula 2011:Table 6-20). These data suggest that the Caddo living in the northern area made pottery designed for use in cooking and food serving in small social groups, perhaps individual households, and only occasionally were foods prepared and served for larger (i.e., more than 10 individuals) groups of people. Later in time, larger vessels used for food service (fine wares), cooking (utility wares), and storage (utility wares) were more frequently produced and used at the Lang Pasture site. In the southern area of the site, then, the ceramics produced and used by the Caddo were apparently made with the presumption that food preparation and serving needs extended to both household and supra-household contexts.

The fine ware vessel sherds at the Lang Pasture site are consistently from vessels made thinner than the decorated utility ware or plain ware sherds, particularly when measured along the rim. These variations in vessel wall thickness are likely related to functional and technological decisions made by 
Caddo potters in how these different wares were intended to be used in local Caddo households. The less substantial vessel walls in some of the utility wares would be well suited to the cooking and heating of foods and liquids and, because heat would have been conducted efficiently while heating rapidly, would have contributed to their ability to withstand heat-related stresses; also, the much thicker utility ware vessels (with rim thicknesses greater than $9 \mathrm{~mm}$ and body wall thicknesses greater than 10-11 mm) would have created stronger and more stable vessels, and would have been well suited for use as long-term storage containers (Rice 1987:227). Fine wares were probably intended for use in the serving of foods and liquids, and thinner and less porous vessel walls would have helped to maintain the temperature of served food and liquids; thinner and lighter vessels would have also contributed to the ease with which serving vessels could be handled, used, and transported.

The vessel sherds found in domestic contexts were primarily fired in a low oxygen or reducing environment. Utility ware, plain ware, and fine ware vessels were fired differently from each other. Fine ware and plain wares were better made and better fired (at least in terms of regulating the firing temperature), and they were probably fired longer in a low oxygen environment than the utility wares. The Caddo potters exerted more control over the end product of fine ware and plain ware vessel manufacture than they did with the utility wares, primarily to produce a harder ceramic. Firing conditions tended to be more heterogeneous among the utility wares, likely the product of the multi-purpose nature of these vessel forms, as they were used for cooking pots and storage containers. As long as the porosity of the utility wares was not excessive, and there was a good balance between clay plasticity and temper constituents, they did not need to be fired for as long a time as the harder fine wares to be serviceable vessels without being subject to diminished strength from cumulative thermal fatigue as well as cracks and fractures (cf. Steponaitis 1984).

Var. A-C elbow pipe forms are present at the Lang Pasture site (Perttula 2011:Figure 6-23). The two whole pipes from mortuary contexts are Var. A forms (Plain L-shaped), while all three forms are present in the 33 sherds from domestic contexts. In other upper Neches River basin sites, Var. A pipes are restricted to pre-A.D. 1480 components. Var. B pipes (with flaring bowls with distal stem knobs and engraved or incised lines on the stem and lower bowl) are present in ca. A.D. 1400-1560 mortuary contexts, as well as $15^{\text {th }}$ century ceremonial contexts at the A. C. Saunders site (41AN19), while Var. C pipes (engraved/ incised lines on the stem and lines on the pipe that extend along the entirety of the stem and basal portions of the bowl) occur from ca. A.D. 1400-1650. Var. D-F are all apparently post-A.D. 1560 elbow pipe forms in the upper Neches River basin.

Other ceramic artifacts from domestic contexts at the Lang Pasture site include a clay pendant (Perttula 2011:Figure 6-26) and two spindle whorls.

The lithic artifacts from the Lang Pasture site are dominated by arrow points $(n=80)$. These fall in two or three different temporal groups, a probable Late Woodland (ca. A.D. 700-800) component marked by Steiner arrow points (see Shafer and Walters 2010), a ca. A.D. 800-1200 component with Catahoula arrow points, and a $15^{\text {th }}$ century Caddo component with Perdiz and Bassett arrow points. Most of the arrow points at the site are apparently from the pre-A.D. 1200 period use of the landform, probably for periodic hunting and re-tooling activities, and not permanent settlement by ancestral Caddo peoples.

There are also 33 dart points in the assemblage, ranging from ca. 6000 year old Calf Creek points, Late Archaic Yarbrough points, and a number of Woodland era contracting stem Gary points. Additionally, there are 27 bifacial preforms, a four-beveled knive made from Edwards chert (Perttula et al. 2011:Figure 7-2v), unifacial drills, and a few ground stone tools. These include pitted stones ( $\mathrm{n}=3)$, a grinding slab, and a celt fragment of a likely Ouachita Mountains igneous raw material. 
Charred plant remains were relatively abundant in habitation contexts at the Lang Pasture site. A total of 45 flotation samples and five macro-botanical samples (of maize cob segments) indicate that oak, pine, willow/cottonwood, and hickory wood likely formed the tree canopy around the site during the $15^{\text {th }}$ century A.D. ancestral Caddo occupation. Plant foods included acorn and hickory nuts, squash, and maize. Hickory nuts were ubiquitous, occurring in 84.4 percent of the flotation samples, and maize (including con segments, cupules, kernels, and glume fragments) was present in 42 percent of the flotation samples. Squash rind occurred in 6.7 percent of the flotation samples.

Faunal remains were not well preserved at the site, or at least in those parts of the site within the TxDOT right-of-way. A total of 1759 individual specimens were recovered, and those that could be identified were from deer, dog, rabbit, turtle, large mammal, and unidentified mammal.

The analysis of the human remains recovered in the burial features at the Lang Pasture indicated that the ancestral Caddo peoples were generally in good health with a high adaptive efficiency - based on low infection rates detected in these remains as well as studied remains from other upper Neches River basin sites (Wilson 2011). Stable isotope and caries data point to a significant use of maize in the diet after the $14^{\text {th }}$ century A.D. in the region (Wilson and Perttula 2013), as well as at the Lang Pasture site.

\section{AN73}

41 AN73 was recorded in July 1970 during the archaeological survey of Lake Palestine by Southern Methodist University (see Anderson 1972). It is a Caddo site on an alluvial terrace north of Caddo Creek, and covered a ca. $80 \times 60 \mathrm{~m}$ area (1.2 acres). The site was described on the site form as a scatter of ceramic sherds and lithic debris.

\section{$41 A N 159$}

Test excavations were completed at 41AN159 in 2004 by TRC Environmental Corporation as part of the scheduled expansion of SH 155 (Lohse et al. 2011:613-636). That work indicated that the site had a low density of Middle to Late Archaic lithic artifacts, including Trinity and Yarbrough dart points, while the recovery of Caddo ceramic vessel sherds $(n=101)$ suggested an occupation that occurred ca. A.D. 1200-1300; a Catahoula arrow point was also recovered in the investigations. The plain to decorated sherd ratio for the assemblage is 3.39 , and only 13 percent of the decorated sherds had brushed decorative elements; almost 14 percent of the sherds are from bone-tempered vessels. No features or substantial archaeological deposits were identified in the project ROW at the site.

\section{Dobbs (41AN169)}

The Dobbs site was recorded in 2006, and suggested to be a Caddo farmstead of Late Caddo Frankston phase age on an upland landform (380 ft. amsl), about $650 \mathrm{~m}$ north of Caddo Creek. When the site was recorded, a single grog-bone-tempered body sherd ( $7 \mathrm{~mm}$ in thickness) with brushing marks was found at the site, but in 1980, when Bernie Ward, an avocational archaeologist from Tyler, Texas, visited the site he noted an abundance of ceramic sherds in a garden, and a Mr. George Adams (now deceased), who had excavated a number of the Caddo burial features in 1933 at the Patton site (41AN26). had a collection of artifacts from the site. The location of this collection is not known at the present time. 


\section{Faith Temple (41AN170)}

The Faith Temple site, recorded in 2006, is located on an upland landform (410 ft. amsl) along Caney Branch, a tributary to Caddo Creek; Caddo Creek lies about $1.75 \mathrm{~km}$ to the northeast. The site is thought to be a Late Caddo period Frankston phase component that covers a ca. 40 x $40 \mathrm{~m}$ area $(0.4$ acres $)$. Caddo artifacts were noted on the surface and along a cut bank, and according to the site form included 33 Caddo sherds (26 plain sherds, five with brushing marks, and two with tool punctated decorative elements), one gray chert flake tool (a unifacial drill), a quartzite biface preform, five pieces of gray or brown chert lithic debris, and one ferruginous sandstone pitted stone on the surface.

The pitted stone is on an unmodified chunk of coarse-grained ferruginous sandstone and has two shallow (7 $\mathrm{mm}$ deep) $25.0 \mathrm{~mm}$ diameter circular pecked pits, one at the top and the other at the bottom of the tool surface. The pitted stone is $95.1 \mathrm{~mm}$ in length, $79.8 \mathrm{~mm}$ in width, and $58.9 \mathrm{~mm}$ thick; its total weight is $450 \mathrm{~g}$. The function of this tool is not presently unknown (Walters et al. 2015:93-100).

A collection of 70 ceramic sherds from the Faith Temple site have been documented for this study of Caddo Creek archaeology. This includes 51 plain rim, body, and base sherds, and 19 decorated sherds (Table 13). About 83 percent of the sherds are from grog-tempered vessels, 15.7 percent are from grogbone-tempered vessels, and 1.4 percent of the sherds are from bone-tempered vessels; overall, 17.1 percent of the sherds are from vessels that have had burned bone added to the paste as a temper.

Table 13. Ceramic wares from the Faith Temple site (41AN170).

\begin{tabular}{|c|c|c|c|c|}
\hline Ware & $\begin{array}{l}\text { Grog- } \\
\text { tempered }\end{array}$ & $\begin{array}{l}\text { Grog-bone- } \\
\text { tempered }\end{array}$ & $\begin{array}{l}\text { Bone- } \\
\text { tempered }\end{array}$ & $\mathrm{N}$ \\
\hline Plain & 42 & 8 & 1 & 51 \\
\hline Fine & 2 & 2 & - & 4 \\
\hline Utility & 14 & 1 & - & 15 \\
\hline Totals & 58 & 11 & 1 & 70 \\
\hline
\end{tabular}

Fine ware sherds account for 21 percent of the decorated sherds from the Faith Temple site, and utility wares comprise 79 percent of the decorated sherds (Table 14). One of the fine ware sherds is from a grog-tempered vessel with an exterior red slip; slipping is an uncommon decorative method in the Upper Neches River basin ceramic tradition (see Perttula 2011). Two other fine ware sherds from bowls or carinated bowls have horizontal and diagonal engraved lines (Figure 150a-b), while the third engraved sherd in the assemblage has finely drawn curvilinear lines (Figure 150c). 
Table 14. Decorative methods and elements in the ceramic sherd assemblage from the Faith Temple site (41AN170).

Decorative method and

$\operatorname{Rim}$

Body

$\mathrm{N}$

Decorative element

\section{Fine ware}

\section{Engraved}

curvilinear engraved lines

horizontal and diagonal engraved lines

$\begin{array}{lll}- & 1 & 1 \\ 1 & 1 & 2\end{array}$

\section{Slipped}

exterior red slip

\section{Utility ware}

\section{Brushed}

opposed brushing marks

parallel brushing marks

vertical brushing marks

$\begin{array}{lll}- & 1 & 1 \\ - & 3 & 3 \\ - & 2 & 2\end{array}$

\section{Brushed-Incised}

parallel brushing marks and overlying incised lines

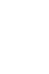

\section{Incised}

diagonal incised lines

opposed incised lines

straight incised line

\section{Punctated}

single fingernail punctate

tool punctated rows

1

1

Totals

3

16

The utility wares from the site include sherds with brushed (31.6 percent of the decorated sherds in the assemblage), brushed-incised (5.3 percent), incised (15.8 percent), fingernail punctated (5.3 percent), and tool punctated (21.1 percent) (see Table 14) elements. The brushed and brushed-incised sherds are likely from Bullard Brushed jars, while the incised sherds are probably from Maydelle Incised vessels.

The proportion of sherds in the Faith Temple ceramic assemblage with brushed decorative elements (36.8 percent of the decorated sherds and 46.7 percent of the utility wares), a plain to decorated sherd ratio of 2.68, a brushed to other wet paste sherd ratio of 0.88 , and the percentage of wet paste sherds in the assemblage (42.1 percent) suggest that the site was occupied in the early part of the Frankston phase, from ca. A.D. 1400-1480 (see Perttula 2011). The range of decorative elements in the few fine ware 

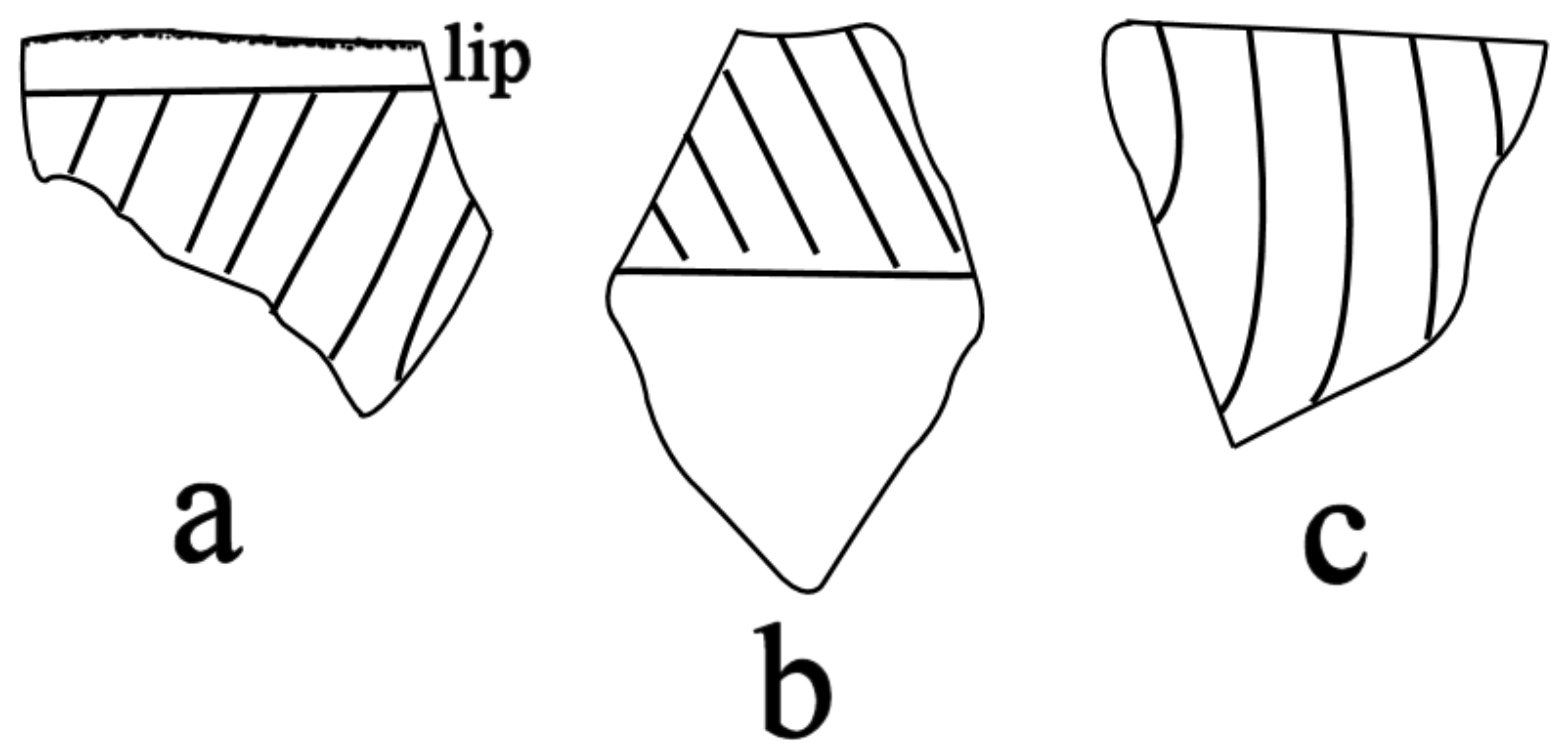

Figure 150. Decorative elements on selected engraved sherds from the Faith Temple site (41AN170).

sherds from the Faith Temple site are characteristic of some of the principal decorative elements in the early Frankston phase ceramic assemblage from the Lang Pasture site (Perttula 2011:Table 6-40).

\section{$41 A N 173$}

The site was also recorded in 2006 during the initial survey efforts along the planned expansion to U.S. 175. It is situated on an upland ridge (400 ft. amsl) about $800 \mathrm{~m}$ north of Caddo Creek. The site area has been estimated at 1.6 acres in size, but based only on four positive shovel tests. One of the shovel tests had two Caddo sherds, but they were not further described on the site form.

\section{$41 A N 190$}

41AN190 is an ancestral Caddo habitation site on a "tree-covered rise that descends onto an open floodplain" (Miller et al. 2014:524). The site covers an estimated 100 x $150 \mathrm{~m}$ area, and five positive shovel tests were excavated there. The archaeological deposits extend to $80 \mathrm{~cm} \mathrm{bs}$, but almost all the artifacts ( $\mathrm{n}=75,94$ percent) were found from $40-60 \mathrm{~cm}$ bs in one shovel test (Miller et al. 2014:Table 10.3). These artifacts are from possibly as many as five different vessels, all brushed jars, and their concentration at this depth suggests that a cultural feature was encountered in the one shovel test. Other recovered artifacts from the site include four pieces of lithic debris and one fire-cracked rock.

As identified by Miller et al. (2014:526-527), Vessel 1 is a brushed (horizontal brushing on the rim and vertical brushing on the body) jar tempered with grog (Miller et al. 2014:Figure 10.17). Vessel 2 is comprised of three grog-tempered brushed body sherds; Vessel 3 includes sherds from a vertically brushed and grog-tempered jar (Miller et al. 2014:Figure 10-21); Vessel 4 includes six brushed body sherds (Miller et al. 2014:Figure 10.23); and Vessel 5 is represented by one grog-tempered body sherd with parallel brushing. The common presence of brushed jar sherds at 41AN190 suggests that the site was occupied by Caddo peoples during the Late Caddo Frankston phase. 


\section{AN191}

This site is also an ancestral Caddo habitation locale. Recorded by Miller et al. (2014:528) as covering a $20 \times 60 \mathrm{~m}$ area of an alluvial terrace near a small stream, four shovel tests contained archaeological deposits a maximum of $80 \mathrm{~cm}$ bs (Miller et al. 2014:Table 10.4).

The artifacts recovered at 41AN191 included nine ceramic sherds and six pieces of lithic debris. The ceramic sherds from the site were described as "two prehistoric utility-ware ceramic sherds, one incised ceramic body sherd, one incised ceramic rim sherd, [and] five ceramic base sherds" (Miller et al. 2014:528). Unfortunately, the decorative elements on the two incised sherds are not described, and the decorative methods on the two utility ware sherds are not mentioned. Another deficiency is that the temper of these sherds is not identified, other than to note that the sherds had a sandy paste and a gray temper (Miller et al. 2014:528); the gray temper is likely grog. Because of the absence of any useful information on the decoration on the ceramic sherds from the site, it is not known when this site was occupied by ancestral Caddo peoples.

\section{S. Mann (41AN201/41HE7)}

The A. S. Mann site is the location of a small ancestral Caddo cemetery and habitation site in the Caddo Creek valley in the upper Neches River basin, about $6.5 \mathrm{~km}$ west of the small town of Frankston, Texas (see Figure 1). The cemetery was found by a Mr. John Riley in June or July, 1935, when he noted a ceramic bottle eroding from a gully that crossed an uncultivated field.

In October 1935, UT archaeologists followed up on this find and excavated a number of areas around the ceramic bottle (Woolsey 1935b). In this work, they identified two Caddo burials (AF-1 and AF-2); the bottle found earlier by Riley was one of the funerary offerings in Burial AF-1 (Figure 151).

Burial AF-1 was that of an adult laid out in an extended supine position, with the head at the eastern end of the grave and facing west. The grave was $208 \times 56 \mathrm{~cm}$ in length and width, and $56 \mathrm{~cm}$ in depth. Eight ceramic vessels were placed in the grave, primarily around the head and the upper body (Figure 152 ), as funerary offerings.

Remnants of a second burial-AF-2 - were found ca. $2.7 \mathrm{~m}$ south of Burial AF-1 (see Figure 151). It had been almost completely disturbed by plowing, and all that remained were pieces of a right femur and the base of a ceramic bottle (Woolsey 1935b). The grave was 122 x $41 \mathrm{~cm}$ in length and width, and only ca. $24 \mathrm{~cm}$ in depth; the size of the grave suggests that Burial AF-2 was that of a child or adolescent.

\section{Ceramic Vessels from Burial AF-1}

The eight vessels from Burial AF-1 at the A. S. Mann site include one bottle, one jar, an olla fragment, three carinated bowls, a small beaker, and an effigy bowl (with the effigy head missing). The decorative styles on several of the vessels indicate that the burial dates to some part of the Late Caddo period Frankston phase (ca. A.D. 1400-1650). 


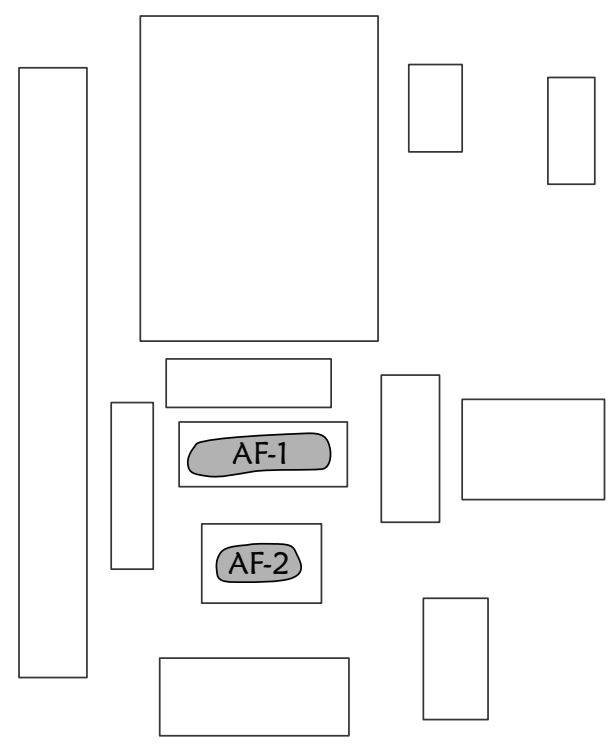

LE GEN D

$\square$ Burial

Excavated Area

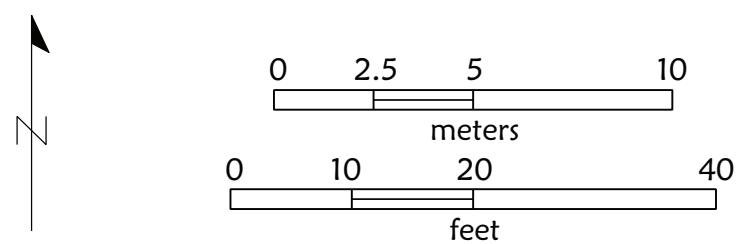

SLH/15

Figure 151. 1935 excavations at the A. S. Mann site.

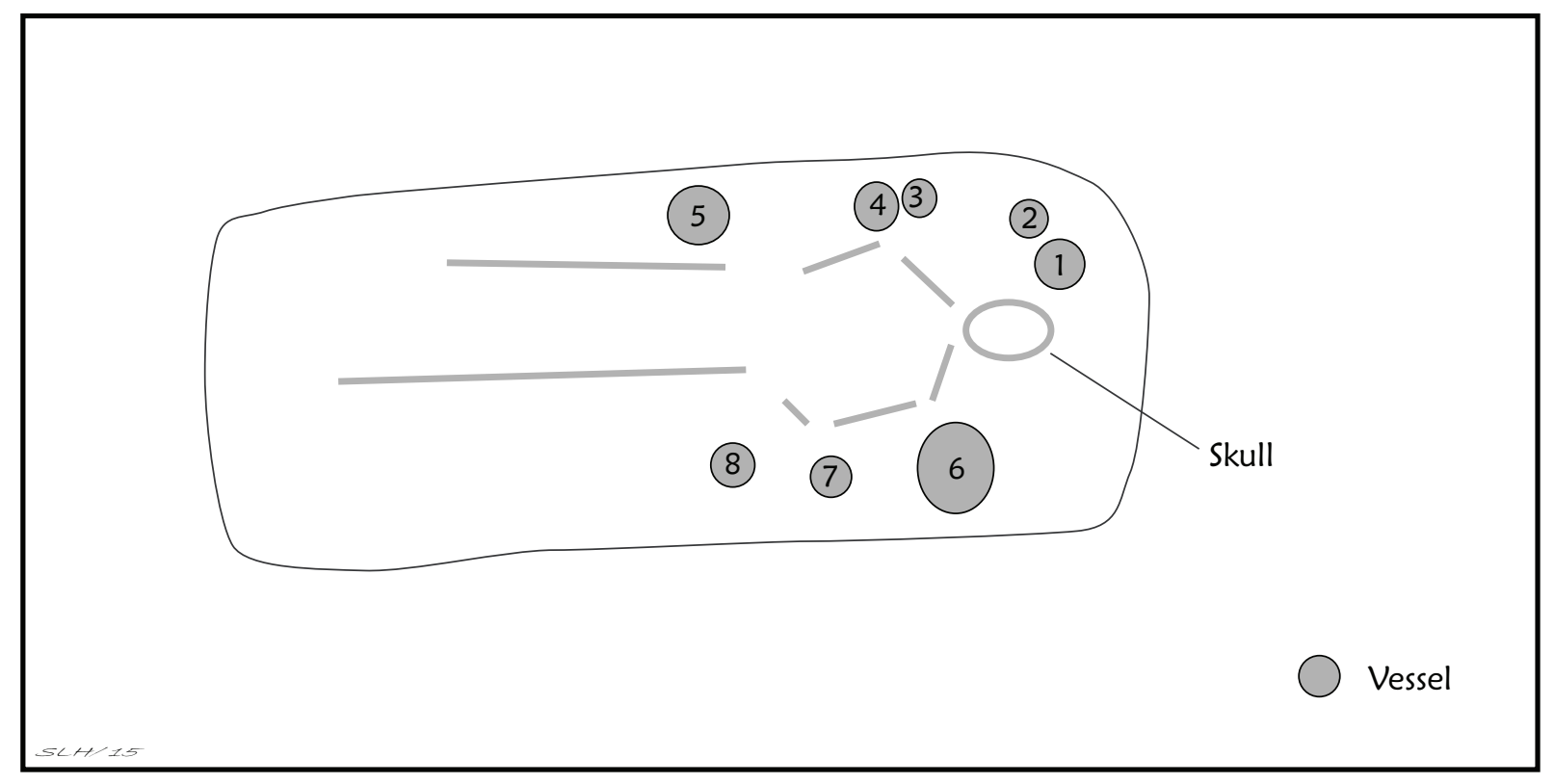

Figure 152. Burial AF-1 at the A. S. Mann site. 
SITE NAME OR SITE NUMBER: A. S. Mann (41AN201/41HE7)

VESSEL NO.: Burial AF-1, Vessel 1 (357-624)

VESSEL FORM: Bottle with a short neck and a cylindrical body

NON-PLASTICS AND PASTE: grog

RIM AND LIP FORM: Direct rim and a flat lip

CORE COLOR: G (fired in a reducing environment and cooled in the open air)

INTERIOR SURFACE COLOR: dark grayish-brown

EXTERIOR SURFACE COLOR: light yellowish-brown; fire clouds on the rim, body, and base

WALL THICKNESS (IN MM): rim, 6.3 $\mathrm{mm}$

INTERIOR SURFACE TREATMENT: none

EXTERIOR SURFACE TREATMENT: smoothed

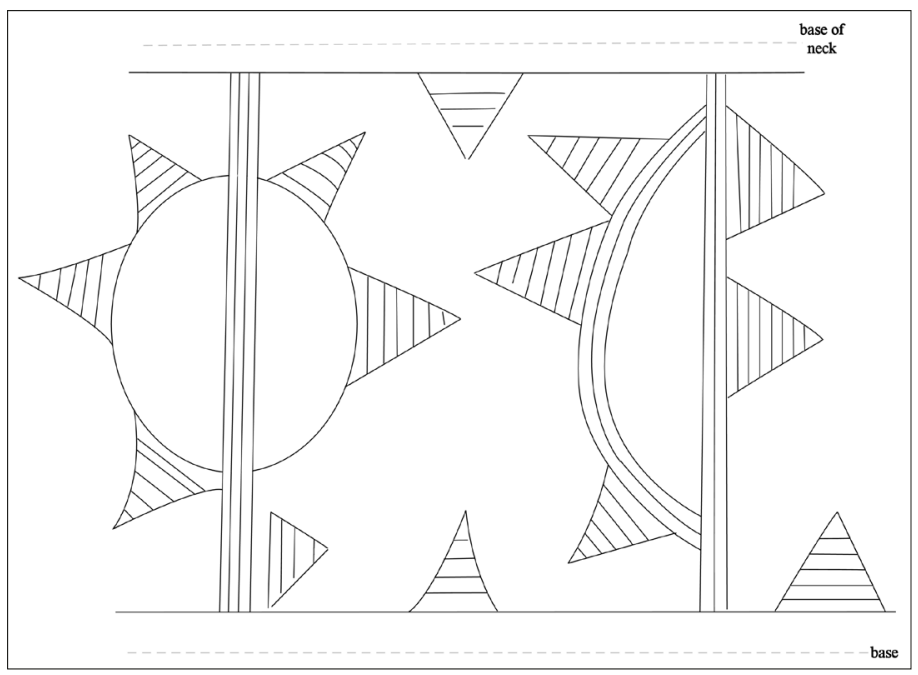

HEIGHT (IN CM): 22.9

ORIFICE DIAMETER (IN CM): 5.0

Figure 153. Decorative elements on a Poynor Engraved, var. unspecified bottle (Vessel 1, Burial AF-1) from the A. S. Mann site.

DIAMETER AT BOTTOM OF RIM OR

NECK (IN CM): $5.0 ; 12.9 \mathrm{~cm}$ maximum body diameter

BASE DIAMETER (IN CM) AND SHAPE OF BASE: 8.8; circular and flat

ESTIMATED VOLUME (IN LITERS): 0.78

DECORATION (INCLUDING MOTIF AND ELEMENTS WHEN APPARENT): The vessel body is divided into four panels by sets of three or four closely-spaced vertical engraved lines (Figure 153). Two of the panels have two or three large hatched pendant triangles along the vertical axis and two upper or lower hatched pendant triangles on the horizontal axis of the panels. The other two panels have sets of semi-circles on the vertical axis, and these semi-circles have either two or three large hatched pendant triangles. There are also single upper and lower hatched pendant triangles in these panels, as well as one stand-alone hatched triangle in the lower left corner of the panels.

PIGMENT USE AND LOCATION ON VESSEL: none

TYPE AND VARIETY (IF KNOWN): Poynor Engraved, var. unspecified 
SITE NAME OR SITE NUMBER: A. S. Mann (41AN201/41HE7)

VESSEL NO.: Burial AF-1, Vessel 2 (357-625)

VESSEL FORM: Jar with two opposed strap handles. The handles extend from the lip to the base of the rim, and are $37-39 \mathrm{~mm}$ in length and $23 \mathrm{~mm}$ in width.

NON-PLASTICS AND PASTE: grog and bone

RIM AND LIP FORM: Everted rim and rounded lip

CORE COLOR: $\mathrm{G}$ (fired in a reducing environment and cooled in the open air)

INTERIOR SURFACE COLOR: dark grayish-brown

EXTERIOR SURFACE COLOR: reddish-brown; fire clouds on the rim, body, and base

WALL THICKNESS (IN MM): rim, $6.4 \mathrm{~mm}$

INTERIOR SURFACE TREATMENT: none

EXTERIOR SURFACE TREATMENT: none

HEIGHT (IN CM): 12.9

ORIFICE DIAMETER (IN CM): 11.3

DIAMETER AT BOTTOM OF RIM OR NECK (IN CM): 10.8

BASE DIAMETER (IN CM) AND SHAPE OF BASE: 6.1; circular and flat

ESTIMATED VOLUME (IN LITERS): 0.87

DECORATION (INCLUDING MOTIF AND ELEMENTS WHEN APPARENT): There are eight horizontal incised lines on the upper part of the vessel, seven on the rim, and the eighth line on the vessel body, and below the attached strap handles. The strap handles are decorated with either two or three vertical pinched ridges.

PIGMENT USE AND LOCATION ON VESSEL: none

TYPE AND VARIETY (IF KNOWN): Unidentified utility ware 
SITE NAME OR SITE NUMBER: A. S. Mann (41AN201/41HE7)

VESSEL NO.: Burial AF-1, Vessel 3 (357-626)

VESSEL FORM: Carinated bowl

NON-PLASTICS AND PASTE: grog

RIM AND LIP FORM: Inverted rim and rounded lip

CORE COLOR: B (fired and cooled in a reducing or low oxygen environment)

INTERIOR SURFACE COLOR: dark grayish-brown

EXTERIOR SURFACE COLOR: dark grayish-brown; fire clouds on the rim and body

WALL THICKNESS (IN MM): rim, $6.7 \mathrm{~mm}$

INTERIOR SURFACE TREATMENT: smoothed

EXTERIOR SURFACE TREATMENT: burnished

HEIGHT (IN CM): 6.0

ORIFICE DIAMETER (IN CM): 12.7

DIAMETER AT BOTTOM OF RIM OR NECK (IN CM): 14.7

BASE DIAMETER (IN CM) AND SHAPE OF BASE: 8.0; circular and flat

ESTIMATED VOLUME (IN LITERS): 0.46

DECORATION (INCLUDING MOTIF AND ELEMENTS WHEN APPARENT): Plain

PIGMENT USE AND LOCATION ON VESSEL: none

TYPE AND VARIETY (IF KNOWN): SITE NAME OR SITE NUMBER: Unidentified plain ware 
SITE NAME OR SITE NUMBER: A. S. Mann (41AN201/41HE7)

VESSEL NO.: Burial AF-1, Vessel 4 (357-627)

VESSEL FORM: Olla with short neck

NON-PLASTICS AND PASTE: grog

RIM AND LIP FORM: N/A

CORE COLOR: F (fired in a reducing environment and cooled in the open air)

INTERIOR SURFACE COLOR: reddish-brown

EXTERIOR SURFACE COLOR: reddish-brown

WALL THICKNESS (IN MM): body, $5.6 \mathrm{~mm}$

INTERIOR SURFACE TREATMENT: none

EXTERIOR SURFACE TREATMENT: smoothed

HEIGHT (IN CM): N/A

ORIFICE DIAMETER (IN CM): N/A

DIAMETER AT BOTTOM OF RIM OR NECK (IN CM): N/A

BASE DIAMETER (IN CM) AND SHAPE OF BASE: N/A

ESTIMATED VOLUME (IN LITERS): N/A

DECORATION (INCLUDING MOTIF AND ELEMENTS WHEN APPARENT): This vessel fragment has seven rows of fingernail punctations on the upper body. The top four rows are angled from right to left, while the bottom three rows are angled from left to right.

PIGMENT USE AND LOCATION ON VESSEL: none

TYPE AND VARIETY (IF KNOWN): Unidentified utility ware 
SITE NAME OR SITE NUMBER: A. S. Mann (41AN201/41HE7)

VESSEL NO.: Burial AF-1, Vessel 5 (357-628)

VESSEL FORM: Carinated bowl

NON-PLASTICS AND PASTE: grog

RIM AND LIP FORM: Direct rim and rounded lip

CORE COLOR: G (fired in a reducing environment and cooled in the open air)

INTERIOR SURFACE COLOR: grayish-brown; fire clouds on the base

EXTERIOR SURFACE COLOR: reddish-brown; fire clouds on the base

WALL THICKNESS (IN MM): rim, 5.5 mm

INTERIOR SURFACE TREATMENT: none

EXTERIOR SURFACE TREATMENT: smoothed

HEIGHT (IN CM): 8.0

ORIFICE DIAMETER (IN CM): 17.8

DIAMETER AT BOTTOM OF RIM OR NECK (IN CM): 17.4

BASE DIAMETER (IN CM) AND SHAPE OF BASE: 7.9; circular and flat

ESTIMATED VOLUME (IN LITERS): 0.89

DECORATION (INCLUDING MOTIF AND ELEMENTS WHEN APPARENT): Plain

PIGMENT USE AND LOCATION ON VESSEL: none

TYPE AND VARIETY (IF KNOWN): SITE NAME OR SITE NUMBER: Unidentified plain ware 
SITE NAME OR SITE NUMBER: A. S. Mann (41AN201/41HE7)

VESSEL NO.: Burial AF-1, Vessel 6 (357-629)

VESSEL FORM: Carinated bowl

NON-PLASTICS AND PASTE: grog

RIM AND LIP FORM: Inverted rim and rounded lip

CORE COLOR: $\mathrm{G}$ (fired in a reducing environment and cooled in the open air)

INTERIOR SURFACE COLOR: grayish-brown

EXTERIOR SURFACE COLOR: yellowish-brown; fire clouds on the rim and body

WALL THICKNESS (IN MM): rim, $5.3 \mathrm{~mm}$

INTERIOR SURFACE

TREATMENT: smoothed

EXTERIOR SURFACE

TREATMENT: burnished

HEIGHT (IN CM): 10.0

ORIFICE DIAMETER (IN

CM): 15.0

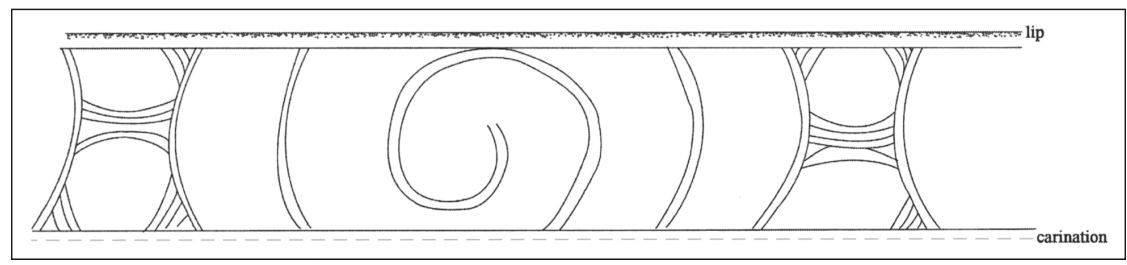

Figure 154. Decorative elements on Poynor Engraved, var. unspecified carinated bowl (Vessel 6, Burial AF-1) from the A. S. Mann site.

DIAMETER AT BOTTOM

OF RIM OR NECK (IN

CM): 16.9

BASE DIAMETER (IN CM) AND SHAPE OF BASE: 7.2; circular and flat

ESTIMATED VOLUME (IN LITERS): 0.90

DECORATION (INCLUDING MOTIF AND ELEMENTS WHEN APPARENT): The rim has a panel defined by single horizontal engraved lines under the vessel lip and just above the vessel carination. The panel has three repeating sets of large ovals (marked by two semi-circular lines on either side of the oval) and a central hooked arm element as seen in Var. $N$ and Var. $P$ of Poynor Engraved (Figure 154; see also Perttula 2011:Figure 6-65). Both varieties are considered regionally distinctive upper Neches River basin varieties of Poynor Engraved. Dividing each of the ovals and hooked arm elements are engraved brackets with upper and lower negative ovals and surrounding curvilinear lines. Both Var. $N$ and $P$ occur in ca. A.D. 1480-1650 contexts in Frankston phase burial features (Perttula 2011:Table 6-37); similar engraved bracket elements have been noted in one of the ceramic vessels from the Isibel-Gene Donnell site cemetery (41AN14; see Figure 68).

PIGMENT USE AND LOCATION ON VESSEL: red pigment in engraved lines

TYPE AND VARIETY (IF KNOWN): Poynor Engraved, var. unspecified 
SITE NAME OR SITE NUMBER: A. S. Mann (41AN201/41HE7)

VESSEL NO.: Burial AF-1, Vessel 7 (357-630)

VESSEL FORM: Beaker

NON-PLASTICS AND PASTE: grog and bone

RIM AND LIP FORM: Everted rim and flat lip

CORE COLOR: F (fired in a reducing environment and cooled in the open air)

INTERIOR SURFACE COLOR: yellowish-brown

EXTERIOR SURFACE COLOR: yellowish-

brown; fire clouds on the body and base

WALL THICKNESS (IN MM): rim, $4.5 \mathrm{~mm}$

INTERIOR SURFACE TREATMENT: none

EXTERIOR SURFACE TREATMENT:

smoothed

HEIGHT (IN CM): 10.4

ORIFICE DIAMETER (IN CM): 5.9

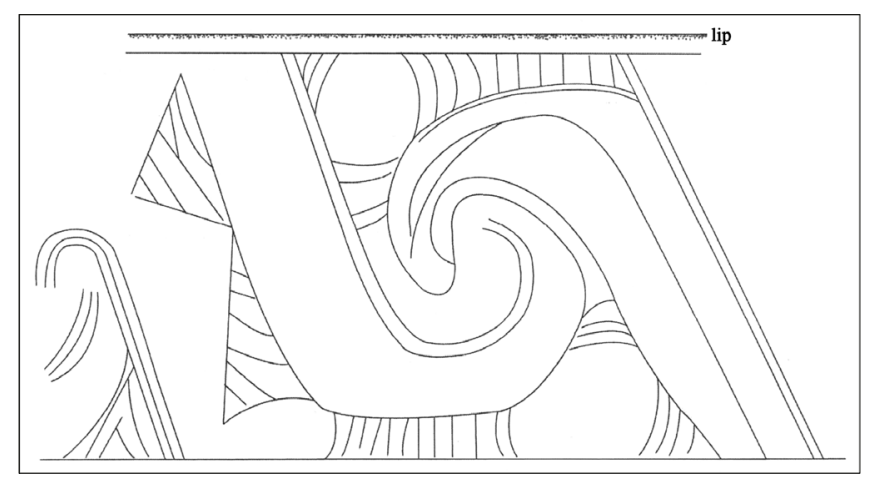

DIAMETER AT BOTTOM OF RIM OR

NECK (IN CM): 5.8

Figure 155. Decorative elements on Poynor Engraved, var. unspecified beaker (Burial AF-1, Vessel 7) from the A. S. Mann site.

BASE DIAMETER (IN CM) AND SHAPE

OF BASE: 5.3; circular and flat

ESTIMATED VOLUME (IN LITERS): 0.36

DECORATION (INCLUDING MOTIF AND ELEMENTS WHEN APPARENT): The beaker has single upper and lower horizontal engraved lines as well as an engraved motif that is repeated three times around the vessel (Figure 155). The motif consists of a slanting scroll that ends in a hooked arm element as well as negative oval elements and short vertical lines in upper and lower scroll elements. There also are large hatched pendant triangles on a curvilinear line adjacent to the slanting scroll as well as two closely-spaced diagonal engraved lines that divide the scroll motifs from each other.

PIGMENT USE AND LOCATION ON VESSEL: red pigment in engraved lines

TYPE AND VARIETY (IF KNOWN): SITE NAME OR SITE NUMBER: Poynor Engraved, var. unspecified 
SITE NAME OR SITE NUMBER: A. S. Mann site (41AN201/41HE7)

VESSEL NO.: Burial AF-1, Vessel 8 (325-631)

VESSEL FORM: Effigy bowl with tab tail (23 x $29 \mathrm{~mm}$ in length and width) at one end of the vessel; the effigy head is missing and has been broken off at the other end of the vessel.

NON-PLASTICS AND PASTE: grog and bone

RIM AND LIP FORM: Direct rim and rounded lip

CORE COLOR: A (fired and cooled in an oxidizing or high oxygen environment)

INTERIOR SURFACE COLOR: reddish-brown

EXTERIOR SURFACE COLOR: reddish-brown; fire clouds on the rim, body, and base

WALL THICKNESS (IN MM): rim, $6.0 \mathrm{~mm}$; base, $7.5 \mathrm{~mm}$

INTERIOR SURFACE TREATMENT: none

EXTERIOR SURFACE TREATMENT: none

HEIGHT (IN CM): 3.5

ORIFICE DIAMETER (IN CM): 7.8

DIAMETER AT BOTTOM OF RIM OR NECK (IN CM): N/A

BASE DIAMETER (IN CM) AND SHAPE OF BASE: 3.4; circular and flat

ESTIMATED VOLUME (IN LITERS): 0.11

DECORATION (INCLUDING MOTIF AND ELEMENTS WHEN APPARENT): The bowl has three horizontal engraved lines on the upper part of the vessel.

PIGMENT USE AND LOCATION ON VESSEL: none

TYPE AND VARIETY (IF KNOWN): Hood Engraved, var. unspecified 
The A. S. Mann (41HE7/41AN201) site is an ancestral Caddo site in the Caddo Creek valley in the upper Neches River basin in East Texas. The site was first investigated by archaeologists from the University of Texas in the early 1930s, and there are collections of artifacts from the site held at TARL: this includes eight ceramic vessels from a single Caddo burial from the A. S. Mann site.

The eight vessels from Burial AF-1 at the A. S. Mann site are funerary offerings in a Frankston phase burial feature; a second burial feature (Burial AF-2) was nearby, but no funerary offerings were recovered from this burial in the University of Texas investigations. As best as can be determined from the few ceramic vessels that are decorated, and comparisons to other burial features in the upper Neches River basin, this burial occurred between ca. A.D. 1480-1560 and was that of an adult individual. This site is just one of many family cemeteries dispersed across the basin and along Caddo Creek.

During a 2015 archaeological survey of the proposed expansion to U.S. 175, the A. S. Mann site was relocated, but it turned out that the site is in Anderson County, not Henderson County (Goodmaster 2015:53; Troell 2016). The site is situated on a broad upland ridge between two southward-flowing tributaries to Caddo Creek. The estimated extent of the site as defined by 18 positive shovel tests in the proposed U.S. 175 ROW expansion is 300 x $45 \mathrm{~m}$, covering ca. 13,100 square meters.

Ancestral Caddo artifacts found at the A. S. Mann site in the 2015 survey investigations included 33 ceramic sherds and one chipped lithic core. The sherds are from grog-tempered vessels, and most have decorative elements: brushed $(n=16)$, brushed-incised $(n=3)$, and incised $(n=2)$ (Goodmaster 2015:Table 4). The proportion of brushed sherds in the decorated sherd assemblage ( 90.5 percent) suggests a Late to Historic Caddo period occupation at the site. Subsequent to the Goodmaster survey, Texas Department of Transportation archaeologists excavated a number of backhoe trenches across the site, where they identified intact archaeological deposits, a cultural feature with a calibrated 2 sigma radiocarbon age of A.D. 1490-1655 (Beta-404775), and a piece of obsidian lithic debris.

Data recovery work was initiated by TxDOT at the A. S. Mann site in May 2015, and was completed in July 2016. A number of ancestral Caddo burial features have been located in this work, as well as several habitation areas. Portions of the 1935 UT excavation area have also been relocated during the TxDOT work. 


\section{S. Roberts (41HE8),}

\section{Timothy K. Perttula, Arlo McKee, Mark Walters, and Bo Nelson}

This ancestral Caddo site was reported to Dr. J. E. Pearce of The University of Texas (UT) in September 1931 by Jeff D. Reagan of Palestine, Texas. In October 1931, a UT crew investigated the site, which had an earthen mound and an associated settlement (Pearce and Jackson 1931).

The site is on an alluvial terrace (430-450 ft. amsl) on the north side of Caddo Creek, an important eastward-flowing tributary to the Neches River, about $1.6 \mathrm{~km}$ west of Poynor, Texas (Figure 156). The M. S. Roberts site has a single earthen mound about $24 \times 20 \mathrm{~m}$ in length and width, and it was estimated to stand $1.7 \mathrm{~m}$ in height. A likely borrow pit depression was noted just to the west of the mound. Artifacts were noted and collected by Pearce and Jackson (1931) from the plowed surface of the mound and surrounding Caddo habitation areas on the alluvial terrace.

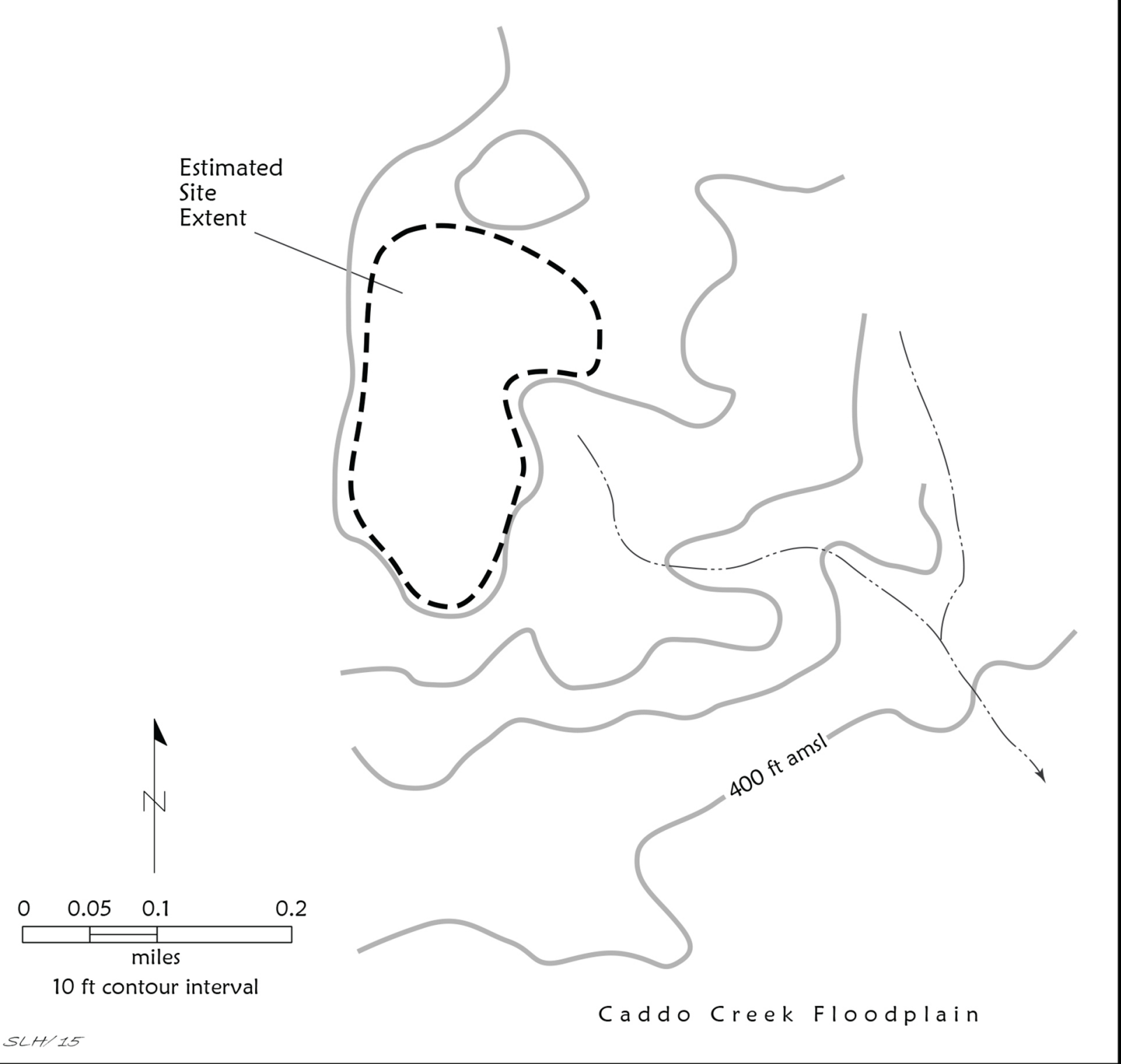

Figure 156. The topographic setting of the M. S. Roberts site. 
The UT work consisted of the excavation of an unknown number of trenches into the earthen mound. The trenches disclosed an undifferentiated mound fill from $0-114 \mathrm{~cm}$ bs that had ash, ceramic sherds, and animal bones. The mound fill rested atop a clay floor (114-122 cm bs) from a burned structure, and this clay floor was placed atop the first mound fill zone, a yellow sand $(122-146 \mathrm{~cm} \mathrm{bs})$ that also had unspecified associated midden materials. These first mound deposits were constructed on top of the natural ground surface, a brown sandy loam A- and E-horizon (146-196+ $\mathrm{cm}$ bs). The mound at the M. S. Roberts site was undoubtedly built to cover an important Caddo structure, most likely a structure used for political and religious ceremonies or used as the residence of an important and elite member of the local Caddo community.

There are 419 sherds from ceramic vessels in the Texas Archeological Research Laboratory (TARL) collections from the 1931 UT work at the M. S. Roberts site. This includes 253 plain sherds and 166 decorated sherds; the plain to decorated sherd ratio is 1.52 . The sherds from the site are from vessels tempered with either grog (i.e., crushed sherds) or burned bone. About 86 percent of the sherds are from grog-tempered vessels; more than 96 percent of the fine ware sherds are from grog-tempered vessels, compared to 84 percent of the utility wares. Overall, 14 percent of the sherds are from bone-tempered vessels: 15.9 percent of the utility wares but only 3.6 percent of the fine wares.

The principal decorative methods represented in the utility ware sherds from the 1931 collection at the M. S. Roberts site have incised ( $n=52,37.7$ percent), punctated ( $n=39,28.3$ percent), and brushed $(n=28,20.3$ percent $)$ decorative elements; another 4.3 percent of the sherds have brushed-incised or brushed-punctated decorative elements (Perttula 2016a:Table 3). The incised sherds are likely from Maydelle Incised jars, as are several of the incised-punctated rim and body sherds (Figures 157 and 158). The sherds from vessels with brushing marks include one rim with horizontal brushing marks and body sherds with diagonal, opposed, overlapping, and parallel (probably oriented vertically) brushing marks. These are from Bullard Brushed jars (see Suhm and Jelks 1962:21). The few brushed-incised and brushed-punctated sherds are likely also from Bullard Brushed vessels with incised lines or punctations made through the brushing marks. The proportion of utility ware sherds with brushing marks (24.6 percent) in the M. S. Roberts assemblage is consistent with an early to mid- $15^{\text {th }}$ century ancestral Caddo occupations in the upper Neches River basin (see Anderson et al. 1974; Perttula 2011). Only after ca. A.D. 1400 do brushed sherds dominate Late Caddo period Frankston phase ceramic assemblages (Perttula 2011:162).

The fine ware sherds are from both engraved ( $n=21,75$ percent of the fine wares) and red-slipped $(\mathrm{n}=7,25$ percent $)$ vessels. The majority of the engraved sherds are from upper Neches River Poynor Engraved vessels (Figure 159a-g), including var. Blackburn (Figure 159f-g), var. Cook (Figure 159e), and var. unspecified with a slanting scroll and curvilinear hatched triangle attachments (Figure 159d). Others have diagonal, horizontal, and vertical hatched zones (Figure 159a-c). Both var. Blackburn and var. Cook vessels are most common in ca. A.D. 1400-1560 Frankston phase sites in the upper Neches River basin (Perttula 2011:Table 6-37). The proportion of red-slipped sherds - from both bowls, carinated bowls, and bottles-in the M. S. Roberts site fine wares is also notable, as red-slipped sherds are not generally common at all in upper Neches River basin sites, or indeed in ancestral Caddo sites in the Neches and Angelina river basins.

A single ceramic pipe sherd from the 1931 UT work was from a bone-tempered pipe with a thick (14.2 mm in diameter) long stem, possibly an L-shaped elbow pipe (Perttula 2011:215 and Figure 6-23); its stem hole opening was $6.0 \mathrm{~mm}$. This form of elbow pipe is the earliest elbow pipe style in the upper Neches River basin and has been found in ca. A.D. 1320 to ca. A.D. 1480 Middle Caddo period to Frankston phase components in the region (see Perttula et al. 2012:15). 


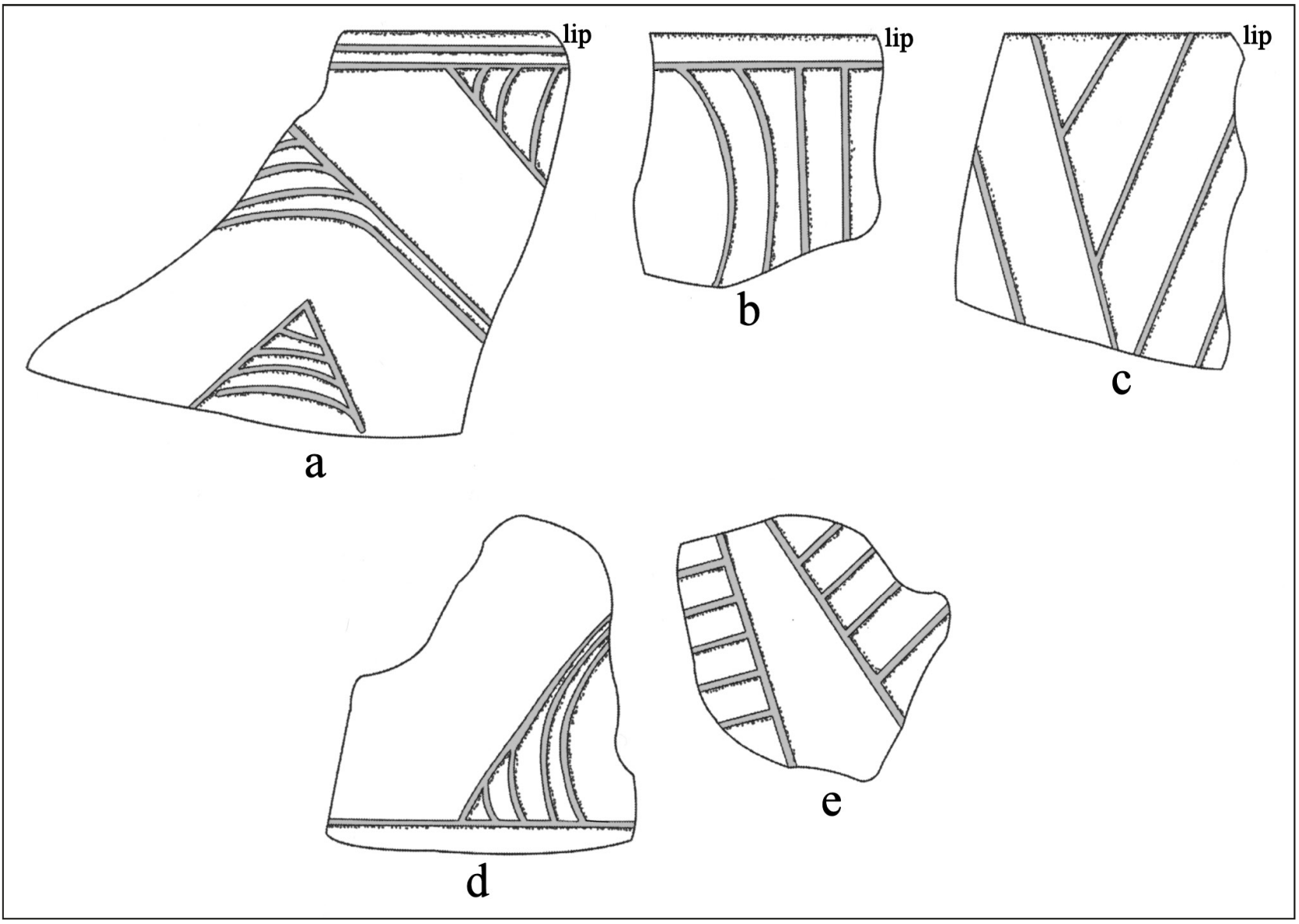

Figure 157. Selected incised decorative elements on sherds from the 1931 UT work at the M. S. Roberts site: a-c, rim sherds; d-e, body sherds.

The ceramic vessel sherds and elbow pipe sherd from the UT work at the M. S. Roberts site suggested that the Caddo construction of the mound and occupation of the settlement took place sometime in the first half of the $15^{\text {th }}$ century A.D. It may well have lasted until as late as ca. A.D. 1480, during the first part of the Frankston phase.

After a hiatus of more than 83 years from the Pearce and Jackson (1931) work, in January 2015, Mark Walters obtained, with the assistance of the landowners, a surface collection of artifacts from the M. S. Roberts site (41HE8), the long-forgotten ancestral Caddo mound center and settlement in the upper Neches River basin in Henderson County, Texas (Figure 160a-b). The January 2015 surface collection of Caddo artifacts from the site came from the mound itself (the mound stands about $1.8 \mathrm{~m}$ in height) as well as an apparently associated ca. $200 \times 200 \mathrm{~m}$ (ca. 10 acres) settlement and habitation areas. The majority of artifacts in the surface collection were ceramic sherds $(n=134)$ from ceramic vessels, but there were a few pieces of chipped stone debris $(n=10)$ and a flake tool also visible on the surface (Perttula and Walters 2016). 


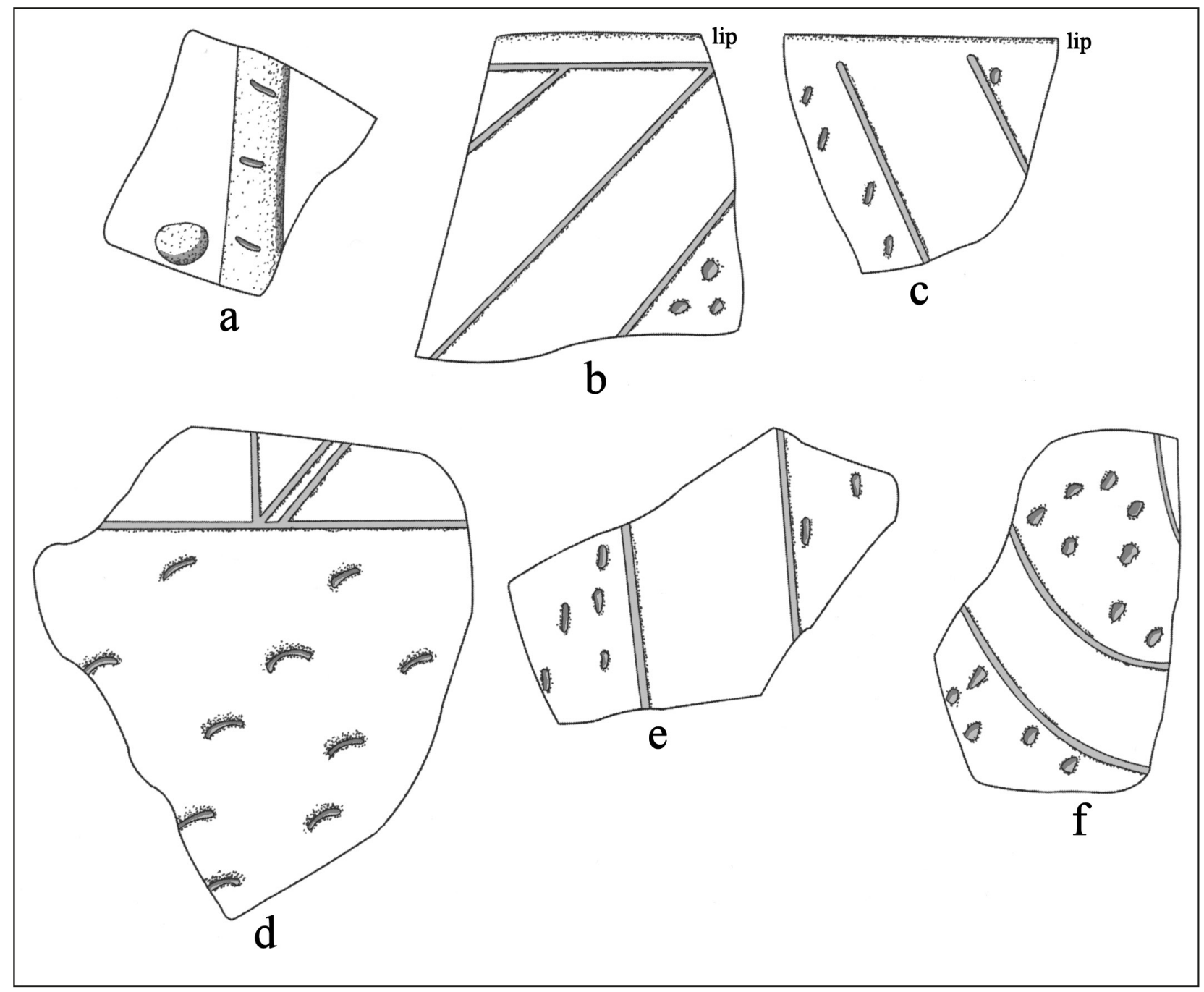

Figure 158. Selected appliqued and incised-punctated elements on sherds from the 1931 UT work at the M.S. Roberts site: a, appliqued; b-f, incised-punctated.

The January 2015 ceramic assemblage of sherds from plain ware, utility ware, and fine ware vessels were primarily grog-tempered, with considerable amounts of plain vessel rims and rim and body sherds from utility ware jars that were decorated with incised, punctated, brushed, and brushed-incised elements. Sherds from fine ware vessels were not well represented in the artifacts from the January 2015 surface collection, but there were sherds from both engraved bottles and carinated bowls as well as red-slipped bowls. Decorative elements on the engraved sherds were consistent with earlier varieties of Poynor Engraved, the principal fine ware type in the upper Neches River basin beginning in the $15^{\text {th }}$ century A.D. As with the collection of artifacts from the 1931 investigations completed by University of Texas archaeologists (Pearce and Jackson 1931; Perttula 2016a), these artifacts also suggested that the Caddo occupation of the settlement at the M.S. Roberts site took place sometime as early as in the first half of the $15^{\text {th }}$ century A.D., and the occupation may have lasted until as late as ca. A.D. 1480. 


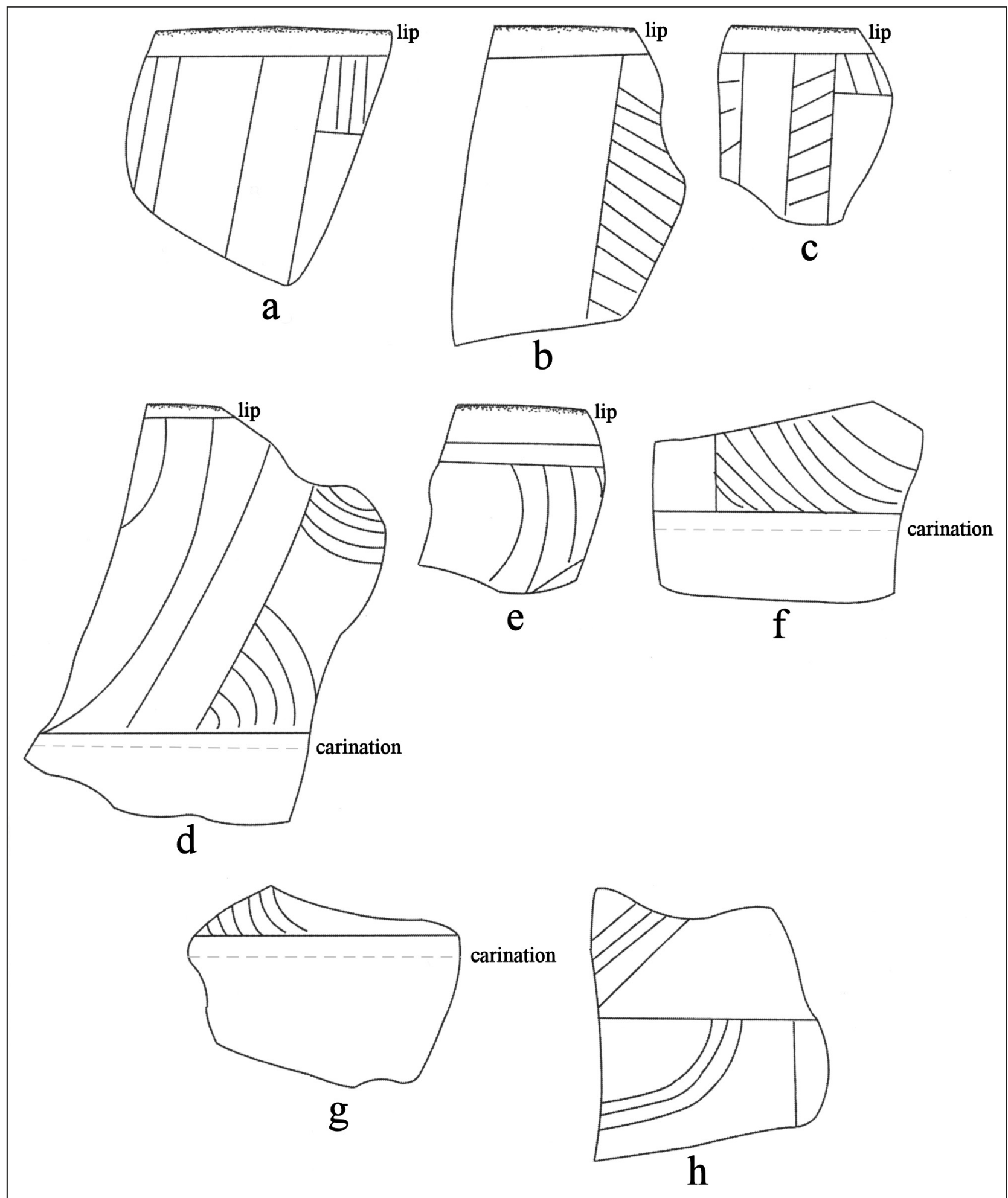

Figure 159. Selected decorative elements on engraved sherds from the 1931 UT work at the M. S. Roberts site: a-e, rim sherd; f-g, lower rim sherds; $h$, bottle sherd. 

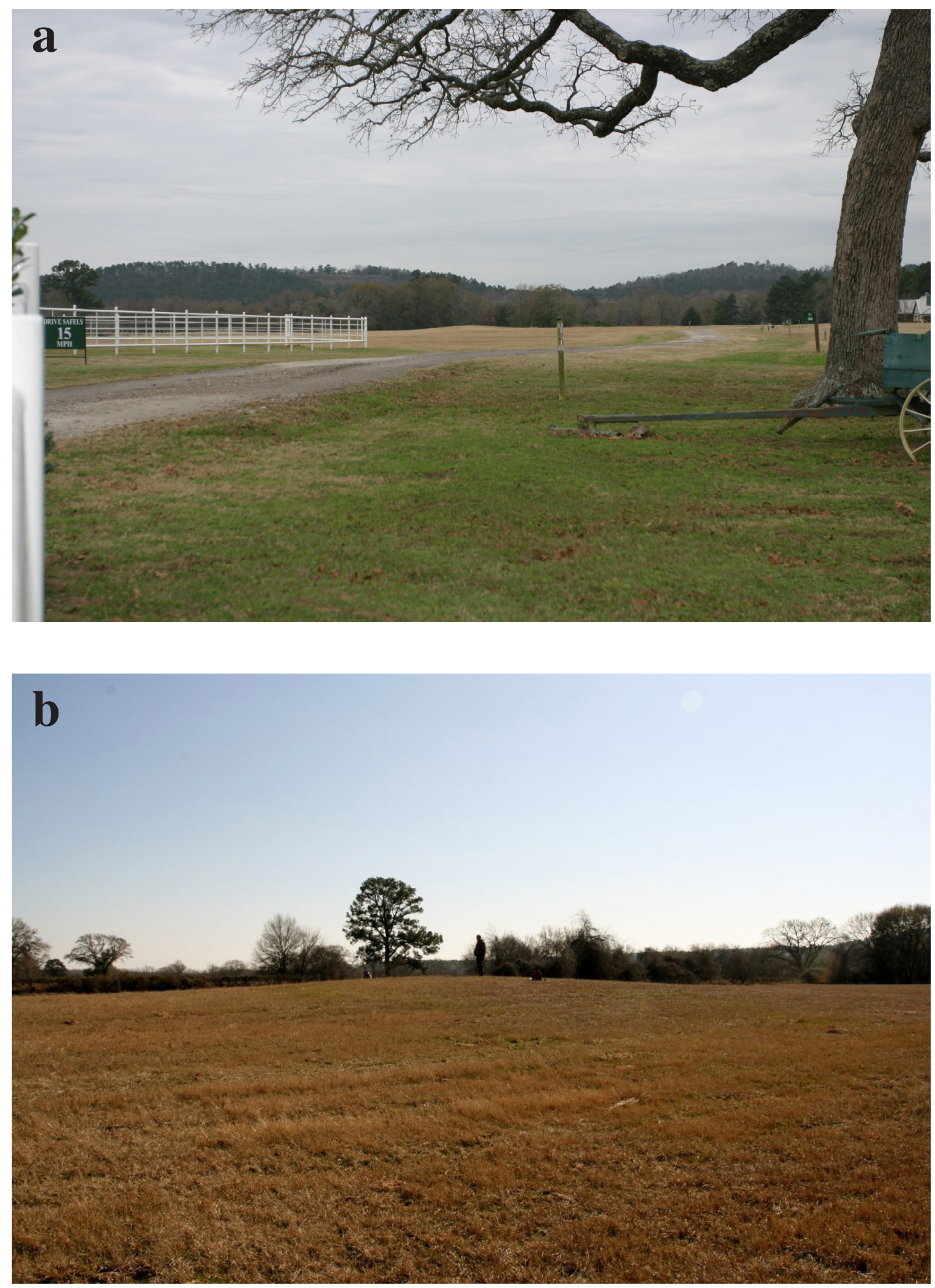

Figure 160. The M.S. Roberts mound (41HE8): a, looking south at the mound and the surrounding pasture; $b$, looking generally east at the mound. 


\section{June 2015 Work}

\section{Aerial Survey Work}

The aerial survey was completed using a DJI Phantom 2 quadrotor unmanned aerial vehicle (UAV) (Figure 161a-b) equipped with a Canon SD4000 IS 10 MP camera. Twelve aerial targets were placed over the survey area and the locations of each target were recorded with a WAAS-enabled Garmin 62S GPS averaging 3 minutes per point.

Prior to the initiation of the field survey a flight plan was generated in ArcGIS using the property boundary, camera specifics, and desired image resolution and photo overlap as inputs for the Photo Survey Planner Add-In developed by Arlo McKee (Table 15). This resulted in the automatic generation of survey waypoints to cover the survey area at a regular grid spacing. The camera was set to shutter priority mode and set to capture images at approximately 2.8 second intervals. The instructions for each flight path were sent to the DJI Ground Station software to allow for the UAV to autonomously fly the regular survey grid. This resulted in the capture of 1079 images and an overlap of generally 38 images over most of the study area.

Table 15. Input parameters for the aerial survey of the M.S. Roberts site (41HE8).

\begin{tabular}{llllllll}
$\begin{array}{l}\text { Camera } \\
\text { focal } \\
\text { length }\end{array}$ & $\begin{array}{l}\text { Sensor } \\
\text { dimensions } \\
(\mathrm{mm})\end{array}$ & $\begin{array}{l}\text { Image } \\
\text { dimensions } \\
\text { (pixels) }\end{array}$ & $\begin{array}{l}\text { Shutter } \\
\text { speed }(\mathrm{s})\end{array}$ & Altitude $(\mathrm{m})$ & $\begin{array}{l}\text { Flight } \\
\text { speed } \\
(\mathrm{m} / \mathrm{s})\end{array}$ & $\begin{array}{l}\text { Transect } \\
\text { spacing } \\
(\mathrm{m})\end{array}$ & $\begin{array}{l}\text { Approximate } \\
\text { photo } \\
\text { spacing }(\mathrm{m})\end{array}$ \\
\hline $4.9 \mathrm{~mm}$ & $\begin{array}{l}6.22-\mathrm{X}- \\
4.17\end{array}$ & $\begin{array}{l}3648-\mathrm{x}- \\
2736\end{array}$ & $1 / 400$ & 25.5 & 3 & 11.58 & 8.54 \\
\hline
\end{tabular}

The images were then loaded into Agisoft Photoscan Pro and a 3D model was generated. Photoscan uses the SIFT method (Lowe 2004) to calculate the 3D positions of objects captured in multiple unordered overlapping images. This method is commonly known as Structure-from-Motion and due to the number of input requirements it has been widely used in archaeological and geomorphological applications (e.g., Gonçalves and Henriques 2015; Hesse 2015; Lerma and Muir 2014; Martínez et al. 2015; Sanger 2015; Tonkin et al. 2014). The primary limitation on the accuracy of data generated from this method arises from the Ground Sample Distance (GSD) of the input photographs. The GSD (after Gonçalves and Henriques 2015) can be determined by the input camera distance $\left(H_{d}\right)$, lens focal length $(f)$, sensor width $\left(S_{w}\right)$, and image pixel width $\left(P_{w}\right)$ as:

$$
G S D=\left(H_{d} S_{w}\right) /\left(f P_{w}\right)
$$

Camera motion during the survey does slightly limit the input GSD due to image blur, but the resulting GSD from the survey was $0.779 \mathrm{~cm} /$ pix. Given that most case studies have yielded results that suggest that the precision of the resulting 3D elevation data from this method can be expected at 1-1.4x GSD (Colomina and Molina 2014), the resulting vertical accuracy of the dataset should be within $1.09 \mathrm{~cm}$. This distance is well within the variation of vegetation height during the time of the survey. 

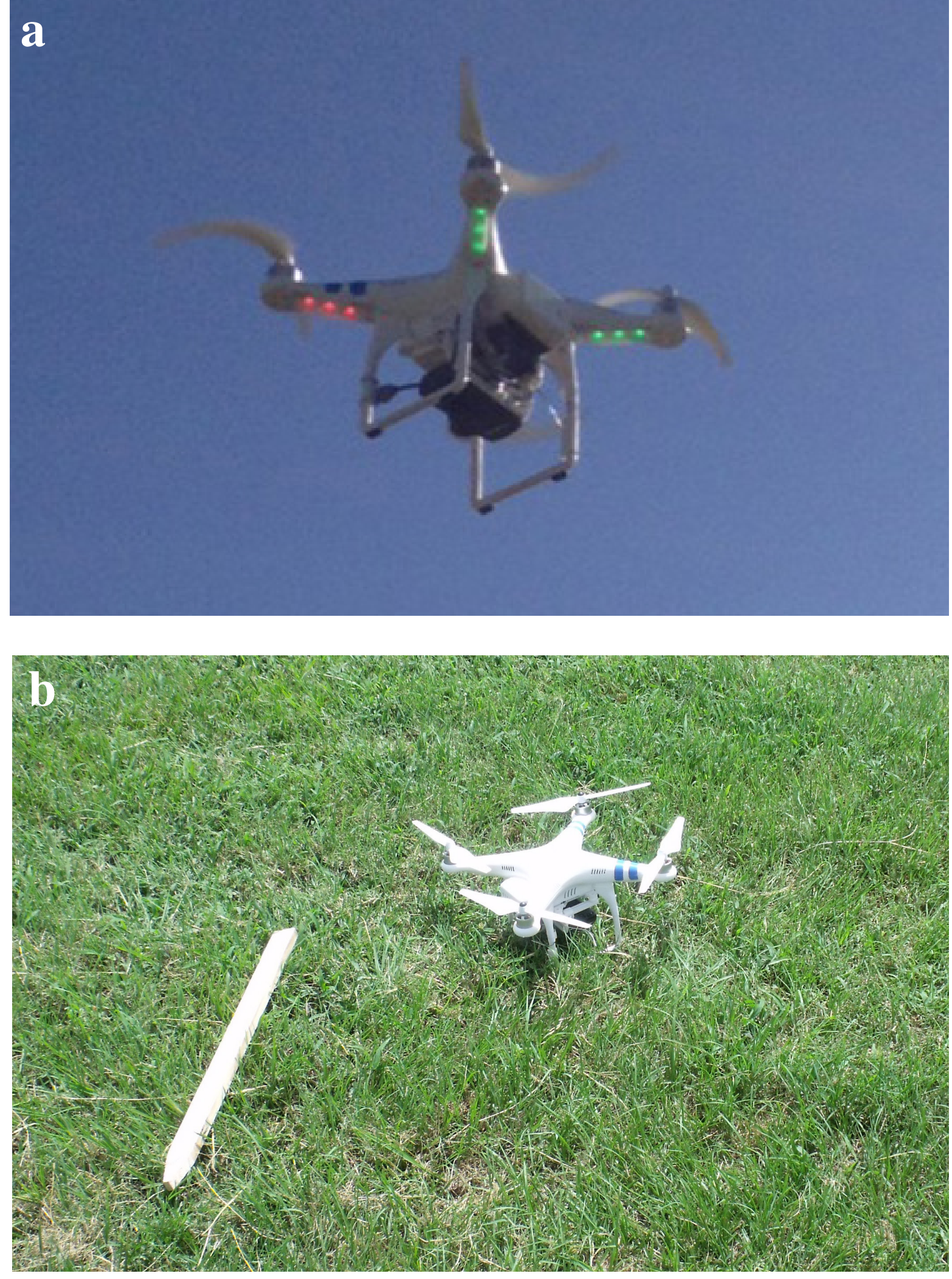

Figure 161. The DJI Phantom 2 quadrotor unmanned aerial vehicle used in the aerial survey work at the M. S. Roberts site (41HE8): $a$, in flight; $b$, on the ground. 
After the photos were aligned, a digital 3D surface was generated in Photoscan, and the data was exported to ArcGIS for additional processing. Both a digital elevation model (DEM) and a seamless orthophoto were exported at a $1 \mathrm{~cm}$ resolution. In order to accurately represent the ground surface heights, rather than vegetation height, additional processing was necessary. To accomplish this, the DEM was first detrended and converted from relative sea level elevation (m AMSL) using a $2^{\text {nd }}$ order Global Polynomial Interpolation. This detrending process helps to remove additional artificial curvature that the camera calibration in Photoscan does not automatically process out of the data. To filter the influence of vegetation and approximate the ground surface elevation, the data was additionally sent through a $1^{\text {st }}$ order Local Polynomial Interpolation with a filter radius of $1 \mathrm{~m}$. This resulted in a relatively smooth representation of the ground surface with the natural terrace height trending toward a relative elevation of $0 \mathrm{~m}$. The resulting elevation dataset ranged from a low of approximately $2.7 \mathrm{~m}$ below the average terrace elevation below the scarp in the northwest part of the study area to a high of approximately $1.7 \mathrm{~m}$ near the artificially terraced edge of the landform. Additional erroneous points sampled from buildings and trees extended the dataset to $18 \mathrm{~m}$.

The mound and borrow pit features were delineated through examining the DEM and a $10 \mathrm{~cm}$ contour interval. The mound was clearly visible as a slightly oblong feature extending from baseline elevation to a maximum height of $91 \mathrm{~cm}$ within an aerial extent of $855 \mathrm{~m}^{2}$ (Figure 162). The edges of the borrow pit are not as clearly defined as the mound, but a clear isolated depression is visible extending from $56 \mathrm{~cm}$ below the baseline elevation to a maximum depth of $87 \mathrm{~cm}$ (Figure 163). In this way, the aerial extent of the borrow pit is mapped as encompassing $2000 \mathrm{~m}^{2}$, although it is likely that the maximum extent of borrowing is beyond this mapped extent. Based on these extents both the mound and borrow pit volumes can be calculated relative to the baseline elevation. The volume of the mound is calculated as 313.68 cubic meters, while the total volume represented by the known borrow pit area is 270.82 cubic meters, or 86 percent of the total estimated mound volume. This is also estimated by the boundary drawn on the figure. This leaves an estimated 42.86 cubic meters of fill in the mound unaccounted for, or perhaps the borrow pit contains fill from the mound that has washed in after the site began to be plowed in the $20^{\text {th }}$ century. It is important to also note that north and northeast of the mound are subtly low-lying areas of the terrace that, when viewing the mound from these locations, gives the impression that the mound is taller above the terrace level than it actually is (Figures 164 and 165). Whether these were artificially lowered areas or that the Caddo mound builders took advantage of this natural feature would need further subsurface testing. Figure 166 shows these areas from a vertical exaggerated 3D perspective.

\section{Shovel Testing}

The first round of shovel testing took place on the western part of the landform, more than $60 \mathrm{~m}$ west to southwest of the mound, which is on the eastern side of the property road. This includes ST 1-4 and ST B-1 to ST B-4, spaced about 20-30 m apart in two north-south rows. Single pieces of lithic debris were recovered in ST 1 (20-40 cm bs), ST 3 (0-20 cm bs), ST 4 (20-40 cm bs), and ST B-4 (40-60 cm bs); no Caddo ceramics were found in this part of the site.

Sediment descriptions for these shovel tests are as follows:

ST 1: 0-80 cm+, yellowish-brown sandy loam;

ST 2: 0-65 cm, yellowish-brown sandy loam; 65-75 cm+, orangish-brown loam;

ST 3: 0-60 cm+, yellowish-brown sandy loam;

ST 4: 0-60 cm+, yellowish-brown sandy loam; 


\section{Legend}

- Selected Auger Test

- Selected Shovel Test

$1-;$, Mound

$\therefore ;$, Borrow Pit

\section{Relative Elevation}
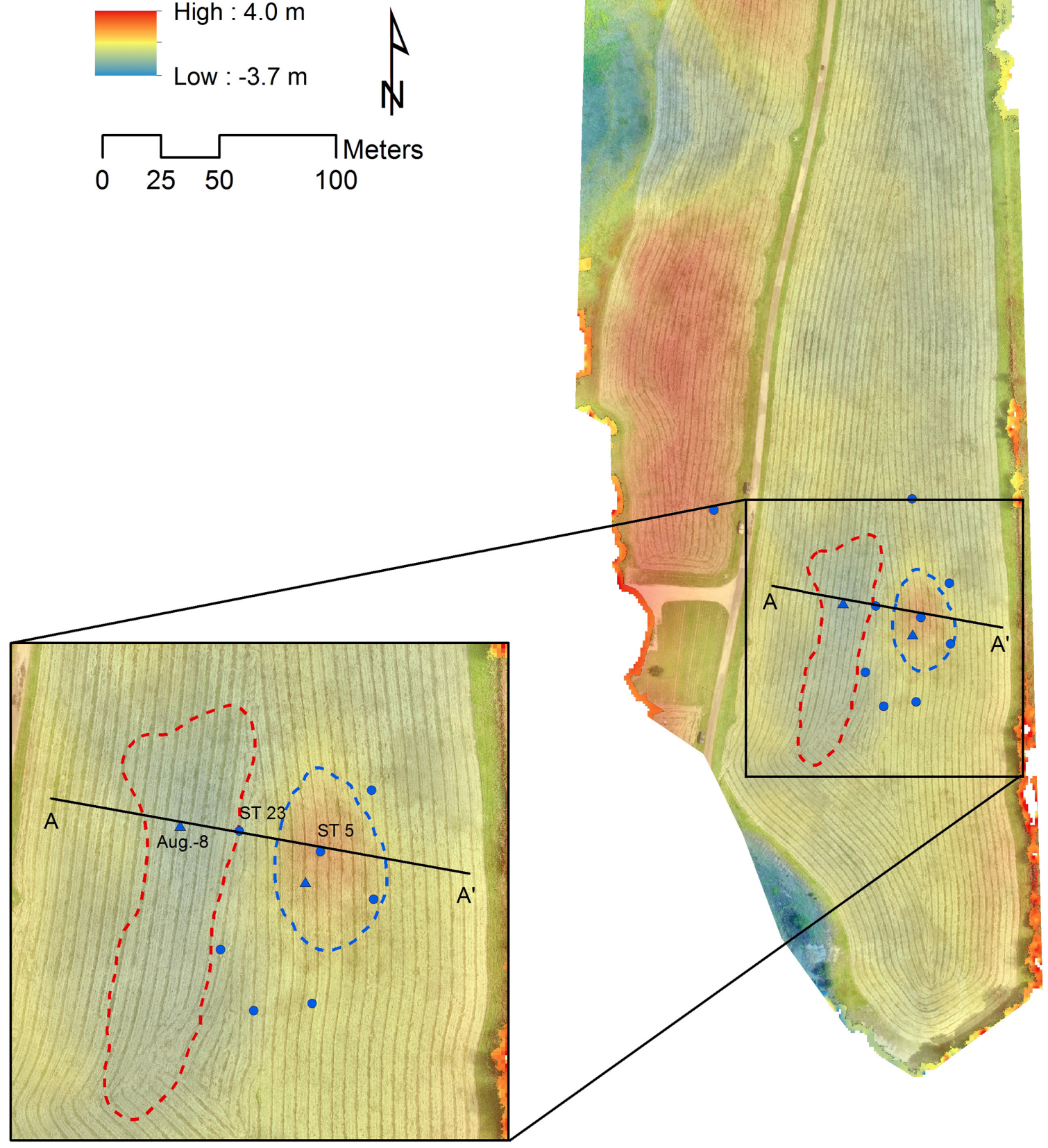

Figure 162. Map showing the DEM and orthophoto overlay of the 41HE8 study area. The locations of representative shovel tests and an artificial cross section (A) through the mound and borrow pit are also shown. 


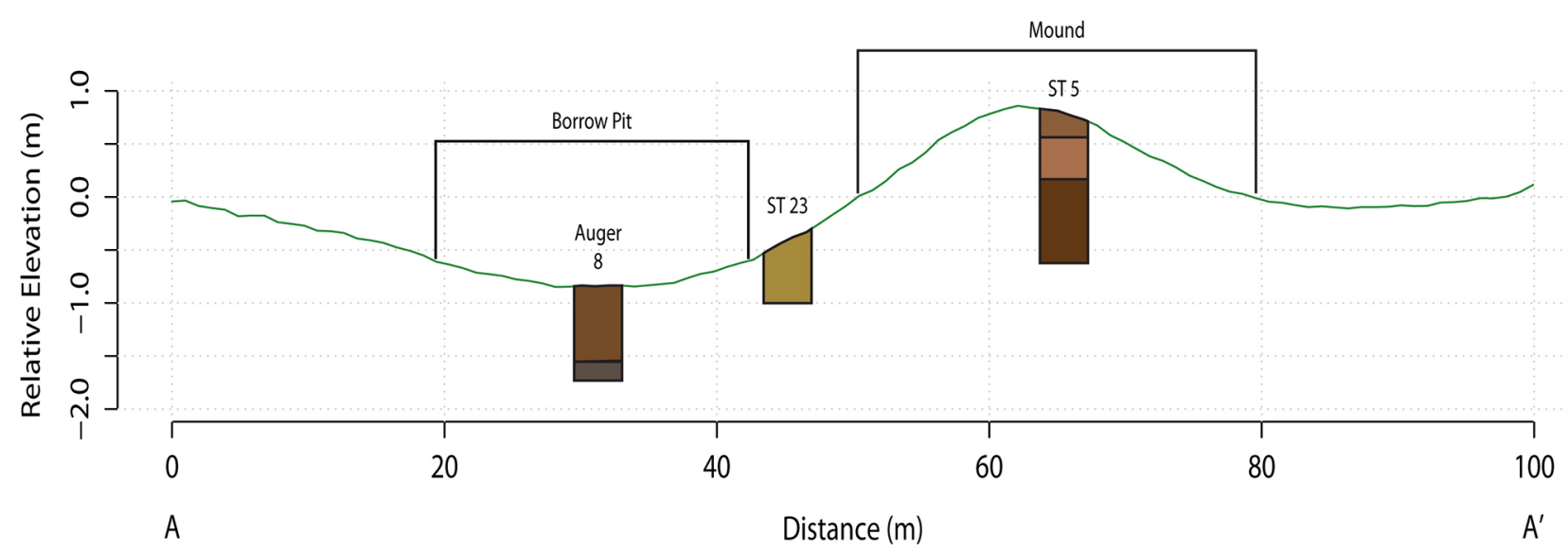

Figure 163. A cross section showing the variation of the ground surface across the mound and borrow pit features.

ST B-1: 0-102 cm+, yellowish-brown sandy loam;

ST B-2: 0-100 cm+, yellowish-brown sandy loam;

ST B-3: 0-89 cm+, yellowish-brown sandy loam; and

ST B-4: 0-86 cm+, yellowish-brown sandy loam.

Two other shovel tests (ST B-5 and ST B-6) were excavated at the southern tip of the landform, about $300 \mathrm{~m}$ south of the mound. The A/E-horizon yellowish-brown sandy loam sediments ranged between $37-$ $41 \mathrm{~cm}$ thick overlying a strong brown clay B-horizon. Neither shovel test contained any archaeological deposits.

All of the shovel tests on the eastern side of the site and property road, including ST 5 in the mound as well as ST 9-24 around and near the mound, contain archaeological deposits from 0-60 cm bs with a considerable density of ancestral Caddo sherds (Figure 167). These shovel tests cover a ca. 100 x $50 \mathrm{~m}$ area, but the overall extent of the archaeological deposit at the site has not been established through this shovel testing effort.

The sediment descriptions for ST 5 and ST 9-24 are:

ST 5: 0-20 cm, brown sandy loam with red and gray clay; 20-60 cm+, dark reddish-brown sandy loam and red and gray clay chunks; an auger hole was subsequently excavated from $60-140 \mathrm{~cm}$ bs in this shovel test (see below);

ST 9: 0-35 cm, yellowish-brown sandy loam; 35-55 cm, dark yellowish-brown sandy loam; 55-60 $\mathrm{cm}+$, yellowish-brown sandy loam;

ST 10: 0-28 cm, yellowish-brown sandy loam; 28-53 cm, dark yellowish-brown sandy loam; 53-60 $\mathrm{cm}+$, yellowish-brown sandy loam;

ST 11: 0-25 cm, yellowish-brown sandy loam; $25-50 \mathrm{~cm}$, dark yellowish-brown sandy loam; 50-60 $\mathrm{cm}+$, yellowish-brown sandy loam; 


\section{Legend}

- Selected Auger Test

- Selected Shovel Test

$\therefore ;$, Mound

$\because-\because$, Borrow Pit

\section{Relative Elevation}
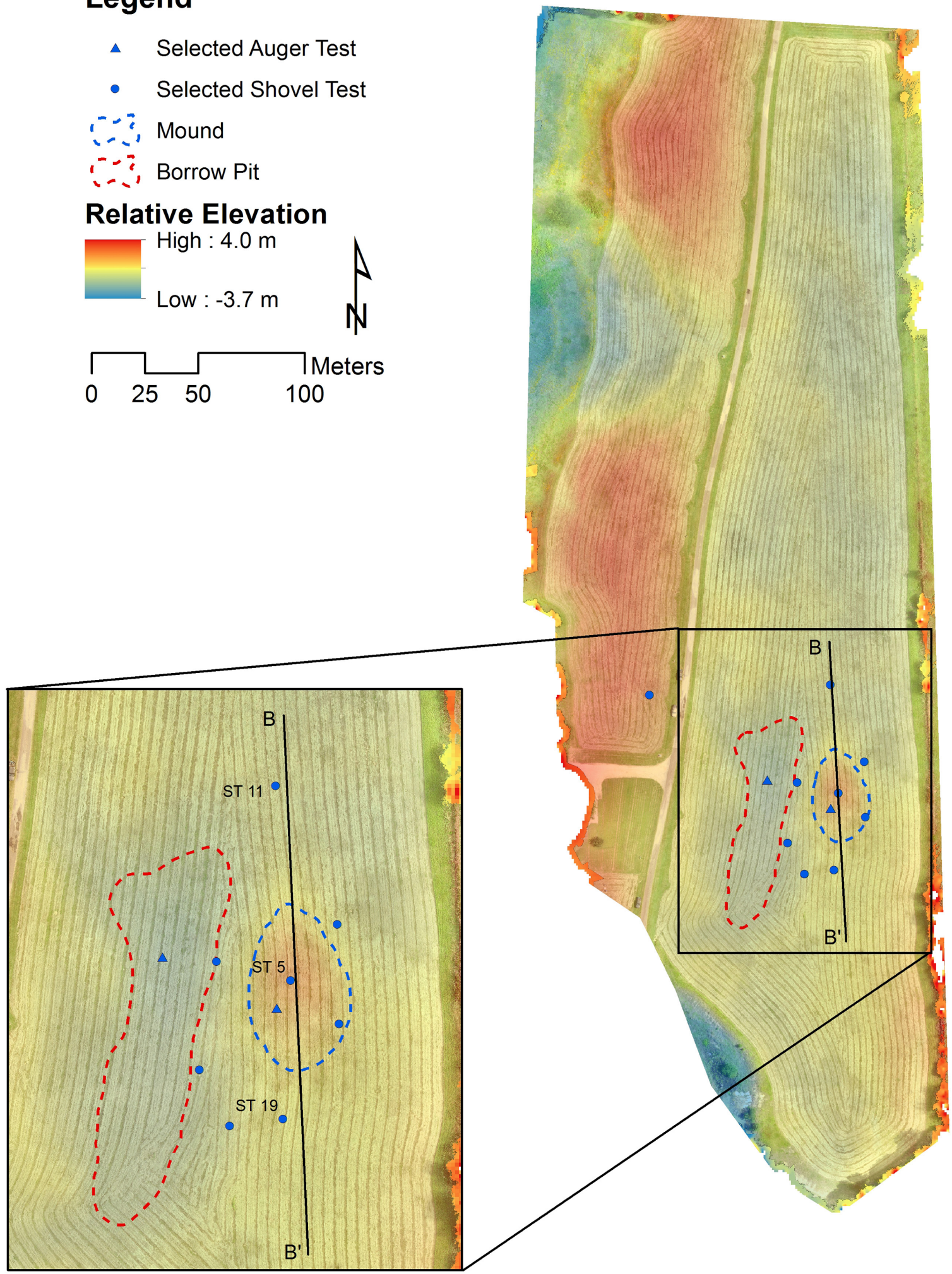

Figure 164. Map showing the DEM and orthophoto overlay of the 41HE8 study area. The locations of representative shovel tests and an artificial cross section (B) through the mound and low lying area to the north are also shown. 


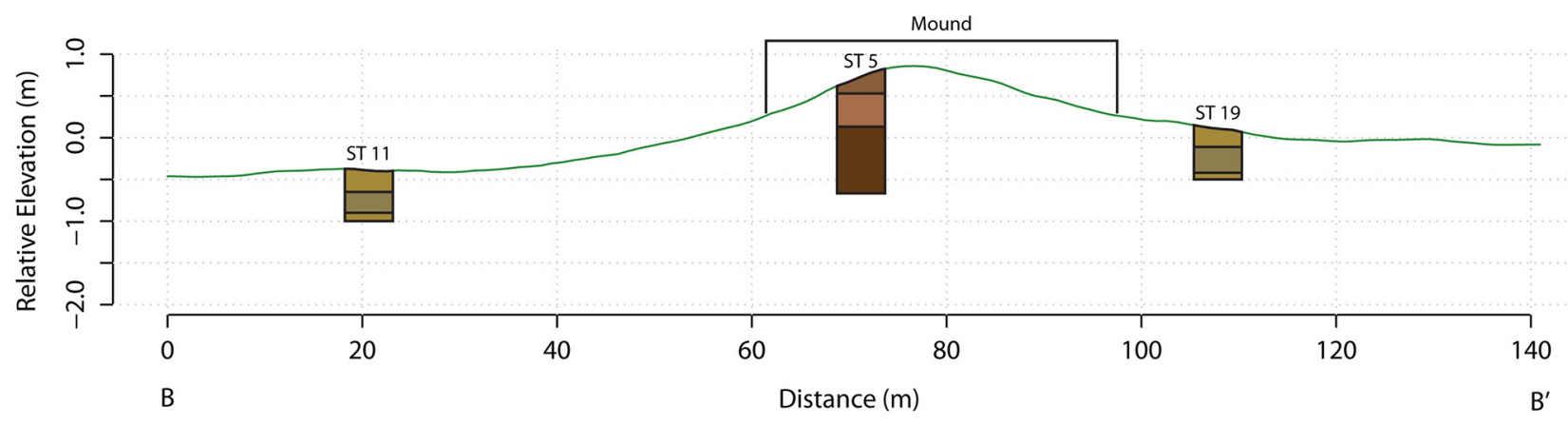

Figure 165. A cross section showing the variation of the ground surface across the mound adjacent terrace surfaces.
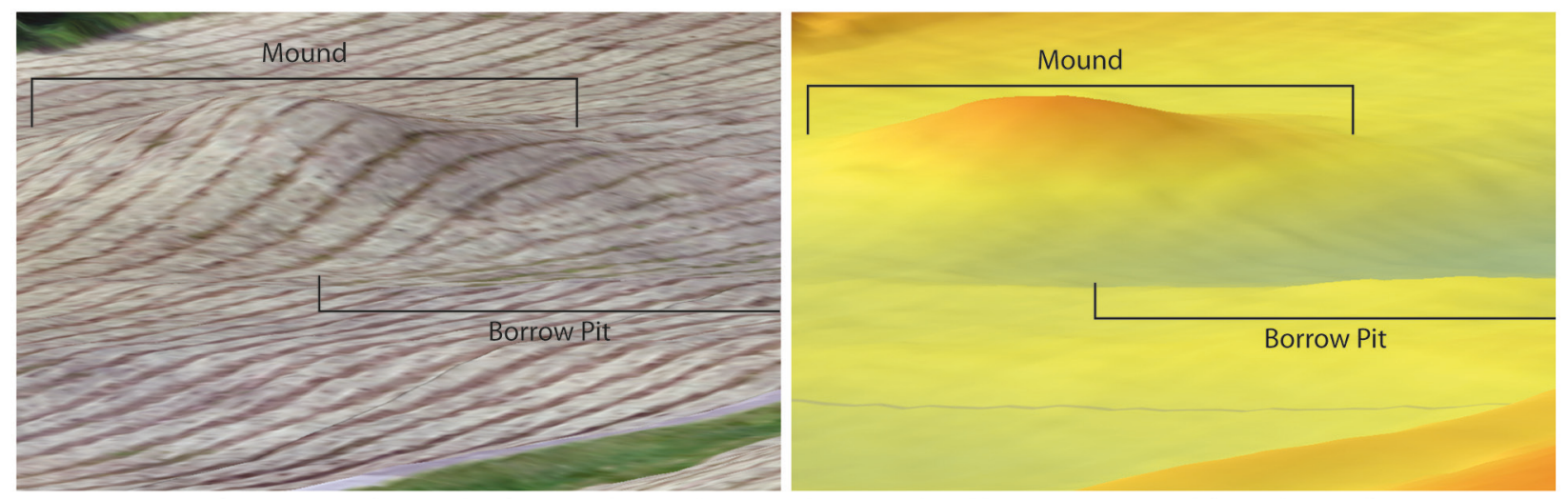

Vertical exaggerated 3D orthophoto and DEM showing the mound and borrow pit viewed from the northeast.

Figure 166. Images showing the vertical exaggerated 3D orthophoto and DEM showing the mound and borrow pit viewed from the northeast.

ST 12: 0-21 cm, yellowish-brown sandy loam; 21-55 cm, dark yellowish-brown sandy loam; 55-60 $\mathrm{cm}+$, yellowish-brown sandy loam;

ST 13: 0-23 cm, yellowish-brown sandy loam; 23-48 cm, dark yellowish-brown sandy loam; 48-60 $\mathrm{cm}+$, yellowish-brown sandy loam;

ST 14: 0-20 cm, yellowish-brown sandy loam; $27-52 \mathrm{~cm}$, dark yellowish-brown sandy loam; 52-60 $\mathrm{cm}+$, yellowish-brown sandy loam;

ST 15: 0-24 cm, yellowish-brown sandy loam; 24-53 cm, dark yellowish-brown sandy loam; 53-60 $\mathrm{cm}+$, yellowish-brown sandy loam;

ST 16: 0-24 cm, yellowish-brown sandy loam; $24-53 \mathrm{~cm}$, dark yellowish-brown sandy loam; 53-60 $\mathrm{cm}+$, yellowish-brown sandy loam;

ST 17: 0-24 cm, yellowish-brown sandy loam; $24-50 \mathrm{~cm}$, dark yellowish-brown sandy loam; 50-60 $\mathrm{cm}+$, yellowish-brown sandy loam; 


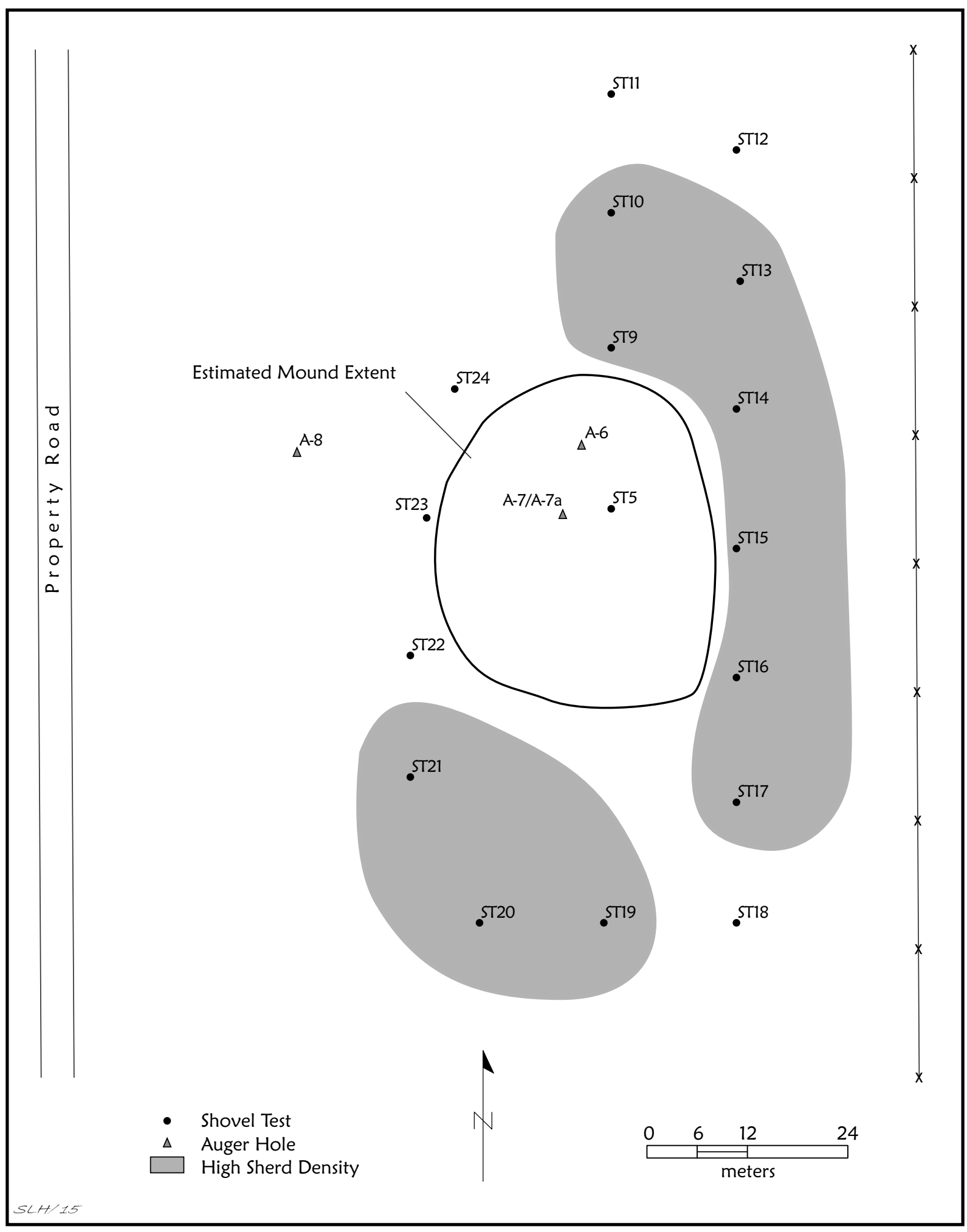

Figure 167. Location of ST 5, and 9-24, and Auger holes 6, 7, 7a, and 8 at the M. S. Roberts site. 
ST 18: 0-52 cm, yellowish-brown sandy loam; 52-60 cm+, light yellowish-brown sandy loam;

ST 19: 0-21 cm, yellowish-brown sandy loam; 21-52 cm, dark yellowish-brown sandy loam; 52-60 $\mathrm{cm}+$, yellowish-brown sandy loam;

ST 20: 0-24 cm, yellowish-brown sandy loam; $24-51 \mathrm{~cm}$, dark yellowish-brown sandy loam; 51-60 $\mathrm{cm}+$, light yellowish-brown sandy loam;

ST 21: 0-25 cm, yellowish-brown sandy loam; 25-51 cm, dark yellowish-brown sandy loam; 51-60 $\mathrm{cm}+$, light yellowish-brown sandy loam;

ST 22: 0-60 cm+, yellowish-brown sandy loam;

ST 23: 0-60 cm+, yellowish-brown sandy loam;

ST 24: 0-26 cm, yellowish-brown sandy loam; 26-50 cm+, dark yellowish-brown sandy loam; moisture increases in sediments below $40 \mathrm{~cm}$ bs.

Many of the shovel tests have a shallowly buried (ca. $20-25 \mathrm{~cm}$ bs to ca. $50 \mathrm{~cm}$ bs) dark yellowishbrown sandy loam deposit with charcoal flecks and numerous sherds. This sediment zone likely represents the unplowed portions of the Caddo habitation deposits at the site. The highest densities of ceramic vessel sherds are in shovel tests to the south and southwest of the mound as well as north, east, and southeast of the mound (see Figure 167).

\section{Mound Augering}

Auger holes were excavated in the mound (below $60 \mathrm{~cm}$ bs in ST 5 and in A-6, A-7, and A-7a) as well as in a likely low borrow pit area about $20 \mathrm{~m}$ west of the northern part of the mound at the M. S. Roberts site (Figure 168). The profiles in the mound have a variety of mound fill zones, including sandy loams, clay loams, and a mixture of sandy loam and red and gray clay chunks. Auger hole excavations in ST 5 and A-6 encountered a very dark sandy loam zone between 102-135 cm bs (A-6) and 120-140 cm bs (ST 5) (Figure 168) that may represent the remains of a burned structure encountered during the 1931 UT work. No clay floor was encountered in any of the auger holes, but significant amounts of gray clay chunks were noted in A-7a between 83-119 cm bs, nor was a basal yellow sand mound zone in our auger holes. The base of the mound may lie at ca. $140 \mathrm{~cm}$ bs, with underlying dark yellowish-brown or yellowish-brown sandy loam or sand deposits representing the buried A- and E-horizons on the landform.

The auger hole excavated in the likely borrow pit (A-8) west of the mound encountered shallow very dark grayish-brown and dark yellowish-brown sandy loam sediments, some with notable charcoal flecks, between $0-72 \mathrm{~cm}$ bs (see Figure 168). These sediments overlie a zone of reddish-brown and gray clay to at least ca. $90 \mathrm{~cm}$ bs. 


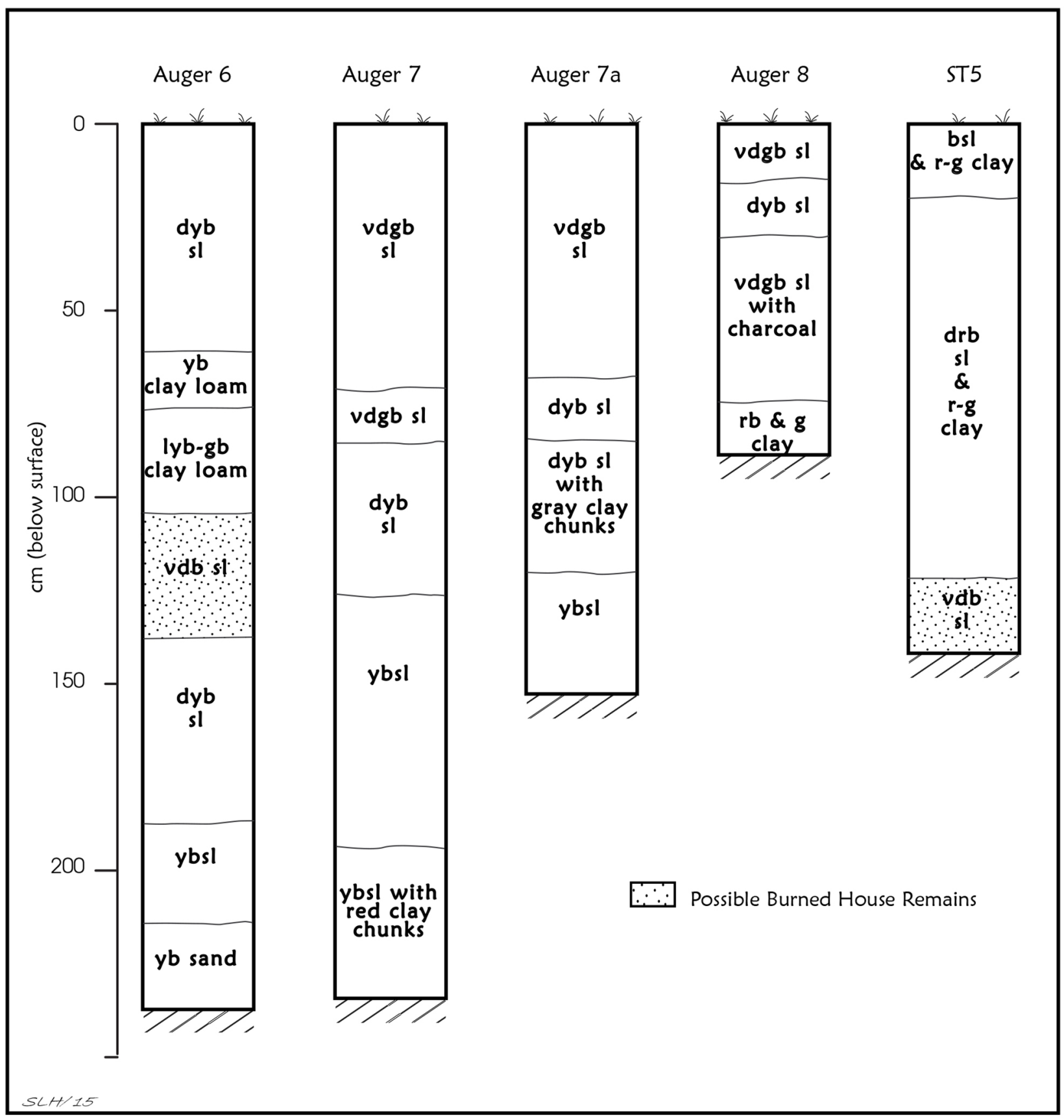

Figure 168. Recorded profiles in ST 5 and Auger holes 6, 7, 7a, and 8.

\section{Recovered Caddo Artifacts}

A total of 248 artifacts have been recovered in the June 2015 archaeological investigations at the M. S. Roberts site, including a general site surface collection obtained by Denise Roberts. Twenty-one shovel tests contain archaeological remains, including plain and decorated sherds (from 17 shovel tests), one chipped stone tool fragment from ST 17, lithic debris (from 10 shovel tests), animal bone (ST 20), burned clay (ST 21), and a ceramic pipe sherd (ST 21). On the western part of the landform, only lithic debris was recovered in the shovel testing investigations (Table 16). 
Table 16. Recovered artifacts in the June 2015 archaeological investigations at the M. S. Roberts site.

\begin{tabular}{|c|c|c|c|c|c|c|c|c|c|}
\hline Provenience & PS & $\mathrm{DS}$ & AP & Tool & LD & Bone & $\mathrm{BC}$ & Pipe Sherd & $\mathrm{N}$ \\
\hline$\overline{\text { Surface }}$ & 25 & 10 & 1 & - & - & - & - & - & 36 \\
\hline ST B-4 & - & - & - & - & 1 & - & - & - & 1 \\
\hline ST 1 & - & - & - & - & 1 & - & - & - & 1 \\
\hline ST 3 & - & - & - & - & 1 & - & - & - & 1 \\
\hline ST 4 & - & - & - & - & 1 & - & - & - & 1 \\
\hline ST 5 & 1 & - & - & - & - & - & - & - & 1 \\
\hline ST 9 & 17 & 1 & - & - & - & - & - & - & 18 \\
\hline ST 10 & 7 & 2 & - & - & - & - & - & - & 9 \\
\hline ST 11 & 2 & 1 & - & - & - & - & - & - & 3 \\
\hline ST 12 & 3 & - & - & - & - & - & - & - & 3 \\
\hline ST 13 & 11 & 3 & - & - & - & - & - & - & 14 \\
\hline ST 14 & 7 & 4 & - & - & 3 & - & - & - & 13 \\
\hline ST 15 & 9 & 6 & - & - & 1 & - & - & - & 16 \\
\hline ST 16 & 7 & 5 & - & - & 3 & - & - & - & 15 \\
\hline ST 17 & 9 & 3 & - & 1 & 1 & - & - & - & 14 \\
\hline ST 18 & 4 & 1 & - & - & - & - & - & - & 5 \\
\hline ST 19 & 11 & 5 & - & - & - & - & - & - & 16 \\
\hline ST 20 & 18 & 2 & - & - & 1 & 1 & - & - & 22 \\
\hline ST 21 & 24 & 14 & - & - & 1 & - & 1 & 1 & 41 \\
\hline ST 22 & 4 & - & - & - & - & - & - & - & 4 \\
\hline ST 23 & 5 & 4 & - & - & - & - & - & - & 9 \\
\hline ST 24 & 3 & 1 & - & - & - & - & - & - & 4 \\
\hline Totals & 167 & 62 & 1 & 1 & 14 & 1 & 1 & 1 & 248 \\
\hline
\end{tabular}

$\mathrm{PS}=$ plain sherd; $\mathrm{DS}=$ decorated sherd; $\mathrm{AP}=$ arrow point; $\mathrm{LD}=$ lithic debris; $\mathrm{BC}=$ burned clay

The mean density of archaeological remains in the shovel tests is 10.1 per positive shovel test, or ca. 81 artifacts per square meter. However, the highest density of artifacts, especially ceramic vessel sherds, are in ST 20 and ST 21 south of the mound (see Figure 168). Densities of artifacts in these shovel tests range from ca. 176-328 per square meter. These shovel tests also have the only recovered burned clay, animal bone, or ceramic pipe sherds in the June 2015 investigations (see Table 16). Other shovel tests with considerable densities of artifacts and ceramic sherds in the archaeological deposits are ST 9 (ca. 144 artifacts per square meter), just north of the mound, and ST 13-17 (ca. 104-128 artifacts per square meter) northeast, east, and southeast of the mound at the M. S. Roberts site (see Figure 168). Clearly there are habitation deposits in the near vicinity of the constructed mound at the site, and were more shovel tests done to the east and south of the mound, these habitation deposits likely extend some distance in those directions from the mound. 
The archaeological deposits in habitation areas at the M. S. Roberts site are at least $60 \mathrm{~cm}$ in thickness, based on the shovel testing (Table 17). The highest densities of artifacts occur from $20-40 \mathrm{~cm}$ bs (43 percent of the recovered artifacts), in deposits primarily below the plow zone; these deposits represent an intact and shallowly buried habitation zone, as may much of the $40-60 \mathrm{~cm}$ zone $(21$ percent of the recovered artifacts). Artifacts in the plow zone comprise 36 percent of the recovered artifacts in the shovel testing at the site.

Table 17. Depth of recovered artifacts in the June 2015 shovel tests at the M. S. Roberts site.

\begin{tabular}{|c|c|c|c|c|c|c|c|c|}
\hline Depth & PS & DS & LD & Tool & Bone & $\mathrm{BC}$ & $\begin{array}{l}\text { Pipe } \\
\text { Sherd }\end{array}$ & $\mathrm{N}$ \\
\hline $0-20 \mathrm{~cm}$ & 50 & 18 & 6 & 1 & 1 & - & - & 76 \\
\hline $20-40 \mathrm{~cm}$ & 60 & 24 & 4 & - & - & 1 & 1 & 90 \\
\hline $40-60 \mathrm{~cm}$ & 32 & 10 & 3 & - & - & - & - & 45 \\
\hline Totals & 142 & 52 & 13 & 1 & 1 & 1 & 1 & 211 \\
\hline
\end{tabular}

$\mathrm{PS}=$ plain sherd; $\mathrm{DS}=$ decorated sherd; LD=lithic debris; $\mathrm{BC}=$ burned clay

\section{Ceramic Vessel Sherds}

There are plain ware, utility ware, and fine ware ceramic vessel sherds in the June 2015 ceramic sherd assemblage (Table 18). The frequency of plain rim sherds in the assemblage (42 percent of the recovered rims) indicates that plain ware vessels are well represented. The utility ware sherds comprise 20.0 percent of the recovered sherds, and fine ware sherds account for only 7.0 percent of the recovered sherds; however, 33 percent of the recovered rim sherds are from fine ware vessels.

Table 18. Ceramic sherds from the June 2015 M. S. Roberts site investigations.

\begin{tabular}{lcccc}
\hline Ware & Rim & Body & Base & N \\
\hline Plain & 5 & 151 & 11 & 167 \\
Utility & 3 & 43 & - & 46 \\
Fine & 4 & 12 & - & 16 \\
- & 12 & 206 & 11 & 229 \\
Totals & & &
\end{tabular}

Approximately 84 percent of the ceramic sherds are from grog-tempered vessels (Table 19). Another 11.4 percent of the sherds are from vessels tempered with both grog and bone, while 5.2 percent of the sherds are from bone-tempered vessels. 
Table 19. Temper use in ceramic sherds from June 2015 investigations at the M. S. Roberts site.

\begin{tabular}{lllll}
\hline Ware & Grog & Grog-Bone & Bone & N \\
\hline Plain & 138 & 22 & 7 & 167 \\
Utility & 37 & 4 & 5 & 46 \\
Fine & 16 & - & - & 16 \\
\hline & 191 & 26 & 12 & 229 \\
\hline
\end{tabular}

The highest proportion of grog-tempered sherds are in the fine wares (100 percent), compared to 80.4 percent of the utility ware sherds and 82.6 percent of the plain ware sherds. The grog-bone and bone-tempered sherds occur only in the plain ware (17.4 percent of the sherds have bone temper inclusions) and utility ware (19.6 percent) (see Table 19).

The 62 decorated sherds identified in the 2015 investigations at the M. S. Roberts site include sherds with a variety of decorative methods and elements (Table 20). Utility ware sherds account for 74 percent of the decorated sherds in the assemblage.

Table 20. Decorative methods and elements in utility ware and fine ware sherds from the June 2015 investigations at the M.S. Roberts site.

Method

Decorative element

$\mathrm{N}$

\section{Utility ware}

Appliqued

horizontal appliqued ridges

straight appliqued ridge

Brushed

parallel brushing marks

10

Brushed-Incised

parallel brushed-incised marks and lines

3

parallel brushing and overlying parallel

incised lines

Incised

diagonal incised lines

diagonal opposed incised lines

2

opposed incised lines

parallel incised lines

1

straight incised line

Incised-Punctated

parallel incised lines and semi-circular

incised zone filled with linear tool punctations

straight incised line and adjacent linear 
Table 20. Decorative methods and elements in utility ware and fine ware sherds from the June 2015 investigations at the M. S. Roberts site, cont.

Method

Decorative element

$\mathrm{N}$

Utility ware, cont.

Punctated

circular punctated rows

1

fingernail punctated rows

1

single fingernail punctate $\quad 2$

linear tool punctated row 2

tool punctated row/rows $\quad 2$

single tool punctate

Subtotal, Utility Ware

Fine ware

Engraved

curvilinear engraved line

curvilinear hatched area

curvilinear and diagonal lines 1

diagonal opposed lines 1

diagonal and horizontal lines $\quad 2$

horizontal engraved lip below lip 3

horizontal line and hatched triangle el. 1

parallel engraved lines

Slipped

exterior brown slip

1

int./ext. red slip

Subtotal, Fine Ware

16

Totals

62

One of the appliqued sherds in the assemblage is a rim and strap handle sherd with horizontal appliqued ridges on the handle (Figure 169a). There are also rounded protuberances on the flat lip of the jar. The brushed and brushed-incised sherds (about 30 percent of the utility ware sherds) in the collection are from Bullard Brushed jars, while the incised and incised-punctated sherds are likely from Maydelle Incised jars. One distinctive incised-punctated sherd has parallel incised lines as well as an incised semicircle element filled with linear tool punctations (Figure 169c). These sherds represent 43 percent of the utility wares. The punctated sherds ( 22 percent of the utility wares) include circular ( $n=1$, Figure 169b), fingernail $(n=3)$, and tool punctated $(n=6)$ decorative elements. 


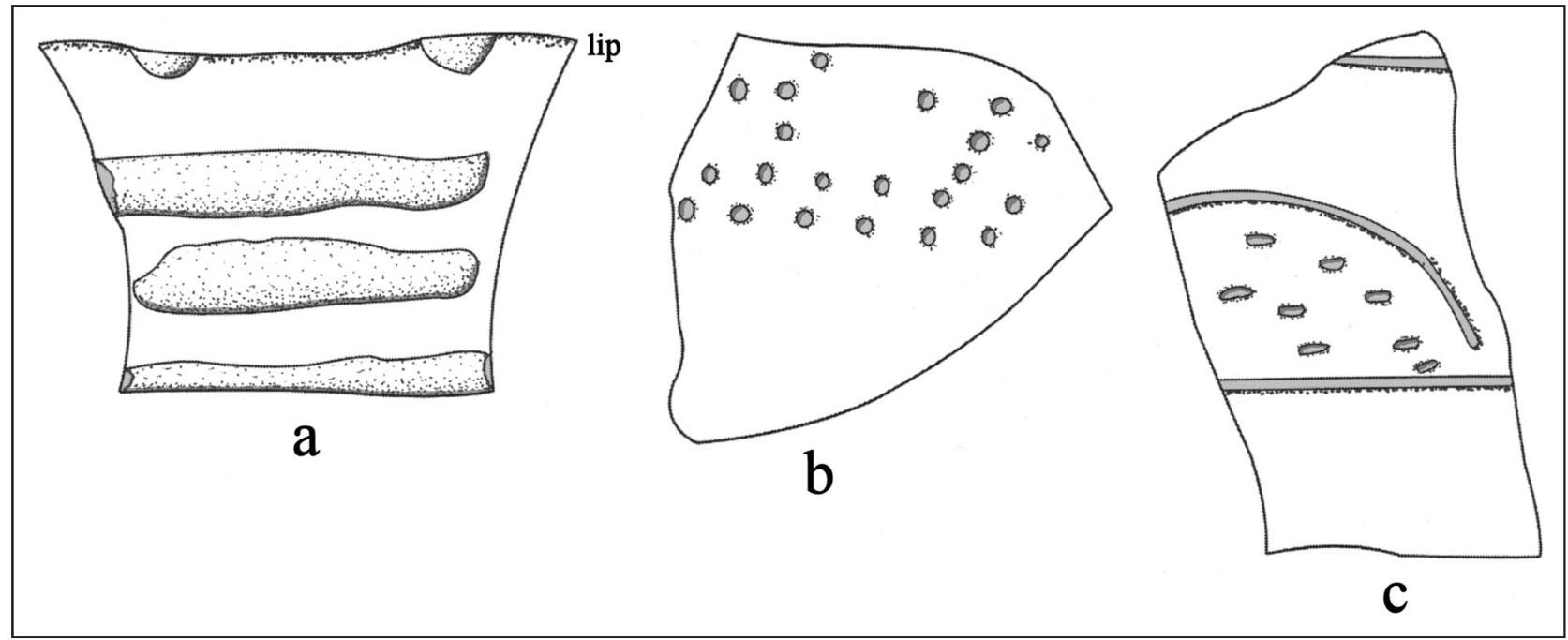

Figure 169. Selected decorative elements on utility ware sherds from the M. S. Roberts site: a, appliqued strap handle (ST 21, $40 \mathrm{~cm}$ bs); b, circular punctated body sherd (ST 14, 0-20 cm bs); c, incised-punctated body sherd (Surface collection).

The fine wares include sherds from both engraved (75 percent of the fine wares) and slipped ( 25 percent) vessels, including sherds from bowls, carinated bowls, and bottles. Several of the sherds are from Poynor Engraved vessels (Figure 170a, e-f), possibly var. Cook, var. Lang, or var. Blackburn (see Perttula 2011:Figure 6-64). The other engraved sherds have various combinations of curvilinear, diagonal, and horizontal engraved lines (Figure 170b-d; see also Table 20).

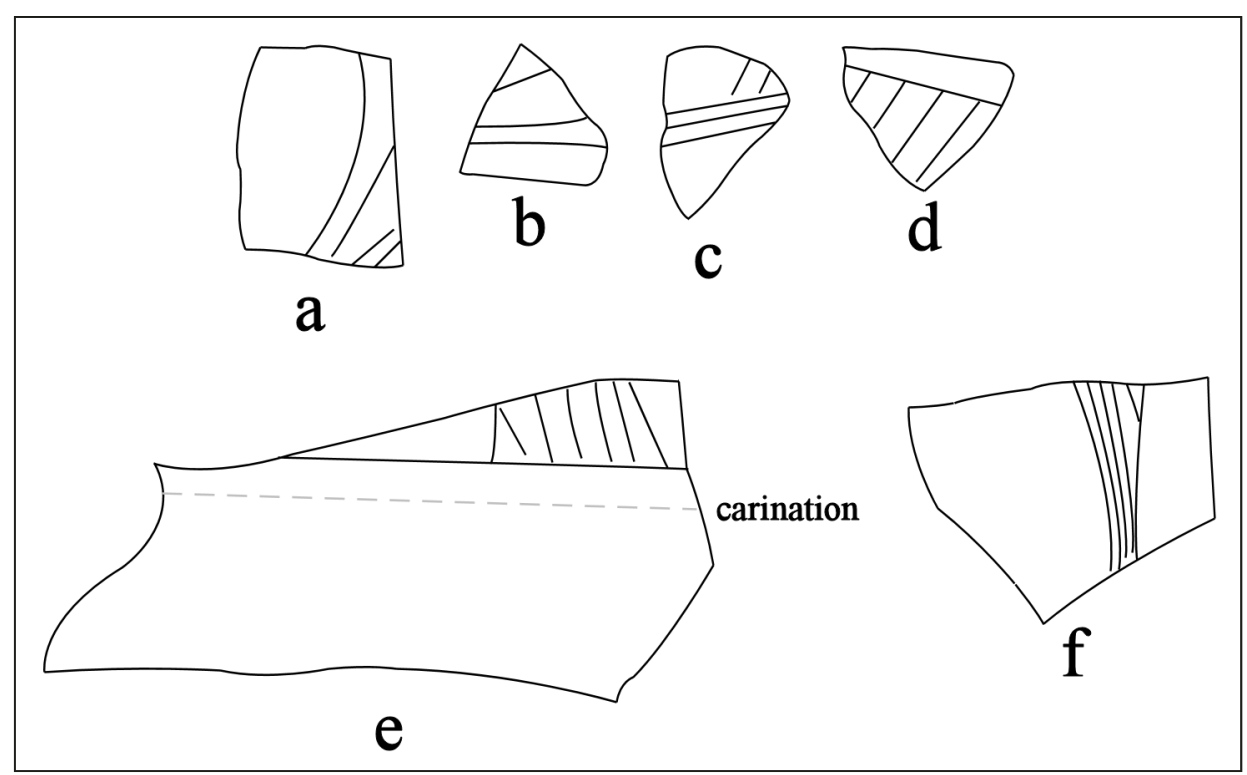

Figure 170. Selected decorative elements on fine ware sherds from the M. S. Roberts site: a, curvilinear and diagonal engraved lines (ST 19, 40-60 cm bs), Poynor Engraved; b, diagonal and horizontal engraved lines (ST 19, 20-40 cm bs); c, diagonal and horizontal engraved lines (ST 21, 20-40 cm bs); d, diagonal opposed engraved lines (ST 17, 0-20 cm bs); e, horizontal engraved line and hatched triangle element (ST 15, 40-60 cm bs), Poynor Engraved; f, curvilinear hatched area (Surface collection), Poynor Engraved. 
The slipped sherds have either a brown slip (on the exterior surface) or a red slip (on both interior and exterior vessel surfaces) (see Table 20).

Table 21 presents a summary of the ceramic sherd assemblage from the known collections obtained from the site in 1931 by UT archaeologists and in two different rounds of work completed in 2015. The assemblage overall is primarily composed of grog-tempered plain, utility, and fine ware vessels, as 90.5 percent of the sherds are from vessels that have had grog temper added in their paste. Nevertheless, the use of bone temper, either as the sole temper or in combination with grog, in the manufacture of vessels used, broken, and discarded at the M. S. Roberts site is substantial: 14.1 percent of the sherds.

Table 21. Summary of the ceramic sherd assemblage from the M. S. Roberts site.

Temper/

Decorative Method

$\mathrm{N} \quad \%$

453

85.9

$24 \quad 4.6$

$50 \quad 9.5$

Bone temper

527

100.0

Utility Ware

Appliqued

5

44

12

1

80

13

59

1.9

16.3

4.4

0.4

29.6

4.8

21.9

Fine Ware

Engraved

44

16.3

Slipped

12

4.4

Totals, Decorated sherds

270

100.0

Source: Perttula 2016a; Perttula and Walters 2016; this section

Over 79 percent of the decorated sherds in the M. S. Roberts site ceramic assemblages are from utility ware vessels (see Table 21). Most of these have incised, punctated, or brushed decorative elements, including sherds likely to be from Maydelle Incised ( $n=93)$ and Bullard Brushed $(n=57)$ vessels. The punctated rim and body sherds cannot currently be assigned to a defined East Texas Caddo ceramic type. 
Recent analyses of the character of ancestral Caddo ceramic sherd assemblages in the upper Neches River basin in East Texas have indicated several temporal changes in the proportion of brushed sherds in decorated sherd assemblages; the percentage of other wet paste decorations (i.e., incised, incised-punctated, punctated, etc.) on sherds; changes in the ratio of plain to decorated sherds (P/DR); and the ratio of brushed sherds to other wet paste decorated sherds (Table 22). These analyses have led to the recognition of six temporal sequent groups of assemblages in the upper Neches, including several sites in the Caddo Creek valley, dating from as early as ca. A.D. 1000-1200 in the Early Caddo period (Group VI) to Historic Caddo ceramic assemblages (Group I) that date after ca. A.D. 1680.

Table 22. Comparative sherd assemblage data from Lake Palestine Caddo sites, nearby Caddo sites, and the M.S. Roberts site in the upper Neches River basin.

\begin{tabular}{|c|c|c|c|c|c|c|}
\hline Site & $\begin{array}{l}\text { No. of Dec. } \\
\text { Sherds }\end{array}$ & \%Brushed & $\begin{array}{l}\text { \%bone- } \\
\text { temper }\end{array}$ & $\begin{array}{l}\text { \% Wet-paste } \\
\text { decorations }\end{array}$ & P/DR & $\begin{array}{l}\text { Brus } \\
\text { paste }\end{array}$ \\
\hline \multicolumn{7}{|c|}{ YOUNGEST SITES: GROUP I, Allen phase, ca. post-A.D. 1680} \\
\hline 41CE421* & 1805 & 88.1 & 5.4 & 7.8 & 0.28 & 8.50 \\
\hline 41CE429* & 465 & 87.7 & 0.8 & 9.7 & 0.22 & 9.07 \\
\hline Pine Snake* & 305 & 85.2 & 5.7 & 8.8 & 0.51 & 9.6 \\
\hline 41CE354* & 474 & 82.7 & 3.1 & 8.9 & 0.20 & 8.1 \\
\hline
\end{tabular}

GROUP II, latest Frankston phase, ca. A.D. 1560-1680

$\begin{array}{lllllll}\text { 41HE22 } & 228 & 85.5 & ? & 7.5 & 0.62 & 11.5 \\ \text { 41AN1 } & 295 & 83.1 & 5.1 & 7.1 & 0.19 & 7.21 \\ \text { 41CE324 } & 188 & 81.9 & 3.2 & 7.3 & 0.48 & 11.0 \\ \text { Attaway } & 814 & 84.4 & ? & 10.6 & 1.71 & 8.0 \\ \text { Debro } & 311 & 80.0 & ? & 10.3 & 0.14 & 7.75 \\ \text { 41SM91 } & 191 & 75.9 & 0.7 & 14.7 & 0.51 & 5.18 \\ \text { 41AN21* } & 133 & 75.9 & 1.1 & 17.1 & 0.30 & 5.32 \\ \text { William } & 525 & 75.8 & ? & 16.2 & 0.44 & 4.68 \\ \quad \text { Sherman } & & & & & & \\ \text { A. C. Saunders } & 5805 & 74.5 & 15.5 & 14.4 & 0.21 & 5.30 \\ \text { 41AN8* } & 98 & 70.4 & 3.3 & 18.3 & 0.55 & 3.83 \\ \text { 41AN2* } & 152 & 67.8 & 11.5 & 17.8 & 0.41 & 3.81\end{array}$

GROUP III, Frankston phase, ca. A.D. 1480-1560

$\begin{array}{lllllll}\text { Forest Drive } & 1693 & 68.6 & ? & 21.9 & 0.56 & 3.12 \\ \text { Halbert } & 1757 & 65.8 & 2.6 & 26.3 & 0.70 & 2.51 \\ \text { Woldert } & 1730 & 62.7 & 0.0 & 28.8 & 0.72 & 2.19 \\ \text { Ferguson } & 4116 & 60.8 & <1.0 & 27.9 & 0.61 & 2.17\end{array}$

GROUP IV, earliest Frankston phase, ca. A.D. 1400-1480

$\begin{array}{lllllll}\text { 41SM87 } & 176 & 56.2 & 1.8 & 34.1 & 1.24 & 1.65 \\ \text { 41HE4/55** } & 70 & 51.4 & ? & 40.0 & 1.54 & 1.29 \\ \text { 41SM90 } & 85 & 50.6 & 2.9 & 31.8 & 2.20 & 1.60 \\ \text { Tomato Patch } & 912 & 49.2 & ? & 41.7 & 1.50 & 1.21 \\ \text { 41HE338 } & 194 & 47.4 & 2.5 & 38.9 & 1.05 & 1.23 \\ \text { 41SM89 } & 136 & 39.0 & 10.4 & 44.1 & 1.96 & 0.88\end{array}$


Table 22. Comparative sherd assemblage data from Lake Palestine Caddo sites, nearby Caddo sites, and the M.S. Roberts site in the upper Neches River basin, cont.

\begin{tabular}{|c|c|c|c|c|c|c|}
\hline Site & $\begin{array}{l}\text { No. of Dec. } \\
\text { Sherds }\end{array}$ & \%Brushed & $\begin{array}{l}\text { \%bone- } \\
\text { temper }\end{array}$ & $\begin{array}{l}\text { \% Wet-paste } \\
\text { decorations }\end{array}$ & $\mathbf{P} / \mathbf{D R}$ & $\begin{array}{l}\text { Brushed/Wet } \\
\text { paste ratio }\end{array}$ \\
\hline \multicolumn{7}{|c|}{ GROUP IV, earliest Frankston phase, ca. A.D. 1400-1480, cont. } \\
\hline 41SM88 & 95 & 37.9 & $?$ & 49.5 & 1.53 & 1.31 \\
\hline $\begin{array}{l}\text { Henderson Co. } \\
\text { site*** }\end{array}$ & 116 & 37.1 & 5.4 & 41.4 & 1.21 & 0.90 \\
\hline Lang Pasture & 2435 & 35.9 & 6.7 & 38.0 & 1.40 & 0.91 \\
\hline 41AN7 & 119 & 35.3 & 3.5 & 35.3 & 2.11 & 1.0 \\
\hline Mitchell, D & 54 & 32.1 & 0.0 & 33.3 & 1.37 & 1.50 \\
\hline 41HE337 & 149 & 35.6 & 5.6 & 46.3 & 2.25 & 0.76 \\
\hline \multicolumn{7}{|c|}{ GROUP V, Middle Caddo period, ca. A.D. $1200-1400$} \\
\hline $41 \mathrm{SM} 73$ & 165 & 26.1 & $?$ & 72.7 & 2.61 & 0.37 \\
\hline M. S. Roberts & 270 & 21.1 & 14.1 & 63.0 & 1.90 & 0.34 \\
\hline 41SM404 & 446 & 16.0 & 8.5 & 60.7 & 1.73 & 0.26 \\
\hline White Mule & 1404 & 18.5 & 1.5 & 63.7 & 2.61 & 0.29 \\
\hline 41HE139 & 40 & 17.5 & 8.1 & 65.0 & 2.51 & 0.33 \\
\hline 41AN159 & 23 & 13.0 & 13.9 & 65.2 & 3.39 & 0.20 \\
\hline 41SM273, Z1/2 & 256 & 10.9 & 28.8 & 70.0 & 3.97 & 0.16 \\
\hline 41SM273, Z3 & 155 & 9.7 & 32.3 & 73.5 & 3.80 & 0.13 \\
\hline \multicolumn{7}{|c|}{ OLDEST SITE: GROUP VI, Early Caddo period, ca. A.D. 1000-1200 } \\
\hline Mitchell, A-C & 56 & 1.3 & 12.0 & 65.7 & 1.71 & 0.03 \\
\hline 41SM87 & 36 & 0.0 & $?$ & 69.4 & 4.44 & 0.00 \\
\hline
\end{tabular}

$\mathrm{P} / \mathrm{DR}=$ plain to decorated sherd ratio

* sites with Patton Engraved sherds

**site is in the adjoining Coon Creek/Catfish Creek drainage in the Trinity River basin

***unrecorded site in the Caddo Creek valley

?=information not provided in Anderson et al. (1974)

Using these sherd assemblage metrics to assess the temporal placement of the Caddo occupation at the M. S. Roberts site indicates that the occupation may well date to the latter part of the Middle Caddo period, given the relatively low proportion of brushed sherds and the proportion of other decorated wet paste sherds, or in Group IV, the earliest part of the Frankston phase (see Table 22), as had been previously suggested. Poynor Engraved, represented by several sherds in the assemblage, is primarily a Frankston phase (ca. A.D. 1400-1680) type, developing in a stylistic tradition that extends back some amount of time before A.D. 1400 (perhaps as early as ca. A.D. 1320 at several sites in the upper Neches River basin), and is also found on Caddo sites in the upper Neches that date after ca. A.D. 1680 (Perttula 2011:281). Given these archaeological findings and the overall character of the sherd metrics summarized in Table 22, we suggest that the Caddo occupation of the M. S. Roberts site may well have begun in the $14^{\text {th }}$ century, perhaps sometime after ca. A.D. 1300, and likely ended sometime in the early Frankston phase (Group IV). Clearly, a well-controlled series of calibrated radiocarbon dates are needed from both 
mound and habitation contexts at the site to definitively establish its age, and thus its relationship to other mound and non-mound sites along Caddo Creek and in the upper Neches River basin.

\section{Ceramic Pipe Sherd}

A single ceramic pipe sherd was recovered in the June 2015 work at the M. S. Roberts site. This was a plain grog-tempered elbow pipe bowl sherd from ST 21, 20-40 cm bs. A Var. B elbow pipe fragment found by a local collector may have come from the site (Figure 171). This elbow pipe form has a flaring bowl and a distal stem knob, with three horizontal engraved lines on the stem and lower bowl (Perttula 2011:215 and Figure 6-23). Such pipes have been found in ca. A.D. 1400-1560 contexts at a number of upper Neches River basin sites.

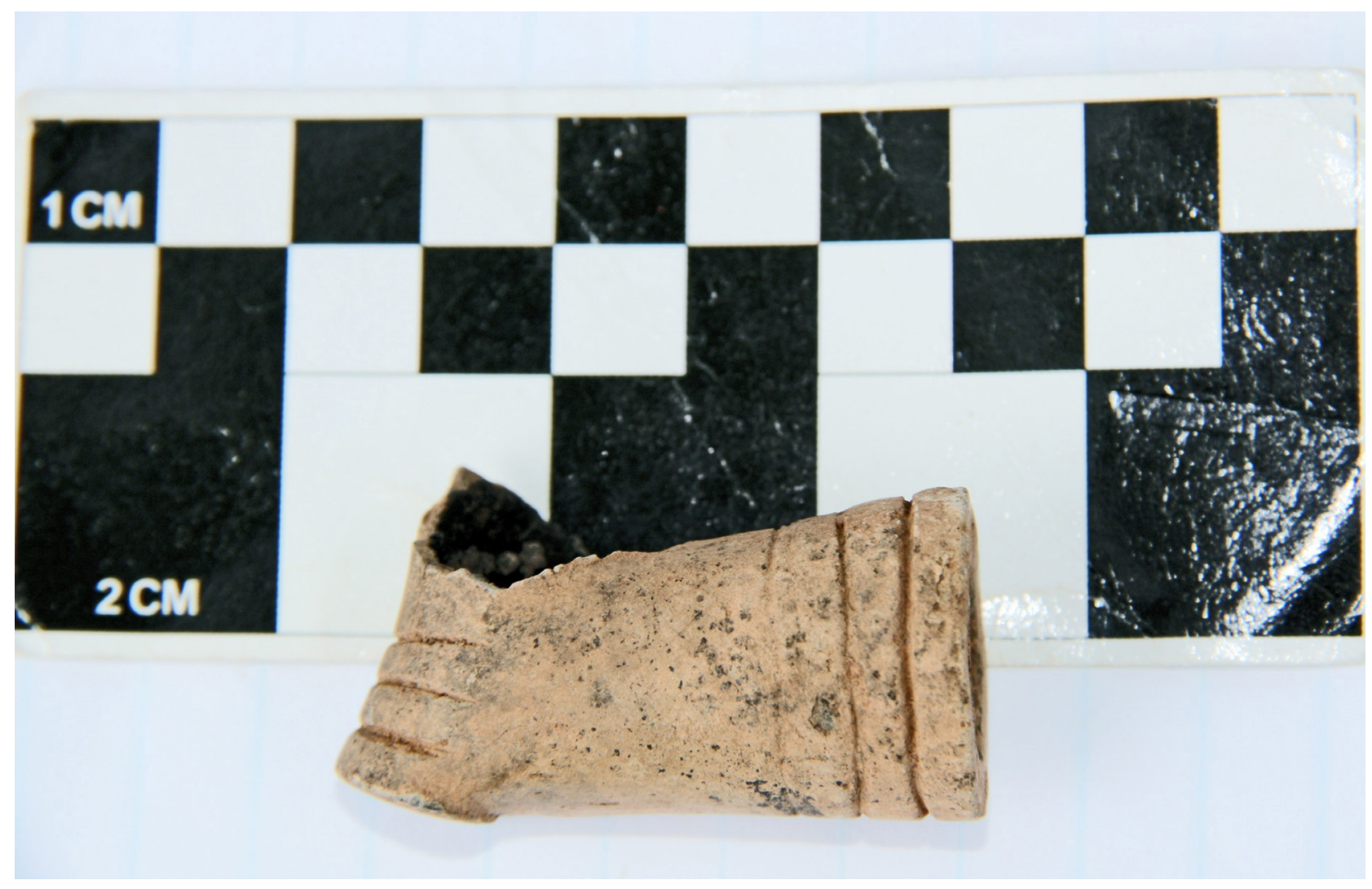

Figure 171. Var. B elbow pipe fragment reportedly from the M. S. Roberts site.

\section{Burned Clay Pieces}

One piece of burned clay was found between $20-40 \mathrm{~cm}$ bs in ST 21. It likely represents the remnants of cooking/heating activities associated with the use of an earth oven or cooking pit by the Caddo group living at the site.

\section{Lithic Artifacts}

Chipped stone lithic artifacts are uncommon in the recovered artifacts from the June 2015 investigations at the M. S. Roberts site. They include a bifacially flaked dark brown chert arrow point blade midsection from the surface of the site - the blade is serrated, $14.5 \mathrm{~mm}$ in maximum width, and $2.4 \mathrm{~mm}$ 
thick - and a possible unifacial gouge fragment from ST $17(0-20 \mathrm{~cm} \mathrm{bs})$ (Table 23). The possible tool fragment has flake removals at one end of the piece, and is made on a local ferruginous sandstone.

Table 23. Lithic artifacts recovered in the June 2015 archaeological investigations at the M. S. Roberts site.

\begin{tabular}{|c|c|c|c|}
\hline Provenience & Tool & Lithic Debris & $\mathrm{N}$ \\
\hline Surface & $\begin{array}{l}1 \text { arrow point } \\
\text { blade fragment }\end{array}$ & - & 1 \\
\hline ST B-4, 40-60 cm & - & 1-dark gray chert & 1 \\
\hline ST $1,20-40 \mathrm{~cm}$ & - & 1-gray chert & 1 \\
\hline ST $3,0-20 \mathrm{~cm}$ & - & 1-brown chert & 1 \\
\hline $\mathrm{ST} 4,0-20 \mathrm{~cm}$ & - & 1-grayish-brown chert & 1 \\
\hline ST $14,0-20 \mathrm{~cm}$ & - & 3-gray chert & 3 \\
\hline ST $15,0-20 \mathrm{~cm}$ & - & 1-petrified wood & 1 \\
\hline ST $16,20-40 \mathrm{~cm}$ & - & 1-gray chert & 1 \\
\hline ST $16,40-60 \mathrm{~cm}$ & - & 2-gray chert & 2 \\
\hline ST $17,0-20 \mathrm{~cm}$ & $\begin{array}{l}1 \text { possible gouge } \\
\text { fragment }\end{array}$ & - & 1 \\
\hline ST $20,20-40 \mathrm{~cm}$ & - & 1-ferruginous sandstone & 1 \\
\hline ST $21,0-20 \mathrm{~cm}$ & - & 1-reddish-brown chert & 1 \\
\hline Totals & 2 & 14 & 16 \\
\hline
\end{tabular}

A total of 14 pieces of lithic debris were recovered in 10 shovel tests, a mean density of 1.4 pieces per shovel test, or ca. 11.2 pieces of lithic debris per square meter. The highest densities (ca. 24 pieces per square meter) are in ST 14 and ST 16 to the east of the mound at the M. S. Roberts site (see Figure 168).

The majority of lithic debris is from gravel raw material sources in either the Neches or Trinity rivers. One piece of lithic debris in ST 16 (20-40 cm bs) has limestone cortex, suggesting it may have been flaked from a piece of gray chert from a Central Texas source. The lithic debris includes various colors of chert (86 percent), as well as petrified wood ( 7 percent), and ferruginous sandstone ( 7 percent). 


\section{Animal Bones}

There was one piece of burned animal bone recovered during the June 2015 work at the M. S. Roberts site. It was found in ST 20 between $0-20 \mathrm{~cm}$ bs.

In summary, the M. S. Roberts site (41HE8) is an ancestral Caddo mound center and habitation site near Caddo Creek in the upper Neches River basin. The site was first investigated by The University of Texas in 1931, and then forgotten by the archaeological community. The site was relocated in January 2015, thanks to access graciously provided by the landowners (who had known about the site for years), and the site appeared to be essentially intact and well-preserved. In June 2015, we initiated further archaeological study of the M. S. Roberts site, beginning with an aerial flyover using a drone to develop a detailed topographic map of the site as well as topographic profiles across the landform, along with shovel testing in mound and non-mound contexts, and the excavation of auger holes in the mound and a likely nearby borrow pit area. The shovel tests excavations were primarily designed to locate associated non-mound ancestral Caddo habitation deposits, while the auger holes were excavated to investigate the internal structure of the one known mound on the M. S. Roberts site.

The aerial survey delineated the mound and borrow pit features through examining the DEM and a 10 $\mathrm{cm}$ contour interval. The mound was visible as a slightly oblong feature extending from the baseline elevation to a maximum height of $91 \mathrm{~cm}$, with an aerial extent of $855 \mathrm{~m}^{2}$. The edges of the borrow pit show as a clear isolated depression visible extending from $56 \mathrm{~cm}$ below the baseline elevation to a maximum depth of $87 \mathrm{~cm}$. The aerial extent of the borrow pit is mapped as encompassing $2000 \mathrm{~m}^{2}$, although it is likely that the maximum extent of borrowing is larger. Based on these extents, the mound and borrow pit volumes were calculated relative to the baseline elevation, with the volume of the mound being 313.68 cubic meters, while the total volume represented by the known borrow pit area is 270.82 cubic meters, or 86 percent of the total estimated mound volume.

Shovel tests on the western side of the landform contained only a low density of prehistoric lithic debris of an unknown age. Shovel tests on the eastern side of the landform contain archaeological deposits from 0-60 $\mathrm{cm}$ bs with a considerable density of ancestral Caddo sherds. These shovel tests covered a ca. $100 \times 50 \mathrm{~m}$ area (ca. 1.2 acres, but the overall extent of the archaeological deposit at the site has not been established through the shovel testing effort; the habitation deposits likely extend to the east onto an adjoining property). These positive shovel tests indicate that there are habitation deposits in the near vicinity of the constructed mound at the site. The archaeological deposits in habitation areas at the M. S. Roberts site are at least $60 \mathrm{~cm}$ in thickness. The highest densities of artifacts occur from $20-40 \mathrm{~cm}$ bs, in deposits primarily below the plow zone; these deposits represent an intact and shallowly buried habitation zone, as may much of the $40-60 \mathrm{~cm}$ bs zone.

Auger holes were excavated in the mound as well as in a likely low borrow pit area about $20 \mathrm{~m}$ west of the northern part of the mound at the M. S. Roberts site. The profiles in the mound have a variety of mound fill zones, including sandy loams, clay loams, and a mixture of sandy loam and red and gray clay chunks. Two auger holes encountered a very dark sandy loam zone between 102-135 cm bs and 120-140 $\mathrm{cm}$ bs that may represent the remains of a burned structure encountered during the 1931 UT work. No clay floor was encountered in any of the auger holes, but significant amounts of gray clay chunks were noted between $83-119 \mathrm{~cm}$ bs in one of the auger holes. The base of the mound may lie at ca. $140 \mathrm{~cm} \mathrm{bs}$, with underlying dark yellowish-brown or yellowish-brown sandy loam or sand deposits representing the buried A- and E-horizons on the landform. 
A total of 248 artifacts have been recovered in the June 2015 archaeological investigations at the M. $\mathrm{S}$. Roberts site, including a general site surface collection. Twenty-one shovel tests contain archaeological remains, including plain and decorated sherds, one chipped stone tool fragment, lithic debris, one animal bone, burned clay, and one ceramic pipe sherd. More than 90 percent of the recovered artifacts are plain and decorated sherds from plain, utility, and fine ware vessels. The ceramic sherd assemblage is primarily composed of grog-tempered vessels, as 90.5 percent of the sherds are from vessels that have had grog temper added in their paste. The use of bone temper, either as the sole temper or in combination with grog, in the manufacture of vessels comprises 14.1 percent of the sherds.

Combining the various sherd assemblages obtained from the M. S. Roberts site, including the June 2015 work (see Perttula 2016a; Perttula and Walters 2016), especially the kind and proportion of decorated sherds, suggests that the occupation of the site by Caddo peoples may date to the latter part of the Middle Caddo period or the earliest part of the Late Caddo period Frankston phase. beginning in the $14^{\text {th }}$ century, perhaps sometime after ca. A.D. 1300, and ended sometime in the early Frankston phase, by ca. A.D. 1480). We hope that future work at the site can obtain a well-controlled series of calibrated radiocarbon dates from both mound and habitation contexts at the M. S. Roberts site to establish its age as well as its relationship to other mound and non-mound sites along Caddo Creek and in the upper Neches River basin.

Additional archaeological investigations at the M. S. Roberts site were completed in January 2016 (see Perttula et al. 2016). This included remote sensing (see McKinnon et al. 2016) of a 2.8 acre area over and around the mound, more shovel tests and the excavation of three $1 \times 1 \mathrm{~m}$ units (Units 1-3), and a surface reconnaissance of landforms to the east of the site to ascertain if the site boundaries continued to the east. The main purpose of the archaeological work was three-fold: (1) to better define the spatial extent of non-mound archaeological deposits; (2) to locate and sample well-preserved non-mound habitation deposits and obtain charred plant remains for AMS dating; and (3) investigate the stratigraphic character of the mound deposits, identify cultural features in the mound, and hopefully obtain charred plant remains or unburned animal bones from these deposits for AMS dating.

\section{E. Harold Fowler Farm (41HE82)}

The E. Harold Fowler farm site is near Poynor, Texas, in the Caddo Creek valley. A ceramic vessel from an ancestral Caddo burial was donated to UT in August 1926.

SITE NAME OR SITE NUMBER: E. Harold Fowler

VESSEL NO.: 1

VESSEL FORM: Bottle with a short neck

NON-PLASTICS AND PASTE: grog

RIM AND LIP FORM: Direct rim and a rounded lip

CORE COLOR: A (fired and cooled in an oxidizing environment)

INTERIOR SURFACE COLOR: light yellowish-brown

EXTERIOR SURFACE COLOR: light yellowish-brown; fire clouds on the rim and body 
WALL THICKNESS (IN MM): neck, $6.3 \mathrm{~mm}$ INTERIOR SURFACE TREATMENT: none

EXTERIOR SURFACE TREATMENT: burnished

HEIGHT (IN CM): 16.5

ORIFICE DIAMETER (IN CM): 3.7

DIAMETER AT BOTTOM OF RIM OR NECK (IN CM): 5.2; maximum body diameter is $9.2 \mathrm{~cm}$

BASE DIAMETER (IN CM) AND SHAPE OF BASE: 5.3; circular and flat

ESTIMATED VOLUME (IN LITERS): 0.35

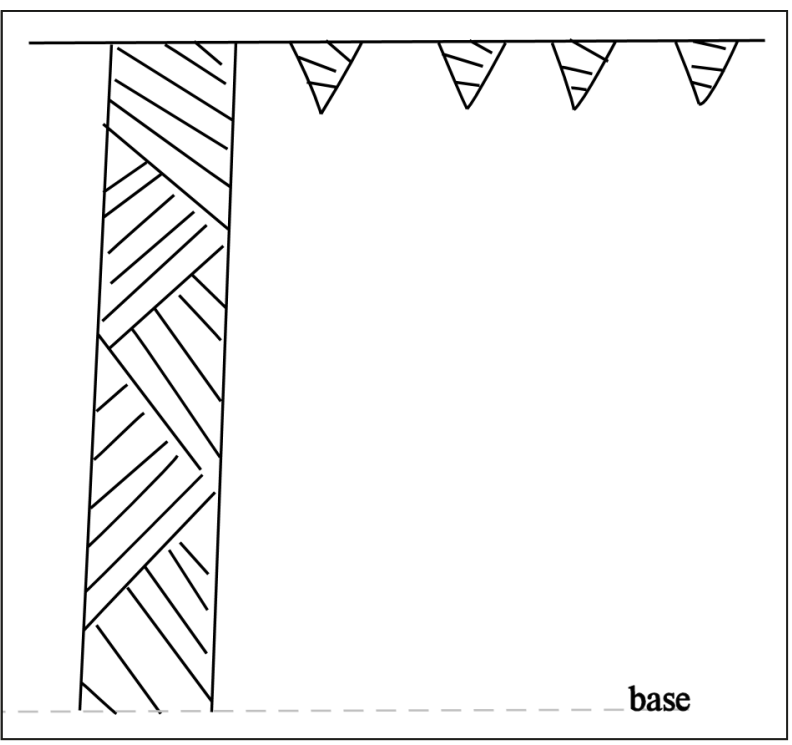

Figure 172. Decorative elements on Hume Engraved, var. unspecified bottle from the $\mathrm{E}$. Harold Fowler site (41HE82).

\section{DECORATION (INCLUDING MOTIF AND}

ELEMENTS WHEN APPARENT): The long and

narrow vessel body is divided into four panels by four narrow vertical engraved zones that run from the base of the neck to the vessel base. These vertical zones are filled with five sets of triangle elements filled with lines that are pitched in opposing directions from one triangle to the other (Figure 172). At the top of the panels and along the single horizontal engraved line at the base of the bottle neck are a series of either three (three times) or four (one time) engraved pendant triangles filled with diagonal hatched lines (Figure 172).

PIGMENT USE AND LOCATION ON VESSEL: red pigment in the engraved lines

TYPE AND VARIETY (IF KNOWN): Hume Engraved, var. unspecified (see Perttula 2011:Figure 6-66g)

The one ancestral Caddo ceramic vessel from the E. Harold Fowler site is a grog-tempered Hume Engraved, var. unspecified bottle. In the upper Neches River basin, Hume Engraved bottles tend to occur only in ca. A.D. 1480-1680 Frankston phase contexts (see Perttula 2011:Table 6-37).

\section{HE192}

This Caddo site was recorded during the 1970 archaeological survey of Lake Palestine, and was found on an alluvial terrace ( $420 \mathrm{ft}$. amsl) in the Caddo Creek drainage. The site was estimated to cover a ca. $40 \times 20 \mathrm{~m}$ area, and had ceramic sherds visible on the surface at the time of the survey.

\section{HE337}

Site 41HE337 is a Late Caddo settlement located on the north side of Caddo Creek, an eastwardflowing tributary to the Neches River, and just west of the city of Poynor, in Henderson County, Texas. Bill Young, an avocational archaeologist that lived in Corsicana, Texas, has a substantial collection of 
Caddo ceramic vessel sherds from the site. He gave his permission to study and document these materials as part of a broader study the senior author was then engaged in of post-A.D. 1300 Caddo ceramic traditions in the upper Neches River basin of East Texas (Perttula 2011).

Young's collection from 41HE337 consists of 485 sherds, including 24 rims, 24 bases, and 437 body sherds (Table 24). Proportionally, almost 70 percent of the sherds are plain wares, but this undoubtedly includes some plain body sherds and bases from the undecorated portions of the decorated utility wares and fine wares.

Table 24. Ceramic vessel sherds from $41 \mathrm{HE} 337$.

\begin{tabular}{lllll}
\hline Category & Rim & Body & Base & N \\
\hline Plain ware & 7 & 305 & 24 & 336 \\
Decorated Utility ware & & & & 28 \\
Incised & 3 & 25 & - & 28 \\
Punctated & 2 & 26 & - & 9 \\
Incised-punctated & 4 & 5 & - & 1 \\
Pinched & - & 1 & - & 52 \\
Brushed & - & 52 & - & 1 \\
Brushed-punctated & - & 1 & - & 2 \\
Appliqued & - & 2 & - & 25 \\
Fine ware & & & - & 2 \\
Engraved & 7 & 18 & - & \\
Lip notched & 1 & - & - & \\
Red-slipped & - & 2 & & \\
\hline
\end{tabular}

To reduce the ambiguity of sherd proportions because of the mix of plain vessel sherds and plain portions of decorated vessel sherds that may be present in the plain wares, a better comparison of the proportions of the different ceramic wares in the Caddo assemblage is the relative frequency of rim sherds (see Table 24). In this case, 29 percent of the rims are from plain vessels, another 37.5 percent are from utility wares (jars or bowls decorated with wet-paste designs, i.e., vessels decorated before firing), and the remaining 33.3 percent are from engraved or lip notched fine wares. On this basis, the proportion of the three wares at $41 \mathrm{HE} 337$ are quite comparable.

As the rim sherd proportions discussed above indicate, plain vessels comprise a significant proportion of the ceramic vessel sherds from 41HE337, including almost 30 percent of the rims. These plain wares appear to be from simple bowls - either smoothed and/or burnished on one or both vessel surfaces - that would have been used by the Caddo for holding and serving foods, most likely for individual use rather than communal use.

Overall, brushing is the most common form of decoration in the 41HE337 utility wares, comprising 43 percent of the utility wares (see Table 24). However, none of the brushed sherds are rims, strongly suggesting that brushed decorations in this assemblage are confined to the body of jars; the rims of those jars are most likely decorated with non-brushed elements, among them incised, incised-punctated, and 
punctated elements (see Table 24), as well as occasionally also being brushed. Brushing on vessel bodies tend to be vertically-oriented or with parallel brushing marks ( 90 percent) if the orientation is uncertain, but overlapping ( 2 percent), and opposed ( 8 percent) brushed body surfaces are also noted in the $41 \mathrm{HE} 337$ assemblage.

One sherd has parallel brushing on it, along with at least one row of tool punctations that have been pushed through the brushing. This kind of brushed-punctated decoration is relatively common in postA.D. 1350 Caddo ceramic assemblages in the Neches and middle Sabine river basins of East Texas.

Sherds with incised decorations $(n=28)$ comprise 23 percent of the utility wares. One Maydelle Incised rim has diagonal opposed lines (Figure 173a), a second Maydelle Incised rim has diagonal incised lines, while another rim has a vertical incised panel (Figure 173g). Body sherds have sets of parallel incised lines $(n=8)$, opposed incised lines $(n=4)$, cross-hatched incised lines $(n=3)$, and a single straight incised line $(\mathrm{n}=10)$.

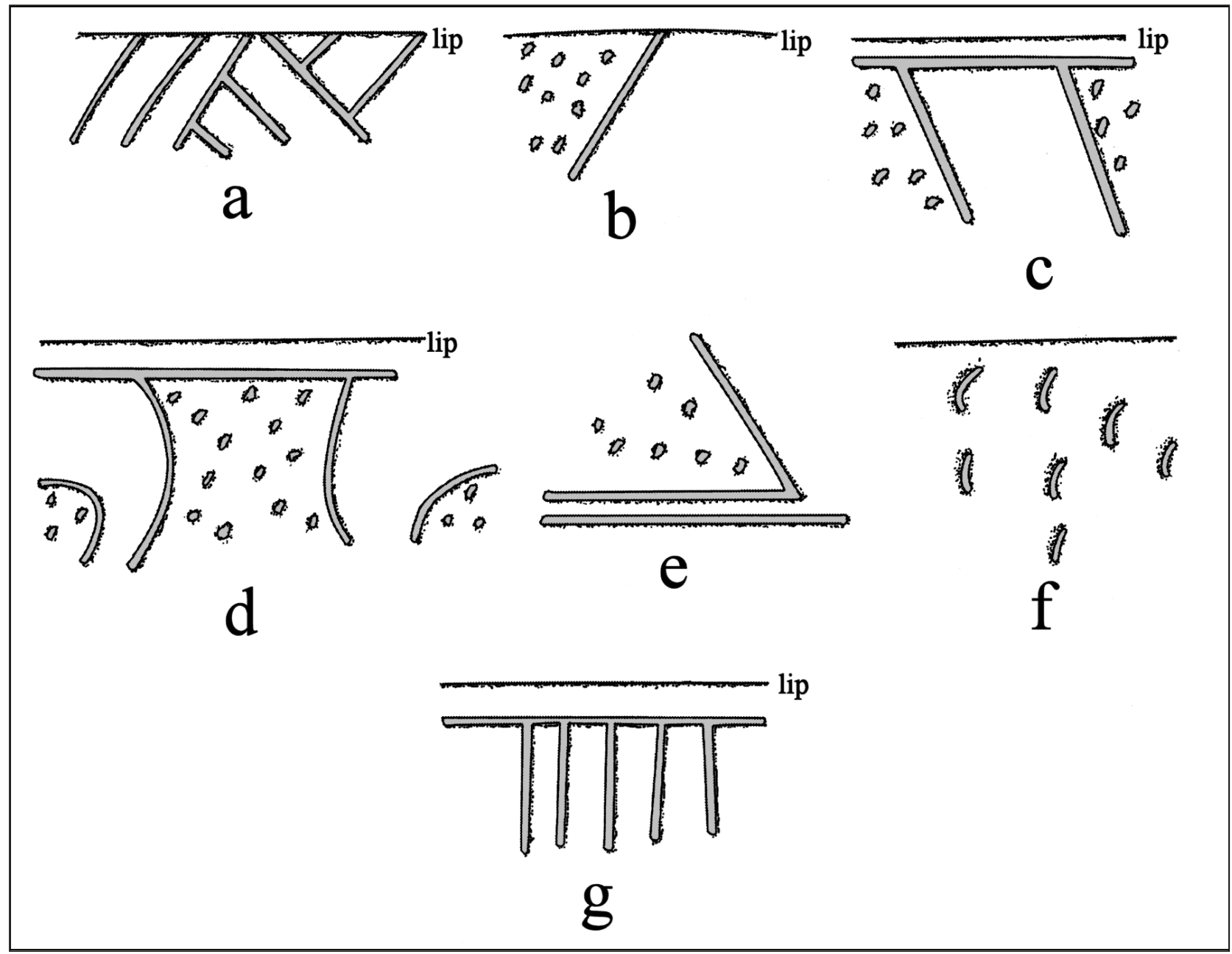

Figure 173. Selected decorative elements in utility wares from 41HE337: a, diagonal opposed Maydelle Incised rim; b, e, incised triangles filled with punctations; $c$, diagonal incised panels filled with tool punctations; $d$, curvilinear incised zones filled with tool punctations; $f$, straight incised line framing fingernail punctated-filled area; g, vertical incised panel. 
One incised-punctated body sherd is from a jar with diagonal incised lines on the rim and tool punctates on the vessel body. Two others have a single straight incised line framing a zone of fingernail punctates (see Figure 173f), and a third with a single straight incised line frames a zone of tool punctations.

Four of the nine incised-punctated sherds are rims of Maydelle Incised vessels; 67 percent of these sherds employ tool punctations as part of the decorative element. Two of these have incised triangles encircling the rim, and the triangles are either filled with tool punctations (see Figure 173e) or circular punctations (see Figure 173b); a body sherd also has a triangular incised zone filled with tool punctations. A third rim has diagonal incised panels filled with tool punctates (see Figure 173c), and the fourth has large and small curvilinear incised zones filled with tool punctates (see Figure 173d).

The 28 punctated sherds ( 23 percent of the utility wares), among them two rims, include 10 (36 percent) with rows of fingernail punctates and 18 (64 percent) with tool punctated rows; the proportion of tool versus fingernail punctation as part of the decorative element is almost exactly the same as seen in the incised-punctated utility wares. There is a single Killough Pinched body sherd in the 41 HE337 assemblage.

Two body sherds (1.6 percent) have straight appliqued ridges on them. These ridges are probably oriented vertically on the body of cooking jars, where their purpose was to divide the body into panels.

There are three kinds of fine wares at 41HE337: sherds from engraved vessels; sherds from redslipped bottles and bowls ( $n=2,7.1$ percent); and lip notched carinated bowl rims $(n=1,3.6$ percent) (see Table 24). The engraved sherds account for 89 percent of the fine wares. The vast majority of the engraved wares from the site are from Poynor Engraved (see Suhm and Jelks 1962) carinated bowls, with decorative motifs encircling the rim panel.

One of the rims from a carinated bowl has a series of horizontal engraved lines, a second has both horizontal and opposed lines (Figure 174b), while another has a hatched triangular zone along one side of an oval-shaped area (Figure 174h). Two others only have diagonal engraved lines on the rim. One rim peaked vessel has both a hatched triangular element (i.e., the quintessential Poynor Engraved decorative element) adjacent to an oval or semi-circular area that is bisected by a series of diagonal engraved lines (Figure 174g). The most unique engraved rim, resembling var. $S$ in the upper Neches River basin Poynor Engraved series (Perttula 2011), has a single horizontal engraved line just below the lip as well as diagonal lines reaching from near the lip to the carination; one of these engraved lines has a set of pendant semi-circles (Figure 174a). Var. $S$ of Poynor Engraved is found in low frequencies in ca. A.D. 1400-1480 Frankston phase sites in the upper Neches (Perttula 2011:Table 6-37).

The body sherds with engraved elements include a number with simple geometric elements: horizontal lines $(n=1)$, diagonal lines $(n=1)$, parallel lines $(n=4)$, and single straight line $(n=3)$. There are also hatched ladder elements $(n=1$, see Figure 174f), ovals $(n=1)$, hatched triangles and circles $(n=1$, see Figure 174e), and nested triangles (see Figure 174c). This particular sherd resembles var. E of Poynor Engraved, a post-A.D. 1480 variety in the upper Neches River basin (Perttula 2011:Table 6-37).

Two other sherds have only hatched triangles. One other, from a carinated bowl, has hatched triangles at the end of a scroll element (see Figure 174d). The last remaining carinated bowl engraved sherd from 41HE337 has horizontal engraved lines and a circle element. 


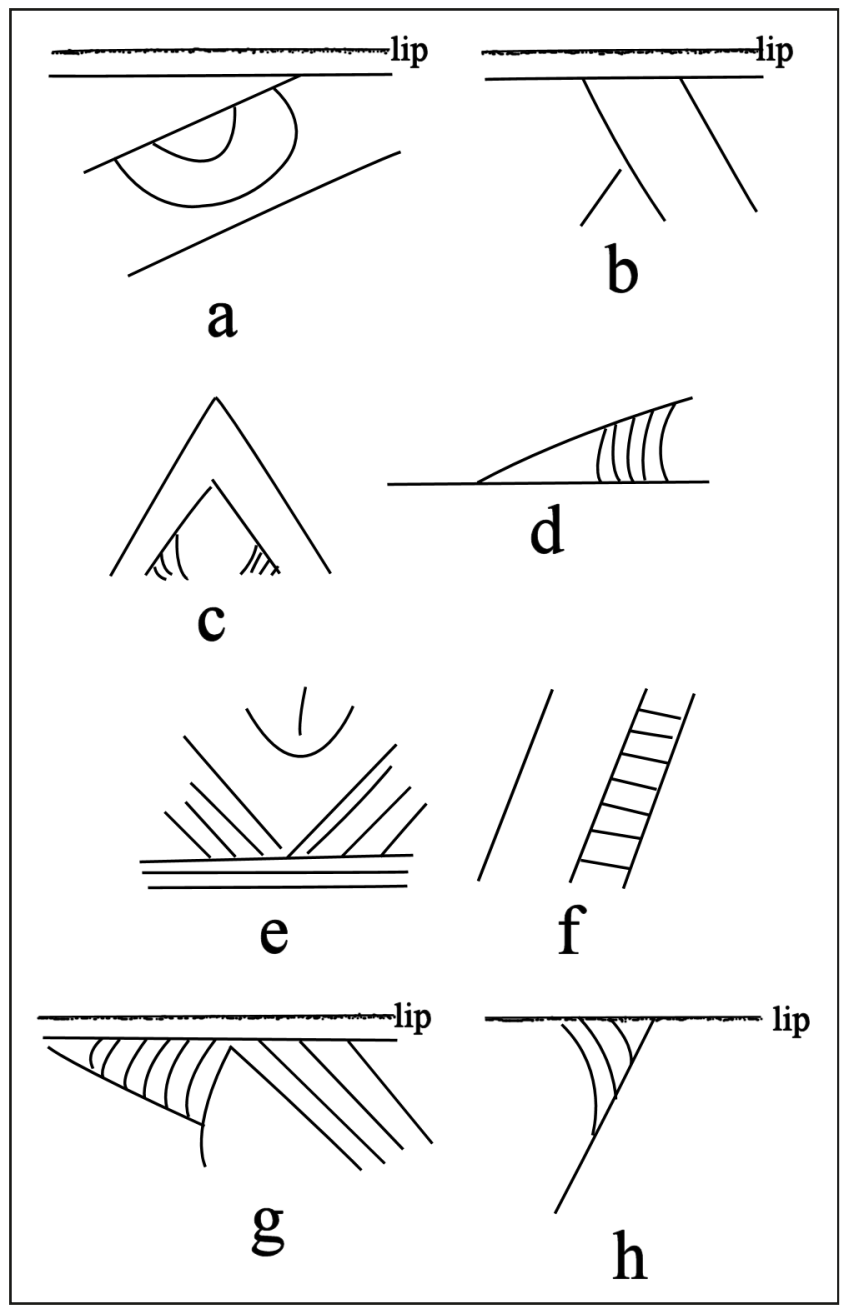

Figure 174. Selected decorative elements on engraved fine ware sherds from 41HE337: a, horizontal and diagonal semi-circle (Poynor Engraved); b, horizontal and opposed engraved lines; c, nested triangle (Poynor Engraved); d, hatched scroll element (Poynor Engraved); e, hatched triangles and circle (Poynor Engraved); f, hatched ladder; $\mathrm{g}$, hatched triangle and diagonal engraved lines (Poynor Engraved); h, hatched triangle (Poynor Engraved).
There is only a single bottle sherd in the engraved fine ware sherd sample from 41HE337. This has an excised triangle element pendant from a straight line.

Red-slipped sherds in the 41HE337 ceramic assemblage are from two different vessels. The first is a red-slipped (on both interior and exterior vessel surfaces) bowl or carinated bowl, and the second is from a bottle with an exterior red slip. In general, red-slipped vessels are rarely seen in post-A.D. 1300-1400 upper Neches River basin Caddo sites.

The one lip notched rim (inverted rim with a beveled lip) has a regular series of notches cut into the lip. Examination of a large series of whole vessels from the upper Neches River basin suggests that lip notching (usually accompanying an engraved design on the rim panel) was a minor decorative element principally in post-A.D. 1480 Frankston phase contexts (Perttula 2011), but it has also been found in earlier habitation contexts in the basin, including among the ceramic sherds in the northern area (ca. A.D. 1320-1400) at the Lang Pasture site (41AN38).

One of the technological features of the post-A.D. 1300 upper Neches River basin Caddo ceramic tradition is the reliance by Caddo potters on the use of grog as the principal tempering aplastic (Perttula 2011). Such is the situation in the ceramic assemblage at 41HE337, where only 5.6 percent of the ceramic vessel sherds have bone temper inclusions (Table 25). Only the plain wares (i.e., bowls used in food serving) and decorated utility wares (i.e., used in cooking and storage tasks) at the site have bone-tempered vessels. 
Table 25. Use of bone temper in the different ceramic wares at $41 \mathrm{HE337.}$

Ware No. of sherds Percent of sherds with bone temper

\begin{tabular}{lll}
\hline Plain ware & 336 & 5.9 \\
Utility ware & 121 & 5.8 \\
Fine ware & 28 & 0.0
\end{tabular}

\begin{tabular}{ll} 
Total & 485 \\
\hline
\end{tabular}

The range of decorative elements and motifs in the utility ware and fine ware vessel sherds from $41 \mathrm{HE} 337$, as well as the infrequent use of bone-tempering in vessel manufacture, indicate that the prehistoric ceramic vessel sherds here are from a $15^{\text {th }}$ century and early Frankston phase occupation. The character of this assemblage is consistent with other documented Caddo sites in the upper Neches River basin that are part of a distinctive post-A.D. 1300 ceramic tradition.

In particular, the ceramic vessel assemblage from 41HE337 includes a number of plain ware vessel sherds, as well as decorated utility wares and fine wares. The utility wares are dominated by incised and incised-punctated Maydelle Incised jars, some of which had been brushed on the vessel body, as well as tool or fingernail punctated jars. There is one Killough Pinched body sherd. The fine wares-including one engraved bottle sherd, two red-slipped sherds, and a well-executed lip notched rim-are dominated by Poynor Engraved carinated bowl sherds, as is the case at all upper Neches River basin Frankston phase sites. These vessels have panels of engraved ovals, semi-circles, and nested triangles, as well as distinctive hatched triangle elements.

\section{$41 H E 338$}

This site was first recorded in 1995 by Dr. James E. Corbin on the basis of information provided by a local avocational archaeologist (Goodmaster 2015:45). In 2015, the site was relocated as part of the archaeological survey of the expansion to U.S. 175 and 22 shovel tests were excavated at $20 \mathrm{~m}$ intervals across a generally flat upland interfluve north of Caddo Creek. The seven positive shovel tests excavated there indicated that the site covered a ca. 5300 square meter area (ca. 1.3 acres) of the proposed U.S. 175 ROW expansion (Goodmaster 2015:45).

A low density of prehistoric artifacts were recovered between $0-60 \mathrm{~cm}$ bs in the shovel tests: 1.0 artifact per positive shovel test. This included six pieces of lithic debris and one plain grog-tempered body sherd. Subsequent to the Goodmaster (2015) survey, TxDOT archaeologists examined the eastern extent of the proposed ROW, an area that was not investigated in any detail during the earlier archaeological survey, and identified intact Late Caddo period Frankston phase archaeological deposits (Goodmaster 2015:48). Data recovery work in these deposits were completed in May 2015, and the ancestral Caddo archaeological deposits are of Late Caddo period, Frankston phase age (Chris Goodmaster, June 2015 and March 2016 personal communications), based on the character of the decorated sherd assemblage and radiocarbon dates from two features. 
A small collection of Caddo sherds were noted by the authors on the surface of smoothed down back dirt piles at the site in June 2015. This included four plain grog-tempered rim, body, and base sherds, and four grog-tempered body sherds with either parallel or vertical brushing marks. A sample of the Caddo ceramic sherd assemblage from the 2015 data recovery work was analyzed in March 2016.

The 2016 sample of ceramic vessel sherds under consideration from 41HE338 was chosen by Christopher Goodmaster (Versar, Inc.) in consultation with the Texas Department of Transportation. It is designed to represent a 17.78 percent sample of the known ceramic vessel sherd assemblage, and includes 398 plain and decorated body sherds and 132 sherdlets $(<1.5 \mathrm{~cm}$ on length and width); the sherdlets were counted but not further analyzed (Table 26).

Table 26. General characteristics of the 17.78 percent sherd sample* from $41 \mathrm{HE338}$.

\begin{tabular}{lllcl}
\hline Unit & Levels & Plain Sherds & Decorated Sherds & N \\
\hline 13 & lv. $4-5$ & 1 & 1 & 2 \\
14 & lv. 3 & 1 & 1 & 2 \\
28 & lv. $1-6$ & 20 & 28 & 48 \\
30 & lv. $1-7$ & 34 & 34 & 68 \\
39 & lv. $2-4,6-7$ & 17 & 9 & 26 \\
41 & lv. $2-6$ & 22 & 16 & 38 \\
50 & lv. $1-5,7$ & 11 & 13 & 24 \\
51 & lv. $1-7$ & 12 & 12 & 24 \\
52 & lv. $1-5$ & 11 & 22 & 56 \\
53 & lv. $1-7$ & 34 & 24 & 47 \\
56 & lv. $1-7$ & 23 & 20 & 38 \\
77 & lv. $1-7$ & 18 & & 398 \\
\hline
\end{tabular}

*does not include 132 sherdlets present in these units and levels

The plain to decorated sherd ratio in the 17.78 percent sample is 1.05 . Approximately 97.5 percent of the sherds are from grog-tempered vessels, and the remainder have burned bone temper inclusions. Vessel forms represented in the sherds include bottles, bowls, carinated bowls, and jars.

The largest samples of decorated sherds are in Units 30, 28, 53, 56, and 77 (Table 27), with between 20-34 decorated sherds per unit. These contiguous units are in the north central part of the block excavations. A total of 11 different decorative methods are represented in the 194 decorated sherds, seven decorative methods from utility wares with wet paste decorations and four decorative methods from fine wares. The sherds from utility ware vessels comprise 78.4 percent of the analyzed decorated sherd sample, and the remaining 21.6 percent are from fine ware vessels. 
Table 27. Decorated sherds in 17.78 percent sample from $41 \mathrm{HE338.}$

\begin{tabular}{|c|c|c|c|c|c|c|c|c|c|c|c|}
\hline Unit & B & B-I & B-P & I & I-P & $\mathrm{tP}$ & $\mathrm{fP}$ & $\mathrm{E}$ & E-P & $\begin{array}{l}\mathrm{RS} / \\
\mathrm{BS}\end{array}$ & $\mathrm{N}$ \\
\hline 13 & - & - & - & - & - & - & - & 1 & - & - & 1 \\
\hline 14 & 1 & - & - & - & - & - & - & - & - & - & 1 \\
\hline 28 & 13 & 3 & - & 6 & 1 & 1 & 1 & 2 & - & $1 /-$ & 28 \\
\hline 30 & 13 & 1 & - & 7 & 4 & 2 & 1 & 6 & - & - & 34 \\
\hline 39 & 3 & 1 & - & 1 & - & - & - & 4 & - & - & 9 \\
\hline 41 & 6 & - & - & 3 & - & 1 & - & 5 & 1 & - & 16 \\
\hline 50 & 7 & 1 & - & - & - & 1 & - & 3 & - & $1 /-$ & 13 \\
\hline 51 & 4 & - & 1 & 4 & - & 2 & - & 1 & - & - & 12 \\
\hline 52 & 5 & - & - & 2 & 1 & 1 & - & 4 & - & $1 /-$ & 14 \\
\hline 53 & 7 & - & 1 & 6 & 1 & - & 1 & 3 & - & $1 / 2$ & 22 \\
\hline 56 & 9 & 3 & - & 6 & 2 & 1 & - & 3 & - & - & 24 \\
\hline 77 & 8 & 5 & - & 4 & - & - & - & 2 & 1 & - & 20 \\
\hline Totals & 76 & 14 & 2 & 39 & 9 & 9 & 3 & 34 & 2 & $4 / 2$ & 194 \\
\hline
\end{tabular}

$\mathrm{B}=$ brushed; $\mathrm{B}-\mathrm{I}=$ brushed-incised; $\mathrm{B}-\mathrm{P}=$ brushed-punctated; I=incised; I-P=incised-punctated; $\mathrm{P}=$ =tool punctated; $\mathrm{PP}=$ fingernail punctated; $\mathrm{E}=$ =ngraved; $\mathrm{E}-\mathrm{P}=$ engraved-punctated; $\mathrm{RS}=$ red slipped; $\mathrm{BS}=$ black slipped.

Sherds with brushed decorative elements - either as the sole decorative treatment or in combination with either incised or punctated elements - comprise 47.4 percent of the decorated sherds in the 17.78 percent sample (see Table 27); these sherds are from Bullard Brushed vessels (see Suhm and Jelks 1962). Sherds from vessels decorated with incised lines account for another 20.1 percent of the assemblage, and 4.6 percent are from vessels with incised-punctated decorative elements. These are from Maydelle Incised vessels, with the exception of four sherds from what have been dubbed Poynor Incised vessels (i.e., the distinctive motifs are executed with incised lines rather than with engraved lines); the Poynor Incised sherds occur in level 1 , level 3 , level 4 , and level 6 deposits. Only 6.2 percent of the decorated sherds in this sample are from utility ware vessels decorated with either tool or fingernail punctated elements.

The engraved fine ware sherds account for 17.5 percent of the decorated sherd assemblage (see Table 27). These are from several varieties of Poynor Engraved, and there is one sherd from a Hood Engraved bowl with a scalloped lip. Another 1.0 percent have engraved-punctated elements; these latter sherds may be from either Poynor Engraved. var. Blackburn or var. Lang vessels (see Perttula 2011:Figure 6-64b', g). Poynor Engraved and Hood Engraved sherds are Late Caddo period, Frankston phase ceramic types. The identified varieties of Poynor Engraved include var. Blackburn, and var. Cook, as well as regional varieties A, E, F, and R (see Perttula 2011:Figure 6-65). These varieties are known from ca. A.D. 1400-1560 contexts in upper Neches River basin sites. The absence of Poynor Engraved, var. Hood or var. Lang (Perttula 2011:Table 6-37) suggest the ancestral Caddo occupation at 41HE338 predates ca. A.D. 1480.

By depth, the uni-modal distribution of decorated sherds indicates that the highest densities of decorated sherds occur in levels 2-4, from $10-40 \mathrm{~cm}$ bs (Table 28). These levels represent the A2 horizon and the upper part of the E horizon sediments identified in the excavations at 41HE338. Although it is likely 
that the vertical distribution of sherds is affected to some degree by pedoturbations processes, changes in the proportional representation of decorated sherd classes by level suggests differences in the assemblages between $0-40 \mathrm{~cm}$ bs and $40-70 \mathrm{~cm}$ bs that may have subtle temporal significance in the Frankston phase component.

Table 28. Depths of decorated sherds by level at 41HE338.

$\begin{array}{llllllllllll}\text { Level B } & \text { B-I } & \text { B-P } & \text { I } & \text { I-P } & \text { tP } & \text { fP } & \text { E } & \text { E-P } & \text { RS/ } & \text { N }\end{array}$

\begin{tabular}{|c|c|c|c|c|c|c|c|c|c|c|c|}
\hline & & & & & & & & & \multicolumn{3}{|c|}{ BS } \\
\hline 1 & 3 & 1 & - & 2 & 1 & 1 & - & $\underline{4}$ & - & - & 12 \\
\hline 2 & 15 & 5 & 1 & 9 & 1 & 2 & - & $\overline{5}$ & - & - & 38 \\
\hline 3 & $\underline{21}$ & 1 & - & 7 & $\underline{4}$ & 2 & 1 & 9 & - & $1 /-$ & 46 \\
\hline 4 & $\overline{17}$ & 1 & - & $\underline{12}$ & $\overline{3}$ & 2 & $\underline{\mathbf{2}}$ & 6 & 1 & - & 44 \\
\hline
\end{tabular}

\begin{tabular}{|c|c|c|c|c|c|c|c|c|c|c|}
\hline 5 & $\underline{10}$ & $\underline{4}$ & - & 1 & - & $\underline{\mathbf{2}}$ & - & 3 & - & $\underline{1 / 1}$ \\
\hline 6 & 6 & - & $\underline{1}$ & $\underline{6}$ & - & - & - & 3 & $\underline{1}$ & $\underline{1 / 1}$ \\
\hline 7 & 4 & $\underline{\mathbf{2}}$ & - & 2 & - & - & - & 4 & - & $1 /-$ \\
\hline
\end{tabular}

$\begin{array}{llllllllllll}\text { Totals } & 76 & 14 & 2 & 39 & 9 & 9 & 3 & 34 & 2 & 4 / 2 & 194\end{array}$

$\mathrm{B}=$ brushed; $\mathrm{B}-\mathrm{I}=$ brushed-incised; $\mathrm{B}-\mathrm{P}=$ brushed-punctated; $\mathrm{I}=$ incised; $\mathrm{I}-\mathrm{P}=$ incised-punctated; $\mathrm{P}=$ tool punctated; $\mathrm{fP}=$ fingernail punctated; $\mathrm{E}=$ =ngraved; $\mathrm{E}-\mathrm{P}=$ engraved-punctated; $\mathrm{RS}=$ red slipped; $\mathrm{BS}=\mathrm{black}$ slipped.

Note: bold and underlined column numbers represent the highest proportions of each decorative class regardless of level

Brushed, incised, tool punctated, and engraved sherds are equally common in both 0-40 $\mathrm{cm}$ and 40$70 \mathrm{~cm}$ contexts (Table 29). However, the highest proportion of brushed-incised, brushed-punctated, engraved-punctated, red-slipped, and black-slipped sherds occur in the $40-70 \mathrm{~cm}$ bs deposits, even though they are present in both subsurface contexts. Incised-punctated and fingernail punctated sheds occur only in $0-40 \mathrm{~cm}$ deposits.

Table 29. Changes by depth in proportional representation of decorated sherd classes at $41 \mathrm{HE} 338$.

\begin{tabular}{llllllllllll}
$\begin{array}{l}\text { Depth } \\
\text { (cm bs) }\end{array}$ & B & B-I & B-P & I & I-P & tP & fP & E & E-P & $\begin{array}{l}\text { RS/ } \\
\text { BS }\end{array}$ & N \\
\hline $0-40$ & $40.0^{*}$ & 5.7 & 0.7 & 21.4 & 6.4 & 5.0 & 2.1 & 17.1 & 0.7 & $0.7 /-$ & 140 \\
$40-70$ & 37.0 & 11.1 & 1.8 & 16.7 & - & 3.7 & - & 18.5 & 1.8 & $5.6 /$ & 54 \\
& & & & & & & & & & 3.7 &
\end{tabular}

*percentage

$\mathrm{B}=$ brushed; $\mathrm{B}-\mathrm{I}=$ brushed-incised; $\mathrm{B}-\mathrm{P}=$ brushed-punctated; $\mathrm{I}=$ incised; $\mathrm{I}-\mathrm{P}=$ incised-punctated; $\mathrm{tP}=$ tool punctated; $\mathrm{P}=$ =fingernail punctated; $\mathrm{E}=$ engraved; $\mathrm{E}-\mathrm{P}=$ engraved-punctated; $\mathrm{RS}=$ red slipped; $\mathrm{BS}=\mathrm{black}$ slipped. 


\section{Sherds from Features and Other Contexts}

The analyzed sherd sample from 41HE338 also includes 10 sherds from grog-tempered vessels and 6 sherdlets from Features 3, 4, 5, 6, 8, 9, 10, and 12. Features 6 and 10 have four sherds, and Features 3 and 9 each have one sherd. The Feature 3 sherd is a parallel brushed body sherd, while Feature 6 has one parallel brushed body sherd and a Poynor Engraved rim sherd with horizontal and closely-spaced diagonal engraved lines. Feature 9 also has a Poynor Engraved sherd with a red-slipped surface. Finally, Feature 10 has a parallel brushed body sherd and a body sherd with parallel engraved lines.

Of the six decorated sherds from features at 41HE338, 50 percent are from brushed vessels; this is not much different than the proportion of brushed sherds in the larger 17.78 percent sample (47.4 percent). Two others are from Poynor Engraved vessels; Poynor Engraved is the principal fine ware in Late Caddo period Frankston phase contexts in the upper Neches River basin, and the primary identified fine ware in the 41HE338 sample. The feature sherds appear to be the product of the same occupation that created the non-feature ceramic assemblage at the site.

Another 12 sherds are from other contexts at the site, including several sherds (FS 615, FS 621, and FS 633) found in the scraping effort after the block excavations were concluded. All these sherds are from grog-tempered vessels. Most of the sherds are from FS 621 (20-30 cm bs). Most are rim (one large conjoined sherd) and body sherds $(n=5)$ from a large Maydelle Incised jar with opposed incised triangles on the rim filled with tool punctations; the vessel body has horizontal brushing marks. A seventh sherd is a rim with diagonal engraved lines, and the eighth sherd is a plain body sherd with a preserved organic residue on its exterior surface. The four remaining sherds from other contexts include a Killough Pinched body sherd (FS 615, $35 \mathrm{~cm}$ bs), a diagonal incised Maydelle Incised rim (FS 633, 20-30 cm bs), a Bullard Brushed jar sherd with parallel and overlapping brushing marks (Unit 29, level 6), and an incised-punctated Maydelle Incised rim sherd (Unit 57, level 5). This rim has opposed incised triangles, one triangle filled with diagonal incised lines and a second visible triangle filled with rows of linear tool punctations. These sherds also appear to be the product of the same Frankston phase occupation that created the nonfeature ceramic assemblage at the site.

\section{Use of Pigments}

Only 2.8 percent of the engraved and engraved-punctated sherds in the 17.78 percent sample from $41 \mathrm{HE} 338$ have a red ochre-rich pigment rubbed in the engraved lines. Another sample of 23 engraved sherds from non-sample units has a higher proportion of red pigment use: 34.8 percent. The exclusive use of red pigment on fine ware vessels is consistent with a pre-A.D. 1560 age, based on the analysis of red versus white pigment use in upper Neches River basin Caddo sites (Perttula 2011:279 and Table 6-34).

\section{Elbow Pipe Sherds}

A total of 14 ceramic pipe sherds, many rather small in size, have been identified in the 41HE338 assemblage (Table 30). All but one pipe sherd are from $20-40 \mathrm{~cm}$ bs. The pipes have been manufactured with grog temper. 
Table 30. Pipe sherds from $41 \mathrm{HE338.}$

\begin{tabular}{|c|c|c|c|}
\hline $\begin{array}{l}\text { Provenience } \\
\qquad(\mathrm{mm})\end{array}$ & Characteristics & Temper & Wall Thickness \\
\hline Unit 16, lv. 2 & elbow pipe bowl & grog & 5.6 \\
\hline Unit 23, lv. 3 & elbow pipe bowl & grog & 3.4 \\
\hline Unit $32,1 v .4$ & $\begin{array}{l}\text { elbow pipe bowl rim, } \\
\text { tool punctated rows }\end{array}$ & grog & 5.3 \\
\hline Unit $43,1 v .4$ & unidentified pipe sherd & grog & 2.3 \\
\hline Unit $52,1 \mathrm{v} .4$ & elbow pipe bowl & grog & 3.1 \\
\hline Unit 53,1 v. 5 & elbow pipe bowl & grog & 3.6 \\
\hline Unit $58,1 v .2$ & unidentified pipe sherd & grog & 2.5 \\
\hline Unit 59, lv. 4 & $\begin{array}{l}\text { elbow pipe basal knob, } \\
\text { singe diagonal incised line }\end{array}$ & grog & 5.4 \\
\hline Unit $63,1 v .2$ & unidentified pipe sherd & grog & 3.8 \\
\hline Unit $63,1 v .3$ & unidentified pipe sherd & grog & 2.1 \\
\hline Unit $64,1 v .3$ & elbow pipe bowl & grog & 3.8 \\
\hline Unit 69, lv. 3 & unidentified pipe sherd & grog & 3.0 \\
\hline \multirow[t]{2}{*}{ Unit 70, lv. 3} & elbow pipe bowl & grog & 3.9 \\
\hline & unidentified pipe sherd & grog & 1.9 \\
\hline
\end{tabular}

Where their form can be identified, the pipe sherds are from elbow pipes, at least one with a basal knob (see Perttula 2011:Figure 6-23). Two of the pipe sherds have decorative elements: a single diagonal incised line on the basal knob, suggesting that this sherd is from a Var. B or Var. C elbow pipe, and three or more rows of small tool punctations below the lip of the bowl; this pipe is probably from what has been referred to as a Neche pipe (Perttula 2011:215)

In summary, the analysis of ceramic sherds $(n=398)$ from a 17.78 percent sample of the 41 HE338 ceramic assemblage (as well as 22 sherds from features and other contexts) indicates that vessels at the site were almost exclusively made from a grog-tempered clay paste. The ceramic vessel sherd assemblage has a high proportion of decorated sherds to plain sherds (plain to decorated sherd ratio [P.DR] of 1.05) and almost 80 percent of the decorated sherds are from utility ware vessels. Almost half of the decorated sherds have brushed decorative elements, either as the sole decoration or in combination with incised lines or punctations. Sherds from the following defined ceramic types are in the 41HE338 assemblage: Bullard Brushed, Hood Engraved, Killough Pinched, Maydelle Incised, Poynor Incised, and Poynor Engraved; all are ceramic types made and used in the upper Neches River basin in Late Caddo period Frankston phase components (ca. A.D. 1400-1680).

Sherd assemblage data from more than 40 ancestral Caddo components in the upper Neches River basin that date from ca. A.D. 1000 to post-A.D. 1680 also indicate that the Caddo occupation at 41HE338 took place during the Frankston phase (see Table 22). Differences in these assemblages in the percentage of brushed sherds among the decorated sherds, the proportion of other wet paste/utility ware sherds, the P/DR, the occurrence of Patton Engraved sherds, and the ratio of brushed sherds to other wet paste sherds has led to the definition of six groups, from oldest (Group VI) to youngest (Group I). Using these ceramic metrics, the decorated sherd assemblage from 41HE338 represents one of a number of early Frankston phase components (Group IV) in the upper Neches River basin. These components are estimated to date from ca. A.D. 1400-1480. 
Further confirmation of the ca. A.D. 1400-1480 age of the 41HE338 Frankston phase component comes from three calibrated dates (at 2 sigma) from site features: A.D. 1400-1440, A.D. 1405-1445, and A.D. 1430-1485. Also consistent with this likely age range for the occupation are a Perdiz arrow point and a Perdiz arrow point preform from $20-30 \mathrm{~cm}$ bs, and the recovery of 13 of the 14 plain and decorated elbow pipe sherds from $0-40 \mathrm{~cm}$ bs in the archaeological deposits.

\section{$41 H E 396$}

This Caddo site was recorded in 2012 during the survey of the TRWD Integrated Pipeline Project. It is on an upland ridge top and covers a ca. $100 \times 85 \mathrm{~m}$ area $(2.1$ acres). A few shovel tests were excavated at the site and nine ceramic sherds were recovered from $0-40 \mathrm{~cm}$ bs in two of the shovel tests (Miller et al. 2014:487-489 and Figure 9.210); inexplicably, the site form stated that 20 ceramic sherds were recovered from the site along with a biface fragment. Miller et al's (2014) description of the recovered ceramic sherds are so perfunctory as to be analytically worthless, only mentioning their tan and gray color, but not their temper. Furthermore, the report does not note if any of the ceramic sherds had decorative elements, and it appears that the sherds were returned to their shovel tests when they were backfilled, an all too common CRM practice these days, rather than being recovered for proper study and eventual curation.

\section{The Walter Brigham Site (41HE410) Bo Nelson, Mark Walters, Kevin Stingley, and Timothy K. Perttula}

The Walter Brigham site (41HE410) is an ancestral Caddo site located a short distance east of the M. S. Roberts site (41HE8). It was recorded during a January 2016 surface reconnaissance of landforms north of Caddo Creek in the upper Neches River basin, in an attempt to determine the spatial extent of the M. S. Roberts site.

This site is on a grass-covered lower ridge slope of an upland landform (400 ft. amsl), about $200 \mathrm{~m}$ west of a southward-flowing tributary of Caddo Creek. The landform has Wolfpen loamy fine sand sediments. The surface reconnaissance of the landform indicates the site covers a ca. 110 x $130 \mathrm{~m}$ area $(3.5$ acres) area; no shovel testing was conducted at that time to determine the depth or extent of its subsurface archaeological deposits.

Archaeological materials recovered in gopher mounds and other surface exposed areas includes 16 Caddo ceramic vessel sherds and 12 pieces of lithic debris. The ceramic sherds are from grog $(n=13,81$ percent) and grog-bone ( $n=3,19$ percent)-tempered vessels. There are six plain body sherds, one grog-tempered base sherd, and nine sherds from decorated vessels; the plain to decorated sherd ratio in this small assemblage is 0.78 . Two of the sherds are from engraved fine ware vessels, including a rim with a horizontal engraved line beneath the lip and a body sherd with parallel engraved lines. The utility ware sherds include a body sherd with a single straight incised line and six body sherds with parallel brushing marks; these sherds are from Bullard Brushed vessels. The proportion of brushed sherds among all the decorated sherds (67 percent) is consistent with a post-A.D. 1480 Late Caddo period Frankston phase occupation (Perttula 2016c).

The lithic debris from the surface of the Walter Brigham site includes pieces of chert $(n=9)$, petrified wood $(n=2)$, and quartzite $(n=1)$. The chert pieces are gray $(n=3,67$ percent cortical), light gray $(n=2)$, grayish-brown $(n=1)$, brownish-gray $(n=1)$, white $(n=1)$, and blackish-gray $(n=1)$ colors. These chert raw materials were probably gathered from gravels in the Neches River, or came from sources in the Trinity River and other western stream basins. 


\section{$41 \mathrm{HE} 412$}

A February 2016 surface collection of ancestral Caddo artifacts $(n=10)$ was obtained from a newly recorded site on property owned by Mr. Jerry Douglas on the north side of the Caddo Creek valley in Henderson County, Texas, along an intermittent and southern-flowing tributary of Caddo Creek. The excavation of three shovel tests disclosed artifact-bearing deposits from 0-60 cm bs. The density of artifacts in the shovel tests is 6.7 per positive shovel test or ca. 53.6 artifacts per square meter of archaeological deposits. The site is estimated to cover a ca. $100 \times 65 \mathrm{~m}$ of the pasture-covered upland landform.

This site is at the location where Mr. Douglas collected a sherd of probable Gallup Black on White type, dating from ca. A.D. 1150-1300. The sample of ancestral Caddo sherds in the surface collection and shovel tests is temporally consistent with that age range, given the absence of post-A.D. 1250 brushed utility ware sherds in the ceramic sherd assemblage.

The ceramic vessel sherd assemblage from $41 \mathrm{HE} 412$ includes 13 grog-tempered body sherds. Ten are plain body sherds and three are from utility $(n=2)$ and fine ware $(n=1)$ vessels. One utility ware sherd, from the surface collection, has a simple row of tool punctations, and the other (ST 2, 40-60 cm bs) has parallel incised lines. The fine ware sherd (ST 1, 0-20 cm bs) has finely executed diagonal opposed engraved lines.

Also recovered in the surface collections and shovel tests are one gray chert non-cortical multiple platform flake core (53 x $36 \times 20 \mathrm{~mm}$ in length, width, and thickness) and 16 pieces of lithic debris. The raw materials represented in the lithic debris includes brownish-gray chert ( $\mathrm{n}=1,100$ percent cortical), gray chert $(n=5,0$ percent cortical), dark gray chert $(n=1,0$ percent cortical), quartzite $(n=7,43$ percent cortical), and ferruginous sandstone ( $\mathrm{n}=2,50$ percent cortical). The quartzite and ferruginous sandstone lithic debris are from locally available pebbles and cobbles, and this material was likely reduced on the site, while the various cherts are from non-local sources, perhaps to the west in Trinity River or Central Texas sources.

\section{An Unrecorded Caddo Site in the Caddo Creek Valley, Henderson County, Texas}

We also are aware of a collection of ancestral Caddo artifacts from an unrecorded site in the upper Neches River basin in northeastern Henderson County in East Texas. The collection had been found by landowners on an unreported Caddo site in this locale - which appears to be in the Caddo Creek valley west of the Neches River-and the collection was recently relocated by Debbie Shelley of Frankston, Texas. Mrs. Shelley brought the collection to the 2015 East Texas Archeological Conference, and provided the opportunity to fully document the ceramic and lithic artifacts in the location.

\section{Ceramic Sherd Assemblage}

The collection contains 257 sherds from ancestral Caddo ceramic vessels (Table 31). The plain to decorated sherd ratio for the assemblage is 1.21 (141/116). As with other upper Neches River basin Caddo sites (see Perttula 2011:301), the vast majority of the sherds are from grog-tempered vessels (94.4 percent) (i.e., crushed sherds used as temper), and only 5.4 percent of the sherds are from burned bonetempered vessels. None of the fine ware sherds in the assemblage are from bone-tempered vessels. 
Table 31. Ceramic sherd assemblage.

\begin{tabular}{lccc}
\hline Ware & Grog-tempered & Bone-tempered & N \\
\hline Plain & 133 & 8 & 141 \\
Utility & 85 & 6 & 91 \\
Fine & 25 & - & 25 \\
\hline & & 14 & 257 \\
\hline
\end{tabular}

The utility ware sherds are from vessels - most commonly cooking jars - with wet paste decorations; wet paste decorations are those that were applied to the vessel body while it was still wet and before the vessel was fired. About 78 percent of the decorated sherds are from utility ware vessels (see Table 31 ). In this assemblage, sherds from vessels decorated with brushing marks are most common, and they represent 36 percent of the utility ware sherds (Table 32). There are also sherds from vessels with both brushed and other decorative elements (i.e., incised, incised-punctated, and punctated) and they comprise another 11 percent of the utility ware sherds. Sherds from vessels decorated with fingernail or tool punctations are also abundant (24 percent of the utility ware sherds). Sherds from incised vessels account for almost 20 percent of the utility ware sherds, and another 7.7 percent of the utility ware sherds have incised-punctated decorative elements. There is only one (1.1 percent) body sherd with appliqued-incised decorative elements (Table 32).

Table 32. Decorative methods and elements in the utility wares in the ceramic sherd assemblage.

Decorative method/

$\operatorname{Rim}$

Body

$\mathrm{N}$

Decorative element

Appliqued-Incised

appliqued node and adjacent straight line

1

Brushed

opposed brushing marks

overlapping brushing marks

parallel brushing marks

parallel brushed panels

\section{Brushed-Incised}

parallel brushed incised marks and lines

parallel brushing marks and overlying parallel

incised lines 
Table 32. Decorative methods and elements in the utility wares in the ceramic sherd assemblage, cont.

Decorative method/

$\operatorname{Rim}$

Body

$\mathrm{N}$

Decorative element

Brushed-Incised-Punctated

vertical brushing marks and overlying incised

triangle filled with tool punctations [on rim], and overlying vertical incised lines [on body]

\section{Brushed-Punctated}

parallel brushed and adjacent fingernail

punctated rows

\section{Incised}

cross-hatched lines

diagonal lines

diagonal opposed lines

horizontal and cross-hatched lines

horizontal and diagonal lines

opposed lines

parallel lines

straight line

\section{Incised-Punctated}

diagonal and curvilinear incised zones with tool punctations

diagonal opposed lines and triangular zone filled with tool punctations

incised triangle element filled with linear tool punctations

horizontal and vertical-oriented rows of finger-

nail punctations divided by single horizontal

line

straight incised line between two panels filled

with rows of tool punctations

straight incised line and adjacent row of tool punctations

\section{Punctated}

fingernail punctated rows

linear tool punctated rows

tool punctated rows

$\begin{array}{lll}2 & 11 & 13 \\ - & 1 & 1 \\ - & 8 & 8\end{array}$


The appliqued-incised sherd in the collection has a large appliqued node adjacent to a single straight incised line (see Table 32); it is likely that this is from a jar with a series of nodes around the rim, with diagonal incised lines between the nodes. The many brushed sherds in the assemblage are from Bullard Brushed vessels that have brushing marks (from drawing a clump of grass across the surface of the vessel when it was still wet) on the body of jars, and the brushed sherds include one with panels of fine parallel brushing marks, as well as sherds with the brushing oriented in opposed, overlapping, and parallel marks (see Table 32). The parallel brushed sherds were likely oriented vertically on the vessel body. The brushed-incised sherds have brushing marks adjacent to parallel incised lines, or the incised lines were laid down over the brushing marks (Figure 175a). One lower rim-upper body sherd was first decorated with vertical brushing marks, after which vertical incised lines were drawn on the vessel body, and a diagonal incised triangle element was drawn on the vessel rim (Figure 175b). Then, the incised triangle element was filled with rows of tool punctations. The one brushed-punctated sherd with rows of fingernail punctations adjacent to parallel brushing marks is also from a Bullard Brushed vessel.

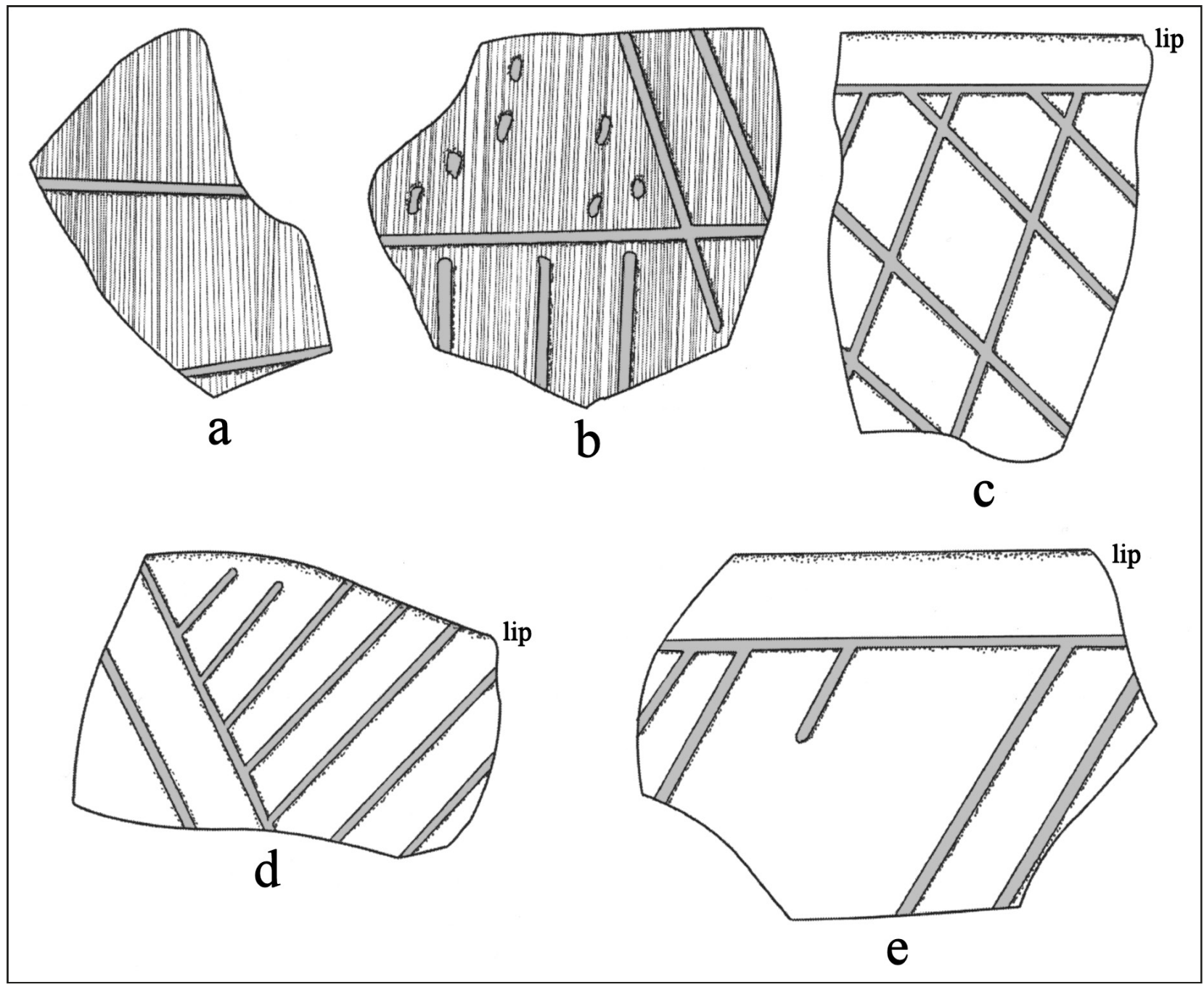

Figure 175. Selected brushed-incised, brushed-incised-punctated, and incised decorative elements on sherds in the ceramic assemblage; $a$, brushed-incised body sherd; b, brushed-incised-punctated body sherd; c-e, incised rim sherds. 
The sherds from incised vessels have cross-hatched, diagonal, and diagonal opposed decorative elements on the rims (see Figure 175c-e). These are common decorative elements on Maydelle Incised vessels found in the upper Neches River basin (see Suhm and Jelks 1962:Plate 52a-d, f). The incised-punctated rim and body sherds from the Henderson County site are also from Maydelle Incised vessels, and these feature "diagonals pitched in alternate directions with punctations filling the areas between them" (Suhm and Jelks 1962:103 and Plate 52e) (Figure 176a, c). One of the incised-punctated rims has diagonal and curvilinear incised zones filled with punctations (Figure 176b), and a body sherd has horizontal incised zones with rows of horizontal and vertically-oriented fingernail punctations (Figure 176d).

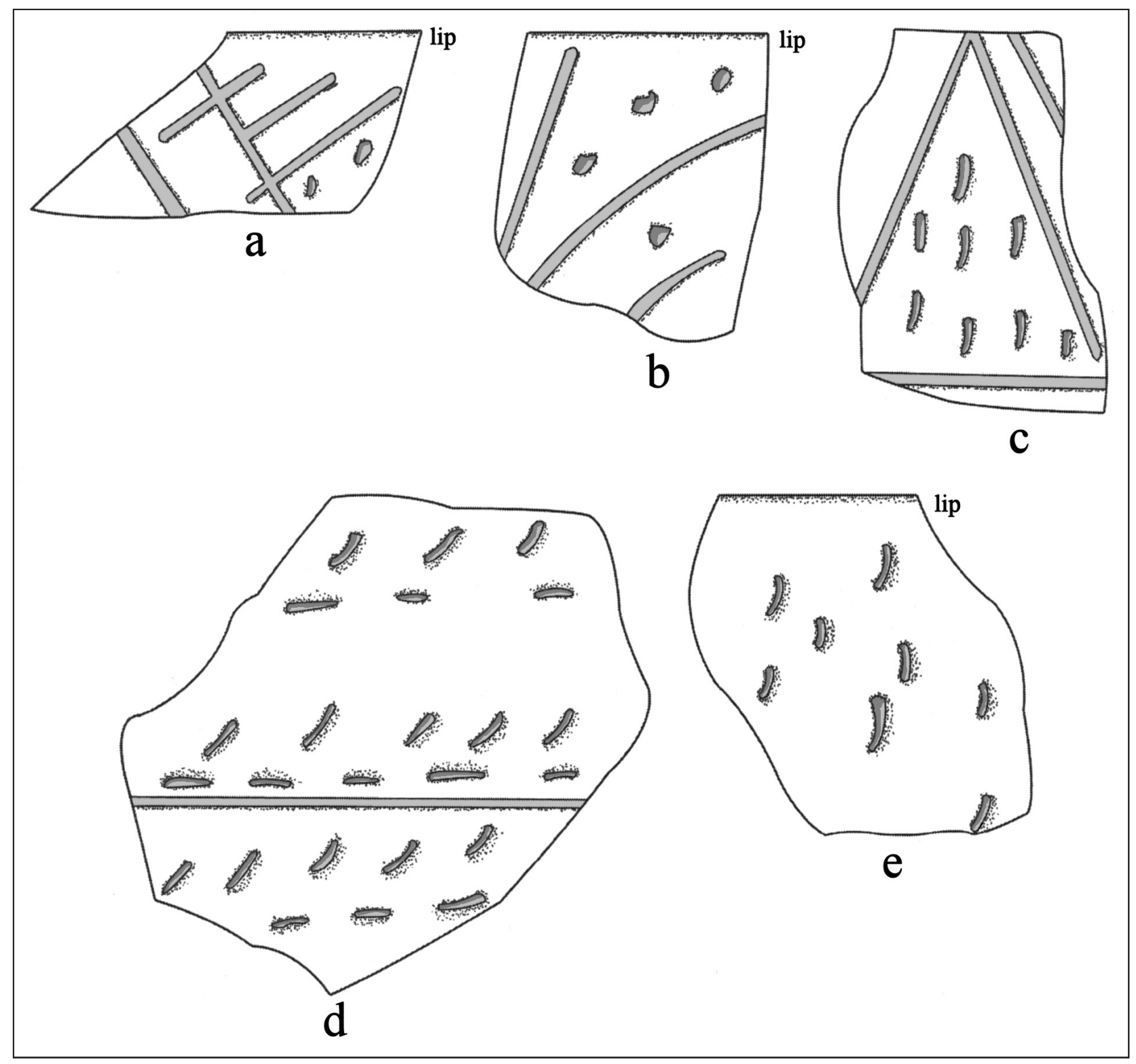

Figure 176. Selected incised-punctated and punctated decorative elements on sherds in the ceramic assemblage: a-d, incised punctated sherds; e, fingernail punctated rim sherd. 
A number of the utility ware sherds in this Henderson County ceramic assemblage have either fingernail or tool punctated decorative elements (see Table 32). The two rims have rows of fingernail punctations (see Figure 176e).

The fine ware sherds from the site are from vessels with engraved (i.e., decorated after the vessel had been fired) decorative elements ( 80 percent) and red-slipping (20 percent) (Table 33). Fifteen percent of the engraved sherds are from bottles, and the remainder appear to be from carinated bowls.

Table 33. Decorative methods and elements in the fine wares in the ceramic sherd assemblage.

Decorative method/

Rim Body

$\mathrm{N}$

Decorative element

\section{Engraved}

concentric semi-circles*

diagonal lines

diagonal opposed lines

diagonal-vertical lines

hatched zones*

hatched triangles on interior thickened rim

horizontal and curvilinear lines

horizontal, diagonal, and curvilinear lines

horizontal and diagonal opposed lines

closely spaced parallel lines*

straight line

$\begin{array}{lll} & & \\ - & 1 & 1 \\ 1 & - & 1 \\ 1 & - & 1 \\ 1 & - & 1 \\ - & 4 & 4 \\ - & 1 & 1 \\ - & 1 & 1 \\ - & 1 & 1 \\ 1 & - & 1 \\ - & 3 & 3 \\ - & 2 & 2\end{array}$

\section{Engraved Bottle Sherds}

horizontal and diagonal lines

parallel lines and curvilinear hatched zone*

straight line and triangular element

$\begin{array}{lll}- & 1 & 1 \\ - & 1 & 1 \\ - & 1 & 1\end{array}$

\section{Red-Slipped}

ext. red-slipped

int./ext. red-slipped

$\begin{array}{lll}- & 3 & 3\end{array}$

Totals

*includes sherds that have a red pigment rubbed in the engraved lines

The engraved rim sherds have vertical panels filled with diagonal lines (Figure 177a), diagonal lines, and diagonal opposed lines (Figure 177b). An interior-thickened rim has a row of hatched triangles (Figure 177c), and is likely from a Spoonbill Engraved carinated bowl. Spoonbill Engraved was defined by Perttula et al. (2009) on the basis of several engraved bowls recovered from Middle Caddo period (ca. A.D. 1200-1400) sites in the upper Sabine River basin. These vessels have interior thickened rims with upper and lower sets of hatched (3-4 hatched lines) engraved triangles. The apex of the upper and lower rows of triangles usually touch (Perttula and Selden 2014:Figure 16). 


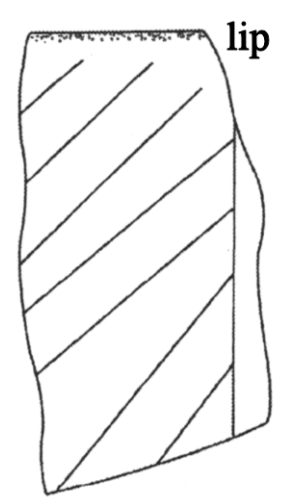

a
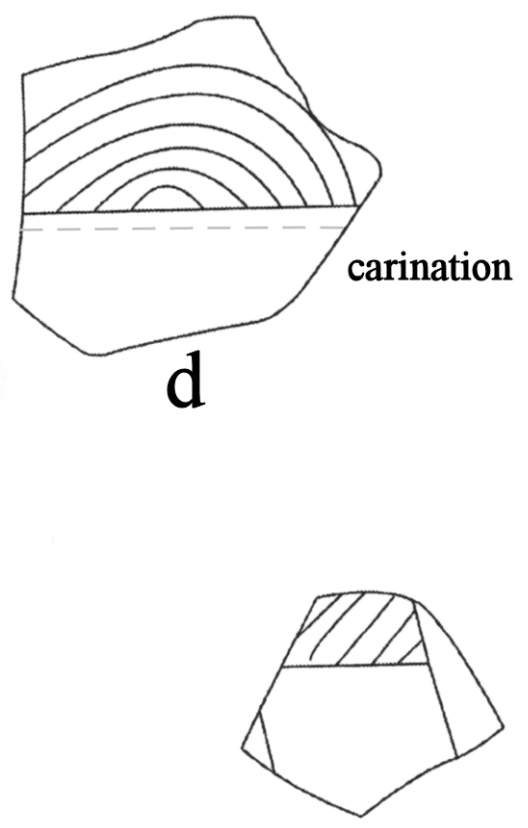

g

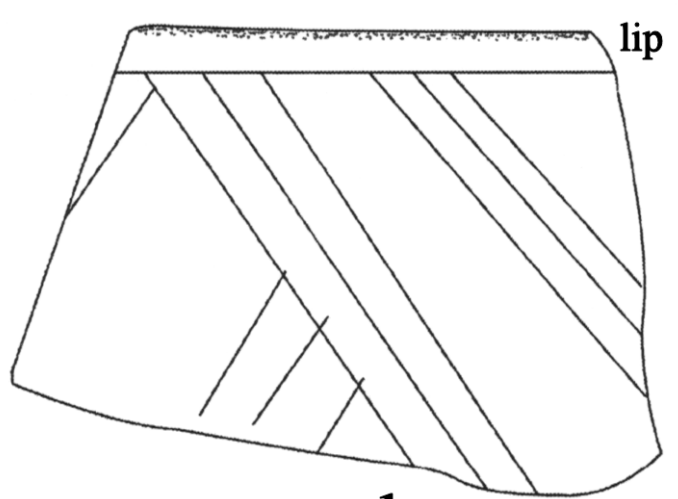

$\mathrm{b}$
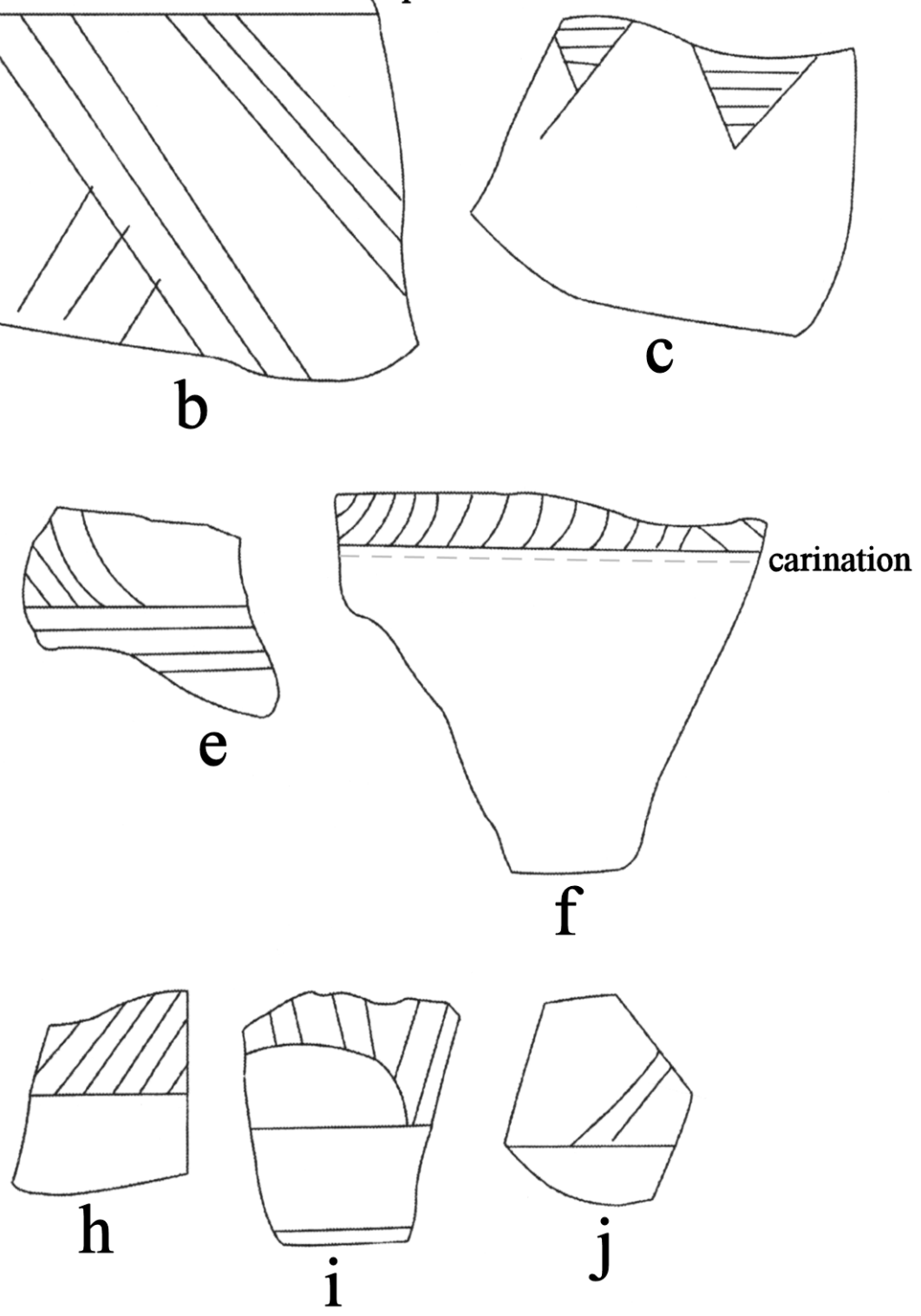

Figure 177. Selected engraved decorative elements on sherds in the ceramic assemblage: a-h, carinated bowl sherds; i-j, bottle sherds.

There are three sherds in the assemblage that may be from early varieties of Poynor Engraved (i.e., found in other assemblages that date from ca. A.D. 1320-1480) (see Perttula 2011:Figures 6-64 and 6-65). These have concentric semi-circles (see Figure 177d), horizontal and curvilinear lines (see Figure 177e), and horizontal-diagonal-and curvilinear lines above the vessel carination (see Figure 177f). Another group of four carinated bowl sherds have hatched engraved zones (see Figure 177g), and one bottle sherd has a curvilinear hatched zone (see Figure 177i). There is also a bottle sherd with horizontal and closely-spaced diagonal engraved lines on the vessel body (see Figure 177j). 
The use of a red, ochre-rich, clay pigment on engraved fine ware vessels was apparently common at this Henderson County site. Among the bottle sherds, 33 percent have a red pigment rubbed in the engraved design, and 22 percent of the sherds from engraved carinated bottles have a red pigment (see Table 28).

The frequency of red-slipped sherds among the fine wares in this site is notable (see Table 33); they also comprise 4.3 percent of all the decorated sherds from the site. Red-slipped vessels are generally far from common in upper Neches River basin Caddo sites. In a sample of 462 ceramic vessels from more than 30 upper Neches River basin Caddo sites in Anderson, Cherokee, Henderson, and Smith counties, only 0.3 percent of the vessels were red-slipped (Perttula 2011:Table 6-35). In a large assemblage of decorated sherds $(n=2572)$ from the Lang Pasture site (41AN38), with components that date from ca. A.D. 1320-1480, only 0.7 percent were red-slipped (Perttula 2011:Table 6-3).

\section{Ceramic Pipe Sherd}

The one grog-tempered ceramic pipe sherd in the collection from this northeastern Henderson County site is the base to an L-shaped elbow pipe. It is $5.2 \mathrm{~mm}$ in diameter and $5.4 \mathrm{~mm}$ thick. The L-shaped elbow pipe is the earliest form of elbow pipe in the upper Neches River basin, and began to be manufactured by the Caddo in the region after ca. A.D. 1350 to as late as ca. A.D. 1480 (Perttula 2011:215).

\section{Arrow point}

There is a single Early Caddo period (ca. A.D. 1000-1200) Catahoula arrow point in the collection. The unifacially flaked arrow point has an expanding stem, corner notching, and broad barbs; there are upward-pointing serrations on the blade. It is made from a gray chert and is $19.9 \mathrm{~mm}$ in length, $15.9 \mathrm{~mm}$ in width, is $3.3 \mathrm{~mm}$ in thickness, and has a $6.7 \mathrm{~mm}$ stem width.

The assemblage of ancestral Caddo artifacts - including ceramic sherds from broken ceramic vessels, an elbow pipe sherd, and a single arrow point - from this site in the Caddo Creek valley in the upper Neches River basin in northeastern Henderson County suggest that they are the product of a domestic settlement or farmstead likely occupied primarily by a Caddo group belonging to a larger community of Caddo peoples for probably no more than one or two generations. The ceramic assemblage is comprised of sherds primarily from grog-tempered vessels, and almost 80 percent of the decorated sherds $(n=116)$ are from utility ware jars decorated with appliqued-incised, brushed, brushed-incised, brushed-incisedpunctated, brushed-punctated, incised, incised-punctated, and punctated decorative elements; most of these sherds are from Bullard Brushed and Maydelle Incised vessels. The fine wares include sherds from engraved carinated bowls and bottles, among them a distinctive Spoonbill Engraved vessel sherd and a few early style Poynor Engraved sherds, along with red-slipped bowls and carinated bowls.

Other than the one Early Caddo period Catahoula arrow point, the ceramic sherd assemblage and the elbow pipe sherd would appear to be from an occupation that took place sometime between ca. A.D. 1350-1480. Various ceramic attributes and indices compiled from domestic Caddo sites in the upper Neches River basin can be employed to reasonably establish when the site in northeastern Henderson County was principally occupied by Caddo peoples. These attributes and indices include such things as the styles of ceramic pipes that are present in the assemblage; as well as the percentage of brushed sherds in the decorated sherd samples from different sites; the percentage of bone temper in the assemblages; the percentage of wet-paste decorations other than brushing (i.e., incised, punctated, appliqued, neck-banded, etc.); the plain/decorated sherd ratio (P/DR); and the brushed sherd/wet paste decorated sherd ratio. The only ceramic pipe from the site is a form of elbow pipe that was in use between ca. A.D. 1350-1480 in this part of the Caddo area. 
From the comparisons of the ceramic attribute data, six different groups of upper Neches River basin Caddo ceramic assemblages can be seriated (see O'Brien and Lyman 1999) from oldest (Group VI) to youngest (Group I). These groups seem to reflect temporal changes due to the high frequency of Late Caddo Frankston phase decorated types, such as Poynor Engraved, Maydelle Incised, Bullard Brushed, Hume Engraved, and engraved effigy vessels, that are found in the Groups II-IV sites (corresponding to the early, middle, and late parts of the Frankston phase) - as well as Patton Engraved sherds from sites in Group I - and the occurrence of Early and Middle Caddo types such as Canton Incised, Dunkin Incised, Holly Fine Engraved, and Pennington Punctated-Incised in the Group V and VI upper Neches River sites (see Table 22).

This particular seriation, focusing on the three different temporal groupings of Frankston phase sites and one group of Allen phase sites, is also supported by differences in: (a) the proportions of vessels of Poynor Engraved varieties, Patton Engraved, engraved effigy vessels, Maydelle Incised, La Rue Neck Banded, and Bullard Brushed in upper Neches River Caddo burials (see Perttula 2011), (b) differences in the relative frequencies of common vessel forms in Poynor and Patton Engraved vessels (Kleinschmidt 1982:Figure 24), as well as (c) the occurrence of European trade goods. The Group I-IV Caddo sites are part of an upper Neches River cluster that represented a conglomeration of constituent groups (i.e., groups related by kinship and close interaction and cultural transmission of knowledge and practices) that shared a broadly similar socio-political organization through time and space (see Story and Creel 1982:30-34).

Based on this seriation, the northeastern Henderson County site discussed herein most likely dates to the same time period as the Group IV assemblages, in the early part of the Frankston phase (see Table 22). This group of sites has been estimated to date between ca. A.D. 1400-1480 (Perttula 2011). 


\section{Caddo Settlement in the Caddo Creek Valley in the Upper Neches River Basin}

There have been a number of archaeological investigations in the Caddo Creek valley of the upper Neches River basin since the early 1930s, and since that time 35 archaeological sites or components of ancestral Caddo age have been identified and recorded there. We have no doubt that there are many more ancestral Caddo sites to be found in the valley, because archaeological surveys have not been comprehensive or especially intensive in most parts of the valley.

The archaeological record of Caddo settlement and use of the Caddo Creek valley indicates that it was first settled in a permanent way by the early $14^{\text {th }}$ century A.D. at sites such as Lang Pasture (41AN38) and M. S. Roberts (41HE8). Both sites have habitation deposits, and there was a family cemetery at the Lang Pasture site. A sole earthen mound was constructed over at least one burned and likely special purpose structure at the M. S. Robert site in the latter years of the $14^{\text {th }}$ century (ca. A.D. 13201400); this is the only constructed Caddo mound site known in the Caddo Creek valley, although a later Frankston phase (ca. A.D. 1400-1680) mound center was built at the A. C. Saunders site (41AN19) just north of the confluence of Caddo Creek and the Neches River.

The peak in Caddo settlement of the Caddo Creek valley was between ca. A.D. 1400-1680 during the Late Caddo period Frankston phase. Approximately 51 percent of the known sites or components in the valley date to this time, and they are apparently farmsteads or small hamlets occupied by sedentary dispersed farming communities; most of the 10 sites or components of unknown Caddo age likely also date to this period of time. Many of these sites or components $(n=12)$ also have associated family cemeteries.

The most common funerary offering in the burials in these cemeteries is ceramic vessels (and their contents) (Table 34). Ten different sites in the Caddo Creek valley have ceramic vessel funerary offerings, and together they comprise 142 vessels.

More than 67 percent of the documented ceramic vessels that were placed in ancestral Caddo burials in the Caddo Creek valley are fine wares, especially Poynor Engraved bottles, beakers, and carinated bowls (32.4 percent of the vessels) at nine of the 10 cemeteries, as well as Patton Engraved (21.1 percent of the vessels) from two different sites (see Table 34). Hume Engraved bottles and bowls represent another 6.3 percent of the Caddo Creek valley vessel assemblage, and these are present at four of the cemetery sites.

Approximately 21.2 percent of the funerary vessels are plain (see Table 34 ). The majority of these are plain bowls and plain carinated bowls. The remainder of the Caddo Creek funerary vessels are utility wares (11.2 percent of the vessels). Killough Pinched, Bullard Brushed, and Maydelle Incised are the most common represented types.

How does the Caddo Creek valley vessel assemblage compare to the larger Caddo ceramic vessel database from 34 sites in the upper Neches River basin (Figure 178)? In the latter sample, fine ware (72.9 percent) and utility ware (15.3 percent) vessels were more common funerary offerings than they were specifically in the Caddo Creek valley, while plain ware vessels are about 80 percent more common in Caddo Creek valley burials than they are in the larger set of upper Neches River basin sites (see Table 34).

The same suite of the better represented ceramic types are present in both local and regional contexts: (a) Killough Pinched, Bullard Brushed, and Maydelle Incised in the utility wares; and (b) Poynor Engraved, Patton Engraved, Hood Engraved, and Hume Engraved. However, Poynor Engraved vessels

are a more common funerary offering in the regional sample (43.0 percent) than is the case in the Caddo Creek valley burial features (32.4 percent), while Patton Engraved-a virtual ceramic vessel marker for 


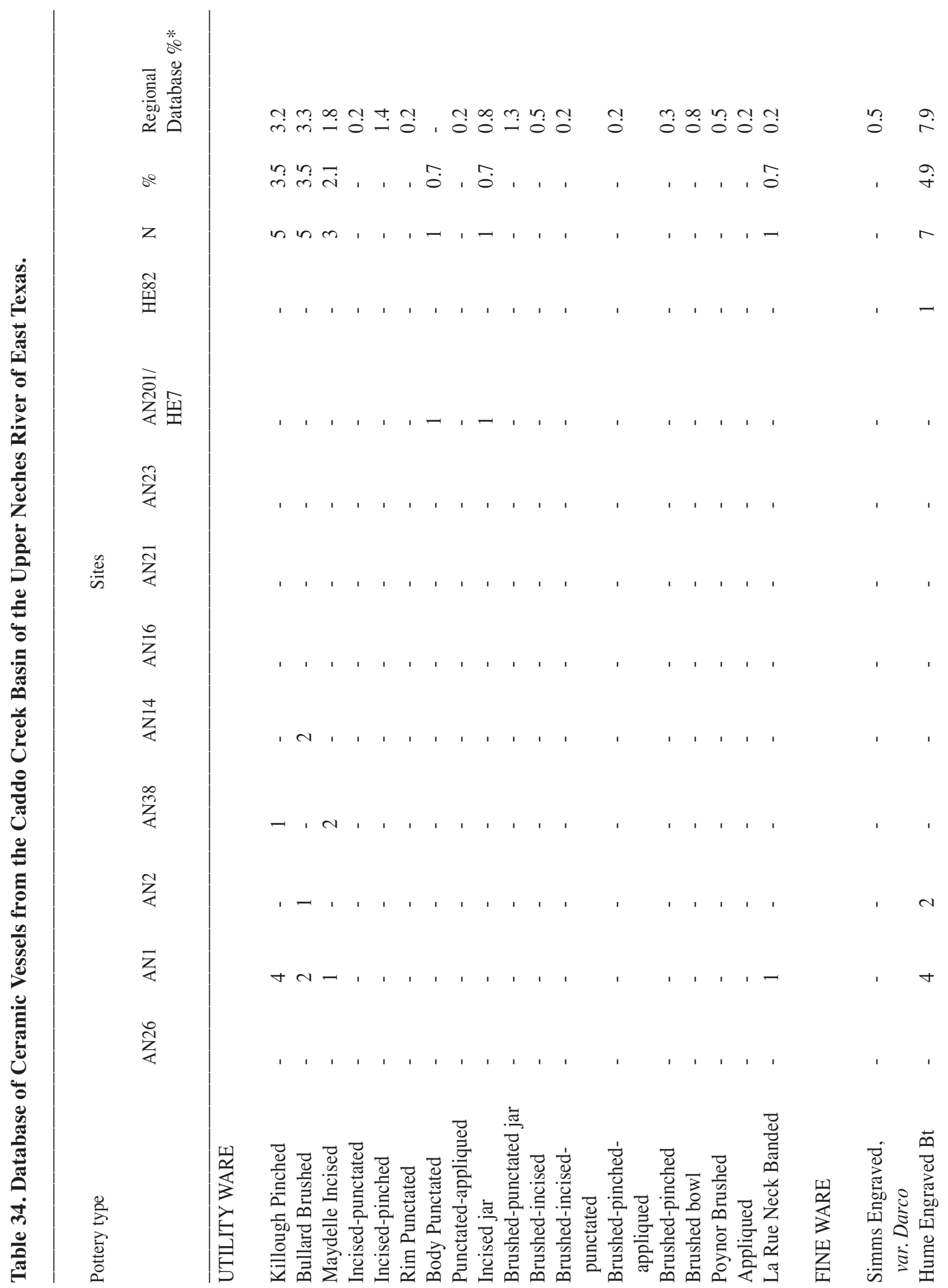




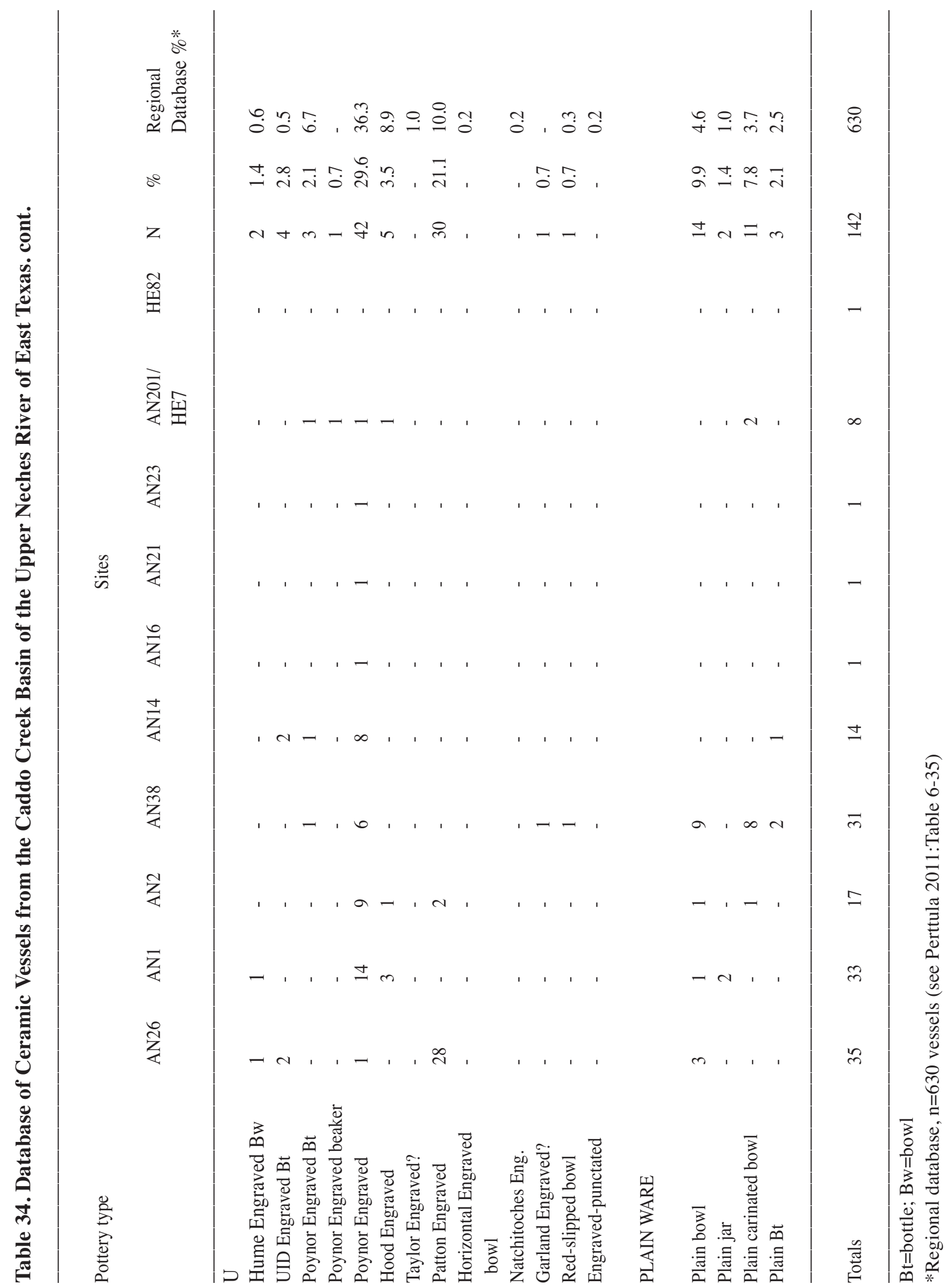




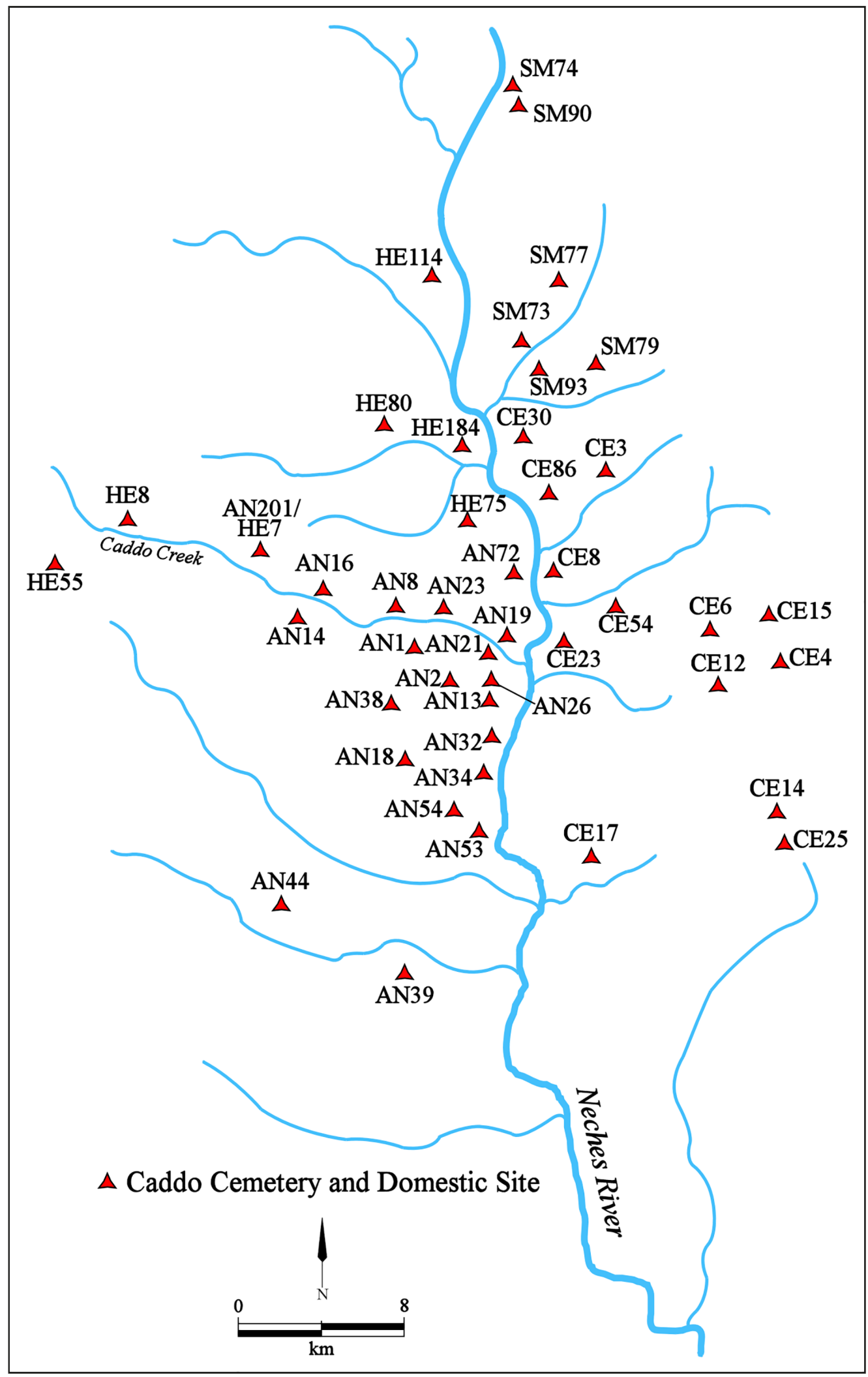

Figure 178. Known Caddo cemetery sites in the upper Neches River basin. 
an Historic Caddo occupation or use - is a much more common funerary offering in Caddo Creek valley sites (21.1 percent) than they are in the larger region (10.0 percent) (see Table 34$)$. This suggests that the post-A.D. 1680 Historic Caddo use of the upper Neches River basin was concentrated in the Caddo Creek valley. However, Patton Engraved vessels are present in only 10 of the 324 upper Neches River basin sites (see Perttula 2011:Table 6-35).

Three sites were occupied after ca. A.D. 1680, during the Historic Caddo Allen phase, including the well-known Richard Patton site (41AN26), and they also have burial features that date to this time. Although the number of Caddo sites occupied after ca. A.D. 1680 is about 80 percent less than during the Late Caddo period, this part of the upper Neches River basin is one of only seven known clusters of historic Allen phase sites in all of the Neches and Angelina river basins in East Texas (see Marceaux 2011). However, the specific ethnic or tribal identity of the Upper Neches cluster of historic Caddo sites has yet to be established through archaeological investigations.

The archaeological evidence suggests that Caddo groups continued to live in the Caddo Creek valley until ca. A.D. 1730, but no later than that; the valley must have been virtually abandoned after that time. During the $19^{\text {th }}$ century, however, Caddo peoples were living again in the Caddo Creek valley. An 1835 village was known on the creek south of the modern town of Poynor, Texas (Figure 179), situated on a Caddo trace that ran northeast towards the Neches Saline and south-southwest towards the Hainai village on Ioni Creek in Houston County.

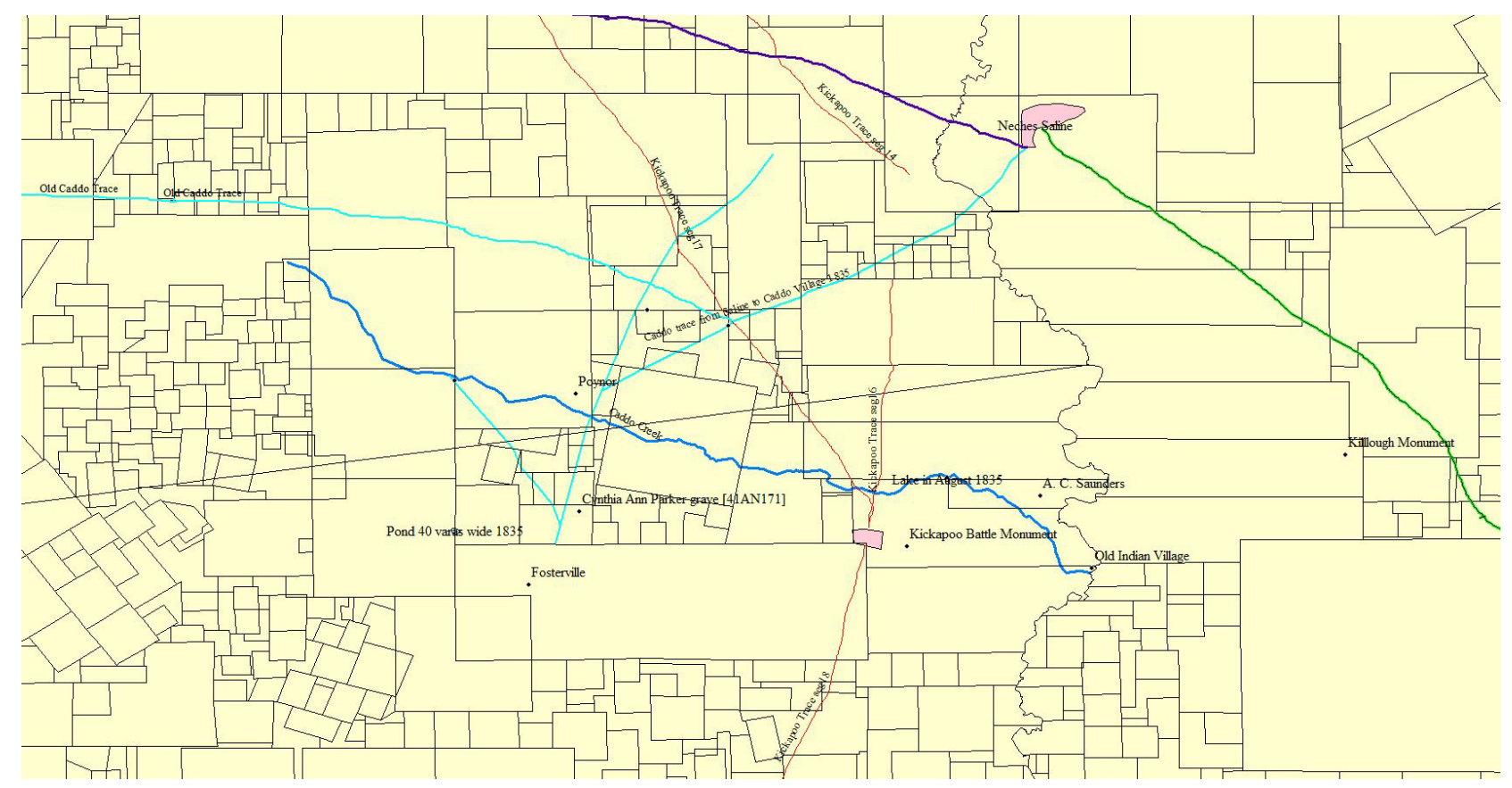

Figure 179. Map of $19^{\text {th }}$ century land surveys, Caddo and Kickapoo villages, and Caddo and Kickapoo trails. Map provided courtesy of Bob D. Skiles. 
At that time, apparently, there was a natural lake in the Caddo Creek floodplain that was ca. $25 \mathrm{~m}$ wide and 200-300 m in length; recent explorations of this area has identified peat deposits, although the lake itself has dried up (Waldo Troell, October 2015 personal communication). The Caddo village was reported to have had a peach orchard with trees 8-10 inches in thickness and 12-15 feet in height. Faulk $(1929: 32,240)$ noted that it was "called the Indian village" and it had peach trees with delicious red peaches.

An 1871 General Land Office (GLO) map depicts an "Old Indian Village" at the mouth of Caddo Creek (Figure 180). Unfortunately, the GLO map failed to identify the tribal affiliation of its occupants; it is likely that they were Caddo. Neither this village, or the 1835 Caddo village south of Poynor, Texas, have been identified by archaeologists or historians.

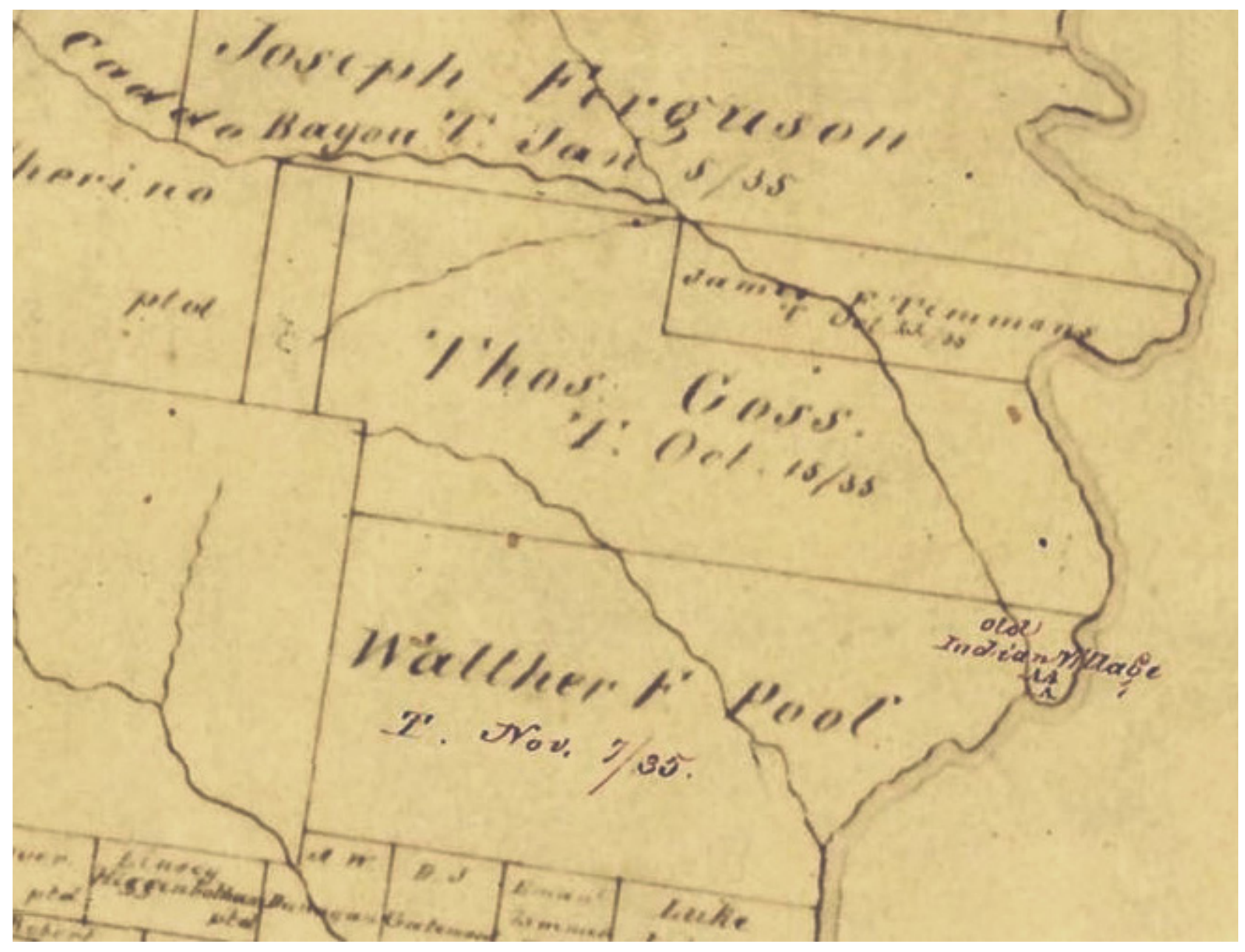

Figure 180.1871 GLO map No. 776 that shows "Old Indian Village" at the mouth of Caddo Creek on the W. F. Pool League in Anderson County, Texas. Map provided courtesy of Bob D. Skiles. 


\section{Summary and Conclusions}

This publication focuses on the character of the ancestral Caddo archaeological record in the Caddo Creek valley of the upper Neches River basin in East Texas. This area has been of archaeological interest since the early 1930s because of the concentration of Caddo settlements and cemeteries there. The early focus of the work was by The University of Texas at the cemeteries and the recovery of the funerary offerings they contained, while recent work (since the 1970s) has been more concerned with understanding the complete character of the Caddo sites in the valley, including the identification and study of their domestic features and material culture assemblages, along with subsistence analyses and bioarchaeological studies, examining trade and long-distance exchange, and investigating the character of mortuary patterning by different Caddo groups. The 2015-2016 excavations at the A. E. Mann site (41AN201/41HE7) and 41HE338 in the Caddo Creek valley, and the consequent study and publication of the archaeological findings, promise to add significantly to the knowledge of ancestral Caddo lifeways and native history.

As with recent studies completed in the Neches River basin of the Caddo archaeological records in the San Pedro Creek valley (Perttula 2016b) and the Saline and County Line creek valleys (Perttula 2016c), the Caddo Creek valley-specific perspective has illuminated the distinctive and diverse character of Caddo settlement and use in these key parts of the upper and mid-Neches River basin. These studies have shown that the Caddo archaeology and native history of these three valleys has not been the same, although each was densely settled at certain times by Caddo peoples in farming communities, as there are significant differences in the intensity of their use by Caddo peoples, particularly in their use during Early Caddo period times (ca. A.D. 1000-1200), and then again in post-A.D. 1680 times by Hasinai Caddo peoples.

The known archaeological record of Caddo settlement and use of the Caddo Creek valley indicates that it was first settled by the early $14^{\text {th }}$ century A.D. at sites such as Lang Pasture (41AN38) and M. S. Roberts (41HE8). Both sites have habitation deposits, and there was a family cemetery at the Lang Pasture site. One earthen mound was constructed over a burned and likely special purpose structure at the M. S. Robert site apparently in the latter years of the $14^{\text {th }}$ century; this is the only Caddo mound site known in the Caddo Creek valley. There is a later Frankston phase (ca. A.D. 1400-1680) mound center (two mounds were built there) at the A. C. Saunders site (41AN19) just north of the confluence of Caddo Creek and the Neches River (see Kleinschmidt 1982).

The peak in Caddo settlement of the Caddo Creek valley was between ca. A.D. 1400-1680 during the Late Caddo period Frankston phase, but within the larger upper Neches River basin, historic Caddo Allen phase settlements and cemeteries are more abundant in the valley, suggesting a concentration of Hasinai Caddo peoples here after ca. A.D. 1680 until at least ca. A.D. 1730. More than half of the known ancestral Caddo sites or components in the valley date to the Late Caddo period and can be culturally affiliated with the Frankston phase. The sites and components appear to be farmsteads or small hamlets occupied by sedentary dispersed farming communities; most of the 10 sites or components of unknown Caddo age likely also date to this period of time. Many of these sites or components $(n=12)$ also have associated family cemeteries. 


\section{References Cited}

Anderson, K. M.

1972 Prehistoric Settlement of the Upper Neches River. Bulletin of the Texas Archeological Society 43:121-197.

Anderson, K. M., K. Gilmore, O. F. McCormick III, and E. P. Morenon

1974 Archaeological Investigations at Lake Palestine, Texas. Contributions in Anthropology No. 11. Department of Anthropology, Southern Methodist University, Dallas.

Arthur, J. W.

2006 Living with Pottery: Ethnoarchaeology among the Gamo of Southwest Ethiopia. The University of Utah Press, Salt Lake City.

Barr, J.

2015 “There's No Such Thing as 'Pre-history': What Chaco, Cahokia, and the Continent's Longue Duree can Tell Us about Colonial America. In World and New Ground: New Early American Histories, edited by C. Grasso, K. Wulf, and P. Mancall. University of Pennsylvania Press, Philadelphia, in press.

Bureau of Economic Geology

1965 Geologic Atlas of Texas: Tyler Sheet. Bureau of Economic Geology, The University of Texas at Austin.

Cole, N. M.

1975 Early Historic Caddoan Mortuary Practices in the Upper Neches Drainage, East Texas. Master's thesis, Department of Anthropology, The University of Texas at Austin.

Colomina, I. and P. Molina

2014 Unmanned aerial systems for photogrammetry and remote sensing: A review. ISPRS Journal of Photogrammetry and Remote Sensing 92:79-97.

Diggs Jr., G. M., B. L. Lipscomb, M. D. Reed and R. J. O’Kennon

2006 Illustrated Flora of East Texas, Volume One: Introduction, Pteridophytes, Gymnosperms, and Monocotyledons Sida, Botanical Miscellany, No. 26. Botanical Research Institute of Texas, Fort Worth.

Early, A. M. (editor)

1993 Caddoan Saltmakers in the Ouachita Valley: The Hardman Site. Research Series No. 43. Arkansas Archeological Survey, Fayetteville.

Faulk, J. J.

1929 History of Henderson County, Texas. Athens Review Printing Co., Athens, Texas.

Gonçalves, J. A. and R. Henriques

2015 UAV photogrammetry for topographic monitoring of coastal areas. ISPRS Journal of Photogrammetry and Remote Sensing 104:101-111. 
Goodmaster, C.

2015 Intensive Archeological Survey of US 175 from FM 804 to SH 155, Anderson and Henderson Counties, Texas. Archeological Studies Program Report No. 166. Texas Department of Transportation, Environmental Affairs Division, Austin.

Hally, D. J.

1983 Use Alteration of Pottery Vessel Surfaces: An Important Source of Evidence for the Identification of Vessel Function. North American Archaeologist 4(1):3-26.

Hatcher, M. A.

1927 Descriptions of the Tejas or Asinai Indians, 1691-1722, Part III (Hidalgo). Southwestern Historical Quarterly 31(No. 1):50-62.

Hesse, R.

2015 Combining Structure-from-Motion with high and intermediate resolution satellite images to document threats to archaeological heritage in arid environments. Journal of Cultural Heritage 16(2):192-201.

Jackson, A. T.

1931 Field Notes, Excavations in Anderson County, Texas, 13 October 1931 to 12 November 1931. MS on file, Texas Archeological Research Laboratory, The University of Texas at Austin.

1933a Some Pipes of East Texas. Bulletin of the Texas Archeological and Paleontological Society 5:6986.

1933b Richard Patton (Negro) Farm Located on Caddo Creek 3 Miles S.E. of Frankston, Anderson County, Texas, Excavated Aug. 25 to Aug. 30, 1933. MS on file, Texas Archeological Research Laboratory, The University of Texas at Austin.

Kleinschmidt, U. K. W.

1982 Review and Analysis of the A. C. Saunders Site, 41AN19, Anderson County, Texas. Master's thesis, Department of Anthropology, The University of Texas at Austin.

La Vere, D.

1998 Life Among the Texas Indians: The WPA Narratives. Texas A\&M University Press, College Station.

Lerma, J. L. and C. Muir

2014 Evaluating the 3D documentation of an early Christian upright stone with carvings from Scotland with multiples images. Journal of Archaeological Science 46:311-318.

Lohse, J. C., with contributions by T. K. Perttula and R. A. Ricklis

2004 Interim Report on Archaeological Testing at 41AN38 and 41AN159, Anderson County, Texas. Submitted to the Texas Department of Transportation, Austin, by Coastal Environments, Inc., Baton Rouge and Corpus Christi.

Lohse, J. C., T. K. Perttula, and R. A. Ricklis

2011 Test Excavations at 41AN159. In Archeological Investigations at the Lang Pasture Site (41AN38) in the Upper Neches River Basin of East Texas, assembled and edited by T. K. Perttula, D. B. Kelley, and R. A. Ricklis, pp. 613-636. Archeological Studies Program Report No. 129, Texas Department of Transportation, Environmental Affairs Division, Austin. 
Lowe, D. G

2004 Distinctive Image Features from Scale-Invariant Keypoints. International Journal of Computer Vision 60(2):91-110.

Marceaux, P. S.

2011 The Archaeology and Ethnohistory of the Hasinai Caddo: Material Culture and the Course of European Contact. Ph.D. dissertation, Department of Anthropology, The University of Texas at Austin.

Martínez, S., J. Ortiz, and M. L. Gil

2015 Geometric documentation of historical pavements using automated digital photogrammetry and high-density reconstruction algorithms. Journal of Archaeological Science 53:1-11.

McKinnon, D. P., T. K. Perttula, and A. McKee

2016 Magnetic Gradient Survey at the M. S. Roberts (41HE8) Site in Henderson County, Texas. Journal of Northeast Texas Archaeology 71, in press.

Miller, M., N. Steinle, K. Korfmacher, D. Sitters, D. Rose, and K. Stone

2014 Cultural Resource Survey of the Proposed Tarrant Regional Water District/City of Dallas Integrated Pipeline Project in Tarrant, Johnson, Ellis, Navarro, Henderson, and Anderson Counties, and Expansion of the Kennedale Balancing Reservoir in Tarrant County, Texas. AmaTerra Environmental, Inc., Austin.

O’Brien, M. J. and R. L. Lyman

1999 Seriation, Stratigraphy, and Index Fossils: The Backbone of Archaeological Dating. Kluwer Academic/Plenum Publishers, New York.

Pearce, J. E. and A. T. Jackson

1931 M. S. Roberts Farm, Henderson County, Texas Oct. 8 to Oct. 11, 1931. MS on file, Texas Archeological Research Laboratory, The University of Texas at Austin.

Perttula, T. K.

2011 The Ceramic Artifacts from the Lang Pasture Site (41AN38) and the Place of the Site within an Upper Neches River Basin Caddo Ceramic Tradition. In Archeological Investigations at the Lang Pasture Site (41AN38) in the Upper Neches River Basin of East Texas, assembled and edited by T. K. Perttula, D. B. Kelley, and R. A. Ricklis, pp. 145-320. Archeological Studies Program Report No. 129, Texas Department of Transportation, Environmental Affairs Division, Austin.

2016b The Caddo Archaeology of the San Pedro Creek Valley, Houston County, in East Texas. Journal of Northeast Texas Archaeology 68, in press.

2016c The Caddo Archaeological Record in the Saline Creek and County Line Creek Valleys in Cherokee and Smith Counties, Texas. Journal of Northeast Texas Archaeology 69, in press.

2016 Utility Ware Ceramic Metrics and Hasinai Caddo Archaeology in East Texas. Journal of Northeast Texas Archaeology 70, in press.

Perttula, T. K., with contributions by W. Troell

2016a The A. S. Mann (41HE7/41AN201) and M. S. Roberts (41HE8) Sites in the Upper Neches River Basin, Henderson County, Texas. Journal of Northeast Texas Archaeology 59:1-19. 
Perttula, T. K. and T. Middlebrook

2008 Prehistoric Caddo Ceramics from the Henry Lake Site (41CE324), Cherokee County, Texas. Journal of Northeast Texas Archaeology 29:9-21.

Perttula, T. K. and R. Z. Selden Jr.

2014 Ancestral Caddo Ceramics in East Texas. Journal of Northeast Texas Archaeology 48:9-58.

2015 Effigy Vessel Documentation, Caddo Collections at the Texas Archeological Research Laboratory at The University of Texas at Austin. Special Publication No. 40. Friends of Northeast Texas Archaeology, Austin and Pittsburg.

Perttula, T. K. and M. Walters

2016 Recent Artifact Surface Collections from the M. S. Roberts (41HE8) Mound Site in the Upper Neches River Basin in East Texas. Journal of Northeast Texas Archaeology 59:69-74.

Perttula, T. K., D. B. Kelley, and R. A. Ricklis (assemblers and editors)

2011 Archeological Investigations at the Lang Pasture Site (41AN38) in the Upper Neches River Basin of East Texas. Report No. 129. Texas Department of Transportation, Archeological Studies Program, Environmental Affairs Division, Austin.

Perttula, T. K., B. Nelson, M. Walters, and L. Schniebs

2007 Archaeological Investigations of the Lang Pasture (41AN38) Midden Deposits on private property west of the SH 155 Right-of-Way, Anderson County, Texas. Caddo Archeology Journal 16:27-36.

Perttula, T. K., M. Walters, and B. Nelson

2012 Archeological Investigations at the Pace McDonald Site (41AN51): A Middle Caddo Mound Center in the Neches River Basin in East Texas. Special Publication No. 21. Friends of Northeast Texas Archaeology, Pittsburg and Austin.

2016 The M. S. Roberts Site (41HE8): Archaeological Investigations at a Caddo Mound Site in the Upper Neches River Basin in East Texas. Journal of Northeast Texas Archaeology 71, in press.

Perttula, T. K., M. Walters, S. Marceaux, and B. Nelson

2009 Caddo Pottery Vessels and Pipes from Sites in the Middle and Upper Sabine and Upper Neches River Basins, Smith and Wood Counties, Texas. Special Publication No. 7. Friends of Northeast Texas Archaeology, Pittsburg and Austin.

Rice, P. M.

1987 Pottery Analysis: A Sourcebook. University of Chicago Press, Chicago.

Rye, O. S.

1981 Pottery Technology: Principles and Reconstruction. Manuals on Archaeology 4. Taraxacum, Washington, D.C.

Sanger, M. C.

2015 Determining depositional events within shell deposits using computer vision and photogrammetry. Journal of Archaeological Science 53:482-491. 
Shafer, H. and M. Walters

2010 The Browning Site (41SM195A) Lithics: Considering Patterns of Identity and Interaction Through Lithic Analysis. Bulletin of the Texas Archeological Society 81:127-151.

Stark, M. T.

2003 Current Issues in Ceramic Ethnoarchaeology. Journal of Archaeological Research 11(3):193-242.

Steponaitis, V. P.

1984 Technological Studies of Prehistoric Pottery from Alabama: Physical Properties and Vessel Function. In The Many Dimensions of Pottery: Ceramics in Archaeology and Anthropology, edited by S. E. van der Leeuw and A. C. Pritchard, pp. 79-122. Universiteit van Amsterdam, Amsterdam.

Story, D. A. and D. G. Creel

1982 The Cultural Setting. In The Deshazo Site, Nacogdoches County, Texas, Vol. 1, edited by D. A. Story, pp. 20-34. Texas Antiquities Permit Series No. 7. Texas Antiquities Committee, Austin.

Suhm, D. A. and E. B. Jelks (editors)

1962 Handbook of Texas Archeology: Type Descriptions. Special Publication No. 1, Texas Archeological Society, and Bulletin No. 4, Texas Memorial Museum, Austin. Reprinted in 2009, Gustav's Library, Davenport, Iowa.

Teltser, P. A.

1993 An Analytic Strategy for Studying Assemblage-Scale Ceramic Variation: A Case Study from Southeast Missouri. American Antiquity 58(3):530-543.

Tonkin, T. N., N. G. Midgley, D. J. Graham, and J. C. Labadz

2014 The potential of small unmanned aircraft systems and structure-from-motion for topographic surveys: A test of emerging integrated approaches at Cwm Idwal, North Wales. Geomorphology 226:35-43.

Troell, W.

2016 Locating the A. S. Mann Site in 2014. Journal of Northeast Texas Archaeology 59:10-11.

Walters, $\mathrm{M}$.

2006 The Lake Clear (41SM243) Site and Crotalus horridus atricaudatus. Caddoan Archeology Journal 15:5-41.

Walters, M., with contributions by T. Middlebrook and T. K. Perttula

2010 Redwine or Pie-Crust Rim Modes in East Texas Caddo ceramics and comparisons with SprocketRims of Southwest Arkansas. Caddo Archeology Journal 20:77-128.

Walters, M., S. Bozarth, and T. H. Guderjan

2015 An Examination of Six "Nutting Stones" from East Texas for Plant Phytoliths. Journal of Northeast Texas Archaeology 54:93-100. 
Wilson, D. E.

2011 Analysis of Human Remains from the Lang Pasture Site. In Archeological Investigations at the Lang Pasture Site (41AN38) in the Upper Neches River Basin of East Texas, assembled and edited by T. K. Perttula, D. B. Kelley, and R. A. Ricklis, pp. 381-401. Report No. 129. Texas Department of Transportation, Archeological Studies Program, Environmental Affairs Division, Austin

Wilson, D. and T. K. Perttula

2013 Reconstructing the Diet of the Caddo through Stable Isotopes. American Antiquity 78(4):702-723.

Woolsey, A. M.

1935a Notes on Field Work De Long Farm 2 Miles Northwest Frankston Anderson County October 17, 1935. MS on file, Texas Archeological Research Laboratory, The University of Texas at Austin.1935b Notes on Field Work Mann Place 4 Mi. West of Frankston Anderson County October 17, 1935. MS on file, Texas Archeological Research Laboratory, The University of Texas at Austin.

1935b Notes on Work Done, Anderson County - Isibel-Gene Donnell Farm, October 14-16, 1935. MS on file, Texas Archeological Research Laboratory, The University of Texas at Austin.

1935c Notes on Field Work L. Cecil Farm 21ำ Miles East of Frankston, Anderson County, October 11, 1935. MS on file, Texas Archeological Research Laboratory, The University of Texas at Austin. 